\title{
Oak Ridge Reservation Annual Site Environmental Report for 2003
}

on the World Wide Web

http://www.ornl.gov/aser

\author{
Project director \\ Joan Hughes \\ Project coordinator \\ Sharon Thompson
}

Technical coordinators

Wayne McMahon

Oak Ridge Y-12 Complex

Joan Hughes

Oak Ridge National Laboratory

Mike Coffey

Electronic publisher

Coordinating editor

Walter Koncinski

Graphic artists

Rosemary Adams

Jane Parrott

Project manager, DOE-ORO
Timothy Joseph, Ph.D.

Date published: September 2004

Prepared by

Oak Ridge National Laboratory

P.O. Box 2008, Oak Ridge, TN 37831-2008

Managed by UT-Battelle, LLC

for the U.S. Department of Energy under Contract No. DE-AC05-00OR22725 and by

the Y-12 National Security Complex

Oak Ridge, TN 37831-8169

Managed by

BWXT Y-12, L.L.C.

for the U.S. Department of Energy under Contract No. DE-AC05-00OR22800 and by

East Tennessee Technology Park

P.O. Box 4699, Oak Ridge, TN 37831-4699

Managed by Bechtel Jacobs Company LLC

for the U.S. Department of Energy under Contract No. DE-AC05-98OR22700 



\section{Contents}

Page

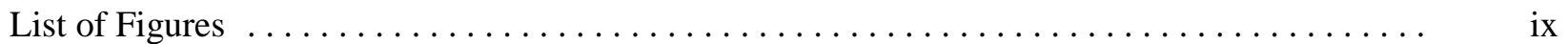

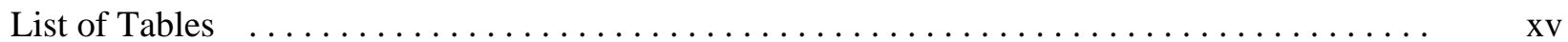

Acronyms and Abbreviations $\ldots \ldots \ldots \ldots \ldots \ldots \ldots \ldots \ldots \ldots \ldots \ldots \ldots \ldots \ldots \ldots \ldots \ldots \ldots \ldots \ldots \ldots$

Acknowledgments $\ldots \ldots \ldots \ldots \ldots \ldots \ldots \ldots \ldots \ldots \ldots \ldots \ldots \ldots \ldots \ldots \ldots \ldots \ldots \ldots \ldots \ldots \ldots \ldots \ldots$

1. SITE AND OPERATIONS OVERVIEW $\ldots \ldots \ldots \ldots \ldots \ldots \ldots \ldots \ldots \ldots \ldots \ldots \ldots \ldots \ldots \ldots \ldots \ldots \ldots$

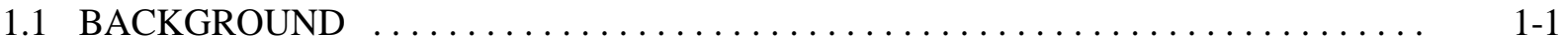

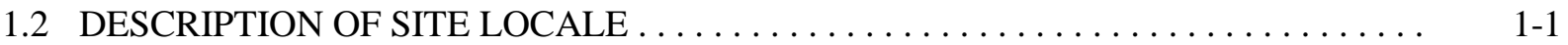

1.3 CLIMATE . . . . . . . . . . . . . . . . . . . . . . . . . . . . . . .

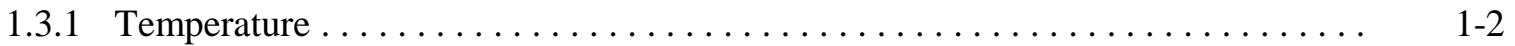

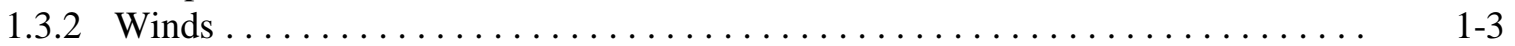

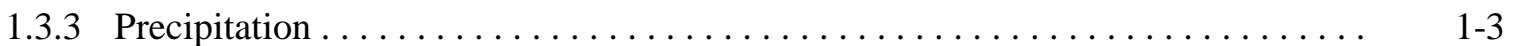

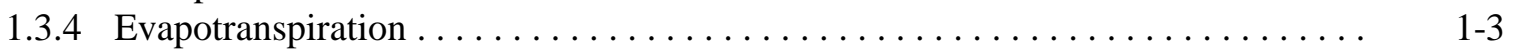

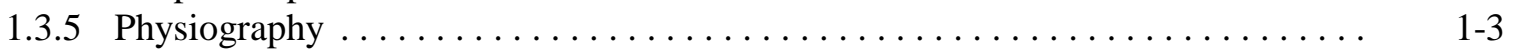

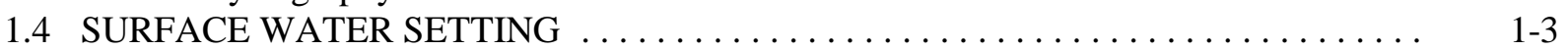

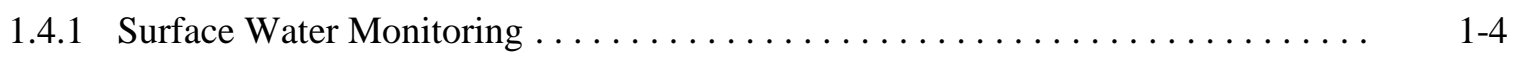

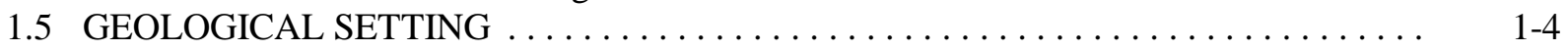

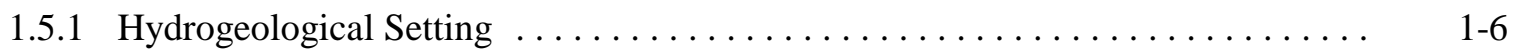

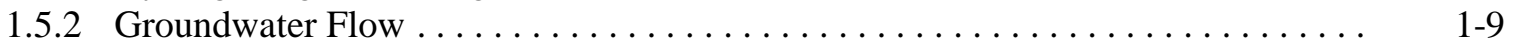

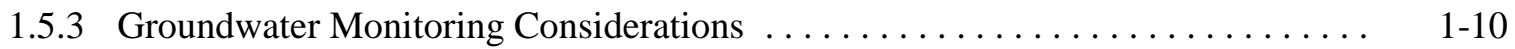

1.6 DESCRIPTION OF SITE FACILITIES AND OPERATIONS $\ldots \ldots \ldots \ldots \ldots \ldots \ldots \ldots . \quad 1-10$

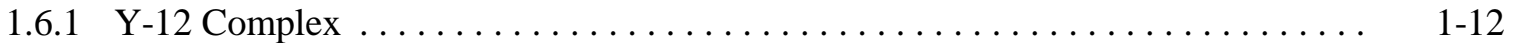

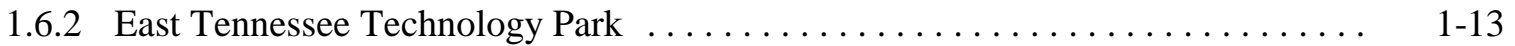

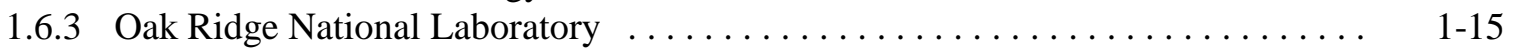

1.6.4 Oak Ridge Institute for Science and Education $\ldots \ldots \ldots \ldots \ldots \ldots \ldots \ldots \ldots \ldots \ldots \ldots$

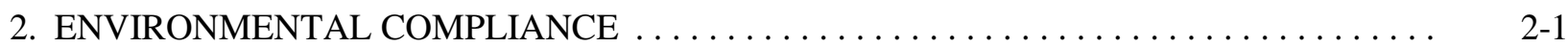

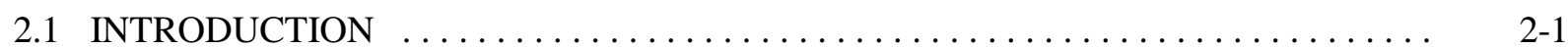

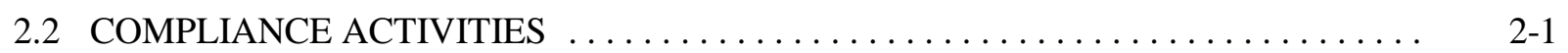

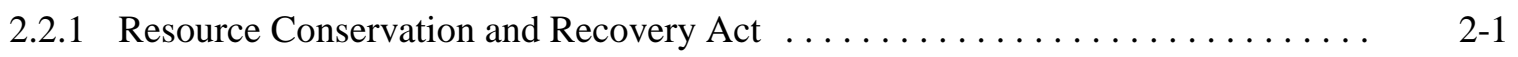

2.2.2 Comprehensive Environmental Response, Compensation, and Liability Act ... . 2-6

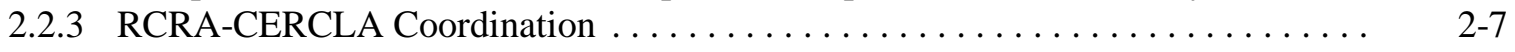

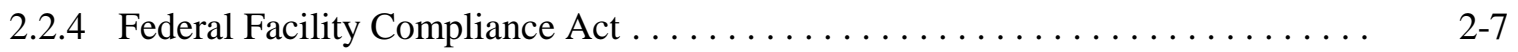

2.2.5 National Environmental Policy Act . . . . . . . . . . . . . . . . . . .

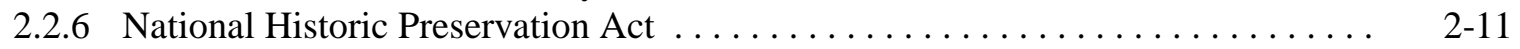

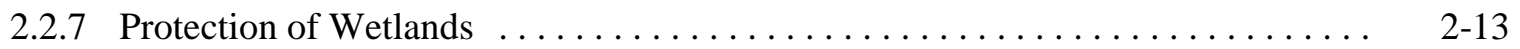

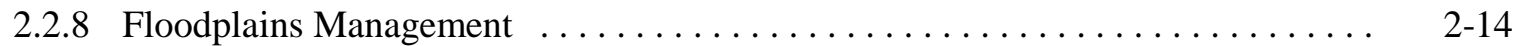

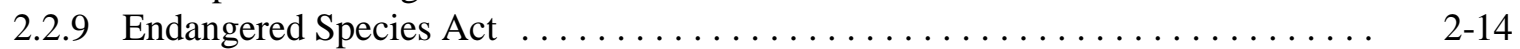

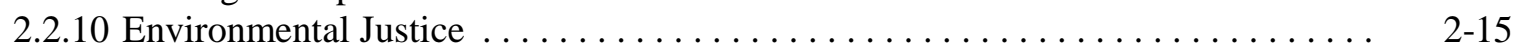

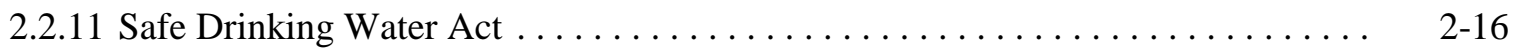

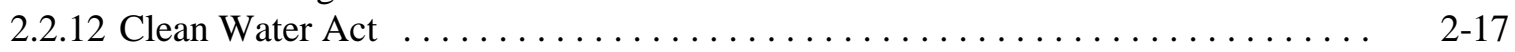

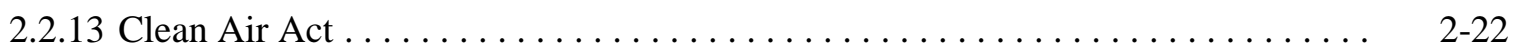


2.2.14 Toxic Substances Control Act .......................... 2-25

2.2.15 Federal Insecticide, Fungicide, and Rodenticide Act $\ldots \ldots \ldots \ldots \ldots \ldots \ldots$ 2-26

2.2.16 Emergency Planning and Community Right-To-Know Act $\ldots \ldots \ldots \ldots \ldots \ldots$ 2-27

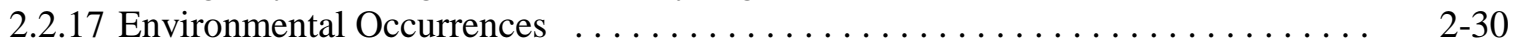

2.2.18 DOE Order 450.1, Environmental Protection Program ............. 2-30

2.3 APPRAISALS AND SURVEILLANCES OF ENVIRONMENTAL PROGRAMS . . . . 2-37

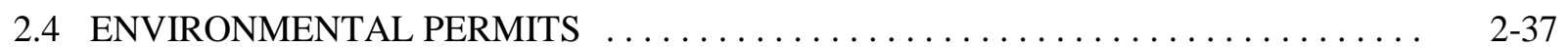

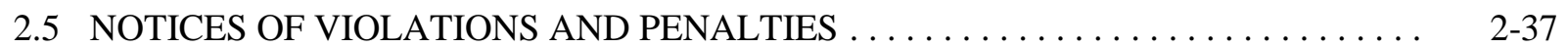

2.6 TENNESSEE OVERSIGHT AGREEMENT $\ldots \ldots \ldots \ldots \ldots \ldots \ldots \ldots \ldots \ldots \ldots \ldots \ldots \ldots$. . . . . . . . . . . .

3. ENVIRONMENTAL MANAGEMENT AND RESERVATION ACTIVITIES $\ldots \ldots \ldots \ldots .3-1$

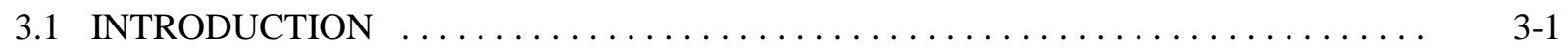

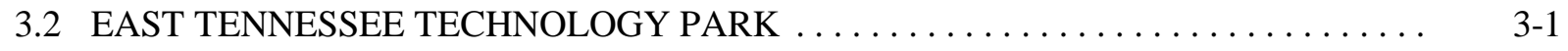

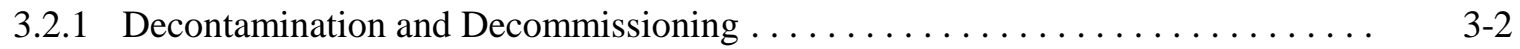

3.3 OAK RIDGE NATIONAL LABORATORY $\ldots \ldots \ldots \ldots \ldots \ldots \ldots \ldots \ldots \ldots \ldots \ldots \ldots$

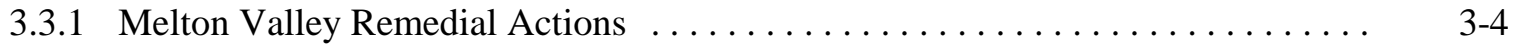

3.3.2 Activities Managed under the ORNL Balance of Program Project . . . . . . . . 3-8

3.3.3 Bethel Valley Groundwater Engineering Study $\ldots \ldots \ldots \ldots \ldots \ldots \ldots \ldots \ldots \ldots$

3.3.4 Surface Impoundment Waste Removed $\ldots \ldots \ldots \ldots \ldots \ldots \ldots \ldots \ldots \ldots \ldots \ldots$. . . . . . . . . . . . . .

3.3.5 Melton Valley Picket Well Installation . . . . . . . . . . . . . . . . . . . . . . . 3-9

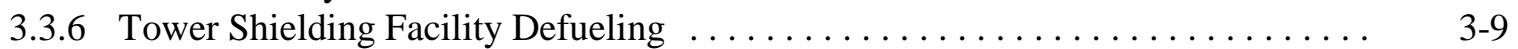

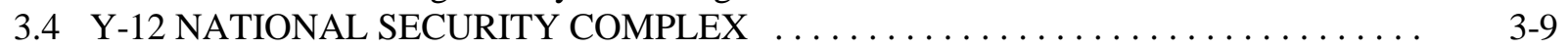

3.4.1 Remediation of Boneyard/Burnyard Completed ............... 3-8

3.4.2 Upper East Fork Poplar Creek Remediation Being Conducted in Phases ...... 3- 3-10

3.4.3 Building 9201-2 Water Treatment System10To Be Constructed ........... 3-9

3.5 OAK RIDGE RESERVATION OPERATIONS $\ldots \ldots \ldots \ldots \ldots \ldots \ldots \ldots \ldots \ldots \ldots \ldots . \quad 3-10$

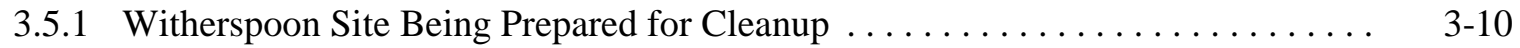

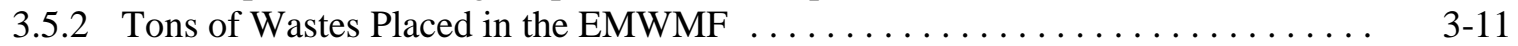

3.5.3 Millions of Gallons of Wastewater Treated in $2003 \ldots \ldots \ldots \ldots \ldots \ldots \ldots$ 3-12

3.5.4 Waste Stockpile Continues to Diminish . . . . . . . . . . . . . . . . . . 3-12

3.5.5 TSCA Incinerator Continues Hazardous Waste Treatment $\ldots \ldots \ldots \ldots \ldots \ldots \ldots$ 3-13

3.5.6 Improved Technologies Being Used for Cleanup $\ldots \ldots \ldots \ldots \ldots \ldots \ldots \ldots$ 3-13

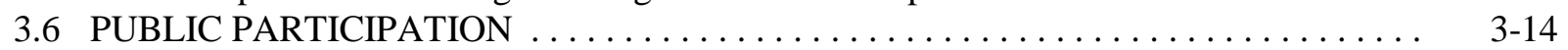

3.6.1 Oak Ridge Site Specific Advisory Board Posts Accomplishments

in Public Involvement, Providing Recommendations to DOE . . . . . . . . . . 3-14

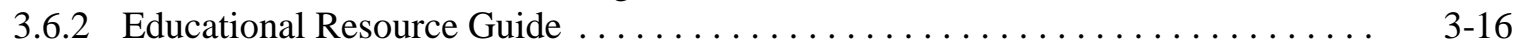

4. ETTP ENVIRONMENTAL MONITORING PROGRAMS $\ldots \ldots \ldots \ldots \ldots \ldots \ldots \ldots \ldots .4-1$

4.1 ETTP RADIONUCLIDE AIRBORNE EFFLUENT MONITORING . . . . . . . . . . $4-1$

4.1.1 Radionuclide Emissions Monitoring Approach $\ldots \ldots \ldots \ldots \ldots \ldots \ldots \ldots \ldots$. 4.1

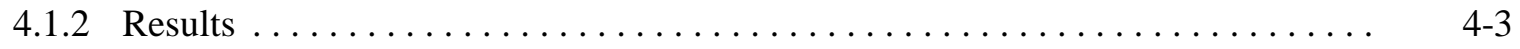

4.2 ETTP NONRADIOLOGICAL AIRBORNE EMISSIONS MONITORING . . . . . . . . 4-3

4.3 LIQUID DISCHARGES—ETTP RADIOLOGICAL MONITORING SUMMARY . . . 4 4-3

4.3.1 Sample Collection and Analytical Procedure $\ldots \ldots \ldots \ldots \ldots \ldots \ldots \ldots \ldots . \ldots \ldots \ldots . \ldots \ldots$

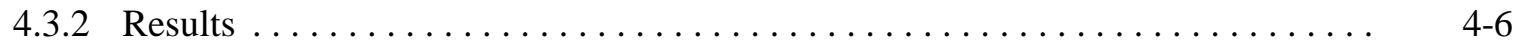

4.4 NONRADIOLOGICAL LIQUID DISCHARGES-ETTP SURFACE
WATER EFFLUENTS $\ldots \ldots \ldots \ldots \ldots \ldots \ldots \ldots \ldots \ldots \ldots \ldots \ldots \ldots \ldots \ldots \ldots \ldots, 4,6 \ldots \ldots$

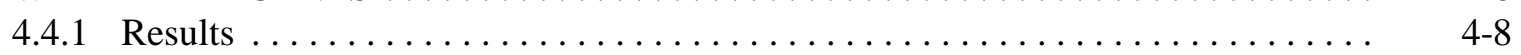

4.5 STORM WATER POLLUTION PREVENTION PROGRAM $\ldots \ldots \ldots \ldots \ldots \ldots \ldots \ldots$. $4-10$

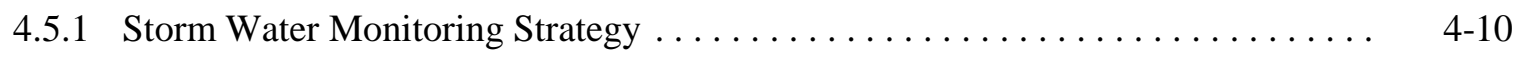

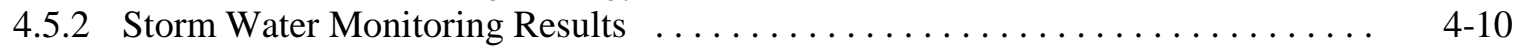

4.6 ETTP TOXICITY CONTROL AND MONITORING PROGRAM $\ldots \ldots \ldots \ldots \ldots \ldots$ 4-12 
4.7 ETTP BIOLOGICAL MONITORING AND ABATEMENT PROGRAM $\ldots \ldots \ldots \ldots \ldots$. $4-12$

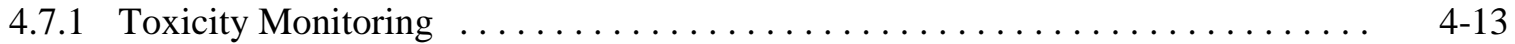

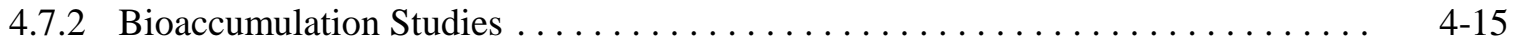

4.7.3 Ecological Surveys of Instream Communities $\ldots \ldots \ldots \ldots \ldots \ldots \ldots \ldots \ldots$ 4 4 .15

4.7.4 Waterfowl Surveys ............................. 4-16

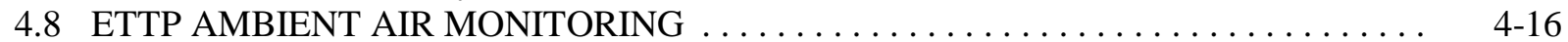

4.8.1 Results . . . . . . . . . . . . . . . . . . . . . . . . . . . . . 4-19

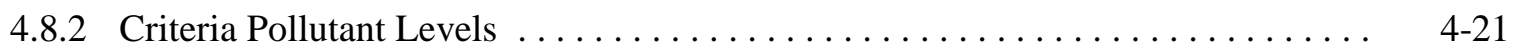

4.8.3 Hazardous Air Pollutant Carcinogenic Metal Levels . . . . . . . . . . . . . . 4-21

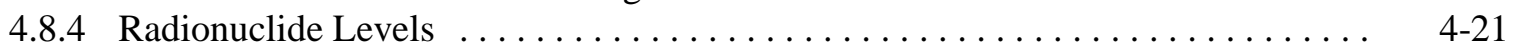

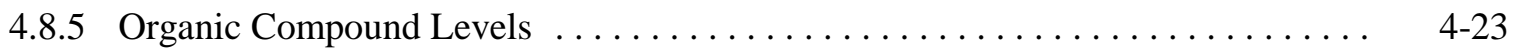

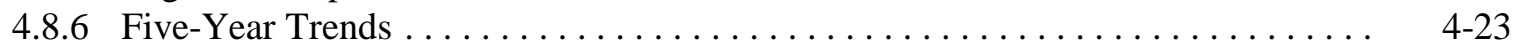

4.9 ETTP SURFACE WATER MONITORING $\ldots \ldots \ldots \ldots \ldots \ldots \ldots \ldots \ldots \ldots \ldots \ldots . \ldots \ldots$

4.10 ETTP SOIL AND SEDIMENT MONITORING $\ldots \ldots \ldots \ldots \ldots \ldots \ldots \ldots \ldots \ldots \ldots .4-25$

4.11 ETTP GROUNDWATER MONITORING $\ldots \ldots \ldots \ldots \ldots \ldots \ldots \ldots \ldots \ldots \ldots \ldots$

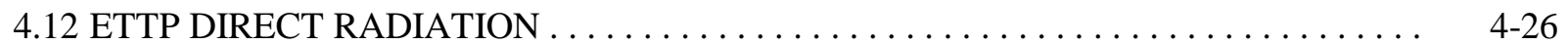

4.13 MODERNIZATION AND REINDUSTRIALIZATION $\ldots \ldots \ldots \ldots \ldots \ldots \ldots \ldots \ldots .4-27$

5. ORNL ENVIRONMENTAL PROGRAMS $\ldots \ldots \ldots \ldots \ldots \ldots \ldots \ldots \ldots \ldots \ldots \ldots \ldots \ldots$

5.1 ORNL RADIOLOGICAL AIRBORNE EFFLUENT MONITORING $\ldots \ldots \ldots \ldots \ldots \ldots$ 5-1

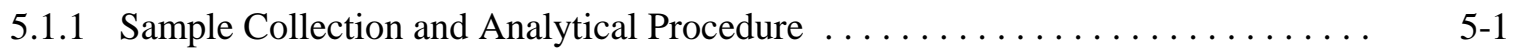

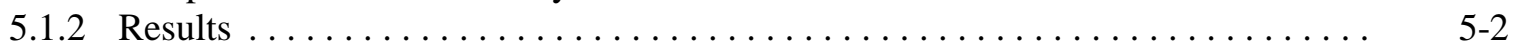

5.2 ORNL NONRADIOLOGICAL AIRBORNE EMISSIONS MONITORING $\ldots \ldots \ldots . \quad 5-4$

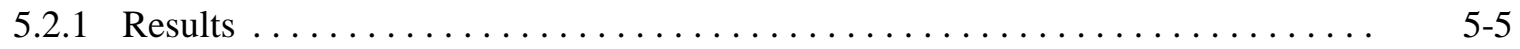

5.3 ORNL AMBIENT AIR MONITORING $\ldots \ldots \ldots \ldots \ldots \ldots \ldots \ldots \ldots \ldots \ldots \ldots \ldots$

5.3 .1 Results . . . . . . . . . .

5.4 LIQUID DISCHARGES—ORNL RADIOLOGICAL MONITORING

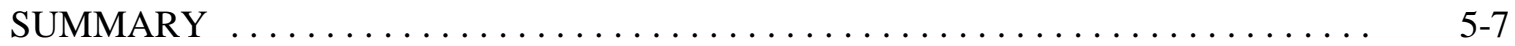

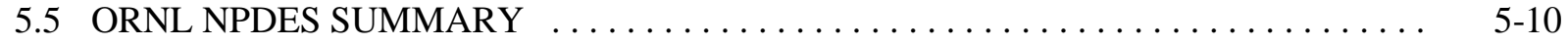

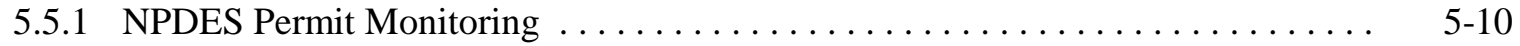

5.5.2 ORNL Results and Progress in Implementing Programs and

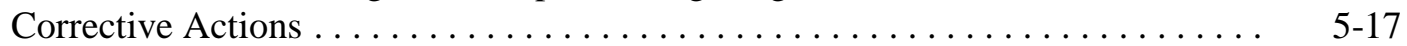

5.6 ORNL WASTEWATER BIOMONITORING $\ldots \ldots \ldots \ldots \ldots \ldots \ldots \ldots \ldots \ldots \ldots \ldots . \quad 5-17$

5.7 ORNL BIOLOGICAL MONITORING AND ABATEMENT PROGRAM $\ldots \ldots \ldots \ldots$ 5-17

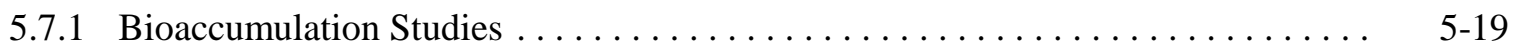

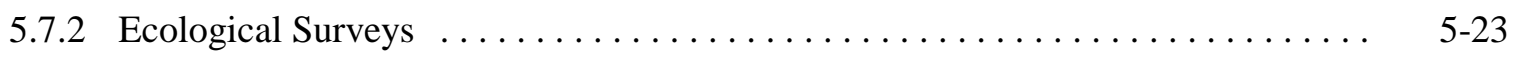

5.8 ORNL SURFACE WATER MONITORING AT REFERENCE LOCATION . . . . . . $5-25$

5.9 ORNL SURFACE WATER SURVEILLANCE MONITORING $\ldots \ldots \ldots \ldots \ldots \ldots \ldots$. $5-26$

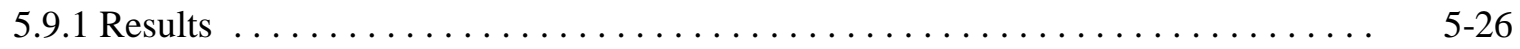

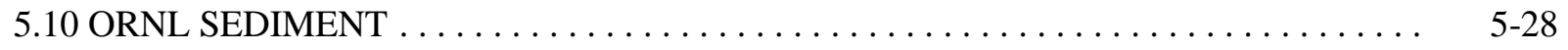

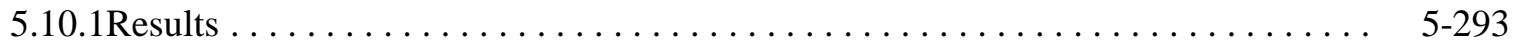

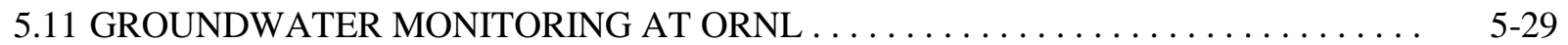

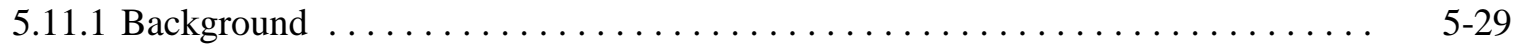

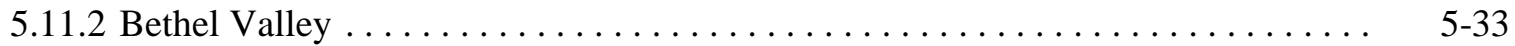

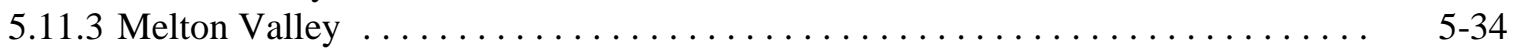

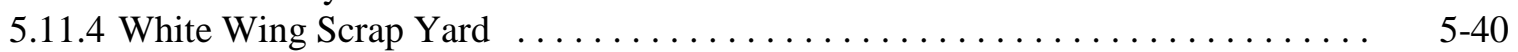


5.12 WELL PLUGGING AND ABANDONMENT AT ORNL $\ldots \ldots \ldots \ldots \ldots \ldots \ldots \ldots$

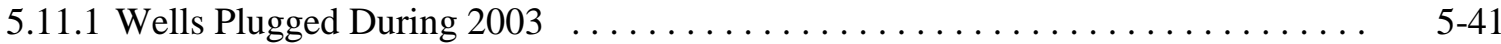

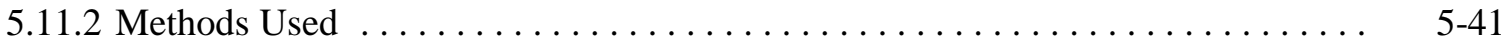

5.13 ORNL MODERNIZATION AND REINDUSTRIALIZATION ACTIVITIES $\ldots \ldots \ldots . \quad 5-41$

5.14 SPALLATION NEUTRON SOURCE $\ldots \ldots \ldots \ldots \ldots \ldots \ldots \ldots \ldots \ldots \ldots \ldots \ldots \ldots \ldots \ldots \ldots$

6. Y-12 ENVIRONMENTAL MONITORING PROGRAMS $\ldots \ldots \ldots \ldots \ldots \ldots \ldots \ldots \ldots$ 6-1

6.1 Y-12 COMPLEX RADIOLOGICAL AIRBORNE EFFLUENT MONITORING . . . . . . 6- 6-1

6.1.1 Sample Collection and Analytical Procedure $\ldots \ldots \ldots \ldots \ldots \ldots \ldots \ldots \ldots$. $6-1$

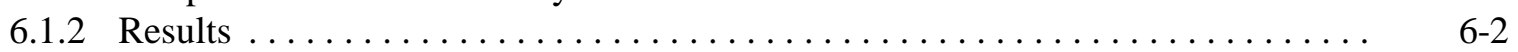

6.2 Y-12 COMPLEX NONRADIOLOGICAL AIRBORNE EMISSIONS

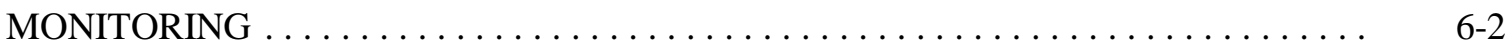

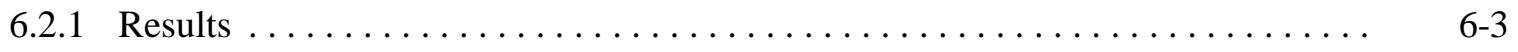

6.3 Y-12 COMPLEX AMBIENT AIR MONITORING $\ldots \ldots \ldots \ldots \ldots \ldots \ldots \ldots \ldots \ldots$

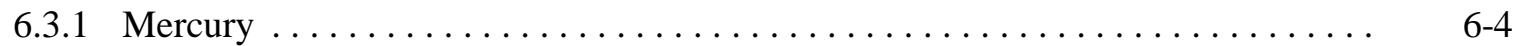

6.4 LIQUID DISCHARGES-Y-12 COMPLEX RADIOLOGICAL

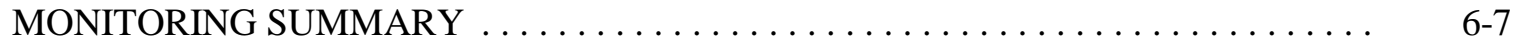

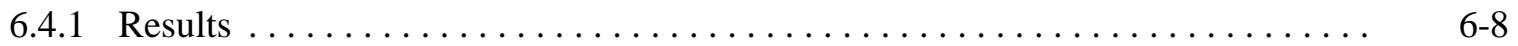

6.5 NONRADIOLOGICAL LIQUID DISCHARGES-Y-12 COMPLEX

SURFACE WATER AND LIQUID EFFLUENTS $\ldots \ldots \ldots \ldots \ldots \ldots \ldots \ldots \ldots \ldots . \ldots \ldots$

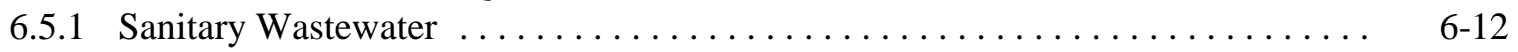

6.5 .2 Storm Water . . . . . . . . .

6.5.3 Results and Progress in Implementing Corrective Actions . . . . . . . . . 6 6

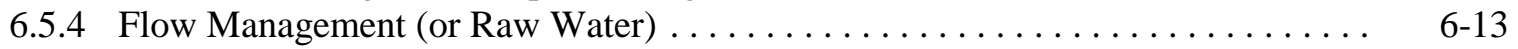

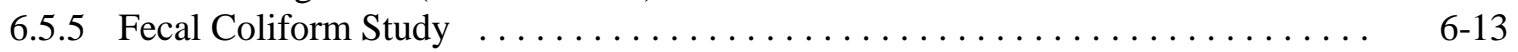

6.5.6 Mercury Removal from Storm Drain Catch Basins $\ldots \ldots \ldots \ldots \ldots \ldots \ldots \ldots$ 6 . $\ldots \ldots$

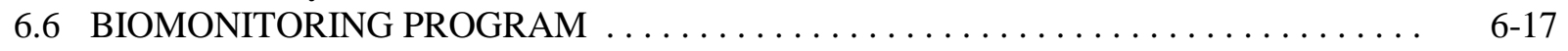

6.7 BIOLOGICAL MONITORING AND ABATEMENT PROGRAMS $\ldots \ldots \ldots \ldots \ldots \ldots .6-6$

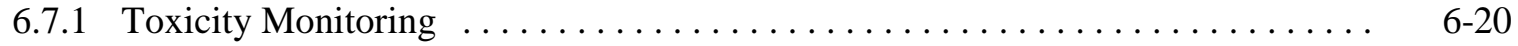

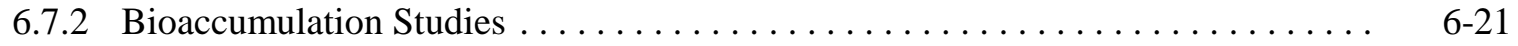

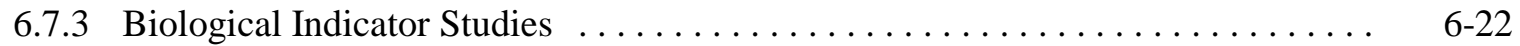

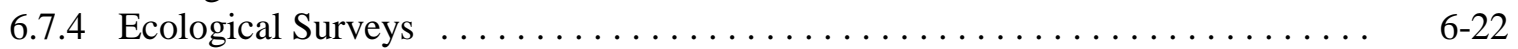

6.8 Y-12 COMPLEX AMBIENT SURFACE WATER MONITORING $\ldots \ldots \ldots \ldots \ldots .6$ 6-23

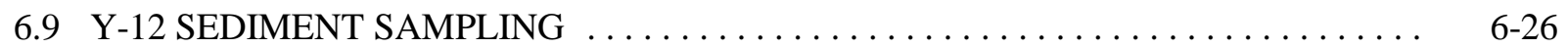

6.10 GROUNDWATER MONITORING AT THE Y-12 COMPLEX $\ldots \ldots \ldots \ldots \ldots \ldots .6-27$

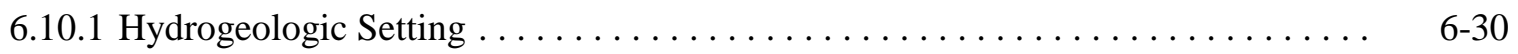

6.10.2 Well Installation and Plugging and Abandonment Activities ............ 6-31

6.10 .3 CY 2003 Monitoring Program ......................... 6-32

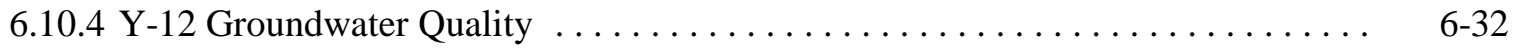

6.11 MODERNIZATION ACTIVITIES AT THE Y-12 NATIONAL
SECURITY COMPLEX $\ldots \ldots \ldots \ldots \ldots \ldots \ldots \ldots \ldots \ldots \ldots \ldots \ldots \ldots \ldots \ldots \ldots \ldots \ldots \ldots$

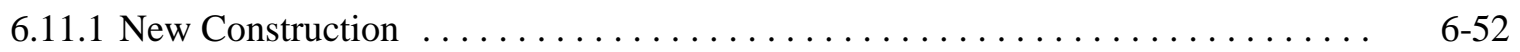

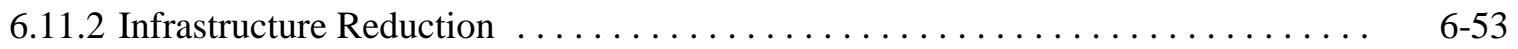

7. ORR ENVIRONMENTAL MONITORING PROGRAMS $\ldots \ldots \ldots \ldots \ldots \ldots \ldots \ldots \ldots .7 .1$

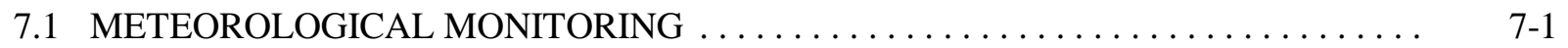

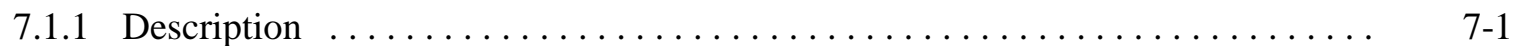

7.1.2 Meteorological Impacts on Modeling Results . . . . . . . . . . . . . . .

7.2 EXTERNAL GAMMA RADIATION MONITORING $\ldots \ldots \ldots \ldots \ldots \ldots \ldots \ldots \ldots$.

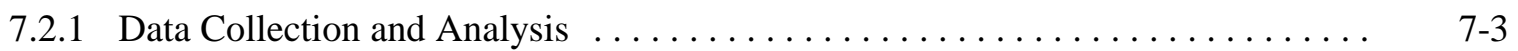

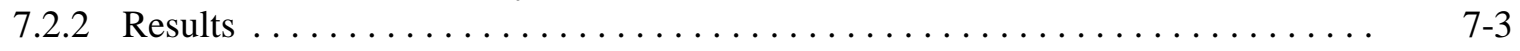

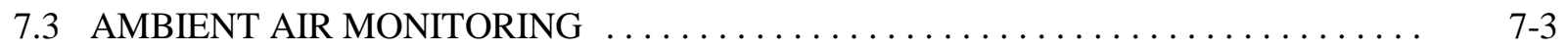




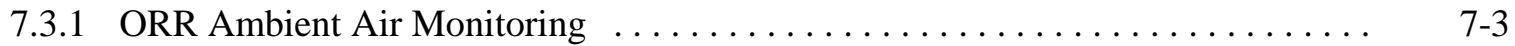

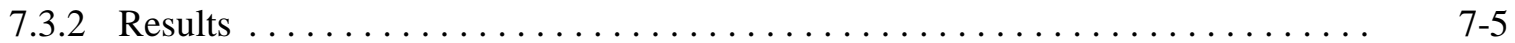

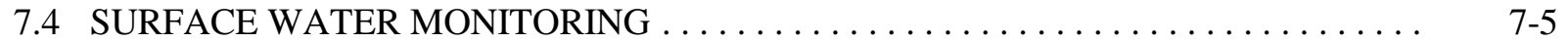

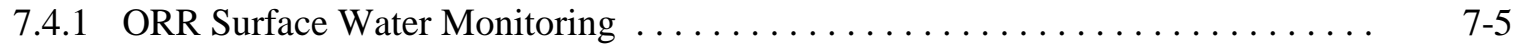

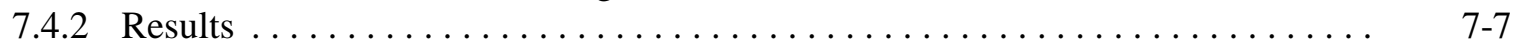

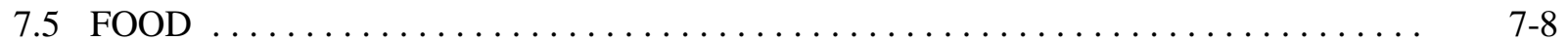

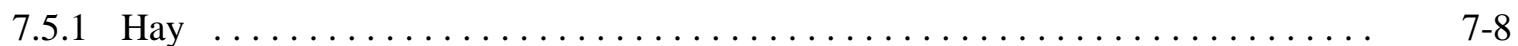

7.5.2 Vegetables .................................... $7-10$

7.5 .3 Milk ..................................... $7-10$

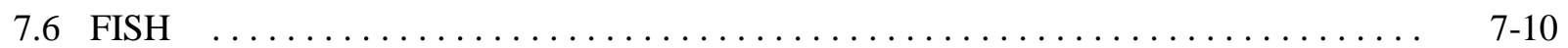

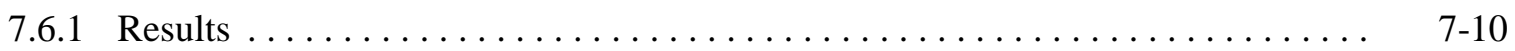

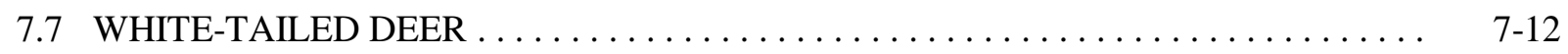

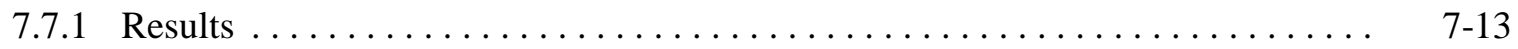

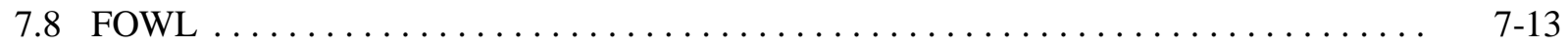

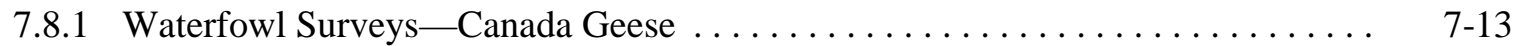

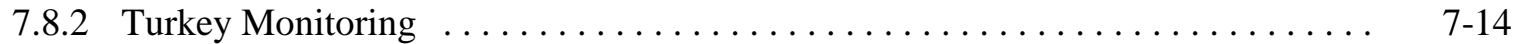

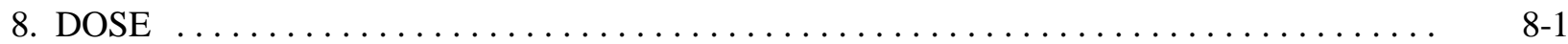

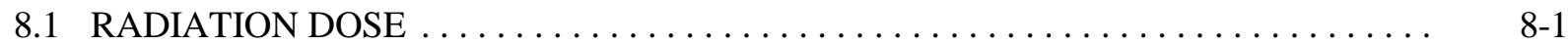

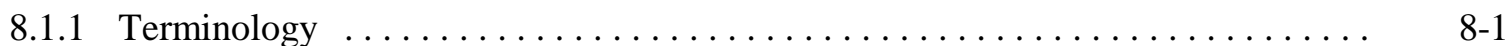

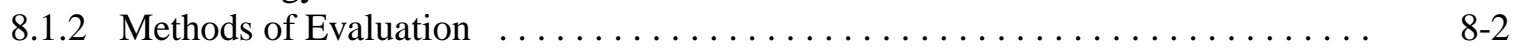

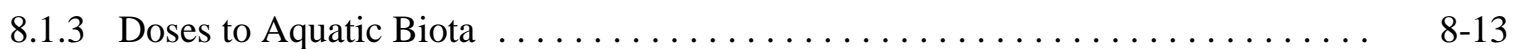

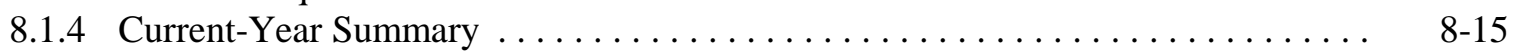

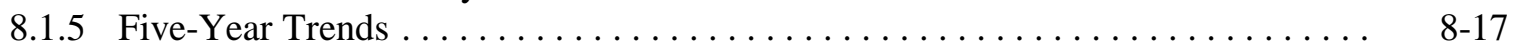

8.1.6 Potential Contributions from Non-DOE Sources $\ldots \ldots \ldots \ldots \ldots \ldots \ldots \ldots . \quad 8-17$

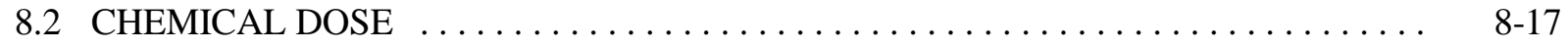

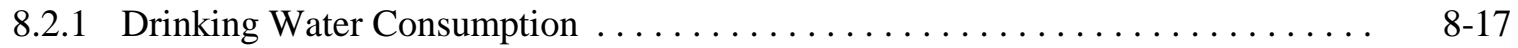

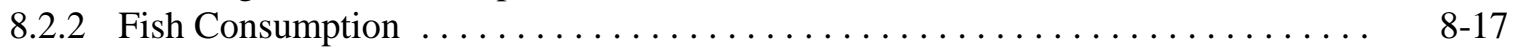

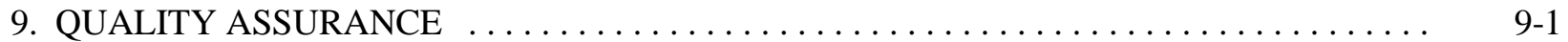

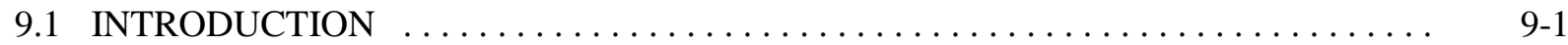

9.2 FIELD SAMPLING QUALITY ASSURANCE $\ldots \ldots \ldots \ldots \ldots \ldots \ldots \ldots \ldots \ldots \ldots . \ldots \ldots$

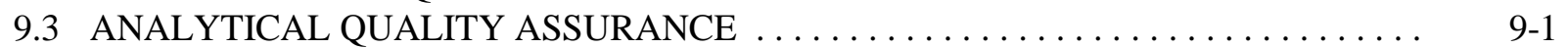

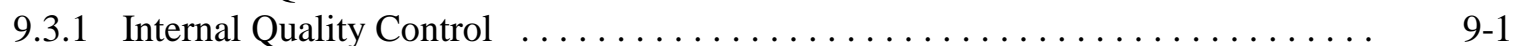

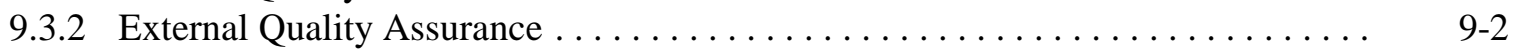

9.3.3 Quality Assessment Program for Subcontracted Laboratories . . . . . . . . . . . . . 9-3

9.4 DATA MANAGEMENT, VERIFICATION, AND VALIDATION $\ldots \ldots \ldots \ldots \ldots \ldots . \quad 9-4$

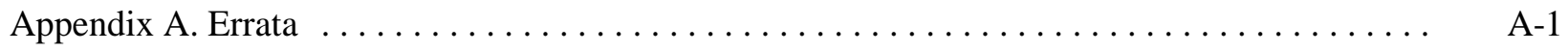

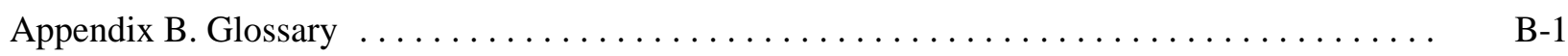

Appendix C. Reference Standards and Data for Water $\ldots \ldots \ldots \ldots \ldots \ldots \ldots \ldots \ldots \ldots \ldots \ldots \ldots$

Appendix D. NPDES Noncompliances $\ldots \ldots \ldots \ldots \ldots \ldots \ldots \ldots \ldots \ldots \ldots \ldots \ldots \ldots \ldots \ldots \ldots \ldots \ldots \ldots$

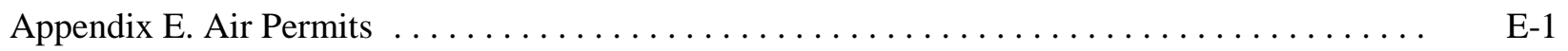

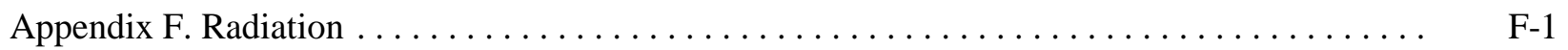

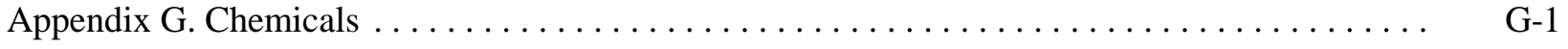

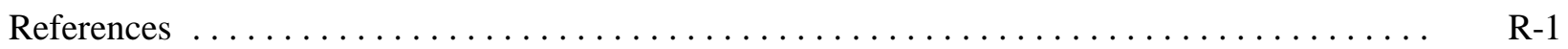





\section{List of Figures}

Figure

Page

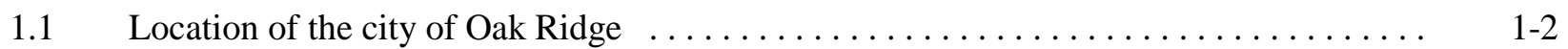

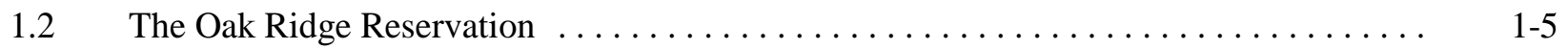

1.3 The ten-county region surrounding the Oak Ridge Reservation $\ldots \ldots \ldots \ldots \ldots \ldots \ldots$

1.4 Locations and populations of towns nearest to the Oak Ridge Reservation . . . . . . . $1-5$

1.5 Vertical relationships of flow zones of the ORR: estimated thicknesses,

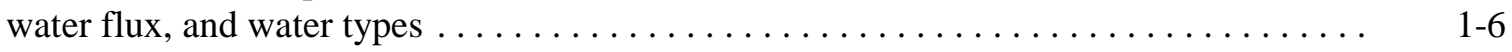

1.6 The Knox Aquifer and the ORR Aquitards on the Oak Ridge Reservation . . . . . . . . 1-7

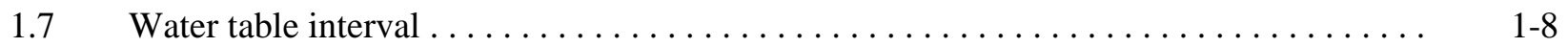

1.8 The Y-12 National Security Complex $\ldots \ldots \ldots \ldots \ldots \ldots \ldots \ldots \ldots \ldots \ldots \ldots \ldots \ldots \ldots$

1.9 The East Tennessee Technology Park $\ldots \ldots \ldots \ldots \ldots \ldots \ldots \ldots \ldots \ldots \ldots \ldots \ldots \ldots \quad 1-14$

1.10 The Oak Ridge National Laboratory $\ldots \ldots \ldots \ldots \ldots \ldots \ldots \ldots \ldots \ldots \ldots \ldots \ldots \ldots \ldots \ldots \ldots \ldots$

1.11 The Oak Ridge National Environmental Research Park covers approximately

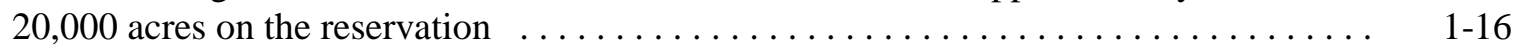

$2.1 \quad$ Five-year summary of NPDES noncompliances $\ldots \ldots \ldots \ldots \ldots \ldots \ldots \ldots \ldots \ldots \ldots$

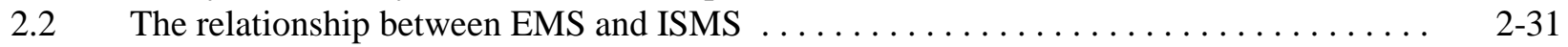

4.1 Locations of airborne radionuclide point sources at the ETTP $\ldots \ldots \ldots \ldots \ldots \ldots .4-2$

4.2 Total curies of uranium discharged from the ETTP to the atmosphere, 1999-2003

4.3 Total kilograms of uranium discharged from the ETTP to the atmosphere, 1999-2003

4.4 ETTP National Pollutant Discharge Elimination System major outfalls and

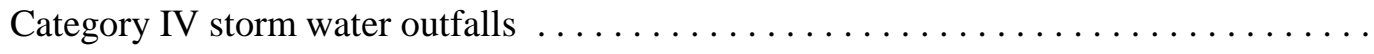

4.5 Five-year trend of uranium releases to surface waters from the ETTP

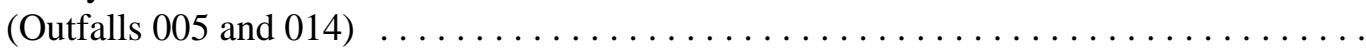

4.6 Percentage of DOE derived concentration guides for uranium isotopes from K-1407-J (Outfall 014) . . . . . . . . . . . . . . . . . . . . . .

4.7 ETTP National Pollution Discharge Elimination System compliance history 


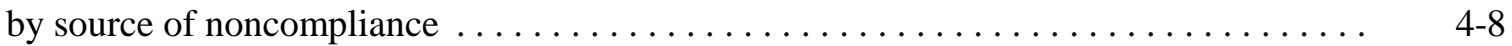

4.8 Total taxonomic richness of pollution-sensitive taxa $\ldots \ldots \ldots \ldots \ldots \ldots \ldots \ldots \ldots .4-17$

4.9 Density of pollution-sensitive and pollution-tolerant species in Mitchell Branch . . . . . 4-17

4.10 Temporal trend in fish density in Mitchell Branch . . . . . . . . . . . . . . . . . . . . 4-18

4.11 Locations of ambient air monitoring stations at the ETTP . . . . . . . . . . . $4-19$

4.12 Ambient air monitoring 5-year trend results for lead at the ETTP $\ldots \ldots \ldots \ldots \ldots \ldots$ 4-21

4.13 Ambient air monitoring 5-year trend results for uranium at the ETTP $\ldots \ldots \ldots \ldots \ldots$ 4-23

4.14 Ambient air monitoring at ETTP Station K2 by ICP/MS vs TSCA Incinerator

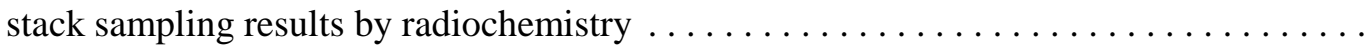

4.15 Monitoring locations for surface water at the ETTP $\ldots \ldots \ldots \ldots \ldots \ldots \ldots \ldots$

4.16 Percentage of DOE derived concentration guides for ETTP surface

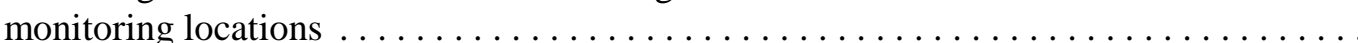

$5.1 \quad$ Locations of major stacks (rad emission points) at ORNL $\ldots \ldots \ldots \ldots \ldots \ldots \ldots \ldots .2$

5.2 Total discharges of ${ }^{3} \mathrm{H}$ from ORNL to the atmosphere, $1999-2003 \ldots \ldots \ldots \ldots \ldots \ldots$

5.3 Total discharges of ${ }^{131}$ I from ORNL to the atmosphere, $1999-2003 \ldots \ldots \ldots \ldots \ldots$. . . .

5.4 Total discharges of ${ }^{41} \mathrm{Ar}$ and ${ }^{138} \mathrm{Cs}$ from ORNL to the atmosphere, 1999-2003 $\ldots \ldots \ldots$

$5.5 \quad$ Locations of ambient air monitoring stations at ORNL $\ldots \ldots \ldots \ldots \ldots \ldots \ldots \ldots$

5.6 ORNL surface water, National Pollutant Discharge Elimination System, and

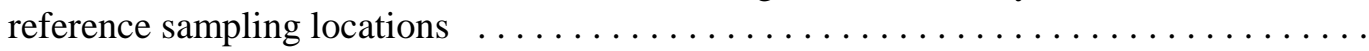

5.7 Radionuclides at ORNL sampling sites having average concentrations greater than $4 \%$ of the relevant derived concentration guides in $2003 \ldots \ldots \ldots \ldots \ldots \ldots$

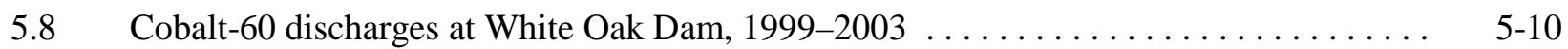

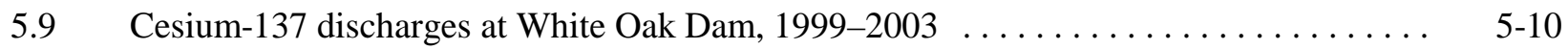

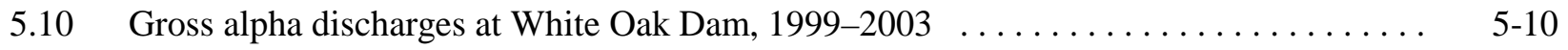

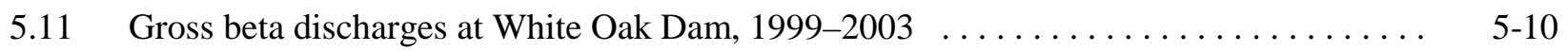

5.12 Total radioactive strontium discharges at White Oak Dam, 1999-2003 . . . . . . . 5-10

5.13 Tritium discharges at White Oak Dam, $1999-2003 \ldots \ldots \ldots \ldots \ldots \ldots \ldots \ldots \ldots$

5.14 ORNL National Pollutant Discharge Elimination System permit limit 
noncompliances in 2003

5.15 Total mercury in water vs time, from November 2002 to September 2003,

at three sites in the White Oak Creek watershed downstream from ORNL

5.16 Total mercury vs time, 1998-2003, at three sites in the White Oak Creek watershed downstream from ORNL .............................

5.17 Temporal trends in mercury concentrations in fish, $1998-2003 \ldots \ldots \ldots \ldots \ldots \ldots$

5.18 Temporal trends in PCB concentrations in fish, $1998-2003 \ldots \ldots \ldots \ldots \ldots \ldots \ldots$

5.19 Taxonomic richness and richness of the pollution-intolerant taxa of the benthic macroinvertebrate communities in White Oak Creek during

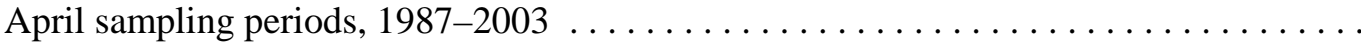

5.20 Taxonomic richness and richness of the pollution-intolerant taxa in the benthic macroinvertebrate communities in First Creek during April sampling

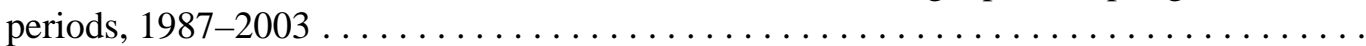

5.21 Taxonomic richness and richness of the pollution-intolerant taxa in the benthic macroinvertebrate communities in Fifth Creek during April sampling periods, $1987-2003$

5.22 ORNL surface water sampling locations

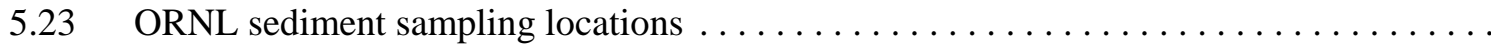

5.24 Locations of ORNL waste area groupings (WAGs) $\ldots \ldots \ldots \ldots \ldots \ldots \ldots \ldots \ldots \ldots$

5.25 Groundwater exit pathways on the Oak Ridge Reservation that are likely to be affected by Oak Ridge operations . . . . . . . . . . . . . . . . . . . .

6.1 Total curies of uranium discharged from the Y-12 Complex to the

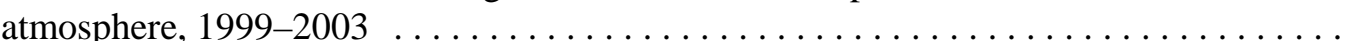

6.2 Total kilograms of uranium discharged from the Y-12 Complex to the

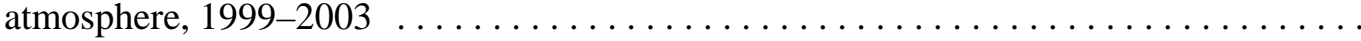

6.3 Locations of ambient air monitoring stations at the Y-12 Complex $\ldots \ldots \ldots \ldots \ldots$

6.4 Temporal trends in mercury vapor concentration for the four active airborne mercury monitoring sites at the Oak Ridge Y-12 Complex,

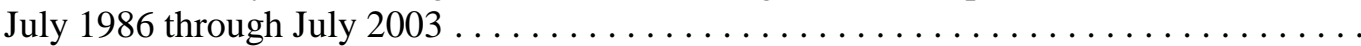

6.5 Surface water and sanitary sewer radiological sampling locations

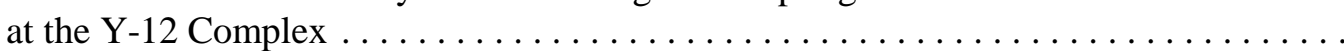

6.6 Five-year trend of Y-12 Complex release of uranium to surface water $\ldots \ldots \ldots \ldots$

$6.7 \quad$ Major Y-12 Complex NPDES outfalls $\ldots \ldots \ldots \ldots \ldots \ldots \ldots \ldots \ldots \ldots \ldots \ldots \ldots \ldots \ldots$ 
6.8 Location of biological monitoring sites on East Fork Poplar Creek in relation to the Oak Ridge Y-12 National Security Complex $\ldots \ldots \ldots \ldots \ldots \ldots \ldots \ldots \ldots$

6.9 Location of biological monitoring reference sites in relation to the Oak Ridge Y-12 National Security Complex . . . . . . . . . . . . . . . . . . . . . .

6.10 Semiannual average mercury concentration in muscle fillets of redbreast sunfish and water in East Fork Poplar Creek at Station 17 through spring 2003 . . . . . . . . .

6.11 Mean concentrations of PCBs in redbreast sunfish muscle fillets in East Fork

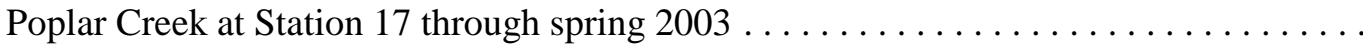

6.12 Trends in three indicators of fish health measured over the last fifteen years in redbreast sunfish from EFK 23

6.13 Comparison of mean abundance of sensitive fish species collected during each year from 1985 through 2003 from four sites in East Fork Poplar Creek and a

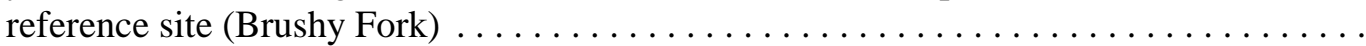

6.14 Total taxonomic richness (mean number of taxa/sample) and total taxonomic richness of the Ephemeroptera, Plecoptera, and Trichoptera (EPT) (mean number of EPT taxa/sample) of the benthic macroinvertebrate communities in East Fork Poplar Creek and two reference sites, one on Brushy Fork and one on Hinds Creek (BFK 7.6 and HCK 20.6),

6.15 Growth and survival of fingernail clams in in situ bioassays in East Fork Poplar Creek, 1998-2003

6.16 Locations of Y-12 Complex surface water surveillance sampling stations $\ldots \ldots \ldots \ldots$ 6-28

6.17 Surface Water Hydrological Information Support System monitoring locations . . . . . 6 6-28

6.18 Known or potential contaminant sources for which groundwater monitoring

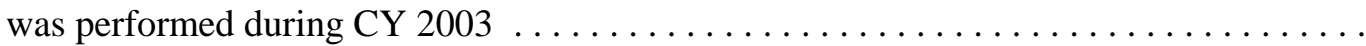

6.19 Hydrogeologic regimes at the $\mathrm{Y}-12$ Complex $\ldots \ldots \ldots \ldots \ldots \ldots \ldots \ldots \ldots \ldots \ldots$

6.20 Locations of ORR perimeter/exit pathway well, spring, and surface water monitoring stations in the Environmental Monitoring Plan for the Oak

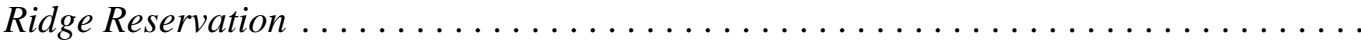

6.21 Nitrate $($ as $\mathrm{N})$ observed in groundwater at the $\mathrm{Y}-12$ Complex $\ldots \ldots \ldots \ldots \ldots \ldots \ldots$

6.22 Nitrate concentrations in well GW-606, at the eastern end of the Y-12 Complex .... 6-35

6.23 Summed volatile organic compounds in groundwater at the Y-12 Complex ...... 6-36

6.24 Summed volatile organic compound concentrations in groundwater in selected wells near source areas in the Upper East Fork Poplar Creek Hydrogeologic Regime . . . . . . . . 
6.25 Summed volatile organic compound concentrations in selected wells near

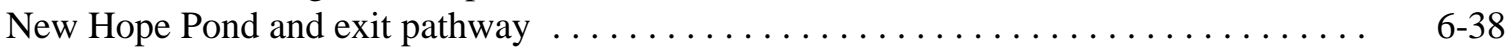

6.26 Gross alpha activity in groundwater at the Y-12 Complex $\ldots \ldots \ldots \ldots \ldots \ldots \ldots \ldots$

6.27 Gross beta activity in groundwater at the Y-12 Complex . . . . . . . . . . 6-39

6.28 Maximum carbon tetrachloride concentrations in Maynardville Limestone

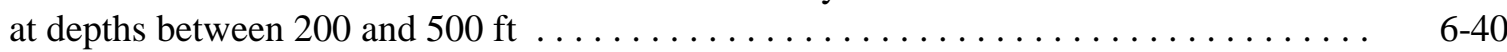

6.29 Surface water sampling locations north of Pine Ridge, $2003 \ldots \ldots \ldots \ldots \ldots \ldots \ldots$. 6 -41

6.30 Volatile organic compound concentrations in Bear Creek Burial Grounds

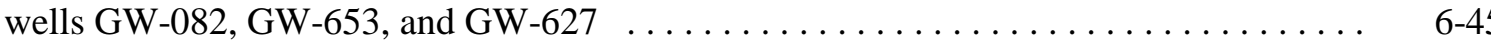

6.31 Concentrations of selected contaminants in exit pathway monitoring wells GW-683, GW-706, and GW-724 in the Bear Creek Hydrogeologic Regime $\ldots \ldots \ldots \ldots \ldots \ldots$ 6-47

6.32 Concentrations of selected groundwater contaminants in Bear Creek . . . . . . . . . . 6-48

6.33 Summed volatile organic compound concentrations in wells GW-177 and GW-798 _. . 6-51

6.24 Volatile organic compound concentrations in Industrial Landfill IV Well GW-305 . . . 6-52

7.1 The ORR meteorological monitoring network $\ldots \ldots \ldots \ldots \ldots \ldots \ldots \ldots \ldots \ldots \ldots \ldots$

7.2 External gamma radiation monitoring locations on the ORR $\ldots \ldots \ldots \ldots \ldots \ldots \ldots$

7.3 Locations of ORR perimeter air monitoring stations $\ldots \ldots \ldots \ldots \ldots \ldots \ldots \ldots \ldots$

7.4 Locations of ORR surface water surveillance sampling stations $\ldots \ldots \ldots \ldots \ldots \ldots \ldots$

7.5 Hay sampling locations on the ORR, indicated by numbered areas $\ldots \ldots \ldots \ldots \ldots$

7.6 Milk sampling locations in the vicinity of the ORR $\ldots \ldots \ldots \ldots \ldots \ldots \ldots \ldots \ldots$

7.7 Fish sampling locations for the ORR $\ldots \ldots \ldots \ldots \ldots \ldots \ldots \ldots \ldots \ldots \ldots \ldots \ldots \ldots \ldots \ldots \ldots \ldots \ldots$

F.1 The hydrogen atom and its isotopes $\ldots \ldots \ldots \ldots \ldots \ldots \ldots \ldots \ldots \ldots \ldots \ldots \ldots \ldots \ldots$

F.2 Examples of radiation pathways $\ldots \ldots \ldots \ldots \ldots \ldots \ldots \ldots \ldots \ldots \ldots \ldots \ldots \ldots \ldots \ldots \ldots$ 



\section{List of Tables}

Table

Page

$1.1 \quad$ Hourly mixing height statistics for the Oak Ridge Reservation during $2003 \ldots \ldots \ldots \ldots$ 1-4

$2.1 \quad$ Resource Conservation and Recovery Act operating permits, $2003 \ldots \ldots \ldots \ldots \ldots$

2.2 Summary of 2003 annual update of ORR solid waste management units (SWMUs) ... 2-5

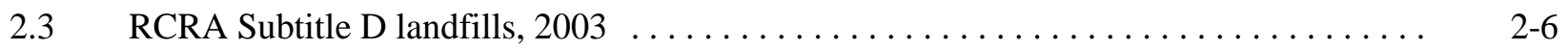

$2.4 \quad$ ORR underground storage tank (UST) status, $2003 \ldots \ldots \ldots \ldots \ldots \ldots \ldots \ldots \ldots$

2.5 RCRA corrective action processes and CERCLA response actions $\ldots \ldots \ldots \ldots \ldots$

2.6 RCRA postclosure status for former treatment, storage, and disposal units at Y-12 . . . 2-9

2.7 National Environmental Policy Act (NEPA) activities during $2003 \ldots \ldots \ldots \ldots \ldots$

2.8 Animal species of concern reported from the Oak Ridge Reservation (ORR) . . . . . . 2-15

2.9 Currently known or previously reported vascular plant species from the Oak

Ridge Reservation (ORR) that are listed by state or federal agencies, $2003 \ldots \ldots \ldots \ldots$. 2-16

2.10 Additional rare plants that occur near and could be present on the

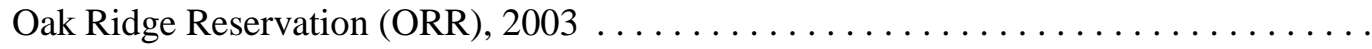

2.11 Descriptions of the main parts of the Emergency Planning and Community

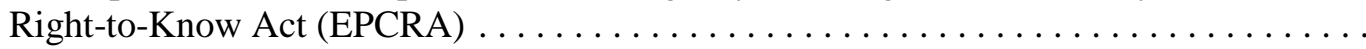

2.12 Emergency Planning and Community Right-to-Know Act Section 313 toxic chemical release and off-site transfer summary for the Oak Ridge

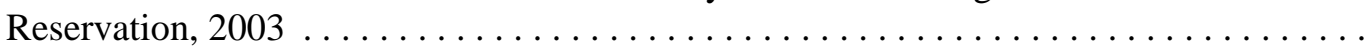

2.132003 ORR pollution prevention project implementation results summary $\ldots \ldots \ldots \ldots \quad 2-34$

2.142003 ORR affirmative procurement and waste reduction progress summary $\ldots \ldots \ldots \quad 2-35$

2.15 Summary of environmental audits and assessments conducted at the

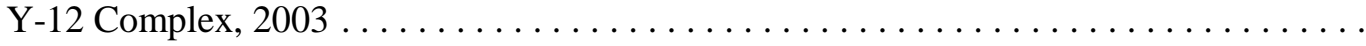

2.16 Summary of environmental audits and assessments conducted at

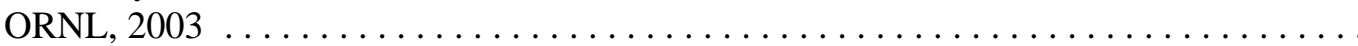

2.17 Summary of environmental audits and assessments conducted at the

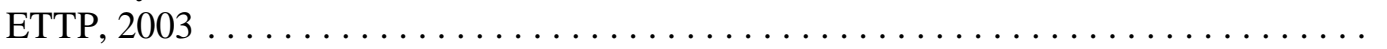

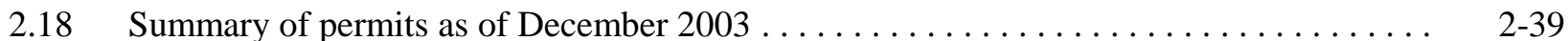


4.1 East Tennessee Technology Park radionuclide air emission totals,

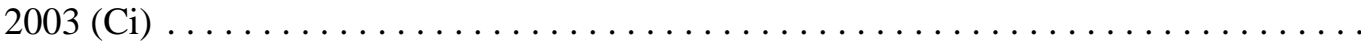

4.2 Allowable emissions of criteria pollutants from the East Tennessee

Technology Park, 1999-2003 . . . . . . . . . . . . . . . . . . . . . . . . . .

4.3 Actual emissions of criteria pollutants from permitted East Tennessee

Technology Park sources, 2003 . . . . . . . . . . . . . . . . . . . . . . . . . . . .

4.4 Actual vs allowable air emissions from the Toxic Substances Control Act

Incinerator at the East Tennessee Technology Park, 2003 .

4.5 Radionuclides released to off-site surface waters from the East Tennessee

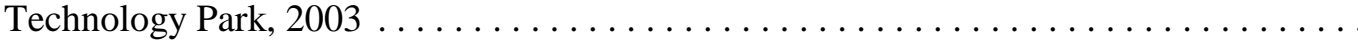

4.6 National Pollutant Discharge Elimination System compliance at the

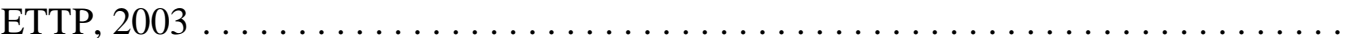

4.7 Maximum exceedances of radiological screening criteria for each

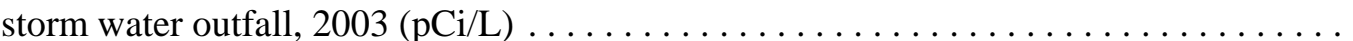

4.8 Radionuclides released to off-site surface waters from the East Tennessee

Technology Park storm water system, 2003

4.9 Maximum exceedances of radiological screening criteria for storm water

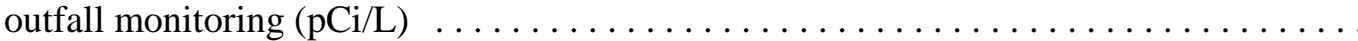

4.10 PCBs detected in sediment at storm water outfalls $\ldots \ldots \ldots \ldots \ldots \ldots \ldots \ldots \ldots .4 . \ldots \ldots$

4.11 East Tennessee Technology Park National Pollutant Discharge Elimination System Permit Number TN 0002950 toxicity tests results, 2003 . . . . . . . . . . . . .

4.12 East Tennessee Technology Park average water quality parameters measured during tests of K-1203 Outfall 005 effluent, 2003

4.13 Mitchell Branch and associated storm water outfall toxicity test results, $2003 \ldots \ldots$. . . 4-13

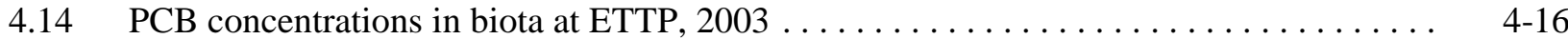

4.15 Summary of types and frequencies of samples collected at East Tennessee Technology Park perimeter ambient air monitoring stations, $2003 \ldots \ldots \ldots \ldots \ldots$

4.16 Lead concentrations in ambient air at the East Tennessee Technology

Park, 2003 . . . . . . . . . . . . . . . . . . . . . . . . . . . . . . . .

4.17 Hazardous air pollutant concentrations in ambient air at the East Tennessee Technology Park, 2003 . . . . . . . . . . . . . . . . . . . . . . . . . . . . . . .

4.18 Total uranium in ambient air by inductively coupled plasma mass spectrometry analysis at the Est Tennessee Technology Park, 2003 
4.19 Radionuclides in ambient air by radiochemistry at the East Tennessee

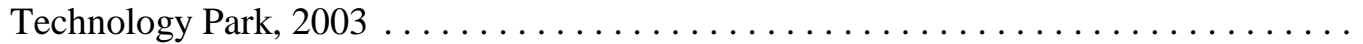

5.1 Major sources of radiological airborne emissions at Oak Ridge National

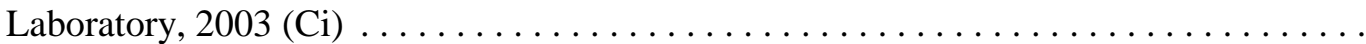

5.2 Actual vs allowable air emissions from Oak Ridge National Laboratory

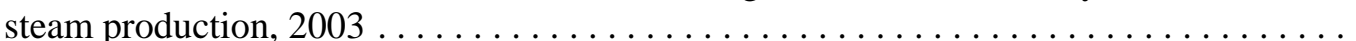

5.3 Radionuclide concentrations measured at Oak Ridge National Laboratory

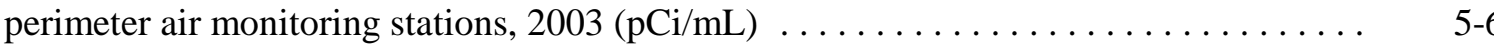

$5.4 \quad$ Oak Ridge National Laboratory NPDES Radiological Monitoring Plan $\ldots \ldots \ldots \ldots \ldots \quad 5-8$

5.5 National Pollutant Discharge Elimination System (NPDES) compliance at

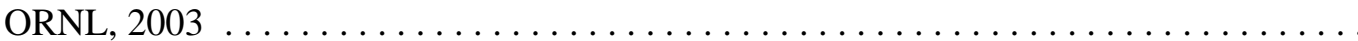

5.6 Toxicity test results of Oak Ridge National Laboratory wastewaters, $2003 \ldots \ldots \ldots$. $\ldots$.

5.7 Total mercury and PCB (Aroclor $1254+1260$ ) concentrations in fish (mean \pm SE; range in parenthesis) from White Oak Creek and reference stream, Hinds Creek, April 2003

5.8 ORNL surface water sampling locations, frequencies, and parameters, 2003

5.9 Summary of the groundwater surveillance program at Oak Ridge National

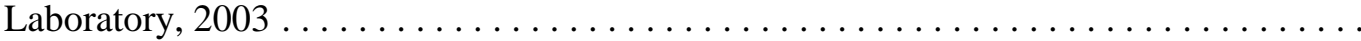

5.10 Summary of the plant perimeter surveillance program at Oak Ridge National Laboratory, 2003 . . . . . . . . . . . . . . . . . . . . . . . . . . . . . . . . .

6.1 Actual vs allowable air emissions from the Oak Ridge Y-12 Complex, $2002 \ldots \ldots \ldots$

6.2 2003 summary results for the Y-12 Complex mercury in ambient air

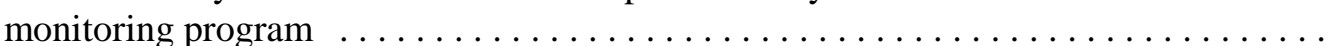

6.3 Radiological parameters monitored at the $\mathrm{Y}-12$ Complex in $2003 \ldots \ldots \ldots \ldots \ldots$

6.4 Summary of Y-12 Complex radiological monitoring plan sample requirements . . . . . 6-9

6.5 Release of uranium from the Y-12 Complex to the off-site environment as a liquid effluent, 1999-2003

6.6 Summary of storm water data above screening levels at the Y-12 Complex $\ldots \ldots \ldots \ldots$

6.7 NPDES compliance monitoring requirements and record for the $\mathrm{Y}-12$ Complex $\ldots \ldots \ldots$ 6-14

$6.8 \quad$ Y-12 Complex Discharge Point SS6, Sanitary Sewer Station $6 \ldots \ldots \ldots \ldots \ldots \ldots \ldots$

6.9 Y-12 Complex Biomonitoring Program summary information for wastewater treatment systems and storm sewer (cooling tower) effluents for 2003 
6.10 Y-12 Complex Biomonitoring Program summary information for Outfall 201

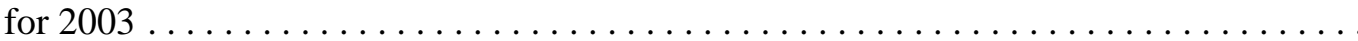

6.11 Results of medaka development toxicity tests conducted on water from ambient sites in East Fork Poplar Creek . . . . . . . . . . . . . . . . . . . . .

6.12 Biomass of periphyton sampled from sites on East Fork Poplar Creek

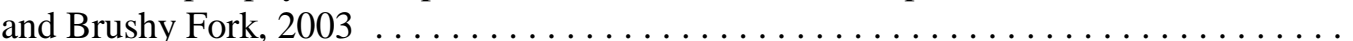

6.13 Surface water surveillance measurements exceeding Tennessee water quality

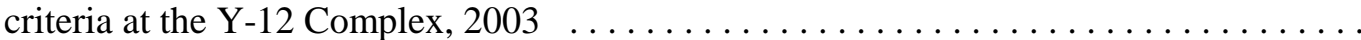

6.14 Results of Y-12 Complex sediment monitoring $\ldots \ldots \ldots \ldots \ldots \ldots \ldots \ldots \ldots$

6.15 Types and numbers of groundwater monitoring stations sampled at the

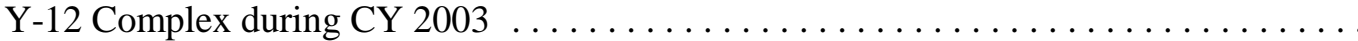

6.16 History of waste management units and underground storage tanks included in CY 2003 groundwater monitoring activities; Upper East Fork Poplar Creek Hydrogeologic Regime . . . . . . . . . . . . . . . . . . . . . . . . . . . . .

6.17 History of waste management units included in CY 2003 groundwater monitoring activities, Bear Creek Hydrogeologic Regime .

6.18 History of waste management units included in CY 2003 groundwater monitoring activities; Chestnut Ridge Hydrogeologic Regime

7.1 External gamma averages for the Oak Ridge Reservation, $2003 \ldots \ldots \ldots \ldots \ldots \ldots$. $\ldots$.

7.2 Average radionuclide concentrations at Oak Ridge Reservation perimeter air

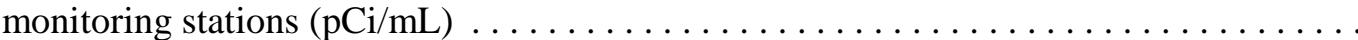

7.3 Uranium concentrations in ambient air on the Oak Ridge Reservation . . . . . . . . . .

7.4 Oak Ridge Reservation surface water sampling locations, frequencies, and parameters, 2003

7.5 Concentration of radionuclides detected in hay, $2003(\mathrm{pCi} / \mathrm{kg})$

7.6 Concentrations of radionuclides detected in vegetables, $2003(\mathrm{pCi} / \mathrm{kg}) \ldots \ldots \ldots \ldots$

7.7 Concentration of radionuclides detected in raw milk, $2003 \ldots \ldots \ldots \ldots \ldots \ldots \ldots \ldots$

8.1 Emission-point parameters and receptor locations used in dose calculations $\ldots \ldots \ldots$ 8-3

8.2 Summary of ORR meteorological towers, sampling heights, and sources $\ldots \ldots \ldots \ldots$

8.3 Calculated radiation doses to maximally exposed off-site individuals

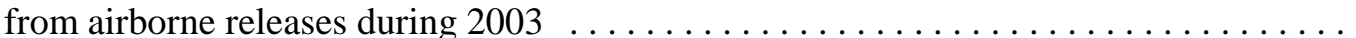

8.4 Calculated collective EDEs from airborne releases during $2003 \ldots \ldots \ldots \ldots \ldots \ldots \ldots$ 
8.5 Hypothetical effective dose equivalents from living at ORR and ETTP

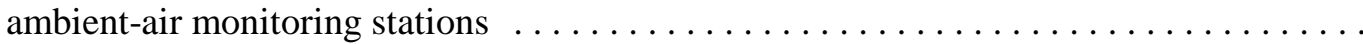

8.6 Summary of annual maximum individual EDEs from waterborne

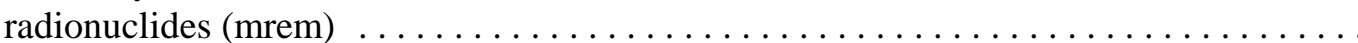

8.7 Summary of maximum potential radiation dose equivalents to an adult during

8.8 Trends in total effective dose equivalent (mrem) for selected pathways $\ldots \ldots \ldots \ldots \ldots \quad 8-18$

8.92003 chemical hazard quotients and estimated risks for drinking water $\ldots \ldots \ldots \ldots$ 8-18

8.10 2003 chemical hazard quotients (HQs) and estimated risks for carcinogens in fish $\ldots . . \quad 8-19$

C.1 Reference standards for radionuclides in water $(\mathrm{pCi} / \mathrm{L}) \ldots \ldots \ldots \ldots \ldots \ldots \ldots \ldots$ C-3

C-2 Reference standards for chemicals and metals in water $\ldots \ldots \ldots \ldots \ldots \ldots \ldots \ldots$

C.3 Surface water analyses (2002) at Environmental Monitoring Plan

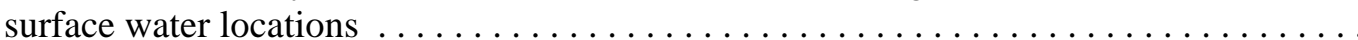

D.1 Summary of Y-12 Complex National Pollutant Discharge Elimination System (NPDES) excursions, 2002

D.2 Summary of East Tennessee Technology Park (ETTP) National Pollutant

Discharge Elimination System (NPDES) excursions, $2002 \ldots \ldots \ldots \ldots \ldots \ldots \ldots$

D.3 Summary of Oak Ridge National Laboratory National Pollutant Discharge

Elimination System (NPDES) excursions, 2002 . . . . . . . . . . . . . . . . .

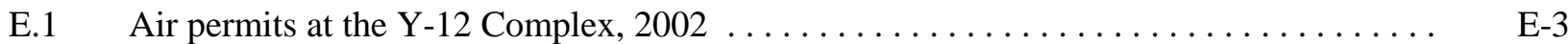

E.2 Oak Ridge National Laboratory air permits, $2002 \ldots \ldots \ldots \ldots \ldots \ldots \ldots \ldots \ldots \ldots \ldots$

E.3 East Tennessee Technology Park air permits, $2002 \ldots \ldots \ldots \ldots \ldots \ldots \ldots \ldots \ldots$

E.4 Periods of excess emissions and out-of-service conditions for Y-12 Steam Plant east and west opacity monitors in $2002 \ldots \ldots \ldots \ldots \ldots \ldots \ldots \ldots \ldots \ldots \ldots \ldots \ldots \ldots \ldots \ldots \ldots$

F.1 Radionuclide nomenclature $\ldots \ldots \ldots \ldots \ldots \ldots \ldots \ldots \ldots \ldots \ldots \ldots \ldots \ldots \ldots \ldots \ldots \ldots$

F.2 Comparison and description of various dose levels $\ldots \ldots \ldots \ldots \ldots \ldots \ldots \ldots \ldots \ldots$ F-9

G.1 Chemical reference doses and slope factors used in drinking water and

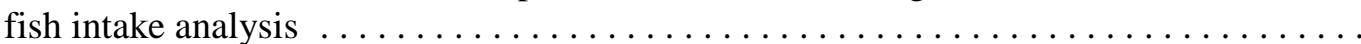





\section{Acronyms and Abbreviations}

\begin{tabular}{|c|c|}
\hline AIHA & American Industrial Hygiene Association \\
\hline ALARA & as low as reasonably achievable \\
\hline ANSI & American National Standards Institute, Inc. \\
\hline ASER & annual site environmental report \\
\hline ATDD & Atmospheric Turbulence and Diffusion Division \\
\hline $\mathrm{BCK}$ & Bear Creek kilometer \\
\hline BERA & Baseline Ecological Risk Assessment \\
\hline BJC & Bechtel Jacobs Company LLC \\
\hline BMAP & Biological Monitoring and Abatement Program \\
\hline CAA & Clean Air Act \\
\hline CERCLA & Comprehensive Environmental Response, Compensation, and Liability Act \\
\hline CFR & Code of Federal Regulations \\
\hline CRK & Clinch River kilometer \\
\hline CROET & Community Reuse Organization of East Tennessee \\
\hline CWA & Clean Water Act \\
\hline $\mathrm{CY}$ & calendar year \\
\hline DCG & derived concentration guide \\
\hline DNAPL & dense nonaqueous phase liquid \\
\hline DOE & U.S. Department of Energy \\
\hline DOE-EM & DOE Office of Environmental Management \\
\hline DOE-HQ & DOE Headquarters \\
\hline DOE-ORO & DOE Oak Ridge Operations Office \\
\hline EA & environmental assessemnt \\
\hline $\mathrm{EC}$ & Environmental Compliance \\
\hline EDE & effective dose equivalent \\
\hline EEMTS & East End Mercury Treatment System \\
\hline EFK & East Fork Poplar Creek kilometer \\
\hline EIS & environmental impact statement \\
\hline EM & (DOE Office of ) Environmental Management \\
\hline EMC & event mean concentration \\
\hline EMS & environmental management system \\
\hline EMWMF & Environmental Management Waste Management Facility \\
\hline EPA & U.S. Environmental Protection Agency \\
\hline EPCRA & Emergency Planning and Community Right-to-Know Act \\
\hline EPT & Ephemeroptera, Plectoptera, and Trichoptera (taxa) \\
\hline ETTP & East Tennessee Technology Park \\
\hline FCK & First Creek kilometer \\
\hline FFK & Fifth Creek kilometer \\
\hline FIFRA & Federal Insecticide, Fungicide, and Rodenticide Act \\
\hline FY & fiscal year \\
\hline GAAT & Gunite and Associated Tanks \\
\hline
\end{tabular}




\begin{tabular}{|c|c|}
\hline HFIR & High Flux Isotope Reactor \\
\hline HQ & hazard quotient \\
\hline HSWA & Hazardous and Solid Waste Amendments \\
\hline $\mathrm{IC}_{25}$ & inhibition concentration for $25 \%$ of organisms \\
\hline $\mathrm{ICP}$ & inductively coupled plasma \\
\hline ICP-MS & inductively coupled plasma mass spectrometry \\
\hline ID & identification (number) \\
\hline INEEL & Idaho National Engineering and Environmental Laboratory \\
\hline ISMS & Integrated Safety Management System \\
\hline ISO & International Organization for Standardization \\
\hline $\mathrm{LC}_{50}$ & $\begin{array}{l}\text { concentration of an aqueous sample lethal to } 50 \% \text { of test organisms in a given time } \\
\text { span. }\end{array}$ \\
\hline LLLW & liquid low-level radioactive waste \\
\hline LLW & low-level radioactive waste \\
\hline MACT & Maximum Achievable Control Technology \\
\hline MEK & Melton Branch kilometer \\
\hline MIK & Mitchell Branch kilometer \\
\hline MSDS & material safety data sheet \\
\hline MSRE & Molten Salt Reactor Experiment \\
\hline NEPA & National Environmental Policy Act \\
\hline NESHAP & National Emission Standards for Hazardous Air Pollutants \\
\hline NHPA & National Historic Preservation Act \\
\hline NIST & National Institute of Standards and Technology \\
\hline NNSA & National Nuclear Security Administration \\
\hline NOAA & National Oceanic and Atmospheric Administration \\
\hline NOEC & no-observed-effect concentration \\
\hline NOV & notice of violation \\
\hline NPDES & National Pollutant Discharge Elimination System \\
\hline NTRC & National Transportation Research Center \\
\hline NWTK & Northwest Tributary kilometer \\
\hline ORAU & Oak Ridge Associated Universities \\
\hline OREIS & Oak Ridge Environmental Information System \\
\hline ORGDP & Oak Ridge Gaseous Diffusion Plant \\
\hline ORISE & Oak Ridge Institute for Science and Education \\
\hline ORNL & Oak Ridge National Laboratory \\
\hline ORR & Oak Ridge Reservation \\
\hline ORR-PCB-FFCA & Oak Ridge Polychlorinate Biphenyl Federal Facilities Compliance Agreement \\
\hline OST & Office of Secure Transportation \\
\hline OSTI & DOE Office of Scientific and Technical Information \\
\hline PAM & perimeter air monitoring \\
\hline PCB & polychlorinated biphenyls \\
\hline PM10 & particulate matter less than 10 microns in diameter \\
\hline QA & quality assurance \\
\hline OC & quality control \\
\hline
\end{tabular}


$\mathrm{R} \& \mathrm{D}$

RAM

RCK

RCRA

RUC

SADA

SARA

SBMS

SDWA

SNS

SODAR

SWSA

TDEC

TDEC/DOE-O

TRU

TSCA

TSDR

TSP

TVA

TWRA

UST

UT

WAG

WBK

WCK

WIPP

WOCHW

WQP

Y-12 research and development

remote air monitoring

Racoon Creek kilometer

Research Conservation and Recovery Act

Rapid Update Cycle

spatial analysis and decision assistance

Superfund Amendments and Reauthorization Act

Standards-Based Management System

Safe Drinking Water Act

Spallation Neutron Source

sonic detection and ranging

solid waste storage area

Tennessee Department of Environment and Conservation

TDEC DOE Oversight

transuranic

Toxic Substances Control Act

treatment, storage, disposal, and recycle

total suspended particulate

Tennessee Valley Authority

Tennessee Wildlife Resources Agency

underground storage tank

University of Tennessee

waste area grouping

Walker Branch kilometer

White Oak Creek kilometer

Waste Isolation Pilot Plant

White Oak Creek Headwaters

water quality project

Y-12 National Security Complex 



\section{Acknowledgments}

The ASER technical coordinators and project team wish to thank those who participated in the publication of the Annual Site Environmental Report. Although we cannot name everyone involved in the environmental monitoring program, we would like to also thank and acknowledge those conducting sampling and analytical support.

ETTP

Kevin Crow

H. B. McElhoe

Jill Mortimore

Jeff Murphy

Tony Poole

Sheila Thornton

Sara Welch

Steven Wood

\section{ORNL}

Kevin Birdwell

Terry Bonine

Rac Cox (ORAU)

Nancy Dailey

Mark Greeley

Scott Gregory

James Hall

Frank Kornegay

Regis Loffman

Susan Michaud

Eric Mulkey

Frank O'Donnell

Pat Parr

Mark Peterson

Pat Scofield

Kyle Rutherford

David Skipper

John Smith

Linda Smith

Charlie Valentine

Joe Wolfe

\section{Y-12 COMPLEX}

Rebekah Bell

L. L. Cunningham

Jennifer Dixon

Stan Duke

Jim Eaton

Jan Gilbert

Kim Hanzelka

Clarence Hill

Robert Johnson

Steve Jones

Cathy McCoy

Bobby Oliver

Stacey Rathke

Johnny Skinner

Lenny Vaughn

Larissa Welch

Mick Wiest 



\section{Site and Operations Overview}

The Oak Ridge Reservation (ORR), a government-owned, contractor-operated facility, contains three major operating sites: the Y-12 National Security Complex, Oak Ridge National Laboratory, and East Tennessee Technology Park. The ORR was established in the early 1940s as part of the Manhattan Project, a secret undertaking that produced the materials for the first atomic bombs. The reservation's role has evolved over the years, and it continues to adapt to meet the changing defense, energy, and research needs of the United States. Both the work carried out for the war effort and subsequent research, development, and production activities have involved, and continue to involve, the use of radiological and hazardous materials.

The Oak Ridge Reservation Annual Site Environmental Report and supporting data are available at $\mathrm{http}: / / \mathrm{ww} w$. ornl.gov/Env_Rpt or from the project director.

\subsection{BACKGROUND}

This document is prepared annually to summarize environmental activities, primarily environmental-monitoring activities, on the ORR and within the ORR surroundings. The document fulfills the requirement of U.S. Department of Energy (DOE) Order 231.1, "Environment, Safety and Health Reporting," for an annual summary of environmental data to characterize environmental performance. The environmental monitoring criteria are described in DOE Order 450.1, "Environmental Protection Program." The results summarized in this report are based on data collected prior to and through 2003. This report is not intended to provide the results of all sampling on the ORR. Additional data collected for other site and regulatory purposes, such as environmental restoration remedial investigation reports, waste management characterization sampling data, and environmental permit compliance data, are presented in other documents that have been prepared in accordance with applicable DOE guidance and/or laws. Corrections to the report for the previous year are found in Appendix A.

Environmental monitoring on the ORR consists primarily of two major activities: effluent monitoring and environmental surveillance. Effluent monitoring involves the collection and analysis of samples or measurements of liquid and gaseous effluents at the point of release to the environment; these measurements allow the quantification and official reporting of contaminants, assessment of radiation and chemical exposures to the public, and demonstration of compliance with applicable standards and permit requirements. Environmental surveillance consists of the collection and analysis of environmental samples from the site and its environs; these activities provide direct measurement of contaminants in air, water, groundwater, soil, foods, biota, and other media subsequent to effluent release into the environment. Environmental surveillance data provide information regarding conformity with applicable DOE orders and, combined with data from effluent monitoring, allow the determination of chemical and radiation dose/exposure assessments of ORR operations and effects, if any, on the local environment.

\subsection{DESCRIPTION OF SITE LOCALE}

The city of Oak Ridge lies within the Great Valley of Eastern Tennessee between the Cumberland and Great Smoky Mountains and is bordered on two sides by the Clinch River. The Cumberland Mountains are $16 \mathrm{~km}$ (10 miles) to the northwest; the Great Smoky Mountains are $51 \mathrm{~km}$ (32 miles) to the southeast (Fig. 1.1).

The ORR encompasses about 13,857 hectares (34,241 acres) of mostly contiguous land owned by DOE in the Oak Ridge area. The majority lies within the corporate limits of the city of Oak Ridge; 246 hectares (608 acres) west of the East Tennessee Technology Park (ETTP), are outside the city limits. The residential section of Oak Ridge forms the northern boundary of the reservation. The Tennessee Valley Authority's (TVA's) Melton Hill and Watts Bar reservoirs on 


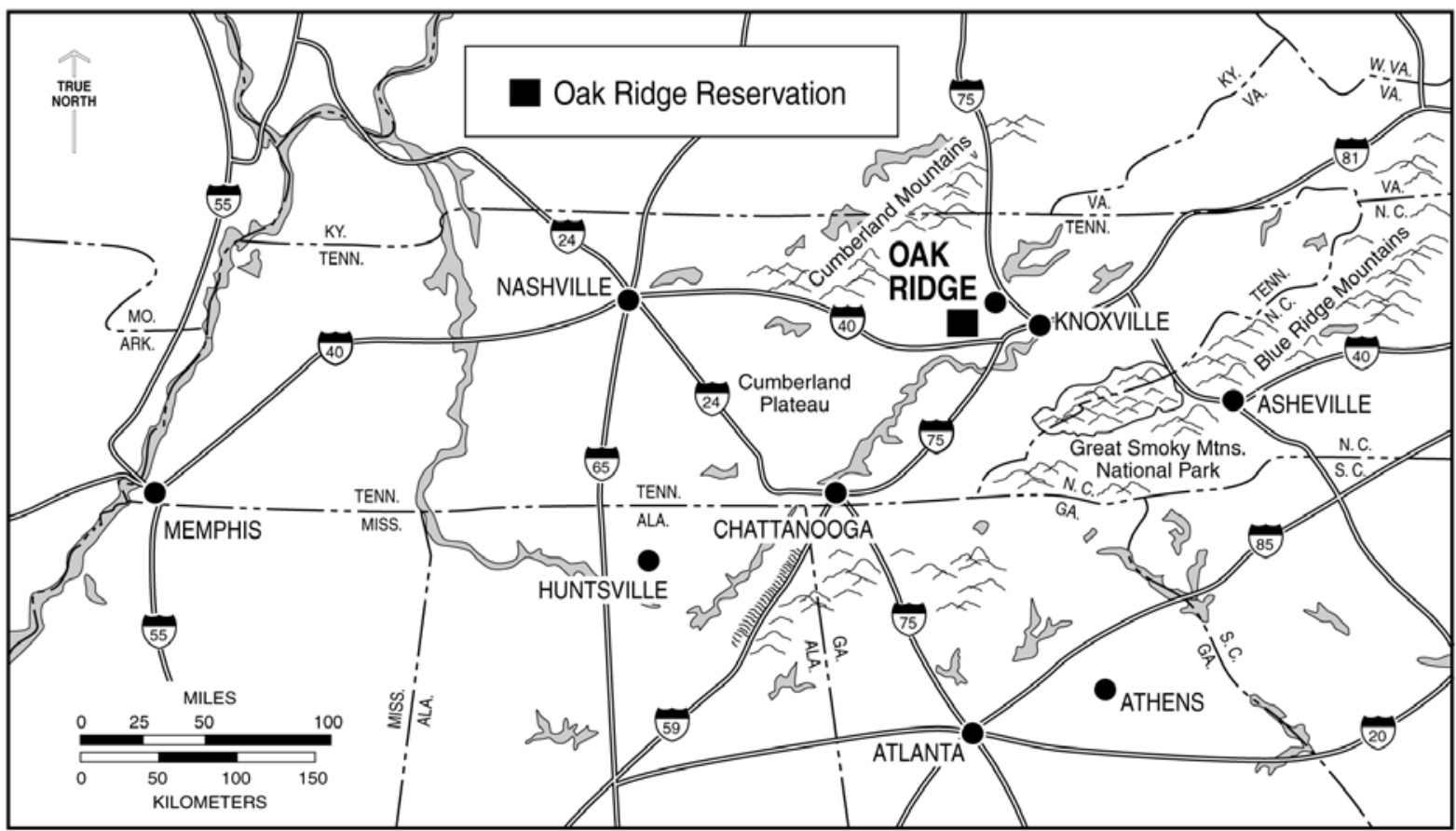

Fig. 1.1 Location of the City of Oak Ridge.

the Clinch and Tennessee rivers form the southern and western boundaries (Fig. 1.2).

The population of the ten-county region surrounding the ORR is approximately 862,424 (Tenneseee Blue Book Online, 2001-2004 Edition), with about $4 \%$ of its labor force employed on the reservation (Fig. 1.3). Other towns in close proximity to the reservation include Oliver Springs, Clinton, Karns, Lenoir City, Farragut, Kingston, and Harriman (Fig. 1.4).

Knoxville, the major metropolitan area nearest Oak Ridge, is located about $40 \mathrm{~km}$ (25 miles) to the east and has a population of about 173,661 (U.S. Census 2002). Except for the city of Oak Ridge, the land within $8 \mathrm{~km}$ (5 miles) of the ORR is semirural and is used primarily for residences, small farms, and cattle pasture. Fishing, boating, water skiing, and swimming are popular recreational activities in the area.

\subsection{CLIMATE}

The climate of the region may be broadly classified as humid continental. The Cumberland Mountains to the northwest help to modify the effects of cold air masses that frequently penetrate far south over the plains and prairies in the central United States during the winter months.
During the summer, tropical air masses from the south provide warm and humid conditions that often produce thunderstorms; however, anticyclonic circulation around high-pressure systems centered in the western Atlantic Ocean can produce subsidence over the region, leading to occasional periods of drought.

\subsubsection{Temperature}

The mean annual temperature for the Oak Ridge area is $14.2^{\circ} \mathrm{C}\left(57.6^{\circ} \mathrm{F}\right)(\mathrm{NOAA} 2001)$. The coldest month is usually January, with temperatures averaging about $2.6^{\circ} \mathrm{C}\left(36.6^{\circ} \mathrm{F}\right)$ but once dipping as low as $-31^{\circ} \mathrm{C}\left(-24^{\circ} \mathrm{F}\right)$. July is typically the hottest month of the year, with temperatures averaging $25.2^{\circ} \mathrm{C}\left(77.3^{\circ} \mathrm{F}\right)$ but rarely peaking at over $37.8^{\circ} \mathrm{C}\left(100^{\circ} \mathrm{F}\right)$. In the course of a year, the difference between maximum and minimum daily temperatures averages $12.6^{\circ} \mathrm{C}\left(22.7^{\circ} \mathrm{F}\right)$. The 2003 average temperature as measured at the official Oak Ridge meteorological tower, near the DOE Oak Ridge Operations Office (DOE-ORO) Headquarters, was $14.8^{\circ} \mathrm{C}\left(58.7^{\circ} \mathrm{F}\right)$. 


\subsubsection{Winds}

Winds in the Oak Ridge area are significantly affected by the ridge-and-valley terrain features as well as by the size and orientation of the Great Valley of Eastern Tennessee. Prevailing winds tend to follow both the axis of the Great Valley and that of the local ridges and valleys, resulting in a dominance of winds from the east-northeast or southwest. Various forcing mechanisms affect the resultant winds on the ORR. These include (1) pressure-driven channeling, (2) vertically coupled flow, (3) thermal forcing, and (4) direct channeling (Birdwell 1996). Wind shear associated with some of these patterns can greatly complicate estimates of atmospheric dispersion, particularly just above local ridge top heights (100 to $200 \mathrm{~m}$ above local valley bottoms). Wind speeds are less than $11.9 \mathrm{~km} / \mathrm{h}(7.4 \mathrm{mph}) 75 \%$ of the time; tornadoes and winds exceeding $30 \mathrm{~km} / \mathrm{h}$ $(18.5 \mathrm{mph})$ are relatively rare. Wind speeds at a height of $10 \mathrm{~m}$ at the ORR meteorological towers averaged $1.4 \mathrm{~m} / \mathrm{s}(3.1 \mathrm{mph})$ during 2003. Air stagnation is relatively common in eastern Tennessee (about twice that of western Tennessee). On average, about two multiple-day air stagnation episodes occur annually in eastern Tennessee, to cover an average of about 8 days per year. August, September, and October are the most likely months for air stagnation episodes.

\subsubsection{Precipitation}

The 30-year annual average precipitation is $1398 \mathrm{~mm}$ (55.05 in.), including about $24.4 \mathrm{~cm}$ (9.6 in.) of snowfall (NOAA 2001). Total rainfall during 2003 as measured at the official Oak Ridge meteorological tower on Laboratory Road in Oak Ridge (near the DOE-ORO Headquarters) was $1699.5 \mathrm{~mm}$ (66.91 in.).

\subsubsection{Evapotranspiration}

Regionally, annual evapotranspiration has been estimated to range from 81 to $89 \mathrm{~cm} \mathrm{(32} \mathrm{to}$ 35 in.), or 60 to $65 \%$ of rainfall (Farnsworth et al. 1982). Evapotranspiration in the Oak Ridge area is 74 to $76 \mathrm{~cm}$ (29 to 30 in.), or 55 to $56 \%$ of annual precipitation (TVA 1972, Moore 1988, and Hatcher et al. 1989). Evapotranspiration is greatest in association with the growing season, which in the vicinity of the ORR encompasses about 220 days, from mid-March through midOctober. During the growing season, evapotranspiration may exceed the rate of precipitation, resulting in soil moisture deficits.

\subsubsection{Mixing Heights}

The mixing height (atmospheric layer nearest the surface where active diffusion and mixing occur) varies significantly with respect to time of day, synoptic weather, and season. The depth of the surface mixing layer is directly related to atmospheric stability (the tendency of the atmosphere to mix vertically). Local ridge-andvalley terrain primarily affects stability through the reduction of surface winds, which tends to allow for the development of very stable surface layers at night, particularly under clear sky and light synoptic winds. Hourly mixing height statistics for the ORR during 2003 are given in Table 1.1. Data were derived primarily from hourly sonic detection and ranging (sodar) data $(<500$ meters) and the National Weather Service Rapid Update Cycle (RUC2) forecast model initializations ( $>500$ meters). The annual average mixing height for 2003 was 682 meters (standard deviation 715 meters).

\subsubsection{Physiography}

The ORR lies within the Valley and Ridge Physiographic Province, which has developed on thick, folded beds of sedimentary rock deposited during the Paleozoic era. The long axes of the folded beds control the shapes and orientations of a series of long, narrow parallel ridges and intervening valleys. The differing degrees of resistance to erosion of the shales, sandstones, and carbonate rocks comprised in the lithology determine local relief.

\subsection{SURFACE WATER SETTING}

Waters drained from the ORR eventually reach the Tennessee River via the Clinch River, which forms the southern and western boundaries of the ORR (Fig. 1.2). The ORR lies within the 


\begin{tabular}{|c|c|c|c|c|c|}
\hline \multirow[b]{2}{*}{ Hour } & \multicolumn{5}{|c|}{ Averages } \\
\hline & Annual & $\begin{array}{l}\text { Dec- } \\
\text { Feb }\end{array}$ & $\begin{array}{l}\text { Mar- } \\
\text { May }\end{array}$ & $\begin{array}{l}\text { Jun- } \\
\text { Aug }\end{array}$ & $\begin{array}{l}\text { Sep- } \\
\text { Nov }\end{array}$ \\
\hline 0100 & 445 & 467 & 492 & 545 & 276 \\
\hline 0200 & 348 & 445 & 360 & 311 & 277 \\
\hline 0300 & 318 & 426 & 310 & 271 & 269 \\
\hline 0400 & 319 & 425 & 323 & 270 & 260 \\
\hline 0500 & 331 & 448 & 308 & 319 & 250 \\
\hline 0600 & 318 & 426 & 293 & 290 & 262 \\
\hline 0700 & 355 & 477 & 301 & 298 & 347 \\
\hline 0800 & 348 & 437 & 308 & 341 & 308 \\
\hline 0900 & 330 & 364 & 309 & 299 & 339 \\
\hline 1000 & 344 & 387 & 295 & 370 & 323 \\
\hline 1100 & 342 & 407 & 300 & 349 & 314 \\
\hline 1200 & 337 & 385 & 331 & 288 & 346 \\
\hline 1300 & 352 & 395 & 354 & 329 & 330 \\
\hline 1400 & 412 & 380 & 412 & 484 & 372 \\
\hline 1500 & 601 & 449 & 530 & 804 & 627 \\
\hline 1600 & 854 & 557 & 709 & 1260 & 884 \\
\hline 1700 & 1094 & 654 & 929 & 1627 & 1155 \\
\hline 1800 & 1228 & 740 & 1017 & 1867 & 1279 \\
\hline 1900 & 1273 & 821 & 1051 & 1777 & 1435 \\
\hline 2000 & 1397 & 881 & 1315 & 1877 & 1505 \\
\hline 2100 & 1463 & 934 & 1374 & 1945 & 1589 \\
\hline 2200 & 1444 & 953 & 1389 & 1895 & 1528 \\
\hline 2300 & 1273 & 760 & 1321 & 1872 & 1126 \\
\hline 2400 & 831 & 509 & 882 & 1536 & 386 \\
\hline
\end{tabular}

Valley and Ridge Physiographic Province, which is composed of a series of drainage basins or troughs containing many small streams feeding the Clinch River. Surface water at each of the major facilities of the ORR drains into a tributary or series of tributaries, streams, or creeks within different watersheds. Each of these watersheds drains into the Clinch River.

The largest of the drainage basins is that of Poplar Creek, which receives drainage from a $352-\mathrm{km}^{2}\left(136-\mathrm{mile}^{2}\right)$ area, including the northwestern sector of the ORR. It flows from northeast to southwest, approximately through the center of the East Tennessee Technology Park (ETTP), and discharges directly into the Clinch River.

East Fork Poplar Creek, which discharges into Poplar Creek east of the ETTP, originates within the Y-12 National Security Complex (Y-12

Complex) near the former S-3 Ponds and flows northeast along the south side of the Y-12 Complex. Various Y-12 Complex wastewater discharges to the upper reaches of East Fork Poplar Creek from the late 1940s to the early 1980s left a legacy of contamination [e.g., mercury, polychlorinated biphenyls (PCBs), uranium] that has been the subject of water quality improvement initiatives over the past 12 to 15 years. Bear Creek also originates within the Y-12 Complex with headwaters near the former S-3 Ponds, where the creek flows southwest. Bear Creek is mostly affected by stormwater runoff, groundwater infiltration, and tributaries that drain former waste disposal sites in the Bear Creek Valley Burial Grounds Waste Management Area.

Both the Bethel Valley and Melton Valley portions of Oak Ridge National Laboratory (ORNL) are in the White Oak Creek drainage basin, which has an area of $16.5 \mathrm{~km}^{2}$ $\left(6.37\right.$ mile $\left.^{2}\right) .0$ White Oak Creek headwaters originate on Chestnut Ridge, north of ORNL, near the Spallation Neutron Source (SNS) site. At the ORNL site, the creek flows east along the southern boundary of the developed area and then flows southwesterly through a gap in Haw Ridge to the western portion of Melton Valley, where it forms a confluence with Melton Branch. The waters of White Oak Creek enter White Oak Lake, which is an impoundment formed by White Oak Dam. Water flowing over White Oak Dam enters the Clinch River after passing through the White Oak Creek embayment area.

\subsubsection{Surface Water Monitoring}

Surface water is monitored at each of the sites as well as elsewhere on the ORR. Program details and results are given in the facility-specific environmental effluent and surveillance chapters: Sect. 7.4 for the ORR, Sects. 4.4 and 4.9 for the ETTP, Sect. 5.8 for ORNL, and Sect. 6.5 for the Y-12 Complex.

\subsection{GEOLOGICAL SETTING}

The ORR is located in the Tennessee portion of the Valley and Ridge Physiographic Province, which is part of the southern Appalachian foldand-thrust belt. As a result of thrust faulting and 


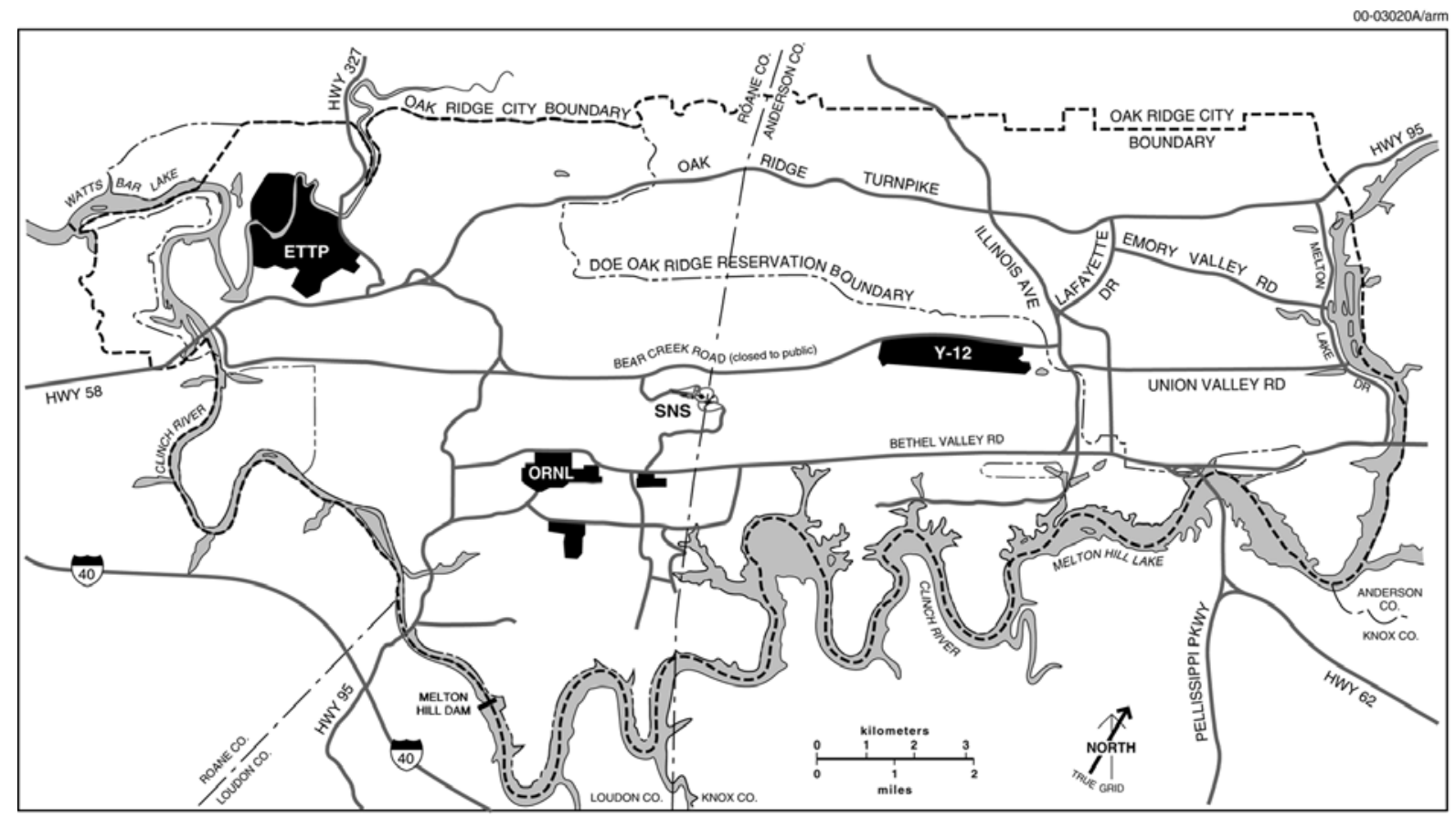

Fig. 1.2. The Oak Ridge Reservation.

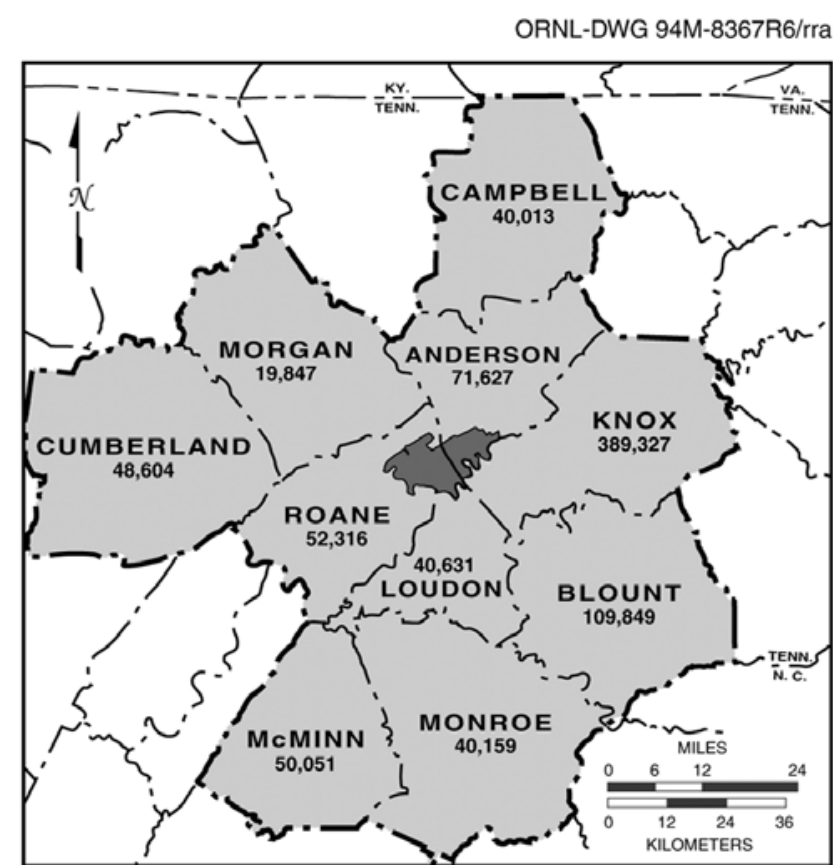

Figure 1.3. The ten-county region surrounding the Oak Ridge Reservation. Source: (U.S. Census 2002.)

differential erosion rates, a series of parallel valleys and ridges have formed that trend southwest-northeast.

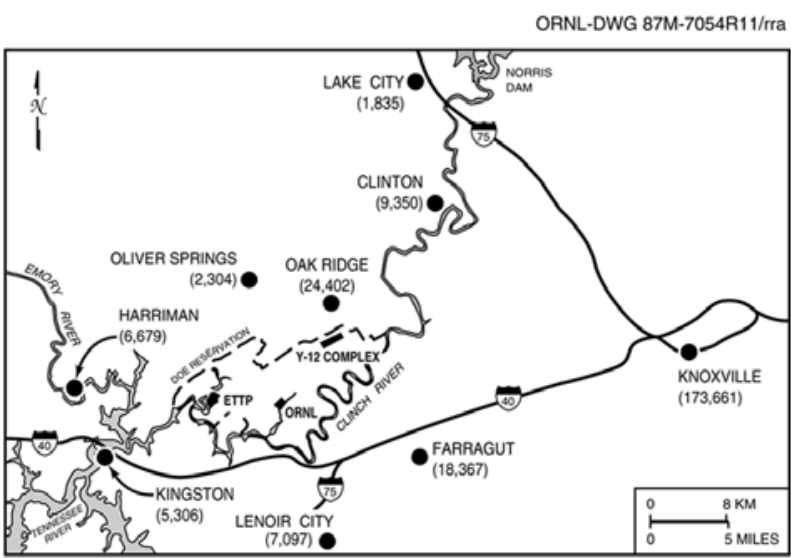

Figure 1.4. Locations and populations of towns nearest to the Oak Ridge Reservation (UTCBER 2000).

Two geologic units on the ORR, designated as the Knox Group and the Maynardville Limestone of the Conasauga Group, both consisting of dolostone and limestone, constitute the Knox Aquifer. A combination of fractures and solution conduits in this aquifer control flow over substantial areas, and large quantities of water may move long distances. Active groundwater flow can occur at substantial depths in the Knox Aquifer [91.5 to $122 \mathrm{~m}$ (300 to $400 \mathrm{ft}$ ) deep]. The Knox Aquifer is the primary source of groundwater to many streams (base flow), and most large springs on the ORR receive discharge from the 
Knox Aquifer. Yields of some wells penetrating larger solution conduits are reported to exceed $3784 \mathrm{~L} / \mathrm{min}$ (1000 gal/min).

The remaining geologic units on the ORR (the Rome Formation, the Conasauga Group below the Maynardville Limestone, and the Chickamauga Group) constitute the ORR Aquitards, which consist mainly of siltstone, shale, sandstone, and thinly bedded limestone of low to very low permeability (Fig. 1.5). Nearly all groundwater flow in the ORR Aquitards occurs through fractures. The typical yield of a well in the ORR Aquitards is less than $3.8 \mathrm{~L} / \mathrm{min}(1 \mathrm{gal} / \mathrm{min})$, and the base flows of streams draining areas underlain by the ORR Aquitards are poorly sustained because of such low flow rates.
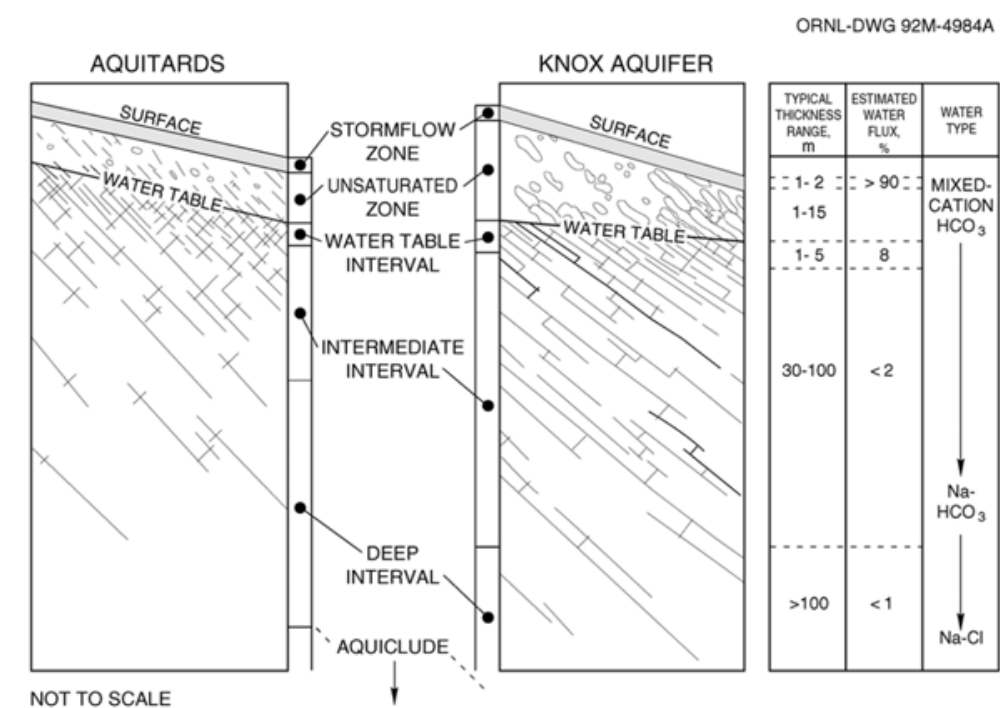

Figure 1.5 Vertical relationships of flow zones of the ORR: estimated thicknesses, water flux, and water types.

\subsubsection{Hydrogeological Setting}

\subsubsection{Groundwater Hydrology}

A portion of the rainwater that falls on the land surface accumulates as groundwater by infiltrating into the subsurface. The accumulation of groundwater in pore spaces of sediments and bedrock creates sources of usable water; the water flows in response to external forces. Groundwater eventually reappears at the surface in springs, swamps, stream and river beds, and pumped wells. Thus, groundwater is a reservoir for which the primary input is recharge from infiltrating rainwater and whose output is discharge to springs, swamps, rivers, streams, and wells.

Because groundwater distribution and movement on the ORR are quite complex and are key components of the pollution potential of the ORR, it is considered important to discuss here some of the technical essentials necessary for understanding the role of groundwater in the overall existence and movement of contaminants on the reservation. Appendix $\mathrm{B}$ contains a glossary of technical terms that may be useful for clarifying some of the language used in this section.

Groundwater on the ORR occurs both in the unsaturated zone as transient, shallow subsurface stormflow and within the deeper saturated zone. An unsaturated zone of variable thickness separates the stormflow zone and water table. Adjacent to surface water features or in valley floors, the water table is found at shallow depths, and the unsaturated zone is thin. Along the ridge tops or near other high topographic areas, the unsaturated zone is thick, and the water table often lies at considerable depth [15 to $50 \mathrm{~m}$ (50 to $175 \mathrm{ft}$ ) deep]. In low-lying areas where the water table occurs near the surface, the stormflow zone and saturated zone are indistinguishable.

Two broad hydrologic units are identified on the ORR: the Knox Aquifer, which includes the Maynardville Limestone and is highly permeable, and the ORR Aquitards, which consist of less permeable geologic units. The geologic regime referred to as the ORR Aquitards comprises bedrock and residuum of the Cambrian age Rome formation and Conasauga Group (excluding the Maynardville Limestone) and the Chickamauga Group. Bedrock included in these formations is predominantly clastic sediment (shales, siltstones, well-cemented sandstones, and argillaceous to silty limestones). The ORR Aquitards, include local zones where groundwater occurs in quantities sufficient to provide a potential resource of limited use. These zones typically occur within karstic carbonate members of the clastic bedrock formations. Although marginal localized groundwater resources occur within the the ORR Aquitards, 
these formations are far less important to regional water resources, including being a source of potable water for private and public water supply and a source of baseflow to regional surface water bodies than is the Knox Aquifer. Figure 1.6 is a generalized map showing surface distribution of the Knox/Maynardville Aquifer and the ORR Aquitards. Many waste areas on the ORR are located in areas underlain by the ORR Aquitards.

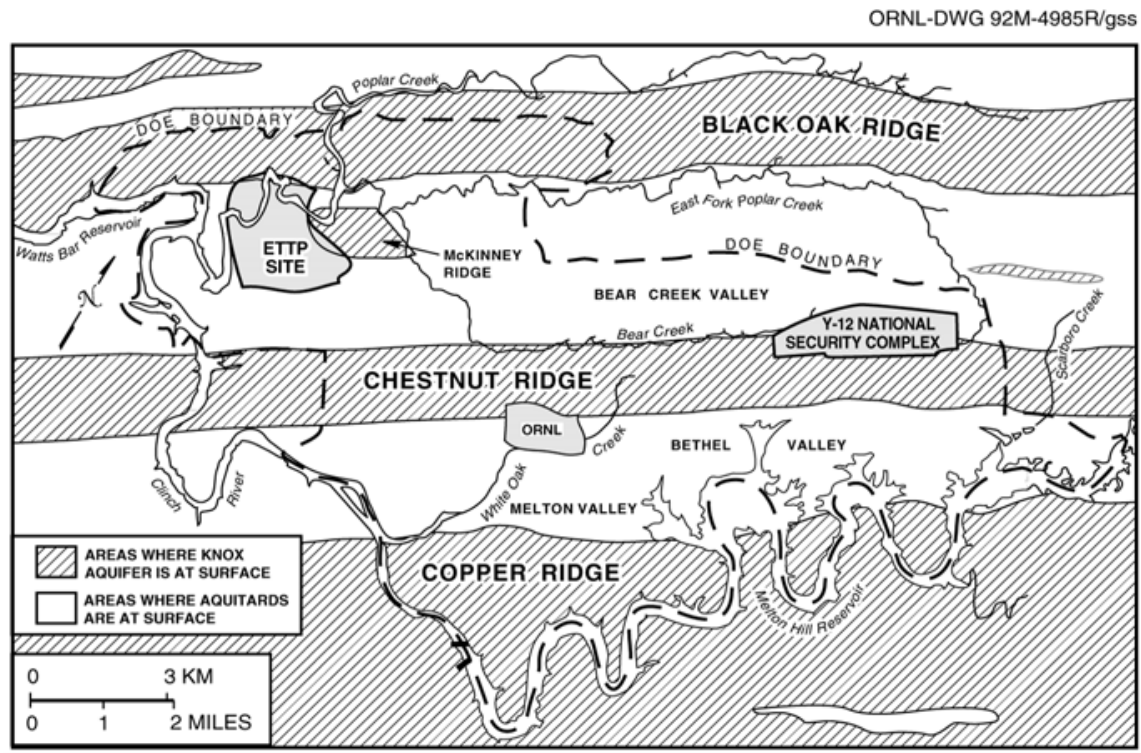

Figure 1.6 The Knox Aquifer and the ORR Aquitards on the Oak Ridge Reservation

Portions of the ORR underlain by carbonate bedrock commonly exhibit karst geomorphic features. Approximately 60 percent of the ORR is underlain by carbonate-dominated bedrock. Karst geomorphic features form in carbonate-rich bedrock and are evident as sinkholes, solution caverns, and sinking creeks. In addition to creation of subsurface voids in bedrock the weathering process leaves behind the insoluble mineral components of the rock that combine with organic residues of decaying plant materials to form a soil mantle over most of the ORR. The soil mantle forms a physical and geochemical filter that reduces the direct infiltration of rainfall and contaminants into the groundwater system. Geochemical retardation of contaminants in the soil mantle reduces the mobility of many types of contaminants. Groundwater flow in most of the carbonates is quite different from flow in porous media where advective flow conditions largely govern flow and solute transport. Groundwater flow in karst terranes manifests itself in multiple scales of porosity ranging from seepage and diffusion in intergranular pores of weathered or inherently porous bedrock, to flow by seepage in rock fractures with water and rock matrix interaction on fracture surfaces, to flow in conduits where rapid velocities limit the interaction between the water and bedrock. Groundwater discharge from springs and seeps is abundant on the ORR and accounts for the normal baseflow of natural stream systems in the area. Most recharge to the groundwater system occurs through dispersed percolation of rainwater through the soil mantle and via capture in surface dolines during the winter and early spring months when evapotranspiration losses of soil moisture are negligible. Groundwater storage in thick soil profiles and in the weathered bedrock zone of the Knox Group outcrop areas such as Blackoak, Chestnut, and Copper Ridges provides most of the dry season baseflow and feeds the area's largest springs. Most of groundwater flow in the carbonate bedrock groundwater basins on the ORR originates as intergranular or fracture seepage through the soil mantle, and flow progresses through coalescing networks of conduits that culminate at spring discharges. Baseflow springs often occur near major geologic outcrop boundaries where semi-confining bedrock lithologies tend to limit the orientation of conduit development and promote upward flow of groundwater to discharge at the land surface. In portions of the ORR underlain by shale-rich bedrock, such as the Conasauga Group bedrock of Bear Creek Valley and Melton Valley groundwater seepage, is typically through fractures in weathered bedrock with discharge to nearby streams. Discrete baseflow springs are not common in the shale-dominated outcrop areas; however, small seeps are abundant.

\subsubsection{Unsaturated Zone Hydrology}

Terrain at the ORR is hilly with slopes that average approximately $7.5 \%$ and range from less 
than $3 \%$ to $>50 \%$. Because ORR landforms consist almost entirely of sloping land surfaces, the concepts of hillslope hydrology are appropriate to describe the active hydrologic process. Based on soil percolation capacity and soil structure, as well as direct measurement of water transmission in soil test areas, it is estimated that in undisturbed, naturally vegetated areas on the ORR, about $90 \%$ of the infiltrating precipitation does not reach the water table but travels through the 1- to 2-m (3- to 7-ft) deep stormflow zone, which approximately corresponds to the root zone. This condition exists because of the permeability contrast between the shallow stormflow zone and the underlying unsaturated zone.

Recharge of the groundwater system is strongly seasonal at the ORR, and percolation processes in the shallow soil are moderated by the amount soil moisture present. During the active growing season (April through October) moisture evapotranspiration by plants removes moisture from the soil within the root zone. When soil moisture levels are low, any percolating rainwater is absorbed in the root zone to replenish the soil moisture deficit. During that phase little or no water reaches the water table. When rainfall amounts exceed any existing soil moisture deficits and saturation of the shallow soils begins to occur, seepage of water begins. When saturation of the shallow soils occurs on sloping land, the downslope gradient allows lateral drainage of water through macropores (e.g., holes left by decay of dead plant roots, animal burrows) as well as vertical seepage to the water table through pervious zones. During the nongrowing season (November through March), there is little evapotranspiration to remove water from the root zone, and saturation of the shallow soils occurs more rapidly than during the summer months. Typical evapotranspiration losses from the root zone range from a low of about 0.01 in./day rainfall equivalent during January and February to a high of about 0.16 in./day rainfall equivalent during July. Thus, development of a 1-in. water deficit would require only a week without rainfall during July but would require over two months without rainfall during the winter.

The amount of water that actually recharges the groundwater zone is highly variable across the ORR, depending on shallow soil characteristics, permeability and degree of fracturing of regolith beneath the surface soils, presence of dolines that capture stormflow and focus recharge in small areas, and the presence of paved or covered areas, where little or no rainfall infiltration occurs. Higher recharge is expected in areas of karst hydrogeology, such as the Knox Aquifer because of internal drainage through dolines than in areas underlain by the clastic bedrock formations.

\subsubsection{Saturated Zone Hydrology}

As shown in Fig. 1.5, the saturated zone on the ORR can be divided conceptually into four flow zones in a vertical cross section: an uppermost water table interval, an intermediate interval, a deep interval, and an aquiclude. The presence and thickness of any zone may vary across the ORR. Available evidence indicates that most water in the saturated zone in the ORR Aquitards is transmitted through a 1- to 6-m (3- to $20-\mathrm{ft}$ ) thick layer of closely spaced, wellconnected fractures near the water table (the water table interval) as shown in Fig. 1.7.

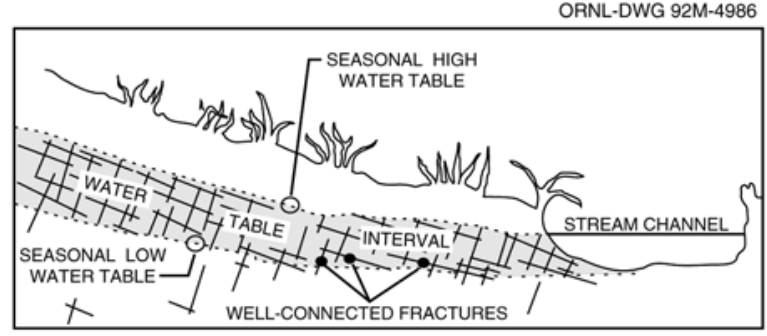

Fig. 1.7. Water table interval.

As in the stormflow zone, the bulk of groundwater in the saturated zone resides within the pore spaces of the rock matrix. The rock matrix typically forms blocks that are bounded by fractures. Contaminants migrating from sources by way of the fractures typically occur in higher concentrations than in the matrix; thus, the contaminants tend to move (diffuse) into the matrix. This process, termed "diffusive exchange" or "matrix diffusion," between water in matrix pores and water in adjacent fractures reduces the overall contaminant migration rates relative to groundwater flow velocities. For example, the leading edge of a geochemically nonreactive contaminant mass such as tritium $\left({ }^{3} \mathrm{H}\right)$ may migrate along fractures at a typical rate of $1 \mathrm{~m} /$ day ( $3 \mathrm{ft} /$ day); however, the center of mass of a 
contaminant plume typically migrates at a rate less than $0.66 \mathrm{~m} /$ day $(2 \mathrm{ft} /$ day $)$.

In the ORR Aquitards, chemical characteristics of groundwater change from a mixedcation- $\mathrm{HCO}_{3}$ water type at shallow depth to an $\mathrm{Na}-\mathrm{HCO}_{3}$ water type at deeper levels $[30.5 \mathrm{~m}$ (about $100 \mathrm{ft}$ )]. This transition, not marked by a distinct change in rock properties, serves as a useful marker and can be used to distinguish the more active water table and intermediate groundwater intervals from the sluggish flow of the deep interval. There is no evidence of similar change with depth in the chemical characteristics of water in the Knox Aquifer; virtually all wells are within the monitoring regime of $\mathrm{Ca}-\mathrm{Mg}-\mathrm{HCO}_{3}$ type water. Although the mechanism responsible for this change in water types is not quantified, it most likely is related to the amount of time the water is in contact with a specific type of rock.

Most groundwater flow in the saturated zone occurs within the water table interval. Most flow is through weathered, permeable fractures and matrix rock and within solution conduits in the Knox Aquifer. The range of seasonal fluctuations of water table depth and rates of groundwater flow vary significantly across the reservation. In areas underlain by the Knox Aquifer, seasonal fluctuations in water levels average $5.3 \mathrm{~m}(17 \mathrm{ft})$, and mean discharge from the active groundwater zone is typically $322 \mathrm{~L} / \mathrm{min}$ ( $85 \mathrm{gal} / \mathrm{min}$ ) per square mile. In the ORR Aquitards of Bear Creek Valley, Melton Valley, East Fork Valley, and Bethel Valley, seasonal fluctuations in water levels average $1.5 \mathrm{~m}(5 \mathrm{ft})$, and typical mean discharge is $98 \mathrm{~L} / \mathrm{min}$ (26 $\mathrm{gal} / \mathrm{min}$ ) per square mile.

In the intermediate interval, groundwater flow paths are a product of fracture density and orientation. In this interval, groundwater movement occurs primarily in permeable fractures that are poorly connected. In the Knox Aquifer, a few cavity systems and fractures control groundwater movement in this zone, but in the ORR Aquitards, the bulk of flow is through fractures, along which permeability may be increased by weathering.

The deep interval of the saturated zone is delineated by a change to an $\mathrm{Na}-\mathrm{Cl}$ water type. Hydrologically active fractures in the deep interval are significantly fewer in number and shorter in length than in the other intervals, and the spacing is greater. Wells finished in the deep interval of the ORR aquitards typically yield less than $1.1 \mathrm{~L} / \mathrm{min}(0.3 \mathrm{gal} / \mathrm{min})$ and thus are barely adequate for water supply.

In the ORR Aquitards, saline water characterized by total dissolved solids ranging up to $275,000 \mathrm{mg} / \mathrm{L}$ and chlorides generally in excess of $50,000 \mathrm{mg} / \mathrm{L}$ (ranging up to $163,000 \mathrm{mg} / \mathrm{L}$ ) lies beneath the deep interval of the groundwater zone, delineating an aquiclude. Chemically, this water resembles brines typical of major sedimentary basins, which originated from evaporating water bodies. The brines are thought to have been pushed westward and trapped by overthrusting rock during the formation of the Appalachian Mountains (approximately 250 million years ago). The chemistry suggests extremely long residence times (i.e., very low flow rates); however, some mixing with shallow groundwater has been observed (Nativ et al. 1997).

The aquiclude has been encountered at depths of 122 and $244 \mathrm{~m}$ (400 and $800 \mathrm{ft}$ ) in Melton and Bethel Valleys, respectively (near ORNL), and it is believed to approach $305 \mathrm{~m}(1000 \mathrm{ft})$ in portions of Bear Creek Valley (near the Y-12 Complex) underlain by aquitard formations. Depth to the aquiclude in areas of the Knox Aquifer is not known but is believed to be greater than $366 \mathrm{~m}$ (1200 ft); depth to the aquiclude has not been established in the vicinity of the ETTP.

\subsubsection{Groundwater Flow}

Many factors influence groundwater flow on the ORR. Topography, surface cover, geologic structure, karst features (see Sect.1.5.1.1), and rock type exhibit especially strong influences on the hydrogeology. Variations in these features result in variations of the total amount of groundwater moving through the system (flux). (Average flux ratios for the ORR Aquitards and the Knox Aquifer formations are shown in Fig. 1.5.) As an example, the overall decrease in open fracture density with depth results in a decreased groundwater flux with depth.

Topographic relief on the ORR is such that most active subsurface groundwater flow occurs at shallow depths. U.S. Geological Survey modeling (Tucci 1992) suggests that $95 \%$ of all groundwater flow occurs in the upper 15 to $30 \mathrm{~m}$ (50 to $100 \mathrm{ft}$ ) of the saturated zone in the ORR Aquitards. As a result, flow paths in the active- 
flow zones (particularly in the aquitards) are relatively short, and nearly all groundwater discharges to local surface water drainages on the ORR. Conversely, in the Knox Aquifer it is believed that solution conduit flow paths may be considerably longer, perhaps as much as $1.6 \mathrm{~km}$ ( 1 mile) long in the along-strike direction. No evidence at this time substantiates the existence of any deep, regional flow off the ORR or between basins within the ORR in either the Knox Aquifer or the ORR Aquitards. Data collected in the calendar years 1994 and 1995, however, have demonstrated that groundwater flow and contaminant transport occur off the ORR in the intermediate interval of the Knox Aquifer, near the east end of the Y-12 Complex.

Migration rates of contaminants transported in groundwater are strongly influenced by natural chemical and physical processes in the subsurface (including diffusion and adsorption). Peak concentrations of solutes, including contaminants such as tritium moving from a waste area, for instance, can be delayed for several to many decades in the ORR Aquitards, even along flow paths as short as a few hundred feet. The processes that naturally retard contaminant migration and store contaminants in the subsurface are less effective in the Knox Aquifer than in the ORR Aquitards because rapid flow along solution features allows minimal time for diffusion to occur.

\subsubsection{Groundwater Monitoring Considerations}

The groundwater monitoring programs on the ORR were designed to gather information to determine the effects of DOE operations, past and present, on groundwater quality. Because of the complexity of the hydrogeologic framework on the ORR, groundwater flow and, therefore, contaminant transport are difficult to predict on a local scale. Also, detailed delineation of groundwater contaminant plumes is not always feasible. Monitoring wells and piezometers are used to perform ongoing surveillance and characterization of groundwater flow and quality. Since stormflow and most groundwater discharge to ORR surface water drainages, springs, and seeps, these features are monitored for water quality to assess the extent to which groundwater from a large portion of the ORR transports contaminants.

\subsubsection{Groundwater Monitoring Programs on the ORR}

Groundwater monitoring programs at each of the major ORR facilities are discussed in the facility-specific chapters: Sect. 4.11 for the ETTP, Sect. 5.11 for ORNL, and Sect. 6.10 for the Y-12 Complex.

\subsection{DESCRIPTION OF SITE FACILITIES AND OPERATIONS}

The facilities on the ORR began operating in 1942 as part of the Manhattan Project, producing components for the first nuclear weapons. The ORR remains government-owned, although the nature of the work at the facility has changed. The primary missions of the three sites have evolved during the past 60 years and continue to adapt to meet the changing defense, energy, and research needs of the United States. The reservation contains three major DOE installations: the Y-12 Complex, ORNL, and the ETTP. DOE also operates a number of facilities that are not within the major installation sites:

- 55 Jefferson,

- American Museum of Science and Energy,

- Atmospheric Turbulence and Diffusion Division-National Oceanic and Atmospheric Administration (ATDD-NOAA) Facility,

- Buildings 2714 and 2715,

- Central Training Facility,

- checking stations (gatehouses),

- Clark Center Recreation Park,

- DOE Information Center,

- Federal Office Building,

- George Jones Memorial Baptist Church,

- National Transportation Research Center (NTRC),

- Office of Scientific and Technical Information (OSTI), Building 1916-T1, Building 1916-T2,

- Parcel ED-1,

- Parcel ED-2,

- Office of Secure Transportation Firing Range,

- Office of Secure Transportation Vehicle Facility, 
- Union Valley Sample Preparation Facility, and

- Vance Road Facility.

The facility at 55 Jefferson is a DOE-owned facility comprising approximately $46,000 \mathrm{ft}^{2}$ on a 3 -acre site located on Jefferson Circle along the Oak Ridge Turnpike in Oak Ridge. The primary facility use is DOE Environmental Management. The building is a temporary wood-frame structure constructed in the 1940s.

In 1975, the American Museum of Science and Energy was moved from its original facility (55-59 Jefferson Circle) to a 17-acre site contiguous to the Oak Ridge Associated Universities (ORAU) campus, on South Tulane Avenue in Oak Ridge. The masonry structure contains about $55,400 \mathrm{ft}^{2}\left(33,932 \mathrm{ft}^{2}\right.$ for exhibition space and $21,468 \mathrm{ft}^{2}$ for offices and related space). This facility contains the energy house, which is licensed to the city of Oak Ridge for use by the Convention and Visitors' Bureau. The museum also has warehouse space in OSTI's Building 1916T-2 complex. The museum is managed by UT-Battelle.

The ATDD-NOAA Facility is composed of a wood-frame building built in the 1940s and several smaller buildings at 456 South Illinois Avenue in Oak Ridge. ATDD conducts meteorological and atmospheric diffusion research that is jointly supported by DOE and NOAA. It also provides services to other DOE contractors and operates the Weather Instrument Telemetering Monitoring System for DOE.

Buildings 2714 (referred to as the "Laboratory Road Facility") and 2715 are DOE-owned facilities that DOE shares with the Oak Ridge Institute of Science and Education (ORISE). The facilities are used for general offices and handson, laboratory-based training in the areas of radiation safety (health physics) . The ORISE occupied facilities comprise approximately 36,084 $\mathrm{ft}^{2}$ and is located in Oak Ridge immediately south of the Federal Office Building.

The Central Training Facility is used primarily by security forces and consists of a small office building, an indoor firing range, two classroom/storage trailers, on-site parking, fitness facilities (an outdoor track), and numerous outdoor firing ranges. The site, including a buffer area, is south of Bear Creek Road, less than 1 mile southeast of ETTP, and currently occupies about 150 acres.

DOE-ORO properties included in the National Register of Historic Places (National Park Service 2003) are three checking stations: (1) the Oak Ridge Turnpike Checking Station (Turnpike Checking Station), (2) the Scarboro Road Checking Station (Midway Checking Station), and (3) the Bethel Valley Road Checking Station. Although these structures are listed as checking stations in the National Register, they were originally called and today are commonly called "gatehouses." The main building of the Bethel Valley Road Checking Station is located on a parcel of land that was transferred to the city of Oak Ridge. However, the small associated block building just opposite the main structure is still owned by DOE-ORO.

Clark Center Recreation Park is an 80-acre public park. It consists of a building containing offices and rest rooms, three shelters, a boat ramp, improved parking areas, two softball fields, an unguarded swimming area, and a paved access road. The park is currently operated by the Corporate and Community Affairs Office of the Recreation Department.

The DOE Information Center, located at 475 Oak Ridge Turnpike, provides centralized public access to DOE documents and information. The Information Center consolidates Freedom of Information Act documents that were previously available at the DOE Public Reading Room and information about the DOE Environmental Management Program that were previously located at the Information Resource Center. The building, which is leased to DOE by $R \& R$ Rental Properties, has about $8000 \mathrm{ft}^{2}$ of space and also provides public meeting rooms and office space for the Oak Ridge Site Specific Advisory Board.

The Federal Office Building, located in Oak Ridge, is owned by the General Services Administration and is maintained by DOE. DOE-ORO offices occupy the vast majority of the $113,000 \mathrm{ft}^{2}$ of space in the building.

George Jones Memorial Baptist Church, located within the ETTP, predates World War II and is included in the National Register of Historic Places.

The NTRC is a collaborative effort among DOE, ORNL, the University of Tennessee (UT), and the Development Corporation of Knox 
County. The NTRC's activities span the whole range of transportation research. The center is an $85,000-\mathrm{ft}^{2}$ building, located on a 6 -acre site in the Pellissippi Corporate Center and is leased to ORNL and UT separately by Pellissippi Investors LLC.

OSTI is located in two masonry buildings constructed as warehouses in the 1940s: Buildings 1916T-1 and 1916T-2. Building 1916T-1 houses the main OSTI functions as well as other occupants. Portions of this building were converted to office space in the 1950s, and additional bays were added in the 1950s and 1960s. Currently, the building has one office bay and seven other bays for a total space of $135,000 \mathrm{ft}^{2}$. Building 1916T-2 houses ORISE and ORO operations, including warehousing, procurement, and safety staff. The two DOE buildings are located on a 7-acre tract that parallels the Oak Ridge Turnpike about 2 miles east of the Federal Office Building. Because of their age and configuration, they are classified as Class B buildings (i.e., semipermanent buildings, constructed primarily of wood, which may need to be renewed, renovated, or rehabilitated in the near future) but are deemed adequate for current functions.

ParcelED-1 ("Horizon Center") was leased to the Community Reuse Organization of East Tennessee (CROET) (effective April 28, 1998), and 489 acres were transferred (by quit claim deed) to CROET in April 2003. The developable portions of the parcel were transferred and the other portions (the natural area that surrounds the East Fork Poplar Creek floodplain and other locations) remain part of the CROET leasehold. CROET may sublease the land transferred to it or may sell it to others for purposes of economic development. CROET is responsible for the protection and maintenance of all portions of the property.

Parcel ED-2 consists of a barge facility and an adjacent 15 -acre area located in the K-700 area west of the main ETTP site. ED-2 and the barge facility have already been leased to CROET, which intends to offer the barge facility to the business community on a fee basis. Present CROET plans are to develop the facility, in conjunction with the adjacent rail service and interstate corridor, as a mini-port authority. The balance of ED-2, also leased to CROET, includes subleased portions and another portion proposed for use as a laydown area supporting the barge facility.

The Office of Secure Transportation Firing Range is located to the east of the Central Training Facility and is operated by the NNSA Albuquerque Service Center. The surface danger zones for the Central Training Facility and the Office of Secure Transportation Firing Range overlap and together comprise about 2500 acres.

The Office of Secure Transportation Vehicle Maintenance Facility, is located about 1 mile east of ETTP, on the south side of State Route 58 (Oak Ridge Turnpike), near the intersection with Blair Road. The building is situated on a 20 -acre site and has undergone major modifications, including the addition of security fencing, paved parking, and paved access around the building. The total site area constitutes about 100 acres. The facility is maintained by the Y-12 Complex's Facilities, Infrastructure, and Services Organization and is funded by the NNSA Albuquerque Service Center.

The Union Valley Sample Preparation Facility is located on Union Valley Road. This facility houses laboratories that provide sample analysis for the three sites.

The Vance Road Facility is a DOE-owned facility operated by ORISE. The $59,800 \mathrm{ft}^{2}$ building is located in the middle of the Oak Ridge Methodist Medical Center complex. ORISE plans to vacate this building by June 30, 2005, to allow DOE to make it available for community reuse.

The Water Intake Station, located at Solway Bend, and the Water Treatment Plant, located on Pine Ridge just north of the Y-12 Complex, were transferred to the city of Oak Ridge on April 1, 2000 .

\subsubsection{Y-12 Complex}

The Y-12 National Security Complex (Fig. 1.8) is a manufacturing facility that plays an integral role in DOE's nuclear weapons complex. The National Nuclear Security Administration (NNSA) is the semi-independent agency within DOE that oversees the operation of the Y-12 National Security Complex. The complex was constructed as part of the World War II Manhattan Project. Construction for the Manhattan Project began with the first shovelful of dirt turned at 


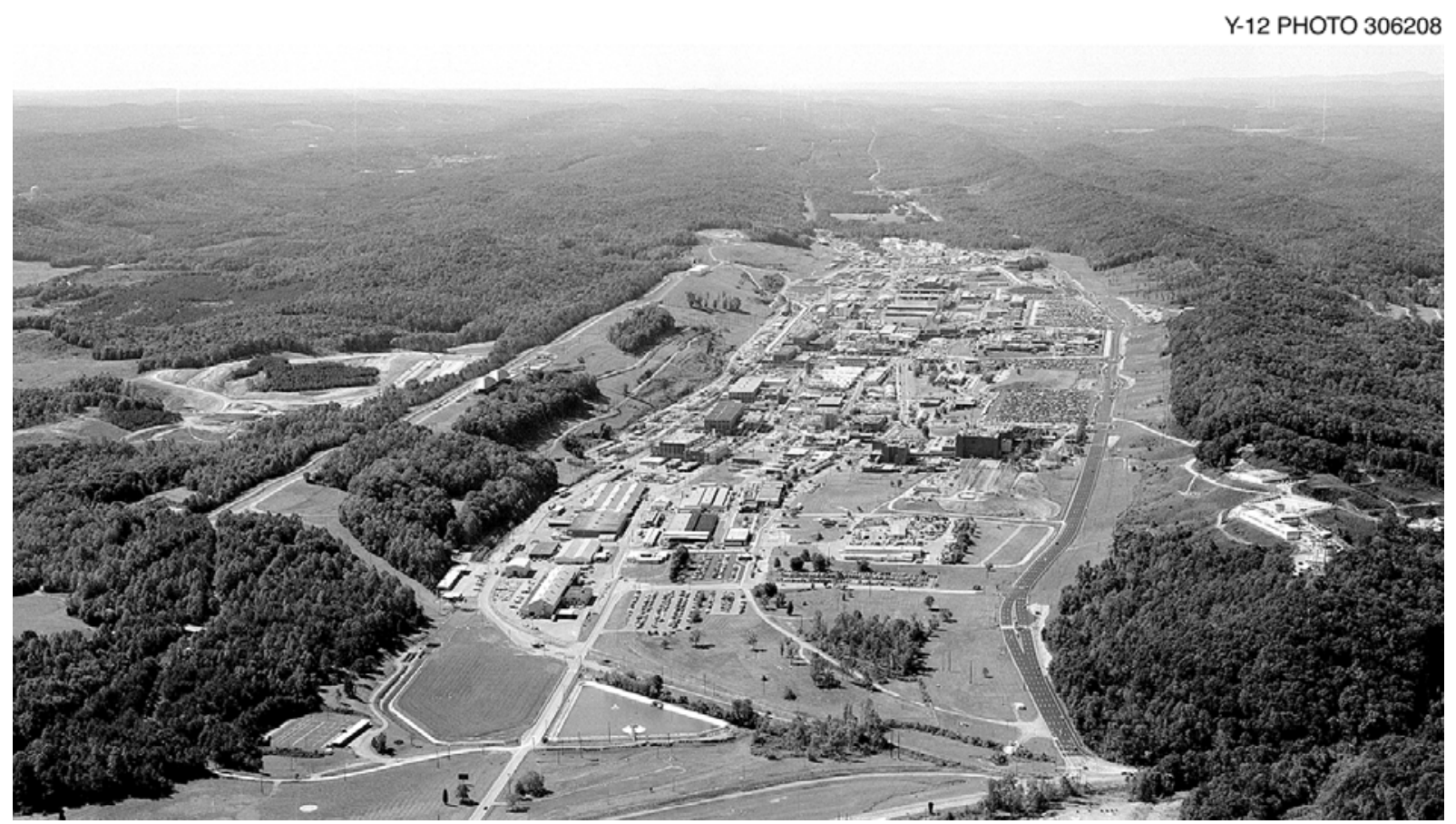

Figure 1.8. The Y-12 National Security Complex.

Y-12 in February 1943, and operations began in November of that year. The first site mission was the separation of uranium-235 from natural uranium by the electromagnetic separation process.

Today the NNSA mission of the Y-12 National Security Complex focuses on remanufacture, surveillance, and assessment of weapon components. The president and the Congress have directed DOE to maintain the safety and reliability of the nation's nuclear deterrent without underground nuclear testing. To do that, DOE has established a program of science-based stockpile stewardship. Y-12 is an integral part of that mission.

The focus at Y-12 on national security ensures its safe operation and management. Y-12 is the nation's "Fort Knox" for highly enriched uranium; the leader in uranium and lithium materials research, development, and processing; and the country's assembly and disassembly plant for nuclear weapon secondary components.

NNSA is in the process of tearing down old buildings, planning new state-of-the-art facilities, revitalizing the workforce, and bringing in new technology to ensure that $\mathrm{Y}-12$ will continue to meet its vital national security missions. Y-12 is pursuing an aggressive program of infrastructure reduction, modernization, and investment in tech- nology to make the plant as safe and efficient as possible and to improve production capabilities. The Y-12 National Security Complex Ten-Year Comprehensive Site Plan (Y/MOD-102) outlines the new construction, recapitalization, maintenance requirements, and excess facility making all these improvements while maintaining demolition required to modernize Y-12. Y-12 is safety, security, and environmental stewardship as its highest priorities.

\subsubsection{East Tennessee Technology Park}

The ETTP was built as the home of the Oak Ridge Gaseous Diffusion Plant (ORGDP) (Fig. 1.9). Construction of ORGDP began in the 1940s as part of the U.S. Army's Manhattan Project. The plant's mission was production of highly enriched uranium for nuclear weapons.

Enrichment was initially carried out in two process buildings, K-25 and K-27. Later, the $\mathrm{K}-29$, K-31, and K-33 buildings were built to increase the production capacity of the original facilities by raising the assay of the feed material entering K-27. After military production of highly enriched uranium was concluded in 1964, the two original process buildings were shut down. For the next 20 years, the plant's primary missions were production of only slightly enriched uranium to be 


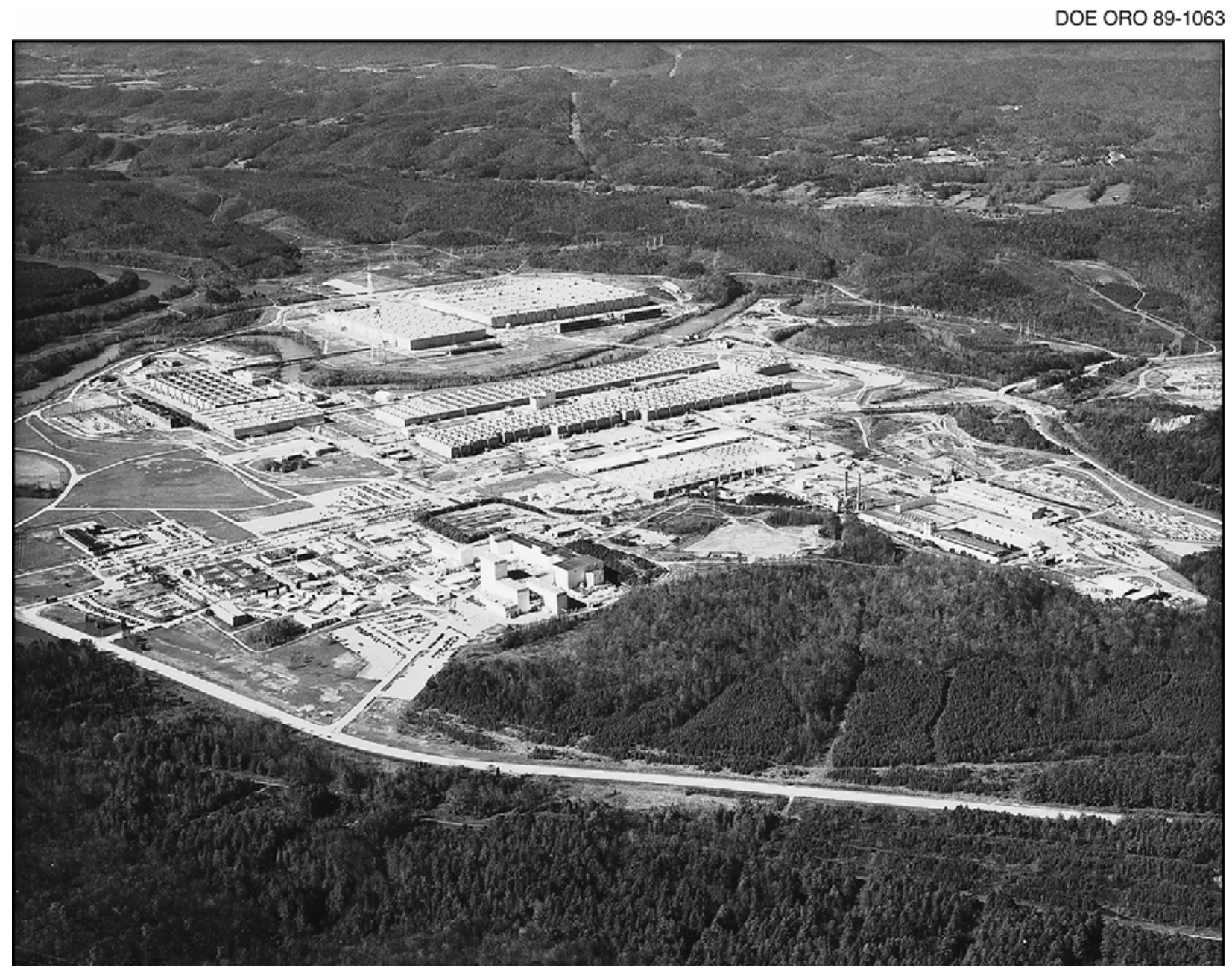

Fig. 1.9. The East Tennessee Technology Park

fabricated into fuel elements for nuclear reactors and the recycling of fuel elements from nuclear reactors. Other missions during the latter part of this 20-year period included development and testing of the gas centrifuge method of uranium enrichment and the laser isotope separation research and development (R\&D).

By 1985, demand for enriched uranium had declined, and the gaseous diffusion cascades at ORGDP were placed in standby mode. That same year, the gas centrifuge program was canceled. The decision to permanently shut down the diffusion cascades was announced in late 1987, and actions necessary to implement that decision were initiated soon thereafter. Because of the termination of the original and primary missions, ORGDP was named the "Oak Ridge K-25 Site" in 1990. In 1997, the K-25 Site was named the "East Tennessee Technology Park" to reflect its new mission.
DOE's long-term goal for ETTP is to convert the site into a private industrial park. The site is undergoing environmental cleanup, which is now expected to be completed on an accelerated schedule. The new accelerated closure plan will achieve cleanup several years ahead of the original plan, and, therefore, environmental and safety risks will be reduced more quickly and will save in long-term maintenance costs. The reuse of key site facilities through title transfer is part of the closure plan for the site.

The accelerated cleanup approach offers uncontaminated buildings, suitable for immediate private industrial use, for title transfer to CROET. CROET then leases the property to private industry and also recruits business to the area. The private entities at ETTP that have leased facilities from CROET are responsible for their own compliance programs, including requirements to obtain environmental permits as applicable. Any 
facilities at ETTP that remain unused will be demolished.

CROET leases portions of ETTP and then subleases these federally owned properties to business and industry. The ETTP mission is to reindustrialize and reuse site assets through leasing of excess or underutilized land and facilities and incorporation of commercial industrial organizations as partners in the ongoing environmental restoration, decontamination and decommissioning, and waste treatment and disposal. Since 2003, DOE has been actively working toward title transfer of a number of ETTP facilities, which is consistent with the Accelerated Closure Plan.

\subsubsection{Oak Ridge National Laboratory}

ORNL was the smallest of the three facilities built on the ORR for the Manhattan Project. (Fig. 1.10). From its modest beginning as a wartime pilot plant, ORNL has grown to become one of the world's premier scientific research centers and is DOE's largest and most diversified multiprogram national laboratory. As a multiprogram national laboratory, ORNL carries out $R \& D$ in support of all four of DOE's major missions: science and technology, energy resources, environmental quality, and national security.

Scientists and engineers at ORNL conduct basic and applied R\&D to create scientific knowl- edge and technological solutions that strengthen the nation's leadership in key areas of science; increase the availability of clean, abundant energy; restore and protect the environment; and contribute to national security. ORNL also performs other work for DOE, including isotope production, information management, and technical program management, and provides research and technical assistance to other organizations.

The management of ORNL also includes the management and planning for most of the ORR's undeveloped land area. This responsibility includes planning for approximately 18,000 acres of undeveloped and developed land.

The SNS site is located on 80 acres of Chestnut Ridge near ORNL. The SNS, an accelerator-based neutron source, will provide neutron beams with up to ten times more intensity than any other such source in the world. Construction began in 1999 and is scheduled for completion in 2006 at a total cost of $\$ 1.4$ billion. Design and construction is being performed by a partnership of six DOE national laboratories (Argonne, Brookhaven, Jefferson, Lawrence Berkeley, Los Alamos, and Oak Ridge). When completed, the SNS will be open to scientists and engineers from universities, industries, and government laboratories in the United States and abroad.

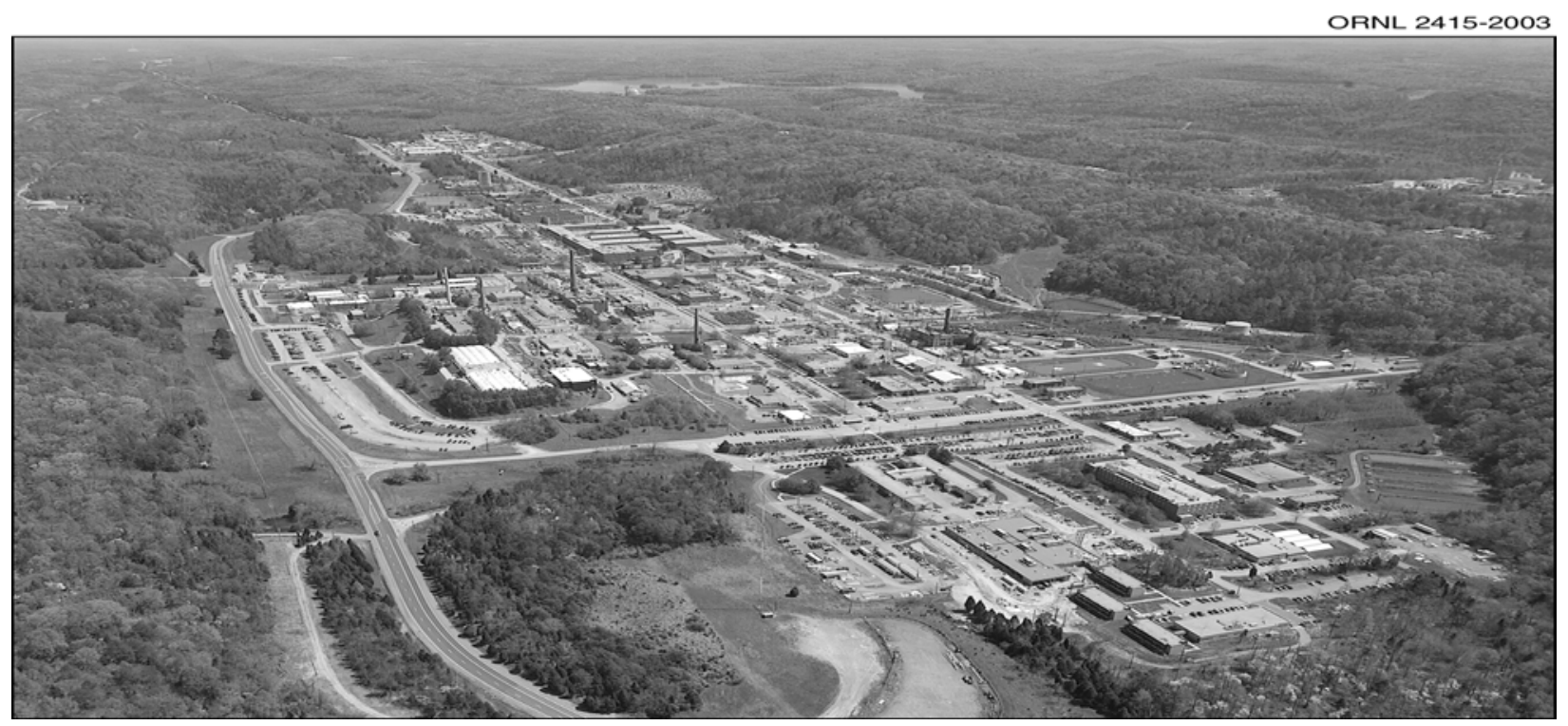

Figure 1.10 The Oak Ridge National Laboratory 


\subsubsection{Oak Ridge National Environmental Research Park}

The Oak Ridge National Environmental Research Park is an approximately 8,100-hectare (20,000-acre) "outdoor laboratory" with relatively undisturbed ecosystems (Fig. 1.11). The Research Park provides a protected, biologically diverse land area for environmental research and education. It represents the eastern deciduous forest, with more than 1100 species of vascular plants, some of which are state-listed rare plants, and 315 wildlife species, some of which are statelisted or federally listed rare wildlife species (see Chap. 2, Tables 2.8, 2.9, and 2.10 for listings). The park is a biosphere reserve, an ORNL user facility, a site that contains seven registered State Natural Areas, an area that plays a significant role in the nesting and migration of breeding birds, and the location of Freel's Cabin and the Graphite Reactor.
As part of a DOE commitment to protect the environmental assets of its sites, the secretary of energy set aside 1215 hectares (3000 acres) of the ORR at Freels, Gallaher, and Solway bends as the "Three Bend Scenic and Wildlife Refuge" in June 1999. The area, which remains part of the Research Park, is managed for conservation and wildlife enhancement by Tennessee Wildlife Resources Agency (TWRA) under a cooperative agreement between TWRA and DOE.

The biological diversity of the Research Park serves as a foundation for ecological research into how the development and use of energy as well as other issues of national importance affect the environment. More than 700 individuals have performed research in the Research Park User Facility during the last 5 years. Users include students and faculty from more than 75 colleges and universities as well as participants from ORNL and other state and federal agencies. Field research facilities occur across the reservation and include Walker Branch Watershed, the Global

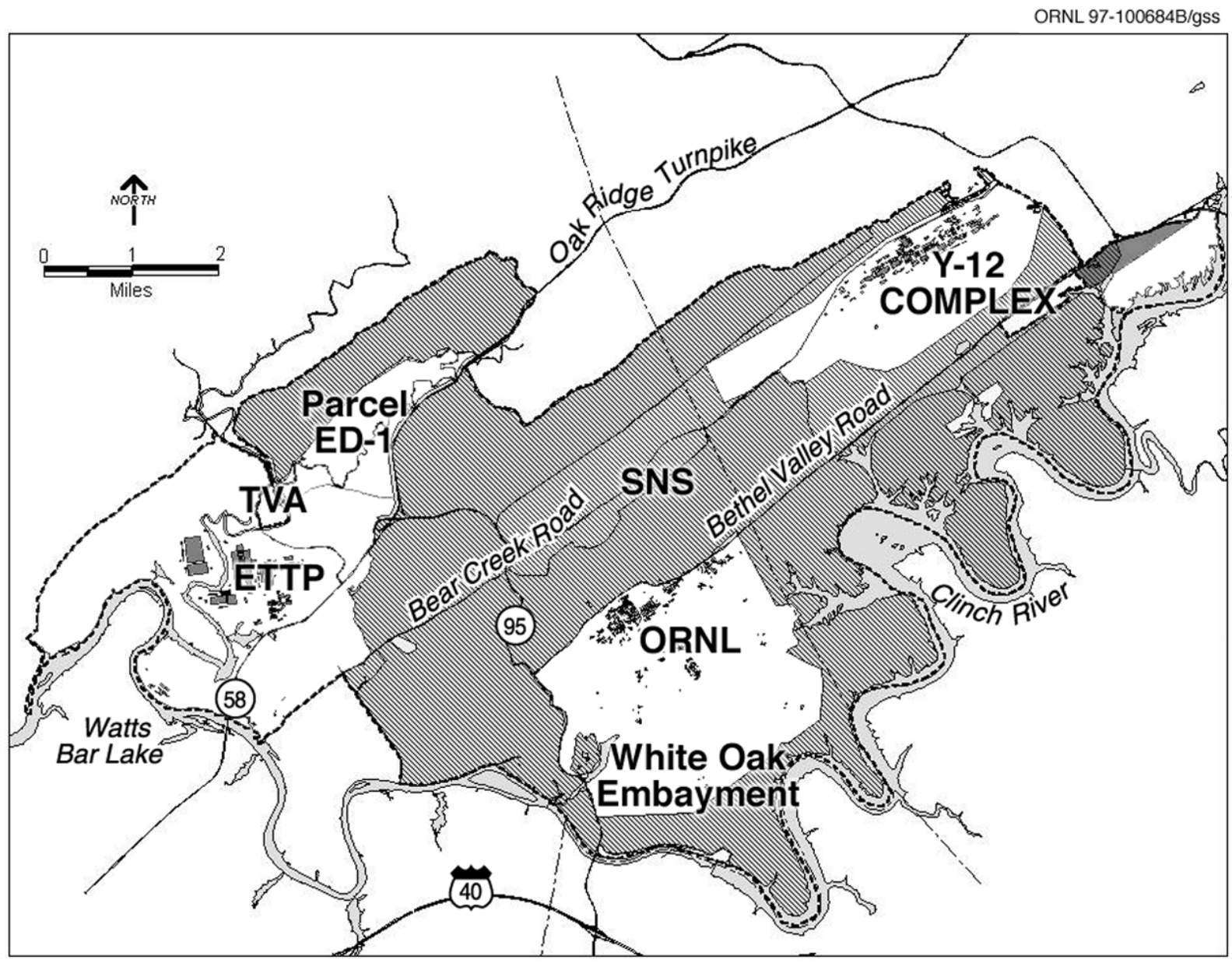

Figure 1.11. The Oak Ridge National Environmental Research Park covers approximately 20,000 acres on the reservation 
Change Field Research Facility, Melton Branch Watershed, and the Bear Creek Valley Hydrology Field Sites.

The park has supported research in the following areas.

- Ecosystems dynamics and biodiversity. The large, unfragmented land provides a base for investigations into biogeochemical cycling, climate-change impacts, air quality, and biotechnology and offers opportunities for wildlife restoration.

- Environmental characterization. As the most hydrologically and geologically complex of all DOE sites, the park provides opportunities for hydrogeologic and geophysical investigations, contaminant transport and fate studies, tracers for fractured media, microbial ecology, wetland surveys, and characterization of flora and fauna and their communities.

\subsubsection{Oak Ridge Institute for Science and Education}

ORISE is managed for DOE by ORAU, a nonprofit consortium of 88 doctoral-granting members and 9 associate members. ORISE includes 94.3 hectares (233 acres) on the southeastern border of the ORR that from the late 1940s to the mid-1980s was part of an agricultural experiment station owned by the federal government and, until 1981, was operated by UT.

The ORISE South Campus lies immediately southeast of the intersection of Bethel Valley Road and Pumphouse Road. The site houses offices, laboratories, and storage areas for ORISE's program offices and support departments, and it is being developed for other productive uses.

For more information, visit the ORAU home page at http://www.orau.org and the ORISE home page at http://www.orau.gov/orise.htm. 



\section{Environmental Compliance}

It is DOE Oak Ridge Operations Office (DOE-ORO) and DOE National Nuclear Security Administration (DOE-NNSA) policy to conduct its operations in compliance with federal, state, and local environmental protection laws, regulations, compliance agreements and decrees, settlement agreements, executive orders, DOE orders (as incorporated into the operating contracts), work smart standards, and best management practices. DOE and its contractors make every effort to conduct operations in compliance with the letter and intent of applicable environmental statutes. The protection of the public, personnel, and the environment is of paramount importance.

Except for the few instances of noncompliance discussed in this chapter, all ORR sites were in compliance with applicable environmental regulations in 2003.

Each site achieved a National Pollutant Discharge Elimination System (NPDES) permit compliance rate greater than $99.9 \%$ in 2003 .

In 2003, all three ORR facilities operated in compliance with the regulatory dose limits of Tennessee Rule 1200-3-11-.08 (Emission Standards for Hazardous Air Pollutants for Radionuclides) and met its emission and test procedures.

No releases of reportable quantities of hazardous chemicals or asbestos were reported under the Comprehensive Environmental Response, Compensation, and Liability Act (CERCLA) by any of the sites.

Several private businesses operate under leasing arrangements at the East Tennessee Technology Park (ETTP) under the DOE Reindustrialization Program. Lessees are accountable for complying with all applicable standards and regulations and for obtaining permits and licenses with local, state, and federal agencies as appropriate. Unless specified, lessee operations are not discussed in this report.

\subsection{INTRODUCTION}

DOE's operations on the reservation are required to be in conformance with environmental standards established by a number of federal and state statutes and regulations, executive orders, DOE orders, contract-based standards, and compliance and settlement agreements. However, numerous facilities at the ETTP site have been leased to private entities over the past several years through the DOE Reindustrialization Program.

Principal among the regulating agencies are the U.S. Environmental Protection Agency (EPA) and the Tennessee Department of Environment and Conservation (TDEC). These agencies issue permits, review compliance reports, participate in joint monitoring programs, inspect facilities and operations, and oversee compliance with applicable regulations.

When environmental issues are identified during routine operations or during ongoing selfassessments of compliance status, the issues are typically discussed with the regulatory agencies. In the following sections, major environmental statutes are summarized for the ORR sites.

\subsection{COMPLIANCE ACTIVITIES}

\subsubsection{Resource Conservation and Recovery Act}

The Resource Conservation and Recovery Act (RCRA) was passed in 1976 to address management of the country's huge volume of solid waste. The law requires that EPA regulate the management of hazardous waste, which includes waste solvents, waste chemicals, and many other substances deemed potentially harmful to human health and to the environment. RCRA also regulates underground storage tanks (USTs) used to store petroleum and hazardous substances; recyclable used oil; and batteries, mercury thermostats, selected pesticides, and fluorescent/hazardous-waste lamps as universal wastes.

Subtitle C of RCRA controls all aspects of the management of hazardous waste, from the point of generation to treatment, storage, disposal, and recycle (TSDR). Hazardous waste generators must follow specific requirements for handling these wastes. In addition, owners and operators of hazardous waste management facilities have operating and/or postclosure care permits.

Y-12, ORNL, and ETTP are considered RCRA large-quantity generators of hazardous 
waste. Each generates both RCRA hazardous waste and RCRA hazardous waste containing or contaminated with radionuclides (mixed waste).

The hazardous and/or mixed wastes are accumulated by individual generators at locations referred to as satellite accumulation areas or 90-day accumulation areas, as appropriate, where they are picked up by waste management personnel and transported to an ORR TSDR facility or shipped directly off site for treatment, storage, or disposal. At the end of 2003, Y-12 had 133 generator accumulation areas for hazardous or mixed waste; ORNL had 333 generator accumulation areas; and ETTP maintained 11. Each site is also regulated as a large-quantity handler of universal waste; however, the types of universal wastes managed as such at each site may vary.

The Union Valley Facility is also a largequantity generator of hazardous waste. At the end of 2003, this facility had nine satellite accumulation areas and one 90-day accumulation area.

ORISE is classified under RCRA as a conditionally exempt small-quantity generator.

The Central Training Facility on Bear Creek Road, the Office of Secure Transportation) Vehicle Maintenance Facility, the National Transportation Research Center, and the Freel's Bend area are also classified as conditionally exempt small-quantity generators.

Y-12 is registered as a large-quantity generator and a TSDR facility under EPA ID Number TN3890090001. Most of the units at the Y-12 Complex are being operated under operating permits; however, two units still operate under interim status in accordance with a Part A permit application. Six RCRA Part B permit applications have been submitted for storage and treatment units at the Y-12 Complex. Four Part B applications have been approved and issued as RCRA operating permits (Table 2.1). One application has been withdrawn because the unit (Interim Reactive Waste Treatment Unit) was closed in 1997. One application has not been acted on.

The first Y-12 permit (TNHW-032) was issued by TDEC in 1994 for tank and container storage units (commonly referred to as OD-7, OD-9, and OD-10). These units were closed in 2001 and 2002, and on April 4, 2003, the permit was terminated by TDEC. In 1995, TDEC issued permit TNHW-083 for container storage units and permit TNHW-084 for production-associated units. In 1996, TDEC issued permit TNHW-092 for the production and storage of classified waste.

These permits are modified whenever a change occurs to the area. During 2003, TNHW083, -084 , and -092 were modified to update the RCRA contingency plans and to change the name of the facility to the Y-12 National Security Complex. TNHW-083 and -092 were also modified to close some units and incorporate CERCLA closing language.

ORNL is registered as a large-quantity generator and a TSDR facility under EPA ID Number TN1890090003. During 2003, 23 units operated as interim-status or permitted units; another 7 units were proposed (new construction).

ORNL's RCRA units operate under three permits, TNHW-097, TNHW-010A, and TNHW-010; TNHW-010 is the existing RCRA Hazardous and Solid Waste Amendments (HSWA) permit for the ORR (see Table 2.1). These permits are modified when necessary. Two class 1 and two class 1-1 modifications were implemented and approved in 2003 addressing changes to the ORNL RCRA Contingency Plan.

ETTP is registered as a large-quantity generator and a TSDR facility under EPA ID Number TN0890090004. ETTP has received three RCRA permits (see Table 2.1). The K-1435 Toxic Substances Control Act (TSCA) Incinerator is a hazardous waste treatment unit operating under a RCRA permit (TNHW-015) issued by TDEC on September 28, 1987. A revised RCRA permit based on trial-burn results was received in December 1995. A reapplication of this permit was submitted to TDEC in March 1997. A second permit (TNHW-015A) is for storage of waste at the incinerator. Permit TNHW-056 covers container storage at various locations throughout the plant.

A RCRA Part B Permit Renewal Application to renew Permit No. TNHW-056 was prepared and submitted in April 2002. A Temporary Authorization was also submitted at this time to update the contingency plan and modify secondary containment language during TDEC review of the renewal application. 
Table 2.1. Resource Conservation and Recovery Act operating permits, 2003

\begin{tabular}{|c|c|}
\hline Permit number & Building/description \\
\hline & Y-12 Complex \\
\hline \multirow[t]{3}{*}{ TNHW-032 ${ }^{\mathrm{a}}$} & Building 9811-1 Tank Storage Unit (OD-7) (closed 2002) \\
\hline & Waste Oil/Solvent Storage Unit (OD-9) (closed 2001) \\
\hline & Liquid Organic Solvent Unit (OD-10) (closed 2001) \\
\hline \multirow[t]{6}{*}{ TNHW-083 } & Building 9720-9 Container Storage Unit \\
\hline & Building 9720-25 Container Storage Unit \\
\hline & Building 9720-31 Container Storage Unit \\
\hline & Building 9720-58 Container Storage Unit (closed 2002) \\
\hline & Building 9811-1 Container Storage Unit (closed 2002) \\
\hline & Portable Buildings $1 \& 2$ Container Storage Unit \\
\hline \multirow[t]{5}{*}{ TNHW-084 } & Building 9206 \\
\hline & Building 9212 \\
\hline & Building 9720-12 \\
\hline & Cyanide Treatment and Storage Unit \\
\hline & Organic Handling Unit \\
\hline \multirow{3}{*}{ TNHW-092 } & Building 9720-32 \\
\hline & Building 9720-59 (closed 2003) \\
\hline & ORNL \\
\hline TNHW-010 & Hazardous and Solid Waste Amendments only \\
\hline \multirow[t]{7}{*}{ TNHW-010A } & Building $7507 \mathrm{~W}$ Container Storage Unit \\
\hline & Building 7651 Container Storage Unit \\
\hline & Building 7652 Container Storage Unit ${ }^{b}$ \\
\hline & Building 7653 Container Storage Unit \\
\hline & Building 7654 Container Storage Unit \\
\hline & Building 7669 Container Storage Unit \\
\hline & Portable Buildings $1 \& 2$ Container Storage Unit \\
\hline \multirow[t]{14}{*}{ TNHW-097 } & Building 7572 Container Storage Unit \\
\hline & Building 7574 Container Storage Unit \\
\hline & Building 7576 Container Storage Unit \\
\hline & Building 7577 Container Storage Unit \\
\hline & Building 7580 Container Storage Unit \\
\hline & Building 7823 Container Storage Unit \\
\hline & Building 7824 Container Storage Unit \\
\hline & Building 7842 Container Storage Unit \\
\hline & Building 7855 Container Storage Unit \\
\hline & Building 7878 Container Storage Unit \\
\hline & Building 7879 Container Storage Unit \\
\hline & Building 7883 Container Storage Unit \\
\hline & Building 7884 Container Storage Unit \\
\hline & ETTP \\
\hline TNHW-015 & K-1435 Toxic Substances Control Act Incinerator \\
\hline TNHW-015A & K-1425 and K-1435 Container and Tank Storage Units \\
\hline TNHW-056 & $\begin{array}{l}\text { Container Storage Units and Waste Pile Units (19 storage } \\
\text { units in 2003) }\end{array}$ \\
\hline
\end{tabular}

${ }^{a}$ This permit was terminated by TDEC April 4, 2003.

${ }^{b}$ Incorporated May 1997; originally under TN1890090003 (TNHW-010) up to May 1997. 


\subsubsection{RCRA Assessments, Closures, and Corrective Measures}

The HSWAs to RCRA, passed in 1984, require any facility seeking a RCRA permit to identify, investigate, and (if necessary) clean up all former and current solid waste management units. The original HSWA permit (HSWA TN-001) for the ORR was issued by the EPA as an attachment to the RCRA permit for Building 7652 at ORNL. The HSWA permit requires DOE to address past, present, and future releases of hazardous constituents to the environment. The HSWA permit requirement for corrective action has been integrated into the ORR Federal Facility Agreement (see Sect. 2.2.2 for details). In March 1998, EPA and TDEC issued separate drafts of the HSWA permit for DOE review and comment. EPA's was issued as a stand-alone permit; TDEC's was issued as a modification to a Y-12 postclosure permit. DOE submitted comments on the draft permits; however, comment resolution is still pending.

The renewed permit will address contaminant releases from solid waste management units and from RCRA areas of concern, but will also integrate RCRA requirements with cleanups conducted under the Federal Facility Agreement and CERCLA programs (see Sect. 2.2.3). "Areas of concern" are areas contaminated by a release of hazardous constituents that originated from something other than a solid waste management unit. Under the existing HSWA permit, DOE must notify EPA within 30 days of identification of a new solid waste management unit or of planned significant changes to units that could alter further investigation or corrective action. DOE has provided to EPA the 2002 Annual Update of the Solid Waste Management Units for the Oak Ridge Reservation (DOE 2002a) (see Table 2.2). The renewed permits (TDEC and EPA versions) have not yet been issued.

At Y-12, 35 RCRA units have been closed since the mid-1980s. One permitted unit, the Building 9720-59 Container Storage Unit was certified closed in 2003.

Since the mid-1980s, ORNL has closed a total of 15 RCRA units. ORNL's Solid Waste Storage Area (SWSA) 6 is an interim-status disposal site (landfill) that underwent partial closure beginning in late 1988. Although a revised closure plan for SWSA 6 (which included the eight interimmeasure caps, the Hillcut Test Facility, and the Former Explosives Detonation Trench) was submitted in July 1995, actual final remediation of SWSA 6 has been deferred to CERCLA. The Melton Valley Record of Decision, which includes the selected remedy under CERCLA for SWSA 6, was signed in September 2000. A postclosure permit application for SWSA 6 was submitted to TDEC in September 2002; issuance of the postclosure permit is pending. The Interim Record of Decision for ORNL's Bethel Valley was issued in May 2002; its goal is to maintain the ORNL main plant as a controlled industrial-use facility.

At ETTP, the RCRA closure of K-1025C was completed. The only remaining RCRA-permitted vault in the K-25 Building is K-309-2A. RCRA Unit K-711 is slated for closure in FY 2004. Closure of K-1036A was deferred to CERCLA action. All other cleanup actions at ETTP are being conducted under CERCLA.

RCRA assessments conducted by TDEC at the facilities resulted in seven notices of violations (NOVs) issued in 2003. At Y-12, there was one NOV; at ORNL, there were four NOVs; and at ETTP, there was one NOV. Details of the violations are presented in Sect. 2.5.

\subsubsection{Land Disposal Restrictions}

The 1984 RCRA amendments established land disposal restrictions, which prohibited the land disposal of untreated hazardous wastes. The amendments require that all untreated wastes meet treatment standards before land disposal or that they be disposed of in a land disposal unit from which there will be no migration of hazardous constituents for as long as the waste remains hazardous. These restrictions also prohibit storage of restricted hazardous or mixed waste except as necessary to facilitate recovery, treatment, or disposal. Because treatment and disposal capacity for mixed wastes was unavailable for many years, DOE's storage of those mixed wastes over a year constituted RCRA land disposal restriction violations. To become compliant with RCRA, DOE entered into agreements with EPA, and later, with TDEC (see Sect. 2.2.4). 
Table 2.2. Summary of 2003 annual update of ORR solid waste management units (SWMUs)

\begin{tabular}{lc}
\hline \multicolumn{1}{c}{ Revision $^{a}$} & $\begin{array}{c}\text { Number of } \\
\text { sites/revisions }\end{array}$ \\
\hline Additional information/revisions made to SWMUs & 11 \\
Addition of SWMUs to A-1(a) list & 8 \\
SWMUs/areas of contamination moved from A-1(a) to A-2 & 19 \\
SWMUs/areas of contamination moved from A-2 to A-1(a) & 14 \\
\hline${ }^{a}$ U.S. Department of Energy. 2002a. Annual Update of the Solid Waste Management Units \\
for the Oak Ridge Reservation. Submitted to the U.S. Environmental Protection Agency (DOE \\
2002a).
\end{tabular}

\subsubsection{RCRA Subtitle D Solid Waste}

Located within the boundary of the Y-12 Complex are two Class II operating industrial solid waste disposal landfills and one operating Class IV construction demolition landfill. These facilities are permitted by TDEC and accept solid waste from DOE operations on the ORR. A second Class IV construction demolition landfill (Landfill VI) is closed pending certification. In addition, one Class IV facility (Spoil Area 1) is overfilled by $11,700 \mathrm{yd}^{3}$ and has been the subject of a CERCLA remedial investigation/feasibility study. A CERCLA record of decision for this unit was signed in 1997. One Class II facility (Landfill II) has been closed and is subject to postclosure care and maintenance. Associated TDEC permit numbers are noted in Table 2.3.

\subsubsection{RCRA Underground Storage Tanks}

USTs containing petroleum and hazardous substances are regulated under Subtitle I of RCRA, 40 CFR 280. TDEC has been granted authority by EPA to regulate USTs containing petroleum under TDEC Rule 1200-1-15; however, hazardous-substance USTs are still regulated by EPA. Table 2.4 summarizes the status of USTs on the ORR.

ORNL has responsibility for 54 USTs registered with TDEC under Facility ID Number 0-730089. These 54 USTs can be classified as follows: 49 USTs closed to meet the RCRA Subtitle I requirements; 3 USTs in service that meet the 1998 standards for new UST installations; 2 USTs still in service that are deferred or exempt from Subtitle I because they are regulated by other statutes [one UST under the RCRA Subtitle C and one UST under the Clean Water Act (CWA)]. Of the 49 closed USTs, 24 were replaced by double-walled, concrete-encased above-ground storage tanks; 3 were replaced by the new, state-of-the-art USTs; and 22 were not replaced because they were no longer needed. Closure approval letters have been received for all USTs closed between 1988 and 1998.

The Y-12 UST Program includes four active petroleum USTs that meet all current regulatory compliance requirements. Two of these are located at the Office of Secure Transportation Vehicle Maintenance Facility. The UST registration certificates for these tanks are current, and certificates are posted at the UST locations, enabling fuel delivery until March 31, 2005.

All legacy petroleum UST sites at Y-12 have either been granted final closure by TDEC or have been deferred to the CERCLA process for further investigation and remediation.

The ETTP UST Program includes two active petroleum USTs that meet all current regulatory compliance requirements. The UST registration certificates are updated annually and are conspicuously posted in accordance with TDEC rules. Fourteen other petroleum USTs have been removed or closed in place with TDEC regulators' recommendation of "case closed" status.

Five hazardous substance USTs at ETTP have been removed since 1996. One other hazardous substance UST designed as a spill overflow tank is present at ETTP but has never been activated.

Sixteen known and/or suspected historical USTs that were out of service before January 1, 1974, are also included in the ETTP UST Program as a best management practice. These historical UST sites could be subject to closure require 
Table 2.3. RCRA Subtitle D landfills, 2003

\begin{tabular}{lll}
\hline \multicolumn{1}{c}{ Facility } & TDEC permit number & \multicolumn{1}{c}{ Comments } \\
\hline Industrial Landfill IV & IDL-01-103-0075 & Operating, Class II \\
Industrial Landfill V & IDL-01-103-0083 & $\begin{array}{l}\text { Operating, Class II } \\
\text { Construction and Demolition Landfill }\end{array}$ \\
$\begin{array}{lll}\text { DML-01-103-0012 } \\
\text { Overfilled, Class IV } \\
\text { Landfruction and Demolition }\end{array}$ & DML-01-103-0036 & $\begin{array}{l}\text { Subject of CERCLA }{ }^{a} \text { record of decision } \\
\text { Postclosure care and maintenance }\end{array}$ \\
$\begin{array}{l}\text { Construction and Demolition } \\
\text { Landfill VII }\end{array}$ & DML-01-103-0045 & Operating, Class IV \\
Centralized Industrial Landfill II & IDL-01-103-0189 & Postclosure care and maintenance \\
\hline
\end{tabular}

${ }^{a}$ Comprehensive Environmental Response, Compensation, and Liability Act

Table 2.4. ORR underground storage tank (UST) status, 2003

\begin{tabular}{lccc}
\hline & Y-12 & ORNL & ETTP \\
\hline Active/in-service & $4^{a}$ & 3 & 2 \\
Closed & 40 & $51^{b}$ & 14 \\
Hazardous substance & $3^{c}$ & $0^{d}$ & $6^{e}$ \\
Known or suspected & 0 & 0 & 16 \\
$\quad$ sites & & & \\
$\quad$ Total & 47 & 54 & 38 \\
\hline
\end{tabular}

${ }^{a}$ Two are located off the Y-12 Complex at the Office of Secure Transportation Vehicle Maintenance Facility.

${ }^{b}$ The 51 "closed" USTs include deferred or excluded tanks of various categories, as detailed in the text.

${ }^{c}$ Two USTs are deferred because they are regulated by the Atomic Energy Act of 1954. The third is a permanently closed methanol UST.

${ }^{d}$ Closed tanks include two hazardous substance tanks, both of which were excavated, removed, and dismantled.

${ }^{e}$ Four USTs were permanently closed that had been used to store natural gas odorant and are regulated under the Pipeline Safety Act. A fifth UST, designed as a spill-overflow tank, has never permanently been placed into service. A sixth UST, which stored a methanolgasoline mixture, was permanently closed.

ments if directed by UST regulators. Magnetic and electromagnetic geophysical techniques are being used for detection and characterization of these historical UST sites and other underground structures to provide property database information for reindustrialization of ETTP.

A detailed description of all ORNL, Y-12, and ETTP USTs and their status is included in Appendix C of the CY 2000 Annual Site Environmental Report (ASER) (DOE 2001d).

\subsubsection{Comprehensive Environmental Response, Compensation, and Liability Act}

CERCLA, also known as Superfund, was passed in 1980 and was amended in 1986 by the Superfund Amendments and Reauthorization Act (SARA). Under CERCLA, a site is investigated and remediated if it poses significant risk to health or the environment. The EPA National Priorities List is a comprehensive list of sites and facilities that have been found to pose a sufficient threat to 
human health and/or the environment to warrant cleanup under CERCLA. The ORR was placed on the National Priorities List on November 21, 1989, ensuring that the environmental impacts associated with past and present activities at the ORR are thoroughly investigated and that appropriate remedial actions or corrective measures are taken as necessary to protect human health and the environment. An interagency agreement, known as the ORR Federal Facility Agreement, under Section 120(c) of CERCLA was signed in January 1991 by EPA, TDEC, and DOE. This agreement establishes the procedural framework and schedule for developing, implementing, and monitoring response actions on the ORR in accordance with CERCLA. Appendix $C$ of the Federal Facility Agreement lists all of the sites/areas that will be investigated, and possibly remediated, under CERCLA. Milestones for completion of CERCLA documents are available in Appendix E of the agreement.

The progress toward achieving these goals is described in the 2003 Remediation Effectiveness Report for the U.S. Department of Energy Oak Ridge Reservation, Oak Ridge, Tennessee (DOE 2003a). This report describes the individual remedial actions and provides an overview of some of the monitoring conducted to evaluate the efficacy of those actions.

Staff from NNSA and BWXT Y-12 have provided periodic updates of $\mathrm{Y}-12$ 's proposed construction and demolition activities (including alternative financing projects) to managers and project personnel from the TDEC DOE Oversight Division, EPA Region 4, and DOE-ORO. A CERCLA screening process has been proposed to identify proposed construction and demolition projects that warrant CERCLA oversight. The goal is to ensure that modernization efforts do not impact the effectiveness of previously completed CERCLA environmental remedial actions, nor adversely impact future CERCLA environmental remedial actions.

\subsubsection{RCRA-CERCLA Coordination}

The CERCLA response action and RCRA corrective action processes are similar and include four steps with similar purposes (Table 2.5). The ORR Federal Facility Agreement is intended to coordinate the corrective action processes of RCRA required under the HSWA permit with CERCLA response actions.

As a further example, three RCRA postclosure permits, one for each of the three hydrogeologic regimes at Y-12, have been issued to address the seven major closed waste disposal areas at Y-12. Because it falls under the jurisdiction of two postclosure permits, the S-3 Pond Site is described as having two parts (east and west) (see Table 2.6). Groundwater corrective actions required under the postclosure permits have been deferred to CERCLA. Reporting of groundwater monitoring data will comply with RCRA postclosure permit conditions as well as with CERCLA requirements.

\subsubsection{Federal Facility Compliance Act}

The Federal Facility Compliance Act was signed by Congress to bring federal facilities (including those under DOE) into full compliance with RCRA. The Federal Facility Compliance Act waives the government's sovereign immunity, allowing fines and penalties to be imposed for RCRA violations at DOE facilities. In addition, the act requires that DOE facilities provide comprehensive data to EPA and state regulatory agencies on mixed-waste inventories, treatment capacities, and development of site treatment plans. It ensures that the public will be informed of waste-treatment options and encourages active public participation in the decisions affecting federal facilities. TDEC is the authorized regulatory agency under the act for the DOE facilities in the state of Tennessee.

The ORR Site Treatment Plan calls for lowlevel waste on the ORR to be treated by a combination of commercial treatment capabilities and existing and modified on-site treatment facilities. Mixed transuranic waste streams on the ORR, composed of both contact- and remotehandled wastes, will be treated in the Transuranic Waste Processing Facility only as necessary to meet the waste acceptance criteria for disposal at the Waste Isolation Pilot Plant (WIPP). Construction of the facility was completed in fall 2003, and operations will begin in early 2004. It is operated by the Foster Wheeler Corporation. 
Table 2.5. RCRA corrective action processes and CERCLA response actions

\begin{tabular}{lll}
\hline \multicolumn{1}{c}{ RCRA } & \multicolumn{1}{c}{ CERCLA } & \multicolumn{1}{c}{ Purpose } \\
\hline RCRA facility assessment & $\begin{array}{c}\text { Preliminary assessment/site } \\
\text { investigation }\end{array}$ & $\begin{array}{c}\text { Identify releases needing further } \\
\text { investigation }\end{array}$ \\
RCRA facility investigation & Remedial investigation & $\begin{array}{c}\text { Characterize nature, extent, and } \\
\text { rate of contaminant releases }\end{array}$ \\
$\begin{array}{l}\text { Corrective measures study } \\
\begin{array}{c}\text { Corrective measures } \\
\text { implementation }\end{array}\end{array}$ & Feasibility study & $\begin{array}{l}\text { Evaluate and select remedy } \\
\text { Design and implement chosen } \\
\text { remedy }\end{array}$ \\
\hline
\end{tabular}

The ORR Site Treatment Plan provides overall schedules, milestones, and target dates for achieving compliance with land disposal restrictions; a general framework for the establishment and review of milestones; and other provisions for implementing the plan that are enforceable under the commissioner's order.

Semiannual progress reports document the quantity of land-disposal-restriction mixed waste in storage at the end of the previous six-month period and the estimated quantity to be placed in storage for the next five fiscal years. All milestones and commitments for the ORR Site Treatment Plan were met for CY 2003. The annual update of the plan has been issued for CY 2004.

The Site Treatment Plan will terminate in accordance with Sect. 2.7.2, when there is no longer any land disposal restriction mixed waste, regardless of when generated, being stored on the ORR, which in the absence of a site treatment plan, would be in violation of RCRA Section 3004(j).

\subsubsection{National Environmental Policy Act}

The National Environmental Policy Act (NEPA) provides a means to evaluate the potential environmental impact of proposed federal activities and to examine alternatives to those actions. The NEPA review process results in the preparation of NEPA documents in which federal, state, and local environmental regulations and DOE orders applicable to the environmental resource areas must be considered. These environmental resource areas include air, surface water, groundwater, terrestrial and aquatic ecology, threatened and/or endangered species, land use, and environmentally sensitive areas. Environmentally sensitive areas include floodplains, wetlands, prime farm land, habitats for threatened and/or endangered species, historic properties, and archaeological sites. Each ORR site NEPA program maintains compliance with NEPA through the use of its site-level procedures and program descriptions. These procedures and program descriptions assist in establishing effective and responsive communications with program managers and project engineers to establish NEPA as a key consideration in the formative stages of project planning. Table 2.7 notes the types of NEPA activities conducted at the ORR during 2003.

During 2003, ORNL operated under a procedure that provided requirements for project reviews and compliance with NEPA. It called for review of each proposed project, activity, or facility for its potential to result in significant impacts to the environment. To streamline the NEPA review and documentation process, DOEORO approved "generic" categorical exclusions that would cover proposed bench- and pilot-scale research activities and generic categorical exclusions that would cover proposed nonresearch activities (i.e., maintenance activities, facilities upgrades, personnel safety enhancements) . A categorical exclusion is one of a category of actions defined in 40 CFR 1508.4 that does not individually or cumulatively have a significant effect on the human environment and for which neither an environmental assessment nor an environmental impact statement is normally 
Table 2.6. RCRA postclosure status for former treatment, storage, and disposal units at Y-12

\begin{tabular}{l}
\hline Unit \\
\hline Uppew Hope Pond \\
New \\
Eastern S-3 Ponds Groundwater \\
Plume
\end{tabular}

Major components of closure

Major postclosure requirements

Upper East Fork Poplar Creek Hydrogeologic Regime (RCRA Postclosure Permit No. TNHW-089)

Plume

Chestnut Ridge Sediment Disposal

Oil Landfarm

Bear Creek Burial Grounds A, B, and Walk-In Pits
Kerr Hollow Quarry

Basin

Chestnut Ridge Security Pits

Former S-3 Ponds (S-3 Site)
Engineered cap, Upper East Fork Poplar Creek distribution channel

None for groundwater plume, see former S-3 Ponds (S-3 Site) for source area closure
Cap inspection and maintenance. No current groundwater monitoring requirements in lieu of ongoing CERCLA actions in the eastern portion of $\mathrm{Y}-12$

Postclosure corrective action monitoring. Inspection and maintenance of monitoring network

\section{Chestnut Ridge Hydrogeologic Regime (RCRA Postclosure Permit No. TNHW-088)}

$$
\text { Engineered cap }
$$

Waste removal, access controls

Engineered cap
Cap inspection and maintenance. Postclosure corrective action monitoring. Inspection and maintenance of monitoring network and survey benchmarks

Access controls inspection and maintenance. Postclosure detection monitoring. Inspection and maintenance of monitoring network and survey benchmarks

Cap inspection and maintenance. Postclosure detection monitoring. Inspection and maintenance of monitoring network and survey benchmarks

Bear Creek Hydrogeologic Regime (RCRA Postclosure Permit No. TNHW-087)

Neutralization and stabilization of

Cap inspection and maintenance. wastes, engineered cap, asphalt cover Postclosure corrective action monitoring. Inspection and maintenance of monitoring network and survey benchmarks

Engineered cap

Engineered cap, leachate collection system specific to the burial grounds
Cap inspection and maintenance. Postclosure corrective action monitoring. Inspection and maintenance of monitoring network and survey benchmarks

Cap inspection and maintenance. Post-closure corrective action monitoring. Inspection and maintenance of monitoring network and survey benchmarks. 
Table 2.7. National Environmental Policy Act (NEPA) activities during 2003

\begin{tabular}{|c|c|c|c|c|}
\hline Types of NEPA documentation & Y-12 Complex & ORNL & ETTP & ORR \\
\hline Categorical exclusion $(\mathrm{CX})$ recommendation & 23 & 4 & 1 & \\
\hline Specific CX granted & 23 & 4 & & \\
\hline Approved under general CX documents & $66,4^{a}$ & $41^{b}$ & 29 & \\
\hline Environmental assessment (EA) & & & & 0.08 \\
\hline \multicolumn{5}{|l|}{ EA determination } \\
\hline \multicolumn{5}{|l|}{ Special EA } \\
\hline \multicolumn{5}{|l|}{ Programmatic EA } \\
\hline Supplemental analysis & $1^{c}$ & 1 & & \\
\hline \multicolumn{5}{|l|}{ Environmental impact statement (EIS) } \\
\hline \multicolumn{5}{|l|}{ Supplemental EIS } \\
\hline \multicolumn{5}{|l|}{ Programmatic EIS } \\
\hline $\begin{array}{l}{ }^{a} \text { NNSA Small Business Projects. } \\
{ }^{b} \text { Projects that were reviewed and documented } \\
{ }^{c} \text { A sitewide environmental impact statement fo } \\
\text { September } 2001 \text {. This supplemental analysis, } \\
\text { oxide. }\end{array}$ & $\begin{array}{l}\text { pugh the ORNL } \\
\text { perations of the } \\
\text { formed by ORNI }\end{array}$ & $\begin{array}{l}\text { Compl } \\
\text { Comples } \\
\text { Iresses st }\end{array}$ & $\begin{array}{l}\text { Soordin } \\
\text { ssued } i \\
\text { of nept }\end{array}$ & $\begin{array}{l}\text { tor. } \\
\text { nium }\end{array}$ \\
\hline
\end{tabular}

required. Table 2.7 provides the number of project-specific categorical exclusions that were submitted to DOE-ORO for review and approval during 2003.

The Standards-Based Management System (SBMS) is the delivery system used to manage and control work at ORNL. This system uses three work-control categories: (1) research and development (R\&D) programs and projects; (2) operations, maintenance and services; and (3) office environment (e.g., management, office support, and clerical activities). NEPA is an integral part of SBMS and often utilizes the division's principal investigators, environmental compliance representatives, and environmental protection officers to determine the appropriate NEPA decision. The NEPA decision is based on the approved generic categorical exclusions for a particular division, NEPA training of the person and, when necessary, guidance from the ORNL NEPA compliance coordinator. Projects involving the assignment of a project engineer from ORNL Facilities Development Division, projects that are outside the scope of generic categorical exclusions, and projects that will adversely impact cultural resources are reviewed and documented by the ORNL NEPA compliance coordinator.

DOE implemented the Facilities Revitalization Project at ORNL, and groundbreaking activities for the various infrastructures (e.g., parking lots, utilities) started in March 2002. The Facilities Revitalization Project is being accomplished through a cooperative effort between DOE, the state of Tennessee, and private entities. The environmental assessment and finding of no significant impact (DOE 2001b) that were prepared by DOE addressed the Facilities Revitalization Project phased program approach to cover construction and upgrading of facilities according to ORNL's Strategic Facilities Plan into FY 2011. A Supplement Analysis was drafted for the proposed change to storage of Neptunium oxide for the Plutonium-238 Program. The Supplement Analysis addressed the temporary storage of neptunium oxide in shipping packages at the Y-12 NNSA complex as an alternative to the temporary storage in wells inside Building 7930 at ORNL prior to use.

DOE has prepared a draft environmental assessment for the United States Enrichment Corporation Centrifuge Research and Development Project at ETTP.

In 2003, an addendum was prepared for the Final Environmental Assessment, Lease of Land and Facilities within the East Tennessee Technology Park, Oak Ridge, Tennessee (ORO 1997). This addendum (ORO 2003) was completed and approved in July 2003 with a finding of no significant impact. This addendum was prepared to transfer title of unneeded DOE 
real property at ETTP to help support the accelerated cleanup of ETTP and to continue to support economic development in the region.

In 2003, NEPA reviews supported five title transfer actions and two potential lease actions as well as tenant modifications and improvements to facilities. Other NEPA reviews covered more routine maintenance actions, such as utility deactivation of several facilities, the decontamination and decommissioning of a facility, and trailer removals. One job-specific categorical exclusion was prepared and approved in 2003 for ETTP. This was for the reuse and recycling of lithium material being stored at ETTP and sodium material being stored at ORNL.

At Y-12, 23 job-specific categorical exclusion documents were prepared and were approved in 2003 in support of the Infrastructure Reduction Program. The Infrastructure Reduction effort is focused on preparing the Y-12 Complex for modernization; during FY 2003 it reduced the Y-12 "footprint" by over 107,000 $\mathrm{ft}^{2}$ through building demolition. In addition, job-specific categorical exclusions prepared by Bechtel Jacobs Company, LLC (BJC) were approved for the closure of Y-12 RCRA container storage unit 9720-59 and for the sale of excess lithium material. A supplemental analysis to the Y-12 sitewide environmental impact statement was conducted by ORNL and approved for the storage of neptunium oxide (a material important to the energy $R \& D$ and isotope production missions in the United States) at the Y-12 Complex. Other general NEPA categorical exclusion reviews covered routine actions, such as office renovations, improvements to security systems, equipment replacements, and infrastructure improvements. A total of 90 NEPA reviews were performed and approved in 2003.

The Defense National Stockpile Center has prepared a Draft Mercury Management Environmental Impact Statement (April 2003) to help determine how to manage its elemental mercury inventory over the long term, because it is no longer needed for our national defense. The center has selected consolidated storage as its preferred alternative based on a combination of environmental, economic and technical factors; policy considerations; and public and stakeholder comments. "Preferred alternative" means that, at this time, storing the mercury at one site is the best way to meet the center's objectives.

\subsubsection{National Historic Preservation Act}

In March 2003, President Bush signed Executive Order 13287, Preserve America, directing federal agencies to improve their management of historic properties and to foster heritage tourism in partnership with local communities. Section 106 of the National Historic Preservation Act (NHPA) requires that federal agencies take into account the effects of their undertakings on properties included in or eligible for inclusion in the National Register of Historic Places (National Park Service 2002). To comply with Section 106 of the NHPA and its implementing regulations at 36 CFR 800, DOEORO was instrumental in the ratification of a programmatic agreement among DOE-ORO, the Tennessee state historic preservation officer), and the Advisory Council (Council) on Historic Preservation concerning management of historical and cultural properties on the ORR. The programmatic agreement was ratified on May 6, 1994, and has been incorporated into the approved Cultural Resource Management Plan, DOE Oak Ridge Reservation (DOE 2001a). The plan was completed in accordance with stipulations in the programmatic agreement, including historical surveys to identify significant historical properties on the ORR.

Compliance with NHPA at ORNL, Y-12, and ETTP is achieved and maintained in conjunction with NEPA compliance. The scope of proposed actions is reviewed in accordance with the Cultural Resource Management Plan. If warranted, consultation is initiated with the state historic preservation officer and the Council, and the appropriate level of documentation is prepared and submitted. A memorandum of agreement was signed by DOE-ORO (September 16, 2002) and the state historic preservation officer (September 30, 2002) for the demolition of ORNL Buildings 2000, 2001, 3013, 3550, 9211, and 9743-2. Buildings 9211 and 9743-2 are ORNLmanaged facilities that are located at the Y-12 Complex. A stipulation in the memorandum required ORNL to prepare and submit a site historic preservation plan and sitewide 
programmatic agreement to the state historic preservation officer and the Council within an 18month period following the signing of the memorandum. A draft of the historic preservation plan/programmatic agreement has been completed, comments have been received and incorporated, and a final version is being prepared for submittal to the state historic preservation officer in March 2004. In addition, a programmatic agreement among DOE-ORO, National Nuclear Security Administration, the state historic preservation officer, and the Council was signed (August 25, 2003) for the demolition of Buildings 9207 and 9210, which are ORNLmanaged facilities at the Y-12 Complex. These two facilities will be captured in an Interpretive Plan that will be developed in consultation with the state historic preservation officer and the Council prior to demolition activities.

A memorandum of agreement (MOA) was signed by NNSA and the state historic preservation officer on May 23, 2002, for the demolition of 10 historic buildings at the Y-12 Complex. A stipulation in the MOA required Y-12 to prepare and submit a Site Historic Preservation plan and site-wide programmatic agreement to the State Historic Preservation Officer and Advisory Council within a 12-month period following the signing of the memorandum.

The Sitewide Programmatic Agreement Among the Department of Energy Oak Ridge Operations Office, the National Nuclear Security Administration, the Tennessee State Historic Preservation Office, and the Advisory Council on Historic Preservation Concerning the Management of Historical and Cultural Properties at the Y-12 Complex provides implementing procedures to ensure the protection of the remaining 77 historic properties and structures at the Y-12 Complex. The historic preservation plan entitled "National Historical Preservation Act Historic Preservation Plan, Y/TS 1893, provides an effective approach to preserving the historically significant features of Y-12's historic buildings and structures. Both the plan and the programmatic agreement were reviewed and approved by DOE NNSA, DOE-ORO, the Tennessee state historic preservation officer, and Advisory Council on Historic Preservation, August 2003 and November 2003, respectively. In accordance with the programmatic agreement,
Section 106 recordation, interpretation, and documentation information was submitted to the state historic preservation officer for the demolition of Buildings 9404-6, 9404-12, 9416-4, 9419-2, 9723-24, and 9729. The state historic preservation officer reviewed and agreed that the Section 106 documentation adequately mitigated project effects upon properties eligible for listing in the National Register of Historic Places.

ETTP was surveyed in 1994 to identify properties eligible for inclusion in the National Register. An archaeological survey was also completed at ETTP. Properties eligible for inclusion in the National Register include the ETTP Main Plant Historic District, which includes facilities within the main plant and contains 120 contributing structures, 37 noncontributing structures, and 11 structures that are not contiguous with the historic district. More detailed information on the properties eligible for inclusion in the National Register is provided in the Cultural Resource Management Plan (DOE 2001a).

In August 2002, DOE submitted a notification of adverse effect of a proposed undertaking for decontamination and decommissioning of properties located at the ETTP. The proposed project is to decontaminate and demolish or transfer all remaining properties located within the K-25 Site Main Plant and Powerhouse Historic Districts located on the ORR in Roane County, Tennessee, as outlined in the Oak Ridge Comprehensive Closure Plan. The Tennessee state historic preservation officer, the Advisory Council, and other interested parties were invited to participate in the planning stages of the proposed undertaking and to enter into the consultation process. Consultation began in 2003 to develop a path forward, and a memorandum of agreement will be negotiated among the consulting parties. During 2003, consultation continued with the Advisory Council, the state historic preservation officer, and other consulting parties on the decontamination and decommissioning of the $\mathrm{K}-25$ and K-27 Buildings to determine actions to avoid, minimize, or mitigate the adverse effects to these two historical properties. A draft memorandum of agreement was prepared and signed by all consulting parties. Other ETTP projects were reviewed in accordance with the programmatic agreement or the Cultural Resource Management 
Plan, and no additional adverse effects to historical properties were identified that required notification to the state historic preservation officer. An architectural and engineering firm was retained to develop design proposals for capturing and presenting the historical significance of the K25 and K-27 facilities in 2003 . The report is scheduled to be completed and presented to the consulting parties in 2004.

A survey of all ORISE structures was conducted to comply with the NHPA. Only one structure currently under ORISE stewardship, the Atmospheric Turbulence and Diffusion Division Laboratory main building, was identified as being included in the National Register. All actions performed at that site conform to the programmatic agreement with the state historic preservation officer.

\subsubsection{Protection of Wetlands}

Executive Order 11990 (issued in 1977) was established to mitigate adverse effects to wetlands caused by their destruction or modification and to avoid construction in wetlands wherever possible. Avoidance of these effects is ensured through implementation of the sensitive-resource analysis conducted as part of the DOE NEPA review process. Protective buffer zones and application of best management practices are required for activities on the ORR. Coordination with TDEC, the U.S. Army Corps of Engineers, and sometimes TVA is necessary for activities involving waters of the United States and waters of the state, which include wetlands and floodplains. Generally, this coordination results in permits from the Corps of Engineers, TVA, and/or the state of Tennessee (see Sect. 2.2.12.4 for permitting details). In addition, TDEC has developed a regulatory position on impacted wetlands that includes mitigation: affected wetlands must be replaced in area and function by restoration of disturbed wetlands, construction of wetlands, or enhancement of previously impacted areas.

The ORR implements protection of wetlands through each site's NEPA program in accordance with 10 CFR 1022, "Compliance With Floodplain/Wetlands Environmental Review Requirements." Each of the sites has also conducted surveys for the presence of wetlands and conducts surveys on a project- or program-as- needed basis. In the early to middle 1990s, an effort was initiated to conduct a wetlands survey of the entire reservation (LMES 1995). That effort was not completed, but it was reported in the 1995 ASER (LMER 1996) that wetland surveys and delineations were conducted on about 14,000 acres (5668 ha) of the 34,424 acres $(13,968 \mathrm{ha})$ that made up the reservation. About 600 acres (243 ha) of wetlands were identified in the areas in which surveys were conducted. Since then, wetland surveys have been conducted on an as-needed basis.

Y-12 has conducted two surveys of its wetlands resources. Identification and Characterization of Wetlands in the Bear Creek Watershed (MMES 1993) was completed in October 1993, and a wetland survey of selected areas in the Y-12 Complex area of responsibility was completed in October 1994. The first report surveys the Y-12 Complex and surrounding areas; the second report, Wetland Survey of Selected Areas in the Oak Ridge Y-12 Plant Area of Responsibility, Oak Ridge, Tennessee (LMES 1997a), surveys additional areas for which restoration activities are planned.

A wetlands survey of ORNL areas, Wetland Survey of the X-10 Bethel Valley and Melton Valley Groundwater Operable Units at Oak Ridge National Laboratory (Rosensteel 1996), serves as a reference document to support wetlands assessments for upcoming ORNL projects and activities.

A wetland mitigation plan, Project Description and Wetland Mitigation Plan, Spallation Neutron Source Bethel Valley Access Road, Anderson County and Roane County, Tennessee (SNS 2001), was developed in March 2000, as a result of projected impacts to a small wetland from the construction of the new SNS access road. In June 2000, TDEC issued an aquatic resources alteration permit for the project. The construction of the new road provided an opportunity to restore the original wetland and its natural hydrology, which had been negatively affected by the old Chestnut Ridge Road that crossed the area. Wetland mitigation activities, which included site grading and the planting of native wetland trees and shrubs, were largely completed in December 2000 , with final seeding of the site with native wetland herbs in March 2001. As required by the aquatic resources alteration permit, annual moni- 
toring is conducted and the results are reported to TDEC. Monitoring results to date suggest that the wetland is on its way to being fully restored.

\subsubsection{Floodplains Management}

Executive Order 11988 (issued in 1977) was established to require federal agencies to avoid to the extent possible adverse impacts associated with the occupancy and modification of floodplains and to avoid direct or indirect support of floodplain development wherever there is a practicable alternative. Agencies must determine whether a floodplain is present that may be affected by an action, assess the impacts on such, and consider alternatives to the action. The executive order requires that provisions for early public review and measures for minimizing harm be included in any plans for actions that might occur in the floodplain. Floodplain assessments and the associated notices of involvement and statements of findings are prepared in accordance with 10 CFR 1022, usually as part of the NEPA review and documentation process.

\subsubsection{Endangered Species Act}

Good stewardship, state laws ("The Rare Plant Protection and Conservation Act of 1985," Tennessee Code Annotated Section 70-8-301 to 314, and "Tennessee Nongame and Endangered or Threatened Wildlife Species Conservation Act of 1974," Tennessee Code Annotated Section 70-8-101 to 110), and federal laws ("Endangered Species Act of 1973," 16 U.S.C. 1531 et seq.) dictate that animal and plant species of concern be considered when a proposed project has the potential to alter their habitat or otherwise harm them. At the federal level, such species are classified as endangered, threatened, or species of concern. At the state level, these species are considered endangered, threatened, of special concern (plants), or in need of management (animals). All such species are termed "special concern" species in this report.

\subsubsection{Special Concern Animals}

Listed animal species known to be present on the reservation (excluding the Clinch River bordering the reservation) are given along with their status in Table 2.8. The list illustrates the diversity of birds on the ORR, which is also habitat for many unlisted species, some of which are in decline nationally or regionally. Other listed species may also be present, although they have not been observed recently. These include several species of mollusks (such as the spiny river snail), amphibians (such as the hellbender), birds (such as Bachman's sparrow), and mammals (such as the smoky shrew). Birds, fish, and aquatic invertebrates are the most thoroughly surveyed animal groups on the ORR. The only federally listed animal species that have been recently observed (e.g., the gray bat) are represented by one to several migratory or transient individuals, or bordering the ORR (e.g., the Clinch River), rather than by permanent residents, although this situation may change as these species continue to recover. The federally threatened bald eagle is increasingly seen in winter and may well begin nesting here within a few years. Similarly, several state-listed bird species, such as the anhinga, olive-sided flycatcher, double-crested cormorant, and little blue heron, are currently uncommon migrants or visitors to the reservation; however, the double-crested cormorant and little blue heron are probably increasing in numbers. Others, such as the cerulean warbler, northern harrier, great egret, and yellow-bellied sapsucker, are migrants or winter residents that do not nest on the reservation. The cerulean warbler is now regarded as a probable nesting bird. Two species have been sighted/collected in the City of Oak Ridge and are possibly present on the ORR: golden-winged warbler (Vermivora chrysoptera, state in need of management) and spotfin chub (Cyprinella monnacha, federal and state threatened).

\subsubsection{Threatened and Endangered Plants}

There are currently 21 listed plant species on the ORR; among them are the pink lady's-slipper and Canada lily (Table 2.9). Two species occurring on the ORR, Carey's saxifrage and the purple fringeless orchid, have been removed from 
Table 2.8. Animal species of concern reported from the Oak Ridge Reservation (ORR)

\begin{tabular}{|c|c|c|c|}
\hline \multirow{2}{*}{\multicolumn{2}{|c|}{ Species }} & \multicolumn{2}{|c|}{ Legal status $^{b}$} \\
\hline & & \multirow[t]{2}{*}{ Federal } & \multirow[t]{2}{*}{ State } \\
\hline \multicolumn{2}{|r|}{ Fish } & & \\
\hline Phoxinus tennesseensis & Tennessee dace & & NM \\
\hline \multicolumn{4}{|c|}{ Amphibians and reptiles } \\
\hline Hemidactylium scutatum & Four-toed salamander & & NM \\
\hline \multicolumn{4}{|c|}{ Birds } \\
\hline Accipiter striatus & Sharp-shinned hawk & & NM \\
\hline Anhinga anhinga & Anhinga & & NM \\
\hline Casmerodius alba & Great egret & & NM \\
\hline Circus cyaneus & Northern harrier & & NM \\
\hline Contopus borealis & Olive-sided flycatcher & & NM \\
\hline Dendroica cerulea & Cerulean warbler & $\mathrm{C}$ & NM \\
\hline Egretta caerulea & Little blue heron & & NM \\
\hline Egretta thula & Snowy egret & & NM \\
\hline Falco peregrinus ${ }^{c}$ & Peregrine falcon & & $\mathrm{E}$ \\
\hline Haliaeetus leucocephalus ${ }^{d}$ & Bald eagle & $\mathrm{T}$ & NM \\
\hline Lanius ludovicianus & Loggerhead shrike & & NM \\
\hline Pandion haliaetus & Osprey & & $\mathrm{E}$ \\
\hline Pooecetes gramineus & Vesper sparrow & & NM \\
\hline Sphyrapicus varius & Yellow-bellied sapsucker & & NM \\
\hline Tyto alba & Common barn owl & & NM \\
\hline \multicolumn{4}{|c|}{ Mammals } \\
\hline Myotis grisescens & Gray bat & $\mathrm{E}$ & $\mathrm{E}$ \\
\hline Sorex longirostris & Southeastern shrew & & NM \\
\hline
\end{tabular}

the state list as of November 17, 1999. Four species (spreading false-foxglove, Appalachian bugbane, tall larkspur, and butternut) have been under review for listing at the federal level and were listed under the formerly used "C2" candidate designation. These species are now informally referred to as "special concern" species by the U.S. Fish and Wildlife Service.

Two additional species listed by the state, the Michigan lily and the hairy sharp-scaled sedge, were identified in the past on the ORR; however, they have not been found in recent years. Another listed species, large-tooth aspen, was reported in two locations on the ORR in 2002. One of the reports was confirmed, but the tree died during the year. The other report has not yet been confirmed. Several state-listed plant species currently found on adjacent lands may be present on the ORR as well, although they have not been located (Table 2.10).

\subsubsection{Environmental Justice}

On February 11, 1994, Executive Order 12898, Federal Actions To Address Environmental Justice in Minority Populations and LowIncome Populations, was promulgated. The executive order requires that federal actions not have the effect of excluding, denying, or discriminating on the basis of race, color, national origin, or income level and that federal agencies must ensure that there are no disproportionate impacts from their actions on low-income and minority communities surrounding their facilities.

An Environmental Justice strategy is in place at DOE-ORO under the direction of the Diversity Programs Office. It addresses the need to communicate DOE activities effectively to minority communities. In addition, the interim scoping team involved in the review and editing of NEPA documents ensures that the language is 
Table 2.9. Currently known or previously reported vascular plant species from the Oak Ridge Reservation (ORR) that are listed by state or federal agencies, 2003

\begin{tabular}{|c|c|c|c|}
\hline Species & Common name & Habitat on ORR & Status code $^{a}$ \\
\hline Aureolaria patula & Spreading false-foxglove & River bluff & $\mathrm{C} 2, \mathrm{~T}$ \\
\hline Carex gravida & Heavy sedge & Varied & $\mathrm{S}$ \\
\hline Carex oxylepis var. pubescens ${ }^{b}$ & Hairy sharp-scaled sedge & Shaded wetlands & $\mathrm{S}$ \\
\hline Cimicifuga rubifolia & Appalachian bugbane & River slope & $\mathrm{C} 2, \mathrm{~T}$ \\
\hline Cypripedium acaule & Pink lady’s-slipper & Dry to rich woods & $\mathrm{E}, \mathrm{CE}$ \\
\hline Delphinium exaltatum & Tall larkspur & Barrens and woods & $\mathrm{C} 2, \mathrm{E}$ \\
\hline Diervilla lonicera & Northern bush-honeysuckle & River bluff & $\mathrm{T}$ \\
\hline Draba ramosissima & Branching whitlow-grass & Limestone cliff & $\mathrm{S}$ \\
\hline Elodea nuttallii & Nuttall waterweed & Pond, embayment & $\mathrm{S}$ \\
\hline Fothergilla major & Mountain witch-alder & Woods & $\mathrm{T}$ \\
\hline Hydrastis canadensis & Golden seal & Rich woods & $\mathrm{S}, \mathrm{CE}$ \\
\hline Juglans cinerea & Butternut & Slope near stream & $\mathrm{C} 2, \mathrm{~T}$ \\
\hline Juncus brachycephalus & Small-head rush & Open wetland & $\mathrm{S}$ \\
\hline Lilium canadense & Canada lily & Moist woods & $\mathrm{T}$ \\
\hline Lilium michiganense $^{c}$ & Michigan lily & Moist woods & $\mathrm{T}$ \\
\hline Liparis loeselii & Fen orchid & Forested wetland & $\mathrm{E}$ \\
\hline Panax quinquifolius & Ginseng & Rich woods & $\mathrm{S}, \mathrm{CE}$ \\
\hline Platanthera flava var. herbiola & Tuberculed rein-orchid & Forested wetland & $\mathrm{T}$ \\
\hline Populus grandidentatad & Large-tooth aspen & Dry, woodlands & $\mathrm{S}$ \\
\hline Ruellia purshiana & Pursh's wild-petunia & Dry, open woods & $\mathrm{S}$ \\
\hline Scirpus fluviatilis & River bulrush & Wetland & $\mathrm{S}$ \\
\hline Spiranthes lucida & Shining ladies-tresses & Boggy wetland & $\mathrm{T}$ \\
\hline Thuja occidentalis & Northern white cedar & Rocky river bluffs & $\mathrm{S}$ \\
\hline Viola tripartita var tripartita & Three-parted violet & Rocky woods & $\mathrm{S}$ \\
\hline
\end{tabular}

${ }^{a}$ Status codes:

C2 Special concern, under review for federal listing; listed under the formerly used C2 candidate designation. More information needed to determine status.

E Endangered in Tennessee.

$\mathrm{T}$ Threatened in Tennessee.

$\mathrm{S} \quad$ Special concern in Tennessee.

CE Status due to commercial exploitation.

${ }^{b}$ Carex oxylepis var. pubescens has not been relocated during recent surveys.

${ }^{c}$ Lilium michiganense is believed to have been extirpated from the ORR by the impoundment at Melton Hill.

${ }^{d}$ Populus grandidentata was reported in two ORR locations. One of the reports was confirmed, but the tree died during the year.

presented in a manner that does not require stakeholders to possess a technical background for them to effectively participate in the decisionmaking process.

Planned DOE actions to be addressed under NEPA include an analysis of the health, envi ronmental, economic, and demographic impacts of the planned action on surrounding minority and low-income communities that could be affected by the action.

\subsubsection{Safe Drinking Water Act}

The Safe Drinking Water Act (SDWA) of 1974 is an environmental statute for the protection of drinking water. This act requires the EPA to establish primary drinking water regulations for contaminants that may cause adverse public health effects. Although many of the requirements of the SDWA apply to public water supply systems, Section 1447 states that each federal agency having jurisdiction over a federally owned or maintained public water system must comply with all federal, state, and local requirements regarding the provision of safe drinking water. 
Table 2.10. Additional rare plants that occur near and could be present on the Oak Ridge Reservation (ORR), 2003

\begin{tabular}{|c|c|c|c|}
\hline Species & Common name & Habitat on ORR & Status code ${ }^{a}$ \\
\hline Agalinis auriculata & Earleaf false foxglove & Calcareous barren & $\mathrm{C} 2, \mathrm{E}$ \\
\hline Allium burdickii or A. tricoccom ${ }^{b}$ & Ramps & Moist woods & $\mathrm{S}, \mathrm{CE}$ \\
\hline Berberis canadensis & American barberry & Rocky bluff, creek bank & S \\
\hline Gnaphalium helleri & Catfoot & Dry woodland edge & S \\
\hline Lathyrus palustris & A vetch & Moist meadows & S \\
\hline Liatris cylindracea & Slender blazing star & Calcareous barren & $\mathrm{E}$ \\
\hline Lonicera dioica & Mountain honeysuckle & Rocky river bluff & S \\
\hline Meehania cordata & Heartleaf meehania & Moist calcareous woods & $\mathrm{T}$ \\
\hline Pedicularis lanceolata & Swamp lousewort & Calcareous wet meadow & $\mathrm{T}$ \\
\hline Pycnanthemum torreic & Torrey's mountain-mint & Calcareous barren edge & S \\
\hline Solidago ptarmicoides & Prairie goldenrod & Calcareous barren & $\mathrm{E}$ \\
\hline
\end{tabular}

${ }^{a}$ Status codes:

C2 Special concern, under review for federal listing; was listed under the formerly used C2 candidate designation. More information needed to determine status.

E Endangered in Tennessee.

T Threatened in Tennessee.

$\mathrm{S} \quad$ Special concern in Tennessee.

CE Status due to commercial exploitation.

${ }^{b}$ Ramps have been reported near the ORR, but there is not sufficient information to determine which of the two species is present or if the occurrence may have been introduced by planting. Both species of ramps have the same state status.

The city of Oak Ridge supplies potable water to Y-12 and ORNL. The water treatment plant, located north of the Y-12 Complex, is owned by the city of Oak Ridge.

Y-12, ORNL, and ETTP perform certain monitoring activities, including free residual chlorine, bacteriological, disinfectant by-products, and copper and lead analyses. The Y-12 and ORNL potable water systems are classified as a nontransient, noncommunity water supply system by TDEC.

The Y-12 and ORNL distribution systems have qualified for triennial lead and copper sampling. The Y-12 distribution system was last sampled in 2002; the ORNL system was sampled in 2003. Y-12 and ORNL were compliant with the lead and copper requirements. In addition, the Y-12 and ORNL drinking water distribution system's bacteriological sample analyses were satisfactory in 2003. ETTP monitors the levels of turbidity and of organic, inorganic, and radioactive contaminants in finished drinking water at its water plant. All test results during 2003 were satisfactory.

Y-12, ORNL, and ETTP have cross-connection prevention programs to prevent the contamination of potable water through the use of backflow preventers, engineering design, and physical separation. Backflow preventers that failed performance checks have been repaired, or the equipment served by the units has been taken out of service.

The K-1515 sanitary water plant provides drinking water for ETTP and for an industrial park located on Bear Creek Road south of the site. The DOE-owned facility is classified as a nontransient, noncommunity water supply system by TDEC and is subject to state regulations. On April 1, 1998, operation of this leased facility became the responsibility of Operations Management International, Inc., (OMI) under contract with CROET.

\subsubsection{Clean Water Act}

The objective of the CWA is to restore, maintain, and protect the chemical, physical, and biological integrity of the nation's waters. With continued amendments, the CWA has established a comprehensive federal and state program to protect the nation's waters from pollutants. Congress continues to work on amendments to and reauthorization of the CWA. (See Appendix C for reference standards and data for water.) 


\subsubsection{National Pollutant Discharge Elimination System}

One of the strategies developed to achieve the goals of the CWA was EPA's establishment of limits on specific pollutants that are allowed to be discharged to waters of the United States by municipal sewage treatment plants and industrial facilities. In 1972, the EPA established the National Pollutant Discharge Elimination System (NPDES) permitting program to regulate compliance with these pollutant limitations. The program was designed to protect surface waters by limiting effluent discharges into streams, reservoirs, wetlands, and other surface waters. Authority for implementation and enforcement of the NPDES program has been delegated by EPA to the state of Tennessee.

\section{Y-12 Complex}

The current Y-12 Complex NPDES Permit TN0002968 became effective on July 1, 1995, and expired on April 28, 2000. In October 1999, a complete application for renewal of the Y-12 NPDES permit was submitted to the TDEC. Y-12 continues to operate under the existing 1995 permit until TDEC completes the renewal process. Presently 90 active point-source discharges or storm water monitoring locations are monitored for compliance with the permit. Monitoring resulted in approximately 9,370 laboratory analyses in 2003 in addition to numerous field observations. Monitoring of discharges demonstrates that the Y-12 Complex continues to achieve an NPDES permit compliance rate of nearly $100 \%$. At the Y-12 Complex, there were six NPDES noncompliances in 2003 (Fig. 2.1). Information on these noncompliances is provided in Appendix D, Table D.1.

In September 1999, a consent order agreed to by DOE and the Tennessee Water Quality Board resolved the outstanding permit appeals regarding biotoxicity and mercury limitations in East Fork Poplar Creek. The requirements for in-stream mercury monitoring and limits were deleted from the NPDES permit and were placed under the CERCLA program. The current permit requires storm water characterizations at selected monitoring locations in accordance with the Storm Water Pollution Prevention Plan for the Oak
Ridge Y-12 Plant, Y/TS-1180/R4 (BWXT 2002). Other documents submitted to TDEC in accordance with the NPDES permit include the Radiological Monitoring Plan (revised in 1997) (LMES 1997b) and the Oak Ridge Y-12 Plant Biological Monitoring and Abatement Program Plan (revised in 2000) (Adams et al. 2000). A report on the analysis of fecal coliform bacteria levels at selected storm water monitoring points has been previously submitted.

\section{ORNL}

ORNL is currently operating under NPDES Permit TN0002941, which was renewed by TDEC on December 6, 1996, and went into effect February 3, 1997. A four-volume permit renewal application was submitted to TDEC and EPA in June 2001. The ORNL NPDES permit lists 164 point-source discharges and monitoring points that require compliance monitoring. Approximately 100 of these are storm drains, roof drains, and parking lot drains. Compliance was determined by approximately 6500 laboratory analyses and measurements in 2003, in addition to numerous field observations by ORNL field technicians. The NPDES permit limit compliance rate for all discharge points for 2003 was nearly $100 \%$, with only two out of about 6500 individual measurements exceeding their respective permit limit (Fig. 2.1). Information on the exceedances is provided in Appendix D, Table D.3.

The current permit requires ORNL to conduct detailed characterization of numerous storm water outfalls, develop and implement a radiological monitoring plan, develop and implement a storm water pollution prevention plan, implement a revised Biological Monitoring and Abatement Program (BMAP) plan, and develop and implement a chlorine-control strategy. DOE appealed certain limits and conditions of the 1996 ORNL permit, including numeric limits on effluent mercury, arsenic, and selenium.

\section{ETTP}

The ETTP NPDES Permit TN0002950 went into effect on October 1, 1992. Effluent limitations in this permit were water-quality based, which reflected the trend toward considering the effects of industrial discharges on 
ORNL-DWG 94M-8366R15/rra
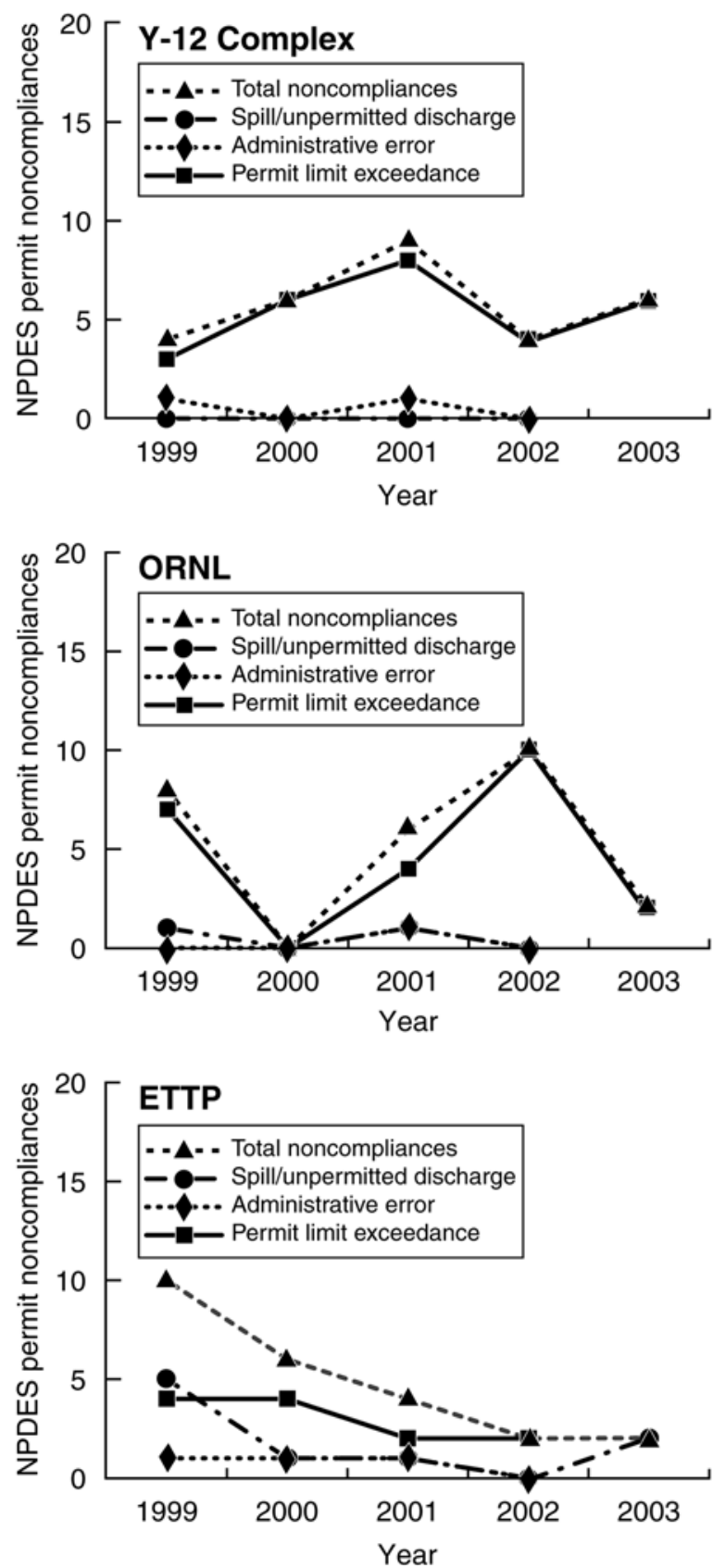

Fig. 2.1. Five-year summary of NPDES noncompliances.

the quality of the receiving streams. In accordance with the federal regulations requiring the inclusion of storm water discharges in the NPDES permitting program, all storm water outfalls were included in this permit, and development of a Storm Water Pollution Prevention Plan was required. A major modification was issued effective June 1, 1995. The modification included removal of inactive outfalls, addition of effluent limits for new treatment technologies at the
Central Neutralization Facility, addition of new storm drains, and clarification of various requirements. In accordance with this NPDES permit, the ETTP is authorized to discharge process wastewater, cooling water, storm water, steam condensate, and groundwater to the Clinch River, Poplar Creek, and Mitchell Branch.

The ETTP NPDES Permit expired on September 29, 1997. An application for renewal of this permit was submitted to TDEC in March 
1997. To facilitate the transfer of ownership and operation of ETTP facilities to other parties, it was determined that separate NPDES permits would be required for each of the ETTP treatment facilities. In addition, it was determined that a separate NPDES permit for the storm water drainage system would be necessary. A general NPDES permit for former outfalls 009 (K-1515 Sanitary Water Plant) and 013 (K-1513 Sanitary Water Intake Backwash Filter) was issued on January 14, 2000, and became effective on March 1, 2000. The issuance of this permit (Permit Number TN0074233) allowed outfalls 009 and 013 to be removed from ETTP NPDES Permit Number TN0002950. A permit for the K1203 sewage treatment plant (permit number TN0074241) was issued by TDEC and became effective on August 1, 2003. This allowed outfall 005 to be removed from ETTP NPDES Permit Number TN0002950. A permit for the K-1407-J Central Neutralization Facility (permit number TN0074225) was issued on October 7, 2003, and became effective on November 1, 2003. This allowed outfall 014 to be removed from ETTP NPDES Permit Number TN0002950. ETTP storm water outfalls continue to discharge under NPDES Permit Number TN0002950; the permit was reissued on March 1, 2004, with an effective date of April 1, 2004.

During most of 2003 the NPDES Permit Number TN0002950 included the K-1203 Sewage Treatment Plant and K-1407-J Central Neutralization Facility outfalls and 136 storm water outfalls. Monitoring resulted in approximately 3100 laboratory analyses in 2003 in addition to numerous field measurements. There were two NPDES noncompliances in 2003, indicating a compliance rate of nearly $100 \%$ (Fig. 2.1). Information on these noncompliances is provided in Appendix D, Table D.2.

\subsubsection{Sanitary Wastewater}

\section{Y-12 Complex}

The CWA includes pretreatment regulations for publicly owned treatment works. Sanitary wastewater from the Y-12 Complex is discharged to the city of Oak Ridge treatment works under an industrial and commercial wastewater discharge permit. City personnel performed semiannual inspections on March 20 and September 10, 2003. No deficiencies of the Y-12 Sanitary Sewer Compliance Program were noted during the inspections.

The current industrial user discharge permit was issued to Y-12 on January 1, 2000, by the city of Oak Ridge. This permit establishes discharge limits for total suspended solids, biochemical oxygen demand, total nitrogen, and various metals, and requires monitoring and reporting of uranium, gross alpha and beta, and several organic compounds. Compliance with the permit is determined from samples taken at the East End Sanitary Sewer Monitoring Station, located on the east end of the complex where the Y-12 system ties into the city's sanitary sewer collection system.

During 2003, the Y-12 Complex experienced three exceedances of the industrial user discharge permit. These exceedances were elevated readings of metals (iron and arsenic) usually associated with coal. It is believed that the elevated readings relate to two isolated upsets at the Steam Plant Wastewater Treatment Facility. Levels have returned to normal. Compliance to a state-issued operating permit for a holding tank/pump-andhaul at office trailer 9983-AZ was also maintained.

Sanitary sewer radiological sample results at the Y-12 Complex are routinely reviewed to determine compliance with DOE Order 5400.5, "Radiation Protection of the Public and Environment." Sample results are compared to the derived concentration guides (DCGs) listed in the order. No radiological parameter that is monitored (including uranium) has exceeded a DCG.

\section{ORNL}

At ORNL, sanitary wastewater is collected, treated, and discharged separately from other liquid wastewater streams through an on-site sewage treatment plant. Wastewater discharged into this system is regulated by means of internally administered waste-acceptance criteria based on the plant's NPDES operating permit parameters. Wastewater streams currently processed through the plant include sanitary sewage from facilities in Bethel and Melton Valleys, area runoff of rainwater that infiltrates the system, and specifically approved small volumes of non- 
hazardous biodegradable wastes such as scintillation fluids. The effluent stream from the sewage treatment plant is ultimately discharged into White Oak Creek through an NPDESpermitted outfall (X-01). Infiltration into the system and the discharge from the on-site laundry have, at times, caused the sludge generated during the treatment process to become slightly radioactive. ORNL has completed a line-item project for comprehensive upgrades of its sanitary sewage system to reduce infiltration of contaminated groundwater and surface water and to redirect discharges from the laundry to appropriate alternative treatment facilities. The radioactivity level of ORNL sewage treatment plant sludge continues to decline. In 1998, ORNL's sewage sludge was accepted into the city of Oak Ridge's Biosolids Land Application Program. ORNL transported no sewage sludge to the Oak Ridge sewage treatment plant in 2002 because the plant was undergoing an expansion project. During 2003, ORNL's sewage sludge was dried and handled as solid low-level waste. Shipments of sludge to the city of Oak Ridge are expected to resume in 2004.

\section{ETTP}

ETTP domestic wastewater is treated at the on-site K-1203 sewage treatment plant and is discharged pursuant to the NPDES Permit TN0074241; this permit became effective on August 1, 2003. Beginning on April 1, 1998, operation of this leased facility became the responsibility of publicly owned treatment works under a contract with CROET. The sewer-use policy of Operations Management International, Inc., and a wastewater control and surveillance program are in effect to ensure adequate treatment of wastewater at the K-1203 plant and to ensure that effluent from the facility continues to meet all NPDES permit limits. BJC operates a holding tank/pump-and-haul system to dispose of sanitary wastewater from the K-1310-DF facility at ETTP. The permit to operate this system (State Operating Permit No. 99-033) was issued April 28, 2000, and expires April 28, 2005. Operations reports are submitted each month to the TDEC Environmental Assistance Center; there were no noncompliances or operational problems in 2003. Weskem LLC, a Bechtel Jacobs Company LLC subcontractor, also operates a pump-and-haul system (State Operating Permit No. SOP-01042) for sanitary waste at ETTP.

\subsubsection{Storm Water Protection Permits}

Storm water discharges associated with construction activities that disturb more than 5 acres of land must be NPDES-permitted. Effective March 2003, the requirement was extended to include construction activities that disturb 1 acre and more. Coverage under a general permit is typically available to a construction project if the proper notice of intent is filed. In June 2003, TDEC issued a General Permit for Storm Water Associated with Construction Activity for the Y-12 Purification Facility. In 2003, ETTP submitted one storm water notice of termination for a power line right-of-way clearing activity after final stabilization had been achieved, all storm water discharges associated with the construction activity had ceased or been eliminated, and temporary erosion and sedimentation control measures had been removed. In 2003, ORNL had seven construction projects covered by the Tennessee General Permit for Storm Water Runoff Associated with Construction Activity. These included the Spallation Neutron Source project, parking lot improvements, Advanced Materials Characterization Laboratory, ORNL Research Support Center, the ORNL Laboratory for Comparative and Functional Genomics, the ORNL Fire Protection Systems Upgrades, and ORNL Water System Upgrade.

\subsubsection{Aquatic Resources Protection}

The Army Corps of Engineers, TVA, and TDEC conduct permitting programs for projects and activities that could potentially affect aquatic resources, including navigable waters, surface waters (including tributaries), and wetlands. These are the Corps of Engineers Section 404 dredgeand-fill permits, TDEC aquatic resource alteration permits, and TVA 26A approvals.

In July 2003, TDEC issued a General Permit for Maintenance Activities for Modification to Storm Drain and NPDES Outfall 113 at the Y-12 
Purification Facility construction project. This permit is basically an aquatic resources type activity. No TVA or Corps of Engineers permits were issued to $\mathrm{Y}-12$ in 2003.

In 2003, ORNL projects that were conducted under aquatic resource alteration permits included upgrades to the ORNL water system and drainage modifications around the swan pond. At ETTP, an aquatic resource alteration permit and a Department of the Army permit were obtained for removal/repair of crossovers on Mitchell Branch; however, no field activities were conducted in 2003.

\subsubsection{Oil Pollution Prevention}

Section 311 of the CWA regulates the discharge of oils or petroleum products to waters of the United States and requires the development and implementation of a spill prevention, control, and countermeasure plan to minimize the potential for oil discharges. Currently, each facility implements a site-specific plan. This section of the CWA was significantly amended by the Oil Pollution Act of 1990, which has as its primary objective the improvement of responses to oil spills. On July 17, 2002, EPA issued the new final rule for 40 CFR Part 112, "Oil Pollution Prevention and Response; Non-TransportationRelated Onshore and Offshore Facilities," in the Federal Register. The rule contains significant changes in the requirements for spill prevention, control, and countermeasure plans, including how the plans are prepared, reviewed, and certified, and the information that must be included in the plans. Existing plans must be amended as necessary to bring them into compliance with rule revisions by August 17, 2004. The amended plans must be fully implemented by February 18, 2005.

\subsubsection{Clean Water Action Plan}

The Clean Water Action Plan, which essentially reflects a commitment by federal agencies to work cooperatively to improve water quality in the United States, is structured around watershed-based approaches in four key areas of need:

- prioritizing and undertaking water quality assessments,

- preparing restoration action strategies,
- developing and refining water quality standards, and

- enhancing stewardship of water resources on federal lands.

On a national level, the Department of Agriculture and the Department of the Interior are developing the Unified Federal Policy for Ensuring a Watershed Approach to Federal Land and Resource Management, to which other agencies (including DOE) are contributing. The goals and principles of this multiagency policy are to

- use a consistent and scientific approach to managing lands and resources and for assessing, protecting, and restoring watersheds;

- identify specific watersheds in which to focus budgetary and other resources and to accelerate improvements in water quality and watershed condition;

- use the results of watershed assessments to guide planning and management activities;

- work closely with states, tribes, local governments, and stakeholders to implement this policy;

- meet CWA responsibilities to adhere to federal, state, tribal, interstate, and local water quality requirements to the same extent as nongovernmental entities; and

- take steps to ensure that federal land and resource management actions are consistent with federal, state, tribal, and, where appropriate, local government water quality management programs.

\subsubsection{Clean Air Act}

Authority for implementation and enforcement of the Clean Air Act (CAA) has been delegated to the state of Tennessee by EPA as described in the State Implementation Plan. Air pollution control rules are developed and administered by TDEC.

\subsubsection{General CAA Compliance}

The TDEC air pollution control rules ensure compliance with the federal CAA. The TDEC Air Permit Program is the primary method by which 
emission sources are reported to and regulated by the state.

CAA compliance program staff participate in regulatory inspections and internal audits to verify compliance with applicable regulations or permit conditions. Air emission sources subject to the permitting requirements are permitted, and relevant compliance documentation for these sources is maintained at each site. In addition, a number of sources that are exempt from permitting requirements under state rules but subject to listing on Title $\mathrm{V}$ major source operation permits are documented, and information about them is available upon request from the state. All other exempt sources are documented for internal purposes. Programs for permitting, compliance inspection, and documentation are in place and ensure that all ORR operations remain in compliance with all federal and state air pollution control regulations.

\subsubsection{Title V Operating Permits}

All three sites are subject to the CAA Title V Operating Permit Program. Permit applications were submitted and were determined to be complete by TDEC. However, no Title V permits had been issued for DOE operations on the ORR as of December 31, 2003. TDEC requested that all permit applications be updated due to the number of years that have passed since the original submittals. All sites have submitted updated permit applications. All sites continue to operate under previously issued air permits until Title $\mathrm{V}$ air permits are issued.

\subsubsection{National Emission Standards for Hazardous Air Pollutants for Radionuclides}

Under Section 112 of the CAA, on December 15, 1989, the EPA promulgated National Emission Standards for Emissions of Radionuclides Other than Radon from Department of Energy Facilities at 40 CFR 61, Subpart H. This emission standard limits emissions of radionuclides to the ambient air from DOE facilities not to exceed amounts that would cause any member of the public to receive in any year an effective dose equivalent of $10 \mathrm{mrem} / \mathrm{year}$. As noted in the preamble to this rule, the entire DOE facility at Oak Ridge, Tennessee, must meet this emission standard.

On June 10, 1996, EPA delegated authority for regulation of airborne radionuclide emissions from DOE facilities in Tennessee to the TDEC Division of Air Pollution Control. TDEC adopted the federal rule verbatim as Tennessee Rule 12003-11-.08, Emission Standards for Emissions of Radionuclides Other than Radon from Department of Energy Facilities. In addition, TDEC codified that all past formal agreements between DOE and EPA, including the May 1994 Compliance Plan (MMES 1994a), would be recognized provided that they are current, valid, and supported by appropriate documentation. The TDEC Division of Air Pollution Control has given primary administrative authority of the radionuclide emission standard to the TDEC Division of Radiological Health, which also licenses nonDOE nuclear facilities in the state.

During 2003, the ORR facilities operated in compliance with the Radionuclide National Emission Standards for Hazardous Air Pollutants (NESHAP) dose limit of $10 \mathrm{mrem} /$ year to the most exposed member of the public. Based on modeling of radionuclide emissions from all major and minor point sources, the effective dose equivalent to the most exposed member of the public was $0.2 \mathrm{mrem} / \mathrm{year}$ in 2003 .

Beginning in 2000, the TDEC Division of Radiological Health required DOE to assess the dose from airborne radionuclide emissions to members of the public located on the ORR. Specifically, dose was determined for lessees located in areas of the ORR where access to the public is not restricted.

Continuous sampling for radionuclide emissions is conducted at the ETTP TSCA Incinerator, the K-33 Supercompactor, the K-33 Decontamination Room, major sources at ORNL, and exhaust stacks serving uranium-processing areas at the Y-12 Complex. Compliance with the off-site dose limit is demonstrated by using grab samples and other EPA-approved estimation techniques on the remaining minor emission points and on grouped area sources to estimate confirmatory measurements of emissions. Fugitive emissions continue to be monitored by the ORR Perimeter Air Monitoring System. In addition to this, ETTP continued to operate a site-specific ambient air monitoring system for surveillance of 
TSCA Incinerator uranium emissions and fugitive emissions from remedial actions and decontamination and decommissioning projects. In addition to the ORR regulatory compliance program, the EPA and DOE Oversight Division also conduct independent ambient air monitoring programs.

\subsubsection{NESHAP for Asbestos}

The ORR facilities have numerous buildings and equipment that contain asbestos-containing materials. The compliance program for management of removal and disposal of asbestoscontaining materials includes demolition and renovation notifications to TDEC and inspections, monitoring, and prescribed work practices for abatement and disposal of asbestos materials. No releases of reportable quantities of asbestos were reported at ETTP, ORNL, or the Y-12 Complex in 2003.

\subsubsection{Air Permits}

BWXT Y-12 has 33 active air permits covering 108 air emission points. All remaining emission sources are categorized as insignificant and exempt from permitting. During 2003, one new construction permit was issued for the Purification Facility.

During CY 2003, ORNL held 11 operating permits and 1 construction permit. All remaining emission sources are categorized as insignificant and are exempt from permitting.

At the end of CY 2002, there were 88 active air emission sources under DOE control at ETTP. The total includes 30 sources covered by 8 TDEC operating permits and two construction permits. All remaining active air emission sources are exempt from permitting requirements. Permitted sources under DOE's Reindustrialization Program are no longer reported in this annual report, except for the portion of the year the source was under DOE control. These sources are under the responsibility of CROET and are operated by Operations Management International, Inc.

Air permit data are summarized in Appendix E.

\subsubsection{NESHAP for Source Categories}

The EPA has missed congressionally established promulgation dates for a number of NESHAP "Maximum Achievable Control Technology" (MACT) standards (see 40 CFR Part 63, Subpart B, starting at $\S 63.50$ ). Sources that may be subject to a delayed standard must comply with the "MACT hammer" permitting provisions in Section 112(j) of the CAA. Impacted sources must submit applications for case-by-case MACT determinations in two parts. Part 1 notified agencies of the applicability of the delayed MACT standard to the facility. Part 2 is a detailed application based on a number of requirements and is due on a specific date, depending upon the applicable MACT standard.

A number of MACT standards potentially applicable to ORR sources are being developed by EPA (e.g., Industrial, Commercial, and Institutional Boilers and Process Heaters; Miscellaneous Metal Parts (surface coating); Site Remediation; and Off-Site Waste and Recovery Operations). In 2003, ORR facilities submitted Part 1 applications regarding applicability of several MACT standards (e.g., Industrial Heaters/Process Boilers, Site Remediation). There are currently only two sources on the ORR subject to MACT standards. One source is the TSCA Incinerator; the other source, registered with the EPA, is a waste drum storage area at ETTP designated for storage of waste received from off site, making this area subject to the Off-Site Waste and Recovery Operations standard.

\subsubsection{Stratospheric Ozone Protection}

DOE remains committed to continued reductions in the use of regulated ozone-depleting substances and, where possible, replacing them with materials reported to have less ozonedepleting potential. For example, DOE has committed to replacing refrigeration appliances at all DOE installations if the appliances were installed before 1984, contain Class I ozone-depleting substances, and have cooling capacities of 150 tons or greater, except in certain cases where replacement is not economical and will not benefit the environment. All units meeting this criterion 
at ETTP, ORNL, and Y-12 have been evaluated and replaced, except for seven units located at ORNL. Six of these units have been or will be decommissioned. Due to a change in facility status, one chiller will be replaced.

\subsubsection{Chemical Accident Release Prevention}

All sites on the ORR have evaluated all DOE processes for inventories of chemicals contained in quantities exceeding thresholds specified in rules pursuant to Title III, Section 112(r), "Prevention of Accidental Releases." No risk management program plans are required for a regulated substance at any DOE facility on the ORR. Administrative measures were implemented for some processes to limit the quantity of a regulated substance that could be present in a process at any given time.

\subsubsection{Toxic Substances Control Act}

TSCA was passed in 1976 to address the manufacture, processing, distribution in commerce, use, and disposal of chemical substances and mixtures that present an unreasonable risk of injury to human health or the environment. TSCA mandated that EPA identify and control chemical substances manufactured, processed, distributed in commerce, and used within the United States. EPA imposes strict information-gathering requirements on both new and existing chemical substances, including PCBs.

\subsubsection{Polychlorinated Biphenyls}

TSCA specifically bans the manufacture, processing, and distribution in commerce of PCBs but authorizes the continued use of some existing PCBs and PCB equipment. TSCA also imposes marking, storage, and disposal requirements for PCBs. The regulations governing PCBs mandated by TSCA are found at 40 CFR 761 and are administered by EPA. Most of the requirements of 40 CFR 761 are matrix- and concentrationdependent. TDEC restricts PCBs from being disposed of in landfills and classifies PCBs as special wastes under Tennessee solid waste regulations. A special waste approval is required from the state of Tennessee to dispose of solid PCB-contaminated waste in landfills. Several special waste approvals for receipt of drained PCB equipment and PCB bulk product waste (painted construction debris and/or equipment) at the Y-12 landfill have been approved by TDEC.

\subsubsection{PCB Compliance Agreements}

The Oak Ridge Reservation PCB Federal Facilities Compliance Agreement (ORR-PCBFFCA) between EPA Region 4 and DOE-ORO became effective on December 16, 1996. The agreement addresses PCB compliance issues at ETTP, ORNL, the Y-12 Complex, and ORISE. The ORR-PCB-FFCA specifically addresses the unauthorized use of PCBs, storage and disposal of PCB wastes, spill cleanup and/or decontamination, $\mathrm{PCBs}$ mixed with radioactive materials, PCB R\&D, and records and reporting requirements for the ORR.

\subsubsection{Authorized and Unauthorized Uses of PCBs}

Specific applications of PCBs are authorized by EPA for continued use under restricted conditions. A variety of PCB systems and equipment have been in service at the ORR during its 60-year history. Many of these systems and equipment were used in accordance with industry standards at the time, and their continued use was authorized under the 1979 PCB regulations. Systems that were authorized included transformers, capacitors, and other electrical distribution equipment; heat-transfer systems; and hydraulic systems. The vast majority of these PCB uses have been phased out on the ORR. Small amounts of PCBs remain in service in PCB light ballasts; however, ballasts containing PCBs are being replaced by non-PCB ballasts during normal maintenance. Most transformers that contained PCBs either have been retrofilled (replacement of PCB fluid with non-PCB dielectric fluid) to reduce the $\mathrm{PCB}$ concentration to below regulated limits or have been removed from service altogether.

The 1979 regulations did not anticipate the use of PCBs in many applications for which they 
were used. The proposals to the 1998 "Mega Rule" that would have addressed uses still prevalent on the ORR were omitted from the final rule. As a result, past uses not specifically authorized continue to present compliance issues for DOE under TSCA.

At the ORR, unauthorized uses of PCBs have been found in building materials, lubricants, paint coatings, paint sealants, and nonelectrical systems (including a rolling mill and a reactor-positioning device). More such unauthorized uses are likely to be found during the course of decontamination and decommission activities. The most widespread of these unauthorized uses of PCBs are PCBs in paint and PCB-impregnated gaskets in the gaseous diffusion process motor ventilation systems at ETTP. The discoveries of such uses include rubber gasket components used to seal glove-box units, paint coatings used on hydraulic equipment at the Y-12 Complex, and interior and exterior wall paints. In 1998, ORNL reported finding PCBs at regulated levels in roofing paint used on Buildings 2000 and 2001. An annual sampling and monitoring plan was prepared and submitted for the site. EPA approval of the sampling and monitoring plan was verbally issued on February 11, 1999. Annual monitoring was conducted in 1999, 2000, 2001, 2002, and 2003. Summaries of the 1999, 2002, and 2003 results of that sampling were submitted to EPA as required. Submittals of the 2000 and the 2001 monitoring results were not required. In 2003, ORNL reported finding PCBs in paint in additional buildings or on equipment (e.g., tanks).

In 2003, BWXT Y-12 reported finding PCBs at regulated levels in interior and exterior paint for several facilities and/or their structural components. The Y-12 Complex issued notification letters to EPA, in accordance with the terms of the ORR-PCB-FFCA, declaring that a pre-TSCA PCB use had been discovered. Administrative controls and postings are in place to ensure that painted surfaces are not disturbed until proper evaluations are conducted. Additionally, administrative and engineering controls are used to ensure the protection of workers and the environment.

A notice of noncompliance from the EPA Region 4, was issued to the Y-12 Complex in October 2002 for the continued use of 51 legacy PCB-contaminated transformer pads. The Y-12 Complex responded by submitting a work plan and schedule to the EPA for achieving compliance. By September 22, 2003, all 51 pads had been cleaned and encapsulated using EPA protocols.

In CY 2003, 42 spills were reported at ETTP, of these only 2 (a diesel fuel leak and a sewer line overflow) resulted in NPDES noncompliances. See Section 4.4 for details.

\subsubsection{ETTP TSCA Incinerator PCB Disposal Approval}

The ETTP TSCA Incinerator is currently operating under an extension of EPA Region 4 approval granted on March 20, 1989. This extension is based on submittal of a reapplication for PCB disposal approval filed with EPA Region 4 on December 20,1991, which was within the time frame allowed for reapplication. Minor amendments, updates, and corrections to this reapplication identified by DOE have been made in the interim and have been submitted to EPA. Since the submittal of the December 20, 1991, reapplication, a joint RCRA/PCB permit reapplication has been under development. This joint reapplication was submitted in March 1997 to TDEC under RCRA for treatment of hazardous wastes and to EPA Region 4 for disposal of PCB wastes. The new reapplication will replace the December 20, 1991, PCB disposal reapplication. In anticipation of this joint application, EPA Region 4 has delayed action on renewal of the PCB incineration approval.

\subsubsection{Federal Insecticide, Fungicide, and Rodenticide Act}

The Federal Insecticide, Fungicide, and Rodenticide Act (FIFRA) governs the sale and use of pesticides and requires that all pesticide products be registered by EPA before they can be sold. If a pesticide can be used according to directions without unreasonable adverse effects on the environment or applicator (i.e., if no special training is required), it is classified for general use. A pesticide that can harm the environment or injure the applicator, even when being used according to directions, is classified for restricted use. The regulations for the application of 
restricted-use pesticides are presented in 40 CFR 171.

The Y-12 Complex, ETTP, and ORNL maintain procedures for the storage, application, and disposition of pesticides. Individuals responsible for application of FIFRA materials are certified by the Tennessee Department of Agriculture.

No restricted-use pesticide products are used at the Y-12 Complex, ETTP, or ORNL. An inventory of pesticide products is maintained at each facility.

\subsubsection{Emergency Planning and Community Right-To- Know Act}

The Emergency Planning and Community Right-to-Know Act (EPCRA), also referred to as SARA Title III, requires reporting to federal, state, and local authorities of emergency planning information, hazardous chemical inventories, and releases of certain toxic chemicals to the environment. The ongoing requirements are contained in Sections 302, 303, 304, 311, 312, and 313 of EPCRA and in 40 CFR Parts 355, 370, and 372. Table 2.11 describes the main parts of EPCRA. All DOE-ORO sites in Oak Ridge are in compliance with all aspects of EPCRA. Executive Order 12856, Federal Compliance with Right-toKnow Laws and Pollution Prevention Requirements, requires all federal agencies to comply with provisions of EPCRA and the Pollution Prevention Act.

\subsubsection{Planning Notification and Extremely Hazardous Substance Release Notifications (Sections 302-304)}

The ORR did not have any releases of extremely hazardous substances, as defined by EPCRA, in 2003.

\subsubsection{Material Safety Data Sheet/Chemical Inventory (Sections 311-312)}

Inventories, locations, and associated hazards of hazardous and extremely hazardous chemicals were submitted as required. Of the chemicals identified for CY 2003 on the ORR, 64 were located at the Y-12 Complex, 30 at ORNL, and 14 at ETTP.

Reindustrialization's private-sector lessees were not included in the CY 2002 submittals. Under terms of their lease, lessees must evaluate their own inventories of hazardous and extremely hazardous chemicals and must submit information as required by the regulations.

\subsubsection{Toxic Chemical Release Reporting (Section 313)}

DOE submits an annual toxic release inventory report to EPA and TDEC on or before July 1 of each year. The report covers the previous calendar year and addresses releases of certain toxic chemicals to air, water, and land as well as waste management, recycling, and pollution prevention activities. Threshold determinations and reports for each of the ORR facilities are made separately. Operations involving toxic release inventory chemicals were compared with regulatory thresholds to determine which chemicals exceeded the reporting thresholds based on amounts manufactured, processed, or otherwise used at each facility. After threshold determinations were made, releases and off-site transfers were calculated for each chemical that exceeded one or more of the thresholds. Filing three separate reports altered threshold determinations of the chemicals to be reported and required the reporting of transfers of the chemicals between the facilities.

The following text explains how the reporting thresholds were exceeded. Table 2.12 summarizes releases and off-site transfers for those chemicals exceeding reporting thresholds.

\section{Y-12 Complex}

Total 2003 reportable toxic releases to air, water, and land and waste transferred off-site for treatment, disposal, and recycling increased 
Table 2.11. Descriptions of the main parts of the Emergency Planning and Community Right-to-Know Act (EPCRA)

\begin{tabular}{|c|c|}
\hline Title & Description \\
\hline $\begin{array}{l}\text { Sections 302-303, Planning } \\
\text { notification }\end{array}$ & $\begin{array}{l}\text { Requires that local planning committee and state emergency response } \\
\text { commission be notified of EPCRA-related planning }\end{array}$ \\
\hline $\begin{array}{l}\text { Section } 304 \text {, Extremely hazardous } \\
\text { substance release notification }\end{array}$ & Addresses reporting to state and local authorities of off-site releases \\
\hline $\begin{array}{l}\text { Section 311-312, Material safety data } \\
\text { sheet/chemical inventory }\end{array}$ & $\begin{array}{l}\text { Requires that either material safety data sheets (MSDSs) or lists of } \\
\text { hazardous chemicals for which MSDSs are required be provided to } \\
\text { state and local authorities for emergency planning. Requires that an } \\
\text { inventory of hazardous chemicals maintained in quantities over } \\
\text { thresholds be reported annually to the U.S. Environmental Protection } \\
\text { Agency. }\end{array}$ \\
\hline $\begin{array}{l}\text { Section } 313 \text {, Toxic chemical release } \\
\text { reporting }\end{array}$ & $\begin{array}{l}\text { Requires that releases of toxic chemicals be reported annually to the } \\
\text { U.S. Environmental Protection Agency }\end{array}$ \\
\hline
\end{tabular}

compared with the amounts reported for the Y-12 Complex in 2002. This increase was due primarily to increases in off-site recycling metals and due to an increase in machining and welding activities. The following describes the reported chemicals for the Y-12 Complex.

- Chromium, cobalt, copper compounds, manganese, and nickel. The processing threshold for each of these metals was exceeded as a result of off-site metal recycling and metal machining and welding operations.

- Freon 113. Freon 113 was otherwise used in excess of the reporting threshold as a result of enriched uranium operations.

- Hydrochloric acid (aerosol form) and sulfuric acid (aerosol form). Both of these acid aerosols were coincidentally manufactured in excess of the reporting threshold as a combustion by-product from burning coal at the steam plant.

- Lead and lead compounds. The otherwiseuse threshold for lead was exceeded at the steam plant and the Central Training Facility firing range. The processing threshold for lead was exceeded as a result of off-site metal for recycling.

- Mercury and mercury compounds. Mercury compounds were otherwise used and coincidently manufactured as a combustion by-product from burning coal in excess of the $10-\mathrm{lb}$ reporting threshold at the steam plant.

- Methanol. Most of the methanol at the Y-12 Complex is otherwise used in the chiller buildings for the brine-methanol system.

- Nitrate compounds. Nitrate compounds were coincidentally manufactured in excess of the reporting threshold as by-products of neutralizing nitric acid wastes.

- Nitric acid. Nitric acid was used in excess of the otherwise-use threshold as a chemicalprocessing aid.

- Ozone. Ozone is manufactured at $\mathrm{Y}-12$ cooling towers for microbial control.

\section{ETTP}

- Lead. The otherwise-use activity threshold for lead was exceeded. Activities and releases being reported for lead at ETTP are primarily those associated with waste management activities at the Central Neutralization Facility and the TSCA Incinerator, off-site waste shipments, and lead contained in storm water discharges. 
Table 2.12. Emergency Planning and Community Right-to-Know Act Section 313 toxic chemical release and off-site transfer summary for the Oak Ridge Reservation, 2003

\begin{tabular}{|c|c|c|c|c|c|}
\hline \multirow{2}{*}{ Chemical } & \multirow{2}{*}{ Year } & \multicolumn{4}{|c|}{ Quantity (lb) $^{a}$} \\
\hline & & Y-12 Complex & ORNL & ETTP & Total \\
\hline \multirow{2}{*}{ Chromium } & 2002 & 604 & $b$ & $b$ & 604 \\
\hline & 2003 & 3,906 & $b$ & $\mathrm{~b}$ & 3,906 \\
\hline \multirow[t]{2}{*}{ Cobalt } & 2002 & $c$ & $b$ & $b$ & $b$ \\
\hline & 2003 & 914 & $b$ & $\mathrm{~b}$ & 914 \\
\hline Copper/Copper & 2002 & 1,665 & $b$ & $b$ & 1,665 \\
\hline Compounds & 2003 & 8,296 & $b$ & $\mathrm{~b}$ & 8,296 \\
\hline \multirow[t]{2}{*}{ Freon 11} & 2002 & 60,800 & $b$ & $b$ & 60,800 \\
\hline & 2003 & $\mathrm{~b}$ & $b$ & $b$ & $b$ \\
\hline \multirow[t]{2}{*}{ Freon 113} & 2002 & 19,755 & $b$ & $b$ & 19,755 \\
\hline & 2003 & 32,020 & $b$ & $b$ & 32,020 \\
\hline \multirow{2}{*}{ Hexachlorobenzene } & 2002 & $\mathrm{~b}$ & $b$ & 0.0051 & 0.0051 \\
\hline & 2003 & b & $b$ & $\mathrm{~b}$ & $b$ \\
\hline \multirow{2}{*}{$\begin{array}{l}\text { Hydrochloric acid } \\
\text { (aerosol) }\end{array}$} & 2002 & 120,574 & $b$ & $b$ & 120,574 \\
\hline & 2003 & 116,899 & $b$ & $b$ & 116,899 \\
\hline \multirow[t]{2}{*}{ Lead/lead compounds } & 2002 & 13,531 & 87,395 & 49,277 & 150,203 \\
\hline & 2003 & 9,342 & 43,876 & 72,047 & 125,265 \\
\hline \multirow[t]{2}{*}{ Manganese } & 2002 & 1,783 & $b$ & $b$ & 1,783 \\
\hline & 2003 & 6,170 & $b$ & $b$ & 6,170 \\
\hline \multirow{2}{*}{$\begin{array}{l}\text { Mercury/mercury } \\
\text { compounds }\end{array}$} & 2002 & 428.7 & $b$ & $b$ & 428.7 \\
\hline & 2003 & 47.6 & $b$ & $b$ & 47.6 \\
\hline \multirow[t]{2}{*}{ Methanol } & 2002 & 65,354 & $b$ & $b$ & 65,354 \\
\hline & 2003 & 77,571 & $b$ & $b$ & 77,571 \\
\hline \multirow[t]{2}{*}{ Nickel } & 2002 & 3,047 & $b$ & $b$ & 3,047 \\
\hline & 2003 & 3,319 & $b$ & $b$ & 3,319 \\
\hline \multirow[t]{2}{*}{ Nitrate compounds } & 2002 & 1,639 & 71,000 & $b$ & 72,639 \\
\hline & 2003 & 5,651 & 80,000 & $b$ & 85,651 \\
\hline \multirow{2}{*}{ Nitric acid } & 2002 & 2,422 & 53,627 & $b$ & 56,048 \\
\hline & 2003 & 2,942 & 81,362 & $b$ & 84,304 \\
\hline \multirow[t]{2}{*}{ Ozone } & 2002 & $c$ & $b$ & $b$ & $\mathrm{~b}$ \\
\hline & 2003 & $c$ & $b$ & $b$ & $b, c$ \\
\hline \multirow[t]{2}{*}{ PCBs } & 2002 & b & $b$ & 296 & 296 \\
\hline & 2003 & $\mathrm{~b}$ & $b$ & 158 & 158 \\
\hline \multirow[t]{2}{*}{ Sulfuric acid (aerosol) } & 2002 & 62,201 & $b$ & $b$ & 62,201 \\
\hline & 2003 & 58,982 & $b$ & $b$ & 58,982 \\
\hline \multirow[t]{2}{*}{ Total } & 2002 & 353,804 & 212,022 & 49,573 & 615,398 \\
\hline & 2003 & 326,060 & 205,238 & 72,205 & 603,503 \\
\hline
\end{tabular}

${ }^{a}$ Represents total releases to air, land, and water and includes off-site waste transfers. Also includes quantities released to the environment as a result of remedial actions, catastrophic events, or one-time events not associated with production processes.

${ }^{b}$ No reportable releases because the site did not exceed the applicable Toxic Release Inventory reporting thresholds.

${ }^{c}$ Not applicable because releases were less than $500 \mathrm{lb}$ and hence a Form A was submitted. 
- PCBs. The otherwise-use activity threshold for PCBs was exceeded at ETTP by the incineration of PCBs in waste received from off site in the TSCA Incinerator.

\section{ORNL}

- $\quad$ Lead. The ORNL Lead Shop processes lead into different shapes for use as shielding in research projects involving radioactive isotopes.

- Nitrate compounds. Nitrate compounds are coincidentally manufactured as by-products of neutralizing nitric acid waste and as byproducts of sewage treatment.

- Nitric acid. Nitric acid is used to regenerate ion-exchange columns at the Process Waste Treatment Complex and at the High Flux Isotope Reactor; in the separation process for californium by the Nuclear Science and Technology Division; and for $\mathrm{pH}$ adjustment at the Process Waste Treatment Complex.

\subsubsection{Environmental Occurrences}

CERCLA requires that the National Response Center be notified if a nonpermitted release of a reportable quantity or more of a hazardous substance (including radionuclides) is released to the environment within a $24-\mathrm{h}$ period. The CWA requires that the National Response Center be notified if an oil spill causes a sheen on navigable waters, such as rivers, lakes, or streams. When notified, the National Response Center alerts federal, state, and local regulatory emergency organizations so that they can determine whether government response is appropriate.

During 2003, Y-12 had no releases of hazardous substances exceeding reportable quantities. There was one reportable oil sheen. The National Response Center and Tennessee Emergency Management Agency were notified of an observed oil sheen on East Fork Poplar Creek on November 24, 2003. Transformer oil was spilled inside a dumpster. A rain event washed a small amount of residual oil from the dumpster to East Fork Poplar Creek.
During 2003, ETTP had no releases of reportable quantities of hazardous substances and no fish kills. There was one reportable oil sheen. The National Response Center and Tennessee Emergency Management Agency were notified of an oil sheen observed on the K-1007-P1 Pond on January 21, 2003. The oil sheen resulted when a vendor vehicle developed a fuel leak at ETTP, and a rain event washed the spilled diesel fuel into the storm drain system. In 2003, ORNL had no releases of reportable quantities of hazardous substances, no reportable oil sheens, and no fish kills.

\subsubsection{DOE Order 450.1, Environmental Protection Program}

In January 2003, DOE Order 450.1, "Environmental Protection Program," was issued; it encompasses environmental management systems (EMSs), pollution prevention, affirmative procurement, ozone depleting substances, energy management and fleet management, and beneficial landscaping requirements. The order consolidates and enhances several previously existing executive orders and affirms DOE's approach to improving environmental performance through the use of management systems and aggressive pollution prevention initiatives.

The ORR sites are addressing the requirements of this order as well as all other requirements related to these areas. The 2003 efforts and associated results across the ORR are summarized in the remainder of this section.

\subsubsection{Implementation of Environmental Management Systems}

An EMS is a continuing cycle of planning, implementing, evaluating, and improving processes and actions undertaken to achieve environmental goals. The EMSs are to be integrated with the sites' Integrated Safety Management System (ISMS) by December 2005. ISMS and EMS both strive for continual improvement, through a plan-do-check-act cycle. Under ISMS, the term "safety" also encompasses environmental safety and health, including pollution prevention, waste minimization, and resource conservation. Therefore, the guiding 
principles and core functions in ISMS are as applicable to the protection of the environment as they are to safety. Figure 2.2 depicts the relationship between EMS and ISMS.

UT-Battelle and BWXT Y-12 have both chosen to implement EMS's that are modeled after the international standard established by ISO 14001. The purpose of this system is to achieve, maintain, and demonstrate continuing environmental improvement by assessing and controlling the impact of activities and facilities on the environment. The system is designed to ensure that activities are in compliance with environmental laws and regulations, and it provides a framework for integrating compliance, pollution prevention, and other environmental considerations into the planning and implementation phases of site activities. The ISO 14001 EMS is consistent with ISMS core functions and guiding principles and includes the following features:

- policy,

- identified significant environmental aspects and controls,

- applicable legal requirements,

- objectives and targets,

- training requirements,

- communication with stakeholders,

- records and document control requirements,

- monitoring and measurement requirements,

- an emergency preparedness and response program, and
- provisions for handling nonconformances and corrective/preventive actions.

Environmental aspects are elements of an organization's activities, products, or services that can interact with the environment. In the ISMS, these may be thought of as environmental hazards associated with a facility operation or work activity.

\subsection{UT-Battelle EMS Implementation Status}

The UT-Battelle EMS is integrated into ISMS through the work control process. All significant environmental aspects are incorporated into work control to ensure appropriate controls are in place.

In 2003, UT-Battelle conducted an EMS audit in preparation for third-party registration in 2004. Several minor deficiencies were noted during the assessment. Corrective action plans have been developed and are being implemented.

ISO 14001 encourages organizations to make their environmental policy and significant environmental aspects of their activities available to the public. These elements of the UT-Battelle EMS are described in the following paragraphs.

The UT-Battelle Policy for ORNL is a highlevel document that contains both scientific/ technical and environment, safety, and health commitments. As required by ISO 14001, the policy contains commitments to (1) comply with

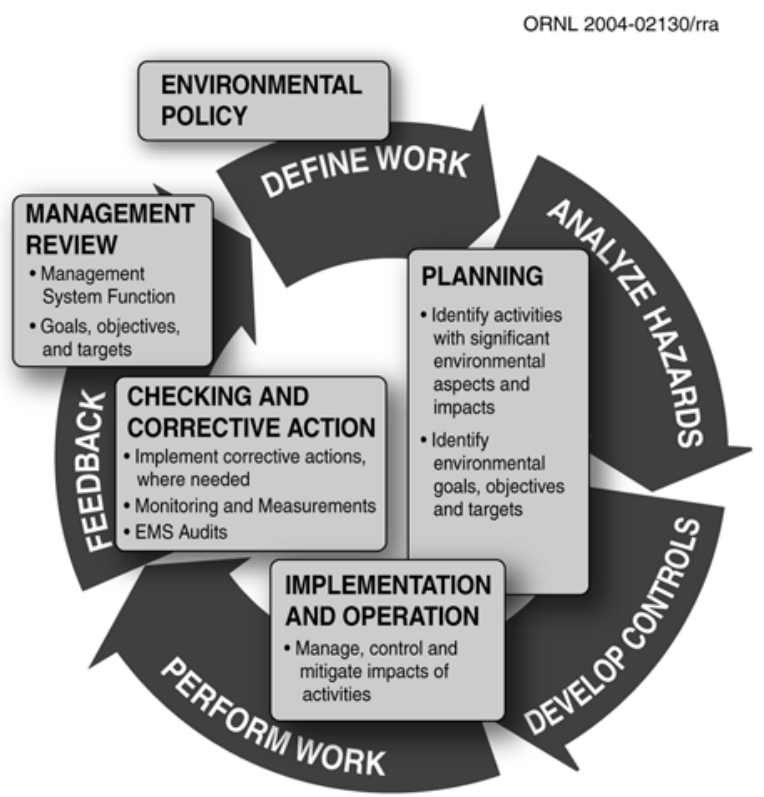

Fig. 2.2. The relationship between EMS and ISMS. 
applicable requirements, (2) prevent pollution, and (3) continually improve. The environmental policy statements in the UT-Battelle Policy for ORNL are available on the external web site at http://train.ornl.gov/wbt/EnvPolicy.cfm.

UT-Battelle has identified the following aspects as potentially having significant environmental impacts:

- industrial waste requiring special approval for disposal;

- hazardous waste;

- radioactive waste;

- PCB waste;

- mixed waste;

- medical waste;

- recyclable materials;

- air emissions;

- liquid discharges;

- storage or use of chemicals or radioactive materials;

- use/storage of PCB-contaminated equipment;

- transuranic or Class III/IV waste;

- historic/cultural resources;

- sensitive/endangered species;

- quarantined soils or plants;

- hold-for-decay wastes;

- universal waste;

- RCRA, PCB, and CERCLA treatability studies;

- excavated soils;

- physical disturbance of aquatic environs; and

- legacy contamination.

Activities containing these aspects are carefully controlled to minimize or eliminate impacts to the environment. Monitoring activities associated with these aspects are described in Chapters 3, 5, and 7 .

\subsection{BWXT Y-12 EMS Implementation Status}

BWXT Y-12 continued the ISO 14001 planning phase during 2003 and is prepared to move to the implementation phase during 2004.

BWXT Y-12 Policy Y72-001, Environment, Safety, and Health, is the top-level guiding principle for protecting the workers, the public, the environment, and preventing pollution whenever activities are planned and performed. In addition, Policy Y72-006, Y-12 Pollution
Prevention and Sustainability Policy, affirms the commitment of BWXT Y-12 to continually integrate sustainability principles into its activities in a safe, compliant, and cost-effective manner. These policies and the commitment of top management are summarized below and may be viewed on the BWXT Y-12 public web page (http://www.y12.doe.gov/bwxt/).

BWXT Y-12 is committed to establishing a safety envelope for all activities by identifying, evaluating, and developing controls for potential hazards. Work in a manner that

- provides safe working conditions and protects workers' health,

- implements behavior-based safety to further reduce risk of exposure,

- protects the public and the environment,

- prevents pollution,

- complies with applicable regulations,

- continuously improves our management systems and performances,

- integrates sustainability principles and practices in a safe, compliant, and costeffective manner.

In addition to established policy, BWXT Y-12 has identified legal and other requirements, evaluated activities for significant environmental aspects, and incorporated them into the ISMS process. The ISMS process includes hazard analysis of work activities (operations, maintenance, and construction) and the appropriate involvement of subject matter experts including environment, safety, and health professionals.

BWXT Y-12 EMS criteria for defining significant aspects are based on actual and perceived impacts and on regulatory requirements. The following aspects have been identified as potentially having significant environmental impact:

- Waste generation - excess materials and chemicals, low-level radiological, hazardous, mixed, PCB waste, universal, special industrial, medical, and sanitary

- Air emissions - criteria pollutants, hazardous air pollutants and other non-radiological air contaminants, ozone, and radiological emissions 
- Liquid discharges - process wastewater, cooling water, sanitary wastewater, flow management, chlorinated water discharges

- Potential releases from spill, leaks, runoff storage of radiological and non-radiological materials, oil and gas, waste, storm water runoff

- Spread of legacy contamination - historical waste management units, legacy mercury and PCB spills, demolition of excess and surplus facilities, groundwater contamination

- Interactions with historical and cultural resources and wildlife habitat

- Natural resource consumption - power and energy usage

- Natural resource conservation - purchasing materials with recycled content, recycling, and pollution prevention.

Activities involving these aspects are evaluated and controlled to minimize potential impacts to the environment. Monitoring activities associated with these aspects are described in Sects. 6 and 7.

Key goals for ISO 14001 implementation during 2004 will be the integrating of EMS audit tools with the ISM processes for independent and management assessment and updating performance measures to monitor continual improvement.

\subsection{BJC EMS Implementation Status}

BJC uses ISMS core functions and guiding principles to integrate EMS considerations into work activities. By integrating EMS considerations within the elements of ISMS, the BJC Environment, Safety, and Health Organization provides procedures and processes for identifying environmental protection controls and compliance impacts and concerns prior to performing a scope of work, during work activities, and after the work is completed. Issued in September 2000, the BJC environmental management policy is a key attribute of the EMS. The policy reflects the mission, goals, and responsibilities of the company with respect to environmental aspects and impacts, including pollution prevention. At the beginning of each project, subject-matter experts, called
Environmental Compliance and Protection (EC\&P) Leads, are assigned to each subcontractor's work activity to support the formation of project and subproject teams in identifying and analyzing environmental hazards and in implementing controls that comply with DOE Work Smart Standards and applicable laws and regulations. The EMS is supported by communication between BJC and its subcontractors through the project's EC\&P Lead. The EMS ensures that periodic assessments against the EMS attributes are conducted to evaluate the ISMS performance of each project and the subcontractor in charge of managing the project.

During CY 2003, DOE conducted a reverification of ISMS as implemented by BJC on all management and integration projects. Also during CY 2003, BJC self-performed a preliminary gap analysis to determine how well EMS is being implemented through each element of the reverified ISMS. During CY 2004, BJC will develop EMS Awareness Training on the EMS. Modifications to enhance the EMS will be made to meet the Executive Order 13148 requirement that a fully implemented EMS be in place by December 2005.

\subsubsection{POLLUTION PREVENTION}

During FY 2003, the ORR continued to implement a substantial number of pollution prevention $(\mathrm{P} 2)$ projects, which were reported to DOE. Reported results are summarized by Program Secretarial Office (PSO) in Table 2.13. Pollution prevention-specific information is also available on the DOE P2 homepage at http://www.eh.doe.gov/p2/.

The ORR Sites' Pollution Prevention Programs are required by federal and state laws and regulations, executive orders, and DOE policies, notices, and orders. During FY 2003, in addition to supporting the implementation of pollution prevention projects, the ORR facilities performed activities to ensure the new requirements established by DOE Order 450.1 were addressed as well as all other existing requirements. The ORR facilities must complete pollution prevention-related requirements such as planning and reporting to comply with many regulatory requirements, including RCRA, the 
Table 2.13. 2003 ORR pollution prevention project implementation results summary

\begin{tabular}{lccc}
\hline $\begin{array}{c}\text { Program secretarial } \\
\text { office }\end{array}$ & $\begin{array}{c}\text { Total number of P2 } \\
\text { projects reported } \\
\text { in FY 2003 }\end{array}$ & $\begin{array}{c}\text { Total quantity of waste } \\
\text { reduced in FY 2003 } \\
(\mathrm{MT} \mathrm{or} \mathrm{m})^{3}\end{array}$ & $\begin{array}{c}\text { Total cost avoidance } \\
\text { in FY 2003 } \\
\text { (Millions of \$) }\end{array}$ \\
\hline $\begin{array}{l}\text { NNSA /DP } \\
\mathrm{EM}^{\mathrm{b}}\end{array}$ & 70 & 18,245 & 4.0 \\
Scc/Other R\&D & 15 & 1,901 & 3.0 \\
\hline $\begin{array}{l}{ }^{\mathrm{a}} \text { National Nuclear Security Administration/Defense Program } \\
\text { b Environmental Management }\end{array}$ & & \\
${ }^{\mathrm{c}}$ Office of Science
\end{tabular}

Tennessee Hazardous Waste Reduction Act, and the Emergency Planning and Community Rightto-Know Act/Pollution Prevention Act. The ORR facilities must also comply with DOE requirements including reporting of pollution prevention project and program activities. The Annual Report on Waste Generation and Pollution Prevention Progress, the annual Affirmative Procurement Report, and reports on pollution prevention projects completed by each site are designed to provide data used to measure progress toward DOE's FY 2005 and 2010 pollution prevention goals. Reported percentages reduction results for FY 2003 (based on a 1993 baseline) are summarized by Program Secretarial Office or by the site as appropriate in Table 2.14.

The ORR also supports DOE's goal of reducing off-site releases and transfers of toxic chemicals by assessing operations associated with these releases and transfers. However, because of substantial changes since 1993 in the operations included in the EPCRA-related reporting from which these values are obtained, the ORR does not anticipate an overall reduction when compared with the 1993 baseline. Information on Program Secretarial Office-specific and site-specific waste generation, recycling, and affirmative procurement is also available on the DOE P2 homepage at http://www.eh.doe.gov/p2/.

Additionally, each site's data are included in DOE's complex-wide reports. Elements of DOE's annual reports are extracted and included in DOE's central internet database, which provides national-level DOE waste management and cleanup data to the public, as required by the December 1998 settlement agreement between DOE and the Natural Resources Defense Council, Inc.
In FY 2003, ORR-related activities received the following DOE pollution-prevention awards in recognition of specific 2002 pollution-prevention accomplishments:

- Recycling - Y-12 Technical Library Book Recycling Project

- Environmental Preferability - Demonstration of a Web-Based Chemical Purchasing and Management System

- Environmental Restoration - Lasagna ${ }^{\mathrm{TM}}$ Soil Remediation Technology

- Model Facility Demonstration/Complexwide Achievement - DOE's Homeland Defense Equipment Reuse Program.

To support future pollution prevention implementation, compliance, and goal achievement, the ORR sites' pollution prevention programs continue to pursue site projects, perform required activities, and complete required reporting.

\subsubsection{OZONE-DEPLETING SUBSTANCES PHASE-OUT EFFORTS}

Significant progress has been made in eliminating use of Class I and Class II ozonedepleting substances at the Y-12 Complex, and a number of projects have been identified to further reduce ozone-depleting substances uses. Y-12 Complex ozone-depleting substances Phase-Out and Management Plan, Y/TS-1880, was issued in 2003 and provides a complete discussion of requirements and compliance activities at the $\mathrm{Y}$ 12 Complex.

One of the pollution prevention goals involving ozone-depleting substances is to retrofit or replace by $2005100 \%$ of chillers using Class 1 refrigerants that have a cooling capacity of 
Table 2.14. 2003 ORR affirmative procurement and waste reduction progress summary

\begin{tabular}{|c|c|c|c|c|c|c|c|}
\hline \multirow{2}{*}{$\begin{array}{c}\text { Program } \\
\text { secretarial office }\end{array}$} & \multicolumn{4}{|c|}{ Reduction by office (\%) } & \multirow[b]{2}{*}{ Site } & \multicolumn{2}{|c|}{ Reduction by site (\%) } \\
\hline & TRU & $\begin{array}{c}\text { Mixed LLW } \\
\text { and RCRA }\end{array}$ & LLW & $\begin{array}{l}\text { Affirmative } \\
\text { procurement }\end{array}$ & & SAN & $\begin{array}{c}\text { SAN } \\
\text { recycling }\end{array}$ \\
\hline $\begin{array}{l}\mathrm{NNSA} / \mathrm{DP}^{a} \\
\mathrm{EM}^{b}\end{array}$ & N/A & 92 & 44 & 87 & $\begin{array}{l}\text { Y-12 } \\
\text { ETTP }\end{array}$ & 87 & 71 \\
\hline $\mathrm{SC}^{c} /$ Other R\&D & 93 & 85 & 77 & 82 & ORNL & 40 & 31 \\
\hline
\end{tabular}

${ }^{a}$ National Nuclear Security Administration/Defense Program

${ }^{b}$ Environmental Management

${ }^{c}$ Office of Science

greater than 150 tons and that were manufactured before 1984. In December 1998, a \$12.8 M line item project, "Retrofit Heating Ventilation and Air Conditioning (HVAC) and Chillers for Ozone Protection" was completed at the Y-12 Complex. A significant number of chillers were retrofitted, replaced, or taken out of service. The last remaining chiller that falls under this definition is located in Building 9767-3 in the biology area at the Y-12 Complex and belongs to ORNL. This chiller was taken out of service and the freon was removed in March 2004.

The second pollution prevention goal involving ozone-depleting substances is to eliminate Class I ozone-depleting substances by 2010 to the extent economically practicable and to the extent that safe alternative chemicals are available for DOE Class 1 applications. The Y-12 Complex has accomplished this goal to the extent economically practicable and to the extent that safe alternative chemicals are available for Y12-specific applications. A number of actions have been initiated to achieve this goal, including product substitutions for solvent uses, retrofitsor replacements for chiller systems, and product substitutions for fire-protection systems. For example, the use of Halon in fire-protection systems has been eliminated. Where availability of safe alternatives or economic factors prevent elimination of ozone-depleting substances use, Y12 Complex continues to pursue viable options (e.g., elimination of Freon 12 and Freon 113 solvent usage in some of Y-12's major production facilities). Four remaining chillers with Class 1 ozone-depleting substances are being assessed to determine the long-term need for these systems while taking into account economic considerations.

ORNL has implemented a plan to eliminate the use of Class I ozone-depleting substances. This plan included the replacement, retrofit, or decommissioning of all chillers that require Class I substances, the gradual phase out of smaller refrigeration systems that require Class I substances, the elimination of all fire-protection systems that use Class I substances, and the elimination of all other systems or processes that require Class I substances. Currently, Class I substances are used in small refrigeration systems such as refrigerators and window air conditioners. As these units fail, they are replaced with new units that use Class II or unregulated refrigerants.

DOE Guidance dated October 1999, requires that all DOE facilities retrofit or replace by 2005 all chillers using Class I refrigerants that are greater than 150 tons of cooling capacity and were manufactured prior to 1984 . ORNL operated a number of chillers that were impacted by this requirement. All of these impacted chillers have been retrofitted, replaced, or decommissioned, except one chiller located in Building 3525. This chiller was to be decommissioned; however, plans for the 3525 facility were changed in 2003, requiring that the chiller be replaced in accordance with the DOE requirement. Plans are being developed to replace this chiller.

ETTP completed the phaseout of Class 1 ozone-depleting substances equipment in the mid90s. At that time, ETTP surplused and moved all Class 1 ozone-depleting substances to other DOE sites so they are no longer part of the ETTP ozone-depleting substances inventory. One exception exists, a small amount -300 pounds of Class 1 R-12 refrigerant - was maintained in the ETTP inventory in CY 2003 for servicing older, small units/appliances (i.e, freezers and refrigerators) for the duration of their expected service life. 


\subsubsection{ENERGY MANAGEMENT (including Fleet Management)}

BWXT Y-12 prepared a multiyear Energy Management Plan that defines the general energy requirements of the $\mathrm{Y}-12$ Complex and provides a brief history of energy reduction efforts and a timetable for further energy savings measures. The primary focus for energy conservation is on electricity, with secondary concentrations on reducing the use of natural gas, fuel (gasoline and diesel), coal, and water.

Over the past 15 years, the energy consumption at $\mathrm{Y}-12$ has been reduced by more than $40 \%$. Much of this reduction came as a result of reduced production activities and energy savings measures, such as replacing chillers, eliminating cooling towers, and regularly overhauling steam plant boilers.

ORNL's Energy Management and Implementation Plan outlines the strategy for managing and implementing short- and long-range energy-related activities. As a result of ORNL's on energy and utilities management and projects, standard building energy intensity has been reduced by approximately $20 \%$ compared with FY 1985 usage (based on Btus per gross square foot). Also, the energy intensity for high-energyuse facilities has been reduced by $65 \%$. Specific activities include the following:

Energy Star. In FY 2000 ORNL was awarded the EPA's Energy Star Award for a building, the first DOE building to achieve this rating and only the second building in the state of Tennessee to do so. ORNL is currently reviewing utilities data to determine whether additional ORNL buildings are eligible for Energy Star Awards in FY 2004.

LEED and Sustainability. The newly constructed East Campus Modernization project at ORNL used third-party financing to add over $300,000 \mathrm{ft}^{2}$ of energy-efficient office, laboratory, and computer space and achieve a savings of $\$ 0.5$ $\mathrm{M}$ in annual energy costs (30\% savings compared with the baseline conventional design). This project was recently certified by the U.S. Green Building Council as a LEED-certified project.

CFC Reductions. As part an aggressive chiller replacement program, ORNL has replaced 16 chillers totaling 8,200 tons in cooling capacity, well ahead of legislated requirements. As a result, chiller energy use has dropped an average of $21 \%$ for an annual savings of $\$ 280 \mathrm{~K}$, and CFC emissions have been cut by 5,000 lb/year. ORNL continues to replace smaller CFC chillers and has transferred all R-113 and most of the R-11 stored refrigerant to a refrigerant recycler.

Water Savings. Water-related projects and management efforts have resulted in water usage being reduced by 108 million gallons, nearly $10 \%$, since FY 2000.

Green Power. ORNL participates in TVA's "Green Power Switch" program. ORNL was TVA's first industrial green power participant and purchases $675 \mathrm{MWh}$ in green power annually.

Distributed Energy Resource. Combining solar power with natural gas-fired turbine technology, ORNL's $30 \mathrm{~kW}$ distributed energy resource research project won a Federal Energy Saver Showcase Award in FY 2002.

Greenhouse Gas Emission Reductions. Even though the gross square feet at ORNL has increased almost 20\% since FY 1995, the relatively recent conversion from coal to natural gas as the primary fuel at the central steam plant has reduced $\mathrm{CO}_{2}$-equivalent greenhouse gas emissions by $29 \%$ over the same time period.

Vehicle Fleet Management. ORNL is working to minimize the use of petroleum-based fuels in the vehicle fleet. To minimize gasoline consumption, 70 ethanol-burning vehicles are in service (12 purchased in FY 2003 and 9 in FY 2004). Additional alternative fuel vehicles are being added to the fleet as funding allows.

\subsubsection{Beneficial Landscaping Practices}

DOE Order 450.1, incorporates Executive Order 13148, "Guidance for Presidential Memorandum on Environmentally and Economically Beneficial Landscape Practices on Federal Landscaped Grounds." The guidance applicable to DOE-site landscaping include: (1) Use of Regionally Native Plants for Landscaping; (2) Design, Use, or Promotion of Construction Practices that Minimize Adverse Effects on the Natural Habitat; (3) Seeking to Prevent Pollution; (4) Implementing Water and Energy Efficient Practices; (5) Creating Outdoor Demonstration Projects; and (6) Other Initiatives.

Y-12/NNSA partners with ORNL regarding stewardship responsibilities for lands on the ORR. 
$\mathrm{Y}-12$ requires extensive use of erosion controls in construction projects (e.g., use of settling ponds and storm water detention areas), minimal use of water for irrigation, and use of trees where possible to provide shade for energy conservation. Active environmental compliance and preservation programs, such as an ongoing sitewide Pollution Prevention Program, Storm Water Pollution Prevention Plan activities, and policies requiring minimal use of pesticides and fertilizers also minimize environmental impacts. Additionally, Y-12 has limited its modernization construction to "brownfield" sites, thereby preserving ORR greenfield space.

ORNL has various ongoing programs and initiatives that involve or facilitate environmentally and economically beneficial landscaping practices. These include incorporation of native plants into planning for restoration or landscaping in areas across ORNL; development in 2003 of the ORNL Conceptual Landscape Plan and Design Guidelines, which calls for use of native plant species; use of an internal stream corridor protection effort to encourage the growth of native plants in the riparian zone surrounding ORNL creeks; use of Native Plant and Invasive Species Workshop held at ORNL in April 2003 to educate planning and landscaping staff; the formation of an interagency Native Grass Working Group; integration of native-plant requirements into facilitiesdevelopment projects; evaluation of upcoming projects by the ORNL Land and Facilities Use Committee on potential impacts, including impact on natural habitat; creation of an ongoing sitewide Pollution Prevention Program and a Storm Water Pollution Prevention Plan and Program; minimal use of pesticides and fertilizers, and use of organic fertilizers; extensive use of erosion controls in construction projects (e.g., settling ponds and bioretention areas); minimal use of water for irrigation; incorporation of plants into project designs for energy conservation by providing shade, and cooling to paved surfaces; provision of public-awareness interaction on invasive plants, nuisance wildlife, and restoration of native grasses; use of brownfield areas for siting new ORNL developments, when practicable; and implementation of an interagency cooperative agreement on conversion of TVA power-line rights-of-way from fescue grass to native grasses and shrubs.

\subsection{APPRAISALS AND SURVEILLANCES OF ENVIRONMENTAL PROGRAMS}

Numerous appraisals, surveillances, and audits of ORR environmental activities were conducted during 2003 (see Tables 2.15, 2.16, and 2.17). These tables do not include internal DOE prime contractor assessments for 2003.

\subsection{ENVIRONMENTAL PERMITS}

Table 2.18 contains a summary of environmental permits for the three ORR sites. Continuing permits, required at each of the ORR facilities, are RCRA operating permits, NPDES permits, and air operating permits.

\subsection{NOTICES OF VIOLATIONS AND PENALTIES}

ORNL received two notices of violations (NOVs) from TDEC and an EPA RCRA inspection report in 2003, for instances of RCRA nonconformances, and one NOV on April 2, 2003, for a NPDES permit nonconformance that occurred at storm water discharge Outfall 302. The RCRA issues included greater than 1 year storage of land disposal restricted wastes, failure to label a few used oil containers properly, failure to follow the Waste Analysis Plan in the RCRA permits, failure to maintain the required training records for operators of permitted units, and failure to identify/manage potassium ferricyanide and potassium ferrocyanide as hazardous wastes. ORNL provided response correspondence to TDEC as to causes and corrective measures for each accepted nonconformance. However, ORNL contested the cyanide issue and TDEC ultimately agreed that it was not a violation. The other RCRA NOVs resulted in a fine of $\$ 10,800$ being levied by the state of Tennessee. The NPDES NOV was for a permit nonconformance that 
Table 2.15. Summary of environmental audits and assessments conducted at the Y-12 Complex, $2003^{a}$

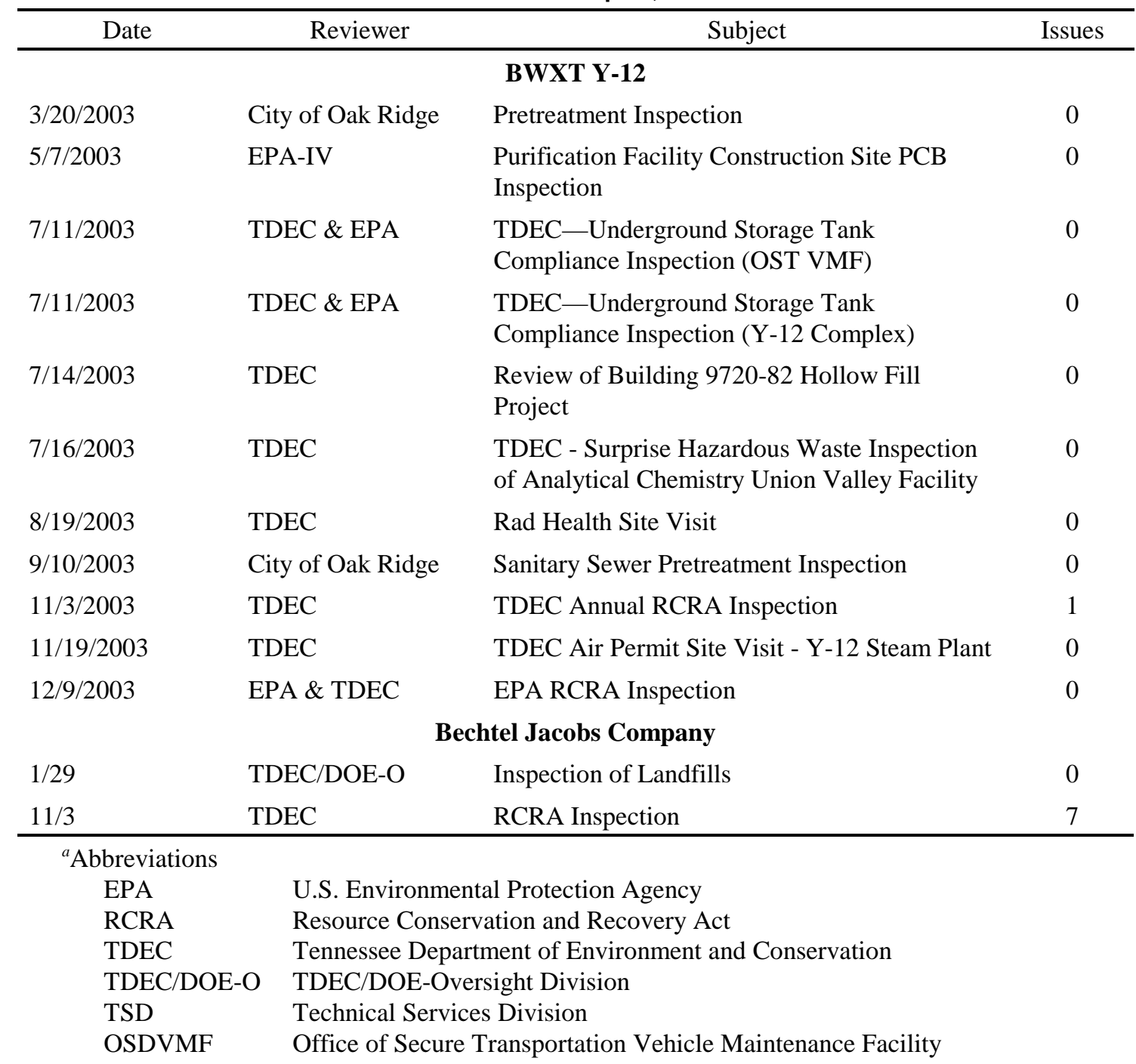

occurred at storm water discharge Outfall 302. A leak in a supply pipe was found at the 3544 wastewater treatment facility; it was releasing sodium hydroxide to the Outfall 302 storm drain pipe. The leak was repaired, and Outfall $302 \mathrm{pH}$ measurement returned to normal.

On December 20, 2002, an NOV was issued to DOE and NNSA from TDEC for violations alleging that "several RCRA manifests were discovered to be missing the required signed copies from the designated waste management facilities." The missing information was cited by TDEC personnel during the process of document review conducted during an inspection of RCRA TSDR (treatment, storage, disposal, and recycle) facilities at Y-12 on November 20, 2002. Followup conversations revealed that although faxed copies were provided to the TDEC inspector, the signed copies were on file at another location away from the facility being inspected. These signed copies were eventually provided to TDEC and no civil penalties were assessed.

Three NOVs were issued by TDEC in 2003 for ETTP operations. On February 18, 2003, an NOV was issued for NPDES permit limit exceedances of the total petroleum hydrocarbons (TPH) parameter occurring during prior years at the Central Neutralization Facility. An in-depth investigation was performed by the operating subcontractor for the Central Neutralization Facility, and a summary report was submitted. No definitive cause for the exceedance was identified.

On March 4, 2003, an NOV was issued by the TDEC for two violations of RCRA waste management requirements. One of the issues was 
Table 2.16. Summary of environmental audits and assessments conducted at ORNL, $2003^{a}$

\begin{tabular}{lllc}
\hline \multicolumn{1}{c}{ Date } & \multicolumn{1}{c}{ Reviewer } & \multicolumn{1}{c}{ Subject } \\
\hline $1 / 9$ & TDEC & \multicolumn{1}{c}{ UT-Battelle } \\
& & $\begin{array}{l}\text { Site visit for inspection of Aquatic Resource Alteration } \\
\text { Permit and Construction Activity Storm Water } \\
\text { Permitting on East Campus }\end{array}$ & 0 \\
$6 / 24-6 / 25$ & EPA & CAA inspections \\
$9 / 29-10 / 1$ & TDEC/DOE-O & CAA inspections \\
& & Bechtel Jacobs Company & 0 \\
& & RCRA inspection & 0 \\
$5 / 6$ & TDEC & RCRA inspection of waste inventories & \\
$5 / 29$ & TDEC & Multimedia inspection & 1 \\
$6 / 23-6 / 27$ & TDEC/DOE-O/EPA & Inspection of White Oak Dam & 0 \\
$9 / 11$ & FERC &
\end{tabular}

${ }^{a}$ Abbreviations

CAA Clean Air Act

FERC Federal Energy Regulatory Commission

RCRA Resource Conservation and Recovery Act

TDEC Tennessee Department of Environment and Conservation

TDEC/DOE-O TDEC/DOE-Oversight Division

Table 2.17. Summary of environmental audits and assessments conducted at the ETTP, $2003^{\mathrm{a}}$

\begin{tabular}{lllc}
\hline \multicolumn{1}{c}{ Date } & \multicolumn{1}{c}{ Reviewer } & \multicolumn{1}{c}{ Subject } & Issues \\
\hline $1 / 16$ & TDEC & Clean air inspection & 0 \\
$2 / 19$ & TDEC & RCRA inspection (permitted storage areas) & 2 \\
$2 / 27$ & TDEC & Title V annual air inspection & 0 \\
$4 / 28$ & TDEC & RCRA inspection CNF and K-1414 garage & 0 \\
$5 / 6$ & EPA & RCRA inspection of TSCA Incinerator & 2 \\
\hline
\end{tabular}

${ }^{a}$ Abbreviations

$\begin{array}{ll}\text { EPA } & \text { U.S. Environmental Protection Agency } \\ \text { TDEC } & \text { Tennessee Department of Environment and Conservation } \\ \text { CNF } & \text { Central Neutralization Facility }\end{array}$

the improper labeling of four drums of used oil at the ETTP garage, and the other issue was the failure to update the name of the emergency coordinator on the Central Neutralization Facility contingency plan (the co-ordinator had recently retired). Both issues were corrected to the satisfaction of the TDEC.

On April 11, 2003 an NOV was issued by the TDEC for a CAA permit exceedance that had occurred at the TSCA Incinerator at ETTP during a series of trial burn tests in 2001. In one of the 2001 tests, particulate emissions rates exceeded permit limits. DOE has submitted a proposed schedule of corrective actions. In the other two instances, TDEC alleges that lead and volatile organic compound emissions exceeded permit limits. However, DOE has challenged these allegations based upon the data submitted to the TDEC in the RCRA/TSCA Trial Burn Report.

BWXT Y-12 received an alleged NOV from TDEC on December 11, 2003, for violation of the Tennessee Hazardous Waste Permit (TNHW)084. The presence of cracks in the floor at a permitted RCRA storage unit (9720-12) was 
Table 2.18. Summary of permits as of December 2003

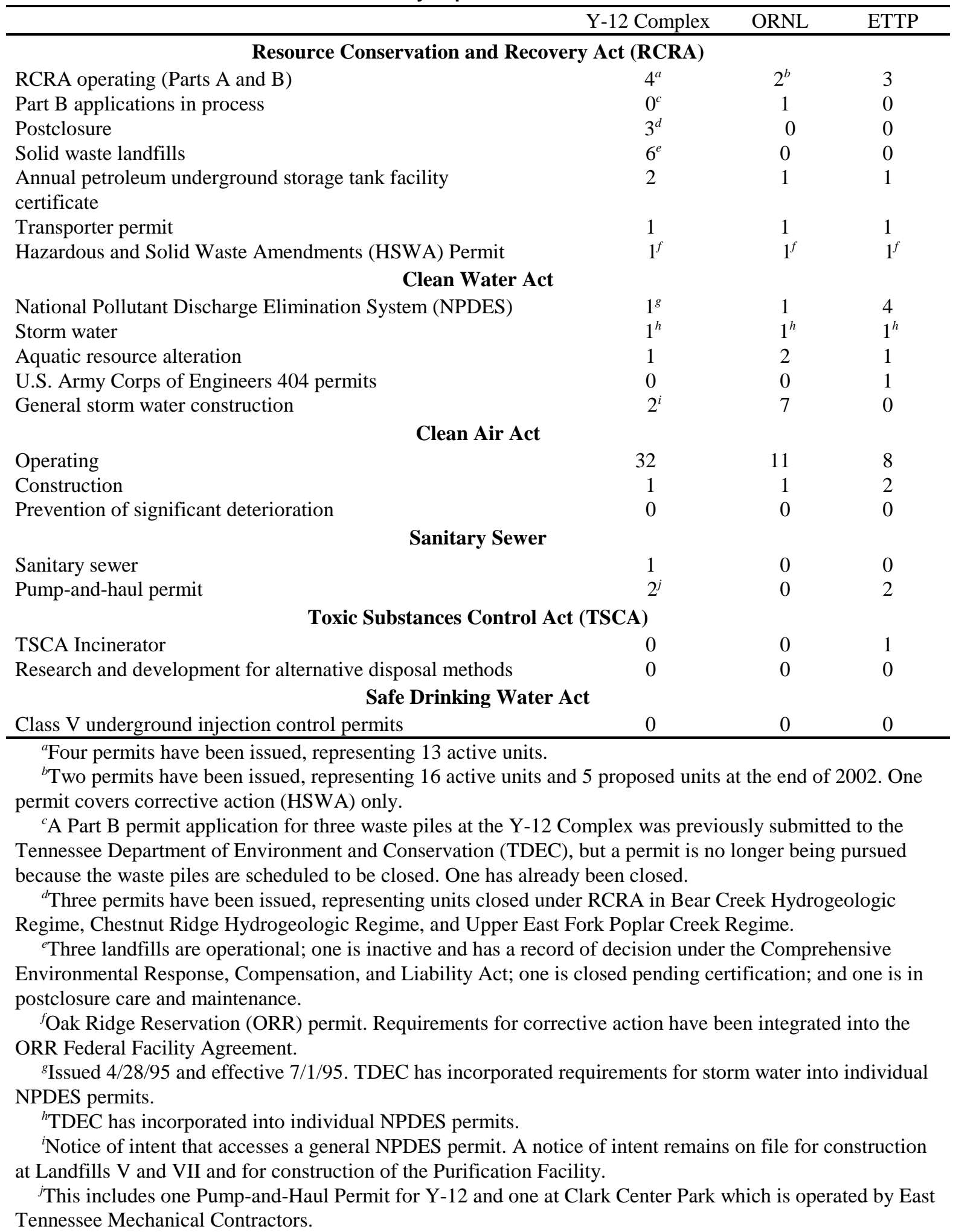


observed during the TDEC inspection in November 2003. TDEC maintained that the cracks violate the permit requirements for the storage area. However, only solid materials are stored in this unit, and the permit does not allow storage of liquids nor require secondary containment since liquid spills cannot occur. To resolve the issue, a Class I permit modification was initiated to note the presence of cracks in the floor of the storage unit. BWXT Y-12's permit modification also clarifies the permit language for other storage units that store only solids, to assure that this issue does not come up again at other storage units.

\subsection{TENNESSEE OVERSIGHT AGREEMENT}

The Tennessee Oversight Agreement is a voluntary agreement entered into between the DOE and the state of Tennessee. This agreement reflects an extension through June 30, 2006, of the agreement between the DOE and the state executed on May 13, 1991, and continues to reflect the obligations and agreements regarding DOE's technical and financial support.
The agreement is designed to assure the citizens of Tennessee that their health, safety, and environment are being protected through existing programs and substantial new commitments by DOE. Through a program of independent monitoring and oversight, the state will advise and assist in verifying that DOE's activities do not adversely impact the public health, safety, or the environment. DOE and the state, in a spirit of partnership and cooperation, agree to find ways to achieve clean air, water, and land in concert with sustainable economic growth.

To date, a variety of activities have been conducted under the agreement. DOE has provided security clearances and training necessary for state employees to gain access to the sites. Environmental data and documents pertaining to the environmental management, restoration, and emergency management programs are provided or are made available to the state for its review. The TDEC/DOE Oversight Division routinely visits the three DOE sites to attend formal meetings and briefings, conduct walk-throughs of buildings and grounds, and conduct observations of site operations to assess compliance with environmental regulations. The TDEC/DOE Oversight Division also prepares an annual environmental monitoring report of its activities (TDEC 2003) and is available on the web at http://www.state.tn.us/ environment/doeo/. 



\section{Environmental Management and Reservation Activities}

Much of the work accomplished by the DOE Oak Ridge Operations Office of Environmental Management (EM) on the ORR is performed as a result of the requirements of the Federal Facility Compliance Act and the Comprehensive Environmental Response, Compensation, and Liability Act (CERCLA). The 1992 Federal Facility Compliance Agreement requires that all DOE facilities manage and dispose of mixed waste in accordance with their respective site treatment plans. Bechtel Jacobs Company LLC has established programs to address the storage, transportation, treatment, disposal, and recycling of legacy and newly generated waste from the ORR. Bechtel Jacobs LLC manages the Toxic Substances Control Act Incinerator, wastewater treatment facilities, landfill operations, and certain other treatment and recycle facilities that also contribute to meeting the requirements of the Federal Facility Compliance Agreement and other EM milestones.

Another large portion of the EM work conducted at ORR is performed according to the requirements of CERCLA, which is implemented by the 1991 Federal Facility Agreement. The Federal Facility Agreement, signed by DOE, TDEC, and EPA, addresses contamination resulting from past activities of DOE operations that remain in structures, buildings, facilities, soil, groundwater, surface water, or other environmental media.

\subsection{INTRODUCTION}

For over half a century, one of the primary missions of DOE and its predecessor agencies was the production of nuclear weapons for the nation's defense. Production of materials for nuclear weapons, which began in 1943, produced hazardous and radioactive waste and resulted in contamination of facilities, structures, and environmental media. Two laws passed by Congress included requirements to address these problems. These two laws are the Federal Facility Compliance Act and CERCLA. The Federal Facility Compliance Agreement, made in accordance with the Federal Facility Compliance Act, requires that all DOE facilities manage and dispose of waste in accordance with their respective site treatment plans. The Waste Disposition and Waste Operations projects address waste stored, treated, disposed of, or recycled on the ORR in accordance with the Site Treatment Plan. The DOE Environmental Management program also operates and maintains waste treatment, storage, disposal, and recycling facilities at each of the three Oak Ridge sites (ETTP, ORNL, and Y-12). These activities are included in the Waste Operations project.

CERCLA addresses any environmental contamination resulting from past industrial operations, not just those performed at federal facilities. CERCLA requires that sites requiring cleanup actions be placed on the National Priorities List. Once on the list, the responsible entities are required to investigate and remedy abandoned or uncontrolled hazardous waste sites where a release has occurred or may occur. The ORR was placed on the National Priorities List in 1989. In 1990, DOE Headquarters (DOE-HQ) established the Office of Environmental Management (EM), making DOE-ORO responsible for cleanup of the reservation. CERCLA also requires public involvement to ensure that citizens will be informed of cleanup decisions that may affect them or the area in which they live.

The following sections highlight some of the EM activities for 2003 and some related activities carried out to ensure good stewardship of the reservation. 


\subsection{EAST TENNESSEE TECHNOLOGY PARK}

\subsubsection{Decontamination and Decommissioning}

\subsubsection{ETTP Three-Building Decontamination and Decommissioning Project Nearing Completion}

The East Tennessee Technology Park (ETTP) Three-Building Decontamination and Decommissioning Project is nearing completion, with $90 \%$ of the work accomplished as of the end of CY 2003. The contractor, under a fixed-price contract with DOE) awarded in August 1997, is dismantling, removing, and dispositioning the materials and equipment within the K-33, K-31, and K-29 gaseous diffusion buildings at ETTP. The three buildings cover more than 4.89 million $\mathrm{ft}^{2}$ of floor space and housed more than 140,000 tons of contaminated or potentially contaminated material.

The purpose of the project is to dismantle, remove, and disposition all of the material from the three buildings and to decontaminate two of the three buildings to certain specifications, making them available for reuse without radiological or other safety concerns.

A total of 144,000 tons of material have been dismantled, removed, and dispositioned as waste or recyclable material for the entire project. During CY 2003, more than $20 \%$ of the overall project was completed, including dismantlement, disassembly, removal, and dispositioning of all of the process equipment and material from the last four remaining cascade units in Building K-31 and two of the three remaining cascade units in Building K-29. More than 54,000 tons of metal have also been processed as low-level waste to the Envirocare Disposal Facility and the Nevada Test Site Disposal Facility. In addition, $8260 \mathrm{yd}^{3}$ of concrete pedestal material has been disposed of in the Environmental Management Waste Management Facility (EMWMF), which is located near the Y-12 National Security Complex.

Completion of the dismantlement, disassembly, and disposal of the remaining cascade unit in Building K-29 and decontamination of the interiors of Bldgs. K-33 and K-31 is expected to be completed in 2004. The interior of Building K-29 will not be decontaminated as part of this project. The decision not to decontaminate the interior of Building K-29 was made in 2003, and the contract modification is being put into place. The project is currently scheduled to be completed by August 2004.

\subsubsection{ETTP K-25/K-27 Facilities Decontamination and Decommissioning Project}

The K-25 building, built during the Manhattan Project, is the largest building on the ORR. The U-shaped building covers 1,637,170 $\mathrm{ft}^{2}$ and contains 3,018 stages of gaseous diffusion process equipment and associated auxiliary systems, which will be removed and disposed of. Each stage consists of a converter, two compressors, two compressor motors, and associated piping. The K-27 building covers $383,000 \mathrm{ft}^{2}$ and contains 540 stages of gaseous diffusion equipment and associated auxiliary equipment.

A public information session was held in 2001 to solicit comments from the public on the engineering evaluation/cost analysis developed for this project. An action memorandum for the decontamination and decommissioning of the $\mathrm{K}$ 25 and K-27 buildings was signed in February 2002. Phase 1, hazardous materials removal, started in spring 2002 and was just over 50\% complete by the end of 2003. Phase 1 activities primarily include the removal of asbestoscontaining building materials from the inside of the K-25 and K-27 facilities. At the close of 2003, hazardous material abatement had been completed in 28 units ( 280 cells), and more than $283,000 \mathrm{ft}^{3}$ of waste from the K-25 building had been disposed of at the EMWMF.

Phase 2, process equipment removal, activities in 2003 included detailed meetings with the decontamination and decommissioning core team to resolve comments on the processequipment-removal waste-handling and characterization plans. The Phase 2 process equipment removal request for proposal was issued during 2003, and the proposal was under review at year end. Additionally, the work on removal of excess materials from the K-25 and K- 
27 buildings was awarded in December 2003. The corresponding draft versions of the wastehandling plan, waste characterization plan, and removal action work plan were also prepared. Excess material removal and the process equipment removal work are planned to begin in 2004.

On September 30, 2003, DOE signed an action memorandum for the remaining facilities (approximately 500) to undergo decontamination and decommissioning under the engineering evaluation/cost analysis for the K-25 Auxiliary Facilities Demolition Project, Group II. The Remaining Facilities Demolition Standard Operating Protocol and the Waste Handling Plan Part I were prepared and submitted to the regulators for approval on September 18, 2003. The standard operating protocol was approved in October 2003; Part I of the Waste Handling Plan was approved in November 2003.

\subsubsection{Group II, Main Plant Area Demolition Project}

All buildings at the ETTP are scheduled for demolition as part of DOE's accelerated cleanup plan. However, up to 26 facilities have been targeted for potential transfer of title under the reindustrialization program. Property transfer is a key component of the accelerated cleanup plan and will result in savings to DOE by avoiding building demolition costs. Additionally, transfer of these properties will contribute to the reduction of DOE mortgage costs at ETTP, making that money available for other cleanup projects.

Buildings and facilities have been divided into two groups: (1) K-25/27 facilities decontamination and demolition and (2) remaining facilities decontamination and demolition, which is organized into several subprojects. Because these subprojects will be managed as interim removal actions, future CERCLA decisions will determine the final remedy for the contaminated slabs, soils, and below-grade structures.

The Main Plant Demolition Project involves (1) characterization, sampling, hazardous material abatement, radiological decontamination, demolition, and disposal of the fluorine and $\mathrm{UF}_{6}$ process vent lines located on the overhead pipe rack between facilities and (2) demolition to grade the following CERCLA facilities: K-1300 Brick Vent Stack, K-1301 Nitrogen Production Facility, K-1302 Fluorine Storage, K-1303 Air Model Test Facility, K-1405 High Temperature Laboratory, K-1407 Laboratory and Storage (which also included the K-1407-D Calcium Hydroxide Tank and K-1407-L Sulfuric Acid Tank), K-1413 Laboratory, and their related appurtenances. Three additional buildings (K1045-A, K-1404, and K1408-A) were not within the scope of the CERCLA removal action and were demolished in accordance with the National Environmental Policy Act of 1969 (NEPA).

This project began in 2001 and was completed in late 2003. During 2003, the K-1300 $\mathrm{UF}_{6}$ vent lines were demolished, and all remaining waste from the facilities was disposed of, with the exception of the low-level classified waste from $\mathrm{K}-1413$. The uncontaminated waste was disposed of at the ORR Industrial Landfill; the bulk of the low-level waste was disposed at the EMWMF. The K-1300 vent line waste was disposed of at the Nevada Test Site.

Classified waste from K-1413 was disposed of at the Nevada Test Site in CY 2003. A removal action report that documents the completed project will be submitted to the regulators.

CY 2004 decontamination and demolition activities at ETTP began on July 31, 2002, when DOE approved the action memorandum for the decontamination and demolition of 17 ETTP facilities and for the removal of contaminated scrap material. These facilities and the scrap material are included in the Group II Buildings, Phase II Demolition Project, and are primarily located in the K-1064 peninsula area of ETTP. During 2003, the regulators approved the removal action work plan and waste-handling plan.

\subsubsection{Remedial Action Completed at K-1070-A Burial Ground}

Organic compounds and radioactively contaminated wastes from 62 pits and 26 trenches at the K-1070-A Burial Ground at ETTP were excavated and disposed of at the EMWMF. The primary waste type disposed of was soil; however, there was some construction debris commingled with the soil. Excavation began in June 2002 and was completed in March 2003; 28,509 tons were 
excavated and shipped in 1,586 shipments to the EMWMF for disposal.

Included in the $21,651 \mathrm{yd}^{3}$ of waste were 344 intact gas cylinders and various-size containers that were unearthed and underwent nondestructive assay analyses to determine uranium-235 enrichment. Three hundred thirty-four of these cylinders were breached and disposed of at the EMWMF; the remaining ten cylinders, including two 10-ton cylinders that had the potential to contain $\mathrm{UF}_{6}$, were transferred to and dispositioned by the $\mathrm{UF}_{6}$ Project. The site has been regraded to its original contours and restored. More than 70,600 hours were worked without incident or injury. The remedial action report for the burial ground was submitted to the regulatory agencies in September 2003, three months ahead of the Federal Facility Agreement milestone.

\subsubsection{Zone 1 Record of Decision Approved}

The record of decision for the ETTP Zone 1 remediation was approved by DOE, EPA, and TDEC in November 2003. Zone 1 encompasses an area of approximately 1400 acres located outside the ETTP main fence and surrounding the former main plant production area. The record of decision specifically addresses known areas of contaminated soil, Blair Quarry, scrap metal and debris in the K-770 Area, and the K-710 Sludge Beds and Imhoff Tanks. In addition, it establishes remediation levels for soil and burial areas and a methodology, referred to as the "dynamic verification strategy," for making action/no action determinations that will be used throughout Zone 1.

The remedial action core team, composed of representatives from DOE, EPA, TDEC, and their contractors, was established. The core team finalized its team charter in February, and through a series of team meetings and workshops, has made progress reaching agreement on a number of issues. A waste handling plan, set of standard operating protocols, land-use control implementation plan, and dynamic verification strategy protocol have been developed by the remedial action core team to guide implementation of the remedy outlined in the record of decision for Zone 1. Additionally, five site summaries have been developed and issued to the regulatory agencies. A request for proposals for remediation of the K-770 scrap metal has been prepared and issued for bid, and a pilot demonstration of dynamic verification strategy implementation has been planned for Blair Quarry in Zone 1.

The focused feasibility study is being developed for Zone 2 soils for submittal to EPA and TDEC for approval. The study includes soil remediation levels for groundwater protection. The proposed plan for Zone 2 soils was initiated concurrently with development of the focused feasibility study.

\subsubsection{K-1070-C/D G-Pit and Waste Disposition Completed}

Portions of the K-1070-C/D Burial Ground were remediated in a two-phase project. Phase I (completed in 1999) consisted of excavation, segregation, characterization, and packaging of buried material in G-Pit, located in the K-1070C/D Burial Ground, and covering of the K-1071 concrete pad, also located at the burial ground. Phase II of the remedial action consisted of the treatment and disposal of the excavated material from G-Pit. This waste was disposed of at the ORR Industrial Landfill at the Y-12 Complex. Approximately $40 \mathrm{yd}^{3}$ of secondary construction waste were accepted for disposal and were incinerated at the TSCA Incinerator in September 2003. The remedial action report was submitted to EPA and TDEC in December 2002, meeting the Federal Facility Agreement milestone, followed by a letter notification of the completion of incineration of the secondary waste stream in September.

\subsection{OAK RIDGE NATIONAL LABORATORY}

\subsubsection{Melton Valley Remedial Actions}

Continued well plugging and abandonment, decontamination and decommissioning of the New Hydrofracture Facility, and hydraulic isolation at SWSA 4 were among the remediation activities in Melton Valley in 2003. 
The Federal Facility Agreement parties signed the Melton Valley record of decision in September 2000. The Melton Valley record of decision presents the selected remedy for environmental remediation of various burial grounds and other contaminated waste units within the ORNL Melton Valley area. Remediation will be accomplished through a combination of responses that includes containment, stabilization, removal, treatment, monitoring, and interim land-use controls.

Regulators approved a remedial design work plan in May 2001, with the approval of the land use control implementation plan still outstanding. The plan specifies what actions must be taken to implement and maintain the required land use controls. Remediation work mandated by the Melton Valley record of decision has been ongoing and will continue through 2006. Individual actions completed before 2003 included remediation of both the Process Waste Sludge Basin and the Old Hydrofracture Facility as well as demolition of various surface structures in Melton Valley.

Two other projects under the Melton Valley record of decision completed subcontractor procurement and remedial design activities in 2003 in preparation for 2004 construction. These projects are hydrologic isolation for the SWSA 5 burial grounds and for the Seepage Pits and Trenches Area.

\subsubsection{Hydrofracture Wells Plugging and Abandonment}

Between the 1960s and mid-1980s, the process of deep waste injection was used at ORNL to dispose of radioactive liquids and sludge in mixtures of waste with cement-based grout and various additives. Two test injection wells were constructed, along with boreholes and wells, so that the behavior of the injected grout in the injection zone bedrock could be observed. At these two test sites, small quantities of radionuclides were added to the injected grout to make the grout sheets detectable by gamma detectors. The third and fourth injection wells, located within the Old Hydrofracture Facility and New Hydrofracture Facility, respectively, were constructed for large-scale waste disposal. More than 5 million gal of liquid waste-grout mix, containing approximately 1.4 million $\mathrm{Ci}$ of activity, were injected into artificially induced fractures in a shale formation at depths of 300 to $1000 \mathrm{ft}$. All large-scale disposals were at depths greater than 780 feet. Contamination levels in hydrofracture monitoring wells have been reported as high as 97 million $\mathrm{pCi} / \mathrm{L}$ gross beta.

These surplus wells are potential pathways for the migration of contaminated fluids from the grout sheets and from deep groundwater to shallower groundwater zones. To prevent this migration, a remedial action was initiated in 2001 to plug and abandon 111 wells consisting of 4 injection and 107 monitoring wells. As of the end of CY 2003, 110 of the 111 wells had been plugged and abandoned. The remaining well (injection well 1968), which is located within the New Hydrofracture Facility, is scheduled for completion in early CY 2004.

\subsubsection{New Hydrofracture Facility Decontamination and Decommissioning}

The New Hydrofracture Facility was built at ORNL between 1979 and 1982 and operated from 1982 to 1984. It replaced the Old Hydrofracture Facility, which operated between the late 1950s to the mid-1970s. The New Hydrofracture Facility was designed to facilitate the injection of a mixture of radioactive waste solutions and grout into an impermeable shale formation at depths between 700 and 1000 feet below grade. The hydrofracture process is essentially a batch process in which the waste/grout mixture is pumped down a tubing string in the injection well and out into the shale formation. The high injection pressure of approximately 3000 psi fractures the subsurface shale and forces the waste/grout mixture into the fractures, where it hardens into "grout sheets."

The objective of the decontamination and decommissioning of the New Hydrofracture Facility is the removal and disposition of the main and ancillary facilities, including some subsurface structures. As of the end of 2003, all New Hydrofracture Facility ancillary facilities, including dry storage tanks, the weighing station, and transfer piping, had been removed and dispositioned and demolition of the main building was under way. Process piping and equipment had 
been removed from two of the three hot cells. The control room and office/support structure had been demolished.

\subsubsection{SWSA 4 Hydrologic Isolation}

Work on the SWSA 4 project includes the hydrologic isolation of the SWSA 4 burial ground, Liquid Waste Disposal Pit 1, the Pilot Pits Area, and the 7819 Decontamination Area, as well as the excavation of the Intermediate Holding Pond. Hydrologic isolation includes the installation of a multilayer cap, upgradient storm-flow diversion trenches, and downgradient collection trenches. To facilitate cap installation, this project also includes plugging and abandonment of unneeded, shallow, non-hydrofracture wells within the cap boundary; developing a borrow area and associated haul roads; and relocating Lagoon Road.

From 1951 to 1959 , DOE used SWSA 4 for disposing various liquid and solid radioactively contaminated wastes in unlined trenches and auger holes. SWSA 4 contains approximately $20,000 \mathrm{Ci}$ of radioactive wastes and contributes approximately $27 \%$ of the total risk in surface water to a hypothetical resident at White Oak Dam.

Pit 1 was constructed in 1951 to test the feasibility of disposing liquid waste in pits excavated in the natural clays in Melton Valley. Pit 1 received liquid waste from August to October 1951. In 1981 Pit 1 was backfilled and covered with an asphalt cap. In 1991 a portion of the wastes disposed of in Pit 1 was stabilized as part of an in situ vitrification technology demonstration. In situ vitrification is a process that uses electrical power to heat and melt contaminated soil, fusing the soil and waste into a glass-like solid.

The remedial design report/remedial action work plan for this project was approved in May 2002. Bridge and haul road upgrades, borrow area development, and the plugging and abandonment of 167 shallow wells have been completed. Approximately 24,300 tons $\left(17,200 \mathrm{yd}^{3}\right)$ of contaminated soil from the Intermediate Holding Pond were excavated and disposed of in the EMWMF. A portion of the Intermediate Holding Pond is being used as a holding pond for the SWSA 4 cap remediation; the remainder has been backfilled and reseeded. An approximately halfmile section of Lagoon Road has been relocated to a position farther to the north of the SWSA 4 cap. A downgradient trench has been constructed for collection of leachate from SWSA 4. As of the end of CY 2003, contour fill placement for the cap construction was approximately $85 \%$ complete, and a landfill liner had been installed over approximately one fourth of SWSA 4. A wastewater treatment plant, which will treat the collected leachate from SWSA 4, was nearing completion. Hydrologic isolation of SWSA 4 will be completed in CY 2004.

\subsubsection{Spent Nuclear Fuel}

Research and development programs related to nuclear reactor fuel have historically been a part of ORNL's mission. Many of these programs involved the post-irradiation examination and testing of spent nuclear fuel from various types of reactors. After these programs were completed, the remaining spent fuel was collected and placed into on-site storage facilities, primarily during the 1970s. Spent fuel was stored in below-grade storage positions in facilities 7823A, 7827, and 7829 , which are located in SWSA 5 North. In addition, one package of spent fuel was placed in SWSA 6 in Melton Valley.

With the issuance of the programmatic environmental impact statement record of decision for spent fuel in 1995, smaller sites, like Oak Ridge, were directed to ship aluminum-clad spent fuel to the Savannah River Site and nonaluminum-clad spent fuel to the Idaho National Engineering and Environmental Laboratory (INEEL). Following the issuance of the record of decision for the programmatic environmental impact statement, an environmental assessment was prepared for the Oak Ridge spent fuel activities, and a finding of no significant impact was issued.

DOE approved the safety basis for loading spent fuel in the shipping cask in March 2003 and then approved readiness to load spent fuel in the shipping cask in June 2003. Immediately following that approval, the first shipment of spent fuel was loaded and prepared for shipment to INEEL. The shipping of spent fuel stored at ORNL began in 2003. The material is being 
consolidated with other spent fuel in storage at the INEEL.

By the end of CY 2003, all five planned shipments to INEEL had been completed. The five shipments completed the removal of more than $100,000 \mathrm{Ci}$ of radionuclides from the ORR. These shipments also transferred 62 spent-fuel canisters and 9 intact Peach Bottom Reactor fuel assemblies with a total of 0.22 metric ton of heavy metal from Oak Ridge to INEEL.

\subsubsection{Molten Salt Reactor Experiment Fuel and Flush Salts Removal}

The Molten Salt Reactor Experiment (MSRE) facility operated from 1965 to 1969 to test the molten salt concept. Unlike most current commercial reactors that have fuel confined to fuel rods, MSRE was fueled by molten salt that flowed through the reactor chamber, where the nuclear chain reaction produced heat.

A CERCLA action to remove the fuel and flush the salt is under way. Testing of fuel salt removal equipment and a cold trap system was successfully completed in 2003. Operating procedures were developed based on results of the testing, and training of operators was conducted. Fuel and flush-salt removal will occur in 2004 and 2005.

\subsubsection{TRU Waste Processing Facility}

The mission of the Oak Ridge Transuranic (TRU) Program is to provide cost-effective, safe, and environmentally compliant treatment and disposal of all TRU waste stored at ORNL. In CY 2003, the TRU Program continued the construction of the Waste Processing Facility. The scope of the facility is to treat and dispose of 900 $\mathrm{m}^{3}$ of remote-handled TRU sludge, $550 \mathrm{~m}^{3}$ of remote-handled TRU/alpha low-level waste (LLW) solids, $1600 \mathrm{~m}^{3}$ of remote-handled-LLW supernate, and $1000 \mathrm{~m}^{3}$ of contact-handled TRU/alpha LLW solids currently stored in Melton Valley.

Construction for the Supernate Processing System of the Waste Processing Facility is complete, and the operational readiness reviews are under way. Supernate processing is to begin in early in CY 2004. Construction and testing of the contact-handled waste system is scheduled to resume shortly after supernate operations begin. Contact-handled waste operations are expected to start in August 2005. Construction and testing of the remote-handled solids and sludge systems will resume early in CY 2006, depending on the status of the remote-handled waste permit for the Waste Isolation Pilot Plant (WIPP) that is currently expected to be approved and in place by July 31 , 2006.

\subsubsection{22-Trench Area TRU Waste Retrieval}

During the 1970s, packages of TRU waste were retrievably stored in the 22-Trench. Since the 1980s, packages of newly generated TRU waste have been stored in constructed facilities. Radionuclides in the TRU waste containers represent some of the most toxic and longest-lived radioisotopes stored on the ORR. In a consent agreement signed in September 2000, DOE committed to the state of Tennessee to retrieve the TRU waste from the 22-Trench Area under DOE's Atomic Energy Act authority.

A request for proposals for the 22-Trench Area retrieval project was issued for bid early in 2003. The proposals were evaluated, and a subcontract was awarded. The scope of work consists of retrieving the TRU waste packages, placing the waste packages in overpacks, and staging the waste in appropriate areas pending transport to the TRU Waste Processing Facility when directed by DOE. There the wastes will be repackaged to meet the acceptance criteria for offsite disposal facilities and then shipped off-site for disposal. Soil exceeding remediation levels in the Melton Valley record of decision and debris waste associated with the excavation will be disposed at the EMWMF or other appropriate facility. Design documents were submitted to and approved by the regulators. Field activities will begin in 2004 and will be completed in 2006 .

\subsubsection{Melton Valley Hydrologic Isolation}

In addition to the SWSA 4 cap, the Melton Valley record of decision calls for construction of caps on several other waste disposal 
areas-SWSA 5, SWSA 6, and selected pits and trenches. Approximately 100 acres of multilayer caps, several groundwater interception trenches, and a groundwater treatment unit will be constructed. Design documents were submitted to the regulators in 2003, and upgrading of a haul road from the Copper Ridge Borrow Area to the solid waste storage areas began in August 2003. In addition, areas to be capped were prepared by cutting trees within the cap footprint. Cap construction will begin in early CY 2004.

\subsubsection{T-1, T-2, and HFIR Tanks Remediation}

The T-1, T-2, and HFIR tanks are the last inactive liquid low-level waste tanks at ORNL to be remediated. The HFIR Tank will be stabilized by being filled with grout. The residual sludge in Tanks T-1 and T-2 will be treated to destroy organic resins. The treated sludge will be transferred to the active LLLW system. Tanks T-1 and T-2 will then be stabilized with grout.

The requirements decision record/remedial action work plan for this work was approved by the regulators in 2003. As of the end of CY 2003, the chemical treatment unit for the sludge was being constructed. Treatment will begin in 2004 .

\subsubsection{Activities Managed under the ORNL Balance of Program Project}

Activities performed under the ORNL Balance of Program Project included remediation activities under CERCLA, environmental monitoring and investigation to support the Bethel Valley and Melton Valley record of decision, and Surveillance and Maintenance activities at facilities that are slated for remediation or decontamination and decommissioning in future years.

The Bethel Valley record of decision, signed by the Federal Facility Agreement parties in May 2002, presents the selected remedy for environmental remediation of various contaminated areas with Bethel Valley at ORNL and waste system components that reach into Melton Valley. Remediation under the Bethel Valley record of decision will be conducted at higher-risk sites first and will continue through 2014.

The first two projects to be performed that are mandated by the Bethel Valley record of decision are the Bethel Valley Groundwater Engineering Study (in Bethel Valley) and the remediation of the T-1, T-2, and HFIR tanks (located in Melton Valley). The remediation of the $\mathrm{T}-1, \mathrm{~T}-2$, and HFIR tanks is being implemented under the Melton Valley Completion Project (see Section 3.3.1.9).

\subsubsection{Bethel Valley Ground- water Engineering Study}

The Bethel Valley record of decision specified that a ground water engineering study be conducted to satisfy data needs for the design of several remedial actions related to groundwater, including (1) deep groundwater extraction at the Corehole 8 Plume, (2) in situ biodegradation at the East Bethel Valley volatile organic compound plume, (3) groundwater monitoring in West Bethel Valley, and (4) soil excavation at known leak sites to minimize impacts to groundwater. Planning for the groundwater engineering study was summarized in the Engineering Study Work Plan for Groundwater Actions in Bethel Valley (DOE 2003c), issued as a final document in 2003. The work plan includes an evaluation of relevant data from previous characterization activities and defines the scope of work to be performed to design groundwater and soil remedial actions under the record of decision. Once the engineering study data have been collected, a report summarizing the results will be issued in 2005 .

\subsubsection{Surface Impoundment Waste Removed}

Waste from four surface impoundments at ORNL was disposed of in 2003. The four impoundments (3513, 3524, 3539, and 3540), known as the "Main Plant Surface Impoundments," were located in the south-central portion of the ORNL main plant in Bethel Valley. They served as intermediate collection, storage, and mixing basins for liquid process wastes. EPA, DOE, and the state of Tennessee signed a record of decision in August 1997 specifying that the 
impoundment sediment to be removed, stabilized, and disposed of.

Sediment was transferred from impoundments 3539 and 3540 to 3513 in 1998 . Sediment was transferred from impoundment 3524 to 3513 in 2000. Following sediment transfer, impoundments 3524,3539 , and 3540 were backfilled with rock, and grout was added to the rock to fill empty spaces. Gravel pads were installed over the backfilled impoundments to provide space for the construction and operation of a sediment treatment system and to create a staging area for treated waste forms before shipment for disposal. The treatment system became operational in late 2001. Since then, all the sediment (approximately $\left.6350 \mathrm{yd}^{3}\right)$ has been removed, treated, and converted to 981 concrete final waste forms. As of the end of 2003, the disposal of waste generated from the dismantling of the treatment plant was wrapping up. The final demobilization os scheduled to be completed in 2004 .

\subsubsection{Melton Valley Picket Well Installation}

In October 2003, the Melton Valley Picket Well Installation Project initiated work in the filed to construct six wells that are up to $500 \mathrm{ft}$ deep to support environmental monitoring required by the Melton Valley record of decision. The project included construction of access roads and drill pads and installation of corrugated steel drainage pipes across two unnamed streams. By the end of December 2003, the surface casings had been installed down to bedrock for all locations.

Each borehole will be continuously cored, and the borings will be geophysically logged and straddle-packer tested. A West Bay MP38 multiple-zone monitoring system will be installed in each well. Completion of the project is scheduled for spring 2004.

\subsubsection{Tower Shielding Facility Defueling}

The defueling of the Tower Shielding Reactor facility in the Melton Valley area was initiated during 2003 and was completed on December 12, 2003. The Tower Shielding Facility was built in 1953 for the Aircraft Nuclear Propulsion Project.
The main feature of the project was a reactor with a 55-ton shield that could be lifted 200 feet into the air where it was used to measure the shielding properties of various materials and radiation that might reach aircrews.

With the fuel removed, the facility can be downgraded to a radiological facility. The downgrade will yield an estimated $\$ 1.95$ million in savings between 2004 and 2009, the original fuel removal date. The reactor fuel was shipped to the Savannah River Site on December 16, 2003. The remainder of the facility will be left in safe shutdown until decontamination and decommissioning of the buildings begins in 2009 .

\subsection{Y-12 NATIONAL SECURITY COMPLEX}

\subsubsection{Remediation of Boneyard/ Burnyard Completed}

The remediation of the Boneyard/Burnyard, a 20-acre disposal area in Bear Creek, was completed in 2003. A total of $80,422 \mathrm{yd}^{3}$ of waste was excavated, of which $63,676 \mathrm{yd}^{3}$ were disposed of at the EMWMF and 16,746 $\mathrm{yd}^{3}$ of lower levels of contaminated waste were consolidated and capped on site. The excavation of waste will permanently remove and/or isolate uranium-contaminated material from surface water and groundwater, thereby reducing the migration of contamination to Bear Creek.

Some of the first wastes disposed of in Oak Ridge were placed in the Boneyard/Burnyard, beginning in 1943. Both radiological and nonradiological wastes were disposed of at this site, which continued receiving wastes until 1970.

Three release sites are associated with the Boneyard/Burnyard remediation project: (1) the Oil Landfarm Soils Containment Pad, (2) the Hazardous Chemical Disposal Area, and (3) the Boneyard/Burnyard, including Bear Creek Tributary 3 floodplain soils. The Oil Landfarm Soils Containment Pad structure was a belowgrade storage pad that contained approximately $570 \mathrm{yd}^{3}$ of PCB-contaminated soils excavated during closure of the Oil Landfarm. The Hazardous Chemical Disposal Area was historically used to dispose of chemicals that were deemed to be hazardous to plant workers, 
including acids, bases, and miscellaneous liquids. The area was covered in the late 1980s with an engineered cap, similar to the type required under RCRA. The Boneyard/Burnyard was used for the disposal of combustible wastes, including uranium turnings, which were placed either on the surface or in unlined trenches and set on fire. The area was also used for storing abandoned equipment, which resulted in surface contamination. These wastes were leaching from the Boneyard/Burnyard to shallow groundwater, which then discharged to surface water.

Remedial actions were divided into three phases. Phase I consisted of the remedial design. Phase II included the hydraulic isolation at the Boneyard/Burnyard to reduce the contaminant flux entering Bear Creek, to dry the site in preparation for the Phase III work, and to remove the Oil Landfarm Soils Containment Pad structure and disposal of the soils at an off-site facility. Phase III consisted of excavation and disposal of Boneyard/Burnyard wastes.

\subsubsection{Upper East Fork Poplar Creek Remediation Being Conducted in Phases}

Remediation of the Upper East Fork Poplar Creek Watershed is being conducted in stages using a phased approach. Phase 1 addresses interim actions for remediation of mercurycontaminated soil, sediment, and groundwater discharges that contribute contamination to surface water. The focus of the second phase is remediation of the balance of contaminated soil, scrap, and buried materials within the Y-12 Complex, the major contaminated area in the Upper East Fork Poplar Creek Watershed. Decisions regarding final land use and final goals for surface water, groundwater, and soils will be addressed in future decision documents.

During 2003, a focused feasibility study for remediation of Upper East Fork Poplar Creek contaminated soils, scrap, and buried materials was conducted. Alternatives were developed and evaluated to protect workers in the industrial plant area and to minimize further contamination of groundwater and surface water by remediating accessible soil, buried waste, or subsurface structures that contribute significantly to contamination above acceptable risk levels. Once regulatory comments are received and incorporated, a proposed plan and record of decision will be developed and public input will be incorporated.

\subsubsection{Building 9201-2 Water Treatment System to Be Constructed}

To mitigate the mercury being released into Upper East Fork Poplar Creek, the Building 92012 Water Treatment System was designed and will be constructed as the first action of the approved record of decision for Phase 1 Interim Source Control Actions in the Upper East Fork Poplar Creek Characterization Area.

The design of the Building 9201-2 Water Treatment System was completed in September 2003. Results of a predesign study completed in the spring and summer of 2002 to evaluate potential methods for removing mercury to the ambient water quality criterion of $51 \mathrm{ppt}$ and to determine design and operational parameters for the water treatment system were incorporated into the design.

A $300-\mathrm{gal} / \mathrm{min}$ water treatment system will be constructed near Building 9201-2. The system will use a series of granular activated-carbon beds to reduce the mercury concentration in the system effluent to levels of $200 \mathrm{ppt}$ or less. The system influent will include Outfall 51 discharge and 9201-2 sump water. The existing East End Mercury Treatment System will be removed. Construction of the new water treatment system and demolition of the old plant are scheduled to be completed in 2004.

\subsection{Oak Ridge Reservation Operations}

\subsubsection{Witherspoon Site Being Prepared for Cleanup}

The David Witherspoon, Inc., 901 Site, located on Maryville Pike in Knoxville, Tennessee, consists of a 9.5-acre parcel formerly owned and operated as the David Wither spoon, Inc., Recycling Center and a 0.5-acre parcel 
owned by CBX Transportation, Inc. A 1993 court order forced cessation of operations at the Wither spoon site, and the property was seized by the Tennessee Division of Superfund.

The objective of this off-site project is to perform interim actions and to complete the supporting documentation resulting in a record of decision at the site.

The scope of this project is to decontaminate and demolish the main building, metal office building, incinerator, magnet house, compactor house, control house, scale house/scale, bailer house, and breaker house. Contaminated soils will be excavated and disposed of as radioactive PCB mixed waste in the EMWMF. The contaminated soils will be excavated and treated to meet land disposal restrictions.

Site brush and vegetation removal, sampling activities, and radiation scoping surveys were completed in 2003. The decontamination and decommissioning debris removal interim action work plan was completed and issued for regulator review. An interim action work plan will also be prepared for soil removal. The interim action will begin in 2004, and the soil removal interim action is scheduled to be completed in 2007.

\subsubsection{Tons of Wastes Placed in the EMWMF}

Despite record rainfalls in 2003, the EMWMF, located near the Y-12 Complex, was able to provide almost uninterrupted disposal services for ongoing cleanup work.

EMWMF operations collected, analyzed, and dispositioned more than 8.5 million gal of leachate and contact water. The operations also effectively controlled site erosion and sediments, resulting in an $80 \%$ reduction in total suspended solids measured in surface waters during the year.

By the end of 2003, 69,486 tons of soil and debris waste had been disposed of at the facility. The following projects have made use of the EMWMF:

- Boneyard/Burnyard Remedial Action Project near the Y-12 Complex,

- Intermediate Holding Pond Remedial Action Project at ORNL,

- K-1070-A Remedial Action Project at ETTP,

- ETTP Main Plant Facilities,
- ETTP K-31 Building Decontamination and Decommissioning,

- Melton Valley Old Hydrofracture Facility Decontamination and Decommissioning at ORNL,

- New Hydrofracture Facility Decontamination and Decommissioning Projects at ORNL, and

- Surface Impoundment Operable Unit Project at ORNL.

The EMWMF, located in East Bear Creek Valley near the Y-12 Complex, is an on-site waste facility that is being used to contain the waste generated during cleanup of ORR and associated sites in Tennessee. The EMWMF and ORR Landfills are serving the disposal needs of the ORR cleanup program as well as the active missions of the Y-12 Complex and ORNL. The EMWMF accepted its first waste shipment in May 2002.

DOE also operates solid waste disposal facilities at the Y-12 Complex, called the ORR Landfills. In 2003 more than 108,000 $\mathrm{yd}^{3}$ of industrial, construction/demolition, classified, and spoil material waste were disposed of - $40 \%$ above the forecast as the result of acceleration of cleanup activities across the ORR.

A major challenge to operations in 2003 was the unusually high rainfall, which resulted in the generation of exceedingly large volumes of contact water that necessitated collection and transport for treatment. This was accomplished while appropriately containing all water resulting from the heavy rain events. Another effect of the high rainfall is the unexpected increase in shallow groundwater levels beneath the facility. DOE is actively engaged with the regulators to implement a remedial action to lower the site-wide shallow groundwater table. An underground rock-core drain is being constructed 25 feet below the liner of the EMWMF to permanently suppress and drain groundwater. The successful implementation of this action will result in continued preparations for expanding the EMWMF starting in late 2004. 


\subsubsection{Millions of Gallons of Wastewater Treated in 2003}

During 2003, the Environmental Management Program treated 25.4 million gal of liquid waste at the Groundwater Treatment Facility, East End Mercury Treatment System, Central Mercury Treatment System, and East End Volatile Organic Compound System.

The West End Treatment Facility and the Central Pollution Control Facility at the Y-12 Complex processed about 640,000 gal of wastewater, primarily in support of National Nuclear Security Administration operation activities. This wastewater included hazardous materials such as PCBs, cyanide, mercury, cadmium, chromium, and uranium. The hazardous materials end up in the sludge that results from wastewater treatment. A total of $900,000 \mathrm{~kg}$ of sludge was treated and shipped for off-site disposal in compliance with site treatment plan milestones. The total quantity of mixed-waste sludge disposed of since the project began in 1997 is $8,300,000 \mathrm{~kg}$ (about 9,200 tons). The remaining sludge inventory will be treated and disposed of by the end of 2004 .

At ETTP, the Central Neutralization Facility treated more than 35 million gal of wastewater in 2003. The facility is ETTP's primary wastewater treatment facility and processes both hazardous and nonhazardous waste streams arising from multiple waste treatment facilities and remediation projects. The facility removes heavy metals and suspended solids from the wastewater, adjusts $\mathrm{pH}$, and discharges the treated effluent into the Clinch River. Sludge from the treatment facility is treated, packaged, and disposed of off site.

At ORNL, approximately 167,000,000 gal of wastewater were treated and released at the Process Waste Treatment Complex. In addition, the LLLW evaporator at ORNL treated 227,500 gal of waste. Finally, 2.3 billion $\mathrm{m}^{3}$ of gaseous waste were treated at the ORNL 3039 Stack Facility. These important waste treatment activities supported both Environmental Management and Office of Science mission activities in a safe and compliant manner.

\subsubsection{Waste Stockpile Continues to Diminish}

Operations at the ORR produce wastes that frequently contain radionuclides. Such wastes are characterized as either LLW or TRU wastes. Mixed LLWs are those that contain materials deemed hazardous and are regulated under RCRA.

TRU wastes from throughout the DOE complex are to be disposed of at the WIPP near Carlsbad, New Mexico. Before being shipped to the WIPP, however, TRU waste must be treated, packaged, and certified to meet the waste acceptance criteria of the WIPP.

DOE awarded a contract to Foster Wheeler Environmental Corporation in 1998 to build and operate a TRU waste treatment facility on the ORR. In 2001, an approximately 1000-ft extension to the access road from White Wing Road (State Route 95) and fencing of the approximately 20 -acre site were completed. Waste processing at the TRU waste treatment facility is poised to begin in early 2004 .

The ORR has the largest inventory of legacy LLW in the DOE complex. In addition, active DOE missions at the Y-12 Complex and ORNL produce newly generated LLW that must be managed and disposed of safely and efficiently. In 2003, DOE shipped 112 legacy LLW monoliths $\left(2161 \mathrm{yd}^{3}\right)$ to the Nevada Test Site for disposal, leaving fewer than 40 of the large legacy LLW containers. Characterization and planning activities are nearly complete for ensuring that the entire inventory of legacy LLW will be disposed of by the end of 2005. Almost $9000 \mathrm{yd}^{3}$ of newly generated LLW was also shipped for disposal in 2003.

The ORR also has a large inventory of mixed LLW, but most mixed waste has been dispositioned since the site treatment plan agreement was signed in 1995. In 2003, 323,069 $\mathrm{kg}$ of waste identified in the site treatment plan were dispositioned. Only $600,000 \mathrm{~kg}$ of such waste remain from an original inventory of more than 4,200,000 kg. In addition, DOE also shipped and disposed of $900,000 \mathrm{~kg}$ of sludge in 2003 , bringing the total quantity of mixed waste sludge disposed of since the project began in 1997 to 8.3 million kg. Approximately 440,000 kg of sludge remain. By the end of 2005, the entire inventory of mixed waste regulated by the site treatment 
plan will be safely disposed of, closing an important chapter in the cleanup of the ORR.

Also in 2003, DOE and its contractors completed a 2-year effort to identify and safely disposition more than 1000 potentially shocksensitive chemical items. Rigorous planning and careful execution brought about a successful outcome to ridding the ORR of these items in a safe and compliant manner.

\subsubsection{TSCA Incinerator Continues Hazardous Waste Treatment}

The Toxic Substances Control Act (TSCA) Incinerator, located at ETTP, plays a key role in the treatment of radioactive PCB and hazardous wastes (mixed wastes) from cleanup projects on the ORR as well as from projects at numerous outof-state DOE sites. The incinerator operates at temperatures of 1500 to $2200^{\circ} \mathrm{F}$. Some $99.99 \%$ of the hazardous organics and $99.9999 \%$ of the PCBs are destroyed during incineration. Plans are in place to increase the throughput at the incinerator to ensure cost-effective operations in support of the DOE complex's cleanup mission.

The TSCA Incinerator operates under rules and regulations issued by DOE, EPA, and the state of Tennessee. It began full operation in 1991 and since then has treated more than 28 million $\mathrm{lb}$ of waste. In 2003, it treated 567,289 lb of liquid waste and 162,664 lb of solid waste. About 900,000 pounds of combined liquid and solid waste are scheduled for treatment at the incinerator in 2004. A comprehensive performance test is also scheduled for 2004, to demonstrate compliance with new emission standards. The TSCA Incinerator is expected to be closed at the end of 2006.

\subsubsection{Improved Technologies Being Used for Cleanup}

The mission of the DOE-ORO Environmental Technology Program is to provide the scientific foundation, new approaches, and new technologies to bring about significant reductions in risk, cost, and schedule for completion of the environmental management accelerated cleanup mission. The need for real-time technology solutions has been made even more urgent with the renewed emphasis on site closure. In 2003, the program focused on several key problem areas at DOE-ORO sites. Also in 2003, development and field testing of a microcantilever sensor for the detection of mercury in water at the parts-pertrillion level were advanced.

The Y-12 Complex has had historical releases of mercury from four main process buildings. The loss of an estimated 2 million lb of mercury to soil and surface waters has created a mercurymanagement problem involving contamination of numerous sumps and outfalls. The Environmental Technology Program is working with academia and the private sector to investigate phytoremediation for the stabilization of mercury; mercury speciation in water, sediments, and fish in the lower reaches of East Fork Poplar Creek; and use of a specialized grout for stabilization of mercury in soils.

Several projects were initiated in 2003 to address ecological risk assessment. At ETTP, a demonstration of the Spatial Analysis and Decision Assistance (SADA) software was conducted to determine the ecological risk assessment capability of SADA as applied to a large, complex site. SADA documents all models and parameters used in an assessment in a form that can be accessed by all members of the decision-making team. Use of SADA facilitates agreement because of its documented quality assurance/quality control process and the fact that the ecological risk assessment modules were developed under guidance from EPA's Ecological Risk Assessment Forum and have been reviewed by EPA. Additionally, the Biological Monitoring and Abatement Program was used to assess environmental impacts and trends and to track compliance and environmental health updates.

The DOE-ORO complex has numerous scrap yards covering a total of 50 acres and containing more than 90,000 tons of scrap metal and debris. Most of the waste is radiologically contaminated. In addition to the existing scrap inventory, a large volume of scrap metal will be generated by decontamination and decommissioning activities at DOE-ORO and around the DOE complex. A more cost-effective, nondestructive characterization technology was needed to characterize waste in a wide variety of configurations and containers. The technology 
also had to be capable of isotopic discrimination and sensitive enough to certify that the waste meets the waste acceptance criteria of the receiving disposal facility. In 2003, in situ gamma spectrometry was successfully demonstrated to characterize the scrap metal piles at K-770. The process proved to be efficient, cost-effective, and accurate in characterizing the scrap metal for disposition.

The reliability and maintainability of reactive barrier systems are important considerations in the long-term treatment of contaminated groundwater. In 2003 the Environmental Technology Program funded the study of a number of operating barriers, including those at the Y-12 Complex S-3 ponds. The purpose of the study was to understand how the barriers function over time. Additionally, new reactive media were developed and tested in 2003, including biogenic apatite (Apatite II ${ }^{\mathrm{TM}}$ ) sorbent for removal of metals from Y-12 Complex groundwater.

Bioremediation continued to be evaluated as a viable treatment process for groundwater contaminated with volatile organic compounds. Bioremediation studies continued for the Y-12 Complex Upper East Fork Poplar Creek carbon tetrachloride plume with a treatability study planned for 2004.

ORNL has a mixture of TRU organic ionexchange resin and sludge stored in two inactive underground storage tanks (the T-1 and T-2 tanks) and radioactive sludge and resin with TRU constituents in the HFIR tank. This waste must be retrieved and treated before disposal to meet the Federal Facility Agreement and achieve accelerated closure of the site by 2006; however, the waste does not meet the waste acceptance criteria for any existing treatment/storage facility. The waste must be pretreated to destroy the organic resins before solidification at the Oak Ridge TRU Waste Treatment Facility and disposal at the WIPP.

In 2003, the Environmental Technology Program focused its efforts on finalizing a process to chemically destroy the ion-exchange resin using Fenton's Reagent (hydrogen peroxide and a ferrous iron catalyst), which oxidizes the resin to carbon dioxide and ammonium sulfate. A specialized treatment tank and mixing system were designed and tested, and the process was successfully tested using both simulated and actual waste. After completion of final safety reviews, the system should be ready for full implementation in 2004.

\subsection{PUBLIC PARTICIPATION}

\subsubsection{Oak Ridge Site Specific Advisory Board Posts Accomplishments in Public Involvement, Providing Recommendations to DOE}

\subsubsection{Public Involvement Continues to Be Key Aspect of Cleanup}

Although many cleanup projects have moved from the decision-making phase to actual field work, public involvement remained a key component of the 2003 Environmental Management efforts in Oak Ridge.

DOE sought public input on the following key documents and decisions:

- Accelerated Cleanup Lifecycle Baseline,

- proposed 2005 budget request for Oak Ridge's Environmental Management Program,

- $\quad$ public health assessment for Y-12 Complex uranium releases,

- action memorandum for demolition of remaining facilities at ETTP,

- Spallation Neutron Source discharge permit, and

- disposal of outdoor LLW at ETTP.

On September 15, 2003, members of the public and more than 700 current and former Oak Ridge K-25 Site workers attended the sixtieth anniversary celebration for the K-25 Site. DOE and local government leaders also participated. The event, held outside the fenced area of ETTP, featured displays, music, and presentations. Participants heard about plans for accelerated cleanup of the site and saw the open spaces where buildings once stood.

Other notable 2003 public involvement initiatives included the following: 
- A new DOE Information Center Web site was established to make information more accessible to the public (www.oakridge.doe.gov/info_cntr/). It provides a centralized electronic source of new documents produced by DOE and an overview of the services offered to the public at the Information Center.

- A readership survey for Public Involvement News, the monthly stakeholder newsletter, was conducted to allow DOE to better mold its content to the type of information the public is seeking. A mailing list update card was also sent to all newsletter recipients to ensure that only those wishing to receive the newsletter would remain on its mailing list.

- $\quad$ The TSCA Incinerator Burn Plan for 2004 to 2006 was made available. The incinerator is tentatively scheduled to be closed in 2006 .

- An information session was held to discuss the title transfer of facilities and land at ETTP. This transfer supports the accelerated environmental cleanup of the site.

- The Oak Ridge Public Tour Program, featuring visits to all three DOE facilities in Oak Ridge, resumed in 2003.

\subsubsection{Oak Ridge Site Specific Advisory Board Provides Public Input to Environmental Management Program Activities}

The Oak Ridge Site Specific Advisory Board posted several accomplishments this year. The board is an independent, volunteer, federally appointed citizens' panel formed in 1995. Its mission is to provide informed advice and recommendations to DOE on its Oak Ridge Environmental Management Program and to involve the public in environmental decision making.

The board generated 17 recommendations this year on a variety of environmental management topics, including the following:

- recommendation to accelerate removal of remote-handled transuranic TRU waste from the ORR,

- recommendation concerning the Depleted Uranium Hexafluoride Disposition Program,
- recommendation concerning the doe action memorandum for the Corehole 8 plume source,

- comments on the environmental assessment for proposed changes to the Sanitary Biosolids Land Application Program, and

- recommendation concerning the RCRA Part B permit renewal for the TSCA Incinerator.

Other significant 2003 accomplishments are described in the following sections.

\subsubsection{TRU Waste Issues}

The ORR is home to the largest quantity of remote-handled TRU waste in the DOE complex. This year the Oak Ridge Site Specific Advisory Board worked on several fronts to expedite its movement to more secure storage, where the risk to workers, the public, and the environment can be reduced. In October 2002 the advisory board wrote to the state of New Mexico to endorse DOE's remote-handled TRU waste permit modification request to allow shipment of this waste to the WIPP as part of DOE's effort to accelerate the disposition of legacy waste. In January 2003, the Oak Ridge Site Specific Advisory Board members attended the SiteSpecific Advisory Board Workshop on TRU Waste Management at the WIPP and subsequently endorsed the workshop's recommendations. The board followed up on these recommendations with a set of site-specific recommendations, transmitted to DOE Assistant Secretary Jessie Roberson in July 2003.

\subsubsection{Environmental Management Waste Management Facility}

A rising groundwater problem was identified beneath the EMWMF in spring 2003. DOE proposed several alternatives to the facility design to remedy the problem, and they were presented to EPA and the state of Tennessee. Because building of the CERCLA waste facility had significant public support, the regulators sought the public's input on the alternatives before making a decision. The Oak Ridge Site Specific Advisory Board provided the forum. Presentations were made to the board, and public notices were placed before 
the board's meetings, resulting in excellent public attendance.

In July 2003, the board endorsed DOE's preferred method for placement of an underdrain to address the high groundwater. Without a quick decision on the design issue, the scheduled buildout of additional waste cells would have significantly affected waste disposition in 2005, forcing off-site disposition, cost increases, and/or slowed remediation activities.

\subsubsection{Long-Term Stewardship}

In 2003, Oak Ridge Site Specific Advisory Board provided six recommendations and comments to DOE on various aspects of long-term stewardship. The board's Stewardship Committee established an Education Subcommittee, which prepared the Oak Ridge Reservation Educational Resource Guide (ORSSAB 2003) and began work on a Stewardship Resource Kit to help educators develop curricula on stewardship and environmental issues. As in past years, these recommendations, comments, and educational efforts reflected the board's commitment to providing DOE with informed stakeholder involvement on long-term stewardship issues-not just at the ORR, but also at the national level.

\subsubsection{Educational Resource Guide}

In June 2003, Oak Ridge Site Specific Advisory Board issued the Oak Ridge Reservation Educational Resource Guide (ORSSAB 2003), to introduce the concepts of radiological and chemical contamination, environmental management, and stewardship to middle and high school students. The guide is the first part of a planned series of educational efforts by the board. The guide was initially distributed to area educators but is also being provided to the community at large through the board's web site (www.oakridge.doe.gov/em/ssab/pubs.htm), the DOE Information Center, and various public outreach events.

\section{Video Lending Library}

In July 2003, Oak Ridge Site Specific Advisory Board launched its video lending library at the DOE Information Center, providing the community with a valuable educational resource regarding environmental management program issues. The library contains more than 30 titles related to waste management, radiation, risk, environmental justice, environmental laws and regulations, history, and environmental management. The library also includes videotapes of the board's monthly meetings from January 1999 through the present. The videos are available at no charge to educators, students, board members, and the public.

All board meetings are open to the public and are announced in newspaper advertisements, in the Federal Register, through the board's 24hour information line [(865) 576-4750], and on its web site (www.oakridge.doe.gov/em/ssab). Information is also available by calling the board's support office at (865) 576-1590 or (800) 382-6938.

\subsection{Land-Use Planning}

DOE programs in Oak Ridge depend not only on the facilities at ORNL, ETTP, and the Y-12 Complex, but also on the land base of the ORR. UT-Battelle, LLC, has the management and planning responsibility for most of the ORR's undeveloped land area. This responsibility includes planning for approximately 18,000 acres of undeveloped and developed land. The 2002 Oak Ridge National Laboratory Land and Facilities Plan (ORNL 2002) has been prepared to assist DOE and contractor personnel in implementing ORNL's land and facility responsibilities for management and planning. The plan is available at http://www.ornl.gov/ dmsi/landUse/.

The ORR includes multiple, overlapping reservation land uses. Details on the various uses are discussed in Sect. 2 of the 2002 Oak Ridge National Laboratory Land and Facilities Plan (ORNL 2002). With major changes in mission at ETTP and at the Y-12 National Security Complex, demonstrating current land use and planning for future land use needs by DOE and ORNL are critical. Decisions on how to use the land area 
have an effect at the local and regional levels as well as on the national and international levels.

The ORR is a unique and irreplaceable resource for DOE to use for its national science and technology missions. The DOE ORR vision, as stated in the ORR Comprehensive Integrated Plan (ORNL 1999), emphasizes that the ORR serves as an integrated science, education, industrial, and technology complex managed by DOE in partnership with the private sector-supporting a dynamic regional and national economy. Future use is to include a mixture of activities that are compatible with and contribute to ongoing and anticipated DOE missions. According to current plans, the reservation will be used to support many of the same programs it currently supports while adapting to changing national goals and interests and reduced federal budgets. Portions of the reservation will be used to promote the development of private-sector enterprises in ways that are consistent with and complementary to DOE missions. DOE's environmental management and reindustrialization initiative is highlighted at the ETTP; defense support, manufacturing, and storage is highlighted at the Y-12 National Security Complex; R\&D is highlighted at ORNL.
In December 2002, DOE and the state of Tennessee signed an agreement in principle to set aside approximately 3000 acres of the ORR for conservation purposes. The agreement was in response to natural resources damages resulting from past U.S. government nuclear weapons production and research activities on the ORR. The agreement was developed through a joint effort by the state, DOE, the U.S. Fish and Wildlife Service, and the Tennessee Valley Authority. The 3000-acre area to be protected is part of the area included in the Land Use Planning Process for the northwest portion of the ORR. 



\section{ETTP Environmental Monitoring Programs}

The East Tennessee Technology Park (ETTP), formerly known as the Oak Ridge Gaseous Diffusion Plant or K-25 Site, was originally built as part of the Manhattan Project. Uranium was enriched for weapons and nuclear reactor fuel elements and included recycling of reactor return fuel elements. Other activities included research and support operations. After the enrichment operations ceased in 1985, the primary focus of the plant shifted to environmental restoration, reindustrialization, and reuse of the facilities.

Environmental monitoring remains a major activity on the ETTP. Environmental monitoring encompasses two activities: effluent monitoring and environmental surveillance. Effluent monitoring consists of the collection and analysis of samples or measurements of liquid or gaseous effluents at their emission points to determine and quantify contaminants released. Environmental surveillance consists of the collection and analysis of samples of air, water, soil, vegetation, biota, and other media from the ETTP and its surroundings. External direct radiation is also measured. Data from environmental monitoring activities are used to assess exposures to members of the public and the environment, to assess the effects of ETTP operations on the public and the environment, to help plan remediation projects, and to evaluate the efficacy of these projects.

In 2003, the emissions of radionuclides from ETTP operations were well within the allowable derived concentration guides published in DOE Order 5400.5, and were similar in most respects to 2002 emissions. Potential direct radiation to the public from uranium hexafluoride cylinder storage yards and the K-770 scrap metal yard at ETTP remained below the requirements in DOE orders. Nonradiological emissions were also within limits, and compliance with permit limits was better than $99 \%$.

\subsection{ETTP RADIONUCLIDE AIRBORNE EFFLUENT MONITORING}

In order to demonstrate compliance with DOE Order 5400.5 and Tennessee Rule 1200-3-11-.08,

"Emission Standards for Emission of Radionuclides Other than Radon from Department of Energy Facilities," i.e., the National Emission Standards for Hazardous Air Pollutants (NESHAP), all airborne radionuclide emissions from DOE sources at ETTP must be determined for purposes of estimating dose to the most exposed member of the public.

Locations of airborne radionuclide point sources at the ETTP are shown in Fig. 4.1. Radionuclide emission information for these release points is compiled under the direction of Bechtel Jacobs Company LLC from operators subject to NESHAP regulations. For 2003, other prime contractors working directly for DOE at ETTP were also subject to NESHAP; data were obtained from the applicable sources and are reported here. Point sources shown in Fig. 4.1 include both individual point sources and grouped point sources, such as laboratory hoods. Radionuclide emissions data were determined from either EPA-approved sampling results or EPA-approved calculation methods.

\subsubsection{Radionuclide Emissions Monitoring Approach}

\subsubsection{Minor sources}

The number of minor sources in 2003 varied from the previous year's total because of fluctuations in site operations. For this reporting period, a total of four point sources and four grouped minor sources subject to NESHAP regulations operated. Minor sources are grouped if they have similar characteristics (e.g., general location, type of activity, or type of control) and provided that any one group does not have potential radionuclide emissions that would cause a dose in excess of $0.1 \mathrm{mrem} /$ year effective dose equivalent (EDE) as defined under the rule. An example of a minor source is the TSCA Incinerator tank farm with 15 emission points.

Emissions from the various minor sources located at the ETTP were estimated by means of one of the following EPA-approved methods:

- radionuclide inventory (i.e., material balance)-four point sources and three grouped sources, 
ORNL 99-04743E/rra

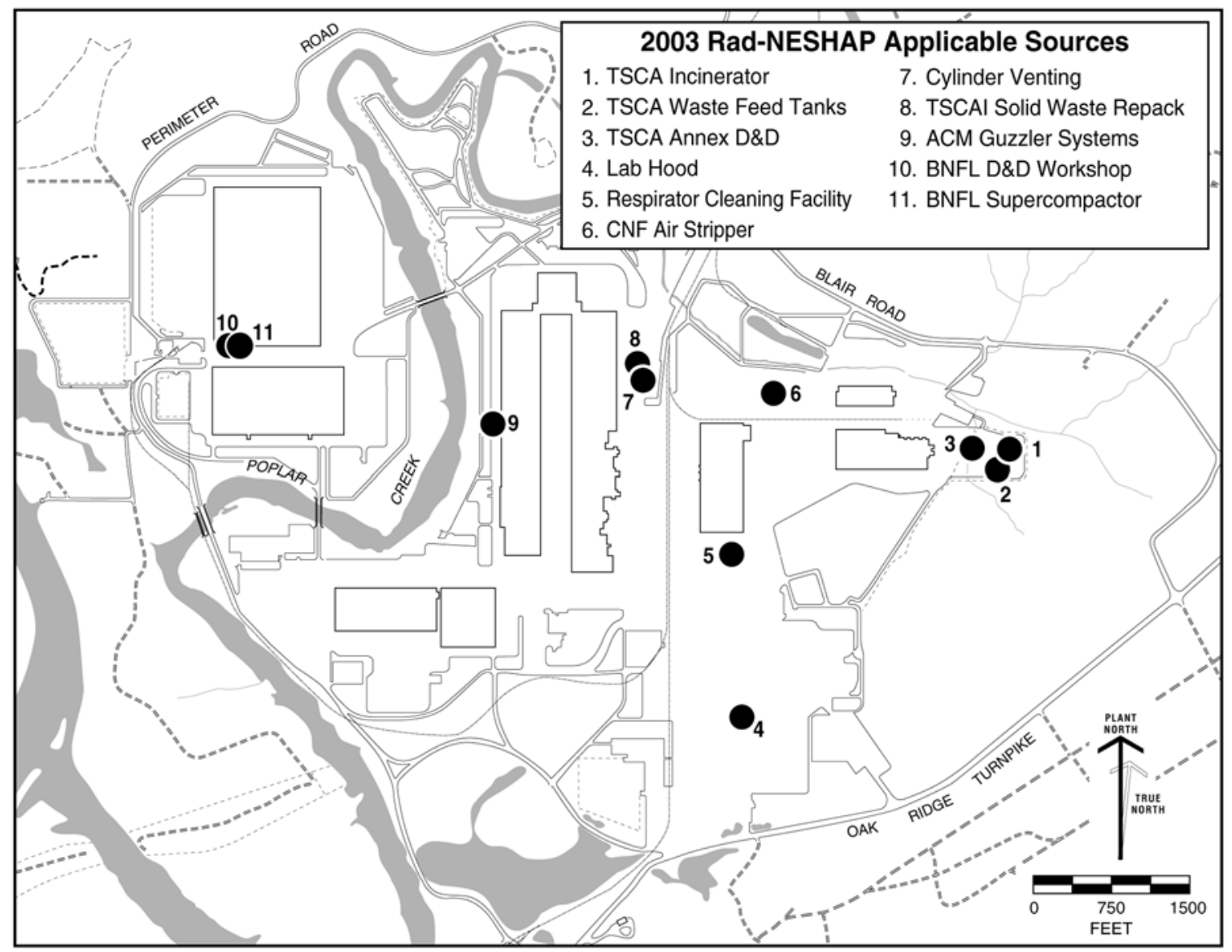

Fig. 4.1. Locations of airborne radionuclide point sources at the ETTP.

- health physics air measurements where room ventilation emissions exceeded $10 \%$ of derived air concentration worker protection guidelines-no sources,

- surrogate emission data from similar sources-one point source, and

- evaporative emissions-one grouped source.

All techniques are conservative methods of estimating emissions based on the physical form of the radionuclides and the maximum operating temperature of the process or activity.

Any remaining emissions were classified as major sources or diffuse/fugitive sources that are spatially distributed in nature or that were not emitted with forced air from a stack, vent, or other confined conduit. Typical examples of diffuse/ fugitive sources include

- emissions from shutdown buildings;

- resuspension of contaminated soils, debris, or other materials;
- unventilated tanks;

- wastewater treatment systems;

- outdoor storage and processing areas;

- emissions from piping, valves, or other piping equipment and pump components; and

- decontamination and demolition activities.

Fugitive emission sources are monitored by way of the ORR and ETTP Ambient Air Surveillance Programs.

\subsubsection{Major sources}

Three ETTP major sources operated during 2003. Radionuclide emission measurements from the TSCA Incinerator were determined by means of a continuous stack-sampling system. The system is designed to automatically adjust sample flow rate to maintain near-isokinetic sampling conditions at the stack. The effluent is passed through filter media to collect particulate matter and through

\section{4-2 ETTP Environmental Monitoring Program}


impingers with absorbing and adsorbing media to collect gaseous radionuclides. Measurements of TSCA Incinerator emissions were based on monthly composites of weekly stack samples.

BNFL, Inc., operated two sources in the K-33 building requiring the continuous monitoring of radiological emissions. The decontamination and decommissioning workshop has two identical atmospheric release points, each equipped with a particulate filtration system and a continuous sampling device. The supercompactor vent continuous sampling system is the same design as the decontamination and decommissioning workshop units.

\subsubsection{Results}

The ETTP 2002 radionuclide emissions from the major and minor emission sources are shown in Table 4.1. Additionally, Figs. 4.2 and 4.3 show a comparison of the total discharges of uranium with those of previous years. The total curies and mass of uranium discharged to the air can vary from year to year. The variations are attributable to changes in project activities and source process rates. The resulting airborne dose from all ETTP radionuclide emissions was less than the reservation maximum limit of $10 \mathrm{mrem} / \mathrm{year}$.

\subsection{ETTP NONRADIOLOGICAL AIRBORNE EMISSIONS MONITORING}

Under an application shield granted by the Tennessee Department of Environment and Conservation (TDEC) Division of Air Pollution Control, the ETTP has eight major air emission sources listed as subject to Tennessee Title V Major Source Operating Permit program rules. No direct monitoring of airborne emissions is required for nonradionuclide air contaminants from permitted sources. Instead, monitoring of key process and air pollution control device parameters is performed to ensure compliance with all permitted emission limits.

The ETTP is required to pay a major source emission fee each year for all regulated pollutants, excluding carbon monoxide and pollutants from exempt emission sources. To verify the air emission fee that is based on a combination of permitted allowable and actual emissions for air pollutants, an inventory of regulated emissions from the permitted sources at the ETTP is updated annually. Table 4.2 shows the results of the annual inventory of emissions of criteria pollutants from ETTP operations for the past 5 years. Beginning in 1999, the ETTP steam plant was transferred to the Community Reuse Organization of East Tennessee (CROET) and is no longer included in the ASER. The ETTP paid an annual fee in 2003 amounting to $\$ 13,800.50$ based on the fee rate of $\$ 17.50$ per ton of emissions during this period. Table 4.3 shows the inventoried regulated emissions during 2003 from the ETTP.

The TSCA Incinerator is permitted as a major source of air emissions from the ETTP. Emissions from the incinerator are controlled by extensive exhaust-gas treatment. Thus, actual emissions from the incinerator are inventoried with respect to determining the ETTP annual fee. A comparison of actual and allowable TSCA Incinerator emissions is presented in Table 4.4. All other permitted sources have emissions inventoried based on permit allowable limits.

\subsection{LIQUID DISCHARGES- ETTP RADIOLOGICAL MONITORING SUMMARY}

The ETTP conducts radiological monitoring of liquid effluent and storm water discharges to determine compliance with applicable dose standards. It also applies the "as low as reasonably achievable" (ALARA) process to minimize potential exposures to members of the public.

\subsubsection{Sample Collection and Analytical Procedure}

The ETTP monitored the treated effluent from the K-1407-J Central Neutralization Facility (Outfall 014). Weekly samples were collected from the Central Neutralization Facility and were composited into monthly samples. These samples were then analyzed for radionuclides. Results of these sampling efforts were compared with the derived concentration guides (DCGs) listed in DOE Order 5400.5. 
Table 4.1.East Tennessee Technology Park radionuclide air emission totals, $2003(\mathrm{Ci})^{a}$

\begin{tabular}{|c|c|c|c|c|}
\hline Radionuclide & Total major & $\mathrm{TSCAI}$ (major) ${ }^{b}$ & Total minor & Total ETTP \\
\hline${ }^{228} \mathrm{Ac}$ & - & - & $1.03 \mathrm{E}-08$ & $1.03 \mathrm{E}-08$ \\
\hline${ }^{241} \mathrm{Am}$ & - & - & $3.31 \mathrm{E}-08$ & $3.31 \mathrm{E}-08$ \\
\hline${ }^{243} \mathrm{Am}$ & - & - & $2.40 \mathrm{E}-10$ & $2.41 \mathrm{E}-10$ \\
\hline${ }^{212} \mathrm{Bi}$ & - & - & $7.34 \mathrm{E}-09$ & $7.34 \mathrm{E}-09$ \\
\hline${ }^{214} \mathrm{Bi}$ & - & - & $8.07 \mathrm{E}-09$ & $8.07 \mathrm{E}-09$ \\
\hline${ }^{14} \mathrm{C}$ & $1.52 \mathrm{E}-\mathrm{B} 05$ & $1.52 \mathrm{E}-05$ & $1.10 \mathrm{E}-05$ & $2.62 \mathrm{E}-04$ \\
\hline${ }^{137} \mathrm{Cs}$ & $1.15 \mathrm{E}-04$ & $1.15 \mathrm{E}-04$ & $5.09 \mathrm{E}-06$ & $1.20 \mathrm{E}-04$ \\
\hline${ }^{57} \mathrm{Co}$ & - & - & $2.20 \mathrm{E}-09$ & $2.20 \mathrm{E}-09$ \\
\hline${ }^{60} \mathrm{Co}$ & - & - & $2.66 \mathrm{E}-07$ & $2.66 \mathrm{E}-07$ \\
\hline${ }^{244} \mathrm{Cm}$ & - & - & $7.34 \mathrm{E}-10$ & $7.34 \mathrm{E}-10$ \\
\hline${ }^{152} \mathrm{Eu}$ & - & - & $7.34 \mathrm{E}-10$ & $7.34 \mathrm{E}-10$ \\
\hline${ }^{154} \mathrm{Eu}$ & - & - & $4.25 \mathrm{E}-07$ & $4.25 \mathrm{E}-07$ \\
\hline${ }^{131} \mathrm{I}$ & - & - & $5.21 \mathrm{E}-08$ & $5.21 \mathrm{E}-08$ \\
\hline${ }^{85} \mathrm{Kr}$ & $1.41 \mathrm{E}-\mathrm{B} 03$ & $1.41 \mathrm{E}-03$ & $1.48 \mathrm{E}+06$ & $1.41 \mathrm{E}-03$ \\
\hline${ }^{210} \mathrm{~Pb}$ & - & - & $6.51 \mathrm{E}-08$ & $6.51 \mathrm{E}-08$ \\
\hline${ }^{212} \mathrm{~Pb}$ & - & - & $7.34 \mathrm{E}-09$ & $7.34 \mathrm{E}-09$ \\
\hline${ }^{214} \mathrm{~Pb}$ & - & - & $6.63 \mathrm{E}-09$ & $6.63 \mathrm{E}-09$ \\
\hline${ }^{237} \mathrm{~Np}$ & $3.98 \mathrm{E}-07$ & $3.98 \mathrm{E}-07$ & $1.56 \mathrm{E}-07$ & $5.53 \mathrm{E}-07$ \\
\hline${ }^{95} \mathrm{Nb}$ & - & - & $7.34 \mathrm{E}-10$ & $7.34 \mathrm{E}-10$ \\
\hline${ }^{238} \mathrm{Pu}$ & $2.75 \mathrm{E}-07$ & $2.75 \mathrm{E}-07$ & $6.60 \mathrm{E}-08$ & $3.41 \mathrm{E}-07$ \\
\hline${ }^{239} \mathrm{Pu}$ & $3.28 \mathrm{E}-07$ & $3.28 \mathrm{E}-07$ & $1.06 \mathrm{E}-07$ & $4.33 \mathrm{E}-07$ \\
\hline${ }^{242} \mathrm{Pu}$ & - & - & $2.23 \mathrm{E}-09$ & $2.23 \mathrm{E}-09$ \\
\hline${ }^{40} \mathrm{~K}$ & - & - & $2.71 \mathrm{E}-07$ & $2.71 \mathrm{E}-07$ \\
\hline${ }^{231} \mathrm{~Pa}$ & - & - & $3.57 \mathrm{E}-10$ & $3.57 \mathrm{E}-10$ \\
\hline${ }^{233} \mathrm{~Pa}$ & - & - & $5.14 \mathrm{E}-09$ & $5.14 \mathrm{E}-09$ \\
\hline${ }^{234} \mathrm{~Pa}$ & - & - & $1.31 \mathrm{E}-07$ & $1.31 \mathrm{E}-07$ \\
\hline${ }^{234 \mathrm{~m}} \mathrm{~Pa}$ & $7.18 \mathrm{E}-03$ & $7.18 \mathrm{E}-03$ & $3.71 \mathrm{E}-05$ & $7.22 \mathrm{E}-03$ \\
\hline${ }^{226} \mathrm{Ra}$ & - & - & $2.53 \mathrm{E}-07$ & $2.53 \mathrm{E}-07$ \\
\hline${ }^{228} \mathrm{Ra}$ & - & - & $7.34 \mathrm{E}-10$ & $7.34 \mathrm{E}-10$ \\
\hline${ }^{89} \mathrm{Sr}$ & $2.94 \mathrm{E}-06$ & $2.94 \mathrm{E}-06$ & - & $2.94 \mathrm{E}-06$ \\
\hline${ }^{90} \mathrm{Sr}$ & - & - & $1.08 \mathrm{E}-06$ & $1.08 \mathrm{E}-06$ \\
\hline${ }^{99} \mathrm{Tc}$ & $9.44 \mathrm{E}-04$ & $9.44 \mathrm{E}-04$ & $2.73 \mathrm{E}-05$ & $9.71 \mathrm{E}-04$ \\
\hline${ }^{208} \mathrm{Tl}$ & - & - & $2.94 \mathrm{E}-09$ & $2.94 \mathrm{E}-09$ \\
\hline${ }^{228} \mathrm{Th}$ & $8.31 \mathrm{E}-06$ & $8.31 \mathrm{E}-06$ & $4.85 \mathrm{E}-08$ & $8.36 \mathrm{E}-06$ \\
\hline${ }^{230} \mathrm{Th}$ & $6.44 \mathrm{E}-05$ & $6.44 \mathrm{E}-05$ & $9.07 \mathrm{E}-08$ & $6.45 \mathrm{E}-05$ \\
\hline${ }^{231} \mathrm{Th}$ & - & - & $1.47 \mathrm{E}-09$ & $1.47 \mathrm{E}-09$ \\
\hline${ }^{232} \mathrm{Th}$ & $3.45 \mathrm{E}-05$ & $3.45 \mathrm{E}-05$ & $5.32 \mathrm{E}-08$ & $3.45 \mathrm{E}-05$ \\
\hline${ }^{234} \mathrm{Th}$ & $3.23 \mathrm{E}-03$ & $3.23 \mathrm{E}-03$ & $2.63 \mathrm{E}-05$ & $3.26 \mathrm{E}-03$ \\
\hline${ }^{3} \mathrm{H}$ & $7.35 \mathrm{E}+00$ & $7.35 \mathrm{E}+00$ & $1.34 \mathrm{E}-02$ & $7.37 \mathrm{E}+00$ \\
\hline${ }^{233} \mathrm{U}$ & - & - & $3.35 \mathrm{E}-06$ & $3.35 \mathrm{E}-06$ \\
\hline${ }^{234} \mathrm{U}$ & $1.94 \mathrm{E}-04$ & $1.94 \mathrm{E}-04$ & $3.79 \mathrm{E}-05$ & $2.32 \mathrm{E}-04$ \\
\hline${ }^{235} \mathrm{U}$ & $8.27 \mathrm{E}-04$ & $8.27 \mathrm{E}-04$ & $2.22 \mathrm{E}-06$ & $8.29 \mathrm{E}-04$ \\
\hline${ }^{236} \mathrm{U}$ & - & - & $5.18 \mathrm{E}-07$ & $5.18 \mathrm{E}-07$ \\
\hline${ }^{238} \mathrm{U}$ & $3.30 \mathrm{E}-04$ & $3.28 \mathrm{E}-04$ & $2.73 \mathrm{E}-05$ & $3.67 \mathrm{E}-04$ \\
\hline Totals & 7.37E+00 & 7.37E+00 & $1.36 \mathrm{E}-02$ & $7.38 \mathrm{E}-00$ \\
\hline
\end{tabular}

${ }^{a} 1 \mathrm{Ci}=3.7 \mathrm{E}+10 \mathrm{~Bq}$.

${ }^{b}$ Toxic Substances Control Act Incinerator. 


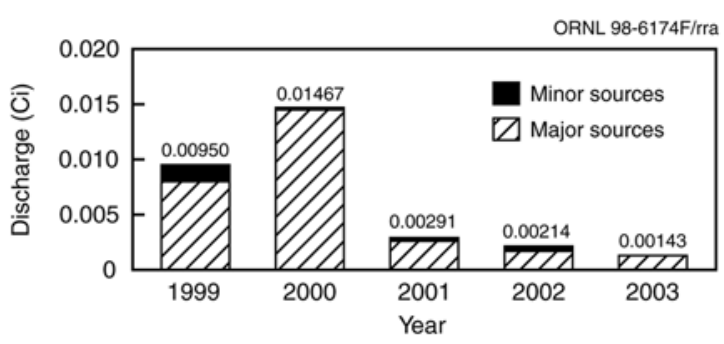

Fig. 4.2. Total curies of uranium discharged from the ETTP to the atmosphere, 1999-2003.

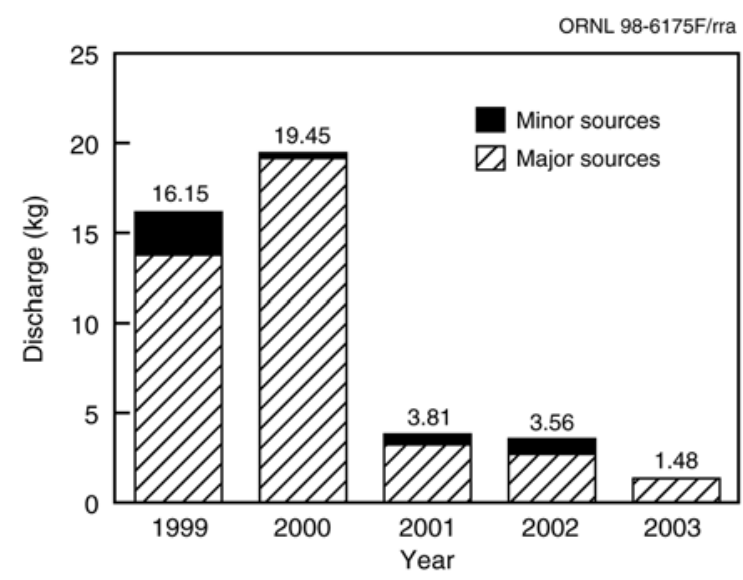

Fig. 4.3. Total kilograms of uranium discharged from the ETTP to the atmosphere, 1999-2003.

Table 4.2. Allowable emissions of criteria pollutants from the East Tennessee Technology Park, 1999-2003

\begin{tabular}{lrrrrr}
\hline \multirow{2}{*}{ Pollutant } & \multicolumn{5}{c}{ Allowable emissions(tons/year) } \\
\cline { 2 - 6 } & 1999 & 2000 & 2001 & 2002 & 2003 \\
\hline Particulate matter & 13 & 13 & 13 & 13 & 13 \\
Volatile organic compounds & 14 & 14 & 14 & 14 & 14 \\
Sulfur dioxide & 39 & 39 & 39 & 39 & 39 \\
Nitrogen oxides & 20 & 20 & 20 & 20 & 20 \\
Carbon monoxide & 20 & 20 & 19 & 19 & 19 \\
Hazardous air pollutants & 21 & 21 & 20 & 21 & 21 \\
Miscellaneous & 0 & 0 & 0 & 0 & 0 \\
$\quad$ Total & 127 & 127 & 125 & 126 & 126 \\
\hline
\end{tabular}

Table 4.3. Actual emissions of criteria pollutants from permitted East Tennessee Technology Park sources, 2003

\begin{tabular}{lcc}
\hline \multirow{2}{*}{ Pollutant } & \multicolumn{2}{c}{ Actual emissions } \\
\cline { 2 - 3 } & lb/year & tons/year \\
\hline Particulate matter & 232.5 & 0.116 \\
Volatile organic compounds & 254.1 & 0.127 \\
Sulfur dioxide & 3.2 & 0.002 \\
Nitrogen oxides & 8,429 & 4.21 \\
Carbon monoxide & 2,120 & 1.06 \\
\hline
\end{tabular}




\begin{tabular}{|c|c|c|c|}
\hline \multirow[t]{2}{*}{ Pollutant } & \multicolumn{2}{|c|}{$\begin{array}{l}\text { Emissions } \\
\text { (tons/year) }\end{array}$} & \multirow{2}{*}{$\begin{array}{l}\text { Percentage } \\
\text { of allowable }\end{array}$} \\
\hline & Actual $^{a}$ & Allowable & \\
\hline Lead & 0.009 & 0.575 & 1.5 \\
\hline Beryllium & 0.00002 & 0.00037 & 4.7 \\
\hline Mercury & 0.002 & 0.088 & 2.3 \\
\hline Hydrogen fluoride & 0.001 & 2.98 & $<0.1$ \\
\hline Hydrogen chloride & 0.050 & 16.12 & 0.3 \\
\hline Sulfur dioxide & 0.002 & 38.5 & $<0.1$ \\
\hline Particulate matter & 0.116 & 13.1 & 0.9 \\
\hline
\end{tabular}

${ }^{a}$ Actual emissions based on removal efficiencies measured during the permit-required air emission test conducted during 2000 with the exception of hydrogen fluoride, which is based on the CY 1995 test.

The Storm Water Pollution Prevention Program, which is described in more detail in Sect 4.5, included sampling for gross alpha and beta radioactivity as well as specific radionuclides at selected storm water outfalls. Results were used to estimate the total discharge of each radionuclide from ETTP via the stom water discharge system. Fig. 4.4 shows the location of the major NPDES outfalls.

\subsubsection{Results}

The sum of the fractions of the DCGs at the Central Neutralization Facility was calculated at $8.4 \%$ for 2003 , down from $18.8 \%$ in 2002 . Table 4.5 lists radionuclides discharged from the ETTP Central Neutralization Facility to off-site surface waters in 2003. Total uranium discharges from the Central Neutralization Facility were $0.0058 \mathrm{Ci}$ in 2003. Total discharge of transuranics was $0.0000385 \mathrm{Ci}$, which is more than two orders of magnitude less than the contribution from uranium.

In terms of total activity of the discharges, ${ }^{3} \mathrm{H}$, ${ }^{14} \mathrm{C}$, and ${ }^{99} \mathrm{Tc}$ were the greatest contributors. However, the allowable DCGs for these isotopes are greater than for the uranium isotopes, so their contribution to the sum of the fractions of the DCGs is relatively small. Uranium discharges from the Central Neutralization Facility during a 5-year period were investigated to observe their trend (Fig. 4.5). Uranium isotopes were the major contributors to the fraction of the DCG, contributing three quarters of the sum of the fraction of the DCG (Fig. 4.6). Thorium-230 was only detected in two of the samples, but due to the low DCG for this isotope, these ${ }^{230} \mathrm{Th}$ results contributed approximately $1 \%$ of the DCGs for this outfall. All of the remaining isotopes cumulatively accounted for approximately $1 \%$ of the allowable DCG. TSCA Incinerator wastewater, which is sent to the Central Neutralization Facility for treatment before discharging at Outfall 014, is a major contributor of uranium; other operations contribute smaller amounts.

\subsection{NONRADIOLOGICAL LIQUID DISCHARGES-ETTP SURFACE WATER EFFLUENTS}

The current ETTP National Pollutant Discharge Elimination System (NPDES) permit (Permit Number TN0002950) went into effect on October 1, 1992, and a major modification was issued effective June 1, 1995. The modification included removal of inactive outfalls, addition of effluent limits for new treatment technologies at the Central Neutralization Facility, addition of new storm drains, and clarification of various requirements.

In accordance with the NPDES permit, the ETTP is authorized to discharge process wastewater, cooling water, storm water, steam condensate, and groundwater to the Clinch River, Poplar Creek, and Mitchell Branch. The permit included 2 process outfalls and 136 storm water outfalls during 2003. Compliance with the permit for the last 5 years is summarized in Fig. 4.7. Table 4.6 details the permit requirements and compliance records for all of the outfalls that discharged during 2003. The table provides a list of the discharge points, effluent analytes, permit limits, number of noncompliances, and the percentage of compliance for 2003. Samples from these outfalls are collected and analyzed as specified in the NPDES permit. 
ORNL-DWG 94M-7183R3

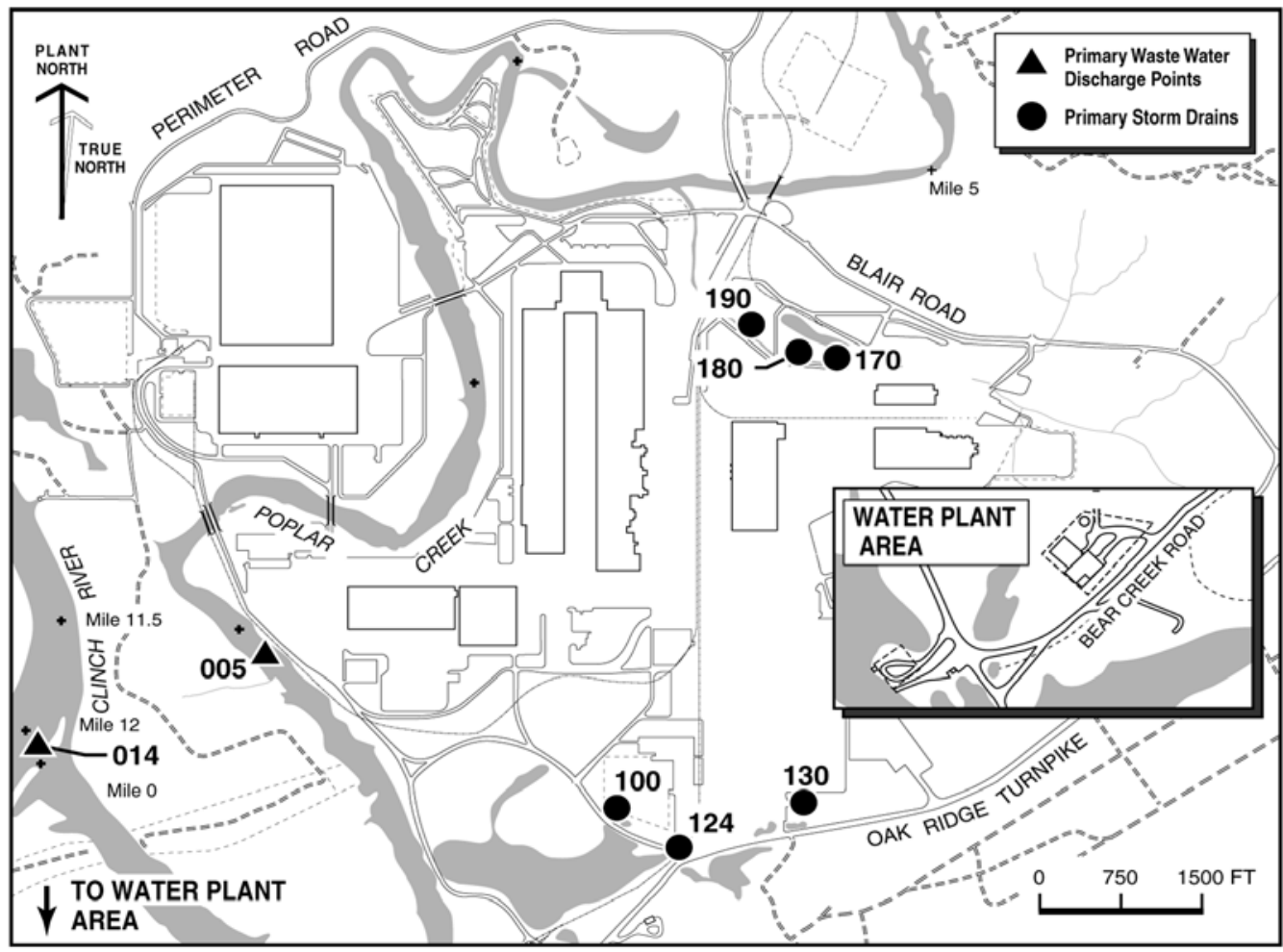

Fig. 4.4. ETTP National Pollutant Discharge Elimination System major outfalls and Category IV storm water outfalls.

Table 4.5. Radionuclides released to off-site surface waters from the East Tennessee Technology Park, 2003 Effluent discharge location: Central Neutralization Facility

\begin{tabular}{cccc}
\hline Radionuclide & Amount $(\mathrm{Ci})^{a}$ & Radionuclide & Amount $(\mathrm{Ci})^{a}$ \\
\hline${ }^{241} \mathrm{Am}$ & $3.7 \mathrm{E}-6$ & ${ }^{90} \mathrm{Sr}$ & $3.5 \mathrm{E}-5$ \\
${ }^{14} \mathrm{C}$ & $4.2 \mathrm{E}-2$ & ${ }^{99} \mathrm{Tc}$ & $5.5 \mathrm{E}-2$ \\
${ }^{137} \mathrm{Cs}$ & $4.0 \mathrm{E}-4$ & ${ }^{228} \mathrm{Th}$ & $3.3 \mathrm{E}-7$ \\
${ }^{60} \mathrm{Co}$ & $2.7 \mathrm{E}-5$ & ${ }^{230} \mathrm{Th}$ & $5.5 \mathrm{E}-4$ \\
${ }^{3} \mathrm{H}$ & $2.5 \mathrm{E}-2$ & ${ }^{234} \mathrm{Th}$ & $2.9 \mathrm{E}-3$ \\
${ }^{40} \mathrm{~K}$ & $9.8 \mathrm{E}-5$ & ${ }^{234} \mathrm{U}$ & $1.9 \mathrm{E}-3$ \\
${ }^{237} \mathrm{~Np}$ & $2.1 \mathrm{E}-6$ & ${ }^{235} \mathrm{U}$ & $2.0 \mathrm{E}-4$ \\
${ }^{238} \mathrm{Pu}$ & $-7.1 \mathrm{E}-7$ & ${ }^{236} \mathrm{U}$ & $1.3 \mathrm{E}-4$ \\
${ }^{239} \mathrm{Pu}$ & $-1.8 \mathrm{E}-7$ & ${ }^{238} \mathrm{U}$ & $3.6 \mathrm{E}-3$ \\
\hline
\end{tabular}

${ }^{a} 1 \mathrm{Ci}=3.7 \mathrm{E}+10 \mathrm{~Bq}$. 


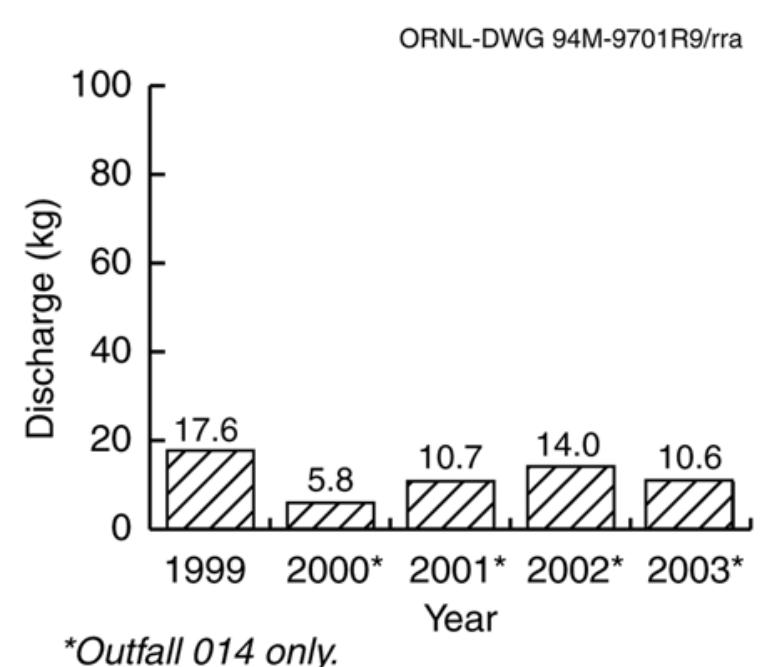

Fig. 4.5 Five-year trend of uranium releases to surface waters from the ETTP (Outfalls 005 and 014).

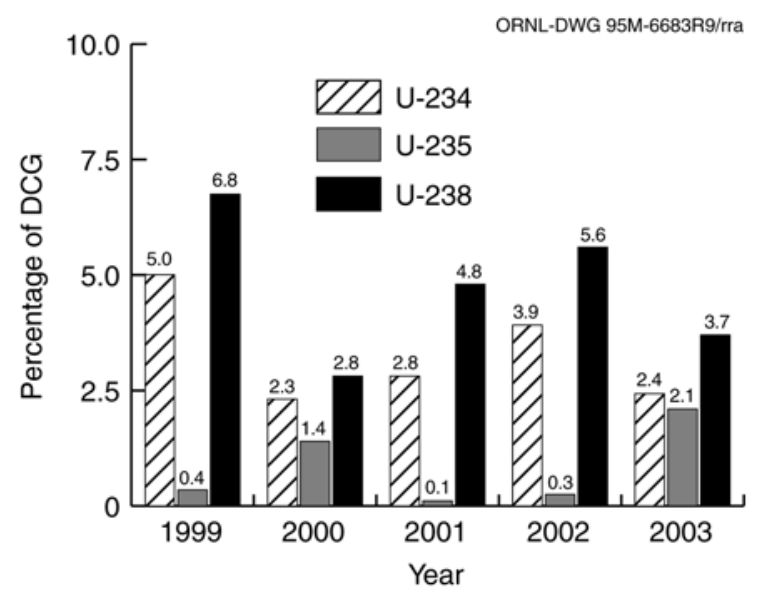

Fig. 4.6.Percentage of DOE derived concentration guides for uranium isotopes from K-1407-J (Outfall 014).

The two permitted outfalls at the ETTP during part of 2003 were Outfall 005, the permitted outfall for discharge of treated effluent from the K-1203 Sewage Treatment Plant to Poplar Creek, and Outfall 014, the permitted outfall for the discharge of effluent from the Central Neutralization Facility to the Clinch River. Individual NPDES permits with new outfall numbers were issued for each of these facilities during 2003.

The current ETTP NPDES Permit expired on September 29, 1997. An application for renewal of this permit was submitted to TDEC in March 1997. To facilitate the transfer of ownership and operation of ETTP facilities to other parties, it was determined that separate NPDES permits

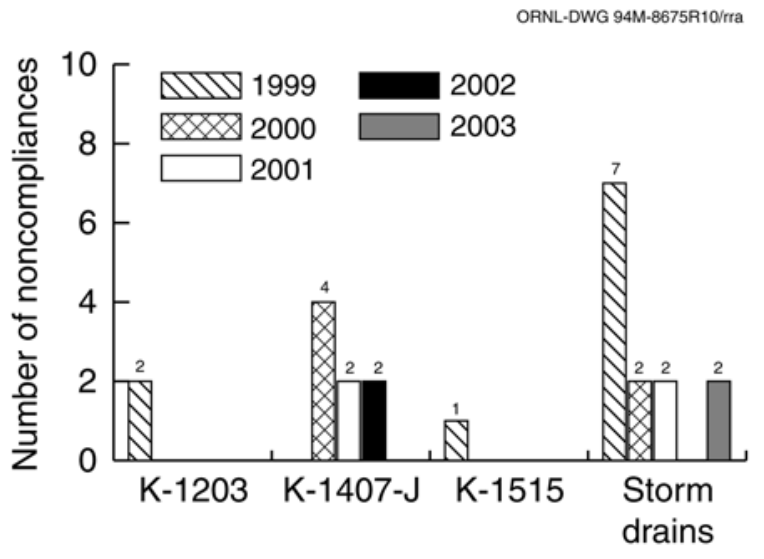

Fig. 4.7. ETTP National Pollutant Discharge Elimination System compliance history by source of noncompliance.

would be required for each of the ETTP treatment facilities. In addition, it was determined that a separate NPDES permit for the storm water drainage system would be necessary. A general NPDES permit (TN0074233) for former outfalls 009 (K-1515 Sanitary Water Plant) and 013 (K-1513 Sanitary Water Intake Backwash Filter) was issued on January 14, 2000, and became effective on March 1, 2000. An NPDES permit (TN0074241) for former outfall 005 (K-1203 Sewage Treatment Plant) was issued on July 1, 2003, and became effective on August 1, 2003. An NPDES permit (TN0074225) for former outfall 014 (Central Neutralization Facility) was issued on October 7, 2003, and became effective on November 1, 2003. The issuance of these three permits allowed outfalls $005,009,013$, and 014 to be removed from ETTP NPDES Permit Number TN0002950.

\subsubsection{Results}

The ETTP had two NPDES noncompliances in 2003 under NPDES Permit No. TN0002950; both were unpermitted discharges through storm water outfalls. On January 21, 2003, a diesel pickup truck belonging to a vendor for an ETTP site lessee leaked approximately $1 / 2$ gallon of diesel fuel onto a parking lot and roads within the ETTP during storm conditions. The spilled fuel quickly entered the storm drain system, and a small quantity discharged through permitted storm water outfall 100 , causing an oil sheen in one area of the 
Table 4.6. National Pollutant Discharge Elimination System compliance at the ETTP, 2003

\begin{tabular}{|c|c|c|c|c|c|c|c|}
\hline \multirow[b]{2}{*}{ Discharge point } & \multirow[b]{2}{*}{ Effluent parameter } & \multicolumn{4}{|c|}{ Effluent limits } & \multirow[b]{2}{*}{$\begin{array}{c}\text { No. of } \\
\text { noncompliances }\end{array}$} & \multirow[b]{2}{*}{$\begin{array}{l}\text { Percentage of } \\
\text { compliance }\end{array}$} \\
\hline & & $\begin{array}{l}\text { Monthly } \\
\operatorname{avg}^{a}\end{array}$ & $\begin{array}{l}\text { Daily } \\
\max ^{a}\end{array}$ & $\begin{array}{c}\text { Monthly } \\
\text { avg } \\
\text { (lb/day) }\end{array}$ & $\begin{array}{l}\text { Daily max } \\
\text { (lb/day) }\end{array}$ & & \\
\hline$\overline{\text { Outfall } 005(\mathrm{~K}-1203}$ & Ammonia nitrogen & 5 & 7 & 27 & 38 & & 100 \\
\hline Sewage Treatment & Biochemical oxygen demand & 15 & 20 & 81 & 109 & & 100 \\
\hline \multirow[t]{10}{*}{ Facility) } & Chlorine, total residual & 0.14 & 0.24 & & & & 100 \\
\hline & Dissolved oxygen & & $5^{b}$ & & & & 100 \\
\hline & Fecal coliform, col/100 mL & $200^{c}$ & 1,000 & & & & 100 \\
\hline & $\mathrm{LC}_{50}$, Ceriodaphnia, $\%$ & & $14.6^{d}$ & & & & 100 \\
\hline & $\mathrm{LC}_{50}$, Pimephales, $\%$ & & $14.6^{d}$ & & & & 100 \\
\hline & NOEL,${ }^{e}$ Ceriodaphnia, $\%$ & & $4.2^{d}$ & & & & 100 \\
\hline & NOEL,${ }^{e}$ Pimephales, $\%$ & & $4.2^{d}$ & & & & 100 \\
\hline & $\mathrm{pH}$, standard units & & $6.0-9.0$ & & & & 100 \\
\hline & Settleable solids, mL/L & & 0.5 & & & & 100 \\
\hline & Suspended solids & 30 & 45 & 27 & 244 & & 100 \\
\hline Outfall 014 (K-1407-J & Benzene & & 0.005 & & & & 100 \\
\hline Central Neutralization & Cadmium & 0.18 & 0.69 & & & & 100 \\
\hline Facility to the Clinch & Carbon tetrachloride & 0.5 & 0.5 & & & & 100 \\
\hline \multirow[t]{20}{*}{ River } & Chloride, total & 35,000 & 70,000 & & & & 100 \\
\hline & Chlorine, total residual & & 1.0 & & & & 100 \\
\hline & Chloroform & 0.5 & 0.5 & & & & 100 \\
\hline & Chromium & 1.71 & 2.77 & & & & 100 \\
\hline & Copper & 1.34 & 2.15 & & & & 100 \\
\hline & Ethylbenzene & & 0.01 & & & & 100 \\
\hline & Lead & 0.38 & 0.69 & & & & 100 \\
\hline & Nickel & 2.38 & 3.98 & & & & 100 \\
\hline & Oil and grease & & 30 & & & & 100 \\
\hline & PCB & 0.00022 & 0.00045 & & & & 100 \\
\hline & Petroleum hydrocarbons & & 0.1 & & & & 100 \\
\hline & $\mathrm{pH}$, standard units & & $6.0-9.0$ & & & & 100 \\
\hline & Silver & 0.24 & 0.43 & & & & 100 \\
\hline & Suspended solids & & 40 & & & & 100 \\
\hline & Tetrachloroethylene & & 0.7 & & & & 100 \\
\hline & Toluene & & 0.01 & & & & 100 \\
\hline & Total toxic organics & & 2.13 & & & & 100 \\
\hline & Trichloroethylene & 0.5 & 0.5 & & & & $100^{f}$ \\
\hline & Vinyl chloride & 0.2 & 0.2 & & & & $100^{f}$ \\
\hline & Zinc & 1.48 & 2.61 & & & & $100^{f}$ \\
\hline Category I storm drains & $\mathrm{pH}$, standard units & & $4.0-9.0$ & & & & 100 \\
\hline Category II storm drains & $\mathrm{pH}$, standard units & & $4.0-9.0$ & & & & 100 \\
\hline \multirow{2}{*}{$\begin{array}{l}\text { Category III storm } \\
\text { drains }\end{array}$} & $\mathrm{pH}$, standard units & & $4.0-9.0$ & & & & 100 \\
\hline & Unpermitted discharge & $f$ & $f$ & & & 1 & $f$ \\
\hline \multirow{3}{*}{$\begin{array}{l}\text { Category IV storm } \\
\text { drains (to Poplar Creek) }\end{array}$} & Chlorine, total residual & & 0.14 & & & & 100 \\
\hline & $\mathrm{pH}$, standard units & & $6.0-9.0$ & & & & 100 \\
\hline & Unpermitted discharge & $f$ & $f$ & & & 1 & $f$ \\
\hline $\begin{array}{l}\text { Category IV storm } \\
\text { drains (to Mitchell }\end{array}$ & Chlorine, total residual & & 0.019 & & & & 100 \\
\hline Branch) & $\mathrm{pH}$, standard units & & $6.0-9.0$ & & & & 100 \\
\hline
\end{tabular}


K-1007-P1 Pond. Containment and cleanup efforts prevented spilled fuel from reaching Poplar Creek. The vehicle was repaired and was hauled from the site on a flatbed truck.

On July 29, 2003, an operator discovered a grayish discharge bubbling out of a sanitary sewer line clean-out port outside the K-1423 building break room. The grayish water was entering a nearby storm drain catch basin that discharges through storm water outfall 200 into Mitchell Branch. The catch basin was isolated, and a hose was inserted in the clean-out port to pump the gray water to a lift station. The amount of gray water discharged through the storm drain system could not be determined, but there was no evidence of any impact in Mitchell Branch. The sanitary sewer line was determined to have blockage; it was later excavated and repaired.

\subsection{STORM WATER POLLUTION PREVENTION PROGRAM}

\subsubsection{Storm Water Monitoring Strategy}

Development and implementation of the ETTP Storm Water Pollution Prevention Program is required by Part IV of ETTP NPDES Permit No. TN0002950. The objective of the program is to minimize the discharge of pollutants in storm water runoff from the ETTP.

The purpose of the ETTP Storm Water Pollution Prevention Program is to assess the quality of storm water discharges from ETTP, determine potential sources of pollutants affecting storm water, and provide effective controls to reduce or eliminate these pollutant sources. It provides a means whereby sources of pollutants that are likely to affect the quality of storm water discharges are identified, best management practices to control the entry of pollutants into storm water discharges are developed, and methods for implementing pollution prevention practices are devised.

Based on knowledge of past processes and activities at the ETTP, only parameters of particular concern were monitored during 2003. These parameters include gross alpha radioactivity, gross beta radioactivity, polychlorinated biphenyls (PCBs), mercury, metals, and volatile organic compounds. Gross alpha and gross beta radioactivity were monitored at those storm drain outfalls where they were detected at levels above screening criteria during more than one previous sampling effort. PCBs were monitored at those storm drain outfalls where they were detected above the detection limit of the analytical method. Metals were monitored at those locations where they were detected in amounts exceeding the screening criteria during more than one previous sampling effort and that may have received runoff from cooling tower areas. Volatile organics were monitored at those storm drain locations that are potentially affected by contaminated groundwater plumes and at locations where they were detected in amounts exceeding the screening criteria during more than one previous sampling effort.

As part of the 2003 SWPP Program and in association with the ETTP Water Quality Project monitoring program, surface water samples were also collected at locations that are exit pathways for contaminants from ETTP. These locations have a direct discharge or potential for direct discharge to Poplar Creek or the Clinch River.

Storm drain water samples were also collected during 2003 to support remedial actions, decontamination and decommissioning activities, the ETTP Water Quality Project, and the NPDES permit renewal process.

\subsubsection{Storm Water Monitoring Results}

\subsubsection{Radiological Monitoring of Storm Water Discharges}

In the ETTP Storm Water Pollution Prevention Program, levels of $15 \mathrm{pCi} / \mathrm{L}$ for gross alpha activity and $50 \mathrm{pCi} / \mathrm{L}$ for gross beta activity are used as radiological screening levels. These screening levels correspond to the National Primary Drinking Water Standards established by the Safe Drinking Water Act. The screening level for a specific radionuclide is equal to $4 \%$ of the DCG for that radionuclide in water, as listed in U.S. DOE Order 5400.5. The screening levels for uranium isotopes are $20 \mathrm{pCi} / \mathrm{L}$ for ${ }^{234} \mathrm{U}$ and ${ }^{236} \mathrm{U}$, and $24 \mathrm{pCi} / \mathrm{L}$ for ${ }^{235} \mathrm{U}$ and ${ }^{238} \mathrm{U}$. The screening level for ${ }^{99} \mathrm{Tc}$ is 4,000 
pCi/L. The screening levels for ${ }^{237} \mathrm{~Np},{ }^{238} \mathrm{Pu}$, and ${ }^{239 / 240} \mathrm{Pu}$ are $1.2,1.6$, and $1.2 \mathrm{pCi} / \mathrm{L}$, respectively.

ETTP storm water outfall monitoring results obtained in 2003 that exceeded radiological screening levels are shown in Table 4.7. Maximum exceedances at each outfall are shown.

Sampling for gross alpha radiation, gross beta radiation, ${ }^{234} \mathrm{U},{ }^{236} \mathrm{U},{ }^{235} \mathrm{U},{ }^{238} \mathrm{U},{ }^{99} \mathrm{Tc},{ }^{237} \mathrm{~Np},{ }^{238} \mathrm{Pu}$, and ${ }^{239 / 240} \mathrm{Pu}$ was also performed at several other storm water outfalls in addition to those listed in the table. No radiological screening levels were exceeded for any of these outfalls.

Table 4.7. Maximum exceedances of radiological screening criteria for each storm water outfall, $2003(\mathrm{pCi} / \mathrm{L})^{\mathrm{a}}$

\begin{tabular}{cllll}
\hline $\begin{array}{c}\text { Storm water } \\
\text { outfall }\end{array}$ & Alpha & Beta & ${ }^{233 / 234} \mathrm{U}$ & ${ }^{238} \mathrm{U}$ \\
\hline 158 & 98.8 & 97.5 & & \\
180 & 19.4 & & & \\
190 & 46.9 & & 29.2 & \\
292 & 38.3 & & & \\
350 & 195 & 68.3 & 74.3 & 57.4 \\
382 & 20.3 & & & \\
490 & & 84.2 & & \\
724 & 118 & 70.6 & 46.5 & 33.8 \\
730 & 40.3 & 198 & 21.0 & \\
740 & 106 & 72.9 & 69.3 & 48.2 \\
750 & 47.1 & 67.3 & 28.2 & \\
760 & 137 & 76.1 & 73.5 & 44.8 \\
\hline
\end{tabular}

${ }^{a}$ Screening levels are $15 \mathrm{pCi} / \mathrm{L}$ alpha radiation, 50 $\mathrm{pCi} / \mathrm{L}$ beta radiation, $20 \mathrm{pCi} / \mathrm{L}{ }^{234} \mathrm{U}, 24 \mathrm{pCi} / \mathrm{L}{ }^{235} \mathrm{U}$, and $24 \mathrm{pCi} / \mathrm{L}{ }^{238} \mathrm{U}$.

Table 4.8 provides an estimate of the total activity of radionuclides discharged from ETTP stormwater outfalls in 2003.

\subsubsection{Nonradiological Monitoring of Storm Water Discharges}

Grab samples were collected at storm water outfalls 100, 124, 170, 180, 190, 200, 210, 220, 230, 280, 292, 294, 490, 724, 730, 740, 750, 760, and 890 as part of the Storm Water Pollution Prevention Program storm water sampling effort, and they were analyzed for PCBs to a detection level of $0.5 \mu \mathrm{g} / \mathrm{L}$. No detectable PCBs were found in samples from any of these locations except outfall 292, where one result for Aroclor-1260 was $0.5 \mu \mathrm{g} / \mathrm{L}$.
Table 4.8. Radionuclides released to off-site surface waters from the East Tennessee Technology Park storm water system, 2003

\begin{tabular}{cccc}
\hline Radionuclide & $\begin{array}{c}\text { Amount } \\
(\mathbf{C i})\end{array}$ & Radionuclide & $\begin{array}{c}\text { Amount } \\
(\mathbf{C i})^{a}\end{array}$ \\
\hline${ }^{237} \mathrm{~Np}$ & $-2.0 \mathrm{E}-5$ & ${ }^{234} \mathrm{U}$ & $1.5 \mathrm{E}-2$ \\
${ }^{238} \mathrm{Pu}{ }^{b}$ & $6.3 \mathrm{E}-5$ & ${ }^{235} \mathrm{U}$ & $7.7 \mathrm{E}-4$ \\
${ }^{239} \mathrm{Pu}$ & $8.6 \mathrm{E}-6$ & ${ }^{236} \mathrm{U}$ & $1.7 \mathrm{E}-4$ \\
${ }^{99} \mathrm{Tc}$ & $6.1 \mathrm{E}-2$ & ${ }^{238} \mathrm{U}$ & $5.1 \mathrm{E}-3$ \\
\hline
\end{tabular}

${ }^{a} 1 \mathrm{Ci}=3.7 \mathrm{E}+10 \mathrm{~Bq} .{ }^{b} \mathrm{All}$ results less than or equal to laboratory error values.

Storm water from a number of outfalls contained metals and/or volatile organics at concentrations above applicable screening levels. These results are shown in Table 4.9.

Table 4.9. Maximum exceedances of nonradiological screening criteria for each storm water outfall $(\mu \mathrm{g} / \mathrm{L})$

\begin{tabular}{llll}
\hline \multirow{2}{*}{ Outfall } & \multicolumn{1}{c}{ Parameter } & $\begin{array}{c}\text { Monitoring } \\
\text { Result }\end{array}$ & Criteria \\
& & & \\
\hline 100 & Zinc & 129 & 104 \\
170 & Aluminum & 900 & 100 \\
180 & Trichloroethene & 16 & 5 \\
190 & $1,1-$ & 23 & 5 \\
190 & Dichloroethane & & \\
190 & Barium & 119 & 100 \\
190 & Boron & 126 & 100 \\
190 & Nickel & 115 & 100 \\
190 & Trichloroethene & 41 & 5 \\
430 & Vinyl chloride & 190 & 2 \\
490 & Trichloroethene & 15 & 5 \\
710 & Trichloroethene & 7 & 5 \\
710 & Copper & 217 & 100 \\
724 & Zinc & 549 & 100 \\
750 & Aluminum & 280 & 100 \\
\hline
\end{tabular}




\subsubsection{Sump Data}

No gross alpha or gross beta contamination above the screening levels was detected in water samples collected from any of the twelve sumps that were included in the 2003 Storm Water Pollution Prevention Program. In addition, no levels of transuranics or isotopic uranium exceeding $4 \%$ of the DCG level were detected in samples from any of the sumps sampled in 2003.

Trichloroethene was detected in water samples from three sumps in buildings K-1210 and K-731 at concentrations that exceeded the Tennessee water quality criteria for Domestic Water Supply, which is $5 \mu \mathrm{g} / \mathrm{L}$. No other volatile organics were detected at levels above the Tennessee water quality criteria at any of the other sumps sampled in 2003. Aroclor-1254 was detected in water samples from three sumps in building K-731 and Aroclor-1260 from one sump in building K-761 at concentrations that exceeded the detection level. PCBs were not found in detectable concentrations in any of the other sumps that were sampled as part of the 2003 Storm Water Pollution Prevention Program.

\subsubsection{Sediment Monitoring at Storm Drains and Oil/Water Separators}

As part of the 2003 Storm Water Pollution Prevention Program sampling effort, sediment samples were collected and analyzed for PCBs at seven oil/water separators that are part of the storm drainage system at ETTP. Aroclor-1260 was detected in each separator, and aroclor-1254 was detected in three of the separators. No other aroclors were detected. The results of this sediment sampling effort are given in Table 4.10.

\subsection{ETTP TOXICITY CONTROL AND MONITORING PROGRAM}

The NPDES permit requires that biannual toxicity testing be performed at Outfall 005 (the Sewage Treatment Plant). Operations Management International currently manages the water treatment plant and the Sewage Treatment Plant as well as some aspects of the storm drain
Table 4.10. PCBs detected in sediment from oil/water separators

\begin{tabular}{ccc}
\hline Arochlor & \multicolumn{2}{c}{ Results $(\mu \mathrm{g} / \mathrm{g})$} \\
\hline \multirow{3}{*}{1254} & K-897 Separator & 1.1 \\
1260 & & 0.7 \\
& K-897-B Separator & \\
1254 & & 2.8 \\
1260 & & 1.2 \\
1260 & K-897-C Separator & 0.5 \\
1260 & K-897-D Separator & 0.9 \\
1260 & K-897-E Separator & 2.3 \\
& & \\
1260 & K-897-F Separator & 1 \\
& & \\
1254 & K-897-G Separator & 0.7 \\
\hline
\end{tabular}

network. The results of the toxicity tests of wastewaters conducted during 2003 are given in Table 4.11, which also provides the wastewater's no-observed-effect concentration (NOEC) and lethal concentration for $50 \%$ of the test organisms $\left(\mathrm{LC}_{50}\right)$ or the inhibition concentration for $25 \%$ of the organisms $\left(\mathrm{IC}_{25}\right)$ for fathead minnows (Pimephales promelas) and Ceriodaphnia dubia for each test. Average water quality measurements obtained during each toxicity test are shown in Table 4.12.

Effluent from Outfall 005 was tested two times during 2003 with fathead minnows and Ceriodaphnia. In all tests, samples did not reduce survival, growth, or reproduction. Thus all NOEC and the $\mathrm{LC}_{50}$ results were within the permit limits.

\subsection{ETTP BIOLOGICAL MONITORING AND ABATEMENT PROGRAM}

The Biological Monitoring and Abatement Program (BMAP) is a requirement of the NPDES permit. Its purpose is to assess the ecological health of the ETTP's receiving streams and ponds. The BMAP consists of four tasks: (1) toxicity monitoring, (2) bioaccumulation monitoring, (3) ecological surveys of instream communities (both fish and benthic macroinvertebrates), and (4) waterfowl monitoring. The BMAP is conducted by the ORNL Environmental Sciences Division under 
Table 4.11. East Tennessee Technology Park National Pollutant Discharge Elimination System Outfall 005 Permit Number TN 0002950/TN 0074241 toxicity test results, 2003

\begin{tabular}{clcccc}
\hline Test date & \multicolumn{1}{c}{ Species } & $\mathrm{NOEC}^{\mathrm{a}}(\%)$ & $\mathrm{LC}_{50}{ }^{b}$ & $\mathrm{IC}_{25}{ }^{c}(\%)$ & $\mathrm{IWC}^{d}(\%)$ \\
\hline \multirow{2}{*}{ April-May } & Fathead minnow & 4.2 & $>14.6$ & & 3. \\
& Ceriodaphnia & 4.2 & $>14.6$ & & 33.3 \\
\multirow{4}{*}{ August } & Fathead minnow & NA & & $>75.2$ & 2. \\
& Ceriodaphnia & NA & & $>75.2$ & 62.6 \\
\hline
\end{tabular}

${ }^{a}$ No-observed-effect concentration.

${ }^{b} 96-\mathrm{h}$ lethal concentration for $50 \%$ of the test organisms.

${ }^{c}$ Inhibition concentration for $25 \%$ of the test organisms

${ }^{d}$ Instream waste concentration (based on critical low flow of Poplar Creek).

Table 4.12. East Tennessee Technology Park average water quality parameters measured during toxicity tests of Outfall 005 effluent, 2003.

Values are averages of full-strength wastewater for each test $(\mathrm{N}=6$ or 7$)$

\begin{tabular}{cccccc}
\hline ETTP Outfall & Test date & $\begin{array}{c}\mathrm{pH}(\text { standard } \\
\text { units })\end{array}$ & Conductivity $(\mu \mathrm{S} / \mathrm{cm})$ & $\begin{array}{c}\text { Alkalinity }(\mathrm{mg} / \\
\left.\mathrm{L} \mathrm{CaCO}_{3}\right)\end{array}$ & $\begin{array}{c}\text { Hardness }(\mathrm{mg} / \\
\left.\mathrm{L} \mathrm{CaCO}_{3}\right)\end{array}$ \\
\hline Outfall 005 & April-May & 8.2 & 210 & 68 & 140 \\
& August & 7.4 & 350 & 85 & 150 \\
\hline
\end{tabular}

the direction of the ETTP Environment, Safety, and Health Division.

\subsubsection{Toxicity Monitoring}

The toxicity monitoring task for the BMAP includes tests of effluent from storm water outfalls 170,180 , and 190 concurrently with surface water from six ambient sites in Mitchell Branch [Mitchell Branch kilometer (MIK) 0.12, MIK 0.45, MIK 0.54, MIK 0.71, MIK 0.78, and MIK 1.43]. (The number following "MIK" indicates the distance in kilometers from the mouth of Mitchell Branch on Poplar Creek.) Ceriodaphnia dubia were used to evaluate effluent from stormwater outfalls 170 and 190, and the ambient monitoring location for toxicity four times during 2003. Survival and growth tests using fathead minnows (Pimephales promelas) were conducted on effluent from storm water outfall 190 at the same time as the Ceriodaphnia dubia tests. These tests were conducted in February and March, June, August, and December. Effluent from storm water outfall 180 was evaluated for toxicity two times in 2003 (in February and March, and again in August).

Results of the toxicity tests are presented in Table 4.13. In the tests on the ambient locations, only one test exhibited toxicity, but this test exhibited toxicity at three locations (three locations at and downstream from MIK 0.54), in the form of reduced Ceriodaphnia reproduction. In Ceriodaphnia tests on effluent from storm water outfall 170, reproduction or survival was reduced in three of the four tests. However, none of the tests on effluent from storm water outfall 180 exhibited toxicity. In all four Ceriodaphnia tests, effluent from storm water outfall 190 reduced reproduction and/or survival. Fathead minnows were not significantly affected in any of the 2003 tests. Thus, the overall trend is one of consistent toxicity to Ceriodaphnia from storm water outfall 190 , slightly less toxicity from storm water outfall 170 , and no toxicity from storm water outfall 180 . Although it was not possible to positively identify the source of the problem, the data gathered indicated that groundwater was percolating through waste in the K-1070-B Classified Burial Ground and leaching out small quantities of metals. Some of this groundwater was then flowing into the storm drain system, and causing the toxicity. Nickel and zinc are present in water collected from the storm drain system near K-1070-B, at levels that have been shown to be toxic to Ceriodaphnia. 
Table 4.13. Mitchell Branch and associated storm water outfall toxicity test results, $\mathbf{2 0 0 3}^{a}$

\begin{tabular}{|c|c|c|c|c|c|c|c|c|c|}
\hline Test & $\begin{array}{l}\text { MIK } \\
1.43 \\
\end{array}$ & $\begin{array}{l}\text { MIK } \\
0.78 \\
\end{array}$ & $\begin{array}{l}\text { SD } \\
170 \\
\end{array}$ & $\begin{array}{l}\text { MIK } \\
0.71 \\
\end{array}$ & $\begin{array}{l}\text { SD } \\
180 \\
\end{array}$ & $\begin{array}{l}\text { MIK } \\
0.54 \\
\end{array}$ & $\begin{array}{l}\text { SD } \\
190 \\
\end{array}$ & $\begin{array}{l}\text { MIK } \\
0.45 \\
\end{array}$ & $\begin{array}{l}\text { MIK } \\
0.12 \\
\end{array}$ \\
\hline \multicolumn{10}{|c|}{ First quarter, February-March } \\
\hline Ceriodaphnia survival & NR & $\mathrm{NR}$ & $\mathrm{NR}$ & NR & $\mathrm{NR}$ & NR & NR & NR & NR \\
\hline Ceriodaphnia reproduction & NR & $\mathrm{NR}$ & NR & NR & NR & NR & $\mathrm{R}$ & NR & NR \\
\hline Pimphales survival & & & & & & & NR & & \\
\hline Pimphales growth & & & & & & & NR & & \\
\hline \multicolumn{10}{|c|}{ Second quarter, June } \\
\hline Ceriodaphnia survival & NR & NR & NR & NR & $b$ & NR & $\mathrm{R}$ & NR & NR \\
\hline Ceriodaphnia reproduction & NR & NR & $\mathrm{R}$ & NR & $b$ & NR & $\mathrm{R}$ & NR & NR \\
\hline Pimphales survival & & & & & & & NR & & \\
\hline Pimphales growth & & & & & & & NR & & \\
\hline \multicolumn{10}{|c|}{ Third quarter, August } \\
\hline Ceriodaphnia survival & NR & $\mathrm{NR}$ & NR & NR & NR & NR & $\mathrm{R}$ & NR & NR \\
\hline Ceriodaphnia reproduction & NR & $\mathrm{NR}$ & $\mathrm{R}$ & NR & NR & $\mathrm{R}$ & $\mathrm{R}$ & $\mathrm{R}$ & $\mathrm{R}$ \\
\hline Pimphales survival & & & & & & & NR & & \\
\hline Pimphales growth & & & & & & & NR & & \\
\hline \multicolumn{10}{|c|}{ Fourth quarter, December } \\
\hline Ceriodaphnia survival & NR & $\mathrm{NR}$ & NR & NR & $b$ & NR & $\mathrm{R}$ & NR & NR \\
\hline Ceriodaphnia reproduction & NR & $\mathrm{NR}$ & $\mathrm{R}$ & NR & $b$ & NR & $\mathrm{R}$ & NR & NR \\
\hline Pimphales survival & & & & & & & NR & & \\
\hline Pimphales growth & & & & & & & NR & & \\
\hline
\end{tabular}

${ }^{a}$ NR: No significant reduction compared with the control population.

R: Significant reduction compared with the control population.

${ }^{b} \mathrm{SD} 180$ is only sampled twice per year. 


\subsubsection{Bioaccumulation Studies}

In June and July, 2003, caged clams (Corbicula fluminea) were placed at several locations around ETTP, including five oil-water separators. The clams were allowed to remain in place for four weeks, then were analyzed for uptake of PCBs. Clams from all of the ETTP monitoring locations accumulated some level of PCBs; results of monitoring in 2003 were generally similar to the 2002 results. As before, the primary source of PCBs to the environment remains Storm Water Outfall 100. Both Mitchell Branch and the K-1007-P1 Pond receive effluent from other storm water outfalls that contain smaller amounts of PCBs. Levels in clams from Mitchell Branch progressively increase with the distance downstream. The PCBs in Mitchell Branch clams were primarily Arochlor 1254, while in the K-1007-P1 Pond clams both Arochlors 1248 and 1254 were present. As before, the concentration of PCBs in K-901-A clams was significantly lower than the concentration found in clams from K-1007-P1 Pond and Mitchell Branch. Clams were also placed in selected oil/water separators and in selected building sumps.

Fish were collected from Mitchell Branch, K1007-P1 Pond and K-901-A Pond in April 2003. Largemouth bass were collected from the pond sites, and redbreast sunfish were collected from Mitchell Branch. Game fish of a size large enough to be taken by sportsfishermen were selected to provide more accurate data of potential human health concerns and to reduce the amount of variation in contamination levels in the individual fish due to age and size differences. Fillets were taken from each game fish and analyzed for PCBs. Table 4.14 gives a synopsis of the results. As in previous years, the fish from the K-1007-P1 pond contained the highest concentrations of PCBs, while those from Mitchell Branch contained smaller concentrations, and the fish from K-901-A contained the lowest concentrations. Average levels at all sites were within historic ranges for the respective locations, although compared to last year's monitoring results the averages had increased slightly in fish from K-901-A and decreased slightly in fish from Mitchell Branch. The maximum concentration was found in a bass from K-1007-P1 Pond (33.7 $\mu \mathrm{g} / \mathrm{g}$, wet weight), where both the average and the maximum values in 2003 were slightly lower than in 2002.

\subsubsection{Ecological Surveys of Instream Communities}

In April 2003, the benthic macroinvertebrate community at four Mitchell Branch locations MIK $0.45,0.71,0.78$, and 1.43 ) were sampled. MIK 1.43 serves as the reference location. Except for a shortterm impact at MIK 0.45 and 0.71 following construction of the interceptor trench, the benthic macroinvertebrate community at all locations in lower Mitchell Branch has generally increased in species richness and numbers of pollutionintolerant species over approximately the last ten years. (Figs. 4.8, 4.9, and 4.10). The results from this year's sampling show declines in species richness and richness of the pollution-intolerant species at MIK 0.45, 0.71, and 0.78 compared with 2002 , suggesting that some level of stress remains. The results to date indicate that, although past ETTP operations had adversely affected the communities of Mitchell Branch, the institution of BMPs and remediation efforts has resulted in gradual, but more or less continuous, improvement of conditions in the stream.

Fish communities in Mitchell Branch (MIK 0.45 and 0.71) were sampled in April, and reference streams were sampled in April and June. Species richness, density, and biomass were examined. The community at MIK 0.45 showed a drastic drop in species richness, density, and biomass. In 2002, species richness, density, and biomass at MIK 0.45 were at the highest levels ever recorded since monitoring began, so the opportunity for a large decrease this year was increased. In the spring of 2003, some of the highest flows on record for the area were recorded, and many of the smaller individuals and eggs may have been washed out of the stream. The combination of these two factors may account for much of the decrease. The community at MIK 0.71 continues to show some improvements from 1998, when that area was extensively disturbed by the groundwater intercept trench project, but it still has not reached the levels existing prior to that disturbance. 
Table 4.14. PCB concentrations in biota at ETTP, 2003

\begin{tabular}{llccc}
\hline Location & \multicolumn{1}{c}{ Species } & $\begin{array}{c}\text { Mean } \\
\text { Concentration } \\
(\mathrm{ppm})\end{array}$ & Range & No.>1ppm/N \\
\hline MIK 0.2 & Redbreast sunfish (Lepomis auritus) & 3.48 & $0.82-6.1$ & $5 / 6$ \\
K-1007-P1 & Largemouth bass (Micropterus salmoides) & 17.02 & $5.93-33.7$ & $6 / 6$ \\
K-901-A & Largemouth bass (Micropterus salmoides) & 0.77 & $0.32-1.5$ & $2 / 6$ \\
Hinds & Redbreast sunfish (Lepomis auritus) & $<0.01$ & $<0.01$ & $0 / 6$ \\
Creek(reference) & Asiatic clams (Corbicula fluminea) & 0.08 & N/A & N/A \\
MIK 0.78 & Asiatic clams (Corbicula fluminea) & 0.14 & N/A & N/A \\
MIK & & & & \\
0.71(SD170) & & 0.17 & N/A & N/A \\
MIK & Asiatic clams (Corbicula fluminea) & & & \\
0.54(SD180) & & 0.92 & N/A & N/A \\
MIK 0.45 & Asiatic clams (Corbicula fluminea) & 2.1 & N/A & N/A \\
(SD190) & Asiatic clams (Corbicula fluminea) & 3.85 & N/A & N/A \\
MIK 0.2 & Asiatic clams (Corbicula fluminea) & 0.79 & N/A & N/A \\
SD100 & Asiatic clams (Corbicula fluminea) & 0.17 & N/A & N/A \\
SD120 & Asiatic clams (Corbicula fluminea) & 0.7 & N/A & N/A \\
SD124 & Asiatic clams (Corbicula fluminea) & 1.71 & N/A & N/A \\
SD480 & Asiatic clams (Corbicula fluminea) & N/A & N/A \\
K-1007-B & Asiatic clams (Corbicula fluminea) & 0.17 & N/A & N/A \\
K-901-A & Asiatic clams (Corbicula fluminea) & 0.03 & \\
Little Sewee & Creek (Ref.) & & &
\end{tabular}

\subsubsection{Waterfowl Surveys}

Waterfowl surveys were conducted each month. One state-listed species, the great egret (Ardea alba) was observed. One "in need of management" species, the vesper sparrow (Pooecetes gramineus) was also observed. Other interesting species found at ETTP include the osprey (Pandion haliateus), double crested cormorant (Phalacrocorax auritus), and the Canada goose (Branta canadensis). During the last several years, the number of species of waterfowl, as well as the number of individuals, has fluctuated. It is not clear at this time whether or not the fluctuations represent a temporary plateau on the route to recovery, or whether the avian community has more or less reached a steady state for the current conditions.

\subsection{ETTP AMBIENT AIR MONITORING}

DOE Order 5400.1 requires surveillance of ambient air to assess the impact of DOE operations on air quality. In addition, airborne radionuclide monitoring is required for compliance with radionuclide NESHAP regulatory agreements. DOE Order 5400.5 specifies requirements for airborne radionuclide surveillance. The ETTP ambient air monitoring program is designed to monitor selected air contaminants for the ongoing monitoring of the impact of plant operations on the immediate environment. Specific locations were selected to determine air contaminant concentrations in the prevailing directions, upwind and downwind of the site, and to obtain airborne radiological measurements in the direction of both the nearest and most exposed member of the public. The current locations of these monitoring stations are shown in Fig. 4.11. The ETTP ambient air monitoring program complies with all requirements of DOE orders. 

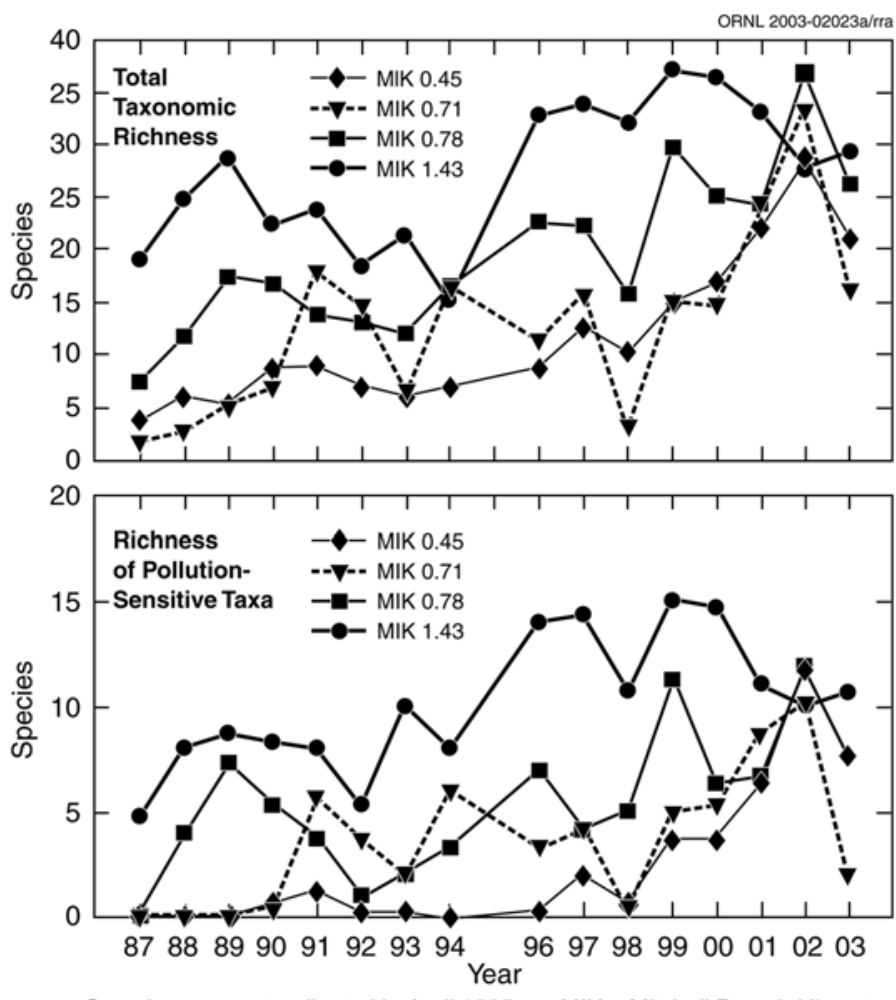

Samples were not collected in April 1995 MIK - Mitchell Branch kilometer

Fig. 4.8. Total taxonomic richness of pollution-sensitive tax ${ }^{a}$.

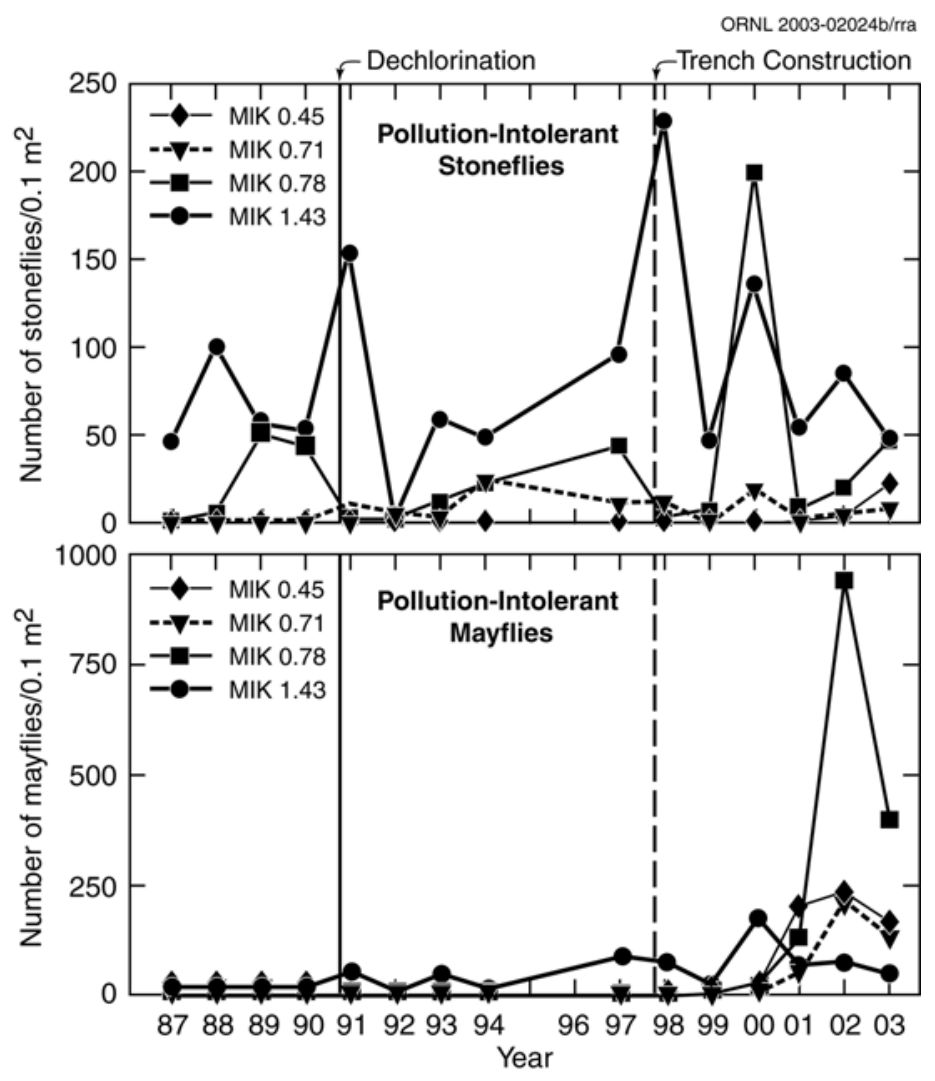

There was no monitoring conducted during 1995.

Fig. 4.9. Density of pollution-intolerant and pollutiontolerant species in Mitchell Branch. 


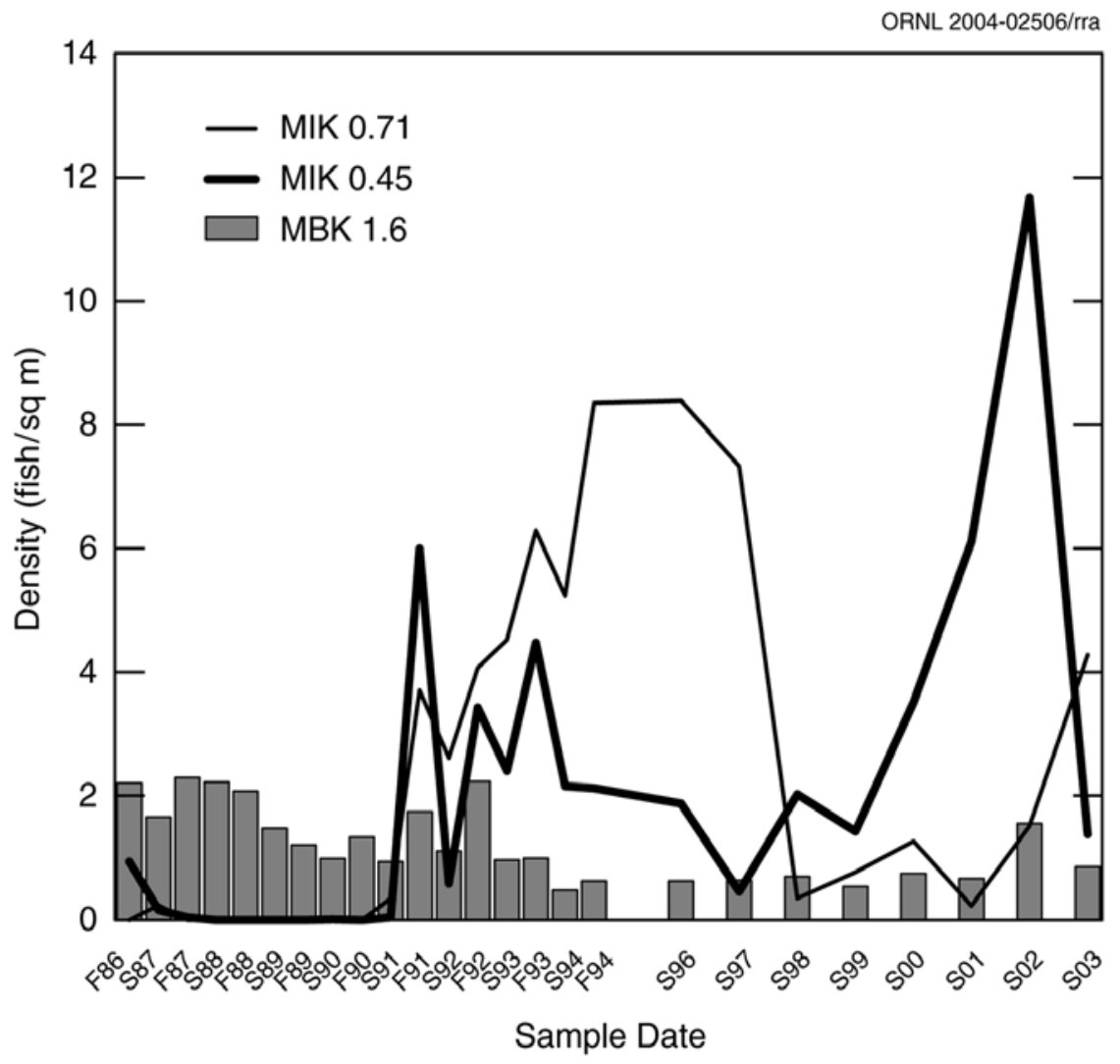

Fig.4.10. Temporal trend in fish density in Mitchell Branch.

National ambient air quality standards are referenced by DOE orders as guidance with respect to ambient air concentrations of certain air contaminants. These regulations specify 24-h, quarterly, and annual standards for specific or criteria pollutants. Additionally, results are compared with any applicable risk-specific dose and reference air concentration listed in 40 CFR 266, Subpart H.

The ambient air sampling schedule and monitored parameters are listed in Table 4.15. All parameters were chosen with consideration of existing and proposed regulations and the nature of operations in and around the ETTP. Changes in emissions, wind profile, site activities, or any other parameter that may alter the potential impact of ETTP activities on nearby communities or the environment may warrant periodic changes of air contaminants measured, number of stations, or relocation of existing stations. The principal parameters monitored during 2003 were arsenic, beryllium, cadmium, chromium, lead, and uranium. Uranium was analyzed by both inorganic and radiochemical methods. Radiochemical analyses included isotopes of uranium ${ }^{234} \mathrm{U},{ }^{235} \mathrm{U}$, ${ }^{236} \mathrm{U}$, and $\left.{ }^{238} \mathrm{U}\right),{ }^{99} \mathrm{Tc},{ }^{228} \mathrm{Th},{ }^{230} \mathrm{Th},{ }^{232} \mathrm{Th},{ }^{237} \mathrm{~Np}$, ${ }^{238} \mathrm{Pu}$, and ${ }^{239} \mathrm{Pu}$.

During this reporting period, the ambient air monitoring network was modified with respect to ETTP operations. Station K11 was established to cover potential fugitive airborne radiological emissions during the K-1070-A Burial Ground Remediation. The sampler was located on the northeast edge of the remediation area in the direction of the modeled maximally exposed member of the public as shown in Fig. 4.11. Measured parameters were selected based on a radiological characterization of the project and the potential dose contribution of each radionuclide. No other sampling procedures or locations were changed from the previous year. Samples were collected weekly from the following stations: K2, $\mathrm{K} 6, \mathrm{~K} 9, \mathrm{~K} 10, \mathrm{~K} 11$, and perimeter air monitors 35 and 42 . 


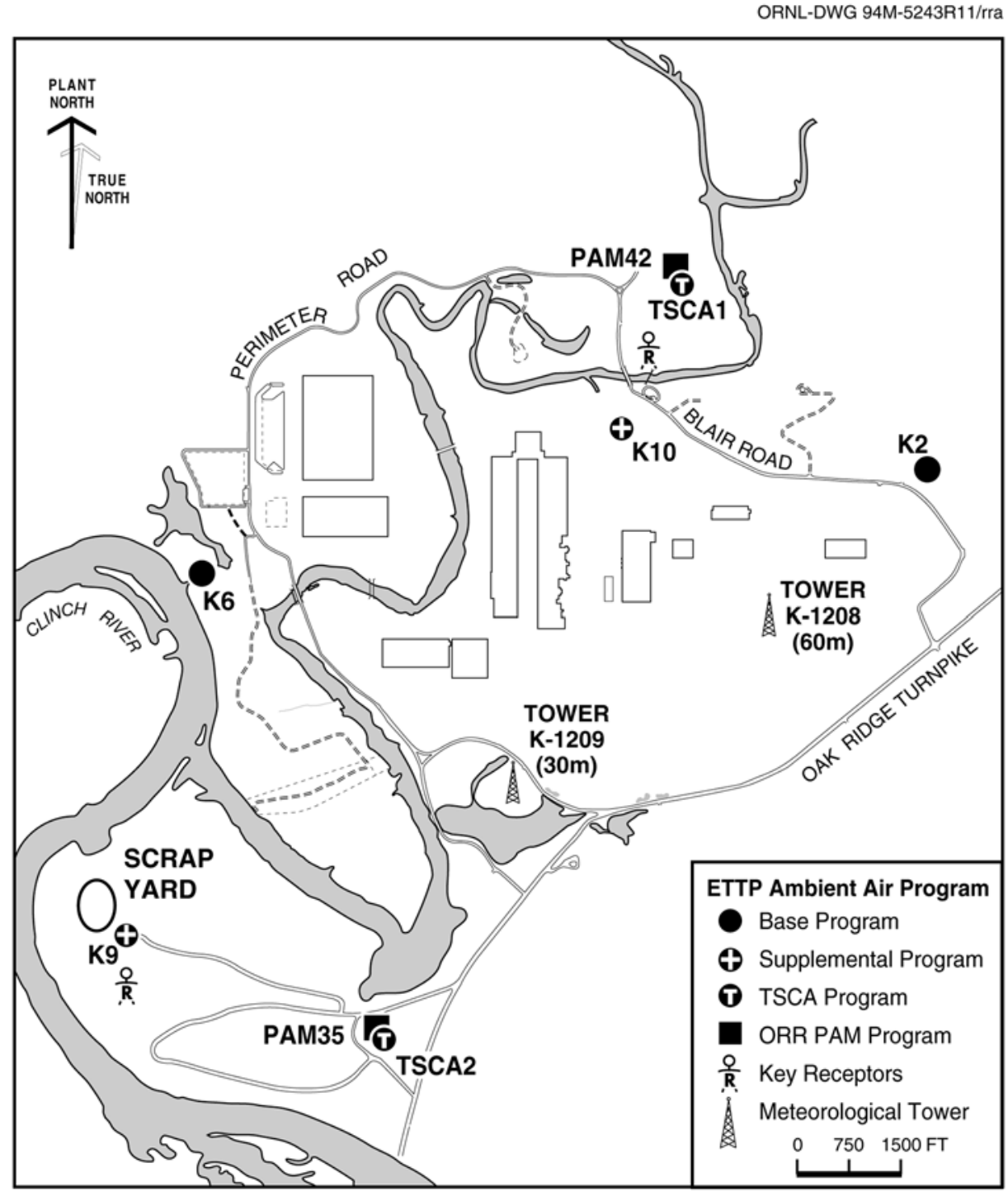

Fig. 4.11. Locations of ambient air monitoring stations at the ETTP.

\subsubsection{Results}

No standards were exceeded, and, with the exception of uranium levels, there were no significant variations of annual pollutant concentrations associated with site operations when compared with data from the previous year. Sampling results assessing the impact of specific site activities on air quality show that the ETTP, including project-specific measurements, did not have any impact of concern on local air quality. Also, radiochemical analyses of ambient air samples confirm low radiological emissions from the ETTP.

\subsubsection{Criteria Pollutant Levels}

Quarterly lead results were determined from analyses of monthly composites of continuous weekly samples from stations $\mathrm{K} 2, \mathrm{~K} 6, \mathrm{~K} 9$, and K10. The total mass quantities of lead for each sample were determined by the inductively coupled plasma mass spectrometry (ICP-MS) analytical technique. Lead analytical results are summarized in Table 4.16 and are compared with the Tennessee and national quarterly ambient air quality standard of $1.5 \mu \mathrm{g} / \mathrm{m}^{3}$. There are no $24-\mathrm{h}$, monthly, or annual ambient air quality standards for lead. The maximum individual lead result was $0.0037 \mu \mathrm{g} / \mathrm{m}^{3}$. This value was only $0.3 \%$ of the quarterly standard for lead. No lead 
Table 4.15. Summary of types and frequencies of samples collected at East Tennessee Technology Park perimeter ambient air monitoring stations, 2003

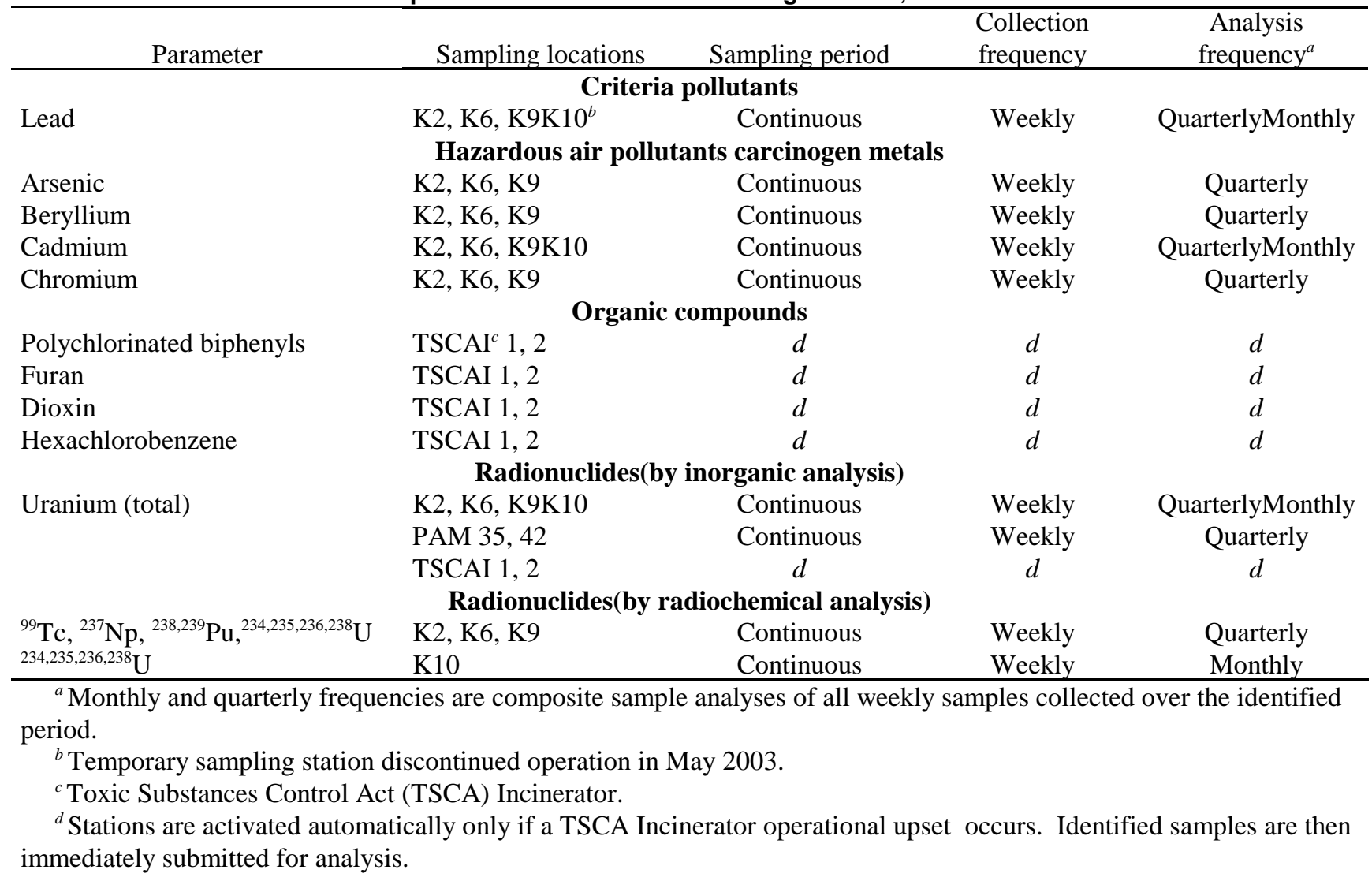

Table 4.16. Lead concentrations in ambient air at the East Tennessee Technology Park, 2003

\begin{tabular}{|c|c|c|c|c|c|c|}
\hline \multirow{2}{*}{ Station } & \multicolumn{4}{|c|}{ Quarterly averages of monthly composites $\left(\mu \mathrm{g} / \mathrm{m}^{3}\right)$} & \multirow{2}{*}{$\begin{array}{l}\text { Max quarterly } \\
\operatorname{result}\left(\mu \mathrm{g} / \mathrm{m}^{3}\right)\end{array}$} & \multirow{2}{*}{$\begin{array}{l}\text { Max percent } \\
\text { of quarterly } \\
\text { standard }^{a, b}\end{array}$} \\
\hline & 1 & 2 & 3 & 4 & & \\
\hline K2 & 0.000876 & 0.000342 & 0.000497 & 0.000531 & 0.000876 & 0.06 \\
\hline K6 & 0.000796 & 0.000350 & 0.000462 & 0.000654 & 0.000796 & 0.05 \\
\hline K9 & 0.000460 & 0.000310 & 0.000712 & 0.000573 & 0.000712 & 0.05 \\
\hline K10 & 0.002242 & 0.000140 & $c$ & $c$ & 0.002242 & 0.15 \\
\hline Quarterly avg & 0.001094 & 0.000286 & 0.000557 & 0.000586 & 0.001094 & 0.07 \\
\hline Quarterly max & 0.002242 & 0.000350 & 0.000712 & 0.000654 & 0.002242 & 0.15 \\
\hline Annual average & $r$ all statio & $=0.0007$ & $\mathrm{~g} / \mathrm{m}^{3}$ & & & \\
\hline
\end{tabular}

${ }^{a}$ Tennessee and national air quality standard for lead is $1.5 \mu \mathrm{g} / \mathrm{m}^{3}$ quarterly arithmetic average.

${ }^{c}$ Conservative comparison of the maximum individual monthly result with the quarterly standard.

'Temporary sampling station discontinued operation in May, 2003. 
concentrations of environmental concern were measured (see Fig 4.12 for 5-year lead trend).

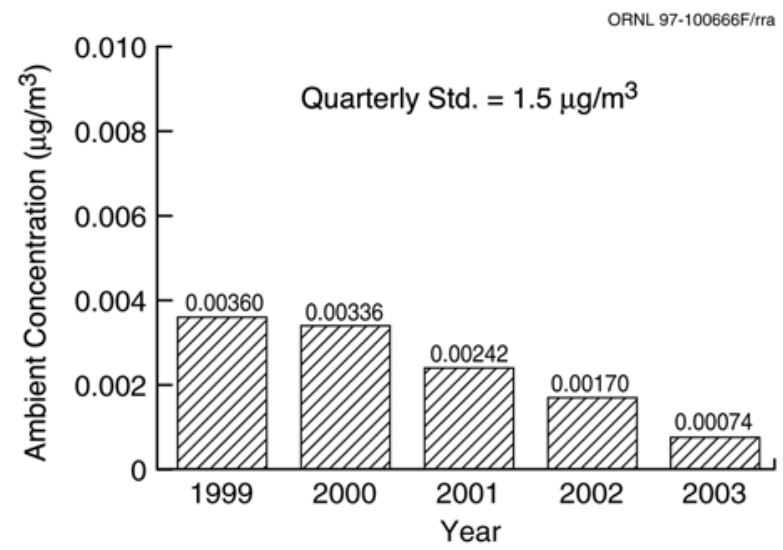

Fig. 4.12 Ambient air monitoring 5-year trend results for lead at the ETTP.

\subsubsection{Hazardous Air Pollutant Carcinogenic Metal Levels}

Analyses of hazardous air pollutant carcinogenic metals (arsenic, beryllium, cadmium, and chromium) were performed on one monthly composite per quarter of continuous weekly samples from stations $\mathrm{K} 2, \mathrm{~K} 6$, and $\mathrm{K} 9$. All monthly composite samples from K10 were only analyzed for cadmium. Total mass of each selected metal was determined by the ICP-MS analytical technique. There are no Tennessee or national ambient air quality standards for these hazardous air pollutant carcinogenic metals. However, comparisons have been made against risk-specific doses and reference air concentrations.

The annual average arsenic concentration for all measurement sites was $0.00075 \mu \mathrm{g} / \mathrm{m}^{3}$, well below the risk-specific dose of $0.0023 \mu \mathrm{g} / \mathrm{m}^{3}$. The individual maximum measured result was 0.00109 $\mu \mathrm{g} / \mathrm{m}^{3}$. Annual beryllium measurements were at or near the minimum detectable concentrations of the analytical method, orders of magnitude below the risk-specific dose of $0.0042 \mu \mathrm{g} / \mathrm{m}^{3}$. The combined beryllium average for all sites was $<0.000007$ $\mu \mathrm{g} / \mathrm{m}^{3}$ with the individual maximum result of $<0.000018 \mu \mathrm{g} / \mathrm{m}^{3}$. Cadmium concentration results ranged from approximately 0.00012 to 0.00042 $\mu \mathrm{g} / \mathrm{m}^{3}$. The cadmium annual average was 0.00021 $\mu \mathrm{g} / \mathrm{m}^{3}$, well below the risk-specific dose of 0.0056 $\mu \mathrm{g} / \mathrm{m}^{3}$. Individual chromium measurements ranged from approximately 0.00014 to $0.00065 \mu \mathrm{g} / \mathrm{m}^{3}$. The annual average result for chromium was $0.0003 \mu \mathrm{g} / \mathrm{m}^{3}$, well below the risk-specific dose of $0.00088 \mu \mathrm{g} / \mathrm{m}^{3}$ for chromium VI. The form of chromium was not determined, and therefore the most conservative risk-specific dose (chromium VI) was used. A summary of the hazardous air pollutant carcinogenic metals measurements is presented in Table 4.17.

\subsubsection{Radionuclide Levels}

Total uranium metal was measured as a monthly composite of continuous weekly samples from stations $\mathrm{K} 2, \mathrm{~K} 6, \mathrm{~K} 9$, and $\mathrm{K} 10$. Analyses were performed on each weekly sample taken at station K11, and quarterly composites of weekly continuous samples were analyzed from perimeter air monitoring stations 35 and 42. The total uranium mass for each sample was determined by the ICP-MS analytical technique. The uranium annual averages and maximum individual concentration measurements for all sites are presented in Table 4.18. Results ranged from a minimum of approximately 0.00006 to 0.00122 $\mu \mathrm{g} / \mathrm{m}^{3}$. The highest monthly result was measured at Station K6, which is in one of the prevailing wind directions from the ETTP. The annual average value for all stations due to uranium was $0.00017 \mu \mathrm{g} / \mathrm{m}^{3}$. The ICP-MS results are compared with a dose based on the DCG for natural uranium. (The DCG is based on an annual air concentration exposure that would give a dose of 100 mrem.) The sampling location with the highest annual average concentration of uranium was at station K10. The annual result was only $0.00040 \mu \mathrm{g} / \mathrm{m}^{3}$, which corresponds to $0.27 \%$ of the DCG (see Fig. 4.13 for 5-year uranium trend).

The highest recorded monthly uranium concentration for CY 2002 was measured at station K6, located near the K-901 area. The K6 May sample result of $0.00122 \mu \mathrm{g} / \mathrm{m}^{3}$, if assumed to be the annual average concentration, would equate to only $0.81 \%$ of the DCG for an individual located at that station for the entire year. Fig. 4.14 shows a comparison of monthly trends of total uranium data from K2 and TSCA Incinerator stack emission data. The intent of this figure is only to show the relative trend of each measurement result. A significant factor that can affect a comparison between the two data sets is 
Table 4.17. Hazardous air pollutant concentrations in ambient air at the East Tennessee Technology Park, 2003

\begin{tabular}{lcccc}
\hline \multirow{2}{*}{ Parameter } & \multicolumn{3}{c}{ Ambient air concentration $\left(\mu \mathrm{g} / \mathrm{m}^{3}\right)$} & \multirow{2}{*}{ Percentage of standard $^{a}$} \\
\cline { 2 - 4 } & Annual avg & Monthly max & Max location & 7.6 \\
\hline Arsenic & 0.000165 & 0.000274 & $\mathrm{~K} 2$ & $<0.1$ \\
Beryllium & $<0.000002$ & $<0.000003$ & $\mathrm{~K} 10$ & 1.5 \\
Cadmium & 0.000083 & 0.000365 & $\mathrm{~K} 10$ & \\
Chromium & 0.000066 & 0.000099 & $\mathrm{~K} 9$ & $<0.1$ \\
Cr-III & & & & 7.5 \\
Cr-VI & & & & \\
\hline
\end{tabular}

${ }^{a}$ There are no Tennessee or national ambient air quality standards; however, annual averages are compared to risk-specific doses for $\mathrm{As}, \mathrm{Be}, \mathrm{Cd}$, and $\mathrm{Cr}-\mathrm{VI}$ and the reference air concentration for Cr-III as listed in 40 CFR 266.

Table 4.18. Total uranium in ambient air by inductively coupled plasma mass spectrometry analysis at the East Tennessee Technology Park, 2003

\begin{tabular}{|c|c|c|c|c|c|c|c|}
\hline \multirow{3}{*}{ Station } & \multirow{3}{*}{ Samples } & \multicolumn{4}{|c|}{ Concentration $^{a}$} & \multirow{2}{*}{\multicolumn{2}{|c|}{ Percent of $\mathrm{DCG}^{b}(\%)$}} \\
\hline & & \multicolumn{2}{|c|}{$\left(\mu \mathrm{g} / \mathrm{m}^{3}\right)$} & \multicolumn{2}{|c|}{$(\mu \mathrm{Ci} / \mathrm{mL})$} & & \\
\hline & & Avg & $\operatorname{Max}^{c}$ & Avg & $\operatorname{Max}^{c}$ & Avg & $\operatorname{Max}^{\mathrm{c}}$ \\
\hline K2 & 6 & 0.000037 & 0.000184 & $2.45 \mathrm{E}-17$ & $1.23 \mathrm{E}-16$ & 0.02 & 0.12 \\
\hline K6 & 6 & 0.000106 & 0.000179 & $7.09 \mathrm{E}-17$ & $1.19 \mathrm{E}-16$ & 0.07 & 0.12 \\
\hline K9 & 6 & 0.000035 & 0.000082 & $2.36 \mathrm{E}-17$ & $5.46 \mathrm{E}-17$ & 0.02 & 0.05 \\
\hline K10 & 5 & 0.000144 & 0.000273 & $9.59 \mathrm{E}-17$ & $1.82 \mathrm{E}-16$ & 0.10 & 0.18 \\
\hline PAM35 & 3 & 0.000100 & 0.000175 & $6.68 \mathrm{E}-17$ & $1.16 \mathrm{E}-16$ & 0.07 & 0.12 \\
\hline PAM42 & 3 & 0.000121 & 0.000146 & $8.05 \mathrm{E}-17$ & $9.72 \mathrm{E}-17$ & 0.08 & 0.10 \\
\hline ETTP total & 29 & 0.000091 & 0.000273 & $6.04 \mathrm{E}-17$ & $1.82 \mathrm{E}-16$ & 0.06 & 0.18 \\
\hline
\end{tabular}

${ }^{a}$ Mass-to-curie concentration conversions assume a natural uranium assay of $0.717 \%{ }^{235} \mathrm{U}$.

${ }^{b}$ DOE Order 5400.5 Derived Concentration Guide (DCG) for naturally occurring uranium is an annual concentration of $1 \mathrm{E}-13 \mu \mathrm{Ci} / \mathrm{mL}$, which is equivalent to a $100 \mathrm{mrem}$ annual dose.

${ }^{c}$ Maximum individual sample analysis result with dose calculations conservatively, assuming the value to be an annual concentration.

the meteorology during each month. Shorter reporting periods increase the potential that the plume from the incinerator may not be in the direction of $\mathrm{K} 2$ when operating. Another factor is the sensitivity of the analytical methods at these low levels of pollutants, which can introduce increased uncertainty in the data. The data show that K2 can detect airborne uranium during periods of waste incineration. All emission sources were operating within permitted limits and within all emission standards.

Periodic radiochemical analyses were initiated during 2000 on selected monthly composite samples collected at Stations K2, K6, K9, and $\mathrm{K} 10$. The selected isotopes of interest were ${ }^{237} \mathrm{~Np}$, ${ }^{238} \mathrm{Pu},{ }^{239} \mathrm{Pu},{ }^{99} \mathrm{Tc}$, and isotopic uranium $\left({ }^{234} \mathrm{U},{ }^{235} \mathrm{U}\right.$, ${ }^{236} \mathrm{U}$, and $\left.{ }^{238} \mathrm{U}\right)$. Weekly analyses were initiated June 2002 at station K11. The selected isotopes were ${ }^{237} \mathrm{~Np},{ }^{228} \mathrm{Th},{ }^{230} \mathrm{Th},{ }^{232} \mathrm{Th},{ }^{99} \mathrm{Tc}$, and isotopic uranium $\left({ }^{234} \mathrm{U},{ }^{235} \mathrm{U},{ }^{236} \mathrm{U}\right.$, and $\left.{ }^{238} \mathrm{U}\right)$. The resulting annual concentrations for all nuclides measured are presented in Table 4.19. Three averaging techniques were used to establish annual results. This was due to measurement results that were for differing periods of sampling time during the year. Results from stations K2, K6, and K9 are averages 


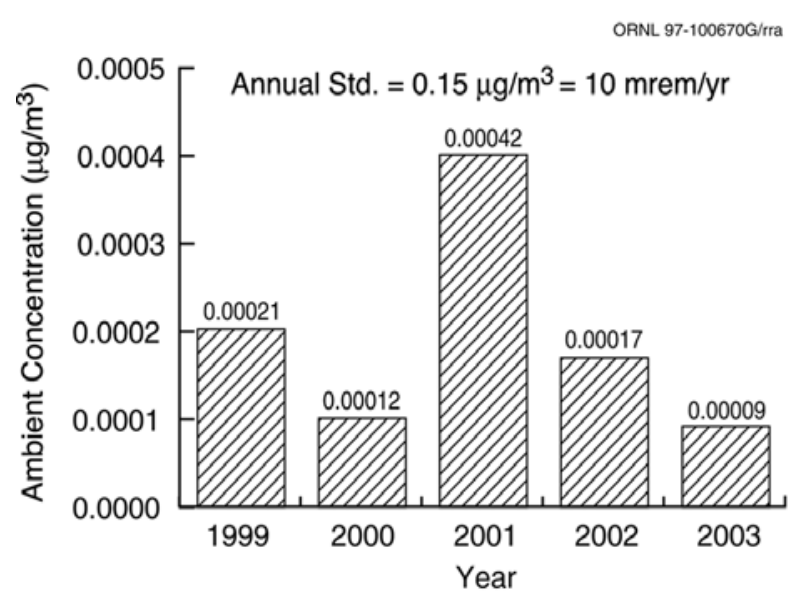

Fig. 4.13. Ambient air monitoring 5-year trend results for uranium at the ETTP.

of four monthly composite sample analyses. Due to ongoing activities at ETTP, this has been conservatively assumed to represent an annual average for this report. Station K10 sample results are based on 12 monthly composite analyses and are directly representative of an annual average. Station K11 began sampling in June, and all weekly samples were submitted for analysis. K11 averages were annualized by adjusting values by the ratio of the number of weeks of analyses and the total weeks in a year. For comparison, the total uranium results associated with ICP-MS analyses of composite samples are comparable with the uranium results determined by radiochemical techniques.

\subsubsection{Organic Compound Levels}

Currently, measurements of selected semivolatile organics are performed only during an operational upset of the TSCA Incinerator. There were no events that required the activation of sampling systems for organic pollutants in the ambient air during this reporting period. In the event that an unplanned release occurred, ambient air sampling stations would be activated automatically or manually.

\subsubsection{Five-Year Trends}

Five-year summaries of ETTP ambient air monitoring data are shown in Figs. 4.12 and 4.13 for lead and uranium, respectively. Variations of lead measurements were insignificant and most likely reflect background concentration variations of air quality. Uranium levels reflect typical levels that can be associated with normal ETTP operations.

Arsenic, beryllium, and cadmium measurements were initiated in 1993, and chromium measurements were initiated in 1986. Over the last 5 years, arsenic, cadmium, and chromium have been typically indistinguishable from background levels except during specific projects that have included major demolition activities. All beryllium measurements, historical and current, have been at or near analytical minimum detectable concentrations. During the 5year period, no ambient air measurements have indicated any level of concern based on comparisons with any applicable standards.

\subsection{ETTP SURFACE WATER MONITORING}

Surface water surveillance is currently conducted at eight locations at the ETTP (Fig. 4.15). Stations K-1710 and MIK 1.4 provide information on conditions upstream of the ETTP. Stations K-716 and Clinch River kilometer (CRK) 16 are located downstream from most ETTP operations and provide information on the cumulative effects of the ETTP activities as well as those upstream. The remaining sampling locations are at points where drainage in the major surface water basins converges before discharging to Poplar Creek (Stations K-1007-B and K-1700) or to the Clinch River (Station K-901-A).

At most surveillance stations, semiannual sampling and analyses for radionuclides and field readings (dissolved oxygen, temperature, and $\mathrm{pH}$ ) are conducted. At CRK 16, samples for radionuclides, volatile organic compounds, and selected metals are collected and analyzed on a monthly basis. Quarterly sampling for volatile organics, in addition to radionuclides and field readings, is conducted at the $\mathrm{K}-1700$ and MIK 1.4 locations. Radionuclide results are compared with 


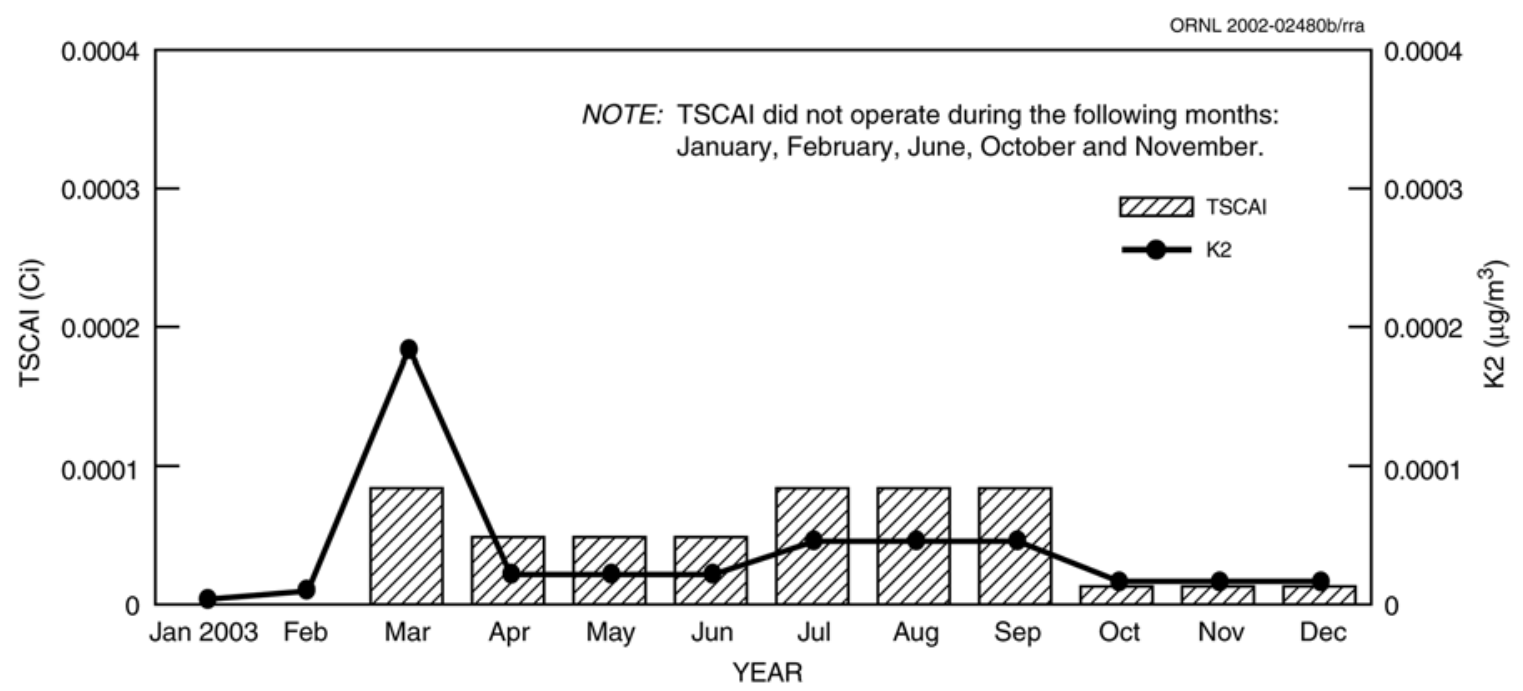

Fig. 4.14 Ambient air monitoring at ETTP Station K2 by ICP/MS vs TSCA Incinerator stack sampling results by radiochemistry.

Table 4.19. Radionuclides in ambient air by radiochemistry at the East Tennessee Technology Park, 2003

\begin{tabular}{|c|c|c|c|c|c|c|c|c|c|c|c|c|}
\hline \multirow[b]{2}{*}{ Station } & \multicolumn{12}{|c|}{ Concentration $(\mu \mathrm{Ci} / \mathrm{mL})^{a}$} \\
\hline & ${ }^{237} \mathrm{~Np}$ & ${ }^{238} \mathrm{Pu}$ & ${ }^{239} \mathrm{Pu}$ & ${ }^{99} \mathrm{Tc}$ & ${ }^{228} \mathrm{Th}$ & ${ }^{230} \mathrm{Th}$ & ${ }^{232} \mathrm{Th}$ & ${ }^{234} \mathrm{U}$ & ${ }^{235} \mathrm{U}$ & ${ }^{236} \mathrm{U}$ & ${ }^{238} \mathrm{U}$ & Total U \\
\hline K2 & $1.84 \mathrm{E}-18$ & $1.26 \mathrm{E}-18$ & $8.25 \mathrm{E}-18$ & $1.00 \mathrm{E}-15$ & $b$ & $b$ & $b$ & $1.22 \mathrm{E}-16$ & $2.29 \mathrm{E}-17$ & $1.38 \mathrm{~EB}-17$ & $9.73 \mathrm{E}-17$ & $2.56 \mathrm{E}-16$ \\
\hline K6 & $3.76 \mathrm{E}-18$ & $1.75 \mathrm{E}-18$ & $9.70 \mathrm{E}-18$ & $3.71 \mathrm{E}-15$ & $b$ & $b$ & $b$ & $5.24 \mathrm{E}-16$ & $4.27 \mathrm{E}-17$ & $1.95 \mathrm{E}-17$ & $2.25 \mathrm{E}-16$ & $8.11 \mathrm{E}-16$ \\
\hline K9 & $7.53 \mathrm{E}-18$ & $1.12 \mathrm{E}-17$ & $2.14 \mathrm{E}-17$ & $2.40 \mathrm{E}-15$ & $b$ & $b$ & $b$ & $1.74 \mathrm{E}-16$ & $1.56 \mathrm{E}-17$ & $8.94 \mathrm{E}-18$ & $7.61 \mathrm{E}-17$ & $2.75 \mathrm{E}-16$ \\
\hline K10 & $b$ & $b$ & $b$ & $b$ & $b$ & $b$ & $b$ & $9.48 \mathrm{E}-17$ & $1.49 \mathrm{E}-17$ & $8.17 \mathrm{E}-18$ & $7.50 \mathrm{E}-17$ & $1.93 \mathrm{E}-16$ \\
\hline
\end{tabular}

${ }^{a} \mathrm{~K} 2, \mathrm{~K} 6, \mathrm{~K} 9$ results are the average of four monthly composite analyses and assumed to represent an annual average value. K10 results are the average of the 12 monthly composite analyses.

${ }^{b}$ Data not available or sample not taken.

the DCGs. Nonradiological results are compared with Tennessee water quality standards for fish and aquatic life. The water quality standards use the numeric values given in the Tennessee general water quality criteria, which are a subset of the water quality standards.

In most instances, results of the monitoring for nonradiological parameters are well within the applicable standards. Heavy metals were often detected at CRK16, K-901-A, and K-1700 (barium was the most common heavy metal detected), and certain volatile organics (primarily trichloroethane, vinyl chloride, and 1,2dichloroethane) were regularly detected at $\mathrm{K}$ 1700 , but in all instances the results were below the applicable water quality standard. Dissolved oxygen measurements at MIK 0.4 fell below the minimum water quality standard during one summer sampling event due to elevated temperatures and the influence of groundwater and storm water at this location. Water bodies in the vicinity of the ETTP are regularly inspected for signs of stress on aquatic organisms during these periods. For the remaining analyses, results were within the reference standards or below detection limits for the instrument and method. Moreover, analytical results for samples collected upstream of the ETTP were chemically similar in most respects to those collected below the ETTP.

The sum of the fractions of the DCGs for most stations remained below $1 \%$ of the DCG values for ingestion (Fig. 4.16). The highest sum of the fractions, $5.6 \%$ of the DCGs, was reported for sampling location CRK 16, with the second highest sum at K-1700 (1.1\%). The results at the other surface water surveillance locations are all below $1 \%$ of the DCGs. These data are consistent with the historical results. Due to this stasis, monitoring at the surveillance locations will continue to be maintained at the reduced frequency until significant changes are detected or until ETTP operations change to include activities with the potential to affect discharges. 


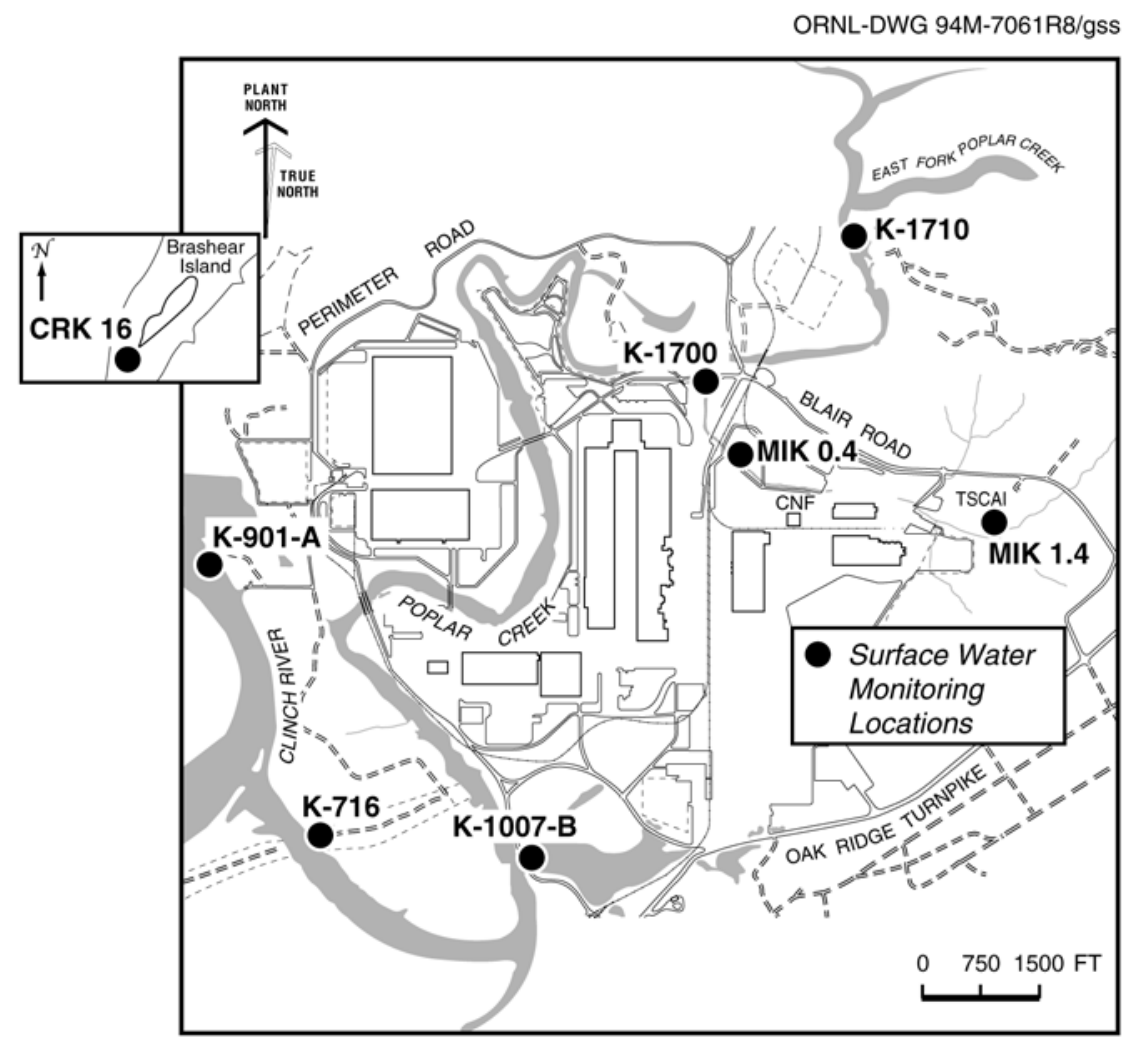

Fig. 4.15. Monitoring locations for surface water at the ETTP.

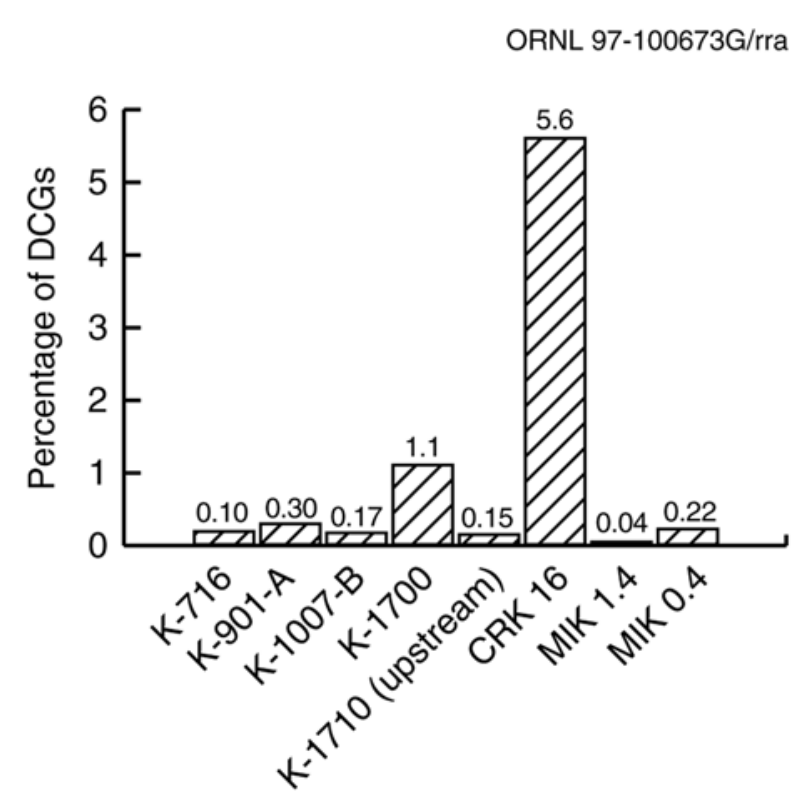

Fig. 4.16. Percentage of DOE derived concentration guides for ETTP surface monitoring locations.

\subsection{ETTP SOIL AND SEDIMENT MONITORING}

In 2001, soil monitoring was reinstated at ETTP. Due to the possibility of aerial deposition of contaminants, the soil monitoring locations are co-located with ambient air monitoring stations (K2, K6, K9, K10, and perimeter air monitors 35 and 42). Samples are collected and analyzed annually for selected radionuclides and metals. Results from the 2003 sampling indicate that ETTP operations have made some impacts on the environment, and comparison with ambient air monitoring results show that these impacts are ongoing. However, the results to date do not indicate that environmentally significant impacts are occurring at this time (for example, radionuclides other than ${ }^{99} \mathrm{Tc}$ and uranium were undetectable in the 2003 soil samples).

Currently, most sediment monitoring is conducted by the Water Resources Restoration Program in association with CERCLA remedial actions. Sediment monitoring is conducted both to provide a baseline for current conditions and to help gauge the effectiveness of the remedial actions. The ETTP Environmental Monitoring 
Program also conducts sediment monitoring at one location, just upstream of the K1700 weir on Mitchell Branch. Monitoring at this location in 2003 indicates that the sediment contains approximately $0.0038 \mathrm{mg} / \mathrm{kg}$ PCBs, $0.36 \mathrm{mg} / \mathrm{kg}$ beryllium, $43 \mathrm{mg} / \mathrm{kg}$ lead, $0.75 \mathrm{mg} / \mathrm{kg}$ mercury, 30 $\mathrm{mg} / \mathrm{kg}$ chromium, and $134 \mathrm{mg} / \mathrm{kg}$ nickel. Results from the sediment monitoring conducted in association with CERCLA activity are described in the 2003 Remediation Effectiveness Report (DOE 2003a).

\subsection{ETTP GROUNDWATER MONITORING}

Groundwater monitoring at the ETTP is focused primarily on investigating and characterizing sites for remediation under CERCLA. As a result of the Federal Facility Agreement and certification of closure of the K-1407-B and K-1407-C Ponds, the principal driver at the ETTP is CERCLA.

The cleanup strategy described in Accelerating Cleanup: Paths to Closure, (DOE 1999) has been developed to accelerate the transition of areas of concern from characterization to remediation by making decisions at the watershed scale based on recommended land use. The watershed is a surface-drainage basin that includes an area of concern or multiple areas of concern to be investigated and/or remediated. This approach allows for the systematic monitoring and evaluation of contaminant sources and migration through the use of integrated surface-water and groundwater monitoring.

ETTP Groundwater Protection Program requirements are incorporated into the Water Resources Restoration Program. The Water Resources Restoration Program, which was established to provide a consistent approach to watershed monitoring across the ORR, is responsible for conducting groundwater surveillance monitoring at the ETTP, including exit pathway monitoring wells. Groundwater discharges into Poplar Creek, the Clinch River, and the three main surface water bodies at ETTP (the K-901 Pond, K-1007 Pond, and Mitchell Branch). Many of the contaminants at ETTP migrate toward one of these surface water bodies, which are monitored by the ETTP Environmental
Monitoring Plan surface water surveillance program. The 2003 Remediation Effectiveness Report (DOE 2003a) includes summaries of groundwater monitoring actions required for individual cleanup actions at the ETTP, along with recommendations to modify any requirements that would further ensure protection of human health and the environment.

\subsection{ETTP DIRECT RADIATION}

The $\mathrm{UF}_{6}$ cylinder storage yards and K-770 Scrap Yard at ETTP may be sources of potential gamma and neutron direct radiation exposure to the public. Measured exposure rates and a hypothetical model of a maximally exposed individual were used to calculate theoretical doses. The calculated EDEs were based on gamma and neutron dose rates measured at the K-1066-J and K-1066-E Cylinder Yards along the near bank of Poplar Creek, the parking lot adjacent to the K1066-K Cylinder Yard, and the near bank of the Clinch River in the vicinity of the K-770 Scrap Yard. The dose levels to the public calculated from the measured exposure rates noted in the discussion that follows are less than the 100 mrem/year required by DOE Order 5400.5.

Gamma and neutron dose rates from each area were measured in March or April 2003 with tissue-equivalent dose rate meters. The neutron dose rate meter used in 2003 was upgraded to provide digital counts, and this allowed lower neutron dose rates to be reported than in previous years. Background readings were established at the ambient air monitoring stations north and northeast of ETTP off Blair Road, south and southwest of ETTP in the Powerhouse Area, and west of ETTP at the K-901 pumping station. The average gamma background was $0.005 \mathrm{mrem} / \mathrm{h}$. Neutron background was not measured in 2003; therefore, the average neutron background of $0.006 \mathrm{mrem} / \mathrm{h}$ measured in February 2004 was used.

The potential maximally exposed individual model used for exposure from the K-1066-J or K1066-E Cylinder Yard is a hypothetical fisherman who was assumed to have spent $250 \mathrm{~h} /$ year near the point of average exposure. This hypothetical individual could have received an EDE above background of about 1.00 mrem from gamma radiation and 0 mrem from neutron radiation 
along the bank of Poplar Creek near the K-1066-J Cylinder Yard, or 1.25 mrem from gamma radiation and 0.75 mrem from neutron radiation along the bank of Poplar Creek near the K-1066-E Cylinder Yard during 2003. This section of the creek runs through the ETTP plant and is used at times by fishermen; however, it is very unlikely that anyone would fish this stretch of Poplar Creek for $250 \mathrm{~h} /$ year.

General area dose rates were recorded in the vicinity of the K-770 Scrap Yard, along the near bank of the Clinch River. The average gamma dose rate was equivalent to the background level of $0.005 \mathrm{mrem} / \mathrm{h}$; however, the average neutron dose rate was $0.01 \mathrm{mrem} / \mathrm{h}$. A hypothetical Clinch River fisherman who was assumed to have spent $250 \mathrm{~h}$ /year near the point of average exposure could have received an EDE above background of about 1.00 mrem from neutron radiation attributable to the K-770 Scrap Yard during 2003.

The parking lot adjacent to the K-1066-K Cylinder Yard is used by workers and the public; therefore, it was included in the survey. This parking lot is intended for employees and has no public facilities. A potential maximally exposed individual is someone assumed to have spent 30 min per work day (125 h/year) waiting in the parking lot at the point of average exposure along the edge closest to the K-1066-K Cylinder Yard. This hypothetical individual could have received an EDE above background of about 1.75 mrem from gamma radiation and 3.00 mrem from neutron radiation during 2003.

\subsection{MODERNIZATION AND REINDUSTRIALIZATION}

The DOE Oak Ridge Operations Office (DOE-ORO) established the Reindustrialization Program in 1996 as an innovative way to address some of the environmental and financial challenges left at the end of the Cold War. Under this program, transfers of underutilized land and facilities are made available. The goal is to accelerate cleanup by reducing costs, while allowing for the productive use of these assets by the private sector. This process helps to offset negative impacts on the community caused by DOE downsizing, facility closeouts, and workforce restructuring. DOE-ORO worked with local officials and business leaders to establish
CROET. Through CROET, the Reindustrialization Program has successfully leased land and facilities at the ETTP. DOE-ORO has transitioned to an accelerated cleanup of ETTP in preparation for its closure as a DOE site. ETTP will then be available for use as a private sector industrial park. As part of this accelerated process, the emphasis is on facility transfer of ownership (title transfer).

In 2003, DOE-ORO completed a "finding of no significant impact" to allow the transfer of property to Horizon Center LLC. The property, in the past known as Parcel ED-1, only consists of the portions suitable for development. The remainder of the property, known as the Natural Area, will continue to be leased by Horizon Center LLC and owned by DOE.

DOE is working with the state of Tennessee to grant the state an indefinite-term conservation easement of approximately 3000 acres to be located on the west end of the Oak Ridge Reservation. This action is the result of an agreement-in-principle related to the Natural Resources Damage Act affecting the Oak Ridge Reservation. 



\section{ORNL Environmental Monitoring Programs}

Compliance and environmental monitoring programs required by federal and state regulations and by DOE orders are conducted for air, water, and a variety of environmental media. These programs include regulatory and monitoring activities for ORNL site facilities and other locations in Bethel Valley, Melton Valley, and the ORR.

\subsection{ORNL RADIOLOGICAL AIRBORNE EFFLUENT MONITORING}

Airborne discharges from DOE Oak Ridge facilities, both radioactive and nonradioactive, are subject to regulation by EPA and the TDEC Division of Air Pollution Control. Radioactive emissions are regulated by EPA under NESHAP regulations in 40 CFR 61, Subpart $\mathrm{H}$, and by the rules of the TDEC Division of Air Pollution Control, 1200-3-11.08. (See Appendix F, Table F.1 for a list of radionuclides and their radioactive half-lives.)

Radioactive airborne discharges at ORNL consist primarily of ventilation air from radioactively contaminated or potentially contaminated areas, vents from tanks and processes, and ventilation for reactor facilities. These airborne emissions are treated and then filtered with highefficiency particulate air filters and/or charcoal filters before discharge. Radiological airborne emissions from ORNL consist of solid particulates, adsorbable gases (e.g., iodine), tritium $\left({ }^{3} \mathrm{H}\right)$, and nonadsorbable gases (i.e., noble gases). The major radiological emission point sources for ORNL consist of the following five stacks located in Bethel and Melton Valleys (Fig. 5.1):

- 2026 High Radiation Level Analytical Laboratory;

- 3020 Radiochemical Processing Plant;

- 3039 central off-gas and scrubber system, which includes 3500 and 4500 areas' cell ventilation system, isotope solid-state ventilation system, 3025 and 3026 areas' cell ventilation system, 3042 ventilation system, and 3092 central off-gas system;

- 7503 (formerly 7512) Molten Salt Reactor Experiment remediation; and

- 7911 Melton Valley complex, which includes the HFIR and the Radionuclide Engineering Development Center.
In 2003, there were 24 minor point/group sources, and emission calculations/estimates were made for each of these sources.

\subsubsection{Sample Collection and Analytical Procedure}

Each of the five major point sources is equipped with a variety of surveillance instrumentation. Only data resulting from analysis of the continuous samples are used in this report. ORNL in-stack source sampling systems comply with criteria in the American National Standards Institute (ANSI) standard ANSI N 13.1 (ANSI 1969). The sampling systems generally consist of a multipoint in-stack sampling probe, a sample transport line, a particulate filter, activated charcoal cartridges, a silica-gel cartridge (if required), flow-measurement and totalizing instruments, a sampling pump, and a return line to the stack. In addition to that instrumentation, the system at Stack 7911 includes a high-purity germanium detector with a NOMAD ${ }^{\mathrm{TM}}$ analyzer, which allows continuous isotopic identification and quantification of radioactive noble gases (e.g., ${ }^{41} \mathrm{Ar}$ ) in the effluent stream. The sample probes are annually removed, inspected, and cleaned.

Velocity profiles are performed quarterly following the criteria in EPA Method 2 at major and some minor sources. The profiles provide accurate stack flow data for subsequent emissionrate calculations. An annual leak-check program is carried out to verify the integrity of the sample transport system.

In addition to the major sources, ORNL has a number of minor sources that have the potential to emit radionuclides to the atmosphere. A minor source is composed of any ventilation system or component such as a vent, a laboratory hood, room exhaust, or stack that does not meet the approved regulatory criteria for a major source but 


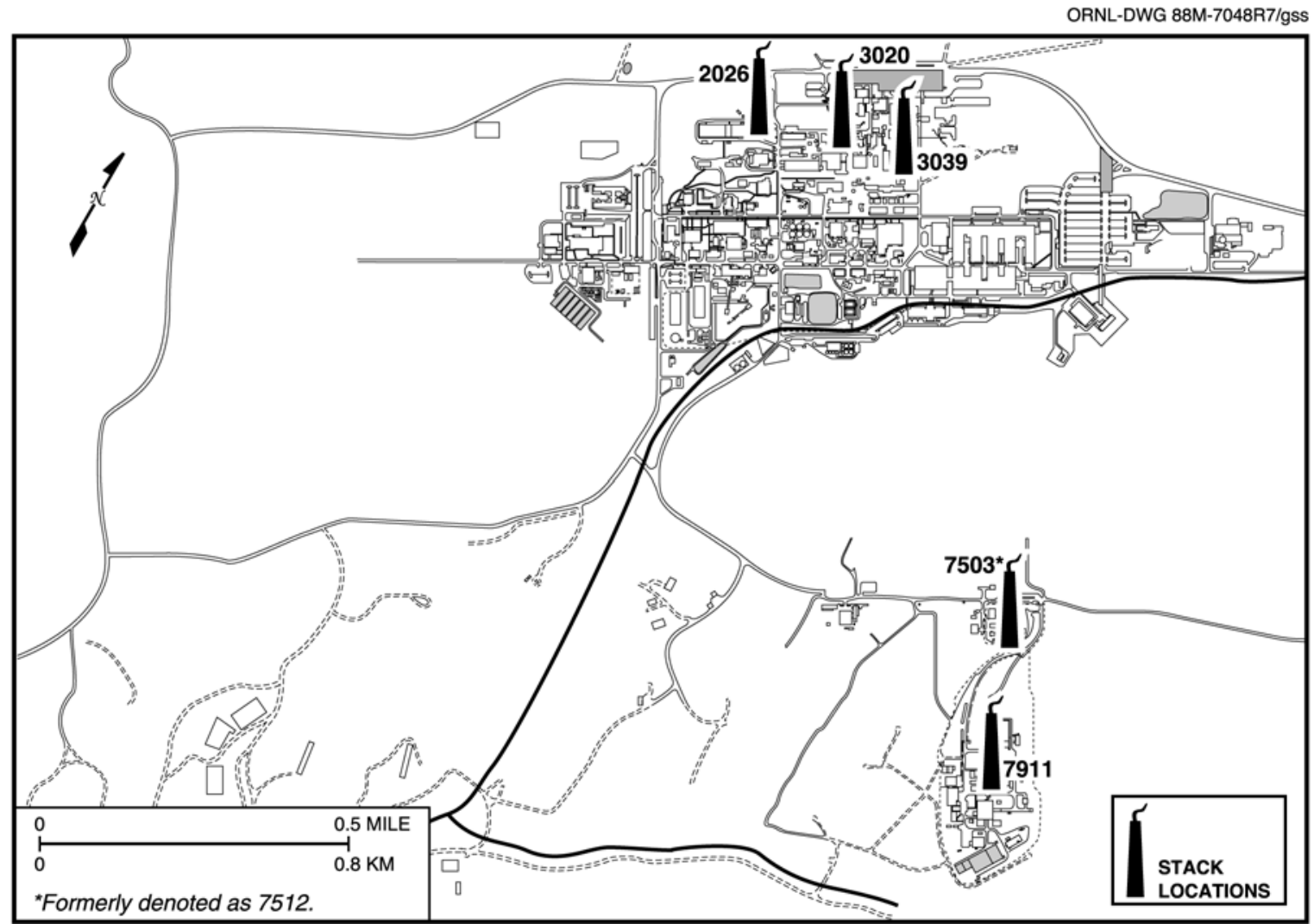

Fig. 5.1. Locations of major stacks (rad emission points) at ORNL.

that is located in or vents from a radiological control area as defined by Radiological Support Services of the ORNL Operational Safety Services Division. A variety of methods are used to determine the emissions from the various minor sources. Methods used for minor source emission calculations comply with criteria agreed upon by EPA. These minor sources are evaluated on a 1- to 5 -year basis. Emissions, both major and minor, are compiled annually to determine the overall ORNL source term and associated dose.

The charcoal cartridges, particulate filters, and silica-gel traps are collected weekly to biweekly. The use of charcoal cartridges is a standard method for capturing and quantifying radioactive iodines in airborne emissions. Gamma spectrometric analysis of the charcoal samples quantifies the adsorbable gases. Analysis is performed weekly to biweekly. Particulate filters are held for 8 days prior to a weekly gross alpha and gross beta analysis to minimize the contribution from short-lived isotopes such as ${ }^{220} \mathrm{Rn}$ and its daughter products. At Stack 7911, a weekly gamma scan is conducted to better detect shortlived gamma isotopes. The weekly to biweekly filters are then composited quarterly and are analyzed for alpha-, beta-, and gamma-emitting isotopes. Compositing provides a better opportunity for quantification of these low-concentration isotopes. Silica-gel traps are used to capture tritium water vapor. Analysis is performed weekly to biweekly. At the end of the year, each sample probe is rinsed, and the rinsate is collected and submitted for isotopic analysis identical to that of the particulate filter. The data from the charcoal cartridges, silica gel, probe wash, and the quarterly filter composites are compiled to give the annual emissions for each major source and some minor sources.

\subsubsection{Results}

Annual radioactive airborne emissions for ORNL major sources in 2003 are presented in Table 5.1. All data presented were determined to be statistically different from zero at the $95 \%$ confidence level. Any number not statistically different from zero was not included in the emission calculation. Because measuring a radio- 
Table 5.1. Major sources of radiological airborne emissions at Oak Ridge National Laboratory, 2003 (Ci)

\begin{tabular}{|c|c|c|c|c|c|}
\hline \multirow{2}{*}{ Isotope } & \multicolumn{5}{|c|}{ Stack } \\
\hline & X-2026 & X-3020 & X-3039 & $X-7503^{b}$ & X-7911 \\
\hline${ }^{241} \mathrm{Am}$ & $2.84 \mathrm{E}-07$ & $2.19 \mathrm{E}-04$ & $1.76 \mathrm{E}-07$ & $1.76 \mathrm{E}-06$ & $9.45 \mathrm{E}-06$ \\
\hline${ }^{41} \mathrm{Ar}$ & & & & & $2.31 \mathrm{E}+03$ \\
\hline${ }^{139} \mathrm{Ba}$ & & & & & $1.44 \mathrm{E}+00$ \\
\hline${ }^{140} \mathrm{Ba}$ & & & $3.41 \mathrm{E}-06$ & & $2.90 \mathrm{E}-04$ \\
\hline${ }^{7} \mathrm{Be}$ & 8.69E-07 & $1.76 \mathrm{E}-07$ & $9.46 \mathrm{E}-06$ & $1.03 \mathrm{E}-07$ & \\
\hline${ }^{252} \mathrm{Cf}$ & & & & & 2.01E-08 \\
\hline${ }^{244} \mathrm{Cm}$ & $2.91 \mathrm{E}-06$ & $1.84 \mathrm{E}-05$ & $5.85 \mathrm{E}-08$ & $1.49 \mathrm{E}-05$ & 7.71E-05 \\
\hline${ }^{60} \mathrm{Co}$ & & & $9.63 \mathrm{E}-06$ & $4.48 \mathrm{E}-08$ & \\
\hline${ }^{137} \mathrm{Cs}$ & $1.01 \mathrm{E}-05$ & $1.26 \mathrm{E}-03$ & $6.39 \mathrm{E}-05$ & $1.75 \mathrm{E}-05$ & 7.10E-03 \\
\hline${ }^{138} \mathrm{Cs}$ & & & & & $2.81 \mathrm{E}+03$ \\
\hline${ }^{152} \mathrm{Eu}$ & & & $1.50 \mathrm{E}-06$ & & \\
\hline${ }^{3} \mathrm{H}$ & $9.45 \mathrm{E}-02$ & & $1.30 \mathrm{E}+01$ & $2.36 \mathrm{E}+00$ & $8.71 \mathrm{E}+01$ \\
\hline${ }^{130} \mathrm{I}$ & & & & & $1.34 \mathrm{E}-10$ \\
\hline${ }^{131} \mathrm{I}$ & & & $3.85 \mathrm{E}-05$ & & $5.92 \mathrm{E}-02$ \\
\hline${ }^{132} \mathrm{I}$ & & & & & $6.98 \mathrm{E}-01$ \\
\hline${ }^{133} \mathrm{I}$ & & & $5.58 \mathrm{E}-04$ & & $3.04 \mathrm{E}-01$ \\
\hline${ }^{134} \mathrm{I}$ & & & & & $9.26 \mathrm{E}-01$ \\
\hline${ }^{135} \mathrm{I}$ & & & & & $9.18 \mathrm{E}-01$ \\
\hline${ }^{85} \mathrm{Kr}$ & & & & & $8.58 \mathrm{E}+02$ \\
\hline${ }^{85 m} \mathrm{Kr}$ & & & & & $3.77 \mathrm{E}+01$ \\
\hline${ }^{87} \mathrm{Kr}$ & & & & & $1.42 \mathrm{E}+02$ \\
\hline${ }^{88} \mathrm{Kr}$ & & & & & $1.06 \mathrm{E}+02$ \\
\hline${ }^{89} \mathrm{Kr}$ & & & & & $6.65 \mathrm{E}+01$ \\
\hline${ }^{140} \mathrm{La}$ & & & & & $1.92 \mathrm{E}-04$ \\
\hline${ }^{191}$ Os & & & $3.10 \mathrm{E}+00$ & & $1.57 \mathrm{E}-05$ \\
\hline${ }^{212} \mathrm{~Pb}$ & $6.38 \mathrm{E}-01$ & $1.54 \mathrm{E}-01$ & $1.18 \mathrm{E}+00$ & $1.06 \mathrm{E}-01$ & 7.64E-02 \\
\hline${ }^{238} \mathrm{Pu}$ & $1.24 \mathrm{E}-07$ & $1.26 \mathrm{E}-04$ & $1.85 \mathrm{E}-08$ & $9.66 \mathrm{E}-07$ & 2.31E-09 \\
\hline${ }^{239} \mathrm{Pu}$ & 4.07E-07 & 2.33E-04 & $6.52 \mathrm{E}-07$ & $3.16 \mathrm{E}-06$ & $1.61 \mathrm{E}-06$ \\
\hline${ }^{75} \mathrm{Se}$ & & & $3.34 \mathrm{E}-05$ & & \\
\hline${ }^{90} \mathrm{Sr}$ & $1.31 \mathrm{E}-06$ & $1.21 \mathrm{E}-03$ & 7.32E-05 & 7.03E-06 & $1.50 \mathrm{E}-03$ \\
\hline${ }^{228} \mathrm{Th}$ & $1.51 \mathrm{E}-08$ & $2.03 \mathrm{E}-06$ & $1.34 \mathrm{E}-08$ & $5.28 \mathrm{E}-07$ & $1.32 \mathrm{E}-08$ \\
\hline${ }^{230} \mathrm{Th}$ & $3.71 \mathrm{E}-09$ & $1.68 \mathrm{E}-06$ & $1.74 \mathrm{E}-08$ & $9.35 \mathrm{E}-10$ & $1.09 \mathrm{E}-08$ \\
\hline${ }^{232} \mathrm{Th}$ & $2.54 \mathrm{E}-09$ & $1.38 \mathrm{E}-06$ & $1.84 \mathrm{E}-08$ & $9.33 \mathrm{E}-10$ & $1.10 \mathrm{E}-08$ \\
\hline${ }^{234} \mathrm{U}$ & $4.38 \mathrm{E}-07$ & $9.09 \mathrm{E}-05$ & $1.20 \mathrm{E}-07$ & $4.75 \mathrm{E}-06$ & $1.34 \mathrm{E}-05$ \\
\hline${ }^{235} \mathrm{U}$ & $1.18 \mathrm{E}-08$ & 8.39E-06 & 2.03E-08 & 5.97E-07 & $3.94 \mathrm{E}-06$ \\
\hline${ }^{238} \mathrm{U}$ & $1.63 \mathrm{E}-08$ & $5.59 \mathrm{E}-06$ & 4.37E-08 & $5.45 \mathrm{E}-07$ & $3.32 \mathrm{E}-06$ \\
\hline${ }^{131 m} \mathrm{Xe}$ & & & & & $1.64 \mathrm{E}+02$ \\
\hline${ }^{133} \mathrm{Xe}$ & & & & & $1.64 \mathrm{E}+02$ \\
\hline${ }^{133 m} \mathrm{Xe}$ & $3.97 \mathrm{E}-05$ & & & & $1.80 \mathrm{E}+01$ \\
\hline${ }^{135} \mathrm{Xe}$ & & & $3.17 \mathrm{E}-05$ & & $1.25 \mathrm{E}+02$ \\
\hline${ }^{135 m} \mathrm{Xe}$ & & & & & $7.17 \mathrm{E}+01$ \\
\hline${ }^{137} \mathrm{Xe}$ & & & & & $2.61 \mathrm{E}+02$ \\
\hline${ }^{138} \mathrm{Xe}$ & & & & & $4.04 \mathrm{E}+02$ \\
\hline${ }^{90} \mathrm{Y}$ & $1.31 \mathrm{E}-06$ & & 7.32E-05 & & $1.50 \mathrm{E}-03$ \\
\hline
\end{tabular}


nuclide requires a process of counting random radioactive emissions from a sample, the same result may not be obtained if the sample is analyzed repeatedly. This deviation is referred to as the "counting uncertainty." Statistical significance at the $95 \%$ confidence level means that there is a $5 \%$ chance that the results could be in error. Historical trends for ${ }^{3} \mathrm{H}$ and ${ }^{131} \mathrm{I}$ are presented in Figs. 5.2 and 5.3, respectively.

The ${ }^{3} \mathrm{H}$ emissions for 2003 totaled approximately $104 \mathrm{Ci}$ (Fig. 5.2), which is an increase from 2002, but consistent with emissions from 1999 and 2000. The ${ }^{131}$ I emissions for 2003 decreased from that for 2002 to $0.06 \mathrm{Ci}$ (Fig. 5.3). The major contributor to the off-site dose at ORNL historically is ${ }^{41} \mathrm{Ar}$, which is emitted as a nonadsorbable gas from the HFIR facility stack (7911). However, due to a long maintenance period in $2001,{ }^{138} \mathrm{Cs}$, also emitted from 7911 , has remained the major contributor to the off-site dose since 2001. The ${ }^{138} \mathrm{Cs}$ emissions for 2003 were 2,810 Ci (Fig. 5.4).

\subsection{ORNL NONRADIOLOGICAL AIRBORNE EMISSIONS MONITORING}

ORNL holds a total of 12 TDEC air permits, including 11 operating permits and 1 construction permit (see Appendix E, Table E.2). The ORNL Steam Plant (six boilers) and four small packageunit boilers account for $75 \%$ of ORNL's allowable emissions. The ORNL steam plant is subject to permitting requirements for fuel monitoring and hourly and annual emissions limits for criteria pollutants. In addition Boiler 6, a $125-\mathrm{MBtu} / \mathrm{h}$ boiler, is subject to $40 \mathrm{CFR} 60$ Subpart $\mathrm{Db}$ continuous emission monitoring requirements for NOx and opacity. During CY 2003, no exceedances of any permit limits occurred.

During CY 2003 ORNL and TDEC negotiated a new operating permit for the ORNL Steam Plant that combined the six fossil-fuel-fired boilers under one operating permit. The new permit applies federally enforceable limits for sulfur dioxide and particulate emissions from the steam plant and applies a federally enforceable

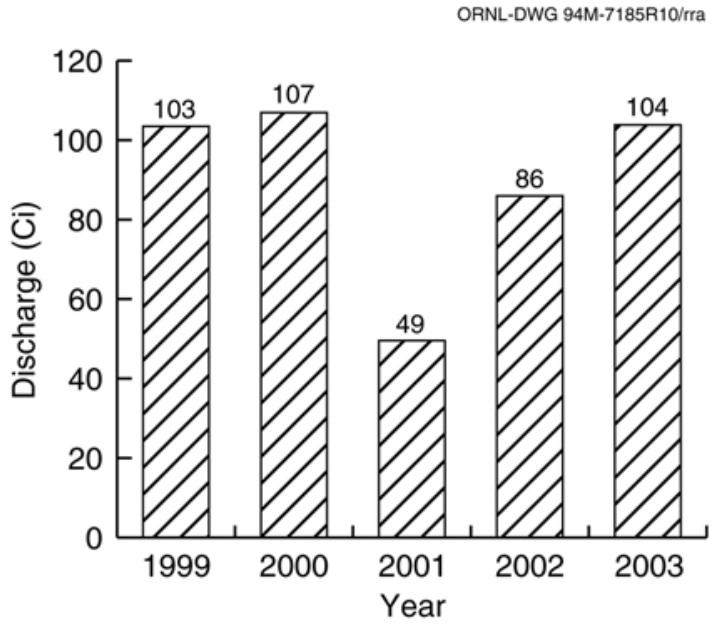

Fig. 5.2. Total discharges of ${ }^{3} \mathrm{H}$ from ORNL to the atmosphere, 1999-2003.

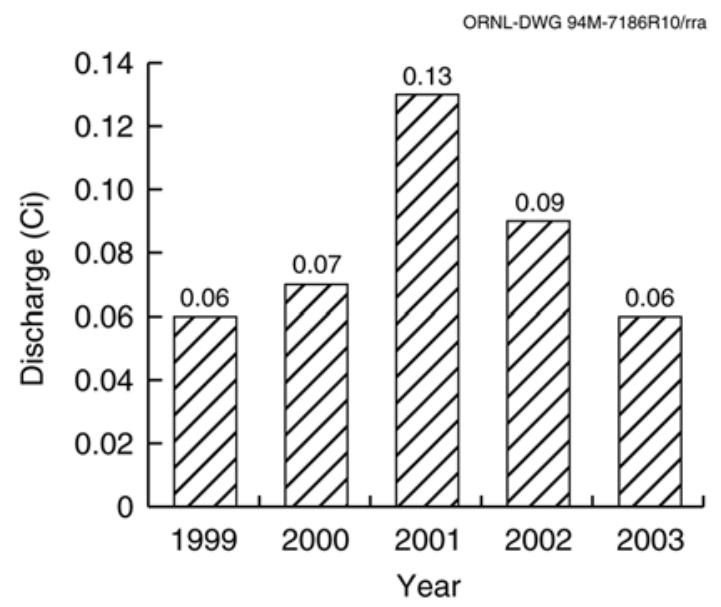

Fig. 5.3. Total discharges of ${ }^{131} \mathrm{I}$ from ORNL to the atmosphere, 1999-2003.

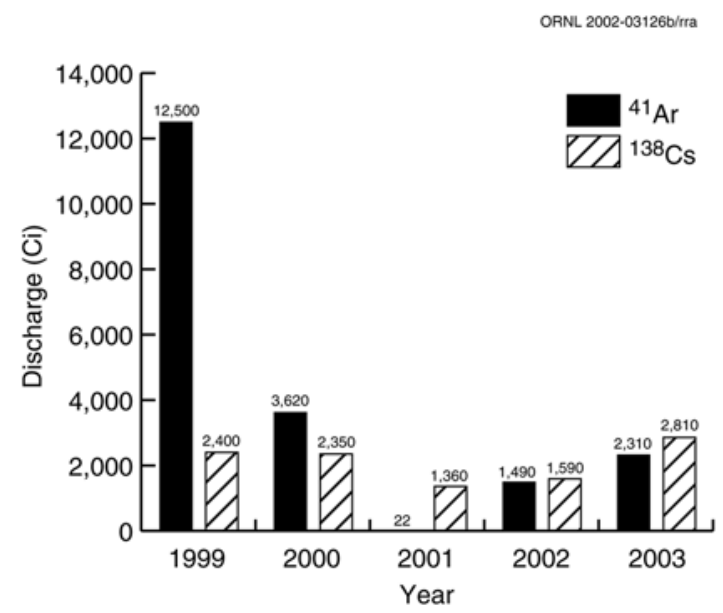

Fig. 5.4. Total discharges of ${ }^{41} \mathrm{Ar}$ and ${ }^{138} \mathrm{Cs}$ from ORNL to the atmosphere, 1999-2003. 
limit on hazardous air pollutant emissions. The limits will reduce annual emission fees and will ensure that hazardous air pollutant emissions are below the major source threshold as defined in 40 CFR 63, "National Emissions Standards for Hazardous Air Pollutants for Source Categories." ORNL could accept these emission limits because emissions have been reduced with the elimination of coal as a fuel. Only natural gas and fuel oil are now used.

For the period from July 1, 2002, through June 30, 2003, ORNL paid $\$ 35,934.50$ in annual emission fees to TDEC. These fees are based on allowable emissions (actual emissions are lower than allowable emissions). During 2003, TDEC and EPA inspected all permitted emissions sources; all were found to be in compliance.

ORNL's Clean Air Act (CAA) Title V Permit application was submitted to TDEC on May 5, 1997. In a letter dated June 5, 1997, TDEC indicated that the application was complete and that ORNL met the requirement to submit an application. ORNL will continue to operate with existing permits until the Title $\mathrm{V}$ permit is issued. TDEC anticipated that ORNL's Title V permit will be issued in 2004 .

As required by Title VI of the CAA Amendments of 1990, actions have been implemented to comply with the prohibition against releasing ozone-depleting substances during maintenance activities performed on refrigeration equipment. In addition, service requirements for refrigeration systems (including motor vehicle air conditioners), technician certification requirements, and labeling requirements have been implemented. ORNL has implemented a plan to phase out the use of all Class I ozone-depleting substances. All critical applications of Class Iozone-depleting substances have been eliminated, replaced, or retrofitted with other materials. Work is progressing as funding becomes available for noncritical applications with no disruption of service.

\subsubsection{Results}

The primary sources of nonradioactive emissions at ORNL include the steam plant, boilers $1-6$ on the main ORNL site, two boilers located at the 7600 complex, and two boilers located at the SNS site. These units use fossil fuels; therefore, criteria pollutants are emitted. Actual and allowable emissions from these sources are compared in Table 5.2. Actual emissions were calculated from fuel usage and EPA emission factors. All ORNL emission sources operated in compliance with permit conditions during 2003.

\subsection{ORNL AMBIENT AIR MONITORING}

The objectives of the ORNL ambient air monitoring program are to collect samples at perimeter air monitoring (PAM) stations most likely to show impacts of airborne emissions from the operation of ORNL and to provide for emergency response capability. Four stations, identified as Stations 1, 2, 3, and 7 (Fig. 5.5), make up the ORNL PAM network. Sampling is conducted at each ORNL station to quantify levels of ${ }^{3} \mathrm{H}$; adsorbable gases (e.g., iodine); and gross alpha-, beta-, and gamma-emitting radionuclides (Table 5.3).

The sampling system consists of a lowvolume air sampler for particulate collection in a 47-mm glass-fiber filter. The filters are collected biweekly, composited annually, then submitted to the laboratory for analysis. Following the filter is a charcoal cartridge used to collect adsorbable gases (e.g., iodine). The charcoal cartridges are analyzed biweekly by gamma spectroscopy for adsorbable gas quantification. A silica-gel column is used for collection of ${ }^{3} \mathrm{H}$ as tritiated water. These samples are collected biweekly or weekly. The silica gel from each station is composited each quarter and is then submitted to the laboratory for ${ }^{3} \mathrm{H}$ analysis.

\subsubsection{Results}

The ORNL PAM stations are designed to provide data for collectively assessing the specific impact of ORNL operations on local air quality. Sampling data from the ORNL PAM stations (Table 5.3) are compared with the DCGs for air and water established by DOE as reference values for conducting radiological environmental pro- 
Table 5.2. Actual vs allowable air emissions from Oak Ridge National Laboratory steam production, 2003

\begin{tabular}{lccc}
\hline \multirow{2}{*}{ Pollutant } & \multicolumn{2}{c}{$\begin{array}{c}\text { Emissions } \\
\text { (tons/year) }\end{array}$} & $\begin{array}{c}\text { Percentage of } \\
\text { allowable }\end{array}$ \\
\cline { 2 - 3 } & Actual & Allowable & \\
\hline Sulfur dioxide & 13 & 1277 & 1.0 \\
Particulate & 3 & 71 & 4.4 \\
Carbon monoxide & 31 & 196 & 16.0 \\
Volatile organic compounds & 2 & 14 & 15.0 \\
Nitrogen oxides & 65 & 380 & 17.2 \\
\hline
\end{tabular}

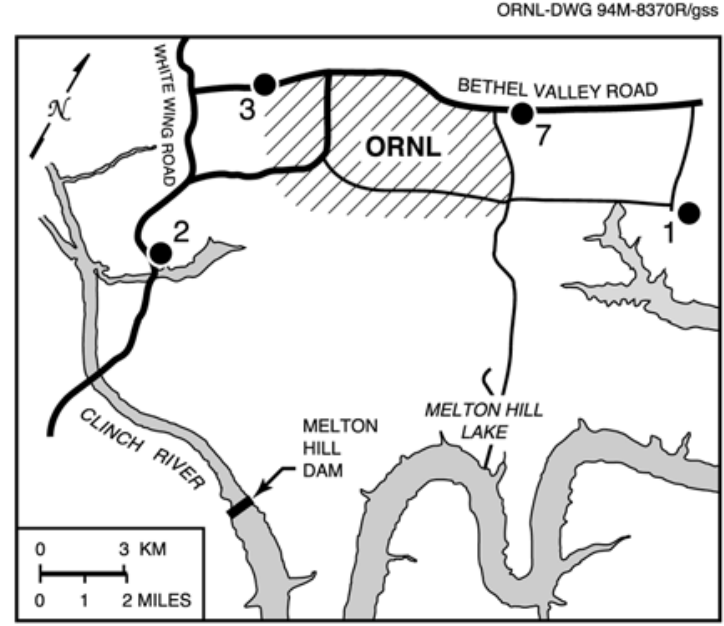

Fig. 5.5. Locations of ambient air monitoring stations at ORNL.

Table 5.3. Radionuclide concentrations measured at Oak Ridge National Laboratory perimeter air monitoring stations, $2003(\mathrm{pCi} / \mathrm{mL})$

\begin{tabular}{lcc|cc}
\hline & \multicolumn{5}{c}{ Station } \\
\cline { 2 - 5 } \multicolumn{1}{c}{ Parameter } & \multicolumn{3}{c}{1} & \multicolumn{2}{c}{2} \\
\cline { 2 - 5 } & Av. concen. & No. detected/total & Av. concen. & No. detected/total \\
\hline${ }^{7} \mathrm{Be}$ & $1.26 \mathrm{E}-08$ & $1 / 1$ & $1.11 \mathrm{E}-08$ & $1 / 1$ \\
${ }^{3} \mathrm{H}$ & $-2.14 \mathrm{E}-06$ & $0 / 4$ & $4.54 \mathrm{E}-05$ & $4 / 4$ \\
${ }^{40} \mathrm{~K}$ & $2.56 \mathrm{E}-07$ & $9 / 23$ & $2.84 \mathrm{E}-07$ & $14 / 23$ \\
${ }^{234} \mathrm{U}$ & $6.97 \mathrm{E}-12$ & $1 / 1$ & $5.90 \mathrm{E}-12$ & $1 / 1$ \\
${ }^{235} \mathrm{U}$ & $8.69 \mathrm{E}-13$ & $0 / 1$ & $4.84 \mathrm{E}-13$ & $0 / 1$ \\
${ }^{238} \mathrm{U}$ & $5.23 \mathrm{E}-12$ & $1 / 1$ & $5.27 \mathrm{E}-12$ & $1 / 1$ \\
\hline & & 3 & & 7 \\
\multicolumn{1}{c}{ Parameter } & Av. concen. & No. detected/total & Av. concen. & No. detected/total \\
\hline${ }^{7} \mathrm{Be}$ & $1.49 \mathrm{E}-08$ & $1 / 1$ & $1.25 \mathrm{E}-08$ & $1 / 1$ \\
${ }^{3} \mathrm{H}$ & $9.95 \mathrm{E}-06$ & $0 / 4$ & $2.89 \mathrm{E}-06$ & $0 / 4$ \\
${ }^{40} \mathrm{~K}$ & $2.57 \mathrm{E}-07$ & $11 / 23$ & $2.82 \mathrm{E}-07$ & $14 / 23$ \\
${ }^{234} \mathrm{U}$ & $1.02 \mathrm{E}-11$ & $1 / 1$ & $6.41 \mathrm{E}-12$ & $1 / 1$ \\
${ }^{235} \mathrm{U}$ & $4.49 \mathrm{E}-13$ & $0 / 1$ & $5.71 \mathrm{E}-13$ & $0 / 1$ \\
${ }^{238} \mathrm{U}$ & $5.70 \mathrm{E}-12$ & $1 / 1$ & $6.38 \mathrm{E}-12$ & $1 / 1$ \\
\hline
\end{tabular}


tection programs at DOE sites. (DCGs are listed in DOE Order 5400.5.) Average radionuclide concentrations measured for the ORNL network were less than $1 \%$ of the applicable DCG in all cases.

\subsection{LIQUID DISCHARGES- ORNL RADIOLOGICAL MONITORING SUMMARY}

ORNL monitors radioactivity at National Pollutant Discharge Elimination System (NPDES) outfalls that have a potential to discharge radioactivity and at three instream monitoring stations under a radiological monitoring plan that is required by Part III, Section J, of the ORNL NPDES permit. The current version of the plan was implemented on November 1, 1999. Table 5.4 contains the details of the locations, frequency, and target analyses for monitoring of dry-weather discharges and instream monitoring locations. Monitoring of radioactivity in effluents occurs at three ORNL treatment facilities: the Sewage Treatment Plant, the Coal Yard Runoff Treatment Facility, and the Process Waste Treatment Complex. Other effluents monitored in 2003 included 23 category discharges, which are relatively minor discharges that receive little or no treatment prior to discharge. Wastewaters discharged through category outfalls are primarily storm water runoff, cooling water, groundwater, and steam condensate. Some category outfalls listed in Table 5.4 were not sampled in 2003, either because they are no longer in service or because they were not discharging or were otherwise unsamplable during sampling attempts. The three instream locations monitored under the Radiological Monitoring Plan are X13 on Melton Branch, X14 on White Oak Creek, and X15 at White Oak Dam (Fig. 5.6).

The DOE Derived Concentration Guide (DCG) values are used in this section as a means of standardized comparison for effluent points with different radioisotope signatures. Annual average concentrations were compared to DCG concentrations if a DCG existed (there are no DCGs for gross alpha and gross beta activities) and if the average concentration was significantly greater than zero at the $95 \%$ confidence level. For analyses that cannot differentiate between two radioisotopes (e.g., ${ }^{89 / 90} \mathrm{Sr}$ ) and for radioisotopes that have more than one DCG for different gastrointestinal tract absorption factors, the most restrictive (lowest) DCG was used in the comparisons. DCGs are not intended for comparison to instream values. However, they are useful as a frame of reference, so instream values were also compared to DCGs. The comparison of effluent and instream concentrations to DCGs for ingestion of water does not imply that effluents from ORNL outfalls or ORNL ambient-watersampling stations are sources of drinking water.

In 2003, no NPDES outfall had measured annual average concentrations of radioactivity equaling or exceeding $100 \%$ of DCG concentrations. (As required by DOE Order 5400.5 , where more than one radionuclide was detected at an outfall, the DCG percentages of the individually measured radionuclides were summed and the sum of percentages was compared with 100\%.) Annual average concentration of at least one radionuclide exceeded $4 \%$ of the relevant DCG concentration at five NPDES outfalls (X01, X12, 086, 302, and 304 ) and at instream sampling locations X13, $\mathrm{X} 14$, and X15 (Figure 5.7). Four percent of the DCG is roughly equivalent to the 4-mrem dose limit on which the EPA radionuclide drinking water standards are based (4\% of a DCG is a convenient comparison point; but it should not be concluded that ORNL effluents or ambient waters are direct sources of drinking water). The annual average concentration of ${ }^{89 / 90} \mathrm{Sr}$ in the ORNL Sewage Treatment Plant discharge (Outfall X01) was $14 \%$ of the DCG. Concentrations of four radionuclides measured in the discharge from the Process Waste Treatment Complex (Outfall X12) were greater than $4 \%$ of the DCG: ${ }^{137} \mathrm{Cs}(13 \%)$, ${ }^{89 / 90} \mathrm{Sr}(10 \%),{ }^{233 / 234} \mathrm{U}(5.6 \%)$, and ${ }^{3} \mathrm{H}(5.5 \%)$. Three category outfalls had measured concentrations of a parameter that was greater than $4 \%$ of a DCG: Outfall $086\left({ }^{3} \mathrm{H}, 6.8 \%\right)$, Outfall $302\left({ }^{89 / 90} \mathrm{Sr}, 5.4 \%\right)$ and Outfall $304\left({ }^{89 / 90} \mathrm{Sr}, 16 \%\right)$. At the instream monitoring station on Melton Branch (Location $\mathrm{X} 13),{ }^{3} \mathrm{H}$ and ${ }^{89 / 90} \mathrm{Sr}$ were measured at concentrations exceeding $4 \%$ of the DCG (18\% and 29\%, respectively). At Monitoring Station $\mathrm{X} 14$ on White Oak Creek, ${ }^{89 / 90} \mathrm{Sr}$ was measured at $4.8 \%$ of the DCG. At the X15 monitoring station 
Table 5.4. Oak Ridge National Laboratory NPDES Radiological Monitoring Plan

\begin{tabular}{|c|c|c|c|c|c|c|c|}
\hline Location & Frequency & $\begin{array}{l}\text { Gross } \\
\text { alpha }^{a}\end{array}$ & $\begin{array}{l}\text { Gross } \\
\text { beta }^{a}\end{array}$ & $\begin{array}{c}\text { Gamma } \\
\text { scan }\end{array}$ & Tritium & $\begin{array}{l}\text { Total } \\
\operatorname{rad~Sr}\end{array}$ & $\begin{array}{l}\text { Isotopic } \\
\text { uranium }\end{array}$ \\
\hline Outfall 001 & Annually & $\mathrm{X}$ & & & & & \\
\hline Outfall 080 & Monthly & $\mathrm{X}$ & $\mathrm{X}$ & $\mathrm{X}$ & $\mathrm{X}$ & $\mathrm{X}$ & \\
\hline Outfall 081 & Annually & & $\mathrm{X}$ & & & & \\
\hline Outfall 085 & Quarterly & $\mathrm{X}$ & $\mathrm{X}$ & & & & \\
\hline Outfall 086 & When discharges & & $\mathrm{X}$ & & $\mathrm{X}$ & & \\
\hline Outfall 087 & Annually & & $\mathrm{X}$ & $\mathrm{X}$ & & & \\
\hline Outfall 203 & Annually & & $\mathrm{X}$ & & & & \\
\hline Outfall 204 & Quarterly & $\mathrm{X}$ & $X$ & & & $\mathrm{X}$ & \\
\hline Outfall 205 & Annually & & $\mathrm{X}$ & & & & \\
\hline Outfall 207 & Quarterly & $\mathrm{X}$ & $\mathrm{X}$ & $\mathrm{X}$ & & $\mathrm{X}$ & \\
\hline Outfall 211 & Quarterly & & $\mathrm{X}$ & & & $\mathrm{X}$ & \\
\hline Outfall 217 & Annually & & $\mathrm{X}$ & & & & \\
\hline Outfall 219 & Annually & & $\mathrm{X}$ & & & & \\
\hline Outfall 234 & Annually & $\mathrm{X}$ & & & & & \\
\hline Outfall $241^{b}$ & Annually & & $\mathrm{X}$ & & & & \\
\hline Outfall 265 & Annually & & $\mathrm{X}$ & $\mathrm{X}$ & & & \\
\hline Outfall 281 & Quarterly & $\mathrm{X}$ & $\mathrm{X}$ & $\mathrm{X}$ & $\mathrm{X}$ & & \\
\hline Outfall 282 & Quarterly & $\mathrm{X}$ & $\mathrm{X}$ & & & & \\
\hline Outfall $284^{b}$ & Annually & & $\mathrm{X}$ & & & & \\
\hline Outfall 290 & Annually & & & $\mathrm{X}$ & & & \\
\hline Outfall 302 & Monthly & $\mathrm{X}$ & $\mathrm{X}$ & $X$ & $\mathrm{X}$ & $\mathrm{X}$ & \\
\hline Outfall 304 & Monthly & $\mathrm{X}$ & $\mathrm{X}$ & $\mathrm{X}$ & $\mathrm{X}$ & $\mathrm{X}$ & \\
\hline Outfall 365 & Quarterly & $\mathrm{X}$ & $\mathrm{X}$ & & & & \\
\hline Outfall 368 & Quarterly & $\mathrm{X}$ & $\mathrm{X}$ & $\mathrm{X}$ & & & \\
\hline Outfall 381 & Quarterly & & $\mathrm{X}$ & $X$ & $X$ & & \\
\hline Outfall $382^{c}$ & Annually & & $\mathrm{X}$ & $\mathrm{X}$ & & & \\
\hline Outfall 383 & Annually & & $\mathrm{X}$ & & $\mathrm{X}$ & & \\
\hline Sewage Treatment Plant (X01) & Monthly & $\mathrm{X}$ & $\mathrm{X}$ & & & $\mathrm{X}$ & \\
\hline $\begin{array}{l}\text { Coal Yard Runoff Treatment } \\
\text { Facility (X02) }\end{array}$ & Monthly & $\mathrm{X}$ & $\mathrm{X}$ & & & & \\
\hline $\begin{array}{l}\text { Process Waste Treatment } \\
\text { Complex (X12) }\end{array}$ & Monthly & $\mathrm{X}$ & $\mathrm{X}$ & $\mathrm{X}$ & $\mathrm{X}$ & $\mathrm{X}$ & $\mathrm{X}$ \\
\hline Melton Branch 1 (X13) & Monthly & $\mathrm{X}$ & $\mathrm{X}$ & $\mathrm{X}$ & $\mathrm{X}$ & $\mathrm{X}$ & \\
\hline White Oak Creek (X14) & Monthly & $\mathrm{X}$ & $\mathrm{X}$ & $X$ & $\mathrm{X}$ & $\mathrm{X}$ & \\
\hline White Oak Dam (X15) & Monthly & $\mathrm{X}$ & $\mathrm{X}$ & $\mathrm{X}$ & $\mathrm{X}$ & $\mathrm{X}$ & \\
\hline
\end{tabular}

${ }^{a}$ Isotopic analyses are performed to identify contributors to gross activities when results exceed screening criteria described in the Radiological Monitoring Plan, June 1999.

${ }^{b}$ No discharge present.

${ }^{c}$ No longer discharges (plugged). 


\section{ORNL-DWG 92M-6985R4/gss}

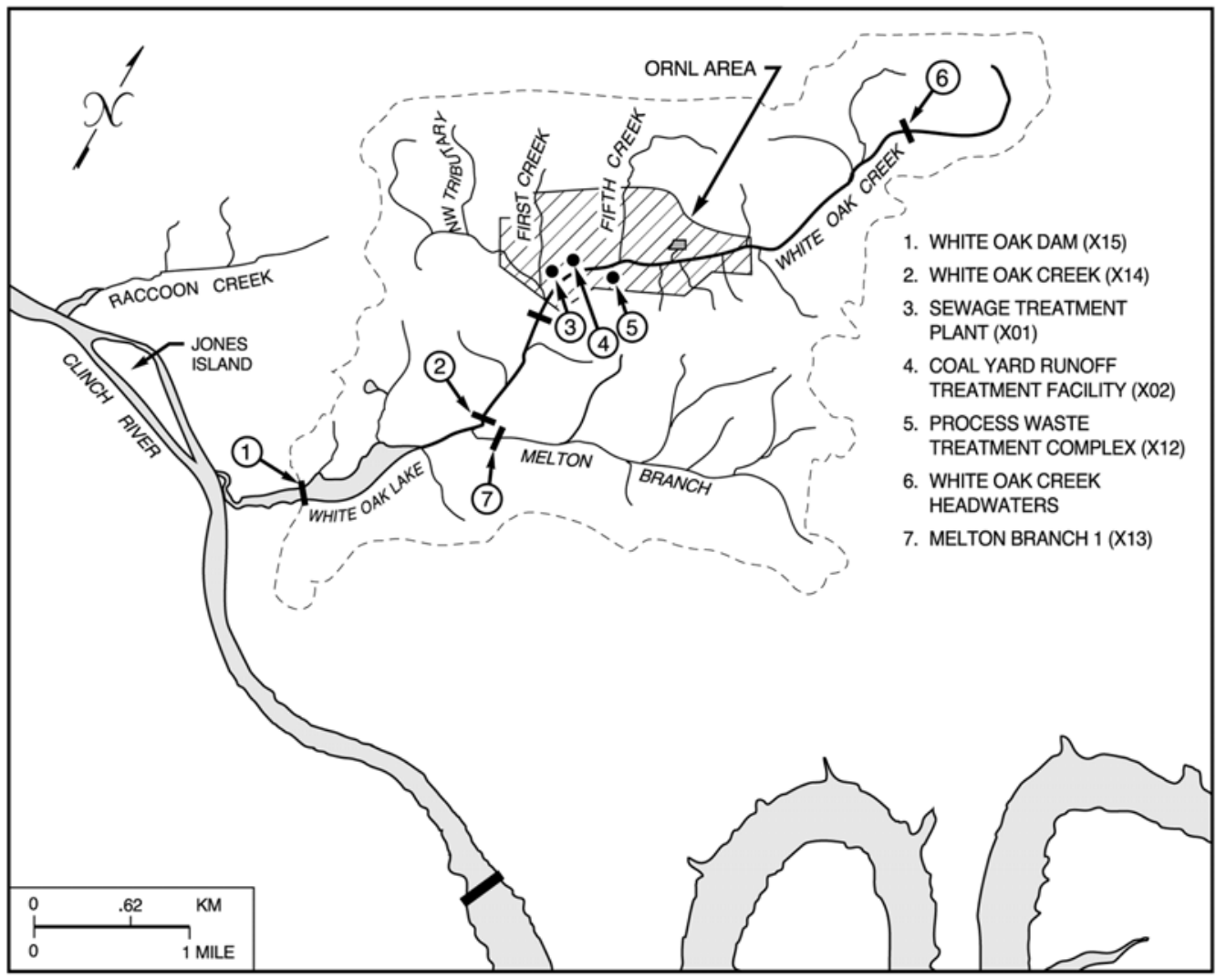

Fig. 5.6. ORNL surface water, National Pollutant Discharge Elimination System, and reference sampling locations.

ORNL-DWG 94M-8673R10/rra

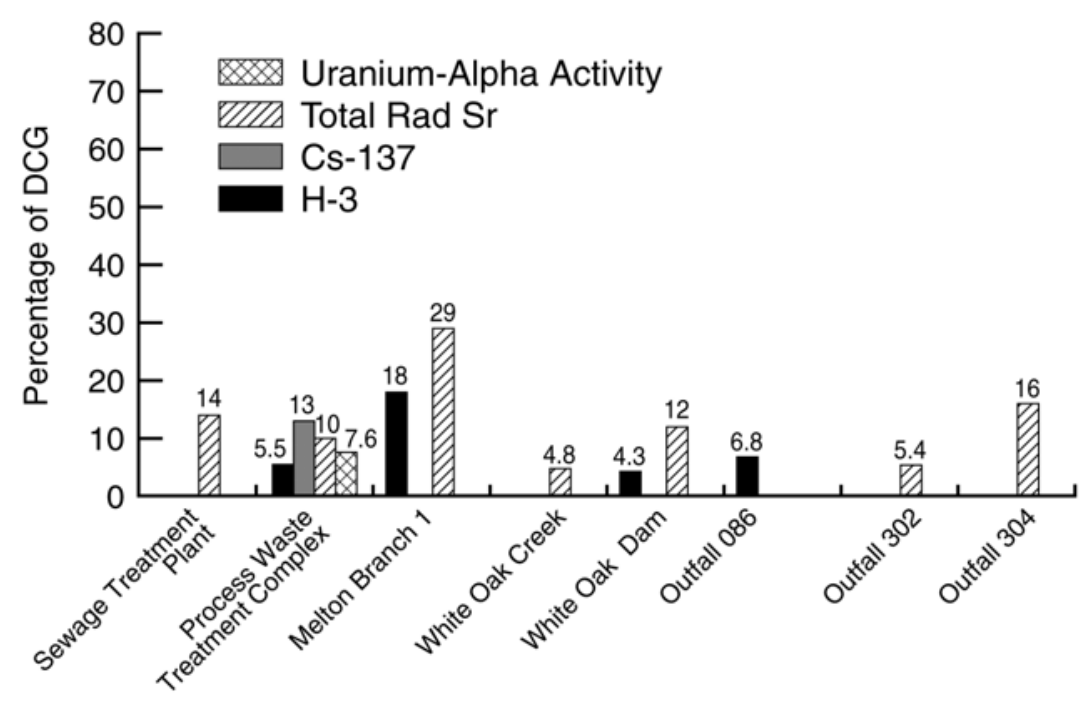

Fig. 5.7. Radionuclides at ORNL sampling sites having average concentrations greater than $4 \%$ of the relevant derived concentration guides in 2003. 
at White Oak Dam, ${ }^{3} \mathrm{H}$ was measured at $4.3 \%$ of the DCG, and ${ }^{89 / 90} \mathrm{Sr}$ was measured at $12 \%$ of the DCG.

The amounts of radioactivity in stream water passing White Oak Dam, the final monitoring point on White Oak Creek before the stream flow leaves ORNL, were calculated from concentration and flow. The total annual discharges (or amounts) of radioactivity released at White Oak Dam during each of the past 5 years are shown in Figs. 5.8 through 5.13. The amounts of radioactivity passing this monitoring station in 2003 were similar to previous years. The elevated level of ${ }^{137} \mathrm{Cs}$ discharge at White Oak Dam that was seen in 2002 (theorized to be caused by disturbances in the White Oak Creek watershed associated with environmental restoration activities) was near normal levels in 2003.

The ORNL Radiological Monitoring Plan also includes monitoring of radioactivity at category outfalls during storm conditions. There were 102 outfalls targeted for periodic storm water sampling when the plan was developed. Since that time, one of those outfalls was physically removed (Outfall 115) and another was plugged (Outfall 382). The storm water outfalls were grouped into eight different categories with the knowledge that outfalls may move from one category to another as storm water data are collected. The storm water categories were defined by the availability of historic data, and when data were available, by the levels of radioactivity detected in past monitoring. The goal set for storm water monitoring in the Radiological Monitoring Plan is to perform monitoring at the rate of 20 outfalls per NPDES permit year (February 3 to February 2). The plan set frequency goals rather than strict requirements because opportunities for storm water sampling are weather dependent.

Monitoring of storm water runoff through NPDES-permitted outfalls for radioactivity is conducted on an NPDES permit-year basis; however, storm water results are discussed on a calendar-year basis in this report. A total of 17 storm water outfalls were monitored in $\mathrm{CY}$ 2003.

When storm water monitoring locations are selected, outfalls are chosen so that various areas of the ORNL site are represented. Storm water samples are analyzed for gross alpha, gross beta, and ${ }^{3} \mathrm{H}$ activities. A gamma scan is also routinely performed. Under the Radiological Monitoring Plan, additional analyses are added when there is enough gross alpha and/or gross beta activity in an outfall's discharges to indicate that DCG levels may be exceeded. In 2003, no storm water discharges required additional analyses.

Of the 85 individual storm water sample results collected in 2003, $62(73 \%)$ were less than the minimum detectable activities of the tests. As was done with non-storm water discharges, storm water discharges were compared to DCGs. Three outfalls had measurements of a radionuclide concentration that was greater than $4 \%$ of DCG levels: Outfall $004\left({ }^{137} \mathrm{Cs}, 6.3 \%\right)$, Outfall $092\left({ }^{3} \mathrm{H}\right.$, $28 \%)$, and Outfall $287\left({ }^{3} \mathrm{H}, 24.5 \%\right)$.

\subsection{ORNL NPDES SUMMARY}

\subsubsection{NPDES Permit Monitoring}

ORNL submitted the application for renewal of NPDES Permit TN0002941 on June 1, 2001, fulfilling the requirement that an application be made six months prior to permit expiration. The December 6, 1996, ORNL NPDES Permit expired in December 2001, and the limits and conditions of that permit remain in effect until renewal by TDEC. Data collected as required by the permit are submitted to the State of Tennessee in the monthly NPDES Discharge Monitoring Report. The 1996 NPDES permit includes 164 separate outfalls and monitoring points.

The ORNL NPDES Permit requires that point-source outfalls be sampled before they are discharged into receiving waters or before they mix with any other wastewater stream (see Fig. 5.6). Under the existing permit, there are numeric and narrative effluent limits applied at the following locations:

- X01-Sewage Treatment Plant;

- X02-Coal Yard Runoff Treatment Facility;

- X12-Process Waste Treatment Complex;

- X13-Melton Branch (MB1);

- X14-White Oak Creek;

- X15-White Oak Dam;

- in-stream chlorine monitoring points (X16-X26);

- $\quad$ steam condensate outfalls;

- groundwater from building foundation drains; 


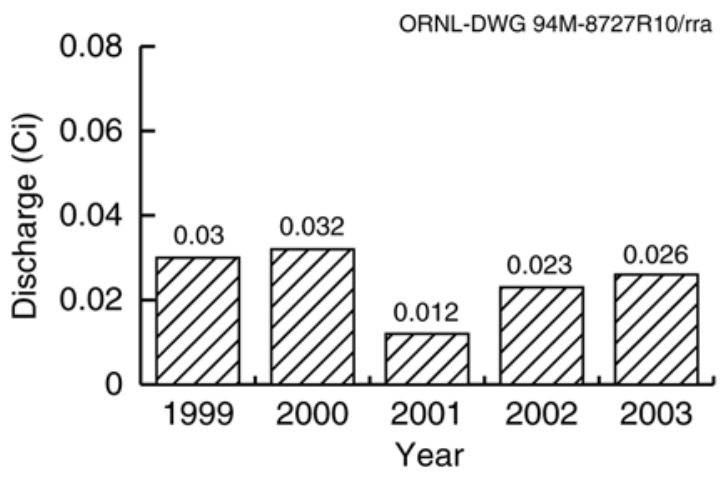

Fig. 5.8. Cobalt-60 discharges at White Oak Dam, 1999-2003.

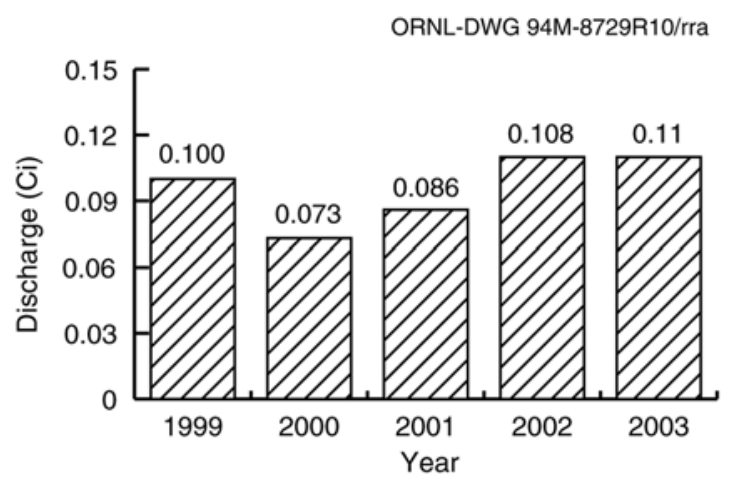

Fig. 5.10. Gross alpha discharges at White Oak Dam, 1999-2003.

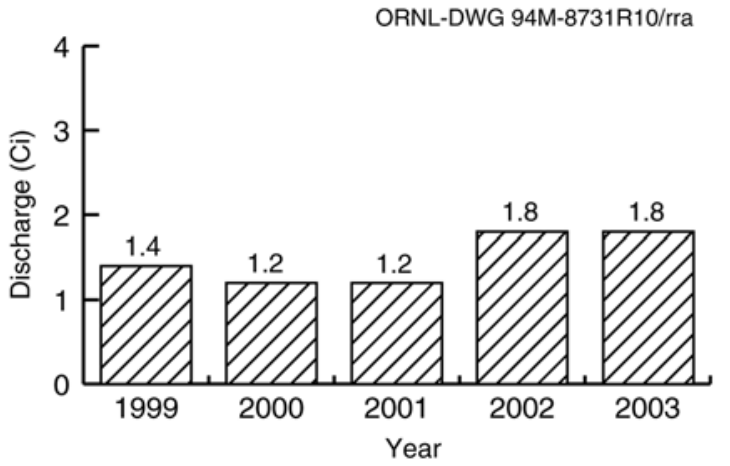

Fig. 5.12. Total radioactive strontium discharges at White Oak Dam, 1999-2003.

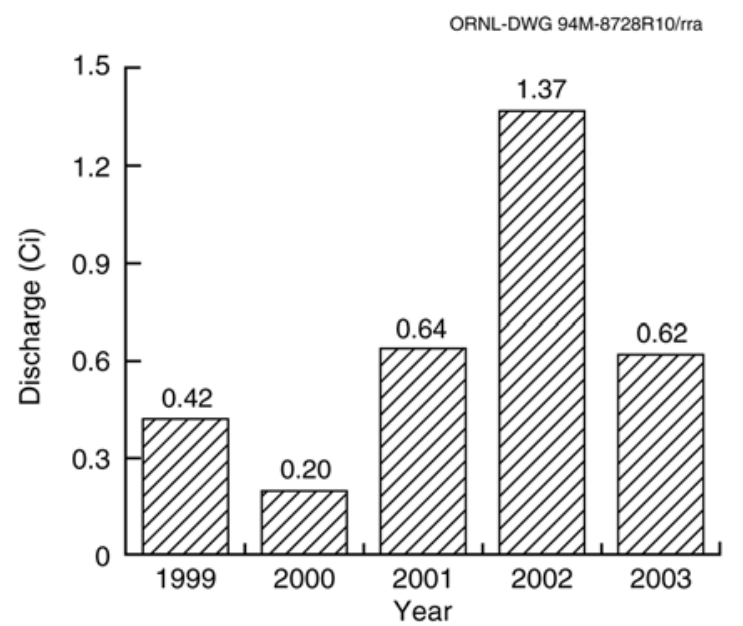

Fig. 5.9. Cesium-137 discharges at White Oak Dam, 1999-2003.

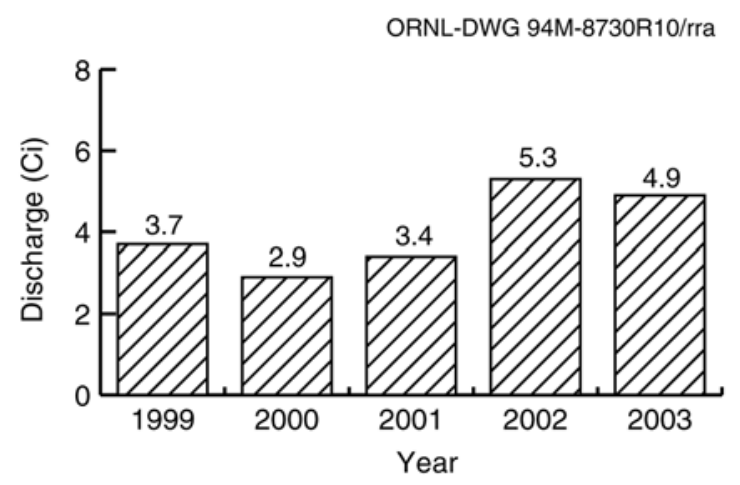

Fig. 5.11. Gross beta discharges at White Oak Dam, 1999-2003.

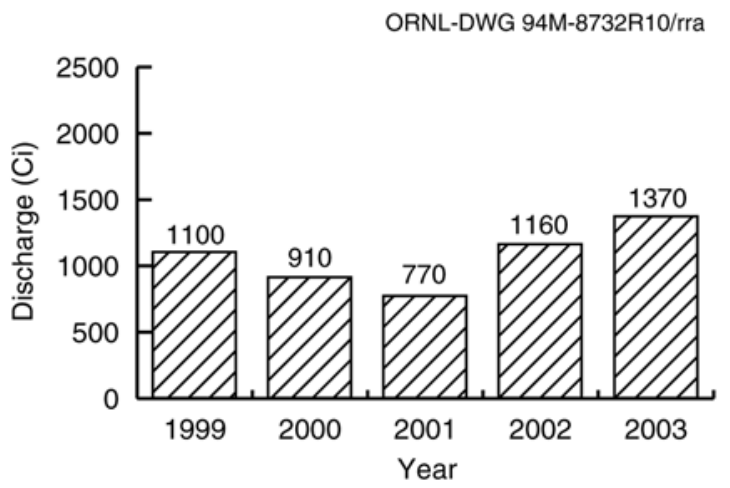

Fig. 5.13. Tritium discharges at White Oak Dam, 1999-2003. 
- Category I outfalls (storm drains, water discharged under best management practices, groundwater, steam, and water condensate);

- Category II outfalls (storm drains, water discharged under best management practices, groundwater, steam, and water condensate);

- Category III outfalls (storm drains, water discharged under best management practices, groundwater, steam, water condensate, cooling water, and cooling tower blowdown);

- Category IV outfalls (storm drains, water discharged under best management practices, groundwater, steam, water condensate, cooling water, and cooling tower blowdown); and

- cooling systems (cooling water and cooling tower blowdown).

Permit limits and compliance statistics are shown in Table 5.5. Instream data collection points X-13, X-14, and X-15 are not included in the table because only flow measurements and narrative conditions are required under the ORNL NPDES Permit at those three points. Permit noncompliances in 2003 are discussed below and are shown in Appendix D.

During 2003, ORNL experienced one instance of noncompliance with numeric NPDES permit limits. Based on approximately 8300 compliance measurements and analyses, the rate of compliance with the ORNL NPDES permit was approximately $99.9 \%$. The instance of nonconformance occurred at the ORNL Sewage Treatment Plant and resulted from a combination of low flow rate and foam accumulation, which are believed to have caused accumulated residue in the compositor and the total suspended solids excursion. During low effluent flow conditions, the water level drops within the transitional effluent chamber to the level of the compositor intake tube, causing any foam that may have accumulated in the chamber to be taken into the compositor. Because it is a vertical drop to the effluent piping, no foam was released from the transitional chamber to White Oak Creek. Tiny solids can be suspended within the foam bubbles. The intake tube has been relocated such that foam will not be taken into the compositor during lowflow conditions. Figure 5.14 shows the number and types of noncompliances at each respective location.
Under the NPDES permit, ORNL conducts several monitoring plans and programs. These include the Radiological Monitoring Plan, the Chlorine Control Strategy, and the Storm Water Pollution Prevention Plan. These are discussed in the following sections.

\subsubsection{Radiological Monitoring Plan}

In 2003, ORNL continued to sample and analyze under the revised Radiological Monitoring Plan implemented on November 1, 1999. Results for the 2003 monitoring are presented in Sect. 5.4.

\subsubsection{Chlorine Control Strategy}

The NPDES permit regulates the discharge of chlorinated water at ORNL by setting either total residual chlorine concentration limits or total residual oxidant mass-loading action levels on outfalls, depending on the outfall's location and the volume of its discharge. At ORNL, total residual oxidant measurements may include both chlorine and bromine residuals. Most outfalls with total residual oxidant mass-loading action levels are monitored semiannually, and the remainder of them are monitored either weekly, semimonthly, or quarterly. A number of outfalls that do not have dry-weather total residual oxidant discharges were dropped from the Chlorine Control Strategy during the duration of the NPDES permit. However, no additional outfalls were dropped in 2002. Outfalls included in the Chlorine Control Strategy have a mass-loading action level for total residual oxidants that requires ORNL to reduce or

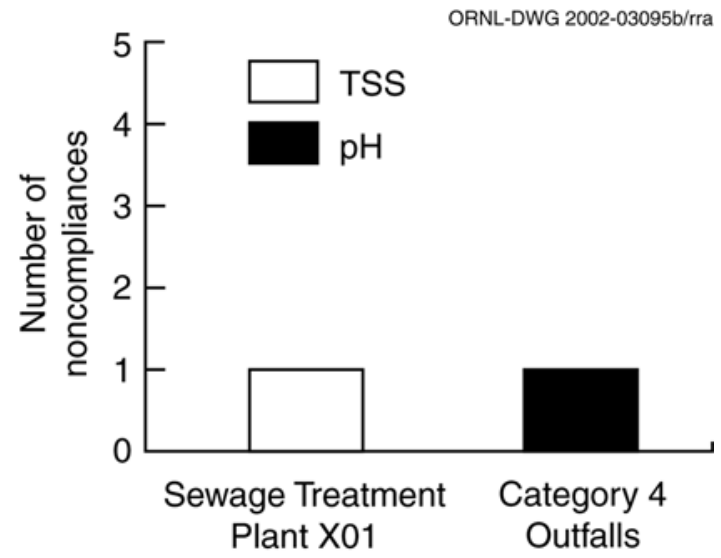

Fig. 5.14. ORNL National Pollutant Discharge Elimination System permit limit noncompliances in 2003. 


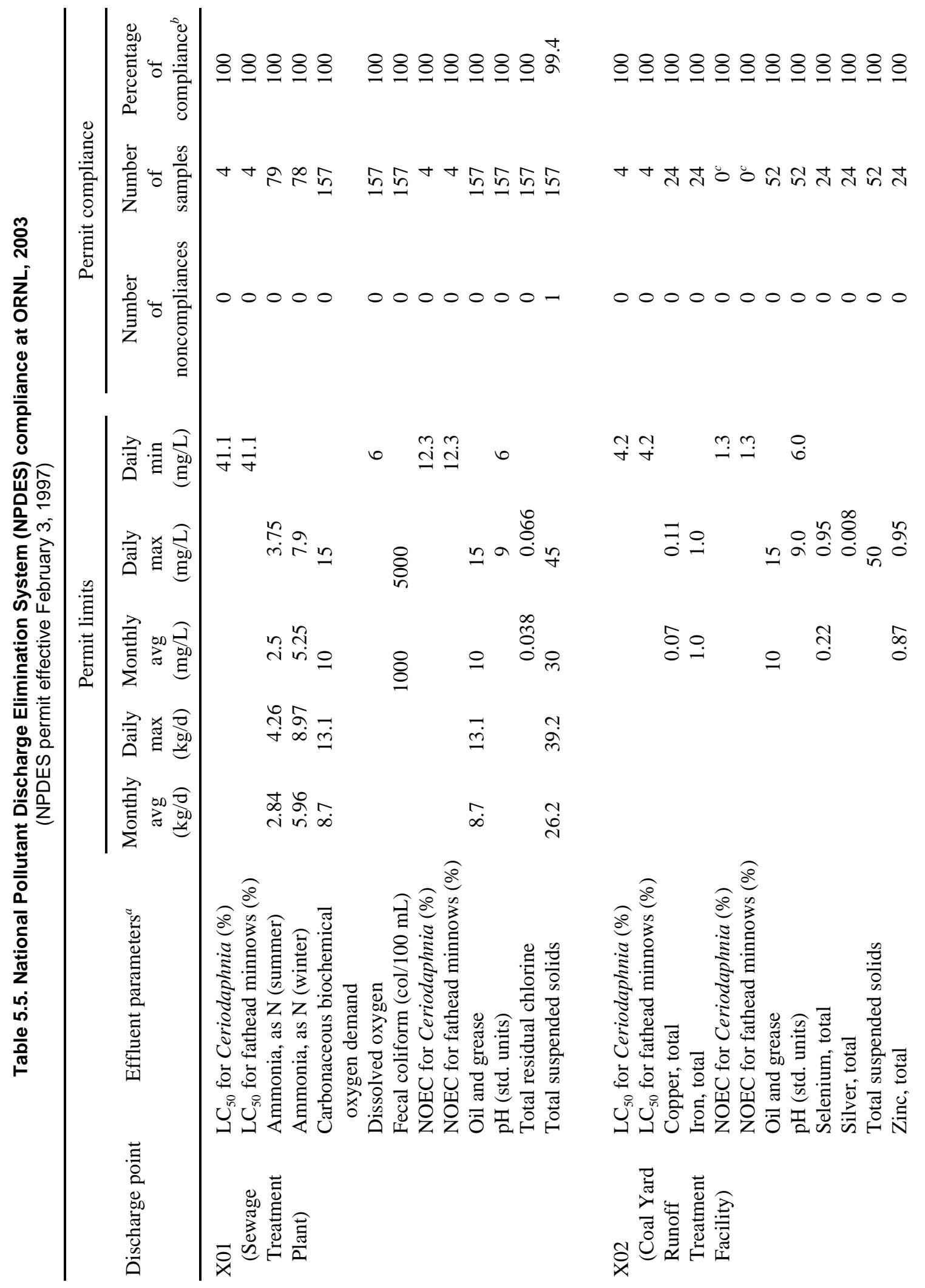




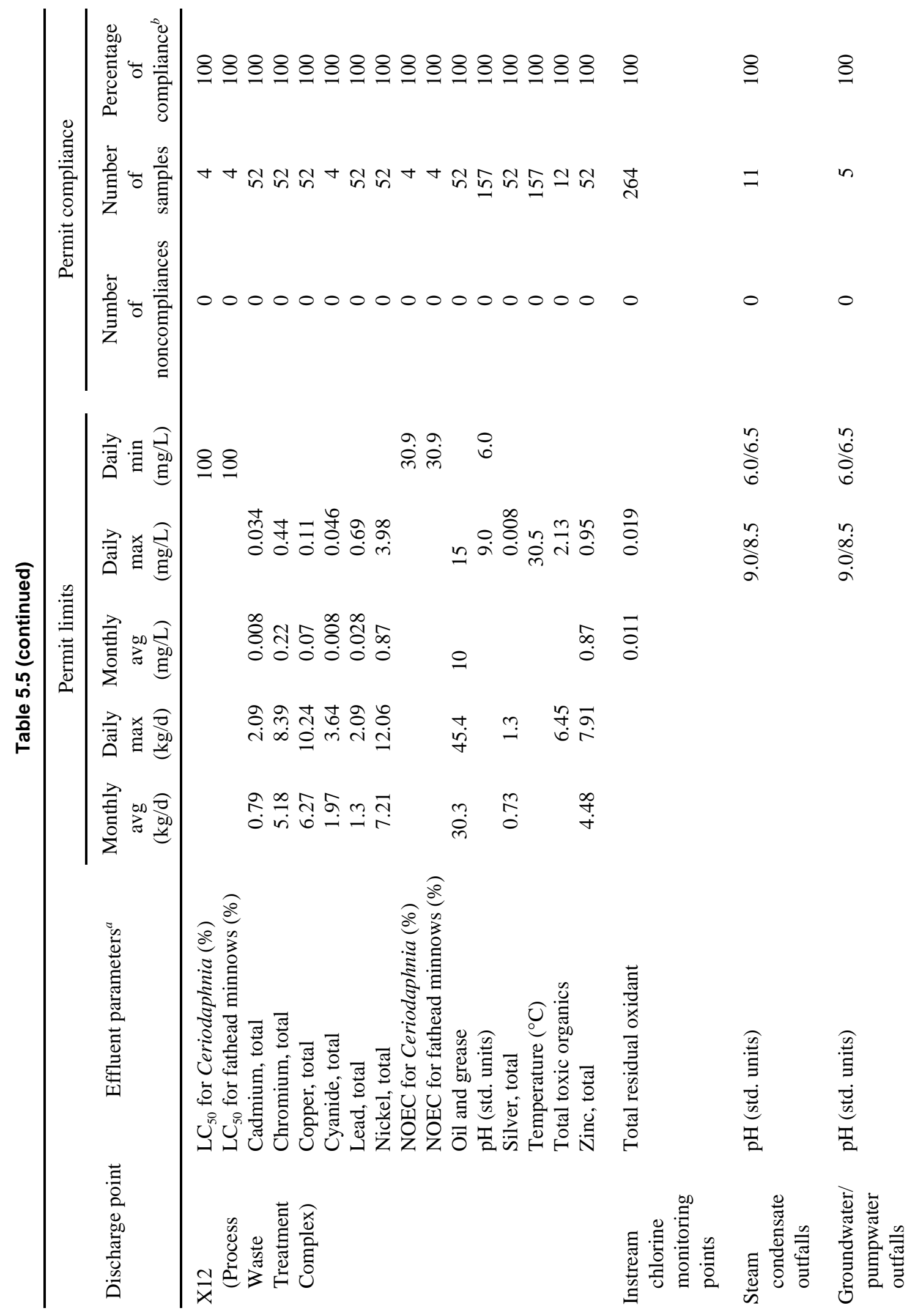




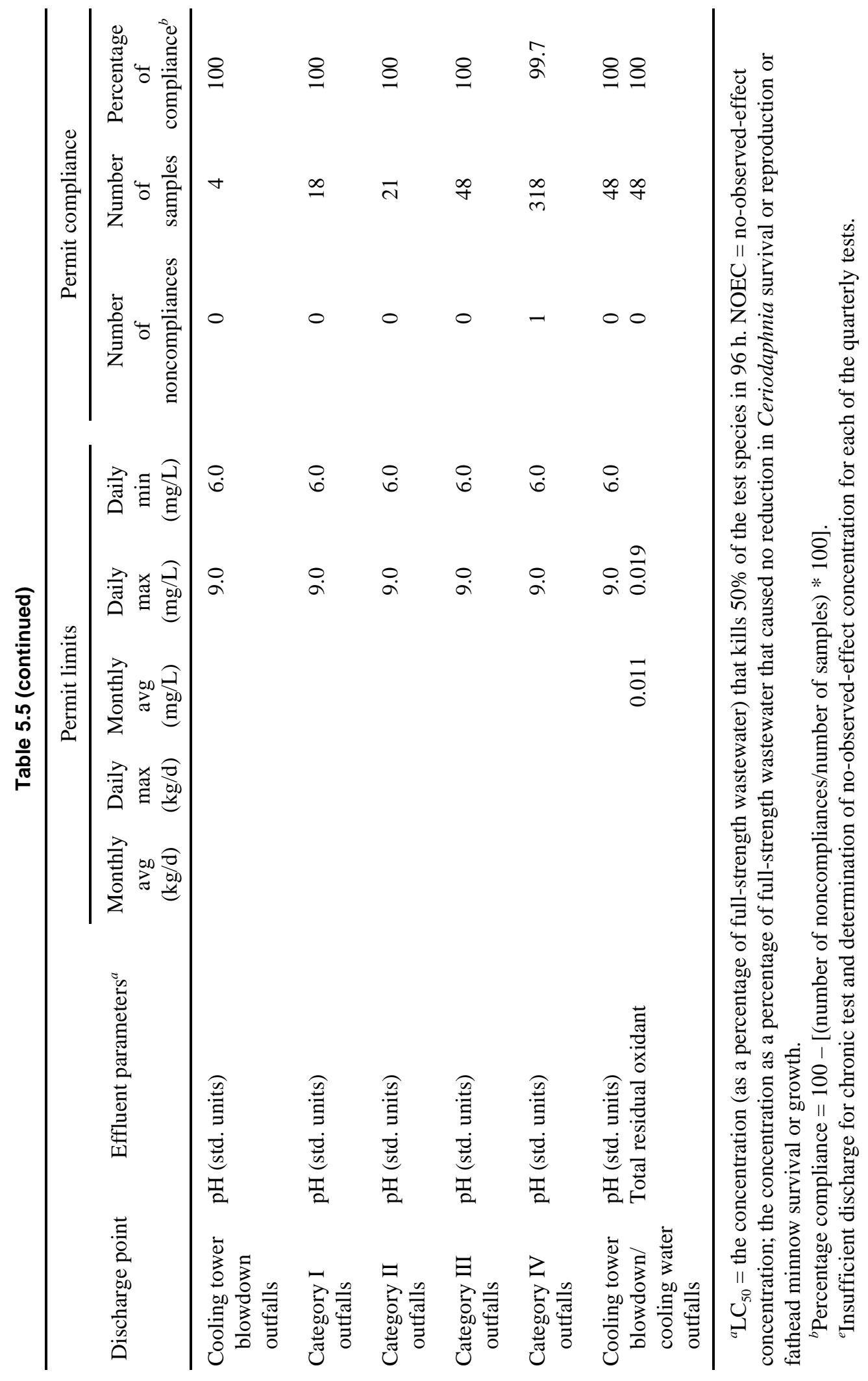


eliminate total residual oxidants in the discharge if they exceed the action level. The action level is $1.2 \mathrm{~g} / \mathrm{d}$ and is calculated by multiplying the instantaneously measured concentration by the instantaneous flow rate of the outfall.

ORNL monitored 153 measurable dry-weather discharges during 2003 at 22 outfalls. Two outfalls exceeded the action level one or more times. Actions to reduce or eliminate chlorine in these effluents are being investigated. A report detailing monitoring results, corrective actions, and proposed modifications is submitted to TDEC annually.

\subsubsection{Storm Water Pollution Prevention Plan}

The Storm Water Pollution Prevention Plan is a requirement of the ORNL NPDES Permit to document existing material management practices and to evaluate the vulnerability of those practices in contributing pollutants to area streams via storm water runoff. The plan consists of four major components:

1. assessment and mapping of outdoor material storage/handling at ORNL,

2. characterization of storm water runoff by monitoring,

3. training of employees, and

4. implementation of measures to minimize storm water pollution in areas of ORNL that may be vulnerable.

These four components of the plan were initiated in 1997 and are reviewed and updated by the facility at least annually. The plan was last updated in June 2003. This update includes observations and data from the previous year. ORNL has a storm water pollution prevention program that includes an inspection program, the analysis of storm water data collected as part of the NPDES program, training for ORNL employees and contractors, and annual review and revision of the program document. (The document is available to personnel on the ORNL site via the ORNL internal web.)

For sampling purposes, ORNL categorizes its storm water outfalls into four broad groups based on common land uses or pollutant sources and storm water pollutant potential. These four groups are further subdivided based on permit categorizations that have different monitoring schedule requirements. The permit requires that Category I and II outfalls be characterized over a 5-year period and that Category III and IV outfalls be characterized over a 3-year period. The outfalls chosen to be sampled were thought to be representative of the group or were thought to be more vulnerable to runoff pollution. Other factors considered in selecting representative outfalls from each group include interest in a particular runoff quality at an outfall and ease of obtaining a representative sample. A rotation of representative outfalls occurs each sampling period as directed by the permit. The results of the storm water outfall effluent sampling as of 2003 are provided in Attachment 6.0 of the Storm Water Pollution Prevention Plan.

The EPA Nationwide Urban Runoff Program was developed to expand the understanding of urban runoff pollution by instituting data collection and applied research projects in the urban areas of the United States. Urban storm water runoff pollutant loading factors for ten standard water quality constituents, called "event mean concentrations" (EMCs), were developed for the 1983 program's final report. Program findings were again updated in 1999 by using results of storm water data collected by the U.S. Geological Survey and the NPDES Storm Water Program to refine the EMCs.

In a comparison of recent ORNL data from 18 storm water outfalls with data from the Nationwide Urban Runoff Program, most values for the ten water quality constituents measured are well below the EMCs. Patterns of values exceeding the EMCs can be generalized by exceedances of copper or zinc. Copper is found naturally in the soils and could also occur from coal-burning activities or corrosion of copper pipes. Zinc can be attributed to vehicular degradation. There were also a few exceedances of suspended solids which can probably be attributed to the numerous construction projects in and around the main ORNL campus. 


\subsubsection{ORNL Results and Progress in Implementing Programs and Corrective Actions}

\subsubsection{ORNL Sink and Drain Survey Program}

In 1997, ORNL completed a comprehensive verification of the routing of all wastewater discharges from points of entry such as sinks and floor drains. As a result, more than 9000 sink and drain records were produced and are stored in a central database. ORNL has continued its efforts annually and in 2003 continued an annual division-by-division recertification of ORNL sinks and drains to ensure that sinks and drains continue to discharge to the proper wastewater collection systems. Program management continues to communicate sink and drain responsibilities to the ORNL site population.

\subsection{ORNL WASTEWATER BIOMONITORING}

Under the NPDES permit, wastewaters from the Sewage Treatment Plant, the Coal Yard Runoff Treatment Facility, and the Process Waste Treatment Complex were evaluated for toxicity. The results of the toxicity tests of wastewaters from the three treatment facilities are given in Table 5.6. This table provides, for each wastewater, the month the test was conducted, the wastewater's no-observed-effect concentration (NOEC), and the concentration that kills $50 \%$ of the test organisms $\left(\mathrm{LC}_{50}\right)$ for fathead minnows (Pimephales promelas) and daphnia (Ceriodaphnia dubia). The NOEC is the highest concentration tested that does not significantly reduce survival or growth of fathead minnows or survival or reproduction of Ceriodaphnia. The 96-h $\mathrm{LC}_{50}$ is the concentration of wastewater that kills $50 \%$ of the test organisms in $96 \mathrm{~h}$. The NPDES permit defines the limits for the biomonitoring tests. For the X01 (Sewage Treatment Plant) discharge, toxicity is demonstrated if more than $50 \%$ lethality of the test organisms occurs in $96 \mathrm{~h}$ in $41.1 \%$ effluent or if the NOEC is less than $12.3 \%$. For the X02 discharge (Coal Yard Runoff Treatment
Facility), toxicity is demonstrated if more than $50 \%$ lethality of the test organisms occurs in $96 \mathrm{~h}$ in $4.2 \%$ effluent or if the NOEC is less than $1.3 \%$. Because of the batch mode of discharge at the Coal Yard Runoff Treatment Facility, the limit for the NOEC only applies if the facility discharges for a sufficient length of time. For the X12 discharge (Process Waste Treatment Complex), toxicity is demonstrated if more than $50 \%$ lethality of the test organisms occurs in $96 \mathrm{~h}$ in $100 \%$ effluent $\left(\mathrm{LC}_{50}\right)$ or if the NOEC is less than $30.9 \%$.

During 2003, the Sewage Treatment Plant, Coal Yard Runoff Treatment Facility, and Process Waste Treatment Complex were each tested four times. Numeric biomonitoring limits in the NPDES permit were not exceeded during 2003.

\subsection{ORNL BIOLOGICAL MONITORING AND ABATEMENT PROGRAM}

As a condition of the NPDES permit issued to ORNL in April 1986, the BMAP was set forth to assess the condition of aquatic life in White Oak Creek, the Northwest Tributary of White Oak Creek, Melton Branch, Fifth Creek, and First Creek (Loar et al. 1991); the BMAP continued as a condition of the most recent NPDES permit that was effective February 3, 1997 (Kszos et al. 1997). The program addresses the following objectives as described in the NPDES permit part III (I).

- Temperature loadings shall be within state water criteria for protection of fish and aquatic life for warm summer conditions. This should be verified and reported annually (see Sect. 5.5.1).

- Instream water analysis for mercury shall be part of the BMAP so that it can be determined whether mercury at the site is being contributed to the stream and, if so, whether it will impact fish and aquatic life or violate the recreation criteria.

- Sediment and oil and grease from storm discharges shall not create stream impacts.

- The status of PCB contamination in fish tissue in the White Oak Creek watershed shall be determined. 
Table 5.6. Toxicity test results of Oak Ridge National Laboratory wastewaters, 2003

\begin{tabular}{|c|c|c|c|c|}
\hline Outfall & Test date & Test species & $\mathrm{NOEC}^{a}$ & $\mathrm{LC}_{50}{ }^{b}$ \\
\hline \multirow[t]{8}{*}{ Sewage Treatment Plant (X01) } & \multirow[t]{2}{*}{ February } & Ceriodaphnia & 41.1 & $>41.1$ \\
\hline & & Fathead minnow & 41.1 & $>41.1$ \\
\hline & \multirow[t]{2}{*}{ May } & Ceriodaphnia & 12.3 & $>41.1$ \\
\hline & & Fathead minnow & 12.3 & 21.6 \\
\hline & \multirow[t]{2}{*}{ August } & Ceriodaphnia & 41.1 & $>41.1$ \\
\hline & & Fathead minnow & 41.1 & $>41.1$ \\
\hline & \multirow[t]{2}{*}{ November } & Ceriodaphnia & 12.3 & $>41.1$ \\
\hline & & Fathead minnow & 41.1 & $>41.1$ \\
\hline \multirow[t]{8}{*}{ Coal Yard Runoff Treatment Facility (X02) } & \multirow[t]{2}{*}{ February } & Ceriodaphnia & $\mathrm{NA}^{c}$ & $>4.2^{d}$ \\
\hline & & Fathead minnow & $\mathrm{NA}^{c}$ & $>4.2^{d}$ \\
\hline & \multirow[t]{2}{*}{ May } & Ceriodaphnia & $\mathrm{NA}^{c}$ & $>4.2^{d}$ \\
\hline & & Fathead minnow & $\mathrm{NA}^{c}$ & $>4.2^{d}$ \\
\hline & \multirow[t]{2}{*}{ August } & Ceriodaphnia & $\mathrm{NA}^{c}$ & $>4.2^{d}$ \\
\hline & & Fathead minnow & $\mathrm{NA}^{c}$ & $>4.2^{d}$ \\
\hline & \multirow[t]{2}{*}{ November } & Ceriodaphnia & $\mathrm{NA}^{c}$ & $>4.2^{d}$ \\
\hline & & Fathead minnow & $\mathrm{NA}^{c}$ & $>4.2^{d}$ \\
\hline \multirow[t]{8}{*}{ Process Waste Treatment Complex (X12) } & \multirow[t]{2}{*}{ February } & Ceriodaphnia & 100 & $>100$ \\
\hline & & Fathead minnow & 100 & $>100$ \\
\hline & \multirow[t]{2}{*}{ May } & Ceriodaphnia & 100 & $>100$ \\
\hline & & Fathead minnow & 100 & $>100$ \\
\hline & \multirow[t]{2}{*}{ August } & Ceriodaphnia & 100 & $>100$ \\
\hline & & Fathead minnow & 100 & $>100$ \\
\hline & \multirow[t]{2}{*}{ November } & Ceriodaphnia & 100 & $>100$ \\
\hline & & Fathead minnow & 100 & $>100$ \\
\hline
\end{tabular}

${ }^{a} \mathrm{NOEC}=$ no-observed-effect concentration; the concentration (as percentage of full-strength wastewater) that caused no reduction in Ceriodaphnia survival or reproduction or fathead minnow survival or growth.

${ }^{b} \mathrm{LC}_{50}=$ the concentration (as percentage of full-strength wastewater) that kills $50 \%$ of the test species in $96 \mathrm{~h}$.

${ }^{c}$ Insufficient duration of discharge for chronic test and determination of NOEC.

${ }^{d} 48-\mathrm{h} \mathrm{LC}_{50}$. 
- The Chlorine Control Strategy's protection of the stream in the main plant area shall be assessed.

- In addition, the BMAP shall continue studies evaluating the receiving streams' biological communities throughout the duration of the permit.

\subsubsection{Bioaccumulation Studies}

The bioaccumulation task for the BMAP addresses two NPDES permit requirements at ORNL: (1) evaluate whether mercury at the site is contributing to a stream such that it will impact fish and aquatic life or violate the recreational criteria (instream water analyses for mercury should be part of this activity), and (2) monitor the status of PCB contamination in fish tissue in the White Oak Creek watershed.

\subsubsection{Mercury in water}

Water samples were collected for mercury analysis from four sites in White Oak Creek on six occasions in FY 2003. Stream conditions were representative of seasonal baseflow (dry weather) conditions at the time of sampling on all dates except April 10, 2003, which represented wetweather flow.

Concentrations of total waterborne mercury in White Oak Creek above the Process Waste Treatment Complex [White Oak Creek kilometer (WCK) 4.1] ranged from $\sim 37 \mathrm{ng} / \mathrm{L}$ to approximately $155 \mathrm{ng} / \mathrm{L}$ (Fig. 5.15). The average for this site during this period was $103 \mathrm{ng} / \mathrm{L} \pm 20$ (mean \pm SE), which clearly exceeded the Tennessee Water Quality Standard of $51 \mathrm{ng} / \mathrm{L}$. The source is presumed to be storm drains under the two buildings adjacent to Fifth Creek just upstream from its confluence with WOC. A pilot plant for the process eventually used at Y-12 was built on the site and probably contaminated soils and drains. Sumps and condensate lines discharging to storm drain from building have high mercury levels.

However, at the two sites further downstream (WCK 3.4 and WCK 1.5), mercury concentrations in FY 2003 were typically much lower than at WCK 4.1. During this period, average aqueous mercury concentrations were $50 \pm 4.9 \mathrm{ng} / \mathrm{L}$ at WCK 3.4 , and $37 \mathrm{ng} / \mathrm{L} \pm 7.8$ at WCK 1.5 (White
Oak Lake). The average annual mercury concentration in water at the upstream reference site (WCK 6.8, data not shown in figure) was much lower than the state standard, averaging 5.0 $\mathrm{ng} / \mathrm{L} \pm 2.1$.

Temporal trends in mercury in White Oak Creek water show that concentrations were generally lower in 2003 than in 1997, but have changed little over the last 2 to 3 years (Fig. 5.16). High temporal variability is characteristic of waterborne mercury in White Oak Creek, with highest concentrations and greatest variability just upstream of the Process Waste Treatment Complex. Highest mercury concentrations at this site appear to coincide with low-flow conditions.

\subsubsection{Bioaccumulation}

For the 2003 sampling year, fish were collected from White Oak Creek primarily on April 15, but a few fish were collected on June 30 to augment the collection. To provide data directly applicable to assessing human health concerns, redbreast sunfish (Lepomis auritus) were collected from WCK 2.9, and bluegill (Lepomis macrochirus) and largemouth bass (Micropterus salmoides) were collected from WCK 1.5 (White Oak Lake). Collections were restricted to fish of a size large enough to be taken by sport fisherman (> $50 \mathrm{~g}$ for sunfish, and $>500 \mathrm{~g}$ for bass). Fillet tissue was taken from six individual fish of each species for both $\mathrm{Hg}$ and PCB analysis.

\section{Mercury}

Mercury concentrations in four fish from White Oak Creek exceeded $0.5 \mu \mathrm{g} / \mathrm{g}$, a level currently used by the state of Tennessee in issuing fish consumption advisories. Average mercury concentration in redbreast sunfish from WCK 2.9 $(0.37 \mu \mathrm{g} / \mathrm{g} \pm 0.04$; mean $\pm \mathrm{SE})$ was approximately five-times higher than in Hinds Creek $(0.07 \mu \mathrm{g} / \mathrm{g}$ \pm 0.01 ), a nearby reference stream (Table 5.7). Concentrations of mercury in bluegill collected at WCK 1.5 were far lower than at WCK 2.9, with mercury approaching reference stream levels $(0.14 \mu \mathrm{g} / \mathrm{g} \pm 0.02)$. Mean concentration of mercury in largemouth bass at WCK 1.5 were $0.49 \mu \mathrm{g} / \mathrm{g} \pm 0.06$. This higher concentration in bass reflects their higher position in the food chain. All fish from WCK 2.9 and all largemouth 


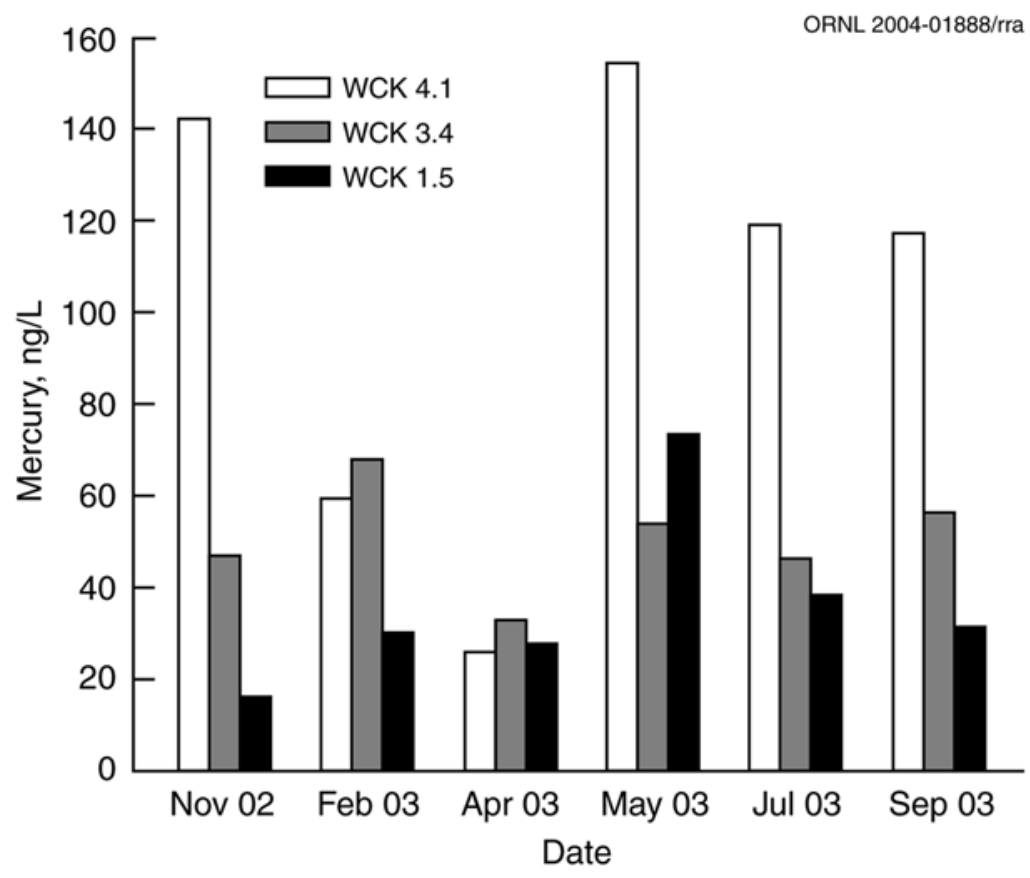

Fig. 5.15. Total mercury in water vs time, from November 2002 to September 2003, at three sites in the White Oak Creek watershed downstream from ORNL.

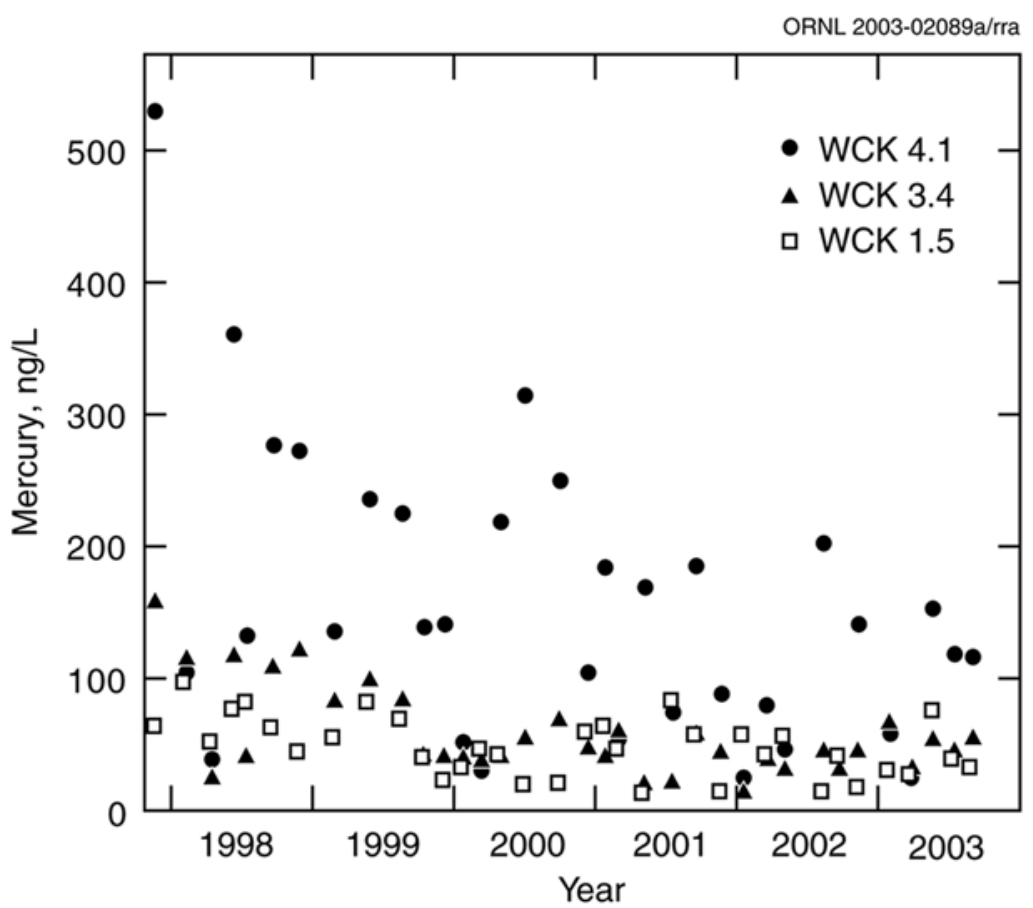

Fig. 5.16. Total mercury in water vs time, 1998-2003, at three sites in the White Oak Creek watershed downstream from ORNL. 
Table 5.7. Total mercury and PCB (Aroclor $1254+1260)$ concentrations in fish (mean \pm SE; range in parenthesis) from White Oak Creek and reference stream, Hinds Creek, April $2003^{a}$

\begin{tabular}{llcc}
\hline Site $^{b}$ & Species $^{c}$ & Mercury $(\mu \mathrm{g} / \mathrm{g})$ & PCBs $(\mu \mathrm{g} / \mathrm{g})$ \\
\hline WCK 3.5 & Stonerollers & - & $3.00 \pm 0.15$ \\
& & $(2.8-3.3)$ \\
WCK 2.9 & Redbreast sunfish & $0.37 \pm 0.04$ & $0.32 \pm 0.05$ \\
& & $(0.31-0.54)$ & $(0.19-0.49)$ \\
WCK 1.5 & Bluegill sunfish & $0.14 \pm 0.02$ & $0.24 \pm 0.09$ \\
& & $(0.11-0.19)$ & $(0.09-0.66)$ \\
& Largemouth Bass & $0.49 \pm 0.06$ & $0.49 \pm 0.11$ \\
& & $(0.30-0.66)$ & $(0.24-0.91)$ \\
Hinds Creek & Redbreast sunfish & $0.07 \pm 0.01$ & $<0.01$ \\
& & $(0.05-0.11)$ & \\
\hline
\end{tabular}

${ }^{a}$ For sunfish and bass, $\mathrm{N}=6$ individual fish for each site/species combination, and samples are of fillet tissue only. Stoneroller values represent 3 composite samples of 10 whole fish. Two bass from WCK 1.5 were collected in June 2003.

${ }^{b} \mathrm{WCK}=$ White Oak Creek kilometer. WCK 1.5 = White Oak Lake.

${ }^{c}$ Stonerollers (Campostoma oligolepis); redbreast sunfish (Lepomis auritus); bluegill sunfish (Lepomis macrochirus); largemouth bass (Micropterus salmoides).

bass from WCK 1.5 exceeded EPA's criterion for mercury in fish tissue of $0.3 \mathrm{mg} / \mathrm{kg}$. However, this level was not exceeded in any bluegill collected from WCK 1.5 in 2003.

Temporal trends in mercury concentrations in fish indicated that levels were slightly higher in 2003 than in 2002 (Fig. 5.17). Whether or not this higher concentration represents a true trend of increasing concentrations or just natural temporal variability should be clearer with results from 2004.

\section{PCBs}

The highest average PCB concentration (3.0 $\mu \mathrm{g} / \mathrm{g} \pm 0.15$; mean $\pm \mathrm{SE}$ ) measured in fish from White Oak Creek in FY 2003 was found in wholebody samples of stonerollers (Campostoma oligolepis) collected from the site nearest the ORNL campus (WCK 3.5, Table 5.7). This indicated that exposures to high levels of PCBs near the main ORNL campus continue, resulting in levels that approach or exceed levels that have been found to cause health problems in some piscivorous wildlife.

Sunfish (bluegill and redbreast) have been used by BMAP since 1985 to evaluate changes in
PCB exposure over time. Sunfish are relatively short-lived and do not move far from their home territory during their life. Therefore, they provide a site-specific and recent measure of contaminant exposure. In general, concentrations of PCBs in White Oak Creek sunfish in 2003 were similar to those in 2002, but slightly lower than the 2000-2001 period (Fig. 5.18). Mean PCB concentrations in sunfish from WCK 2.9 and WCK 1.5 were $0.32 \mu \mathrm{g} / \mathrm{g} \pm 0.05$ and $0.24 \mu \mathrm{g} / \mathrm{g} \pm$ 0.09 , respectively. Such levels of PCBs are relatively high for short-lived, lipid-poor fish such as sunfish. Concentrations of PCBs in sunfish from the reference site (Hinds Creek) averaged < $0.01 \mu \mathrm{g} / \mathrm{g}$ in 2003 .

Largemouth bass are better indicators of the maximum PCB concentrations likely in a body of water because of their age, lipid content, and presence at the top of the food chain. The mean PCB concentration in bass from WCK 1.5 in the spring of 2003 was $0.49 \mu \mathrm{g} / \mathrm{g} \pm 0.11$ (Fig. 5.18). Although concentrations of PCBs in bass were higher than in sunfish from the same site, the concentrations in bass were substantially lower in 2003 than in the recent past. No individual bass exceeded the U.S. Food and Drug Administration threshold limit (for fish sold commercially) 


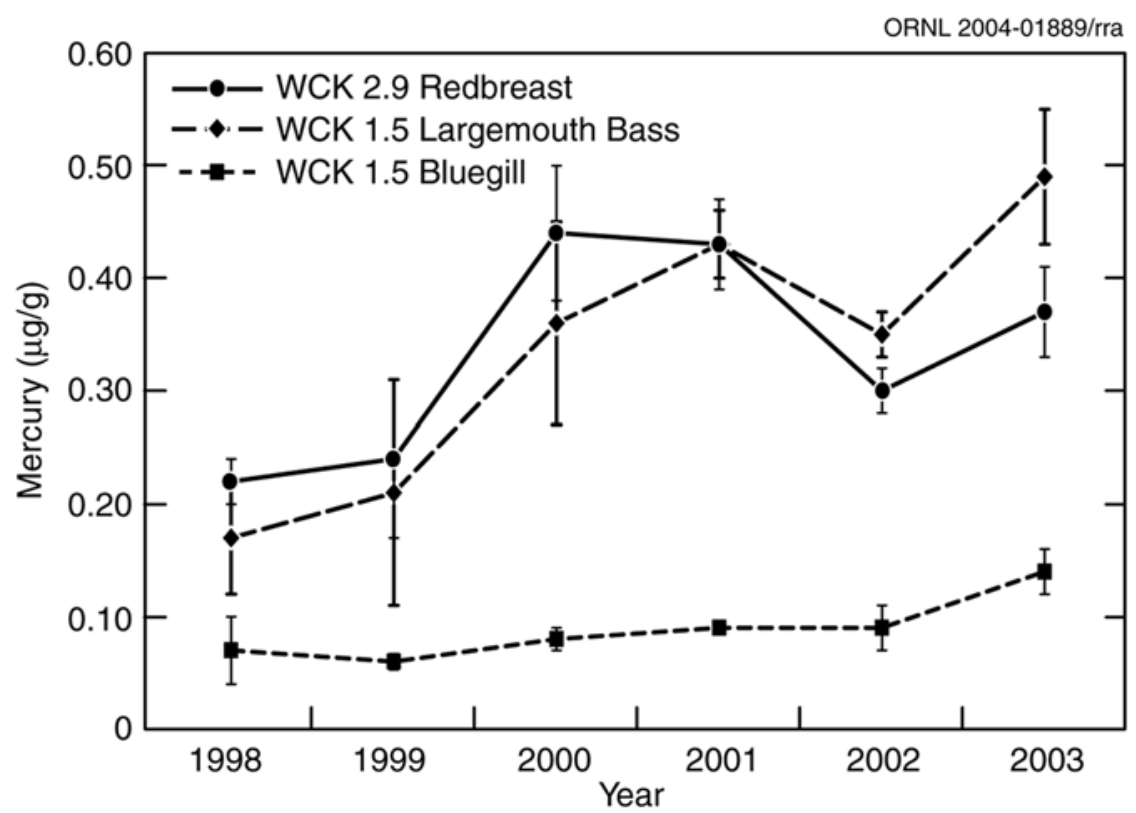

Fig. 5.17. Temporal trends in mercury concentrations in fish, 1998-2003.

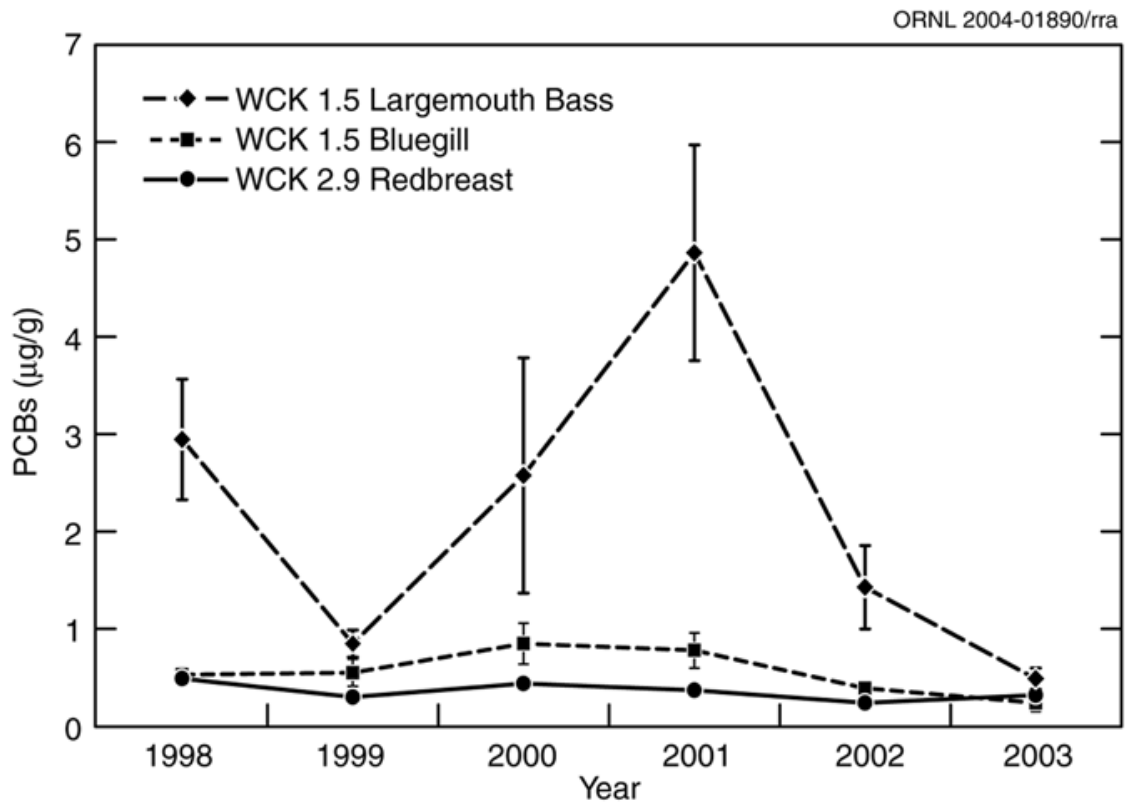

Fig. 5.18. Temporal trends in PCB concentrations in fish, 1998-2003.

of $2 \mu \mathrm{g} / \mathrm{g}$, and only one fish exceeded the typical state advisory threshold of 0.8 to $1 \mu \mathrm{g} / \mathrm{g}$. The decrease in PCBs in both largemouth bass and sunfish the last two years could be a result of changes in PCB exposure. A potential explanation for this change could be that increases in silt particles in the water from recent construction activities have acted to bind PCBs and make them less bioavailable. The most dramatic decreases, however, have been in largemouth bass; a species well known for exhibiting highly fluctuating levels of PCBs. Changes in concentrations in bass could be a result of changes not related to source decreases, but rather factors such as changes in prey (e.g., shad can be relatively high in PCBs, bluegill much lower), health condition (lipid 
changes in muscle can affect PCB concentrations), or greater fish movement from nearby source areas.

\subsubsection{Ecological Surveys}

\subsubsection{Benthic Macroinvertebrate Communities}

Monitoring of the benthic macroinvertebrate communities in White Oak Creek, First Creek, and Fifth Creek continued in 2003. Benthic macroinvertebrate samples are collected at sites upstream and downstream of the influence of ORNL operations. These sites include impacted and unimpacted (reference sites) locations. The objectives of benthic macroinvertebrate community task are to (1) help assess ORNL's compliance with the current NPDES permit requirements, and (2) evaluate and verify the effectiveness of pollution abatement and remedial actions taken at ORNL.

Results for April 2003 showed that the benthic macroinvertebrate communities in First Creek, Fifth Creek, and White Oak Creek continued to exhibit characteristics of degraded ecological conditions (Figs. 5.19, 5.20, and 5.21). The macroinvertebrate communities in lower First Creek [First Creek kilometer (FCK) 0.1] and Fifth Creek [Fifth Creek kilometer (FFK) 0.2] appear to have stabilized in the past 8 years. Other than the normal fluctuations between years that are characteristic of all streams, including reference locations, the total number of taxa and the number
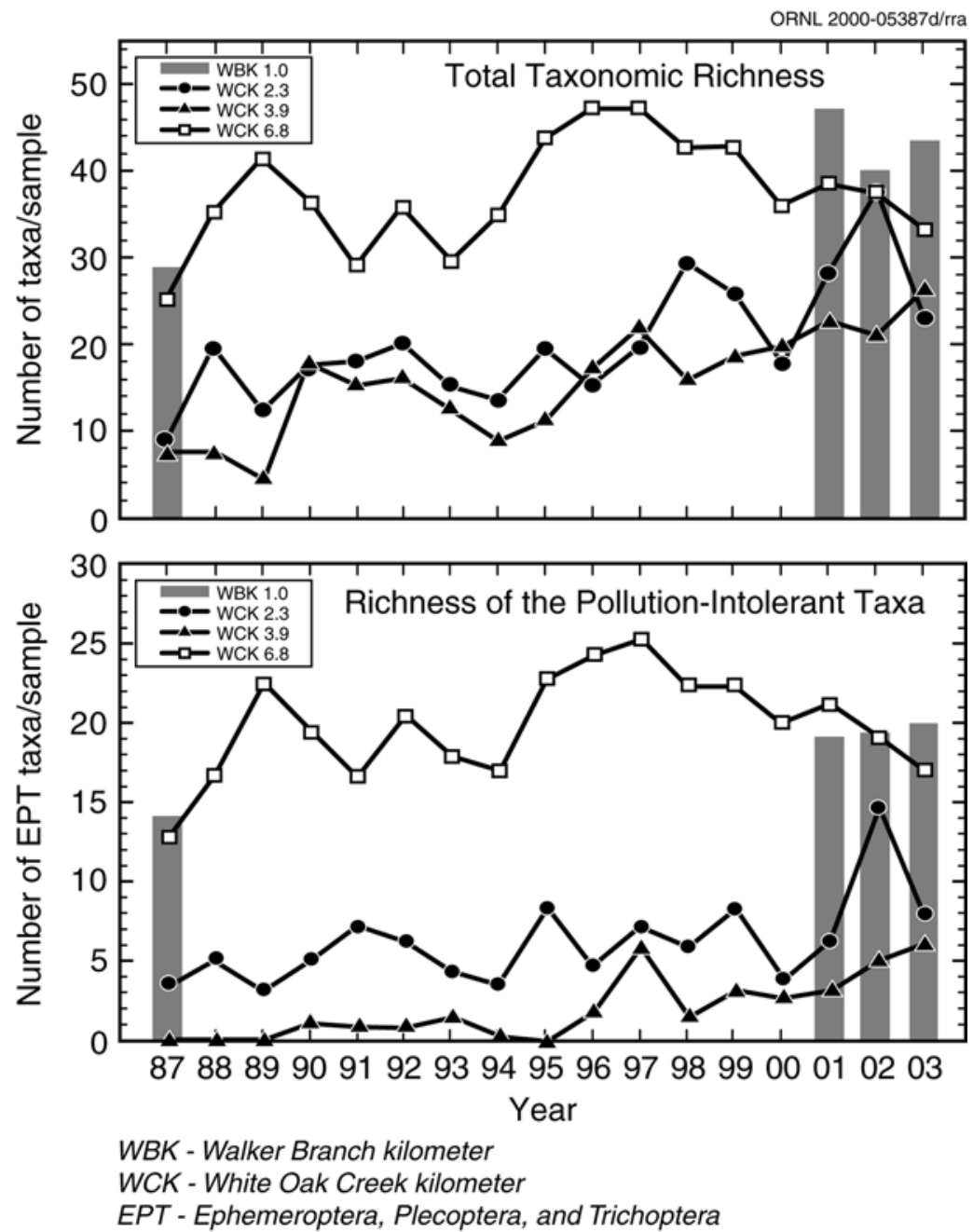

Fig. 5.19. Taxonomic richness and richness of the pollutionintolerant taxa of the benthic macroinvertebrate communities in White Oak Creek during April sampling periods, 1987-2003. 
of pollution-intolerant taxa have changed little at these two sites (Figs 5.20 and 5.21). In White Oak Creek in contrast, further improvements in the condition of the macroinvertebrate community at sites WCK 3.9 (near coal yard) and WCK 2.3 (downstream of White Oak Creek's confluence with Melton Branch) were observed, particularly at WCK 3.9 (Fig. 5.19). While still lower than at reference locations, both the total number of taxa and number of pollution-intolerant taxa have steadily increased at WCK 3.9, most notably since April 2000. Although these results continue to show that the benthic macroinvertebrate communities in streams affected by ORNL operations remain degraded, they also show that the earlier improvements observed in First Creek and Fifth Creek are persisting and that further improvements have occurred in White Oak Creek.

\subsubsection{Fish Communities}

Monitoring of the fish communities in White Oak Creek and its major tributaries continued in 2003. Samples were taken at 11 sites in White Oak Creek watershed and 3 additional nearby reference sites in spring 2003; sites closest to ORNL facilities were emphasized. In White Oak Creek, the fish community continued to display characteristics of degraded conditions, with sites closest to the outfalls having lower species richness (number of species), fewer pollution-
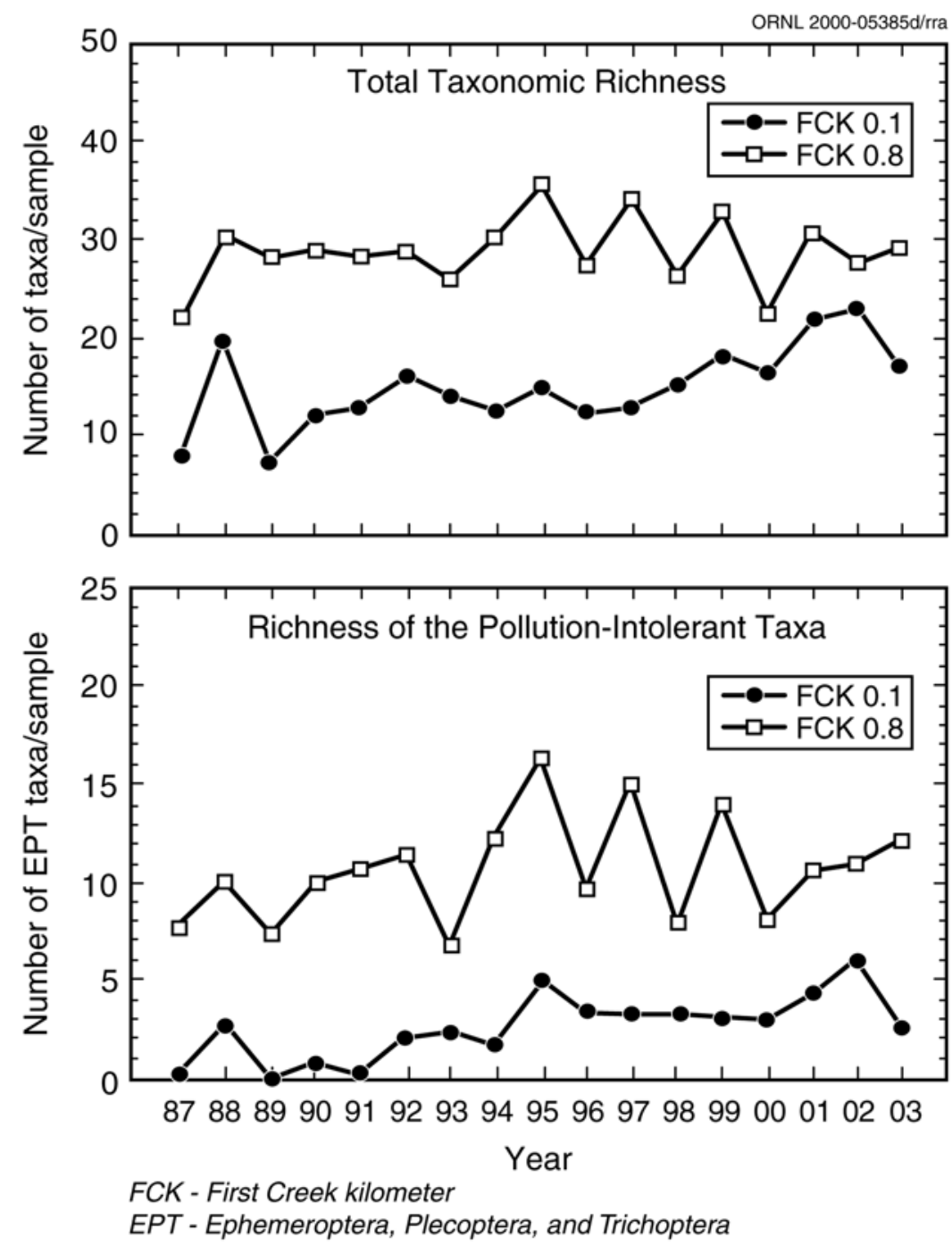

Fig. 5.20. Taxonomic richness and richness of the pollutionintolerant taxa in the benthic macroinvertebrate communities in First Creek during April sampling periods, 1987-2003. 

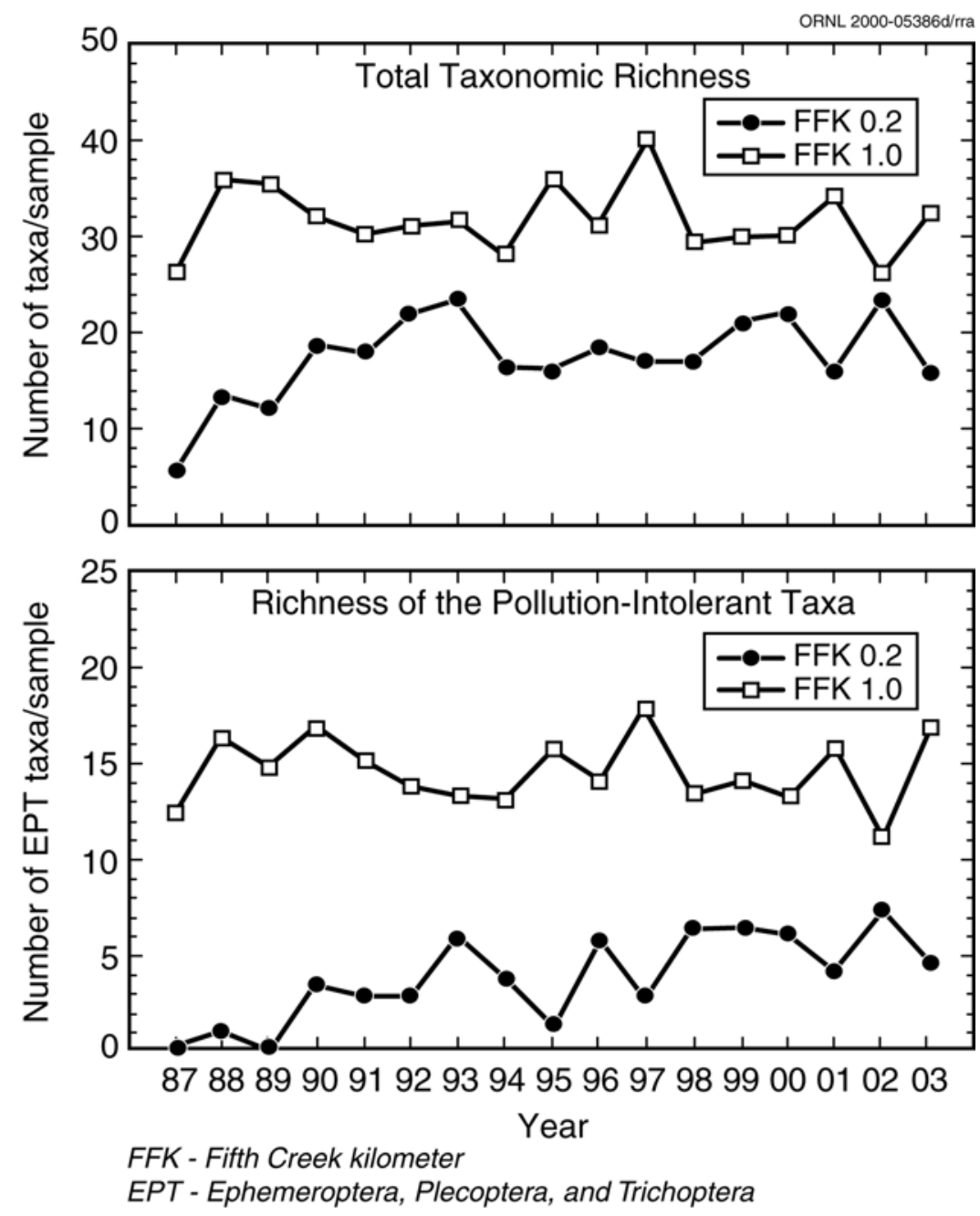

Fig. 5.21. Taxonomic richness and richness of the pollutionintolerant taxa in the benthic macroinvertebrate communities in Fifth Creek during April sampling periods, 1987-2003.

sensitive species, more pollution-tolerant species, and higher total densities (number of fish per square meter) than similar-sized reference streams. Compared with results in April 2002, no major changes were apparent in the White Oak Creek fish community.

Species richness of fish in tributaries of White Oak Creek remained low in April 2003, relative to reference streams not in the White Oak Creek watershed. However, as observed in White Oak Creek, the fish communities of First Creek and Melton Branch showed little change in density in spring 2003 relative to spring 2002; sites adjacent to and downstream of ORNL remained somewhat impacted relative to reference streams. The fish community in Fifth Creek, in contrast, showed notable declines in abundances at the reference (FFK 1.0) and downstream sites (FFK 0.2). The decline at FFK 1.0 continues a trend that has been occurring since 1998. The low species richness seen in White Oak Creek watershed, relative to off-site reference locations, is partially a result of barriers that limit immigration from the Clinch River drainage.

\subsection{ORNL SURFACE WATER MONITORING AT NPDES REFERENCE LOCATION}

White Oak Creek headwaters were monitored in 2003 as a background or reference location for ORNL NPDES surface water monitoring.

In an effort to provide a basis for evaluation of analytical results and for assessment of nonradiological surface water quality, Tennessee 
General Water Quality Criteria have been used as reference values. The criteria for fish and aquatic life have been used at White Oak Creek headwaters (see Appendix C, Table C.2, for Tennessee General Water Quality Criteria for all parameters in water and Appendix C, Table C.3, for surface water analyses).

\subsection{ORNL Surface Water Surveillance Monitoring}

The ORNL surface water monitoring program includes sample collection and analysis from 18 locations at ORNL and around the ORR. This program is conducted in conjunction with the ORR surface water monitoring activities discussed in Chapter 7, to enable an assessment of the impacts of past and current DOE operations on the quality of local surface water. These programs are conducted in addition to the surface water monitoring required by NPDES permits at ORNL facilities; sampling location, frequency, and analytical parameters vary among them. Sampling locations include streams downstream of ORNL waste sources, reference points on streams and reservoirs upstream of waste sources, and public water intakes (see Fig. 5.22).

Sampling frequency and parameters vary by site. Grab samples are collected and analyzed for general water quality parameters at all locations and all are screened for radioactivity and analyzed for specific radionuclides when appropriate. White Oak Lake at White Oak Dam is also checked for volatile organic compounds, PCBs, and metals. Table 5.8 lists the specific locations and their sampling frequencies and parameters.

Ten of the 18 sampling locations are classified by the state of Tennessee for certain uses (e.g., domestic water supplies or recreational use). Tennessee water quality criteria for domestic water supplies, for freshwater fish and aquatic life, and for recreation (water and organisms) are used as references for locations where they are applicable. The Tennessee water quality criteria do not include criteria for radionuclides.

\subsubsection{Results}

Radionuclides were detected above minimum detectable activity at all surface water locations in 2003. The highest levels of gross beta, total radioactive strontium, and tritium continue to be at Melton Branch kilometer (MEK) 0.2, White Oak Creek at White Oak Dam (WCK 1.0), and WCK 2.6. These data are consistent with historical data and with the processes or legacy activities nearby or upstream from these locations.

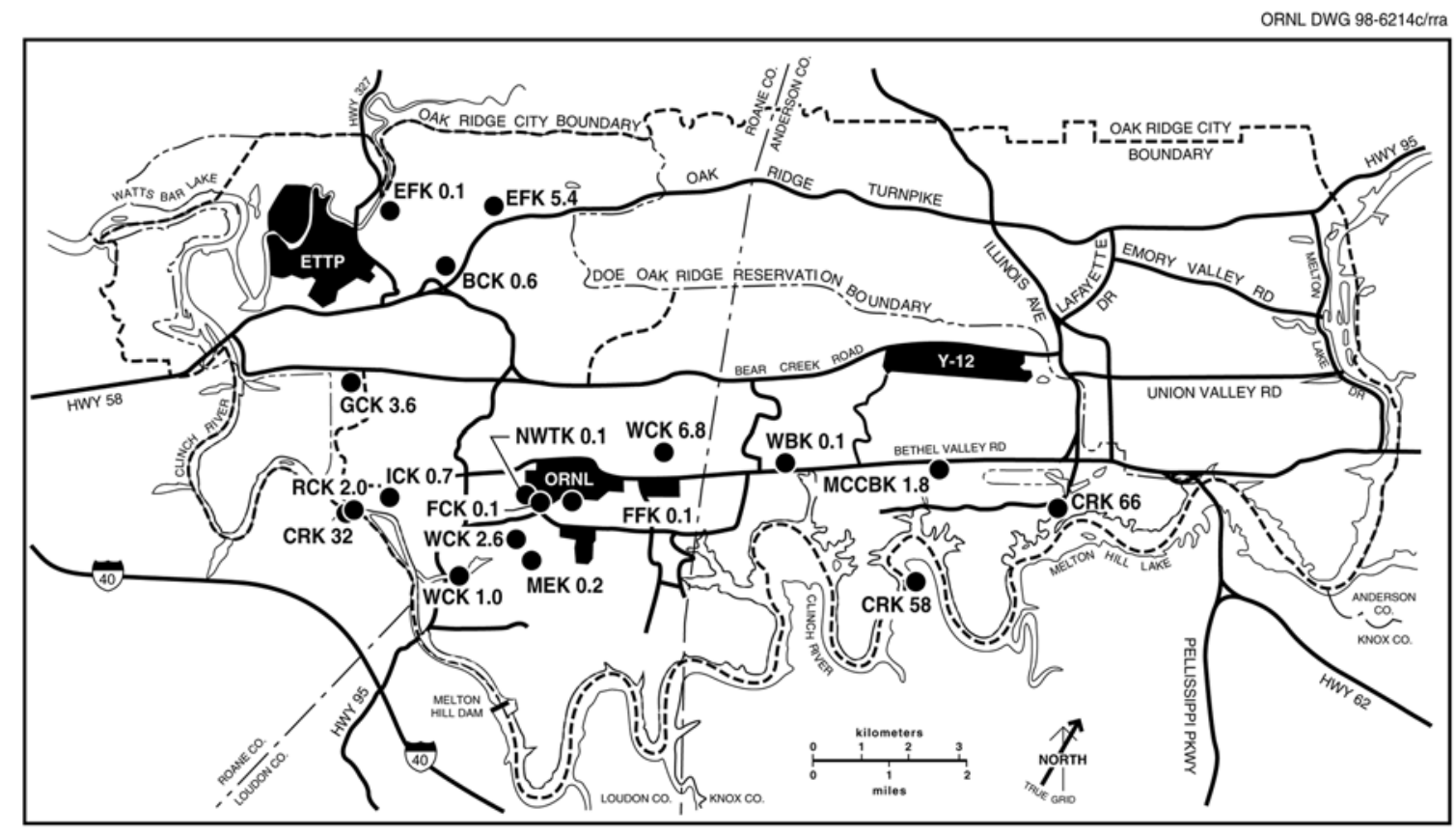

Fig. 5.22. ORNL surface water sampling locations. 
Table 5.8. ORNL surface water sampling locations, frequencies, and parameters, 2003

\begin{tabular}{|c|c|c|c|}
\hline Location $^{a}$ & Description & Frequency & Parameters \\
\hline BCK 0.6 & $\begin{array}{l}\text { Bear Creek downstream from } \\
\text { DOE inputs }\end{array}$ & $\begin{array}{l}\text { Semiannually } \\
\text { (Apr, Oct) }\end{array}$ & $\begin{array}{l}\text { Gross alpha, gross beta, gamma scan, field } \\
\text { measurements }{ }^{b}\end{array}$ \\
\hline CRK 32 & $\begin{array}{l}\text { Clinch River downstream from } \\
\text { ORNL }\end{array}$ & Monthly & $\begin{array}{l}\text { Gross alpha, gross beta, gamma scan, total } \\
\text { radioactive strontium, }{ }^{3} \mathrm{H} \text {, field measurements }{ }^{b}\end{array}$ \\
\hline CRK 58 & $\begin{array}{l}\text { Water supply intake for Knox } \\
\text { County }\end{array}$ & Monthly & $\begin{array}{l}\text { Gross alpha, gross beta, gamma scan, field } \\
\text { measurements }{ }^{b}\end{array}$ \\
\hline CRK 66 & $\begin{array}{l}\text { Melton Hill Reservoir above } \\
\text { city of Oak Ridge water intake }\end{array}$ & Monthly & $\begin{array}{l}\text { Gross alpha, gross beta, gamma scan, field } \\
\text { measurements }^{b}\end{array}$ \\
\hline EFK 0.1 & $\begin{array}{l}\text { East Fork Poplar Creek prior } \\
\text { to entering Poplar Creek }\end{array}$ & $\begin{array}{l}\text { Semiannually } \\
\text { (Apr, Oct) }\end{array}$ & $\begin{array}{l}\text { Gross alpha, gross beta, gamma scan, field } \\
\text { measurements }{ }^{b}\end{array}$ \\
\hline EFK 5.4 & $\begin{array}{l}\text { East Fork Poplar Creek } \\
\text { downstream from floodplain }\end{array}$ & $\begin{array}{l}\text { Semiannually } \\
\text { (Apr, Oct) }\end{array}$ & $\begin{array}{l}\text { Gross alpha, gross beta, gamma scan, field } \\
\text { measurements }{ }^{b}\end{array}$ \\
\hline MEK 0.2 & $\begin{array}{l}\text { Melton Branch downstream } \\
\text { from ORNL }\end{array}$ & $\begin{array}{l}\text { Bimonthly } \\
\text { (Jan, Mar, May, } \\
\text { Jul, Sep, Nov) }\end{array}$ & $\begin{array}{l}\text { Gross alpha, gross beta, gamma scan, total } \\
\text { radioactive strontium, }{ }^{3} \mathrm{H} \text {, field measurements }{ }^{b}\end{array}$ \\
\hline WCK 1.0 & $\begin{array}{l}\text { White Oak Lake at White Oak } \\
\text { Dam }\end{array}$ & Monthly & $\begin{array}{l}\text { Volatiles, metals, PCBs, gross alpha, gross } \\
\text { beta, gamma scan, total radioactive strontium, } \\
{ }^{3} \mathrm{H} \text {, field measurements }{ }^{b}\end{array}$ \\
\hline WCK 2.6 & $\begin{array}{l}\text { White Oak Creek downstream } \\
\text { from ORNL }\end{array}$ & $\begin{array}{l}\text { Bimonthly } \\
\text { (Jan, Mar, May, } \\
\text { Jul, Sep, Nov) }\end{array}$ & $\begin{array}{l}\text { Gross alpha, gross beta, gamma scan, total } \\
\text { radioactive strontium, }{ }^{3} \mathrm{H} \text {, field measurements }\end{array}$ \\
\hline WCK 6.8 & $\begin{array}{l}\text { White Oak Creek upstream } \\
\text { from ORNL }\end{array}$ & $\begin{array}{l}\text { Quarterly } \\
\text { (Feb, May, Aug, } \\
\text { Nov) }\end{array}$ & $\begin{array}{l}\text { Gross alpha, gross beta, total radioactive } \\
\text { strontium, gamma scan, }{ }^{3} \mathrm{H} \text {, field } \\
\text { measurements }{ }^{b}\end{array}$ \\
\hline WBK 0.1 & $\begin{array}{l}\text { Walker Branch prior to } \\
\text { entering CRK } 53.4\end{array}$ & $\begin{array}{l}\text { Semiannually } \\
\text { (Apr, Oct) }\end{array}$ & $\begin{array}{l}\text { Gross alpha, gross beta, gamma scan, field } \\
\text { measurements }{ }^{b}\end{array}$ \\
\hline GCK 3.6 & $\begin{array}{l}\text { Grassy Creek upstream of } \\
\text { SEG and IT Corp. at CRK } 23\end{array}$ & $\begin{array}{l}\text { Semiannually } \\
\text { (Apr, Oct) }\end{array}$ & $\begin{array}{l}\text { Lead, gross alpha, gross beta, gamma scan, } \\
\text { field measurements }{ }^{b}\end{array}$ \\
\hline ICK 0.7 & $\begin{array}{l}\text { Ish Creek prior to entering } \\
\text { CRK } 30.8\end{array}$ & $\begin{array}{l}\text { Semiannually } \\
\text { (Apr, Oct) }\end{array}$ & $\begin{array}{l}\text { Gross alpha, gross beta, gamma scan, field } \\
\text { measurements }{ }^{b}\end{array}$ \\
\hline MCCBK 1.8 & $\begin{array}{l}\text { McCoy Branch prior to } \\
\text { entering CRK } 60.3\end{array}$ & $\begin{array}{l}\text { Semiannually } \\
\text { (Apr, Oct) }\end{array}$ & $\begin{array}{l}\text { Gross alpha, gross beta, gamma scan, field } \\
\text { measurements }^{b}\end{array}$ \\
\hline RCK 2.0 & $\begin{array}{l}\text { Raccoon Creek sampling } \\
\text { station prior to entering } \\
\text { CRK } 31\end{array}$ & $\begin{array}{l}\text { Semiannually } \\
\text { (Apr, Oct) }\end{array}$ & $\begin{array}{l}\text { Gross alpha, gross beta, total radioactive } \\
\text { strontium, gamma scan, }{ }^{3} \mathrm{H} \text {, field } \\
\text { measurements }{ }^{b}\end{array}$ \\
\hline NWTK 0.1 & $\begin{array}{l}\text { Northwest Tributary prior to } \\
\text { the confluence with First } \\
\text { Creek }\end{array}$ & $\begin{array}{l}\text { Semiannually } \\
\text { (Apr, Oct) }\end{array}$ & $\begin{array}{l}\text { Gross alpha, gross beta, total radioactive } \\
\text { strontium, gamma scan, }{ }^{3} \mathrm{H} \text {, field } \\
\text { measurements }{ }^{b}\end{array}$ \\
\hline
\end{tabular}


Table 5.8 (continued)

\begin{tabular}{llll}
\hline \multicolumn{1}{c}{ Location $^{a}$} & \multicolumn{1}{c}{ Description } & \multicolumn{1}{c}{ Frequency } & \multicolumn{1}{c}{ Parameters } \\
\hline FCK 0.1 & $\begin{array}{l}\text { First Creek prior to the } \\
\text { confluence with Northwest } \\
\text { Tributary }\end{array}$ & $\begin{array}{l}\text { Semiannually } \\
\text { (Apr, Oct) }\end{array}$ & $\begin{array}{l}\text { Gross alpha, gross beta, total radioactive } \\
\text { strontium, gamma scan, }{ }^{3} \mathrm{H}, \text { field } \\
\text { measurements }\end{array}$ \\
FFK 0.1 & $\begin{array}{l}\text { Fifth Creek just upstream of } \\
\text { White Oak Creek (ORNL) }\end{array}$ & $\begin{array}{l}\text { Semiannually } \\
\text { (Apr, Oct) }\end{array}$ & $\begin{array}{l}\text { Gross alpha, gross beta, total radioactive } \\
\text { strontium, gamma scan, }{ }^{3} \mathrm{H}, \text { field } \\
\text { measurements }\end{array}$ \\
\hline
\end{tabular}

${ }^{a}$ Locations identify bodies of water and locations on them (e.g., CRK $32=$ CRK $32 \mathrm{~km}$ upstream from the confluence of the Clinch and the Tennessee Rivers).

${ }^{b}$ Field measurements consist of dissolved oxygen, $\mathrm{pH}$, and temperature.

Remediation efforts by Bechtel Jacobs Company (BJC) have resulted in decreases in levels of gross alpha, gross beta, and total radioactive strontium at the First Creek location. The levels are seasonal; for example, they are lower in the spring (wet season) because of dilution. Uranium isotopes, including ${ }^{233} \mathrm{U},{ }^{234} \mathrm{U}$, ${ }^{235} \mathrm{U}$, and ${ }^{238} \mathrm{U}$, were determined to be the primary alpha emitters. These phenomena are related to radiologically contaminated groundwater whose source is leakage to backfill and soil from Tank $\mathrm{W}-1 \mathrm{~A}$, an underground radioactive waste storage tank located in the North Tank Farm within the main ORNL facilities complex. Work conducted in 1998 indicates that there is infiltration of storm drains that discharge into Outfall 341, which discharges into First Creek. BJC began pumping a well south of the North Tank Farm in 2000 to remediate the groundwater; one of the consequences of this effort is the decline in radionuclides detected in surface water at First Creek (DOE 2001f). This groundwater extraction effort will continue until a final groundwater action is implemented for Bethel Valley.

Volatile organic compounds were detected at White Oak Creek at White Oak Dam in 2003: some chloroform and acetone, which is a common laboratory contaminant.

Two locations, one on Northwest Tributary [Northwest Tributary kilometer (NWTK) 0.1] and one on Raccoon Creek [Raccoon Creek kilometer (RCK) 2.0], also had elevated levels of gross beta and total radioactive strontium. Historically, results at both locations have a seasonal pattern; concentrations at Northwest Tributary are usually higher in the spring, whereas concentrations at
Raccoon Creek are usually higher in the fall. This pattern has been disrupted in the past several years. The apparent change in rainfall precipitation patterns since fall 2000 probably accounts for the change in the seasonality pattern. Both of these locations are impacted by contaminated groundwater from SWSA 3.

\subsection{ORNL SEDIMENT}

Stream and lake sediments act as a record of some aspects of water quality by concentrating and storing certain contaminants. Sampling sites for sediment are the Clinch River downstream from all DOE inputs [Clinch River kilometer (CRK) 16], the Clinch River downstream from ORNL (CRK 32), and the Clinch River at the Solway Bridge, upstream from all DOE inputs (CRK 70) (Fig. 5.23). The locations are sampled annually, and gamma scans are performed on the samples.

In addition, two samples per year containing settleable solids are collected in conjunction with a heavy rain event to characterize sediments that exit ORNL during a storm event. The sampling locations are Melton Branch upstream from ORNL (MEK 2.1), White Oak Lake at White Oak Dam (WCK 1.0), White Oak Creek downstream from ORNL (WCK 2.6), and White Oak Creek Headwaters as a reference location (Fig. 5.23). These samples are filtered, and the residue (settleable solids) is analyzed for gross alpha, gross beta, and gamma emitters. 


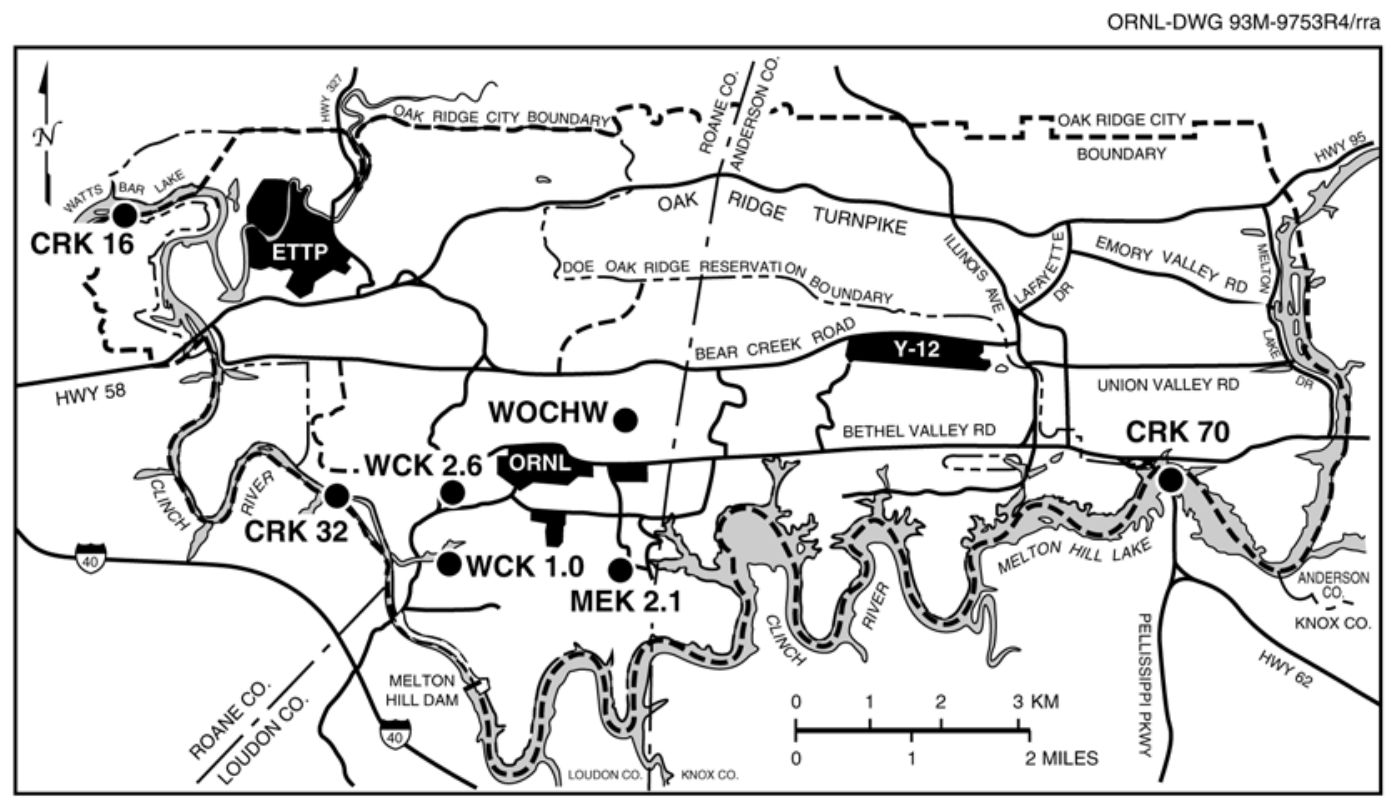

Fig. 5.23. ORNL sediment sampling locations.

\subsubsection{Results}

Potassium-40, which is a naturally occurring radionuclide, was detected in sediments at all three locations; ${ }^{137} \mathrm{Cs}$ was also detected in the sample collected at CRK 32.

Heavy-rain-event sampling took place in April and May 2003. The concentrations of radionuclides associated with each of these rain events are variable, which is common for these types of samples. Concentrations of ${ }^{137} \mathrm{Cs}$ were higher downstream than upstream, which is consistent with historical results.

\subsection{GROUNDWATER MONITORING AT ORNL}

\subsubsection{Background}

The groundwater monitoring program at ORNL consists of a network of wells of two basic types and functions: (1) water quality monitoring wells built to RCRA specifications and used for site characterization and compliance purposes and (2) piezometer wells used to characterize groundwater flow conditions. The Environmental Management and Enrichment Facilities Program, formerly the Environmental Restoration Program, provides comprehensive cleanup of sites where past $\mathrm{R} \& \mathrm{D}$ and waste management activities have resulted in contamination of the environment. The Environmental Management and Enrichment Facilities Program is managed by BJC. Impacts of current R\&D activities on groundwater at ORNL are monitored by UT-Battelle via the exit pathway monitoring program. The groundwater exit pathway monitoring program is a major part of the groundwater surveillance monitoring program managed by UT-Battelle for the DOE Office of Science.

Individual monitoring and assessment programs are impractical for each of the waste management and $R \& D$ sites because their boundaries are indistinct and there are hydrologic interconnections among many of them. Consequently, the concept of waste area groupings (WAGs) was developed in the late 1980 s to facilitate evaluation of potential sources of releases to the environment. A WAG is a grouping of multiple sites that are geographically contiguous and/or that occur within geohydrologically defined areas. WAGs and a watershed-based remediation approach established by BJC allow establishment of suitably comprehensive groundwater and surface water monitoring and remediation programs in a far shorter time than that required to deal with every facility, site, or solid waste management unit individually. At ORNL, 20 WAGs were identified by the RCRA Facility Assessment conducted in 1987. Water quality monitoring 
wells were established around the perimeters of the WAGs determined to have a potential for release of contaminants. Figure 5.24 shows the location of each of the 20 WAGs.

Groundwater quality monitoring wells for the WAGs are designated as hydraulically upgradient or downgradient (perimeter), depending on their location relative to the general direction of groundwater flow. Upgradient wells are located to provide groundwater samples that are not expected to be affected by possible leakage from the site. Downgradient wells are positioned along the perimeter of the site to detect possible groundwater contaminant migration from the site. No groundwater quality monitoring wells were installed for the WAG 10 grout sheets.

In 1996, DOE established the Integrated Water Quality Program to conduct long-term environmental monitoring throughout the ORR. The Water Resources Restoration Program succeeded the Integrated Water Quality Program in fall 1999. The Integrated Water Quality Program was managed by the Environmental Restoration Program at the time of its initiation.

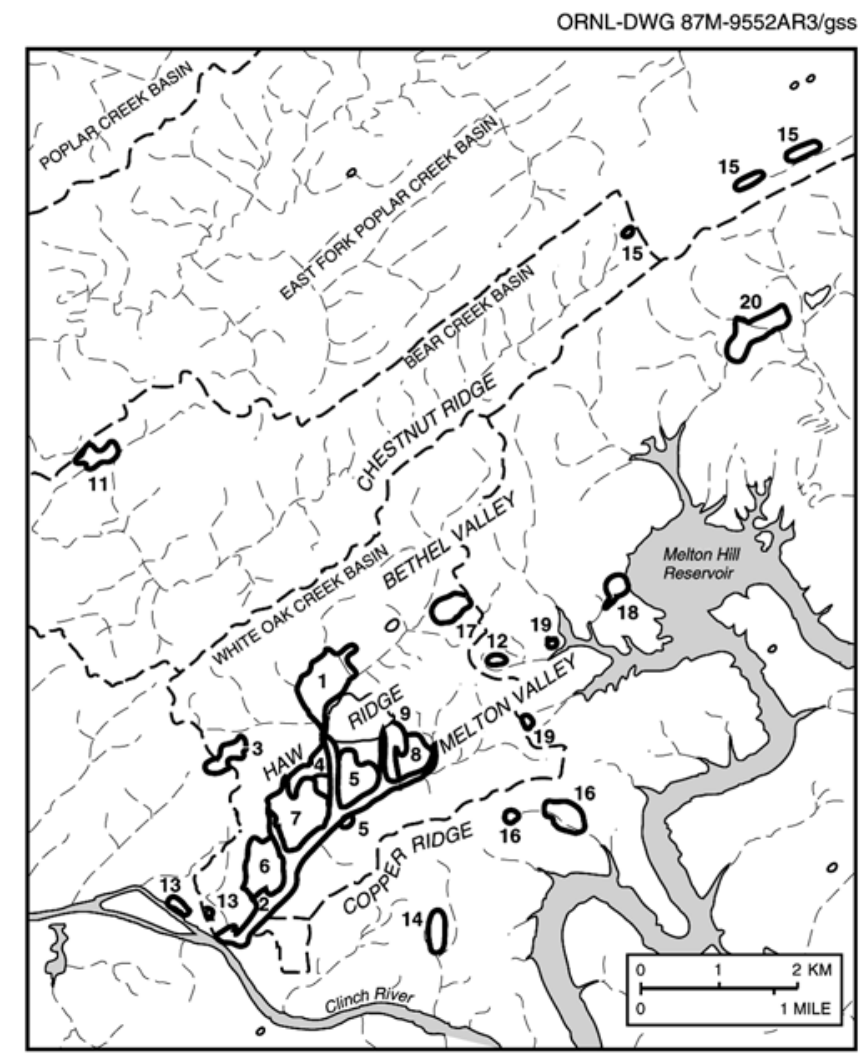

Fig. 5.24. Locations of ORNL waste area groupings (WAGs).
The Water Resources Restoration Program is currently managed by the Environmental Management and Enrichment Facilities Program through BJC and is the vehicle for the DOE to carry out the regulatory requirement from the Federal Facility Agreement to conduct postremedial action monitoring. The Water Resources Restoration Program has shifted away from the use of the WAG concept to more of a watershed approach to remediation, which resulted in the assignment of two watersheds to ORNL: Bethel Valley and Melton Valley.

The ORNL groundwater program was reviewed in 1996, and modifications included transfer of monitoring responsibility for some of the WAGs to the Water Resources Restoration Program. A summary of the ORNL groundwater surveillance program is presented in Table 5.9, which indicates whether WAGs are within Bethel Valley or Melton Valley. To provide continuity with previous annual site environmental reports and to allow comparison of activities and sampling results, the WAG concept is used in the following discussions. In the current ORNL program, groundwater quality wells are sampled on an annual basis (Table 5.9).

Monitoring results for remedial actions (under Water Resources Restoration Program purview) that are in progress or that have been completed within specific WAGs are reported annually in the Environmental Management and Enrichment Facilities Program Remediation Effectiveness Report (DOE 2003a). Additionally, in the case of WAG 6, which is regulated under both RCRA and CERCLA, specific monitoring results and interpretations required by RCRA are reported in the annual Groundwater Quality Assessment Report for Solid Waste Storage Area 6 (BJC 2003d), which is issued in February of each year.

UT-Battelle's WAG perimeter monitoring network and the ORNL plant perimeter groundwater surveillance program involved 49 wells in 2003. The ORNL exit pathway program is designated to monitor groundwater at locations that are thought to be likely exit pathways for groundwater affected by activities at ORNL. The program was initiated in 1993 and 
Table 5.9. Summary of the groundwater surveillance program at Oak Ridge National Laboratory, $\mathbf{2 0 0 3}^{\mathrm{a}}$

\begin{tabular}{|c|c|c|c|c|c|c|}
\hline \multirow{2}{*}{ WAG } & \multirow{2}{*}{ Regulatory status } & \multicolumn{2}{|c|}{ Wells } & \multirow{2}{*}{$\begin{array}{c}\text { Frequency and last } \\
\text { date sampled in } \\
2003\end{array}$} & \multirow{2}{*}{ Locations } & \multirow{2}{*}{ Parameters } \\
\hline & & Upgradient & Downgradient & & & \\
\hline \multicolumn{7}{|c|}{ Bethel Valley } \\
\hline 1 & $\begin{array}{l}\text { CERCLA and } \\
\text { DOE Orders } \\
5400.1 \text { and } 5400.5\end{array}$ & 3 & 24 & $\begin{array}{l}\text { Annually, April } \\
2003\end{array}$ & 4 wells & $\begin{array}{l}\text { Radionuclides }^{b} \text { and field } \\
\text { measurements }^{c}\end{array}$ \\
\hline 3 & $\begin{array}{l}\text { DOE Orders } \\
5400.1 \text { and } 5400.5\end{array}$ & 3 & 12 & $d$ & $d$ & $d$ \\
\hline 17 & $\begin{array}{l}\text { DOE Orders } \\
5400.1 \text { and } 5400.5\end{array}$ & 4 & 4 & $\begin{array}{l}\text { Annually, March - } \\
\text { April } 2003\end{array}$ & All wells & $\begin{array}{l}\text { Volatile organics, } \\
\text { radionuclides, }^{b} \text { and field } \\
\text { measurements }^{c}\end{array}$ \\
\hline \multicolumn{7}{|c|}{ Melton Valley } \\
\hline 2 & $\begin{array}{l}\text { CERCLA and } \\
\text { DOE Orders } \\
5400.1 \text { and } 5400.5\end{array}$ & 12 & 8 & $\begin{array}{l}\text { Annually, February } \\
2003\end{array}$ & $\begin{array}{l}4 \text { wells } \\
16 \text { wells }\end{array}$ & $\begin{array}{l}\text { Full set }{ }^{e} \text { and field } \\
\text { measurements }{ }^{c} \\
\text { Radionuclides }^{b} \text { and field } \\
\text { measurements }^{c}\end{array}$ \\
\hline 4 & $\begin{array}{l}\text { CERCLA and } \\
\text { DOE Orders } \\
5400.1 \text { and } 5400.5\end{array}$ & 4 & 11 & $d$ & $d$ & $d$ \\
\hline 5 & $\begin{array}{l}\text { CERCLA and } \\
\text { DOE Orders } \\
5400.1 \text { and } 5400.5\end{array}$ & 2 & 20 & $d$ & $d$ & $d$ \\
\hline 6 & $\begin{array}{l}\text { RCRA/CERCLA } \\
\text { and DOE Orders } \\
5400.1 \text { and } 5400.5\end{array}$ & 7 & 17 & $f$ & $f$ & $f$ \\
\hline 7 & $\begin{array}{l}\text { CERCLA and } \\
\text { DOE Orders } \\
5400.1 \text { and } 5400.5\end{array}$ & 2 & 14 & $d$ & $d$ & $d$ \\
\hline 8 and 9 & $\begin{array}{l}\text { DOE Orders } \\
5400.1 \text { and } 5400.5\end{array}$ & 2 & 9 & $\begin{array}{l}\text { Annually, March } \\
2003\end{array}$ & All wells & $\begin{array}{l}\text { Radionuclides }^{b} \text { and field } \\
\text { measurements }^{c}\end{array}$ \\
\hline \multicolumn{7}{|c|}{ White Wing Scrap Yard } \\
\hline 11 & $\begin{array}{l}\text { DOE Orders } \\
5400.1 \text { and } 5400.5\end{array}$ & 6 & 5 & $d$ & $d$ & $d$ \\
\hline
\end{tabular}

${ }^{a}$ Abbreviations

CERCLA = Comprehensive Environmental Response, Compensation, and Liability Act

DOE $=$ U.S. Department of Energy

RCRA $=$ Resource Conservation and Recovery Act

$\mathrm{WAG}=$ waste area grouping.

${ }^{b} \mathrm{Gross}$ alpha and beta, ${ }^{3} \mathrm{H},{ }^{137} \mathrm{Cs},{ }^{60} \mathrm{Co}$, and total radioactive strontium.

${ }^{c}$ Standard field measurements: $\mathrm{pH}$, conductivity, turbidity, oxidation/reduction potential, temperature, and dissolved oxygen.

${ }^{d}$ Water Resources Restoration Program (formerly Integrated Water Quality Program) samples selected wells for various purposes; other wells are inactive.

${ }^{e}$ Volatile organics, metals, gross alpha and beta, ${ }^{3} \mathrm{H},{ }^{137} \mathrm{Cs},{ }^{60} \mathrm{Co}$, and total radioactive strontium.

${ }^{f}$ Sampled by Environmental Management and Enrichment Facilities and data reported in the Groundwater Quality Assessment Report for Solid Waste Storage Area 6 at Oak Ridge National Laboratory, Oak Ridge,

Tennessee CY 2002, February 2003, Bechtel Jacobs Company, LLC (BJC 2003d). 
was reviewed in 1996, which resulted in White Oak Creek and Melton Valley being the focus of the program (Fig. 5.25). A summary of the current program is presented in Table 5.10.

Four of the ten wells that make up ORNL's exit pathway monitoring program are also part of the WAG perimeter monitoring program. These four wells are located on WAG 2, and 2003 data from these four wells were used in conjunction with data from the six exit pathway wells for analyzing the exit pathway monitoring program. The results of the plant perimeter and exit pathway monitoring programs are discussed in part in the following sections.

None of the ORNL WAGs monitored under UT-Battelle's surveillance groundwater

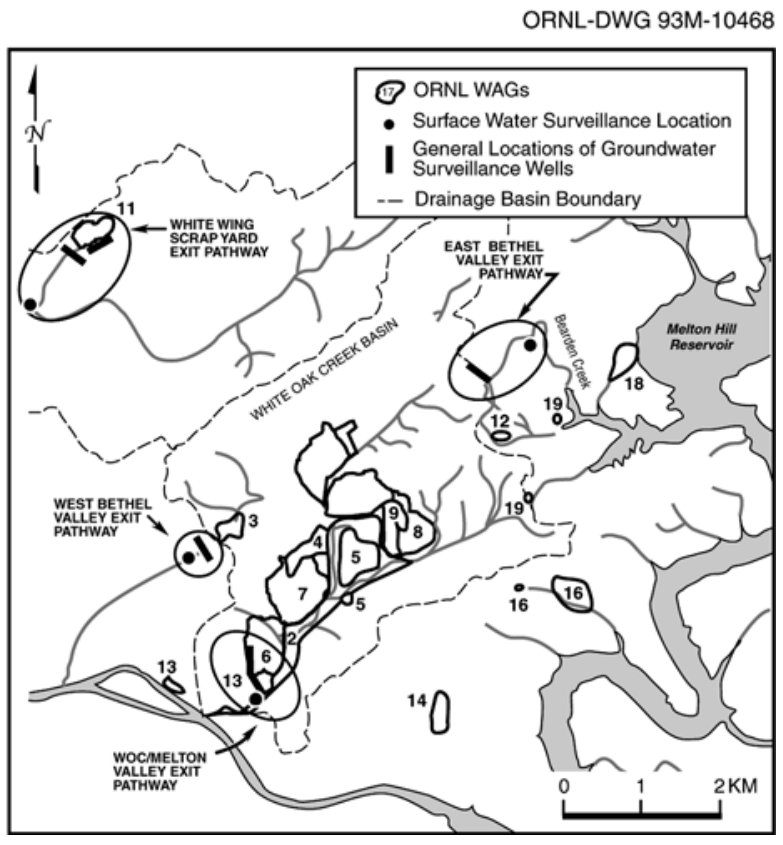

Fig. 5.25. Groundwater exit pathways on the Oak Ridge Reservation that are likely to be affected by Oak Ridge operations. monitoring program are regulated under RCRA permits; therefore, no permit standards exist withwhich to compare sampling results. WAG 6 is monitored under a combined RCRA/CERCLA regulatory strategy and is not monitored under the UT-Battelle surveillance groundwater monitoring program. In an effort to provide a basis for evaluation of analytical results and for assessment of groundwater quality monitored by UT-Battelle at the ORNL WAGs, federal drinking water standards, and Tennessee Water Quality Criteria for domestic water supplies are used as reference values in the following discussions. When no federal or state standard has been established for a radionuclide, then $4 \%$ of the DOE DCG is used. Although drinking water standards are used, it is important to realize that no members of the public consume groundwater from ORNL WAGs, nor do any groundwater wells furnish drinking water to personnel at ORNL.

Trend analyses were performed on exit pathway wells of interest, e.g., wells which monitor areas or facilities actively managed by UT-Battelle whose organic, heavy metal (RCRA metals), or radiological contaminants exceeded their respective reference values during 2003. Naturally occurring inorganic contaminants (metals such as aluminum, iron, manganese, and zinc) whose 2003 concentrations exceeded their reference values were not subjected to trend analysis because these constituents are commonly found in the soil and rock composing the earth's crust and are regularly found in groundwater samples collected from wells at ORNL. The trend analysis was performed using historical data collected from 1991 through the 2003 monitoring period.

Table 5.10. Summary of the plant perimeter surveillance program at Oak Ridge National Laboratory, 2003 ${ }^{a}$

\begin{tabular}{lccll}
\hline \multicolumn{1}{c}{ Exit pathway } & WAG & $\begin{array}{c}\text { Number } \\
\text { of wells }\end{array}$ & Surface water locations & Parameters \\
\hline $\begin{array}{l}\text { White Oak Creek/ } \\
\text { Melton Valley }\end{array}$ & 6 and $2^{b}$ & 10 & $\begin{array}{l}\text { White Oak Creek at } \\
\text { White Oak Dam }\end{array}$ & $\begin{array}{l}\text { Volatile organics, ICP metals, }{ }^{3} \mathrm{H}, \\
\text { total radioactive strontium, gross } \\
\text { alpha and beta, }{ }^{60} \mathrm{Co}, \text { and }{ }^{137} \mathrm{Cs}\end{array}$ \\
\hline
\end{tabular}

${ }^{a}$ Abbreviations

ICP = inductively coupled plasma.

$\mathrm{WAG}=$ waste area grouping.

${ }^{b}$ Four wells are part of the ORNL WAG 2 perimeter network. 


\subsubsection{Bethel Valley}

Bethel Valley, located in the southeastern portion of the ORR, lies between two prominent, parallel, northeast-southwest trending ridges, Chestnut Ridge to the north and Haw Ridge to the south. Research and development facilities have been located within it for 50 years, and it contains the main ORNL facilities complex, including buildings, reactors, surface impoundments, and buried waste tank farms with transfer pipelines. In most instances, groundwater flow in Bethel Valley is from the northeast to southwest (i.e., parallel to the strike direction), and contaminant plumes generally enter the surface water system.

\subsubsection{WAG 1 Area}

WAG 1 , the ORNL main plant area, contains about one-half of the remedial action sites identified to date by the Environmental Management and Enrichment Facilities Program. WAG 1 lies within the Bethel Valley portion of the White Oak Creek drainage basin. The boundaries of the basin extend to the southeast and northeast along Chestnut Ridge and Haw Ridge. The WAG boundary extends to the water gap in Haw Ridge. The total area of the basin in Bethel Valley is about 2040 acres. Bedrock beneath the main plant area is composed of limestone, siltstone, and calcareous shale facies of the Ordovician Chickamauga Group.

Many of the WAG 1 sites were used to collect and store low-level waste in tanks, ponds, and waste treatment facilities, but some sites also include landfills and contaminated sites resulting from spills and leaks that have occurred over the last 50 years. Because of the nature of cleanup and repair, it is not possible to determine which spill or leak sites still represent potential sources of release. Most of the solid waste management units are related to ORNL's past waste management operations.

\section{WAG 1 Results}

UT-Battelle activities to monitor groundwater discharging from WAG 1 include sampling four wells $(807,808,809$, and 830) in the southwest area of WAG 1, near the water gap in Haw Ridge that separates Bethel Valley from Melton Valley.
These four wells are located downgradient of the main plant facilities in WAG 1 . Shallow groundwater flow within WAG 1 is southward toward White Oak Creek. In 2003, these wells were sampled for radiological contaminants (gross alpha, gross beta, total radioactive strontium, tritium, and gamma-emitting radionuclides). The radiological contaminant concentrations in these wells in 2003 did not exceed reference values used for comparison. Recent Environmental Management and Enrichment Facilities Program activities in WAG 1 are summarized in the annual Water Resources Restoration Program Remediation Effectiveness Report (DOE 2003a).

\subsubsection{WAG 3 Area}

WAG 3 is located in Bethel Valley, about 0.6 mile $(1 \mathrm{~km})$ west of the main plant area. WAG 3 is composed of three solid waste management units: Solid Waste Storage Area (SWSA) 3, the Closed Scrap Metal Area (1562), and the Contractors' Landfill (1554).

SWSA 3 and the Closed Scrap Metal Area are inactive landfills known to contain radioactive solid wastes and surplus materials generated at ORNL from 1946 to 1979. Burial of solid waste ceased at this site in 1951; however, the site continued to be used as an aboveground scrap metal storage area until 1979. Sometime during the period from 1946 to 1949 , radioactive solid wastes removed from SWSA 2 were buried at this site. In 1979, most of the scrap metal stored aboveground at SWSA 3 was either transferred to other storage areas or buried on site in a triangleshaped disposal area immediately south of SWSA 3.

Records of the composition of radioactive solid waste buried in SWSA 3 were destroyed in a fire in 1961. Sketches and drawings of the site indicate that alpha and beta-gamma wastes were segregated and buried in separate areas or trenches. Chemical wastes were probably also buried in SWSA 3 because there are no records of disposal elsewhere. Although the information is sketchy, the larger scrap metal equipment (such as tanks and drums) stored on the surface at this site was also probably contaminated. Because only a portion of this material is now buried in the Closed Scrap Metal Area, it is not possible to 
estimate the amount of contamination that exists in this solid waste management unit.

The Contractors' Landfill was opened in 1975 and is now closed. It was used to dispose of various uncontaminated construction materials. No contaminated waste or asbestos was allowed to be buried at the site. ORNL disposal procedures required that only non-RCRA, nonradioactive solid wastes were to be buried in the Contractors' Landfill.

\section{WAG 3 Results}

Groundwater monitoring in WAG 3 is performed under the Water Resources Restoration Program. Any activities to be reported are published in the annual Water Resources Restoration Program Remediation Effectiveness Report (DOE 2003a).

\subsubsection{WAG 17 Area}

WAG 17 (7000 Area) is located about 1 mile $(1.6 \mathrm{~km})$ directly east of the ORNL main plant area and is situated on a relatively flat limb of the northwest-facing slope of Haw Ridge. It has served as the major craft and machine shop area for ORNL since the late 1940s. The area includes the receiving and shipping departments, machine shops, carpenter shops, paint shops, lead-melting facilities, garage facilities, welding facilities, and material storage areas needed to support ORNL's routine and experimental operations. WAG 17 is composed of 18 solid waste management units. A former septic tank is now used as a sewage collection/pumping station for the area. Photographic waste tanks have been removed. Four old petroleum underground storage tanks (USTs) were removed during the period from 1987 to 1990, and closure approval for them was received from TDEC in 1997. Two relatively new USTs were registered with TDEC and are used to store diesel fuel and gasoline at the ORNL gas station.

\section{WAG 17 Results}

Upgradient and downgradient wells surround WAG 17. The upgradient wells $(1196,1197$, 1198, and 1199) are located on the eastern boundary of WAG 17, and the downgradient wells
(1200, 1201, 1202, and 1203) are located on its western boundary. General groundwater flow is to the north and west toward White Oak Creek. A portion of the area's groundwater flow is to the southeast toward an unnamed tributary to Bearden Creek. In 2003, these wells were sampled for radiological contaminants (gross alpha, gross beta, total radioactive strontium, tritium, and gammaemitting radionuclides) and volatile organic compounds. The radiological contaminant concentrations in 2003 were below their respective reference values. In 2003, several volatile organic contaminants were observed to exceed their respective reference values in Well 1201. Included in this suite were 1,1dichloroethene, benzene, tetrachloroethene, trichloroethene, and vinyl chloride. Trichloroethene was observed to exceed its reference value in Well 1202.

Trend analysis was performed on those organic contaminants that exceeded their respective reference values during 2003. The trend analysis was performed using historical data collected through 2003. No statistically significant trends were observed for 1,1-dichloroethene, tetrachloroethene, trichloroethene, or vinyl chloride in Well 1201. A statistically significant downward trend was observed for benzene in Well 1201 (at a level of significance of 0.01). A statistically significant upward trend was detected for trichloroethene in Well 1202 (at a significance level of 0.2). The presence of the organic contaminants at the western periphery of WAG 17 is related to continued discharges of legacy contamination associated with past usage of cleaning solvents and operation of garage facilities within WAG 17.

\subsubsection{Melton Valley}

Melton Valley is the second of the two valleys that comprise ORNL. Melton Valley is of primary importance on the ORR because it is one of the major waste storage areas on the reservation. In addition to containing surface structures, it is the location of shallow waste burial trenches and auger holes, landfills, tanks, impoundments, seepage pits, hydrofracture wells and grout sheets, and waste transfer pipelines and associated leak sites. As with plumes in Bethel Valley, groundwater plumes within Melton Valley 
generally enter the surface water system where contaminants are frequently encountered.

\subsubsection{WAG 2 Area}

WAG 2 is composed of White Oak Creek discharge points and includes the associated floodplain and subsurface environment. It represents the major drainage system for ORNL and the surrounding facilities.

In addition to natural drainage, White Oak Creek has received treated and untreated effluents and reactor cooling water from ORNL activities since 1943. Controlled releases include those from the Process Waste Treatment Complex, the Sewage Treatment Plant, and a variety of process waste holding ponds throughout the ORNL main plant area (WAG 1). It also receives groundwater discharge and surface drainage from WAGs 1,4 , 5, 6, 7, 8, and 9 (see Fig. 5.24).

WAG 2 represents a source of continuing contaminant release (radionuclides and/or chemical contaminants) to the Clinch River. Although it is known that WAG 2 receives groundwater contamination from other WAGs, the extent to which it may be contributing to groundwater contamination has yet to be completely resolved.

\section{WAG 2 Results}

Many of the wells sampled within WAG 2 monitor discharges to White Oak Creek and are therefore classified as downgradient wells. These wells are generally located to the southwest and downstream of the main plant area of ORNL. Downgradient wells monitored during 2003 include 1152, 1154, 1155, 1156, 1185, 1186, 1187, 1188, 1189, 1190, 1191, 1192, 1193, 1194, 1195, 1244, and 1245. Upgradient wells are located upslope and to the south of the main plant area of ORNL. Upgradient wells monitored during 2003 include 1150, 1151, and 1153. In 2003, the following wells were sampled for metals, volatile organic compounds, and radiological contaminants (gross alpha, gross beta, total radioactive strontium, tritium, and gammaemitting radionuclides): 1189, 1190, 1191, and 1192 (all four wells are WAG 2 and exit pathway wells); all other WAG 2 wells were sampled for radiological contaminants only. Three radiological contaminant constituents exceeded their respective reference values in 2003: tritium in Well 1152, tritium in Well 1156, gross beta activity and tritium in Well 1191, tritium in Well 1190, gross alpha activity in Well 1194, and gross beta activity in Well 1244 .

Trend analysis was performed for those wells that are part of the exit pathway monitoring program that exceeded their respective reference values during 2003. Statistically downward trends are observed (at a significance level of 0.01) for tritium in Well 1190 and for gross beta and tritium in Well 1191. Because Well 1152 is located downgradient of the HFIR complex, trend analysis was performed on its historical tritium data collected through 2003. A statistically significant upward trend continues to be observed for tritium in Well 1152 (at a level of significance of 0.01). Well 1152 is located downgradient of the HFIR; the upward trend is most likely due to the tritium leak from the process waste drain line.

The presence of the radiological contaminants is related to continued discharges of legacy contamination associated with past waste disposal activities within the WAGs that drain into WAG 2. Several metal contaminants exceeded their respective reference values during 2003, but these metals (e.g., aluminum, iron, and manganese) are commonly found in the soil and rock composing the earth's crust. No volatile organic compounds were present above their respective detection limits in 2003. Recent Environmental Management and Enrichment Facilities Program activities in WAG 2 are summarized in the annual Water Resources Restoration Program Remediation Effectiveness Report (DOE 2003a).

\subsubsection{WAG 4 Area}

WAG 4 is located in Melton Valley about 0.5 mile $(0.8 \mathrm{~km})$ southwest of the main ORNL plant site. It comprises the SWSA 4 waste disposal area, liquid low-level radioactive waste (LLLW) transfer lines, and the experimental Pilot Pit Area (Area 7811).

SWSA 4 was opened for routine burial of solid radioactive wastes in 1951. From 1955 to 1959, ORNL' SWSA 4 was designated by the Atomic Energy Commission as the Southern Regional Burial Ground. As such, SWSA 4 
received a wide variety of poorly characterized solid wastes (including radioactive waste) from about 50 sources. These wastes consisted of paper, clothing, equipment, filters, animal carcasses, and related laboratory wastes. About $50 \%$ of the waste was received from sources outside of Oak Ridge facilities. Wastes were placed in trenches, shallow auger holes, and in piles on the ground for covering at a later date.

From 1954 to 1975 , LLLW was transported from storage tanks at the main ORNL complex to waste pits and trenches in Melton Valley (WAG 7), and later to the hydrofracture disposal sites through underground transfer lines. The Pilot Pit Area was constructed for use in pilot-scale radioactive waste disposal studies from 1955 to 1959; three large concrete cylinders containing experimental equipment remain embedded in the ground.

\section{WAG 4 Results}

Groundwater monitoring in WAG 4 was transferred to the Integrated Water Quality Program (now the Water Resources Restoration Program) in 1996. Recent monitoring activities to be reported are published in the annual Water Resources Restoration Program Remediation Effectiveness Report (DOE 2003a).

\subsubsection{WAG 5 Area}

WAG 5 contains 33 solid waste management units, 13 of which are tanks that were used to store LLLW prior to disposal by the hydrofracture process. WAG 5 also includes the surface facilities constructed in support of both the old and new hydrofracture facilities. The largest land areas in WAG 5 are the areas devoted to transuranic waste in SWSA 5 South and SWSA 5 North. The remaining sites are support facilities for ORNL's hydrofracture operations, two LLW pipeline leak/spill sites, and an impoundment in SWSA 5 used to dewater sludge from the original Process Wastewater Treatment Facility. Currently, LLW tanks at the new hydrofracture facility are being used to store evaporator concentrates pending a decision regarding ultimate disposal of these wastes.

SWSA 5 South was used to dispose of solid low-level radioactive waste (LLW) generated at
ORNL from 1959 to 1964 . During this time, the burial ground served as the Southern Regional Burial Ground for the Atomic Energy Commission. At the time SWSA 5 burial operations were initiated, about 10 acres of the site were set aside for the retrievable storage of transuranic wastes.

The WAG 5 boundary includes the Old Hydrofracture Facility and the New Hydrofracture Facility. Because Melton Branch flows between these facilities, the New Hydrofracture Facility has a separate boundary.

\section{WAG 5 Results}

Groundwater monitoring in WAG 5 was transferred to the Water Resources Restoration Program in 1996. Recent monitoring activities to be reported are published in the annual Water Resources Restoration Program Remediation Effectiveness Report (DOE 2003a).

\subsubsection{WAG 6 Area}

WAG 6 consists of four solid waste management units: (1) SWSA 6, (2) Building 7878 , (3) the explosives detonation trench, and (4) Building 7842. SWSA 6 is located in Melton Valley, northwest of White Oak Lake and southeast of Lagoon Road and Haw Ridge. The site is about 1.2 miles $(2 \mathrm{~km})$ south of the main ORNL complex. Waste burials at this 68 -acre site were initiated in 1973, when SWSA 5 was closed. Various radioactive and chemical wastes were buried in trenches and auger holes. SWSA 6 is the only currently operating disposal area for LLW at ORNL. The emergency waste basin was constructed in 1961 to provide storage of liquid wastes that could not be released from ORNL to White Oak Creek. The basin, located northwest of SWSA 6, has a capacity of 15 million gal but has never been used. Radiological sampling of the small drainage from the basin has shown the presence of some radioactivity. The source of this contamination is not known.

WAG 6 was among the first WAGs to be investigated at ORNL by the Environmental Management and Enrichment Facilities Program. Several RCRA interim status units (having received RCRA-regulated hazardous waste) are 
located in WAG 6. Environmental monitoring is carried out under CERCLA and RCRA.

\section{WAG 6 Results}

Information about WAG 6 monitoring results in 2003 is available in the 2003 Groundwater Quality Assessment Report for Solid Waste Storage Area 6 (BJC 2003d).

\subsubsection{WAG 7 Area}

WAG 7 is located in Melton Valley about 1 mile $(1.6 \mathrm{~km})$ south of the ORNL main plant area. The major sites in WAG 7 are the seven pits and trenches used from 1951 to 1966 for disposal of LLLW. WAG 7 also includes a decontamination facility, three leak sites, a storage area containing shielded transfer tanks and other equipment, and seven fuel wells used to dispose of acid solutions primarily containing enriched uranium from Homogeneous Reactor Experiment fuel.

\section{WAG 7 Results}

Groundwater monitoring in WAG 7 was transferred to the Integrated Water Quality Program (now the Water Resources Restoration Program) in 1996. Recent monitoring results activities to be reported are published in the annual Water Resources Restoration Program Remediation Effectiveness Report (DOE 2003a).

\subsubsection{WAG 8 and 9 Areas}

Because of the small number of groundwater monitoring wells in WAGs 8 and 9, they are sampled together. The analytical results for the two WAGs are also reported together. Wells monitored within WAGs 8 and 9 include 1087, 1088, 1090, 1089, 1090, 1091, 1092, 1093, 1094, and 1095 . Wells monitored within WAG 9 include 1096 and 1097.

WAG 8, located in Melton Valley, south of the main plant area, is composed of 36 solid waste management units associated with the reactor facilities in Melton Valley. The solid waste management units consist of active LLLW collection and storage tanks, leak/spill sites, a contractors' soils area, radioactive waste ponds and impoundments, and chemical and sewage waste treatment facilities. WAG 8 includes the Molten Salt Reactor Experiment facility, the HFIR, and the Radionuclide Engineering Development Center. A removal action was initiated at the Molten Salt Reactor Experiment during 1995 to remove filtration devices contaminated with uranium.

Radioactive wastes from WAG 8 facilities are collected in on-site LLLW tanks and are periodically pumped to the main plant area (WAG 1) for storage and treatment. The waste includes demineralizer backwash, regeneration effluents, decontamination fluids, experimental coolant, and drainage from the compartmental areas of filter pits.

An abnormally high tritium concentration was reported in October 2000, in the foundation drain system associated with the HFIR building (Building 7900). As a result, characterization monitoring was conducted to determine the location of the leak site and the extent of contamination. This monitoring included sampling a number of wells, drains, outfalls, and a groundwater seep located in the immediate vicinity of Building 7900. The characterization effort revealed a leak in the process waste drain system for HFIR. Characterization efforts continued throughout 2001 and revealed a general drop in tritium concentrations during the winter and spring of 2001. Using the data generated during the characaterization effort, the Operational Monitoring Plan for the High Flux Isotope Reactor Site (Bonine 2002) was implemented in June 2001. The plan required that upgradient and downgradient wells, drain systems, outfalls, and the seeps be monitored over a period of one year (June 2001 through June 2002). As a result, several monitoring wells were installed hydraulically upgradient and downgradient of Building 7900 to supplement the existing well network used during the characterization effort. The monitoring plan was designed to (1) provide early detection of groundwater contamination due to operational activities or system failures at the HFIR site, (2) monitor significant changes in groundwater contamination caused by the tritium leak, and (3) monitor sources of groundwater contamination located hydraulically upgradient of the HFIR site. 
Analysis of monitoring data acquired from the inception of monitoring was used to update the conceptual model of groundwater flow and contaminant movement at the HFIR site. The conceptual model identifies rapid-flow and slowflow components of the groundwater system. The rapid-flow pathways of subsurface water and contaminant movement are associated with human-made features, including pipelines and their excavated trenches and the HFIR building foundation drainage system. The slow-flow region in the HFIR area is groundwater in soil and bedrock as monitored by the monitoring-well network. Under the Operational Monitoring Plan, tritium and gamma-emitting radionuclides were the main contaminants of concern being monitored because their presence would be indicative of further releases from the HFIR. The leak in the process waste drain pipe was repaired during the summer of 2001.

Monitoring required by the Operational Monitoring Plan was completed during 2002. Data generated by the Operational Monitoring Plan were analyzed, and the findings of the analysis were reported in the Summary of Baseline Operational Monitoring Activities at the High Flux Isotope Reactor Site (Bonine and Ketelle 2002).

The information gathered from monitoring activities pursued under the Operational Monitoring Plan was used to generate the Annual Monitoring Plan for the High Flux Isotope Reactor Site (Bonine 2003) for the period August 2002 through August 2003. This monitoring plan was conducted to meet the three design elements outlined in the Operational Monitoring Plan. Under the Annual Monitoring Plan, gammaemitting radionuclides were dropped from consideration as contaminants of concern. Consequently, tritium was the only contaminant of concern monitored during 2003. Additional changes made to the Operational Monitoring Plan as outlined in the Annual Monitoring Plan included changes in monitoring point locations and sampling frequencies. Details of the changes in the monitoring program from 2002 to 2003 can be found in the Annual Monitoring Plan. A summary of the findings of the Annual Monitoring Plan are found in the next section.

\section{HFIR Annual Monitoring Plan Results}

The report Summary of 2002/2003 Annual Monitoring Activities at the High Flux Isotope Reactor Site: Monitoring Period August 2002 through August 2003 (Bonine and Ketelle 2004) presents and interprets the data obtained from the annual tritium monitoring efforts completed at the HFIR site during the period of August 2002 through August 2003. The primary purpose of the monitoring program is to provide continued early detection of releases to groundwater from HFIR operational activities or system failures. Additional objectives are to track the mass of the tritium plume in the vicinity of HFIR and to monitor potential sources of groundwater contamination located hydraulically upgradient of the HFIR.

During the August 2002 through August 2003 monitoring period, the discharge of tritium from the groundwater plume increased because of above average rainfall. Normal annual average rainfall in Oak Ridge is approximately 54 inches compared to the 70 inches of rainfall recorded at the ORNL site for FY 2003. The increased rainfall caused higher recharge to the groundwater system, resulting in increased plume discharge from the bedrock zone into the rapid-flow discharge pathways monitored at the Building 7900 foundation drain system. Tritium concentration action levels and notification requirements established in the Annual Monitoring Plan were exercised frequently during the winter of 2003 because of the increased plume discharge. Nonetheless, no evidence of additional contaminant discharge from the HFIR facility or associated systems was detected during 2003.

Despite exceedances of action levels set forth in the Annual Monitoring Plan for the foundation drain monitoring points, overall trends in tritium concentration continued to decrease at most monitoring points during 2003. The principal exceptions to the general downward tritium concentration trend were in downgradient wells 661 and 4532, which exhibited a statistically insignificant increase in tritium concentration during 2003. Moreover, tritium concentration achieved its maximum concentration in downgradient Well 892 in June 2002, and during 2003 tritium concentrations showed a statistically significant decrease in Well 892. These wells are 
located in an area of less permeable bedrock downgradient of the HFIR facility, and migration of tritium into less permeable material is expected to occur more slowly than the rate of tritium movement through the remainder of the hydrologic system (rapid flow associated with the HFIR drain system). The statistically insignificant increases in tritium trend in Wells 661 and 4532 and the statistically significant decrease in trend in Well 892 indicates that the deeper-seated portion of the tritium plume is moving downgradient away from Building 7900 toward eventual discharge into Melton Branch.

No evidence was found that significant sources of contaminant release to the environment have occurred upgradient of the HFIR facility. Monitoring results from three upgradient groundwater monitoring wells installed in response to the tritium investigation showed consistently low to nondetectable concentrations of tritium during 2003.

The 2002/2003 annual monitoring summary report (Bonine and Kettelle 2004) includes a summary of the evolution of the tritium plume and applies a water balance model and trended groundwater tritium concentration information to simulate the tritium concentration history observed in the Building 7900 foundation drain system.

\section{WAGs 8 and 9 Results}

Wells in WAGs 8 and 9 were sampled for total radioactive strontium, tritium, gross alpha, gross beta, and gamma-emitting radionuclides in 2003. A total of two radiological constituents exceeded their respective reference values during 2003 in wells located in WAGs 8 and 9 (gross beta activity in Wells 1087, 1096, and 1097 and tritium in Well 1088).

\subsubsection{WAG 10 Area}

WAG 10 consists of the Old Hydrofracture Facility grout sheets, the New Hydrofracture Facility, and the New Hydrofracture Facility grout sheets. The surface facilities are also associated with WAGs 5,7 , and 8.

Hydrofracture Experiment Site 1, located within the boundary of WAG 7 (south of Lagoon Road), was the site of the first experimental injection of grout (October 1959) in a testing program for observing the fracture pattern created in the shale and for identifying potential operating problems. Injected waste was water-tagged with ${ }^{137} \mathrm{Cs}$ and ${ }^{141} \mathrm{Ce}$. Grout consisted of diatomaceous earth and cement.

Hydrofracture Experiment Site 2 is located about $0.8 \mathrm{~km}$ ( 0.5 mile) south of the 7500 (experimental reactor) area in WAG 8 . The second hydrofracture experiment was designed to duplicate, in scale, an actual disposal operation; however, radioactive tracers were used instead of actual waste. Cement, bentonite, and water tagged with ${ }^{137} \mathrm{Cs}$ were used in formulating the grout.

The Old Hydrofracture Facility is located about $1.6 \mathrm{~km}$ (1.0 mile) southwest of the main ORNL complex, near the southwest corner of WAG 5. Commissioned in 1964, the facility was used to dispose of liquid radioactive waste in impermeable shale formations at depths of 800 to $1000 \mathrm{ft}$ by hydrofracture methods. Wastes used in the disposal operations included concentrated LLLW from the gunite tanks in WAG $2,{ }^{90} \mathrm{Sr}$, ${ }^{137} \mathrm{Cs},{ }^{244} \mathrm{Cm}$, transuranics, and other (unidentified) radionuclides.

The New Hydrofracture Facility, constructed to replace the Old Hydrofracture Facility, is located $900 \mathrm{ft}$ southwest of the Old Hydrofracture Facility, on the south side of Melton Branch. Wastes used in the injections were concentrated LLLW and sludge removed from the gunite tanks, ${ }^{90} \mathrm{Sr},{ }^{137} \mathrm{Cs},{ }^{244} \mathrm{Cm}$, transuranics, and other nuclides. Recent Environmental Management and Enrichment Facilities Program activities at WAG 10 are summarized in the annual Water Resources Restoration Program Remediation Effectiveness Report (DOE 2003a).

\subsubsection{Melton Valley Exit Pathway Results}

Ten monitoring wells are located on the groundwater exit pathway for Melton Valley. Four of these wells $(1189,1190,1191$, and 1192) are also part of the WAG 2 groundwater monitoring program and have been discussed in Sect. 5.11.3.1. Consequently, only six wells (860, $857,858,859,1236$, and 1239) will be discussed in this section. The six exit pathway wells were monitored for volatile organic compounds, metals, gross alpha and beta, tritium, total radioactive 
strontium, and gamma emitters during 2003. None of the concentrations of contaminants of concern in samples collected during 2003 from these six wells exceeded their respective reference values for contaminants of concern. (There were exceedances for iron and aluminum.)

Surface water is also sampled at White Oak Dam (monitoring station WCK 1.0) and is considered part of the exit pathway monitoring program. Gross beta activity exceeded its reference values during 2003. It most likely originated from legacy contamination associated with past waste disposal practices in the Melton Valley WAGs. Sen's slope/Mann Kendall trend analysis was performed on gross beta data using historical data accumulated through 2003. The gross beta data exhibited a statistically significant decreasing trend throughout its monitoring history at a level of significance of 0.2 .

\subsubsection{White Wing Scrap Yard}

\subsubsection{White Wing Scrap Yard (WAG 11) Area}

The White Wing Scrap Yard (WAG 11), a largely wooded area of about 30 acres, is located in the McNew Hollow area on the western edge of East Fork Ridge. It is $1.4 \mathrm{~km}(0.9$ mile $)$ east of the junction of White Wing Road and the Oak Ridge Turnpike. Geologically, the White Oak thrust fault bisects WAG 11. Lower-Cambrian-age strata of the Rome Formation occur southwest of the fault and overlie the younger Ordovician-age Chickamauga Limestone northeast of the fault. There is only one solid waste management unit in WAG 11.

The White Wing Scrap Yard was used for aboveground storage of contaminated material from ORNL, the ETTP, and the Y-12 Complex. The material stored at the site by ORNL consisted largely of contaminated steel tanks; trucks; earthmoving equipment; assorted large pieces of steel, stainless steel, and aluminum; and reactor cell vessels removed during cleanup of Building 3019. TDEC, EPA, and DOE agreed to an interim record of decision that required the removal of surface debris from the site. This work was completed in 1994.

The area began receiving material (primarily metal, glass, concrete, and trash with alpha, beta, and gamma contamination) in the early 1950s. Information regarding possible hazardous waste contamination has not been found. The precise dates of material storage are uncertain, as is the time when the area was closed to further storage. In 1966, efforts were begun to clean up the area by disposing of contaminated materials in SWSA 5 and by the sale of uncontaminated material to an outside contractor for scrap. Cleanup continued at least into 1970, and removal of contaminated soil began in the same year. Some scrap metal, concrete, and other trash are still located in the area. Numerous radioactive areas, steel drums, and PCB-contaminated soil were identified during surface radiological investigations conducted in 1989 and 1990 at WAG 11. The amount of material or contaminated soil remaining in the area is not known. Recent Environmental Management and Enrichment Facilities Program activities in WAG 11 are summarized in the annual Water Resources Restoration Program Remediation Effectiveness Report (DOE 2003a).

\section{White Wing Scrap Yard (WAG 11) Results}

Groundwater monitoring in WAG 11 was transferred to the Integrated Water Quality Program (now the Water Resources Restoration Program) in 1996. Any activities to be reported are published in the annual Water Resources Restoration Program Remediation Effectiveness Report (DOE 2003a).

\subsection{WELL PLUGGING AND ABANDONMENT AT ORNL}

The purpose of the ORNL well plugging and abandonment program is to remove unneeded wells and boreholes as possible sources of crosscontamination of groundwater from the surface or between geological formations. Because of the complex geology and groundwater pathways at ORNL, it has been necessary to drill many wells and boreholes to establish the information base needed to predict groundwater properties and behavior. However, many of the wells established before the 1980s were not constructed to serve current long-term monitoring requirements. Where existing wells do not meet monitoring requirements, they become candidates for plugging and abandonment. 


\subsubsection{Wells Plugged During 2003}

During CY 2003 BJC completed plugging and abandonment of 29 hydrofracture-related wells.

To support closure activities included in the Melton Valley Record of Decision, BJC initiated well plugging and abandonment of nonhydrofracture wells in Melton Valley in September 2003 (DOE 2001a and BJC 2003e). During the months of September through December 2003, a total of 394 nonhydrofracture wells were plugged and abandoned.

\subsubsection{Methods Used}

Plugging and abandonment of wells are accomplished by splitting the existing well casing and filling the casing and annular voids with grout or bentonite to create a seal between the ground surface and water-bearing formations, and between naturally isolated water-bearing formations.

Splitting and abandoning the well casing in place minimizes the generation of waste that would be created if other methods were used. Specialized tools have been developed to split well casings of different sizes and compositions and are used when wells are plugged and abandoned at ORNL.

Detailed procedures have been developed and documented regarding the use of specific grout materials in different well environments. These procedures were tested and evaluated during the 1993 plugging and abandonment activities.

\subsection{ORNL MODERNIZATION AND REINDUSTRIALIZATION ACTIVITIES}

FY 2003 was a peak year for construction activities at ORNL associated with ORNL modernization activities. At the main ORNL campus, the private sector building construction was completed, and the laboratory and office complex is now fully operational. This upgrade added more than $40,000 \mathrm{ft}^{2}$ of new supercomputer space, more than 750 offices, more than 30 new wet/dry laboratories, and high bay space. Construction progress continued as well on the companion State of Tennessee Joint Institute for Computational Sciences and the DOE-sponsored Research Support Center (cafeteria and visitors' center) being built adjacent to the private sector facilities in the East Campus area. Both of those projects will be completed in FY 2004. Other modernization initiatives, including upgrades at the HFIR, construction of a new Advanced Materials Characterization Laboratory, significant removal of legacy materials and equipment, and deactivation of more than $500,000 \mathrm{ft}^{2}$ of excess space, were accomplished during FY 2003. The first phase of ORNL modernization will be completed by FY 2004, with plans under way for construction of additional state and private sector facilities to begin again in FY 2005.

\subsection{SPALLATION NEUTRON SOURCE}

DOE prepared and issued a final environmental impact statement (SNS 1999a and 1999b) and a record of decision to construct and operate the SNS. This state-of-the-art pulsedneutron facility is under construction on Chestnut Ridge at ORNL. A mitigation action plan was developed to document the goals and objectives by which the potential environmental impacts from construction and operation identified in the environmental impact statement will be mitigated. The SNS Project is on schedule and within budget, and in 2003 significant progress was made on the target building, accelerator tunnel, central laboratory and office complex, and site infrastructure. Construction of the SNS is currently approximately $80 \%$ complete, and technical components of the accelerator are being installed and commissioned. The facility will become operational in FY 2006.

On November 3, 2003, the TDEC Division of Water Pollution Control issued an NPDES permit that became effective on December 1, 2003. It authorized DOE to discharge cooling tower blowdown and heating, ventilation, and air conditioning condensate water from the SNS to a storm water detention pond that discharges to White Oak Creek at approximate stream mile 4.2 through Outfall 435. Furthermore, the pond emergency spillway, designated as Outfall 437, 
will discharge in large storm runoff situations to mile 0.6 of a tributary to White Oak Creek. The SNS began discharging blowdown waters to the detention pond in December 2, 2003. For December, 2003, the SNS was fully compliant with all permit limits.

Potential adverse impacts of SNS construction and operations were identified for wetlands, protected species, cultural resources, transportation infrastructure, and research projects in the Walker Branch Watershed. Mitigation measures were identified for each of the potential subjects.

Construction of the SNS access roads affected wetlands. Routes were evaluated, and improving the Chestnut Ridge Road was selected as the action affecting the smallest area of wetlands. Construction affected 0.055 acres, and careful attention to erosion control and equipment movement limited impacts to other nearby wetland areas. The SNS developed a wetlands mitigation plan to compensate for the impacts to the 0.055 acres by restoring 0.138 acres (a mitigation ratio of 2.511) of wetlands located in the same watershed. TDEC accepted the wetlands mitigation plan on June 29, 2000, and the 0.138 acres of wetlands were restored in August 2000. This mitigation action is complete, and the restored areas are routinely monitored to ensure the survival rate of the indigenous shrubs and vegetation planted in the restored area. No significant impacts on the wetlands have resulted from construction activities. The wetlands mitigation activities were evaluated and reported in 2002 and 2003. These reviews have found that the SNS mitigation wetland is functioning as a viable wetland community. The site has the necessary wetland vegetation, soils, and hydrology to be classified as a jurisdictional wetland.

No federally listed or proposed threatened or endangered species were identified in the site surveys of the SNS. However, construction and operation of the SNS could affect protected species that were not identified during the site surveys. Definitive surveys were conducted during three seasons (spring, summer, and fall) in 1999 to ensure that any protected species, including those that can be identified only during flowering, would be noted. No protected species were identified during these surveys, and this mitigation action is complete.

No prehistoric or historic sites listed on or eligible for inclusion on the National Register of Historic Places (National Park Service 2003) were identified on the SNS site. A survey of cultural resources was conducted for the access road rights-of-way, and no significant cultural resources were located or disturbed. This mitigation action is complete for the SNS roads and utility corridors. The TVA powerline upgrades associated with the SNS have been evaluated for cultural resources, and no issues were identified.

Increased traffic resulting from SNS construction and operation on local roads was evaluated by SNS staff. Traffic issues were also coordinated with other activities on the ORR. Improvements to Bethel Valley Road, including acceleration and deceleration lanes, marked turn lanes, lighting, and traffic signals, have been identified to reduce the effects on traffic flow in the vicinity of the SNS. Improvements to the roads, including widening and lane marking, were made in the spring of 2001. Traffic signals and lighting became operational in 2002. This mitigation action is complete.

Emissions of water vapor and $\mathrm{CO}_{2}$ during construction and operation of the SNS could impact the research activities at the Walker Branch Watershed, located approximately 0.75 mile $(1.2 \mathrm{~km})$ east of the SNS on Chestnut Ridge. The emissions would affect a small amount of the data collected at Walker Branch Watershed, and a committee was established in 1999 to evaluate the impacts of the SNS. The committee reviewed the impacts and potential mitigation measures and determined that establishing a satellite monitoring location in an area not affected by SNS was the preferred solution. The satellite tower will be established before SNS operates to allow development of statistical correlations between the locations, thereby preserving the quality of the data. The location of the satellite tower was identified in FY 2001, and plans to develop the site are under way by the Walker Branch researchers. Funding for the tower and instruments has been provided to the researchers, and this corrective action is now closed. 
Incorporating superconducting accelerator technology at SNS was evaluated in a supplement to the final environmental impact statement in 2000. The impacts of the technology on the Walker Branch Watershed were evaluated and were found to be not significant; the change to superconducting was determined to have no significant environmental impacts. Funding for the satellite tower has been provided by SNS, and this mitigation action is complete. 



\section{Y-12 Environmental Monitoring Programs}

Compliance and environmental monitoring programs required by federal and state regulation and by DOE orders are conducted at the Y-12 National Security Complex for air, water, and groundwater environmental media.

\subsection{Y-12 COMPLEX RADIO- LOGICAL AIRBORNE EFFLUENT MONITORING}

The release of radiological contaminants, primarily uranium, into the atmosphere at the Y-12 National Security Complex (Y-12 Complex) occurs almost exclusively as a result of plant production, maintenance, and waste management activities. NESHAP regulations for radionuclides require continuous emission sampling of major sources (a "major source" is considered to be any emission point that potentially can contribute more than $0.1 \mathrm{mrem} /$ year EDE equivalent to an off-site individual). During 2002, 42 of the 55 stacks suitable for continuous monitoring were judged to be major sources. Eighteen of the stacks with the greatest potential to emit significant amounts of uranium are equipped with alarmed breakthrough detectors, which alert operations personnel to process-upset conditions or to a decline in filtration-system efficiencies, allowing them to investigate and correct the problem before a significant release occurs. As of January 1, 2002, the Y-12 Complex had continuous monitoring capability on a total of 55 stacks, 44 of which were active and 11 of which were temporarily shut down.

Emissions from unmonitored process and laboratory exhausts, categorized as minor emission sources, are estimated according to calculation methods approved by the EPA. In 2002, there were 41 unmonitored processes operated by $\mathrm{Y}-12$. These are included as minor sources in the Y-12 Complex source term.

Uranium and other radionuclides are handled in millicurie quantities at facilities within the boundary of the Y-12 Complex as part of BJC, ORNL, and BWXT Y-12 laboratory activities. Twenty-eight minor emission points were identified from laboratory activities at facilities within the boundary of the Y-12 Complex as being operated by BWXT Y-12. In addition, the BWXT Y-12 Analytical Chemistry Organization laboratory is operated in a leased facility that is not within the ORR boundary and is located approximately $1 / 3$ mile east of the Y-12 Complex on Union Valley Road. The emissions from the Analytical Chemistry Organization Union Valley laboratory are included in the Y-12 Complex source term. Eight minor emission points were identified at the laboratory. The releases from these emission points are minimal, however, and have a negligible impact on the total $\mathrm{Y}-12$ Complex dose.

Emissions from Y-12 Complex room ventilation systems are estimated from radiation control data collected on airborne radioactivity concentrations in the work areas. Areas where the monthly average concentration exceeded $10 \%$ of the DOE derived air concentration worker-protection guidelines are included in the annual emission estimate. One emission point in Building 9212 was identified in 2002 where room ventilation emissions exceeded $10 \%$ of the guidelines. However, because this enclosure exhausted to stack UB-110, its contribution was not specifically identified and was included in the stack emissions.

\subsubsection{Sample Collection and Analytical Procedure}

Uranium stack losses were measured continuously on monitored operating process exhaust stacks in 2003. Particulate matter (including uranium) was filtered from the stack emissions. Filters at each location were changed routinely, from one to three times per week, and were analyzed for total uranium. In addition, the sampling probes and tubing were removed quarterly and were washed with nitric acid; the washing was analyzed for total uranium. At the end of the year, the probe-wash data were 
included in the final calculations in determining total emissions from each stack.

\subsubsection{Results}

An estimated $0.012 \mathrm{Ci}(2.01 \mathrm{~kg})$ of uranium was released into the atmosphere in 2003 as a result of Y-12 activities (Figs. 6.1 and 6.2). The specific activity of enriched uranium is much greater than that of depleted uranium, and about $83 \%$ of the curie release was composed of emissions of enriched uranium particulate, even though approximately $8 \%$ of the total mass of uranium released was enriched material.

\subsection{Y-12 COMPLEX NONRADIOLOGICAL AIRBORNE EMISSIONS MONITORING}

The release of nonradiological contaminants into the atmosphere at the Y-12 Complex occurs as a result of plant production, maintenance, waste management operations, and steam generation. Most process operations are served by ventilation systems.

In CY 2003, the Y-12 Complex had 33 individual air permits. Approximately three-fifths of the permitted air sources release primarily nonradiological contaminants. The remaining twofifths of the permitted sources process primarily radiological materials. TDEC air permits for the nonradiological sources do not require stack

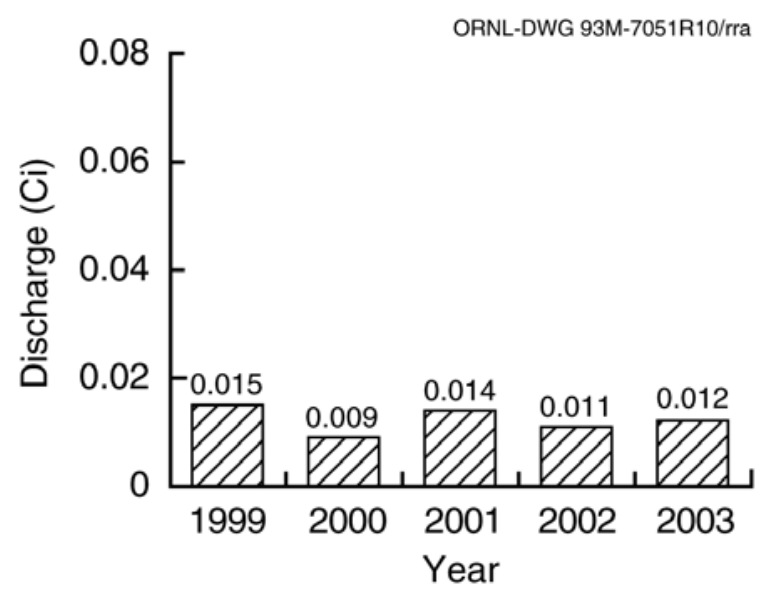

Fig. 6.1. Total curies of uranium discharged from the Y-12 Complex to the atmosphere, 1999-2003. sampling or monitoring except for the opacity monitors used at the steam plant to ensure compliance with visible emission standards. For nonradiological sources where direct monitoring of airborne emissions is not required, monitoring of key process parameters is done to ensure compliance with all permitted emission limits. In the future, when the Y-12 Complex is issued its first-ever major-source (Clean Air Act Title V) operating permit, reporting of key process parameters is expected to increase. Also, a new requirement for the steam plant requires continuous emission monitoring for nitrogen oxides in which the compliance period begins in 2004.

The 2003 Y-12 Complex annual emission fee was calculated based on 10,033 tons per year of allowable emission of regulated pollutants, with an annual emission fee of $\$ 175,577.50$. In accordance with TDEC regulations, Rule 1200-326-.02(9)(i), when there is no applicable standard or permit condition for a pollutant, the allowable emissions are based on the maximum actual emissions calculations (maximum design capacity for $8760 \mathrm{~h} /$ year). More than $90 \%$ of the $\mathrm{Y}-12$ Complex pollutant emissions to the atmosphere are attributed to the operation of the steam plant. The emission fee rate was based on $\$ 17.50$ per ton of regulated-pollutant allowable emissions. The actual emissions are much lower than the allowable amount; however, major sources are required to pay their annual emission fees based on allowable emissions until the issuance of the major source operating permit.

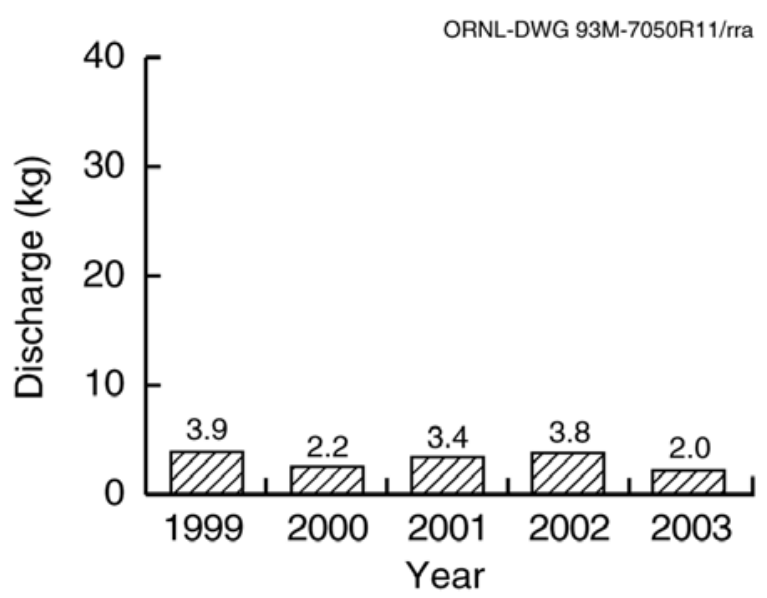

Fig. 6.2. Total kilograms of uranium discharged from the Y-12 Complex to the atmosphere, 1999-2003. 


\subsubsection{Results}

The primary source of criteria pollutants at the Y-12 Complex is the steam plant, where coal and natural gas are burned. Information regarding actual vs allowable emissions from the steam plant is provided in Table 6.1. In addition, the annual toxic release inventory report (required by EPCRA Sect. 313) provides information on other nonradiological Y-12 Complex air emissions (Sect. 2.2.16).

The opacity monitoring systems for both the east and west at the Y-12 Steam Plant were taken out of service on March 5, 2003, for replacement with new opacity monitors. The new opacity monitors have been installed and certified. The certification reports were submitted to the Technical Secretary in June 2003 for his review and approval. Condition 8 of the current Y-12 Steam Plant air permit requires the opacity monitoring systems to be fully operational $95 \%$ of the operational time of the monitored units during each month of the calendar quarter. Due to the new opacity monitors installation, the east and west stack monitors did not meet the 95\% operational availability level for the second quarter of 2003. TDEC personnel were informed of the new opacity monitors and approved their installation.

Condition 9 of the current Y-12 Steam Plant air permit requires that calibration error tests of the opacity monitoring systems be performed on a biennial basis. The calibration error tests for the opacity monitoring systems were part of the new opacity monitor certification reports submitted to TDEC personnel in June 2003. The next tests will be performed on a semiannual basis in accordance with Title $\mathrm{V}$ requirements. There were no periods of excess emissions due to the control device malfunction during 2003. The opacity monitors were inoperative during 2003. Quarterly reports of the status of the Y-12 Steam Plant opacity monitors are submitted to personnel at TDEC within 30 days after the end of each calendar quarter. Table E. 4 in Appendix E is a record of excess emissions and out-of-service conditions for the east and west stack opacity monitors for 2003.

\section{$6.3 \quad \mathrm{Y}-12$ COMPLEX AMBIENT AIR MONITORING}

In 1994, Y-12 Complex personnel issued Evaluation of the Ambient Air Monitoring

Table 6.1. Actual vs allowable air emissions from the Oak Ridge Y-12 Complex, 2003

\begin{tabular}{|c|c|c|c|}
\hline \multirow[t]{2}{*}{ Pollutant } & \multicolumn{2}{|c|}{$\begin{array}{l}\text { Emissions } \\
\text { (tons/year) }\end{array}$} & \multirow{2}{*}{$\begin{array}{l}\text { Percentage of } \\
\text { allowable }\end{array}$} \\
\hline & Actual & Allowable & \\
\hline Particulate & 32 & 945 & 3.4 \\
\hline Sulfur dioxide & 2,606 & 20,803 & 12.5 \\
\hline Nitrogen oxides ${ }^{a}$ & 718 & 5,905 & 12.2 \\
\hline Volatile organic compounds ${ }^{a}$ & 3 & 41 & 7.3 \\
\hline Carbon monoxide $^{a}$ & 27 & 543 & 5.0 \\
\hline
\end{tabular}

${ }^{a}$ When there is no applicable standard or enforceable permit condition for some pollutants, the allowable emissions are based on the maximum actual emissions calculation as defined in Tennessee Department of Environment and Conservation Rule 1200-3-26-.02(2)(d)3 (maximum design capacity for $8760 \mathrm{~h} /$ year). The emissions for both the actual and allowable emissions were calculated based on the latest EPA compilation of air pollutant emission factors. (EPA 1995 and 1998. Compilation of Air Pollutant Emission Factors AP-42, Fifth Edition, Volume 1: Stationary Point and Area Sources. U.S. Environmental Protection Agency, Research Triangle Park, N.C. January 1995 and September 1998.) 
Program at the Oak Ridge Y-12 Plant (MMES 1994b) and worked with DOE and TDEC in reviewing the ambient air program for applicability and usefulness of the data. There are no federal regulations, state regulations, or DOE orders that require this monitoring. All ambient air monitoring systems at the Y-12 Complex are operated as a best management practice. With the reduction of plant operations and improved emission and administrative controls, levels of measured pollutants have decreased significantly during the past several years. In addition, major processes that result in emission of enriched and depleted uranium are equipped with stack samplers that have been reviewed and approved by EPA to meet requirements of the NESHAP regulations. ORR air sampling stations, operated by ORNL in accordance with DOE orders, are located around the reservation. Their locations were selected so that areas of potentially high exposure to the public are monitored continuously for parameters of concern.

With agreement from TDEC personnel, the ambient air-sampling program at the Y-12 Complex was significantly reduced, effective at the end of 1994. All sampling for fluoride, total suspended particulates, and particulate matter less than 10 microns in diameter (PM10) was discontinued, and all but 3 of the 12 uranium samplers were shut down. Effective April 1, 1999, an agreement was reached according to which TDEC personnel took over responsibility for sampling and analysis of the three remaining uranium samplers at the Y-12 Complex. The uranium samplers were operated by the TDEC during 2003. On December 6, 1999, DOE submitted to TDEC a letter providing justification for reducing the number of on-site mercurymonitoring stations from four to two. Effective January 1, 2000, operation of the two monitors located in the interior of the Complex (near Buildings 9805-1 and 9422-13) was discontinued. The two boundary mercury-monitoring stations (stations 2 and 8) remain in operation. The locations of these monitoring stations are shown in Fig. 6.3. During 2003, the project to restart the hydrogen fluoride system at Building 9212 was placed on hold. It is scheduled for restart in the summer of 2004.

\subsubsection{Mercury}

The Oak Ridge Y-12 Complex ambient air monitoring program for mercury was established in 1986 as a best management practice. The objectives of the program have been to maintain a database of mercury concentration in ambient air, to identify long-term spatial and temporal trends in ambient mercury vapor, and to demonstrate protection of the environment and human health from releases of mercury at the Y-12 Complex to the atmosphere. The two atmospheric mercury monitoring stations currently operating at the $\mathrm{Y}$ 12 Complex , Ambient Air Station No. 2 (AAS2) and Ambient Air Station No. 8 (AAS8), are located near the east and west boundaries of the

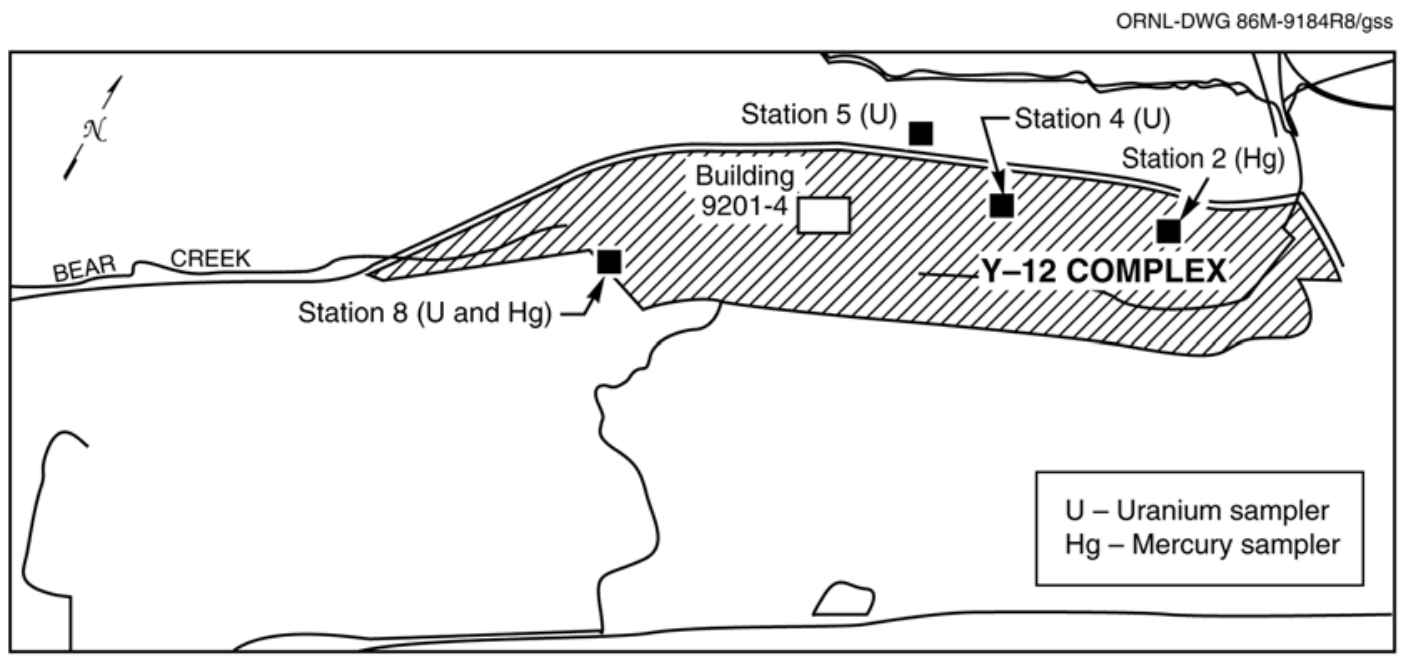

Fig. 6.3. Locations of ambient air monitoring stations at the Y-12 Complex. 

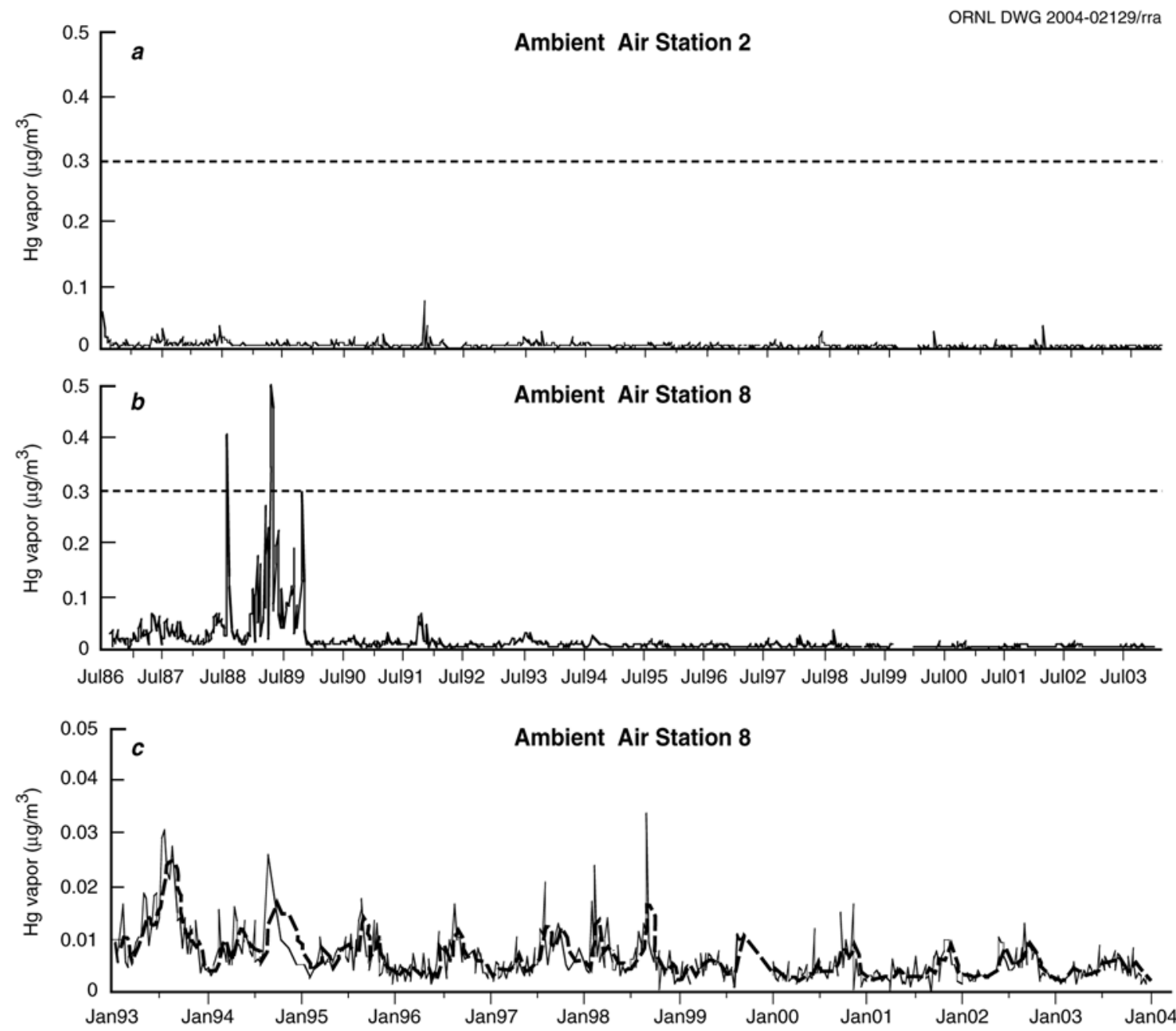

Fig. 6.4. Temporal trends in mercury vapor concentration for the four active airborne mercury monitoring sites at the Oak Ridge Y-12 Complex, July 1986 through July 2003. The dashed line represents the EPA reference concentration of $0.3 \mu \mathrm{g} / \mathrm{m}^{3}$.

Complex, respectively (see Fig. 6.4). Since their establishment in 1986, AAS2 and AAS8 have monitored mercury in ambient air continuously with the exception of short periods of downtime because of electrical or equipment outages. In addition to the plant monitoring stations, a control or reference site (Rain Gauge No. 2) was operated on Chestnut Ridge in the Walker Branch Watershed for a 20-month period in 1988 and 1989 to establish local background concentrations at that time.

At each of the monitoring sites, airborne mercury vapor is collected by pulling ambient air through a sampling train consisting of a Teflon filter, a flow-limiting orifice, and an iodated charcoal-filled sampling tube or trap. The flowlimiting orifice restricts airflow through the sampling train to $\sim 1 \mathrm{~L} / \mathrm{min}$, although actual flow rates are measured weekly with a calibrated Gilmont flowmeter. The sampling traps are changed out weekly. The charcoal in each trap is analyzed for total mercury absorbed using cold vapor atomic fluorescence after acid digestion. Average concentration of mercury vapor in the ambient air for each 7-day sampling period is calculated by dividing the total quantity of mercury collected on the charcoal by the total volume of air pulled through the charcoal trap. During the early years of the mercury airmonitoring program, Teflon filters in the sampling train were analyzed for particulate mercury. This practice was discontinued in 1989 after results revealed very low to nondetectable levels of particulate mercury. The filters are still present in 
the sampling train but solely to prevent particulates from clogging the flow-limiting orifice.

As reported in previous annual environmental reports, average mercury vapor concentrations at the Y-12 Complex mercury monitoring sites have declined significantly, especially after the initial three years of the monitoring program, with average mercury vapor concentrations at AAS8 declining almost tenfold and AAS2 threefold since the late 1980s. Recent average annual concentrations at the two boundary stations located at the east and west ends of the Y-12 Complex are comparable to those measured in 1988 and 1989 at the Chestnut Ridge reference site (see Table 6.2) and only slightly elevated above concentrations reported for continental background (i.e., $~ 0.002 \mu \mathrm{g} / \mathrm{m}^{3}$ ). For 2003 , the average mercury concentration was $0.0036 \mu \mathrm{g} / \mathrm{m}^{3}$ for AAS2 $(\mathrm{N}=52 ;$ S.E. $= \pm 0.0002)$ and 0.0043 $\mu \mathrm{g} / \mathrm{m}^{3}$ for AAS8 $(\mathrm{N}=52$; S.E. $= \pm 0.0002)$. These concentrations are comparable to average concentrations measured in 2001 (AAS2 = $0.0034 \mu \mathrm{g} / \mathrm{m}^{3}$, AAS $8=0.0042 \mu \mathrm{g} / \mathrm{m}^{3}$ ) and slightly lower, though not significantly different (Student's t-test), to those reported for 2002 $\left(\right.$ AAS $2=0.0040 \mu \mathrm{g} / \mathrm{m}^{3} ;$ AAS $\left.8=0.0050 \mu \mathrm{g} / \mathrm{m}^{3}\right)$. Table 6.2 summarizes the 2003 mercury results and the results from the 1986 through 1988 period for comparison. Graphs A, B, and C (Fig. 6.4) illustrate temporal trends in mercury concentration for the two active mercury monitoring sites since the inception of the program in 1986 through December 2003 and seasonal trends at AAS8 from 1993 to 2004.

In conclusion, annual average mercury concentrations during 2003 at the Y-12 east and west boundary monitoring stations are comparable to reference levels measured on Chestnut Ridge in 1988 and 1989 and approach values reported for continental background. These concentrations are well below current environmental and occupational health standards for inhalation exposure to mercury vapor. For example, they were less than the National Institute for Occupational Safety and Health recommended exposure limit of $50 \mu \mathrm{g} / \mathrm{m}^{3}$ (time-weighted average for an 8-h workday), the American Conference of Governmental Industrial Hygienists workplace threshold limit value of $25 \mu \mathrm{g} / \mathrm{m}^{3}$ (time-weighted average for an 8-h workday and 40-h workweek), the Agency for Toxic Substances and Disease Registry minimal risk level of $0.2 \mu \mathrm{g} / \mathrm{m}^{3}$ for inhalation exposure, and the current EPA reference concentration of $0.3 \mu \mathrm{g} / \mathrm{m}^{3}$ ) for elemental mercury for daily inhalation exposure without appreciable risk of harmful effects during a lifetime.

Table 6.2. 2003 summary results for the Oak Ridge Y-12 Plant mercury in ambient air monitoring program

Results of the 1986 through 1988 monitoring period are shown for reference

\begin{tabular}{lcccc}
\hline \multirow{2}{*}{\multicolumn{1}{c}{ Ambient air monitoring stations }} & \multicolumn{3}{c}{ Mercury vapor concentration $\left(\mu \mathrm{g} / \mathrm{m}^{3}\right)$} \\
\cline { 2 - 5 } & $\begin{array}{c}2003 \\
\text { Average }\end{array}$ & $\begin{array}{c}2003 \\
\text { Maximum }\end{array}$ & $\begin{array}{c}2003 \\
\text { Minimum }\end{array}$ & $\begin{array}{c}1986-1988 \\
\text { Average }\end{array}$ \\
\hline AAS2 (east end of the Y-12 Plant) & 0.0036 & 0.0071 & 0.0018 & 0.010 \\
AAS8 (west end of the Y-12 Plant) & 0.0043 & 0.0091 & 0.0018 & 0.033 \\
Reference site, Rain Gauge No.2 $\left(1988^{a}\right)$ & N/A & N/A & N/A & 0.006 \\
Reference site, Rain Gauge No.2 $\left(1989^{b}\right)$ & N/A & N/A & N/A & 0.005 \\
\hline
\end{tabular}

${ }^{a}$ Data for period from February 9 through December 31, 1988.

${ }^{b}$ Data for period from January 1 through October 31, 1989. 


\subsection{LIQUID DISCHARGES- Y-12 COMPLEX RADIO- LOGICAL MONITORING SUMMARY}

A radiological monitoring plan is in place at the Y-12 Complex to address compliance with DOE orders and NPDES Permit TN002968. The permit, issued in 1995, required Y-12 to reevaluate its radiological monitoring plan and to submit results from the monitoring program quarterly as an addendum to the NPDES Discharge Monitoring Report. There were no discharge limits set by the NPDES permit for radionuclides; the requirement is to monitor and report. A revised plan (LMES and H\&R 1995) was fully implemented in 1995. The radiological monitoring plan was expanded at that time to allow sufficient collection of data such that an assessment of alpha, beta, and gamma emitters could be made. The intent was to more appropriately identify parameters to be monitored and to establish analytical detection limits necessary for dose evaluations.

Based on an analysis of operational history, expected chemical and physical relationships, and historical monitoring results, the plan was updated again in October 1997 (LMES 1997b). Under the existing plan, effluent monitoring is conducted at three types of locations: (1) treatment facilities,
(2) other point-source and area-source discharges, and (3) instream locations. Operational history and past monitoring results provide a basis for parameters routinely monitored under the plan (Table 6.3).

The radiological monitoring plan also addresses monitoring of the sanitary sewer. The Y-12 Complex is permitted to discharge domestic wastewater to the city of Oak Ridge publicly owned treatment works under Industrial and Commercial User Wastewater Discharge Permit No. 1-91. As required by the discharge permit, radiological monitoring of this discharge is conducted and reported to the city of Oak Ridge, although there are no city-established limits. Potential sources of radionuclides discharging to the sanitary sewer have been identified in previous studies at the Y-12 Complex as part of an initiative to meet the "as low as reasonably achievable" goals. The radiological monitoring needs for the sanitary sewer were reviewed and were summarized in the 1997 update to the plan (LMES 1997b).

Radiological monitoring of storm water is also required by the NPDES permit. A comprehensive monitoring plan has been designed to fully characterize pollutants in storm water runoff. The most recent revision of this plan was issued in November 2002, Storm Water Pollution Prevention Plan for the Oak Ridge Y-12 Plant (BWXT 2002) and incorporates

Table 6.3. Radiological parameters monitored at the Y-12 Complex in 2003

\begin{tabular}{lll}
\hline \multicolumn{1}{c}{ Parameters } & \multicolumn{1}{c}{ Specific isotopes } & \multicolumn{1}{c}{ Rationale for monitoring } \\
\hline Uranium isotopes & $\begin{array}{l}{ }^{238} \mathrm{U},{ }^{235} \mathrm{U},{ }^{234} \mathrm{U}, \text { total } \mathrm{U}, \\
\text { weight } \%{ }^{235} \mathrm{U}\end{array}$ & $\begin{array}{l}\text { These parameters reflect the major activity, } \\
\text { uranium processing, throughout the history of } \\
\text { Y-12 and are the dominant detectable radiological } \\
\text { parameters in surface water }\end{array}$ \\
Fission and activation products & ${ }^{90} \mathrm{Sr},{ }^{3} \mathrm{H},{ }^{99} \mathrm{Tc},{ }^{137} \mathrm{Cs}$ & $\begin{array}{l}\text { These parameters reflect a minor activity at Y-12, } \\
\text { processing recycled uranium from reactor fuel } \\
\text { elements, from the early 1960s to the late 1980s, } \\
\text { and will continue to be monitored as tracers for } \\
\text { beta and gamma radionuclides, although their } \\
\text { concentrations in surface water are low }\end{array}$ \\
Transuranium isotopes & & $\begin{array}{l}{ }^{241} \mathrm{Am},{ }^{237} \mathrm{~Np},{ }^{238} \mathrm{Pu},{ }^{239 / 240} \mathrm{Pu} \\
\text { These parameters are related to recycle uranium } \\
\text { processing. Monitoring has continued because of } \\
\text { their half-lives and presence in groundwater }\end{array}$ \\
& & $\begin{array}{l}\text { These parameters reflect historical thorium } \\
\text { processing and natural radionuclides necessary to } \\
\text { characterize background radioisotopes }\end{array}$ \\
\hline
\end{tabular}


radiological-monitoring requirements. There are 75 storm water outfalls and monitoring points located at the Y-12 Complex, and the NPDES permit requires characterization of a minimum of 25 storm water outfalls per year.

\subsubsection{Results}

Radiological monitoring plan locations sampled in 2003 are noted in Fig. 6.5. Table 6.4 identifies the monitored locations, the frequency of monitoring, and the sum of the percentages of the DOE derived concentration guides (DCGs) for radionuclides measured in 2003. Radiological data were well below the allowable DCGs.

In 2003, the total mass of uranium and associated curies released from the Y-12 Complex at the easternmost monitoring station, Station 17 on Upper East Fork Poplar Creek, and the westernmost monitoring station, at Bear Creek kilometer (BCK) 4.55 (the former NPDES Outfall 304), was $346 \mathrm{~kg}$, or 0.151 Ci (Table 6.5). Figure 6.6 illustrates a 5-year trend of these releases. The total release is calculated by multiplying the average concentration (grams per liter) by the average flow (million gallons per day). Converting units and multiplying by 365 days per year yields the calculated discharge.

The City of Oak Ridge Industrial and Commercial User Wastewater Discharge Permit allows the Y-12 Complex to discharge wastewater to be treated at the Oak Ridge publicly owned treatment works through the East End Sanitary Sewer Monitoring Station, also identified as SS-6 (Fig. 6.5). Compliance samples are collected at this location. No single radionuclide in the Y-12 contribution to the sanitary sewer exceeded $4 \%$ of the DCGs. Summed percentages of DCGs calculated from the Y-12 contribution to the sewer is about one. Results of radiological monitoring were reported to the city of Oak Ridge in quarterly monitoring reports.

Table 6.6 presents a summary of 2003 storm water data that exceeded screening levels. More detailed results are given in Environmental Monitoring on the Oak Ridge Reservation: 2003 Results (DOE 2004c). (See http://www.ornl.gov/ aser.) Uranium remains the dominant radiological constituent and increases during storm flow. This increase is likely due to increased groundwater flow and storm water runoff from historically contaminated areas.

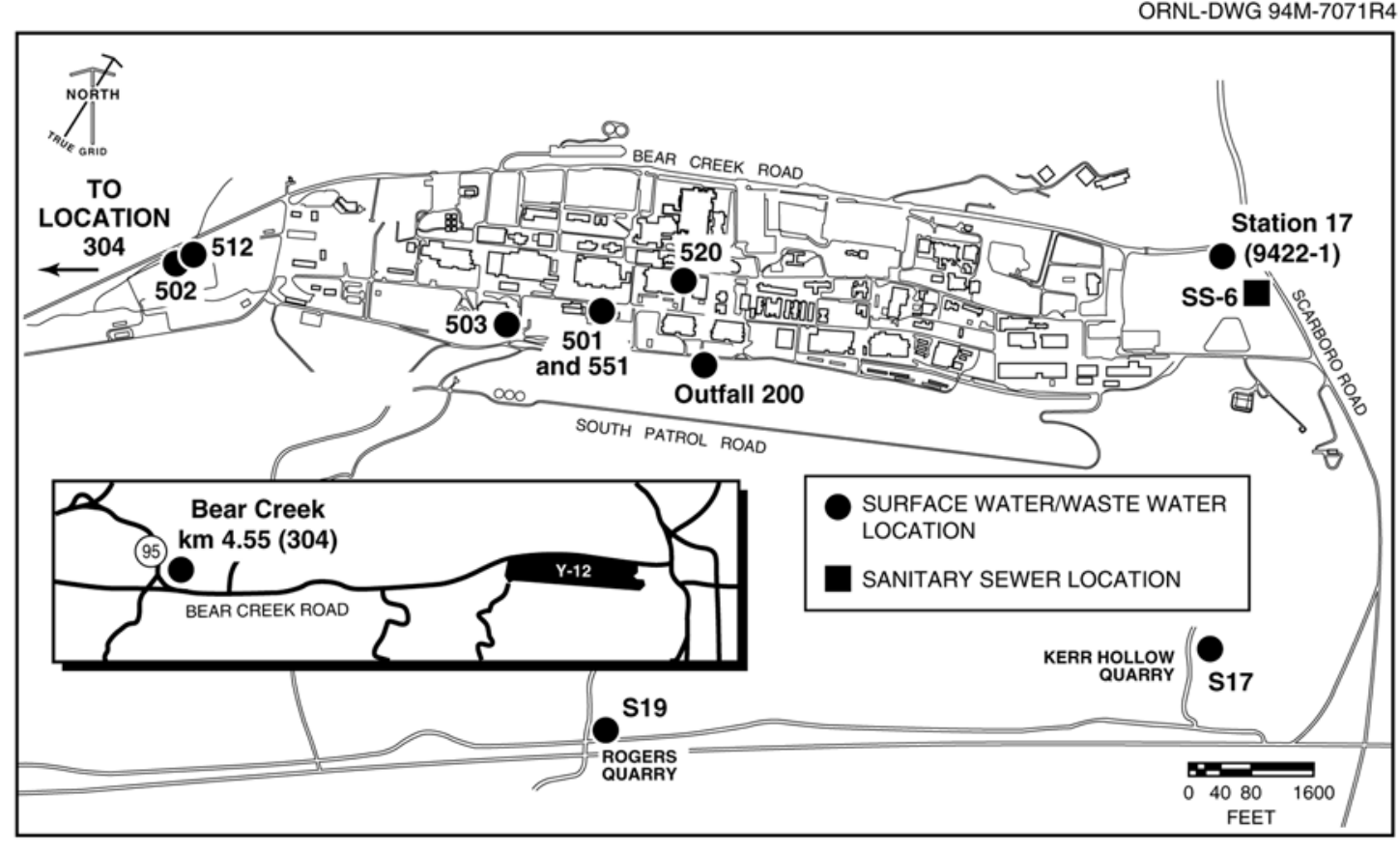

Fig. 6.5. Surface water and sanitary sewer radiological sampling locations at the Y-12 Complex. 
Table 6.4. Summary of $\mathrm{Y}-12$ Complex radiological monitoring plan sample requirements

\begin{tabular}{|c|c|c|c|c|}
\hline $\begin{array}{l}\text { Outfall } \\
\text { No. }\end{array}$ & Location & $\begin{array}{l}\text { Sample } \\
\text { frequency }\end{array}$ & Sample type & $\begin{array}{c}\text { Sum of DCG }^{a} \\
\text { percentage }\end{array}$ \\
\hline \multicolumn{5}{|c|}{ Y-12 Complex wastewater treatment facilities } \\
\hline 501 & Central Pollution Control Facility & $1 /$ week & $\begin{array}{l}\text { Composite during } \\
\text { batch operation }\end{array}$ & 1.7 \\
\hline 502 & West End Treatment Facility & $1 /$ week & 24-hour composite & No flow \\
\hline 503 & Steam Plant Wastewater Treatment Facility & $1 /$ week & 24-hour composite & No flow \\
\hline 512 & Groundwater Treatment Facility & $1 /$ week & 24-hour composite & 2.1 \\
\hline $520(402)^{b}$ & Steam condensate & $1 /$ week & Grab & 1.5 \\
\hline 551 & Central Mercury Treatment Facility & $1 /$ month & 24-hour composite & 2.3 \\
\hline \multicolumn{5}{|c|}{ Other Y-12 Complex point and area source discharges } \\
\hline $\mathrm{S} 17(301)^{b}$ & Kerr Hollow Quarry & $1 /$ month & 24-hour composite & 0.83 \\
\hline $\mathrm{S} 19(302)^{b}$ & Rogers Quarry & $1 /$ month & 24-hour composite & 1.1 \\
\hline \multicolumn{5}{|c|}{ Y-12 Complex instream locations } \\
\hline BCK $4.55(304)^{b}$ & Bear Creek, plant exit (west) & 1/week & 7-day composite & 2.0 \\
\hline Station 17 & East Fork Poplar Creek, plant exit (east) & $1 /$ week & 7-day composite & 2.1 \\
\hline 200 & North/south pipes & $1 /$ week & 24-hour composite & 4.2 \\
\hline \multicolumn{5}{|c|}{ Y-12 Complex Sanitary Sewer } \\
\hline SS-6 & East End Sanitary Sewer Monitoring Station & $1 /$ week $^{c}$ & 7-day composite & 1 \\
\hline
\end{tabular}

${ }^{a} \mathrm{DCG}=$ the derived concentration guide found in DOE Order 5400.5.

${ }^{b}$ Outfall identifications were changed by the National Pollutant Discharge Elimination System permit effective July 1, 1995. Former outfall identifications are shown here in parentheses.

${ }^{c}$ Gamma emitters are analyzed once per year.

\begin{tabular}{|c|c|c|}
\hline \multirow{2}{*}{ Year } & \multicolumn{2}{|c|}{ Quantity released } \\
\hline & $\mathrm{Ci}^{a}$ & $\mathrm{~kg}$ \\
\hline \multicolumn{3}{|c|}{ Station 17} \\
\hline 1999 & 0.07 & 123 \\
\hline 2000 & 0.063 & 126 \\
\hline 2001 & 0.043 & 82 \\
\hline 2002 & 0.062 & 140 \\
\hline 2003 & 0.073 & 167 \\
\hline \multicolumn{3}{|c|}{ BCK $4.55^{b}$} \\
\hline 1999 & 0.096 & 183 \\
\hline 2000 & 0.093 & 168 \\
\hline 2001 & 0.065 & 136 \\
\hline 2002 & 0.07 & 141 \\
\hline 2003 & 0.078 & 179 \\
\hline
\end{tabular}

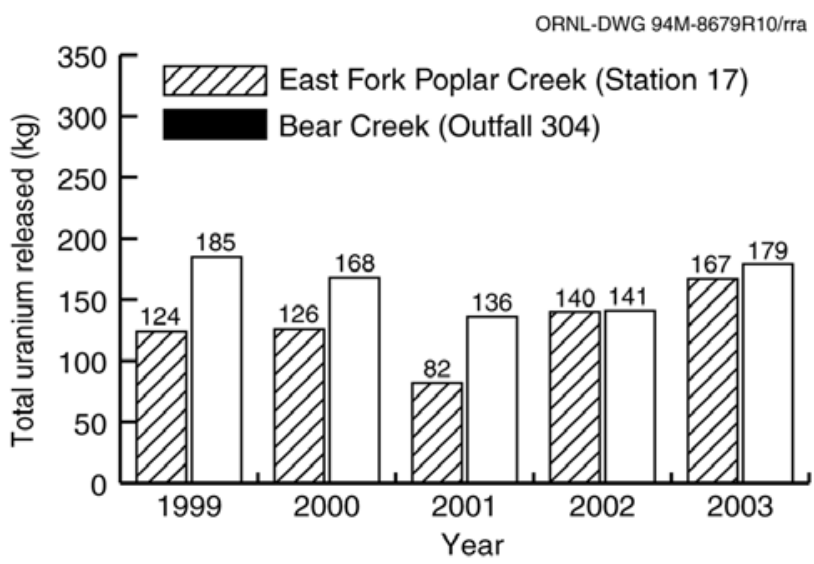

Fig. 6.6. Five-year trend of $\mathrm{Y}-12$ Complex release of uranium to surface water.

${ }^{a} 1 \mathrm{Ci}=3.7 \mathrm{E}+10 \mathrm{~Bq}$.

${ }^{b}$ Formerly, NPDES outfall 304. 


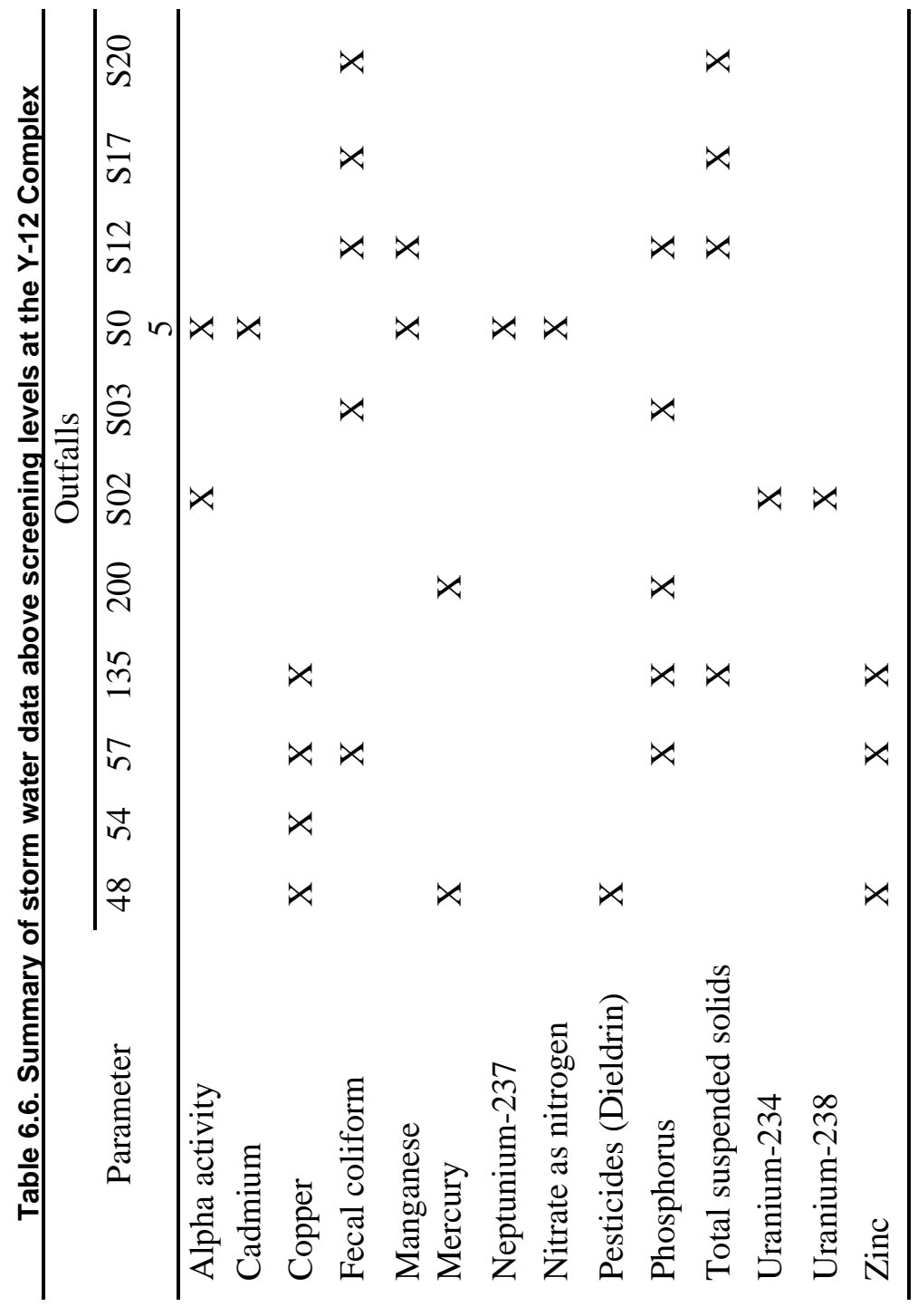




\subsection{NONRADIOLOGICAL LIQUID DISCHARGES- Y-12 COMPLEX SURFACE WATER AND LIQUID EFFLUENTS}

The current Y-12 NPDES permit, issued on April 28, 1995, and effective on July 1, 1995, requires sampling, analysis, and reporting for approximately 90 outfalls. Major outfalls are noted in Fig. 6.7. The number is subject to change as outfalls are eliminated or consolidated or if permitted discharges are added. Currently, Y-12 has outfalls and monitoring points in the following water drainage areas: East Fork Poplar Creek, Bear Creek, and several unnamed tributaries on the south side of Chestnut Ridge. These creeks and tributaries eventually drain to the Clinch River.

Discharges to surface water allowed under the permit include storm drainage, cooling water, cooling tower blowdown, steam condensate, and treated process wastewaters, including effluents from wastewater treatment facilities. Groundwater inflow into sumps in building basements and infiltration to the storm drain system are also permitted for discharge to the creek. The monitoring data collected by the sampling and analysis of permitted discharges are compared to NPDES limits if a limit exists for each parameter. Some parameters, defined as "monitor only," have no specified limits.
The water quality of surface streams in the vicinity of the Y-12 Complex is affected by current and historical legacy operations. Discharges from the Y-12 Complex processes flow into East Fork Poplar Creek before the water exits the Y-12 Complex. East Fork Poplar Creek eventually flows through the city of Oak Ridge to Poplar Creek and into the Clinch River. Bear Creek water quality is affected by area source runoff and groundwater discharges. The NPDES permit requires regular monitoring and storm water characterization in Bear Creek and several of its tributaries.

The effluent limitations contained in the permit are based on the protection of water quality in the receiving streams. The permit emphasizes storm water runoff and biological, toxicological, and radiological monitoring. Some of the requirements in the permit and the status of compliance are as follows:

- chlorine limitations based on water quality criteria at the headwaters of East Fork Poplar Creek (monitoring ongoing);

- instream pH limitations on tributaries to Bear Creek and various other tributaries on the south side of Chestnut Ridge (monitoring ongoing);

- a radiological monitoring plan requiring monitoring and reporting of uranium and other isotopes at pertinent locations (see Sect. 6.4);

ORNL-DWG 2001-03739a/rra

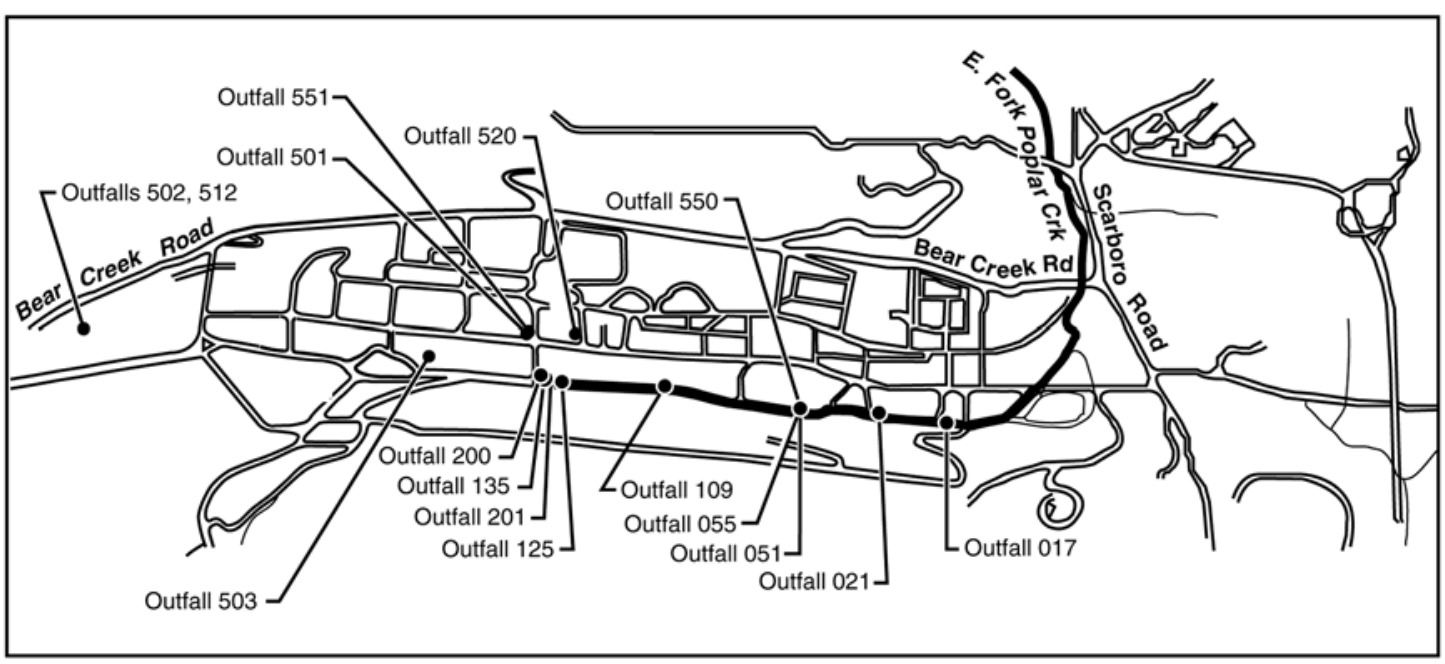

Fig. 6.7. Major Y-12 Complex NPDES outfalls. 
- implementation of a storm water pollution prevention plan and sampling and characterization of storm water at a minimum of 25 locations per year (see Sect. 6.5.2);

- a requirement to manage the flow of East Fork Poplar Creek such that a minimum flow of 7 million gal/day is guaranteed by adding raw water from the Clinch River to the headwaters of East Fork Poplar Creek (see Sect. 6.5.4);

- toxicity limitation for the headwaters of East Fork Poplar Creek (see Sect. 6.6); and

- quarterly toxicity testing at the wastewater treatment facilities and storm drain locations (see Sect. 6.6).

An agreed-to consent order, dated September 27, 1999, resolved outstanding appeals to the NPDES permit by deleting mercury monitoring requirements and instream limits from the permit and deferring them to the CERCLA program. The CERCLA record of decision will define any mercury remediation requirements for East Fork Poplar Creek. As required, an NPDES permit application was submitted in October 1999, six months prior to the expiration date of the current permit (April 28, 2000). Since April 28, 2000, the Y-12 Complex has continued operation under the current permit.

\subsubsection{Sanitary Wastewater}

Sanitary wastewater from the Y-12 Complex is discharged to the city of Oak Ridge publicly owned treatment works under Industrial and Commercial Users Wastewater Permit Number 191. Monitoring is conducted under the terms of the permit for a variety of organic and inorganic pollutants. During 2003, the wastewater flow in this system averaged about $642,000 \mathrm{gal} /$ day $(2,430,000 \mathrm{~L} /$ day $)$.

Compliance sampling is conducted at the East End Sanitary Sewer Monitoring Station (SS-6, Fig. 6.5) weekly. This monitoring station is also used for 24-h flow monitoring. As part of the city of Oak Ridge pretreatment program, city personnel use this monitoring station to perform compliance monitoring as required by pretreatment regulations.

\subsubsection{Storm Water}

The development and implementation of a storm water pollution prevention plan at the Y-12 Complex is designed to minimize the discharge of pollutants in storm water runoff. This plan requires (1) characterization of storm water by sampling during storm events, (2) implementation of measures to reduce storm water pollution, (3) facility inspections, and (4) employee training.

Storm water outfalls at the Y-12 Complex are located in subbasins (drainage areas) and are routinely sampled as required by the NPDES permit. The outfalls are categorized into four categories based on characteristics of the discharged water and are grouped within each category based on similarity as to land use of area drained and possible pollutants. A full chemical and radiological characterization of the discharge during a rain event is not required of all storm water outfalls each year. Representative sampling is permitted due to similarity within the same outfall groupings. A minimum of 25 storm water outfalls is required to be sampled and characterized each year during storm events, including both grab and composite sampling.

During 2003 approximately 5,000 data points were generated from storm water samples at the Y-12 Complex. By assessing the quality of storm water discharges from the site and by determining potential sources of pollutants affecting storm water, effective controls can be identified and put into place to reduce or eliminate these pollutant sources.

The storm water pollution prevention plan is reviewed at least annually and is updated as necessary to reflect changes in operations and to incorporate revised monitoring strategies based on data from past years. The most recent revision of this plan was issued in November 2002.

\subsubsection{Results and Progress in Implementing Corrective Actions}

In 2003, the Y-12 Complex experienced six NPDES excursions. There were four excursions in 2002, nine excursions in 2001, and six in 2000. Additional details on all Y-12 NPDES permit excursions recorded in 2003 and the associated 
corrective actions are summarized in Appendix D, Table D.1. Table 6.7 lists the NPDES compliance monitoring requirements and the 2003 compliance record.

During 2003, the Y-12 Complex experienced three exceedances of the Industrial and Commercial Users Wastewater Permit for discharge of sanitary wastewater to the city of Oak Ridge publicly owned treatment works. Table 6.8 lists the Industrial and Commercial Users Wastewater Permit compliance monitoring requirements and the 2003 compliance record. Two of the exceedances, iron $(19.1 \mathrm{mg} / \mathrm{L}$ compared to the permit limit of $15.0 \mathrm{mg} / \mathrm{L}$ ) and arsenic $(0.0262 \mathrm{mg} / \mathrm{L}$ compared to the permit limit of $0.015 \mathrm{mg} / \mathrm{L}$ ) occurred on July 29. A sample taken on December 22 indicated arsenic $(0.0175$ $\mathrm{mg} / \mathrm{L}$ ) to be slightly above the permit limit. These exceedances are believed to be related to upsets at the Steam Plant Wastewater Treatment Facility. Follow-up sampling conducted of the effluent from the treatment facility and at SS6 has indicated that both parameters are being maintained within permit limits. Upgrades in conduct of operations and the physical condition of the facility are under way. A project to remove sludge from the treatment facility equalization basin is being planned for 2004 .

Review of storm water data from past years indicates that pollutant loads increase during storm events and that water quality may be affected by uncovered scrap metal storage sites. For example, some outfalls are showing levels above screening limits of total suspended solids, fecal coliform, PCBs, and metals during storm events (see Table 6.6). However, some monitored pollutants are not present at specific outfalls. Detailed storm water data summary tables are given in Environmental Monitoring on the Oak Ridge Reservation: 2003 Results (DOE 2004c). (See http://www.ornl.gov/ aser/.)

\subsubsection{Flow Management (or Raw Water)}

Because of concern about maintaining water quality and stable flow in the upper reaches of East Fork Poplar Creek, the NPDES permit requires addition of Clinch River water to the headwaters of East Fork Poplar Creek (North/ South Pipe-Outfall 200 area) so that a minimum flow of 7 million gal/day (26.5 million L/day) is maintained at the point where East Fork Poplar Creek leaves the reservation (Station 17). The permit required that this project be implemented by March 1997, but the work was completed ahead of schedule (August 1996). With the completion of this project, instream water temperatures decreased approximately $5^{\circ} \mathrm{C}$ (from approximately $26^{\circ} \mathrm{C}$ at the headwaters).

During CY 2003 the flow of Upper East Fork Poplar Creek was maintained in accordance with the permit conditions. The average daily flow during CY 2003 was 9.7 million gal/day.

\subsubsection{Y-12 Fecal Coliform Study}

Studies conducted by Y-12 personnel in the mid 1990s of fecal coliform concentrations in East Fork Poplar Creek and at NPDES outfalls recorded elevated levels during or immediately following rain events. Although the storm water monitoring program analyzes for fecal coliform at various outfalls each year, monitoring for bacteria in East Fork Poplar Creek where it exits from Y12 property is not routinely performed. A major project to upgrade the sanitary sewer system within the Y-12 Complex and the sewer line along Scarboro Road, which connects into the city of Oak Ridge collection system was completed by the end of 2000. In 2002, a new bacteria-sampling project for the upper reach of East Fork Poplar Creek inside the Y-12 Complex was initiated to determine whether a reduction of bacteria levels in the stream followed completion of the sewer improvement project.

Two sampling events one in the spring and another in the fall of 2002 were performed at two in stream monitoring locations. Samples for $E$. coli and fecal coliform were taken at Station 17 (also known as 9422-1) located near to the point where East Fork Poplar Creek flows off the Y-12 Complex, and outfall 20, located near to the point where a major portion of the Y-12 storm drain system surfaces to form East Fork Poplar Creek. All results from samples taken at outfall 201 were very low and well within water quality criteria. Measurements of fecal coliform from samples taken at Station 17 were also below water criteria values. However, some individual values for $E$. coli and the geometric mean ( 132 colonies per 100 $\mathrm{mL}$ ) for one group of results obtained during the 
Table 6.7. NPDES compliance monitoring requirements and record for the $\mathrm{Y}-12$ Complex January through December 2003

\begin{tabular}{|c|c|c|c|c|c|c|c|}
\hline \multirow[b]{2}{*}{ Discharge point } & \multirow[b]{2}{*}{ Effluent parameter } & \multicolumn{4}{|c|}{ Effluent limits } & \multirow[b]{2}{*}{$\begin{array}{l}\text { Percentage } \\
\text { of } \\
\text { compliance }\end{array}$} & \multirow[b]{2}{*}{$\begin{array}{l}\text { No. of } \\
\text { samples }\end{array}$} \\
\hline & & $\begin{array}{c}\text { Daily } \\
\text { avg } \\
(\mathrm{lb} / \mathrm{d}) \\
\end{array}$ & $\begin{array}{c}\text { Daily } \\
\max \\
(\mathrm{lb} / \mathrm{d})\end{array}$ & $\begin{array}{c}\text { Daily } \\
\text { avg } \\
(\mathrm{mg} / \mathrm{L})\end{array}$ & $\begin{array}{c}\text { Daily } \\
\max \\
(\mathrm{mg} / \mathrm{L})\end{array}$ & & \\
\hline Outfall 066 & $\mathrm{pH}$, standard units & & & $a$ & 9 & $b$ & 0 \\
\hline Outfall 068 & $\mathrm{pH}$, standard units & & & $a$ & 9 & $b$ & 0 \\
\hline Outfall 117 & $\mathrm{pH}$, standard units & & & $a$ & 9 & $b$ & 0 \\
\hline Outfall 073 & $\begin{array}{l}\mathrm{pH} \text {, standard units } \\
\text { Total residual chlorine }\end{array}$ & & & $a$ & $\begin{array}{l}9.0 \\
0.5\end{array}$ & $\begin{array}{l}b \\
b\end{array}$ & 0 \\
\hline Outfall 077 & $\begin{array}{l}\mathrm{pH} \text {, standard units } \\
\text { Total residual chlorine }\end{array}$ & & & $a$ & $\begin{array}{l}9.0 \\
0.5\end{array}$ & $\begin{array}{l}100 \\
100\end{array}$ & $\begin{array}{l}12 \\
12\end{array}$ \\
\hline Outfall 122 & $\begin{array}{l}\mathrm{pH} \text {, standard units } \\
\text { Total residual chlorine }\end{array}$ & & & $a$ & $\begin{array}{l}9.0 \\
0.5\end{array}$ & $\begin{array}{l}b \\
b\end{array}$ & 0 \\
\hline Outfall 133 & $\begin{array}{l}\mathrm{pH} \text {, standard units } \\
\text { Total residual chlorine }\end{array}$ & & & $a$ & $\begin{array}{l}9.0 \\
0.5\end{array}$ & $\begin{array}{l}b \\
b\end{array}$ & 0 \\
\hline Outfall 125 & $\begin{array}{l}\mathrm{pH} \text {, standard units } \\
\text { Total residual chlorine }\end{array}$ & & & $a$ & $\begin{array}{l}9.0 \\
0.5\end{array}$ & $\begin{array}{r}100 \\
92\end{array}$ & $\begin{array}{l}12 \\
12\end{array}$ \\
\hline $\begin{array}{l}\text { Category I outfalls } \\
\text { (storm water, } \\
\text { steam condensate, } \\
\text { cooling tower } \\
\text { blowdown, and } \\
\text { groundwater) }\end{array}$ & $\mathrm{pH}$, standard units & & & $a$ & 9 & 100 & 70 \\
\hline $\begin{array}{l}\text { Category I outfalls } \\
\text { (Outfalls S15 } \\
\text { and S16) }\end{array}$ & $\mathrm{pH}$, standard units & & & $a$ & 10 & 100 & 4 \\
\hline $\begin{array}{l}\text { Category II outfalls } \\
\text { (cooling water, } \\
\text { steam condensate, } \\
\text { storm water, and } \\
\text { groundwater) }\end{array}$ & $\begin{array}{l}\mathrm{pH} \text {, standard units } \\
\text { Total residual chlorine }\end{array}$ & & & $a$ & $\begin{array}{l}9.0 \\
0.5\end{array}$ & $\begin{array}{l}100 \\
100\end{array}$ & $\begin{array}{r}137 \\
73\end{array}$ \\
\hline $\begin{array}{l}\text { Category II outfalls } \\
\text { (S21, S22, S25, } \\
\text { S26, S27, S28, } \\
\text { and S29) }\end{array}$ & $\mathrm{pH}$, standard units & & & $a$ & 10 & 100 & 25 \\
\hline $\begin{array}{l}\text { Outfall S19 } \\
\text { (Rogers Quarry) }\end{array}$ & $\mathrm{pH}$, standard units & & & $a$ & 9 & 100 & 14 \\
\hline $\begin{array}{l}\text { Category III outfalls } \\
\text { (storm water, } \\
\text { cooling water, } \\
\text { cooling tower } \\
\text { blowdown, steam } \\
\text { condensate, and } \\
\text { groundwater) }\end{array}$ & $\begin{array}{l}\mathrm{pH} \text {, standard units } \\
\text { Total residual chlorine }\end{array}$ & & & $a$ & $\begin{array}{l}9.0 \\
0.5\end{array}$ & $\begin{array}{l}100 \\
100\end{array}$ & $\begin{array}{l}161 \\
144\end{array}$ \\
\hline $\begin{array}{l}\text { Outfall } 201 \text { (below } \\
\text { the North/South } \\
\text { pipes) }\end{array}$ & $\begin{array}{l}\text { Total residual chlorine } \\
\text { Temperature, }{ }^{\circ} \mathrm{C} \\
\text { pH, standard units }\end{array}$ & & 8.5 & $\begin{array}{l}0.011 \\
a \\
a\end{array}$ & $\begin{array}{l}0.019 \\
30.5\end{array}$ & $\begin{array}{r}99 \\
100 \\
100\end{array}$ & $\begin{array}{l}156 \\
157 \\
157\end{array}$ \\
\hline $\begin{array}{l}\text { Outfall } 200 \text { (North/ } \\
\text { South pipes) }\end{array}$ & $\begin{array}{l}\text { Oil and grease } \\
\text { Hexane extractable } \\
\text { material }\end{array}$ & & & $\begin{array}{l}10 \\
10\end{array}$ & $\begin{array}{l}15 \\
15\end{array}$ & $\begin{array}{r}99 \\
100\end{array}$ & $\begin{array}{l}77 \\
82\end{array}$ \\
\hline
\end{tabular}


Table 6.7 (continued)

\begin{tabular}{|c|c|c|c|c|c|c|c|}
\hline \multirow[b]{2}{*}{ Discharge point } & \multirow[b]{2}{*}{ Effluent parameter } & \multicolumn{4}{|c|}{ Effluent limits } & \multirow{2}{*}{$\begin{array}{l}\text { Percentage } \\
\text { of } \\
\text { compliance }\end{array}$} & \multirow[b]{2}{*}{$\begin{array}{l}\text { No. of } \\
\text { samples }\end{array}$} \\
\hline & & $\begin{array}{c}\text { Daily } \\
\text { avg } \\
\text { (lb/d) } \\
\end{array}$ & $\begin{array}{c}\text { Daily } \\
\max \\
(\mathrm{lb} / \mathrm{d}) \\
\end{array}$ & $\begin{array}{c}\text { Daily } \\
\text { avg } \\
(\mathrm{mg} / \mathrm{L}) \\
\end{array}$ & $\begin{array}{c}\text { Daily } \\
\max \\
(\mathrm{mg} / \mathrm{L}) \\
\end{array}$ & & \\
\hline \multirow[t]{3}{*}{ Outfall 021} & Total residual chlorine & & & 0.080 & 0.188 & 100 & 157 \\
\hline & Temperature, ${ }^{\circ} \mathrm{C}$ & & & $a$ & 30.5 & 100 & 158 \\
\hline & $\mathrm{pH}$, standard units & & & & 9.0 & 100 & 158 \\
\hline \multirow[t]{2}{*}{ Outfall 017} & $\mathrm{pH}$, standard units & & & $a$ & 9.0 & 100 & 55 \\
\hline & Ammonia as $\mathrm{N}$ & & & 32.4 & 64.8 & 100 & 52 \\
\hline \multirow[t]{3}{*}{ Outfall 055} & $\mathrm{pH}$, standard units & & & $a$ & 9.0 & 100 & 105 \\
\hline & Mercury & & & & 0.004 & 98 & 105 \\
\hline & Total residual chlorine & & & & 0.5 & 99 & 118 \\
\hline \multirow[t]{2}{*}{ Outfall 55A } & $\mathrm{pH}$, standard units & & & $a$ & 9.0 & $b$ & 0 \\
\hline & Mercury & & & & 0.004 & $b$ & 0 \\
\hline \multirow[t]{2}{*}{ Outfall 550} & $\mathrm{pH}$, standard units & & & $a$ & 9.0 & 100 & 52 \\
\hline & Mercury & & & 0.002 & 0.004 & 100 & 52 \\
\hline \multirow[t]{2}{*}{ Outfall 551} & $\mathrm{pH}$, standard units & & & 0.002 & 9.0 & 100 & 52 \\
\hline & Mercury & & & & 0.004 & 100 & 52 \\
\hline Outfall 051 & $\mathrm{pH}$, standard units & & & $a$ & 9 & 100 & 106 \\
\hline \multirow{14}{*}{$\begin{array}{l}\text { Outfall } 501 \\
\text { (Central } \\
\text { Pollution Control } \\
\text { Facility) }\end{array}$} & $\mathrm{pH}$, standard units & & & $a$ & 9.0 & 100 & 2 \\
\hline & Total suspended solids & & & 31.0 & 40.0 & 100 & 2 \\
\hline & Total toxic organics & & & & 2.13 & 100 & 1 \\
\hline & Oil and grease & & & 10 & 15 & 100 & 2 \\
\hline & Cadmium & 0.16 & 0.4 & 0.075 & 0.15 & 100 & 2 \\
\hline & Chromium & 1.0 & 1.7 & 0.5 & 1.0 & 100 & 2 \\
\hline & Copper & 1.2 & 2.0 & 0.5 & 1.0 & 100 & 2 \\
\hline & Lead & 0.26 & 0.4 & 0.1 & 0.2 & 100 & 2 \\
\hline & Nickel & 1.4 & 2.4 & 2.38 & 3.98 & 100 & 2 \\
\hline & Nitrate/nitrite & & & & 100 & 100 & 2 \\
\hline & Silver & 0.14 & 0.26 & 0.05 & 0.05 & 100 & 2 \\
\hline & Zinc & 0.9 & 1.6 & 1.48 & 2.0 & 100 & 2 \\
\hline & Cyanide & 0.4 & 0.72 & 0.65 & 1.20 & 100 & 2 \\
\hline & Polychlorinated biphenyls & & & & 0.001 & 100 & 1 \\
\hline \multirow{14}{*}{$\begin{array}{l}\text { Outfall } 502 \\
\text { (West End } \\
\text { Treatment } \\
\text { Facility) }\end{array}$} & $\mathrm{pH}$, standard units & & & $a$ & 9.0 & $b$ & 0 \\
\hline & Total suspended solids & 18.6 & 36.0 & 31.0 & 40.0 & $b$ & 0 \\
\hline & Total toxic organics & & & & 2.13 & $b$ & 0 \\
\hline & Nitrate/nitrite & & & 100 & 150 & $b$ & 0 \\
\hline & Oil and grease & & & 10 & 15 & $b$ & 0 \\
\hline & Cadmium & 0.16 & 0.4 & 0.075 & 0.15 & $b$ & 0 \\
\hline & Chromium & 1.0 & 1.7 & 0.5 & 1.0 & $b$ & 0 \\
\hline & Copper & 1.2 & 2.0 & 0.5 & 1.0 & $b$ & 0 \\
\hline & Lead & 0.26 & 0.4 & 0.10 & 0.20 & $b$ & 0 \\
\hline & Nickel & 1.4 & 2.4 & 2.38 & 3.98 & $b$ & 0 \\
\hline & Silver & 0.14 & 0.26 & 0.05 & 0.05 & $b$ & 0 \\
\hline & Zinc & 0.9 & 1.6 & 1.48 & 2.0 & $b$ & 0 \\
\hline & Cyanide & 0.4 & 0.72 & 0.65 & 1.20 & $b$ & 0 \\
\hline & Polychlorinated biphenyls & & & & 0.001 & $b$ & 0 \\
\hline
\end{tabular}


Table 6.7 (continued)

\begin{tabular}{|c|c|c|c|c|c|c|c|}
\hline \multirow[b]{2}{*}{ Discharge point } & \multirow[b]{2}{*}{ Effluent parameter } & \multicolumn{4}{|c|}{ Effluent limits } & \multirow{2}{*}{$\begin{array}{l}\text { Percentage } \\
\text { of } \\
\text { compliance }\end{array}$} & \multirow[b]{2}{*}{$\begin{array}{c}\text { No. of } \\
\text { samples }\end{array}$} \\
\hline & & $\begin{array}{c}\text { Daily } \\
\text { avg } \\
\text { (lb/d) }\end{array}$ & $\begin{array}{c}\text { Daily } \\
\max \\
(\mathrm{lb} / \mathrm{d}) \\
\end{array}$ & $\begin{array}{c}\text { Daily } \\
\text { avg } \\
(\mathrm{mg} / \mathrm{L})\end{array}$ & $\begin{array}{c}\text { Daily } \\
\max \\
(\mathrm{mg} / \mathrm{L}) \\
\end{array}$ & & \\
\hline Outfall 503 & $\mathrm{pH}$, standard units & & & $a$ & 9.0 & $b$ & 0 \\
\hline (Steam Plant & Total suspended solids & 125 & 417 & 30.0 & 40.0 & $b$ & 0 \\
\hline Wastewater & Oil and grease & 62.6 & 83.4 & 10 & 15 & $b$ & 0 \\
\hline Treatment & Iron & 4.17 & 4.17 & 1.0 & 1.0 & $b$ & 0 \\
\hline \multirow{5}{*}{ Facility) } & Cadmium & & & 0.075 & 0.15 & $b$ & 0 \\
\hline & Chromium & 0.83 & 0.83 & 0.20 & 0.20 & $b$ & 0 \\
\hline & Copper & 4.17 & 4.17 & 0.20 & 0.40 & $b$ & 0 \\
\hline & Lead & & & 0.10 & 0.20 & $b$ & 0 \\
\hline & Zinc & 4.17 & 4.17 & 1.0 & 1.0 & $b$ & 0 \\
\hline Outfall 512 & $\mathrm{pH}$ & & & $a$ & 9.0 & 100 & 143 \\
\hline (Groundwater & Iron & & & & 1.0 & 100 & 142 \\
\hline $\begin{array}{l}\text { Treatment } \\
\text { Facility) }\end{array}$ & Polychlorinated biphenyls & & & & 0.001 & 100 & 12 \\
\hline Outfall 520 & $\mathrm{pH}$, standard units & & & & 9 & 100 & 25 \\
\hline Outfall 05A & $\mathrm{pH}$ & & & & 9 & $b$ & 0 \\
\hline
\end{tabular}

${ }^{a}$ Not applicable.

${ }^{b}$ No discharge.

Table 6.8. Y-12 Complex Discharge Point SS6, Sanitary Sewer Station 6 January through December 2003

\begin{tabular}{lcccc}
\hline \multicolumn{1}{c}{ Effluent parameter } & $\begin{array}{c}\text { Number of } \\
\text { samples }\end{array}$ & $\begin{array}{c}\text { Daily average value } \\
\text { (effluent limit) }^{a}\end{array}$ & $\begin{array}{c}\text { Daily maximum value } \\
\text { (effluent limit }^{b}\end{array}$ & $\begin{array}{c}\text { Percentage of } \\
\text { compliance }^{\text {com }}\end{array}$ \\
\hline pH, standard units & 55 & $c$ & $9 / 6^{d}$ & 100 \\
Silver & 53 & 0.05 & 0.1 & 100 \\
Arsenic & 53 & 0.01 & 0.015 & 96 \\
Benzene & 11 & 0.01 & 0.015 & 100 \\
Biochemical oxygen demand & 53 & 200 & 300 & 100 \\
Cadmium & 53 & 0.0033 & 0.005 & 100 \\
Chromium & 53 & 0.05 & 0.075 & 100 \\
Copper & 53 & 0.14 & 0.21 & 100 \\
Cyanide & 13 & 0.041 & 0.062 & 100 \\
Iron & 53 & 10 & 15 & 98 \\
Mercury & 53 & 0.023 & 0.035 & 100 \\
Kjeldahl nitrogen & 53 & 45 & 90 & 100 \\
Methylene chloride & 11 & 0.027 & 0.041 & 100 \\
Nickel & 53 & 0.021 & 0.032 & 98 \\
Oil and grease & 53 & 25 & 50 & 100 \\
Lead & 53 & 0.049 & 0.074 & 100 \\
Phenols-total recoverable & 53 & 0.3 & 0.5 & 100 \\
Suspended solids & 53 & 200 & 300 & 100 \\
Toluene & 11 & 0.01 & 0.02 & 100 \\
Trichloroethene & 11 & 0.018 & 0.027 & 100 \\
Zinc & 53 & 0.35 & 0.75 & 100 \\
\hline
\end{tabular}

${ }^{a}$ Units in milligrams per liter unless otherwise indicated.

${ }^{b}$ Industrial and Commercial Users Wastewater Permit limits.

'Not applicable.

${ }^{d}$ Maximum value/minimum value. 
fall event was above the recreational criteria of 126 colonies per $100 \mathrm{~mL}$.

Comparison of 2002 data at Station 17 with earlier studies showed that an increase in levels during rain events still occur. The 2002 data appear to show some improvement or a reduction of bacteria levels obtained in the earlier studies. A review of fecal coliform data taken at locations throughout the Y-12 area as part of the ongoing Stormwater Pollution Prevention Program has also been conducted. The data demonstrate that elevated levels of fecal coliform often occur in areas remote from the central part of the complex that are not served by the sanitary sewer system. Several of the higher readings in Y-12 also occur at outfalls that drain areas known to be frequented by wildlife. In 2004, additional monitoring in East Fork Poplar Creek and at designated outfalls is planned during a rain event to ascertain the location of bacteria sources to the stream.

\subsubsection{Mercury Removal from Storm Drain Catch Basins}

In May 2003, metallic mercury was observed in two storm drain catch basins located along $\mathrm{G}$ Road and southeast of Building 9201-4. The storm drain line on which the catch basins are located flows into East Fork Poplar Creek at outfall 200. Mercury tends to collect at these low spots in the drain system following heavy rains. During 2003, Y-12 spill response and waste services personnel conducted ten removals and recovered an estimated $28 \mathrm{lb}$ of mercury. Recovery of mercury is expected to continue in 2004 .

\subsection{BIOMONITORING PROGRAM}

In accordance with the 1995 NPDES permit (Part III-C, p. 39), a biomonitoring program is required that evaluates an East Fork Poplar Creek instream monitoring location (Outfall 201), wastewater treatment system discharges, and locations in the storm drain system. Table 6.9 summarizes the results of biomonitoring tests conducted during 2003 on effluent samples from wastewater treatment systems and storm drainage systems. The results of the biomonitoring tests are expressed as the concentration of effluent that is lethal to $50 \%$ of the test organisms $\left(\mathrm{LC}_{50}\right)$ during a 48-hour period. Thus, the lower the value, the more toxic an effluent. The $\mathrm{LC}_{50}$ is compared with the effluent's calculated instream waste concentration to determine the likelihood that the discharged effluent would be harmful to aquatic life in the receiving stream. If the $\mathrm{LC}_{50}$ is much greater than the instream waste concentration, it is less likely that there is an instream impact.

Effluent samples from three of the four wastewater treatment system discharges were tested on Ceriodaphnia dubia at least once during 2003. The West End Treatment Facility did not discharge in 2003. With $\mathrm{LC}_{50}$ s greater than $100 \%$ in each of four tests, effluents from the Central Mercury Treatment System were consistently nontoxic throughout the year. Effluent from the Central Pollution Control Facility was also nontoxic, with an $\mathrm{LC}_{50}$ greater than $100 \%$ in the one test conducted in 2003. In four tests during 2003, the $\mathrm{LC}_{50}$ s for effluent from the Groundwater Treatment Facility ranged from $44.1 \%$ to greater than $100 \%$. In all cases, the calculated instream waste concentrations of the effluent were less than the $\mathrm{LC}_{50} \mathrm{~s}$, suggesting that effluents from the individual treatment facilities would not be acutely toxic to the aquatic life of East Fork Poplar Creek.

Various locations in the storm drainage system upstream of outfalls 200 and 201 were also monitored during the year. When chlorine or similar chemicals (i.e., bromine) were detected in a sample, side-by-side tests were conducted with a sample that was treated (dechlorinated) to remove the chlorine or chlorine-like chemical. In all cases where toxicity was detected in the nontreated sample $\left(\mathrm{LC}_{50}\right.$ less than $\left.100 \%\right)$, survival was higher in the dechlorinated sample than in the nontreated sample. In most cases, the full-strength dechlorinated sample did not continue to reduce Ceriodaphnia survival, indicating that toxicity was due solely to chlorine or similar chemicals. In the few cases where Ceriodaphnia survival continued to be reduced after dechlorination, additional sources of toxicity are implicated. Because flow is not measured at these storm-drain points, it is not possible to know the contribution of each to the total flow at Outfall 201 (i.e., the instream waste concentration). It is notable, however, that the results of the biomonitoring 
Table 6.9. Y-12 Complex Biomonitoring Program summary information for wastewater treatment systems and storm sewer (cooling tower) effluents for $2003^{a}$

\begin{tabular}{|c|c|c|c|c|}
\hline Site/building & $\begin{array}{l}\text { Test } \\
\text { date }\end{array}$ & Species & $\begin{array}{c}\text { 48-h } \mathrm{LC}_{50}{ }^{b} \\
(\%)\end{array}$ & $\begin{array}{r}\mathrm{IWC}^{c} \\
(\%)\end{array}$ \\
\hline Groundwater Treatment Facility (512) & $1 / 8 / 03$ & Ceriodaphnia & 88.0 & 0.10 \\
\hline Cooling tower 9409-15 & $1 / 9 / 03$ & Ceriodaphnia & $<6$ & $d$ \\
\hline Cooling tower 9409-15 (dechlorinated) & $1 / 9 / 03$ & Ceriodaphnia & $>100$ & $d$ \\
\hline Cooling tower 9409-26 & $1 / 9 / 03$ & Ceriodaphnia & $>100$ & $d$ \\
\hline Cooling tower 9409-26 (dechlorinated) & $1 / 9 / 03$ & Ceriodaphnia & $>100$ & $d$ \\
\hline Central Mercury Treatment System (551) & $1 / 10 / 03$ & Ceriodaphnia & $>100$ & 0.09 \\
\hline Cooling tower 9409-20 & $1 / 14 / 03$ & Ceriodaphnia & 8.3 & $d$ \\
\hline Cooling tower 9409-20 (dechlorinated) & $1 / 14 / 03$ & Ceriodaphnia & $>100$ & $d$ \\
\hline Cooling tower $9409-23$ & $1 / 14 / 03$ & Ceriodaphnia & 9.6 & $d$ \\
\hline Cooling tower 9409-23 (dechlorinated) & $1 / 14 / 03$ & Ceriodaphnia & $>100$ & $d$ \\
\hline Cooling tower 9409-15 & $4 / 3 / 03$ & Ceriodaphnia & 8.7 & $d$ \\
\hline Cooling tower 9409-15 (dechlorinated) & $4 / 3 / 03$ & Ceriodaphnia & $>100$ & $d$ \\
\hline Cooling tower 9409-32 & $4 / 3 / 03$ & Ceriodaphnia & $<6$ & $d$ \\
\hline Cooling tower 9409-32 (dechlorinated) & $4 / 3 / 03$ & Ceriodaphnia & $>100$ & $d$ \\
\hline Central Mercury Treatment System (551) & $4 / 4 / 03$ & Ceriodaphnia & $>100$ & 0.07 \\
\hline Groundwater Treatment Facility (512) & $4 / 8 / 03$ & Ceriodaphnia & 44.1 & 0.09 \\
\hline Cooling tower 9409-10 & $4 / 8 / 03$ & Ceriodaphnia & $>100$ & $d$ \\
\hline Cooling tower 9409-10 (dechlorinated) & $4 / 8 / 03$ & Ceriodaphnia & $>100$ & $d$ \\
\hline Cooling tower $9409-26$ & $4 / 8 / 03$ & Ceriodaphnia & $>100$ & $d$ \\
\hline Cooling tower 9409-26 (dechlorinated) & $4 / 8 / 03$ & Ceriodaphnia & $>100$ & $d$ \\
\hline Outfall 520 & $5 / 2 / 03$ & Ceriodaphnia & 11.8 & $d$ \\
\hline Central Pollution Control Facility (501) & $5 / 21 / 03$ & Ceriodaphnia & $>100$ & 0.08 \\
\hline Groundwater Treatment Facility (512) & $7 / 9 / 03$ & Ceriodaphnia & 47.0 & 0.13 \\
\hline Central Mercury Treatment System (551) & $7 / 9 / 03$ & Ceriodaphnia & $>100$ & 0.10 \\
\hline Outfall 520 & $7 / 9 / 03$ & Ceriodaphnia & 28.2 & $d$ \\
\hline Storm sewer $9422-10$ & $7 / 10 / 03$ & Ceriodaphnia & 75.8 & $d$ \\
\hline Storm sewer 9422-10 (dechlorinated) & $7 / 10 / 03$ & Ceriodaphnia & $>100$ & $d$ \\
\hline Storm sewer 9422-15 & $7 / 10 / 03$ & Ceriodaphnia & $>100$ & $d$ \\
\hline Storm sewer 9422-11 & $7 / 15 / 03$ & Ceriodaphnia & $>100$ & $d$ \\
\hline Storm sewer 9422-12 & $7 / 15 / 03$ & Ceriodaphnia & 17.3 & $d$ \\
\hline Storm sewer 9422-12 (dechlorinated) & $7 / 15 / 03$ & Ceriodaphnia & $>100$ & $d$ \\
\hline Outfall 520 & $10 / 8 / 03$ & Ceriodaphnia & 30.4 & $d$ \\
\hline Storm sewer $9422-10$ & $10 / 9 / 03$ & Ceriodaphnia & 34.3 & $d$ \\
\hline Storm sewer 9422-10 (dechlorinated) & $10 / 9 / 03$ & Ceriodaphnia & $>100$ & $d$ \\
\hline Storm sewer $9422-11$ & $10 / 9 / 03$ & Ceriodaphnia & $>100$ & $d$ \\
\hline Storm sewer 9422-12 & $10 / 14 / 03$ & Ceriodaphnia & 70.7 & $d$ \\
\hline Storm sewer 9422-12 (dechlorinated) & $10 / 14 / 03$ & Ceriodaphnia & 73.0 & $d$ \\
\hline Storm sewer 9422-15 & $10 / 14 / 03$ & Ceriodaphnia & $>100$ & $d$ \\
\hline Groundwater Treatment Facility (512) & $10 / 16 / 03$ & Ceriodaphnia & $>100$ & 0.18 \\
\hline Central Mercury Treatment System (551) & $10 / 17 / 03$ & Ceriodaphnia & $>100$ & 0.12 \\
\hline
\end{tabular}

${ }^{a}$ Summarized are the effluents and their corresponding $48-\mathrm{h} \mathrm{LC}_{50} \mathrm{~s}$ and instream waste concentrations. Note: Discharges from treatment facilities are intermittent because of batch operations.

${ }^{b}$ The concentration of effluent (as a percentage of full-strength effluent diluted with laboratory control water) that is lethal to $50 \%$ of the test organisms in $48 \mathrm{~h}$.

${ }^{c}$ IWC $=$ instream waste concentration based on actual flows at Outfall 201 in East Fork Poplar Creek

${ }^{d}$ This point is in the storm sewer system; therefore, an IWC is not applicable. 
tests at Outfall 201 (Table 6.10) demonstrated that when all discharges each to the total flow at Outfall 201 (i.e., the instream waste concentration). It is notable, however, that the results of the biomonitoring tests at Outfall 201 (Table 6.10) demonstrated that when all discharges were combined (treated effluent, storm sewer contribution, plus flow management water) the result was a consistent absence of toxicity at Outfall 201.

Table 6.10 summarizes the "no-observedeffect concentrations" (NOECs) and 96-hour $\mathrm{LC}_{50} \mathrm{~s}$ for the instream monitoring location Outfall 201. The NOEC is the concentration of effluent that does not reduce survival, growth, or reproduction of the biomonitoring test organisms during a 6- or 7-day test. Thus, like the $\mathrm{LC}_{50}$, the lower the value, the more toxic the effluent. Water from the instream monitoring point, Outfall 201, was tested four times in 2003 using fathead minnow larvae (Pimephales promelas) and Ceriodaphnia dubia. The NOECs were $100 \%$ for all Ceriodaphnia and fathead minnow tests; the 96-h $\mathrm{LC}_{50} \mathrm{~s}$ were consistently greater than $100 \%$ for both Ceriodaphnia and fathead minnows.

\subsection{BIOLOGICAL MONITORING AND ABATEMENT PROGRAMS}

The NPDES permit issued to the Y-12 National Security Complex in 1995 mandates a Biological Monitoring and Abatement Program (BMAP) with the objective of demonstrating that the effluent limitations established for the facility protect the classified uses of the receiving stream, East Fork Poplar Creek. The BMAP consists of four major tasks that reflect complementary approaches to evaluating the effects of Y-12 Complex discharges on the aquatic integrity of East Fork Poplar Creek. These tasks are (1) toxicity monitoring; (2) biological indicator studies; (3) bioaccumulation studies; and (4) ecological surveys of the periphyton, benthic macroinvertebrate, and fish communities.

Monitoring is currently being conducted at five primary East Fork Poplar Creek sites, although sites may be excluded or added, depending upon the specific objectives of the

Table 6.10. Y-12 Complex Biomonitoring Program summary information for Outfall 201 for $2003^{a}$

\begin{tabular}{cccc}
\hline Test date & Species & $\begin{array}{c}\mathrm{NOEC}^{b} \\
(\%)\end{array}$ & $\begin{array}{c}96-\mathrm{h} \mathrm{LC}_{50}{ }^{c} \\
(\%)\end{array}$ \\
\hline \multirow{2}{*}{$1 / 8$} & Ceriodaphnia & 100 & $>100$ \\
& Fathead minnow & 100 & $>100$ \\
$4 / 2$ & Ceriodaphnia & 100 & $>100$ \\
& Fathead minnow & 100 & $>100$ \\
$7 / 9$ & Ceriodaphnia & 100 & $>100$ \\
& Fathead minnow & 100 & $>100$ \\
\multirow{2}{*}{$10 / 8$} & Ceriodaphnia & 100 & $>100$ \\
& Fathead minnow & 100 & $>100$ \\
\hline
\end{tabular}

${ }^{a}$ Summarized are the no-observed effect concentrations (NOECs) and the 96-h $\mathrm{LC}_{50} \mathrm{~s}$ for the instream monitoring location, Outfall 201.

${ }^{b} \mathrm{NOEC}$ as a percentage of full-strength effluent from Outfall 201 diluted with laboratory control water. The NOEC must equal one of the test concentrations and is the concentration that does not reduce Ceriodaphnia survival or reproduction or fathead minnow survival or growth.

'The concentration of effluent (as a percentage of full-strength effluent diluted with laboratory control water) that is lethal to $50 \%$ of the test organisms in $96 \mathrm{~h}$. 
various tasks. The primary sampling sites include upper East Fork Poplar Creek at East Fork Poplar Creek kilometer (EFK) 24.4 and 23.4 (upstream and downstream of Lake Reality, respectively); EFK 18.7 (also EFK 18 and 19), located off the ORR and below an area of intensive commercial and light industrial development; EFK 13.8 (also EFK 14), located upstream from the Oak Ridge Wastewater Treatment Facility; and EFK 6.3, located approximately $1.4 \mathrm{~km}$ below the ORR boundary (Fig. 6.8). Brushy Fork at Brushy Fork kilometer 7.6 is used as a reference stream in most tasks of the BMAP. Additional sites off the ORR are also occasionally used for reference, including Beaver Creek, Bull Run, Cox Creek, Hinds Creek, Paint Rock Creek, and the Emory River in Watts Bar Reservoir (Fig. 6.9).

Trends of increases in species richness and diversity at upstream locations over the last decade, along with similar but more subtle trends in a number of other BMAP indicators, demonstrate that the overall ecological health of East Fork Poplar Creek continues to improve. However, the pace of improvement in the health of East Fork Poplar Creek has slowed in recent years, and fish and invertebrate communities continue to be degraded in comparison with similar communities in reference streams. minnows to provide systematic information that is used to verify the biological water quality of East Fork Poplar Creek at intervals throughout the year. Ceriodaphnia tests were conducted quarterly in 2003 for one site upstream of Bear Creek Road (EFK 24.1). In addition, quarterly toxicity tests with both fathead minnows and Ceriodaphnia were conducted at Outfall 201 as required by the Y-12 Complex's NPDES permit. Because of the close proximity of Outfall 201 (an instream NPDES location in Upper East Fork Poplar Creek) to EFK 25.1, the tests of water from Outfall 201 also met the intent of the Y-12 BMAP Plan (Adams et al. 2000) to conduct quarterly toxicity tests at the latter location.

No evidence for toxicity was observed in any of the 2003 Ceriodaphnia tests (both East Fork Poplar Creek sites) or fathead minnow tests (Outfall 201). These results are consistent with the findings of previous Ceriodaphnia and fathead minnow tests conducted since flow management began in the latter half of 1996. Similarly, toxicity of East Fork Poplar Creek water in other chronic tests involving fish embryos and clams, which appear more sensitive to water quality conditions in the stream, continues to decrease. Fish embryolarval test results are discussed in Sect. 6.7.3; clam tests are discussed in Sect. 6.7.4.

\subsubsection{Toxicity Monitoring}

Toxicity monitoring employs EPA-approved methods with Ceriodaphnia dubia and fathead

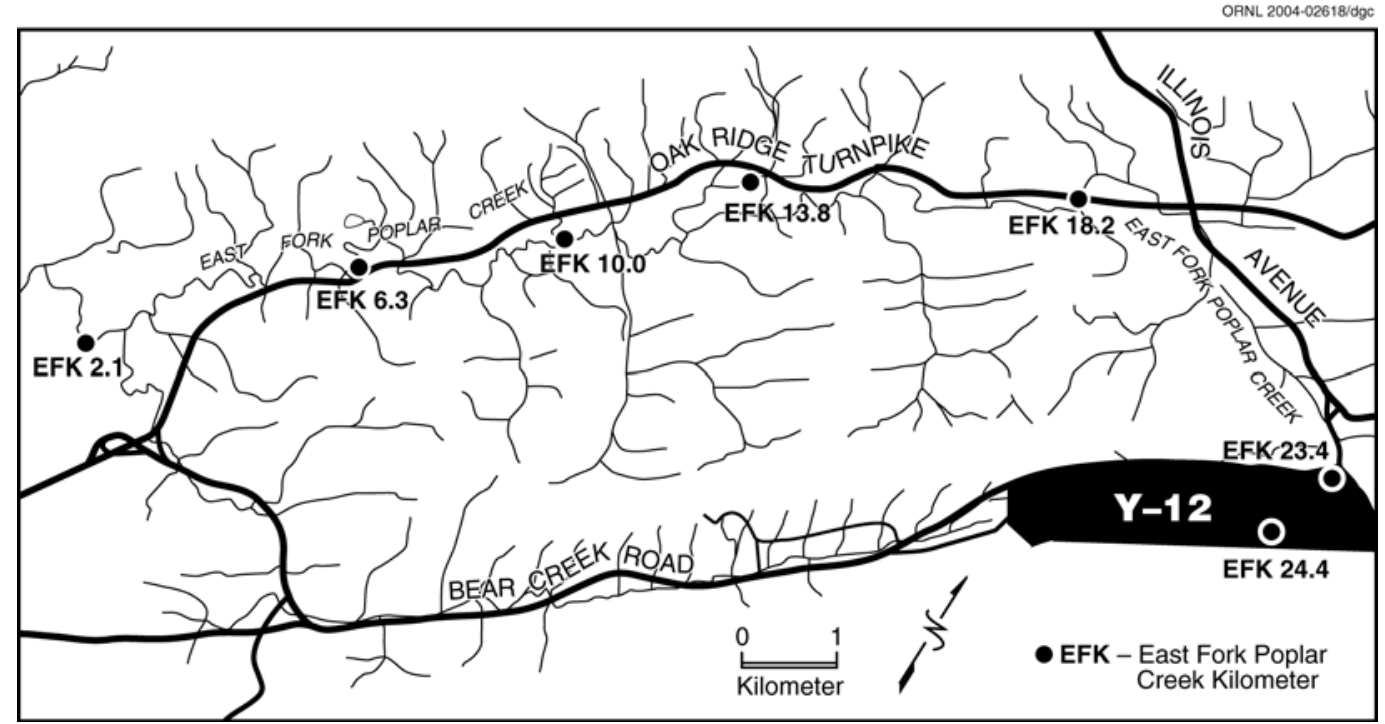

Fig. 6.8. Location of biological monitoring sites on East Fork Poplar Creek in relation to the Oak Ridge Y-12 National Security Complex. 


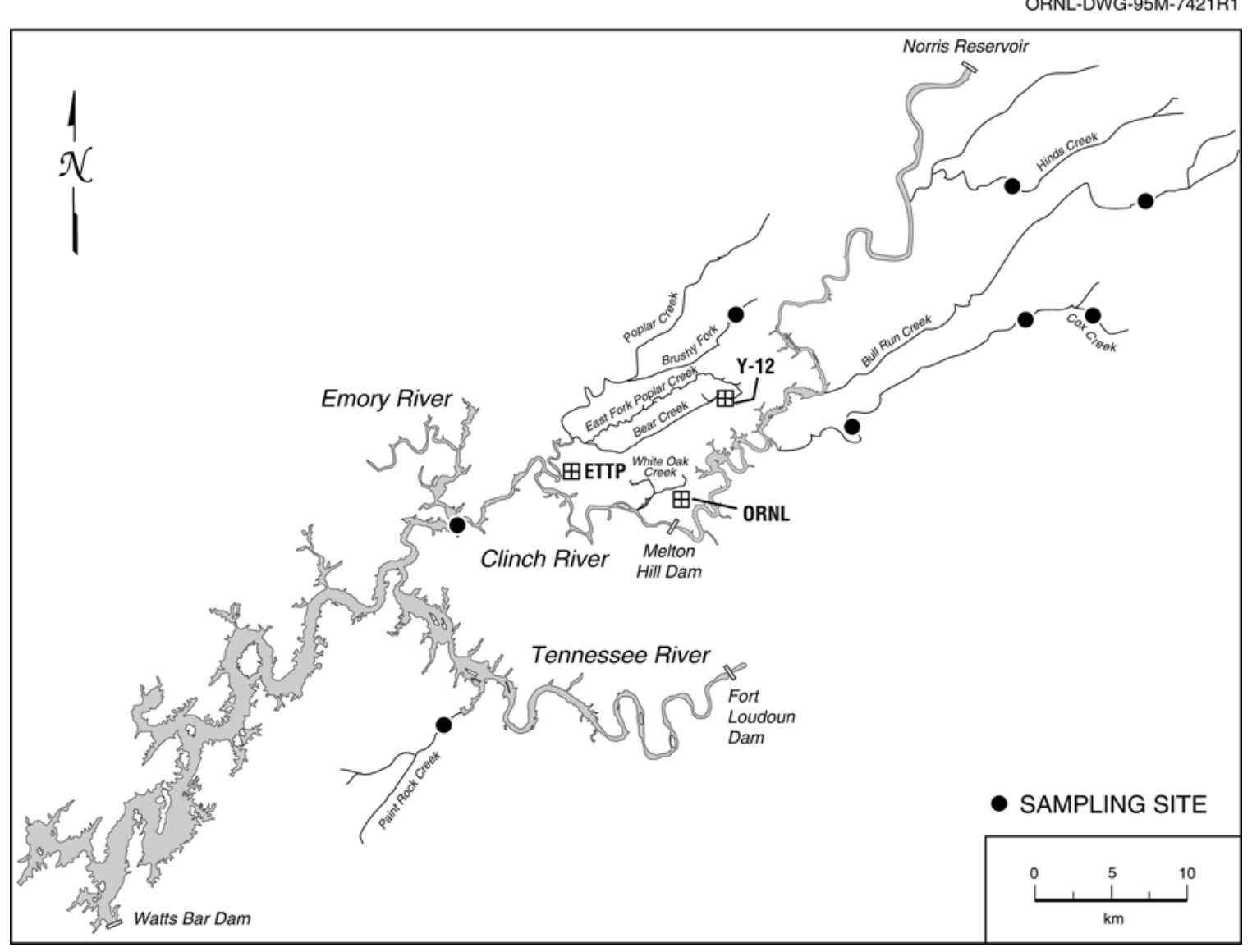

Fig. 6.9. Location of biological monitoring reference sites in relation to the Oak Ridge Y-12 National Security Complex.

\subsubsection{Bioaccumulation Studies}

Mercury and PCBs have been historically elevated in East Fork Poplar Creek fish relative to fish in uncontaminated reference streams. Fish are monitored regularly in East Fork Poplar Creek for mercury and PCBs to assess spatial and temporal trends in bioaccumulation associated with ongoing remedial activities and plant operations. As part of this monitoring effort, redbreast sunfish (Lepomis auritus) were sampled twice during 2003 from the mid to upper reaches of East Fork Poplar Creek and were analyzed for tissue concentrations of these two environmental contaminants. Largemouth bass (Micropterus salmoides) were collected once in 2003 from a site in Upper East Fork Poplar Creek (EFK 23.4) to monitor maximum bioaccumulation in larger piscivorous fish of the system. Stoneroller minnows (Campostoma anomalum) were collected from EFK 24.5 to evaluate potential ecological concerns associated with the accumulation of other metals by these prey fish. Mercury concentrations remained much higher during 2003 in fish from East Fork Poplar Creek than in fish from reference streams. Elevated mercury concentrations in fish from the upper reaches of East Fork Poplar Creek indicate that the Y-12 Complex remains a continuing source of mercury to fish in the stream. Although concentrations have leveled off in recent years, mercury concentrations in water in Upper East Fork Poplar Creek have decreased significantly over much of the last decade. In contrast, mercury concentrations in fish have remained relatively constant since the late 1980s (Fig. 6.10).

PCB concentrations measured in East Fork Poplar Creek sunfish during 2003 were within ranges typical of past monitoring efforts at these sites (Fig. 6.11). Mean PCB concentrations were again highest at sampling locations upstream of Bear Creek Road, indicating a continuing PCB source or sources within the Y-12 Complex. 


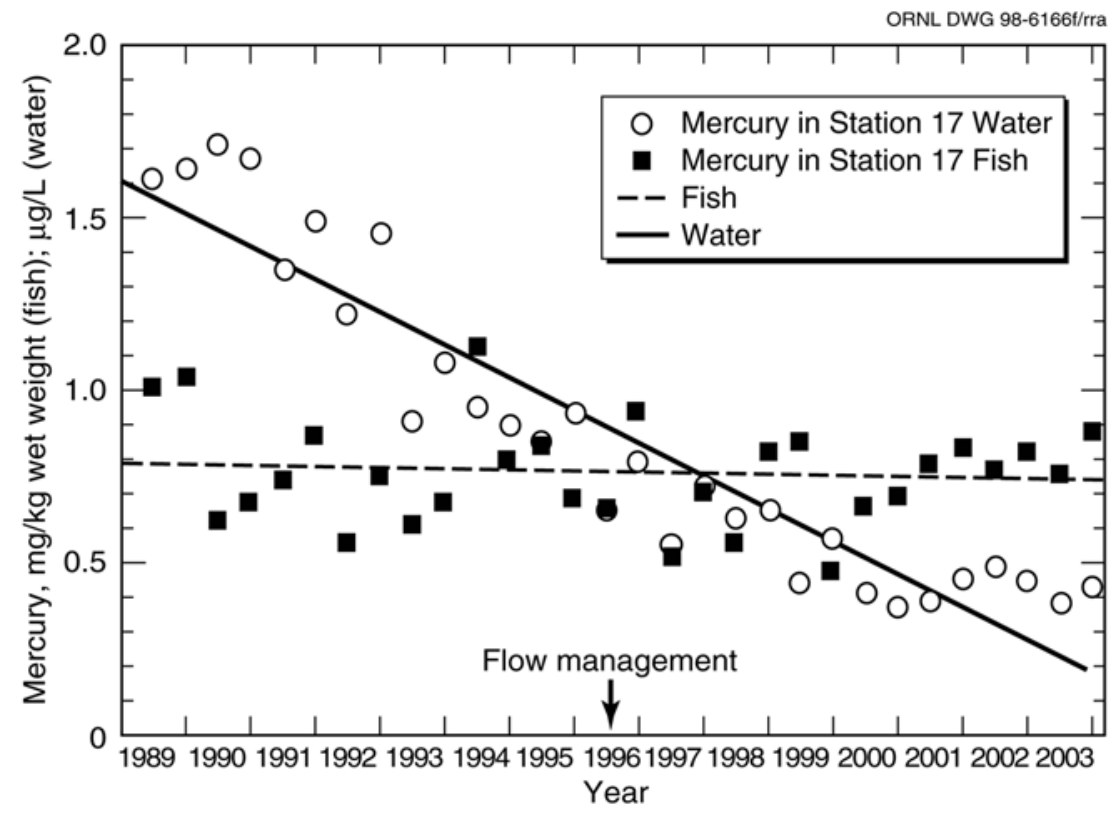

Fig. 6.10. Semiannual average mercury concentration in muscle fillets of redbreast sunfish and water in East Fork Poplar Creek at Station 17 through spring 2003.

\subsubsection{Biological Indicator Studies}

The biological indicator task is designed to evaluate the effects of water quality and other environmental variables on the health and reproductive condition of individual fish and fish populations in East Fork Poplar Creek. Redbreast sunfish were sampled from three sites in East Fork Poplar Creek and from two reference streams in the spring of 2003 prior to the onset of the breeding season. A fish embryo-larval test using the medaka (Oryzias latipes), a small model fish, was conducted on water from several sites in East Fork Poplar Creek in order to test the ability of fish young to successfully develop in the stream.

Overall trends in many contamination-related bioindicators suggest that there has been measurable improvement in overall fish health in Upper East Fork Poplar Creek in recent years (Fig. 6.12). However, the health and reproductive condition of sunfish from East Fork Poplar Creek sites upstream of Bear Creek remain lower in several respects than in fish from reference sites or downstream East Fork Poplar Creek sites. Furthermore, the abundance of redbreast sunfish, which is not native to the region, continues to decline in both East Fork Poplar Creek and reference streams.
Water from East Fork Poplar Creek upstream of the Oak Ridge Wastewater Treatment Facility adversely affected fish embryos in only one of four medaka embryo-larval toxicity tests conducted during 2003 (Table 6.11). This continues a recent trend of significant improvement in the results of these tests.

\subsubsection{Ecological Surveys}

Periphyton was monitored quarterly during 2003 from three sites along East Fork Poplar Creek. Algal biomass (Table 6.12) and photosynthetic rates remained higher than in reference streams. Concentrations of various metals $(\mathrm{Cu}, \mathrm{Zn}, \mathrm{Ag}$, and $\mathrm{Cd}$ in particular) continued to be elevated in East Fork Poplar Creek periphyton.

Fish communities were monitored in the spring and fall of 2003 at five sites along East Fork Poplar Creek and at two reference streams. Over the past decade, overall species richness and the number of pollution-sensitive fish species have increased at all sampling locations below Lake Reality (Fig. 6.13). However, improvement in the fish community of East Fork Poplar Creek has slowed in recent years, and the community continues to lag behind reference stream communities in these and other important metrics of community health. 


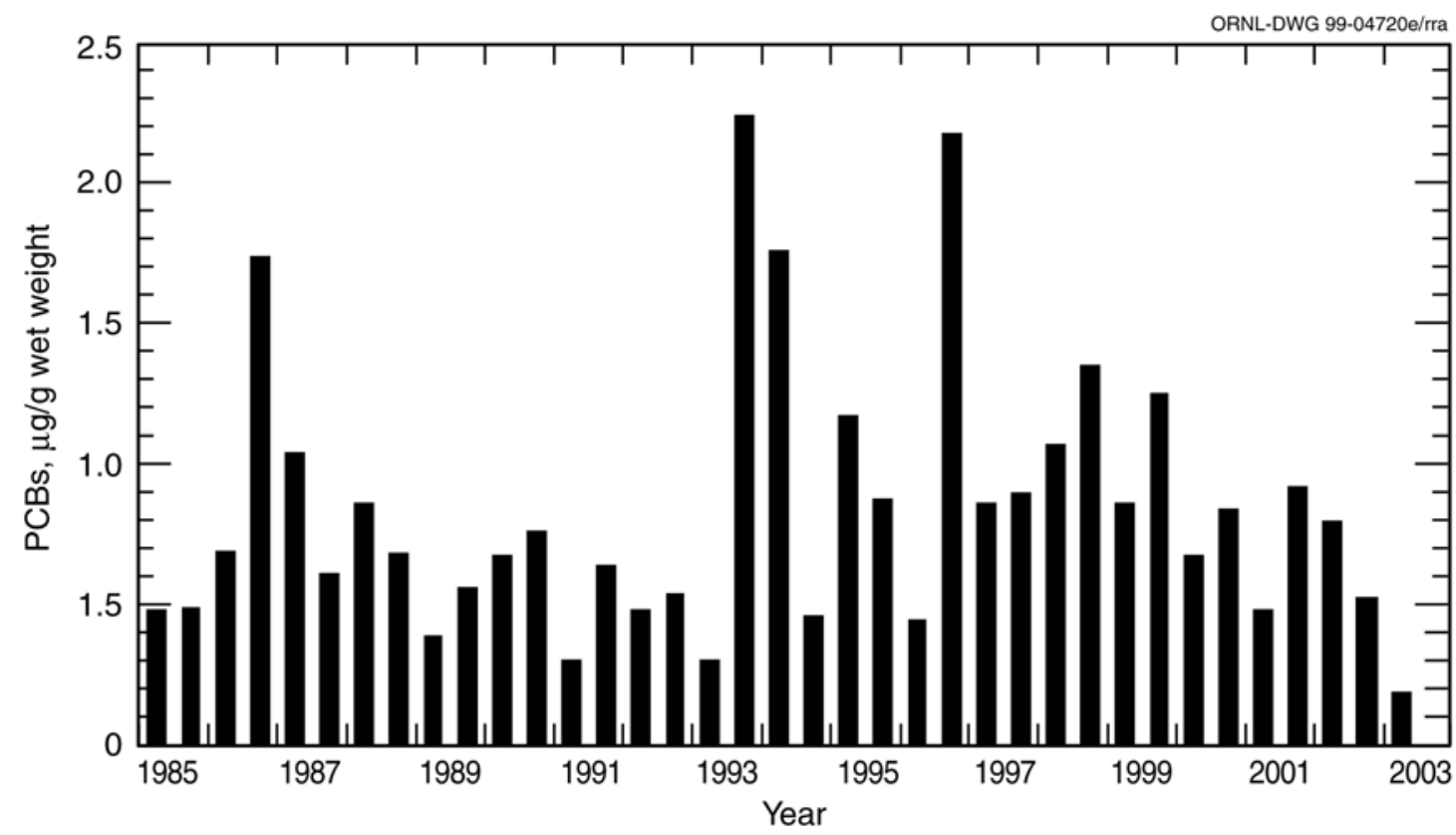

Fig. 6.11. Mean concentrations of PCBs in redbreast sunfish muscle fillets in East Fork Poplar Creek at Station 17 through spring 2003.

Benthic macroinvertebrate communities were monitored at three sites in East Fork Poplar Creek and at two reference streams in the spring and fall of 2003. The macroinvertebrate communities at EFK 23.4 and EFK 24.4 remained significantly degraded as compared with reference communities (Fig. 6.14). Increases in total richness and the richness of pollution-tolerant taxa continue at the Upper East Fork Poplar Creek sites, although the pace of improvement in benthic macroinvertebrate communities has slowed in recent years.

The effects of in situ exposure on clam growth and survival were tested during 2003 at three sites in East Fork Poplar Creek and at three reference streams. As in similar tests conducted in previous years, clam survival was significantly reduced at EFK 23.4 and EFK 24.4, while growth was reduced at each of the tested East Fork Poplar Creek sites. However, clam survival at the two Upper East Fork Poplar Creek locations has markedly improved over the last few years, continuing a recent trend of significant improvement in the results of these sensitive toxicity tests (Fig. 6.15).

\section{$6.8 \quad \mathrm{Y}-12$ COMPLEX AMBIENT SURFACE WATER MONITORING}

Routine surface water surveillance monitoring, above and beyond that required by the NPDES permit, is performed as a best management practice. The Y-12 Environmental Compliance Department staff monitor the surface water as it exits from each of the three hydrogeologic regimes that serve as an exit pathway for surface water (Fig. 6.16).

Monitoring is conducted in East Fork Poplar Creek at Station 17 (9422-1), near the junction of Scarboro and Bear Creek roads. The current sampling program consists of two 48-h composites plus a 3-day weekend composite. These samples are analyzed for mercury, ammonia-N, inductively coupled plasma (ICP) metals, and total suspended solids.

Monitoring is conducted in Bear Creek at BCK 4.55 (former NPDES Station 304), which is at the western boundary of the Y-12 Complex area of responsibility. A surveillance sample (a 7-day composite sample) is collected monthly for analysis for mercury; anions (sulfate, chloride, nitrate, nitrite); ICP metals; total phenols; and total suspended solids. 

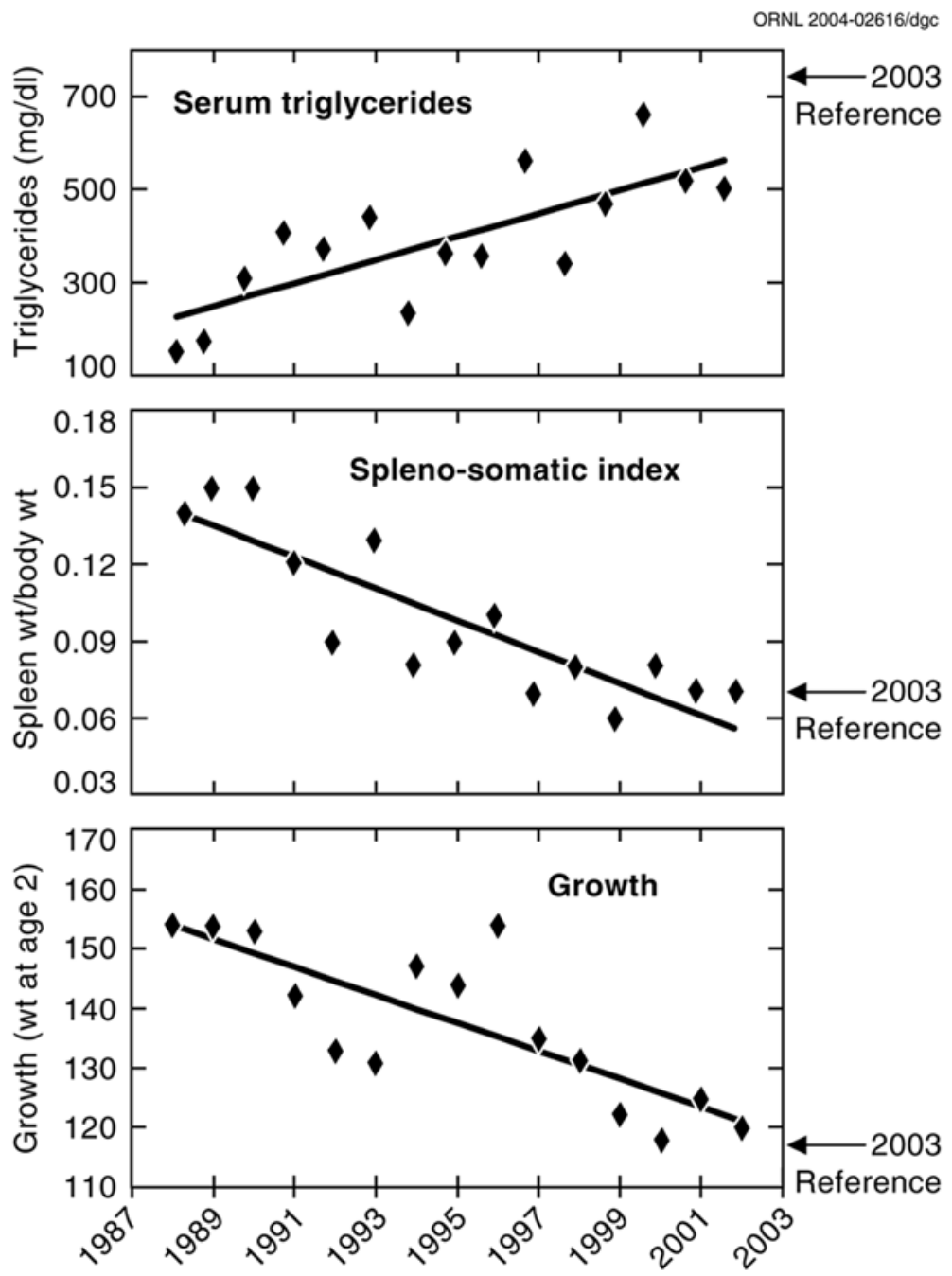

Fig. 6.12. Trends in three indicators of fish health measured over the last fifteen years in redbreast sunfish from EFK 23. Latest values for samples from the reference stream (Hinds Creek) are shown to the right (see arrows) for comparison purposes.

Table 6.11. Results of medaka development toxicity tests conducted on water from ambient sites in East Fork Poplar Creek, 2003 Embryo larval survival (\%)

\begin{tabular}{|c|c|c|c|c|}
\hline \multirow[t]{2}{*}{ Sample $^{a}$} & \multicolumn{4}{|c|}{ Quarter } \\
\hline & First & Second & Third & Fourth \\
\hline Control & 100 & 100 & 96 & 92 \\
\hline EFK 25.1 & 80 & 85 & 100 & 92 \\
\hline EFK 24.6 & 90 & 90 & $75^{b}$ & 92 \\
\hline EFK 23.4 & 90 & 95 & $62^{b}$ & 96 \\
\hline EFK 18.2 & 85 & 95 & $75^{b}$ & 100 \\
\hline EFK 13.8 & 100 & 90 & $75^{b}$ & 96 \\
\hline EFK 10.0 & $25^{b}$ & $75^{b}$ & $29^{b}$ & $33^{b}$ \\
\hline EFK 6.3 & $40^{b}$ & 85 & $33^{b}$ & $33^{b}$ \\
\hline
\end{tabular}

${ }^{a}$ EFK = East Fork Poplar Creek kilometer

${ }^{b}$ Significant difference from control at $p=0.05$
Table 6.12. Biomass of periphyton sampled from sites on East Fork Poplar Creek and Brushy Fork, 2003 Algal biomass $\left(\mu \mathrm{g} / \mathrm{Chla} / \mathrm{cm}^{2}\right)$

\begin{tabular}{lcccc}
\hline \multirow{2}{*}{ Sample $^{a}$} & \multicolumn{4}{c}{ Quarter } \\
\cline { 2 - 5 } & First & Second & Third & Fourth \\
\hline EFK 24.4 & $56.1 \pm 5.5$ & $41.0 \pm 14.2$ & $28.7 \pm 7.0$ & $50.9 \pm 17.4$ \\
EFK 23.4 & $50.2 \pm 12.0$ & $52.6 \pm 24.2$ & $25.7 \pm 8.2$ & $42.1 \pm 6.5$ \\
EFK 6.3 & $31.8 \pm 5.7$ & $33.9 \pm 25.9$ & $20.9 \pm 5.5$ & $59.8 \pm 5.5$ \\
BFK 7.6 & $16.3 \pm 10.6$ & $13.9 \pm 4.1$ & $13.7 \pm 9.2$ & $39.2 \pm 12.9$ \\
\hline
\end{tabular}

${ }^{a}$ EFK = East Fork Poplar Creek kilometer

$\mathrm{BFK}=$ Brushy Fork kilometer 


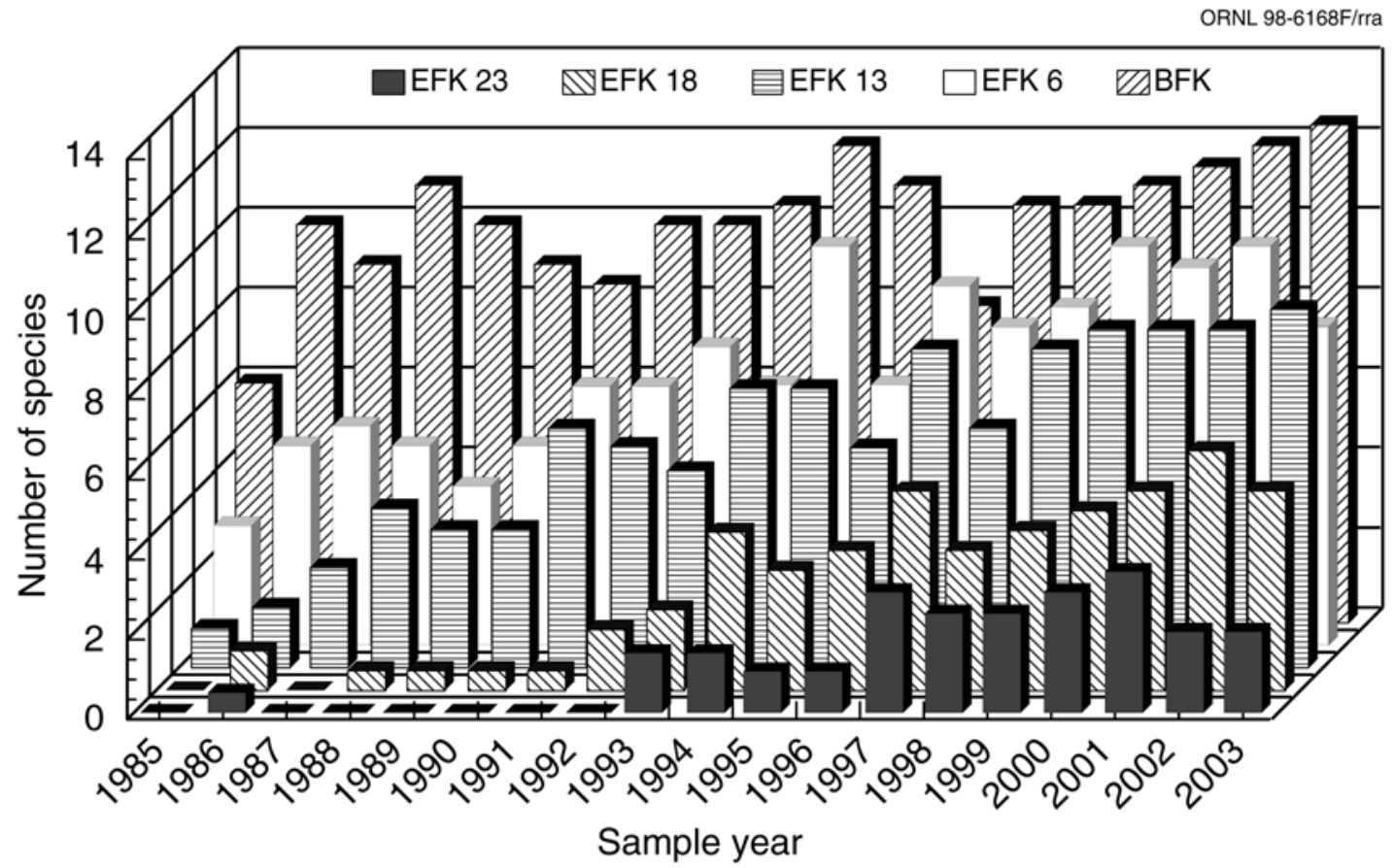

EFK = East Fork Poplar Creek kilometer; BFK = Brushy Fork kilometer.

Fig. 6.13. Comparison of mean abundance of sensitive fish species collected during each year from 1985 through 2003 from four sites in East Fork Poplar Creek and a reference site (Brushy Fork). Results for an additional site in Upper East Fork Poplar Creek (EFK 24.4) and a second reference cite (Hinds Creek) are not shown.

The exit pathway from the Chestnut Ridge Hydrogeologic Regime is monitored via NPDES location S19 (former NPDES Station 302) at Rogers Quarry. S19 is an instream location of McCoy Branch and is sampled monthly (a 24-h composite) for ICP metals. The NPDES requirement for this location other than a $\mathrm{pH}$ limit is to monitor and report metals data only.

In addition to these exit pathway locations, a network of real-time monitors is located at instream locations along Upper East Fork Poplar Creek and at key points on the storm drain system that flows to the creek. The Surface Water Hydrological Information Support System is available for real-time water quality measurements, such as $\mathrm{pH}$, temperature, dissolved oxygen, conductivity, and chlorine. The locations are noted in Fig. 6.17. Not all locations or parameters are operated on a routine basis.

For nonradiological parameters that are sampled and detected above the analytical method reporting detection limit, the data are compared with Tennessee water quality criteria. The most restrictive of either the "freshwater fish and aquatic life criterion maximum concentration" or the "recreation concentration for organisms only" standard is used. This comparison serves as a record of water quality, and the comparison to state water quality criteria limits is for informational purposes only; as such, no attempt is made to achieve the lowest possible detection limit for all parameters.

More than 5000 surface water surveillance samples were collected in 2003. Comparisons with Tennessee water quality criteria indicate that only mercury, zinc, and copper from samples collected at Station 17 were detected at values exceeding a criteria maximum. Results are shown in Table 6.13. Of all the parameters measured in the surface water as a best management practice, mercury is the only demonstrated contaminant of concern.

Additional surface-water sampling is conducted on Bear Creek in accordance with the Y-12 Groundwater Protection Program to monitor trends throughout the Bear Creek Hydrogeologic Regime (see Sect. 6.10.4.3). 

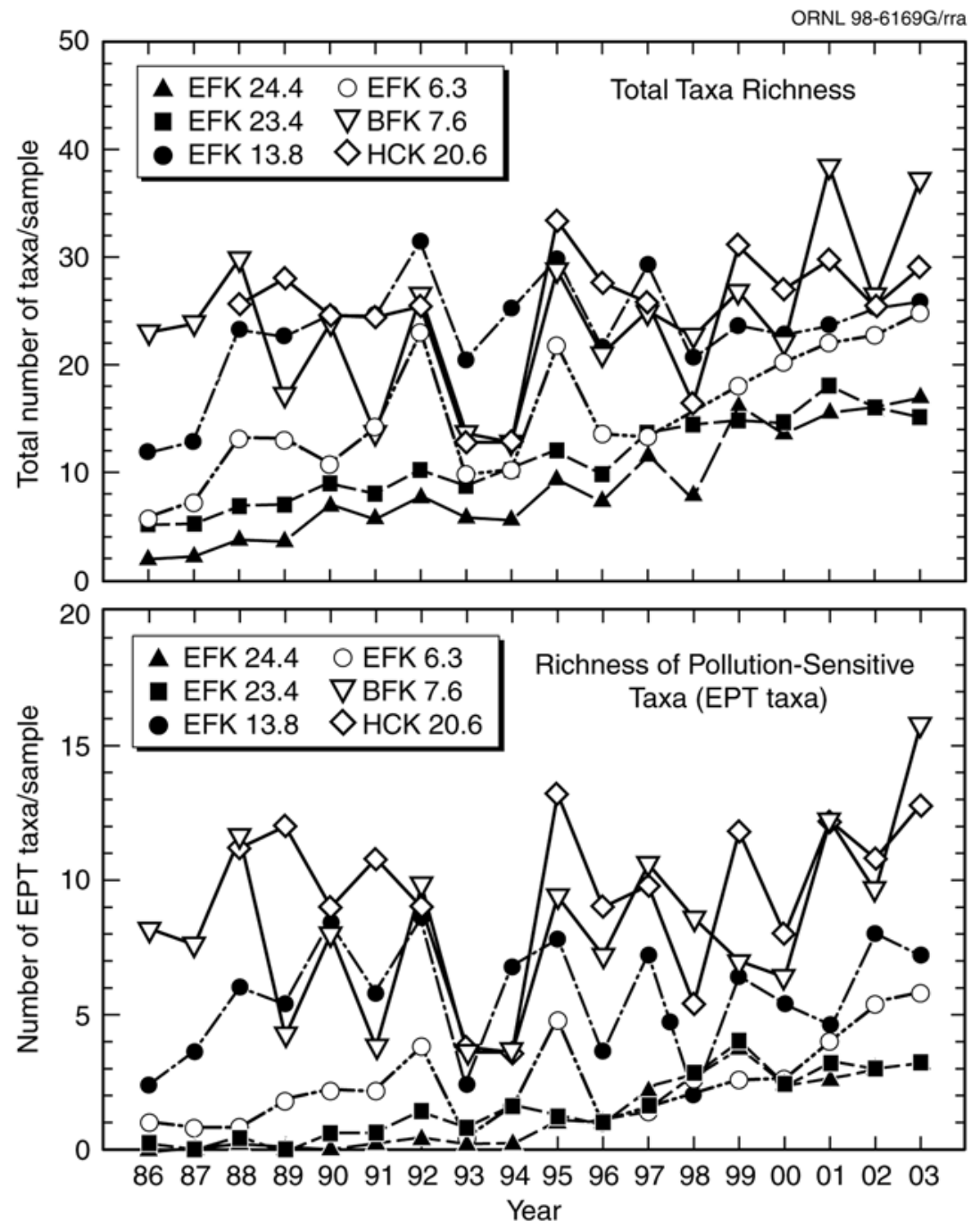

Fig. 6.14. Total taxonomic richness (mean number of taxa/sample) and total taxonomic richness of the Ephemeroptera, Plecoptera, and Trichoptera (EPT) (mean number of EPT taxa/sample) of the benthic macroinvertebrate communities in East Fork Poplar Creek and two reference sites, one on Brushy Fork and one on Hinds Creek (BFK 7.6 and HCK 20.6), spring data only. (EPT taxa include relatively pollutionsensitive species.)

\section{$6.9 \quad$ Y-12 SEDIMENT SAMPLING}

Historical data have shown that mercury, PCBs, and isotopes of uranium are present at detectable levels in sediment. Therefore, as a best management practice, the Y-12 Complex maintains an annual sampling program to determine whether these constituents are accumulating in the sediments of East Fork Poplar
Creek and Bear Creek as a result of Y-12 Complex discharges. Results of the most recent monitoring activity are given in Table 6.14. The monitoring results indicate that the radiological levels including isotopes of uranium and thorium have not significantly changed. The mercury level increased this year at the Station 17 site, but this finding is based on only one result.

This activity is also used to comply with DOE Order 5400.5, which states in Chapter II.3 a.2 that measures be taken to prevent the buildup of 

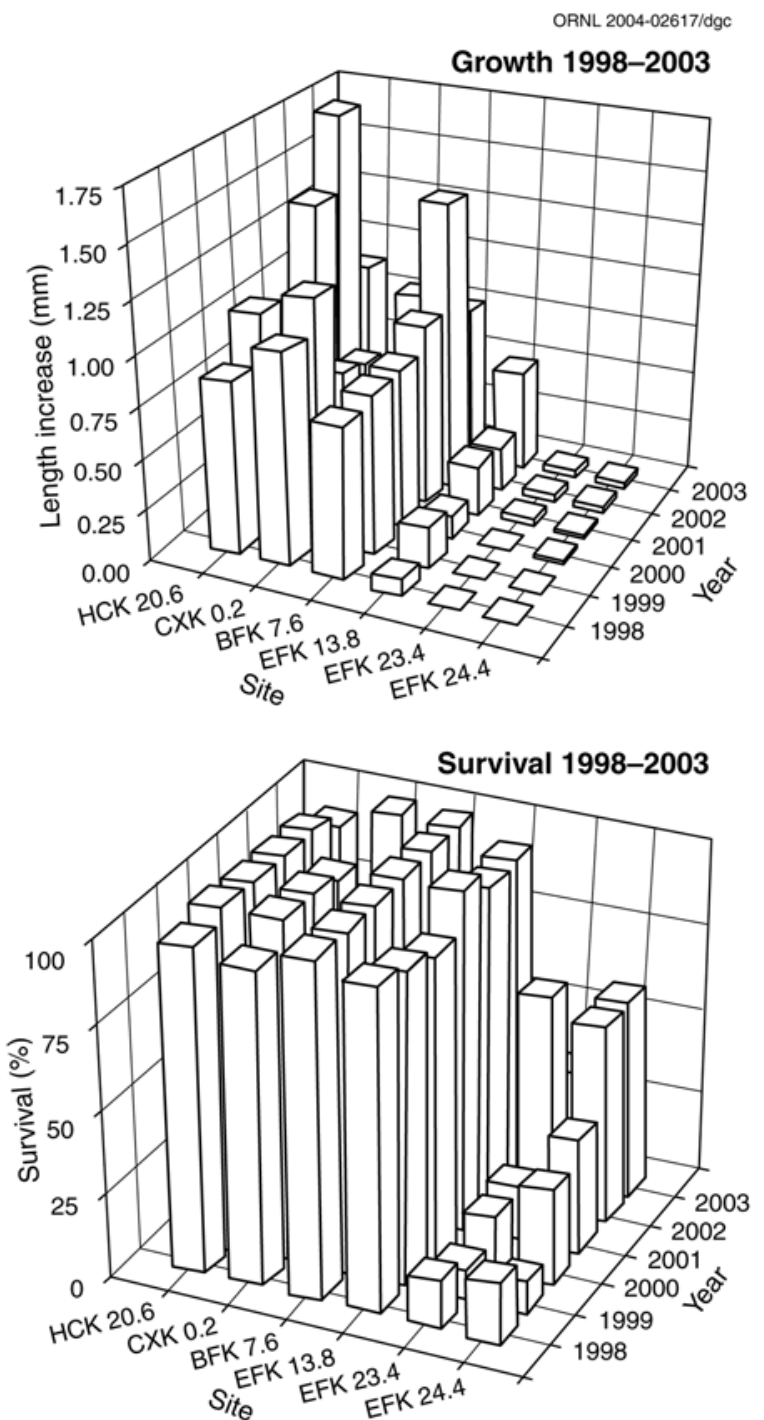

Fig. 6.15. Growth and survival of fingernail clams in situ bioassays in East Fork Poplar Creek, 1998-2003. Length of study is 80 to 86 days per test. No 2002 data are presented for Cox Creek because the bioassay units were lost to vandalism.

radionuclides in sediments caused by releases of waste streams to natural waterways. The order limits the amount of activity that may be present in released settleable solids. Because waste streams from the Y-12 Complex have very low settleable-solid contents, this sampling program to measure activity in the sediments of East Fork Poplar Creek and Bear Creek is used to determine whether a buildup of radionuclide concentrations is occurring.

\subsection{GROUNDWATER MONITORING AT THE Y-12 COMPLEX}

More than 200 sites have been identified at the Y-12 Complex that represent known or potential sources of contamination to the environment as a result of past waste management practices. Figure 6.18 depicts the major facilities considered as known and/or potential contaminant source areas for which groundwater monitoring was performed during CY 2003. Because of this 


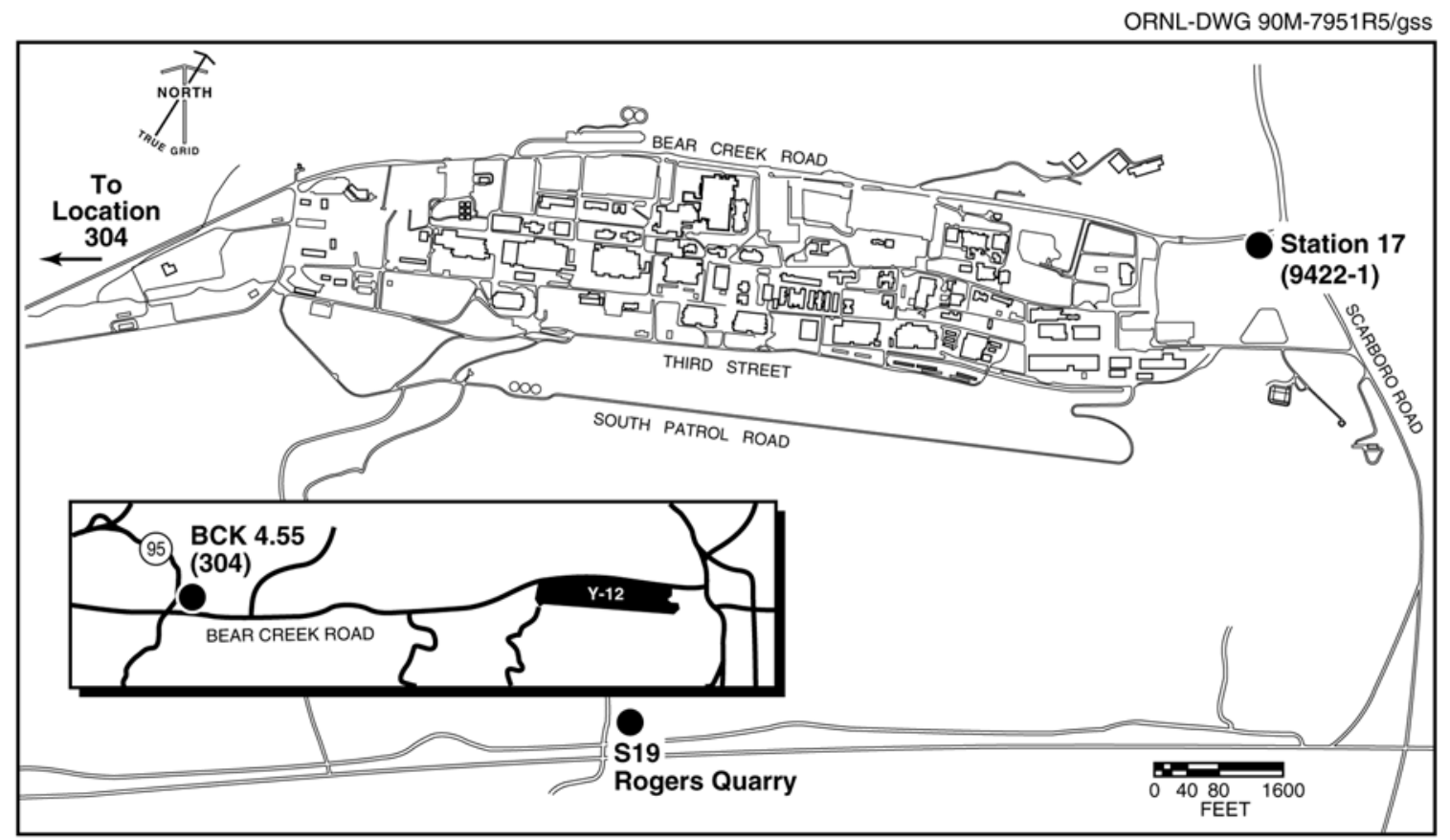

Fig. 6.16. Locations of $Y-12$ Complex surface water surveillance sampling stations.

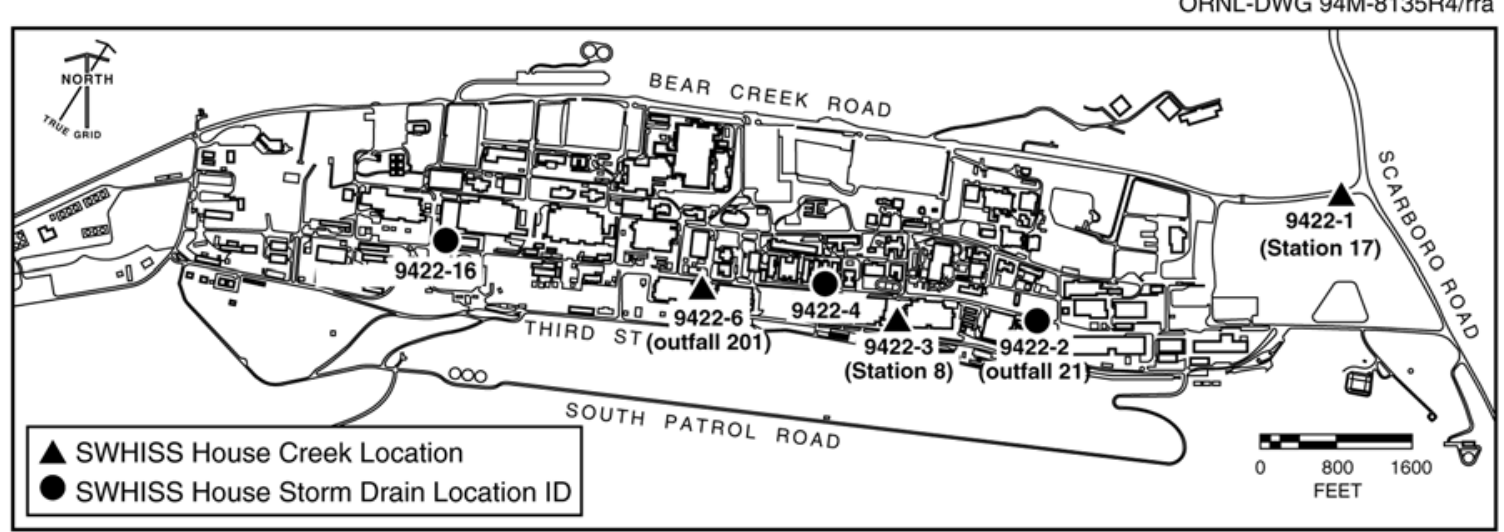

Fig. 6.17. Surface Water Hydrological Information Support System monitoring locations.

Table 6.13. Surface water surveillance measurements exceeding Tennessee water quality criteria at the Y-12 Complex, 2003

\begin{tabular}{|c|c|c|c|c|c|c|c|}
\hline \multirow{2}{*}{$\begin{array}{l}\text { Parameter } \\
\text { detected }\end{array}$} & \multirow[b]{2}{*}{ Location } & \multirow{2}{*}{$\begin{array}{c}\text { Number of } \\
\text { samples }\end{array}$} & \multicolumn{3}{|c|}{ Concentration $(\mathrm{mg} / \mathrm{L})$} & \multirow{2}{*}{$\begin{array}{c}\text { Water quality } \\
\text { criteria } \\
(\mathrm{mg} / \mathrm{L})\end{array}$} & \multirow{2}{*}{$\begin{array}{c}\text { Number of } \\
\text { measurements } \\
\text { exceeding criteria }\end{array}$} \\
\hline & & & $\begin{array}{c}\text { Detection } \\
\text { limit }\end{array}$ & Max & Avg & & \\
\hline Copper & Station 17 & 148 & 0.02 & 0.0307 & $<0.02$ & 0.0177 & 1 \\
\hline Mercury & Station 17 & 398 & 0.00021 & 0.0086 & $<0.0005$ & 0.000051 & 393 \\
\hline Zinc & Station 17 & 148 & 0.05 & 0.138 & $<0.05$ & 0.177 & 1 \\
\hline
\end{tabular}




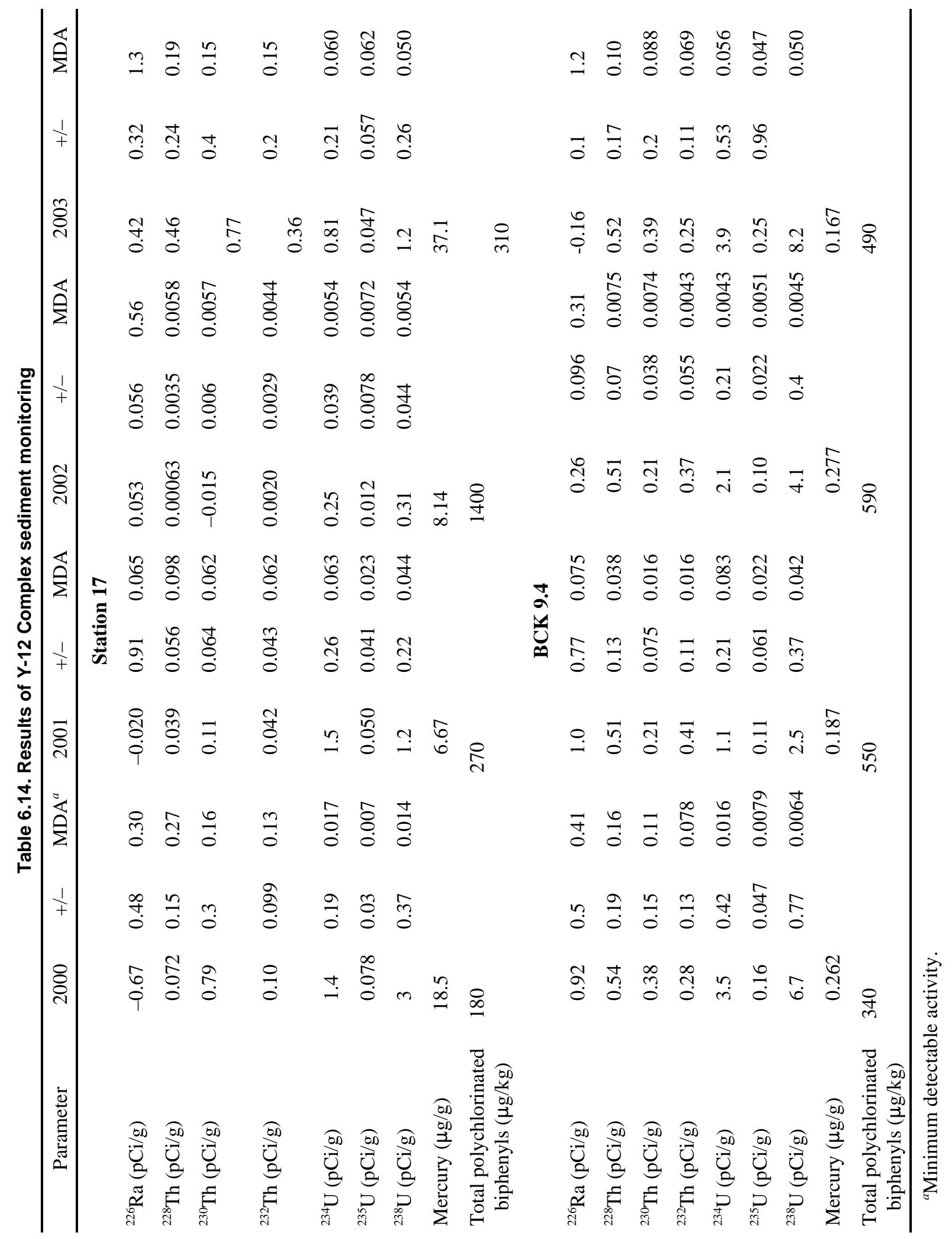




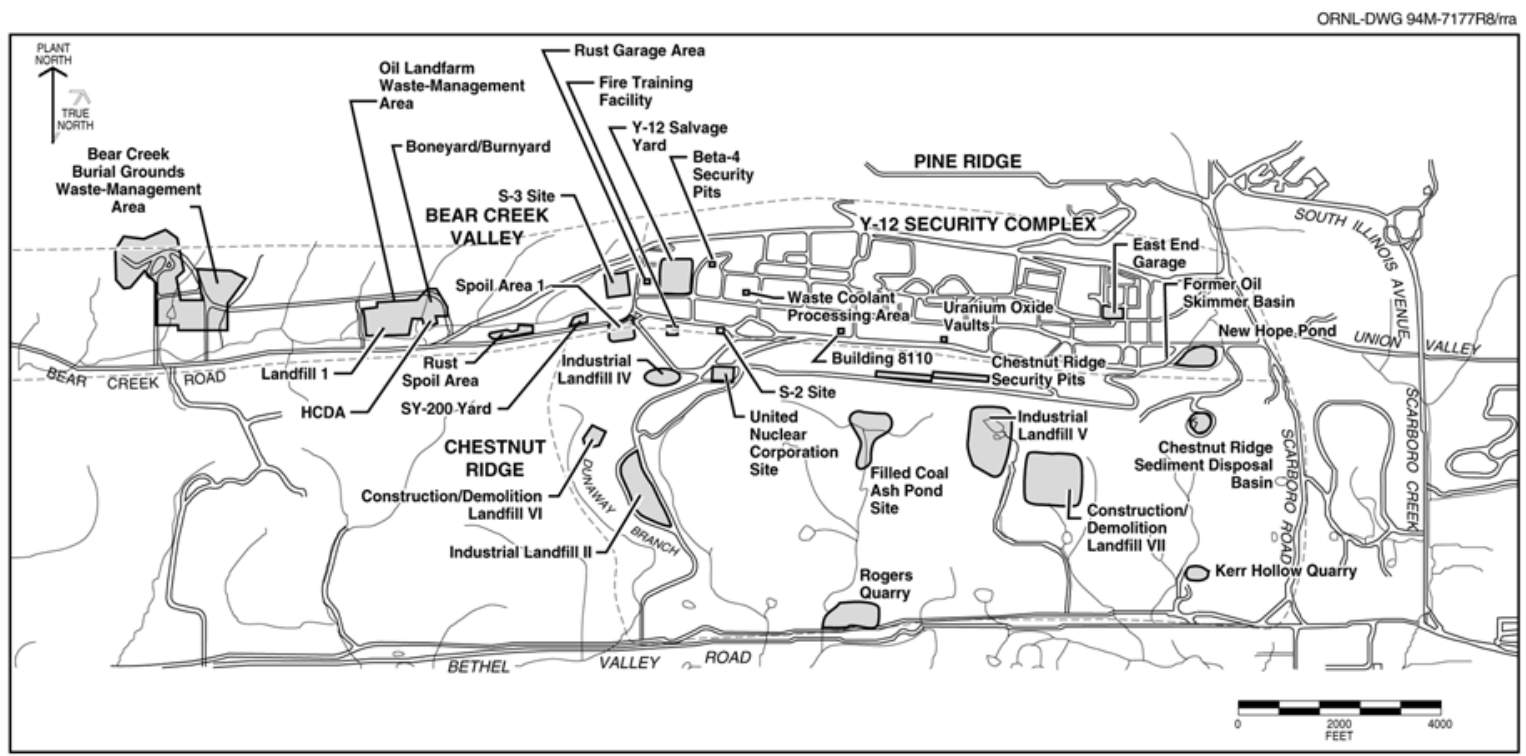

Fig. 6.18. Known or potential contaminant sources for which groundwater monitoring was performed during CY 2003.

contamination, extensive groundwater monitoring is required to comply with regulations and DOE orders.

During CY 2003, routine groundwater monitoring at $\mathrm{Y}-12$ was conducted primarily by two programs, the Y-12 Groundwater Protection Program, managed by BWXT Y-12 LLC, and the Water Resources Restoration Program, managed by Bechtel Jacobs Company, LLC (BJC). Each program is responsible for monitoring groundwater to meet specific compliance requirements. In CY 2003, the Groundwater Protection Program performed monitoring to comply with DOE orders, while the Water Resources Restoration Program performed groundwater monitoring in compliance with CERCLA and RCRA. In addition to the monitoring performed by the Water Resources Restoration Program, BJC monitors groundwater at the solid waste disposal landfills on Chestnut Ridge and the Environmental Management Waste Management (CERCLA) Facility in Bear Creek Valley.

Although the Groundwater Protection Program, the Water Resources Restoration Program, and other projects have differing technical objectives and responsibilities, considerable efforts are made to maintain consistency in groundwater monitoring activities at the Y-12 Complex. Communication among the programs has been crucial in eliminating any redundancies in monitoring activities. In addition, communication and mutual cooperation provided for more consistent and efficient data collection, evaluation, and overall quality. All groundwater monitoring data obtained by all programs are evaluated to provide a comprehensive view of groundwater quality at the Y-12 Complex.

\subsubsection{Hydrogeologic Setting}

The Y-12 Complex is divided into three hydrogeologic regimes, which are delineated by surface water drainage patterns, topography, and groundwater flow characteristics. The regimes are further defined by the waste sites they contain. These regimes include the Bear Creek Hydrogeologic Regime, the Upper East Fork Poplar Creek Hydrogeologic Regime, and the Chestnut Ridge Hydrogeologic Regime (Fig.6.19). Most of the Bear Creek and Upper East Fork Poplar Creek regimes are underlain by the ORR Aquitards. The extreme southern portion of these two regimes is underlain by the Maynardville Limestone, which is part of the Knox Aquifer. The entire Chestnut Ridge regime is underlain by the Knox Aquifer (Fig. 1.6). In general, groundwater flow in the water table interval follows topography. Shallow groundwater flow in the Bear Creek regime and the Upper East Fork regime is divergent from a topographic and groundwater divide located near the western end of the Y-12 Complex that defines the boundary between the two regimes. In addition, flow 


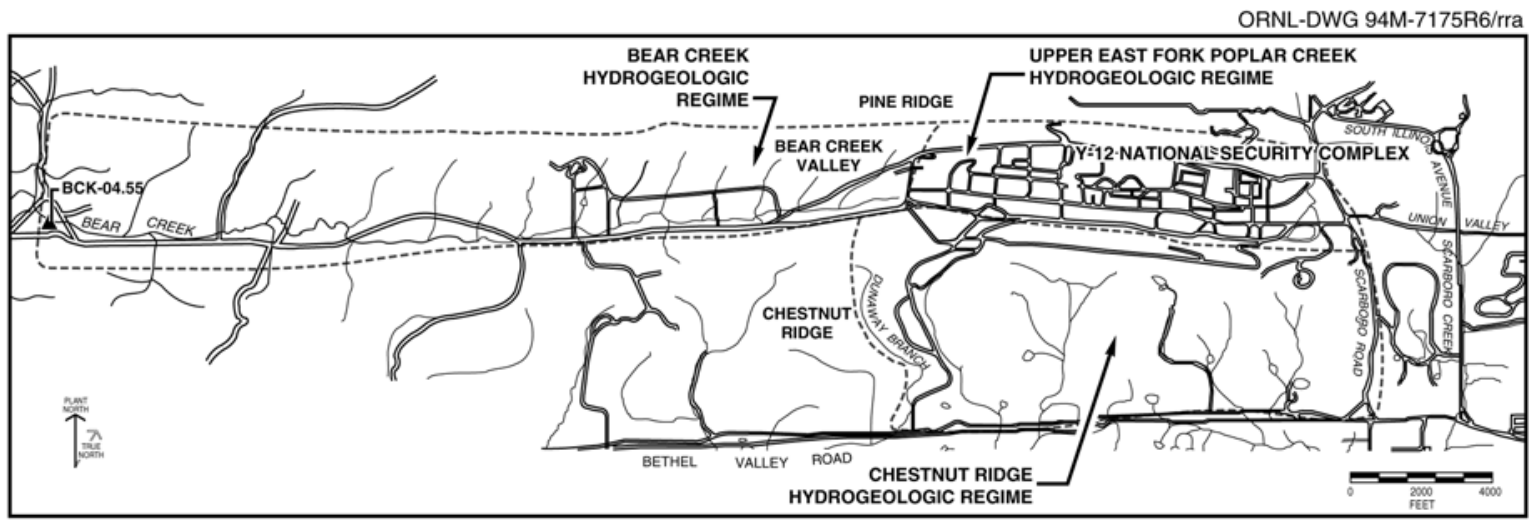

Fig. 6.19. Hydrogeologic regimes at the Y-12 Complex.

converges on the primary surface streams from Pine Ridge and Chestnut Ridge. In the Chestnut Ridge regime, a groundwater divide exists that approximately coincides with the crest of the ridge. Shallow groundwater flow tends to be toward either flank of the ridge, with discharge primarily to surface streams and springs located in Bethel Valley to the south and Bear Creek Valley to the north.

In Bear Creek Valley, groundwater in the intermediate and deep intervals moves predominantly through fractures in the ORR Aquitards, converging on and then moving through fractures and solution conduits in the Maynardville Limestone. Karst development in the Maynardville Limestone has a significant impact on groundwater flow paths in the water table and intermediate intervals. In general, groundwater flow parallels the valley and geologic strike. Groundwater flow rates in Bear Creek Valley vary widely; they are very slow within the deep interval of the ORR aquitards but can be quite rapid within solution conduits in the Maynardville Limestone.

The rate of groundwater flow perpendicular to geologic strike from the ORR aquitards to the Maynardville Limestone has been estimated to be very slow below the water table interval. Most contaminant migration appears to be via surface tributaries to Bear Creek or along utility traces and buried tributaries in the Upper East Fork regime. In the Bear Creek regime, strike-parallel transport of some contaminants can occur within the ORR aquitards for significant distances. Continuous elevated levels of nitrate within the ORR Aquitards are known to extend east and west from the S-3 Site for thousands of feet. Volatile organic compounds at source units in the ORR
Aquitards, however, tend to remain close to source areas because they tend to adsorb to the bedrock matrix, diffuse into pore spaces within the matrix, and degrade prior to migrating to exit pathways, where rapid transport occurs for long distances. Regardless, extensive volatile organic compound contamination occurs throughout groundwater in both the Bear Creek and Upper East Fork regimes.

Groundwater flow in the Chestnut Ridge regime is almost exclusively through fractures and solution conduits in the Knox Group. Discharge points for intermediate and deep flow are not well known. Groundwater is currently presumed to flow primarily toward Bear Creek Valley to the north and Bethel Valley to the south. Groundwater from intermediate and deep zones may discharge at certain spring locations along the flanks of Chestnut Ridge. Following the crest of the ridge, water table elevations decrease from west to east, demonstrating an overall easterly trend in groundwater flow.

\subsubsection{Well Installation and Plugging and Abandonment Activities}

A number of monitoring devices are routinely used for groundwater data collection at Y-12. Monitoring wells are permanent devices used for the collection of groundwater samples; they are installed according to established regulatory and industry specifications. Piezometers are primarily temporary devices used to measure groundwater table levels and are often constructed of polyvinyl chloride or other low-cost materials. Other 
devices or techniques are sometimes employed to gather data, including well points and push probes. No compliance monitoring wells were installed in CY 2003. However, 15 piezometers were installed at the Environmental Management Waste Management Facility (EMWMF) site in Bear Creek Valley to evaluate groundwater elevations for design of a second waste cell.

Well plugging and abandonment activities are conducted to protect human health and the environment, maintain the Y-12 monitoring well network, and meet operational needs. Wells that are damaged beyond rehabilitation, that interfere with planned construction activities, or from which no useful data can be obtained, are selected for plugging and abandonment. In 2003, seven wells were plugged and abandoned. Three wells are located in the Y-12 Coal Pile and were plugged due to damage or potential risk of damage caused by heavy equipment operations in the area. Four other wells were plugged to make way for construction of building 9720-82.

\subsubsection{CY 2003 Monitoring Program}

Groundwater monitoring in CY 2003 was performed to comply with DOE orders and regulations by the Groundwater Protection Program, Water Resources Restoration Program, and other BJC projects. Compliance requirements were met by the monitoring of 168 wells, 14 springs, and 37 surface water locations (Table 6.15). Figure 6.20 shows the locations of ORR perimeter/exit pathway groundwater monitoring stations as specified in the ORR Environmental Monitoring Plan (DOE 2003).

Comprehensive water quality results of monitoring activities at Y-12 in CY 2003 are presented in the annual Groundwater Monitoring Report (BWXT 2004).

Details of monitoring efforts performed specifically for CERCLA baseline and remediation evaluation are published in the FY 2003 and FY 2004 Water Resources Restoration Program Sampling and Analysis Plans (BJC 2002 and BJC 2003), and the 2004 Remediation Effectiveness Reports (DOE 2004).

Groundwater monitoring compliance reporting to meet RCRA postclosure permit requirements can be found in the RCRA annual reports (BJC 2004a, BJC 2004b, BJC 2004c).

\subsubsection{Y-12 Groundwater Quality}

Historical monitoring efforts have shown that four types of contaminants have affected groundwater quality at Y-12: nitrate, volatile organic compounds, metals, and radionuclides. Of those, nitrate and volatile organic compounds are the most widespread. Some radionuclides, particularly uranium and ${ }^{99} \mathrm{Tc}$, are significant, principally in the Bear Creek regime and the western and central portions of the Upper East Fork regime. Trace metals, the least extensive groundwater contaminants, generally occur in a small area of low-pH groundwater at the western end of Y-12, near the S-2 and S-3 sites. Historical data have shown that plumes from multiple source units have mixed with one another and that contaminants (other than nitrate and ${ }^{99} \mathrm{Tc}$ ) are no longer easily associated with a single source.

\subsubsection{Upper East Fork Poplar Creek Hydrogeologic Regime}

The Upper East Fork regime contains contaminant source areas and surface water and groundwater components of the hydrogeologic system within the Y-12 production complex and Union Valley to the east and off the ORR. Among the three hydrogeologic regimes at Y-12, the Upper East Fork regime encompasses most of the known and potential sources of surface and groundwater contamination. A brief description of waste management sites is given in Table 6.16. Chemical constituents from the S-3 Site (primarily nitrate and $\left.{ }^{99} \mathrm{Tc}\right)$ dominate groundwater contamination in the western portion of the Upper East Fork regime, while groundwater in the eastern portion, including Union Valley, is predominantly contaminated with volatile organic compounds.

\section{Plume Delineation}

The primary groundwater contaminants in the Upper East Fork regime are nitrates, volatile organic compounds, trace metals, and radionuclides. Sources of these contaminants 
Table 6.15. Types and numbers of groundwater monitoring stations sampled at the Y-12 Complex during CY 2003

\begin{tabular}{lcccc}
\hline & Bear Creek & Chestnut Ridge & $\begin{array}{c}\text { Upper East Fork } \\
\text { Poplar Creek }\end{array}$ & Total \\
\hline Conventional wells & 51 & 39 & 77 & 167 \\
Multiport wells & 0 & 0 & 1 & 1 \\
Surface water & 23 & 5 & 9 & 37 \\
Springs & 7 & 5 & 2 & 14 \\
Total number of monitoring stations & 81 & 49 & 89 & 219 \\
\hline
\end{tabular}

ORNL-DWG 94M-7176R10/rra

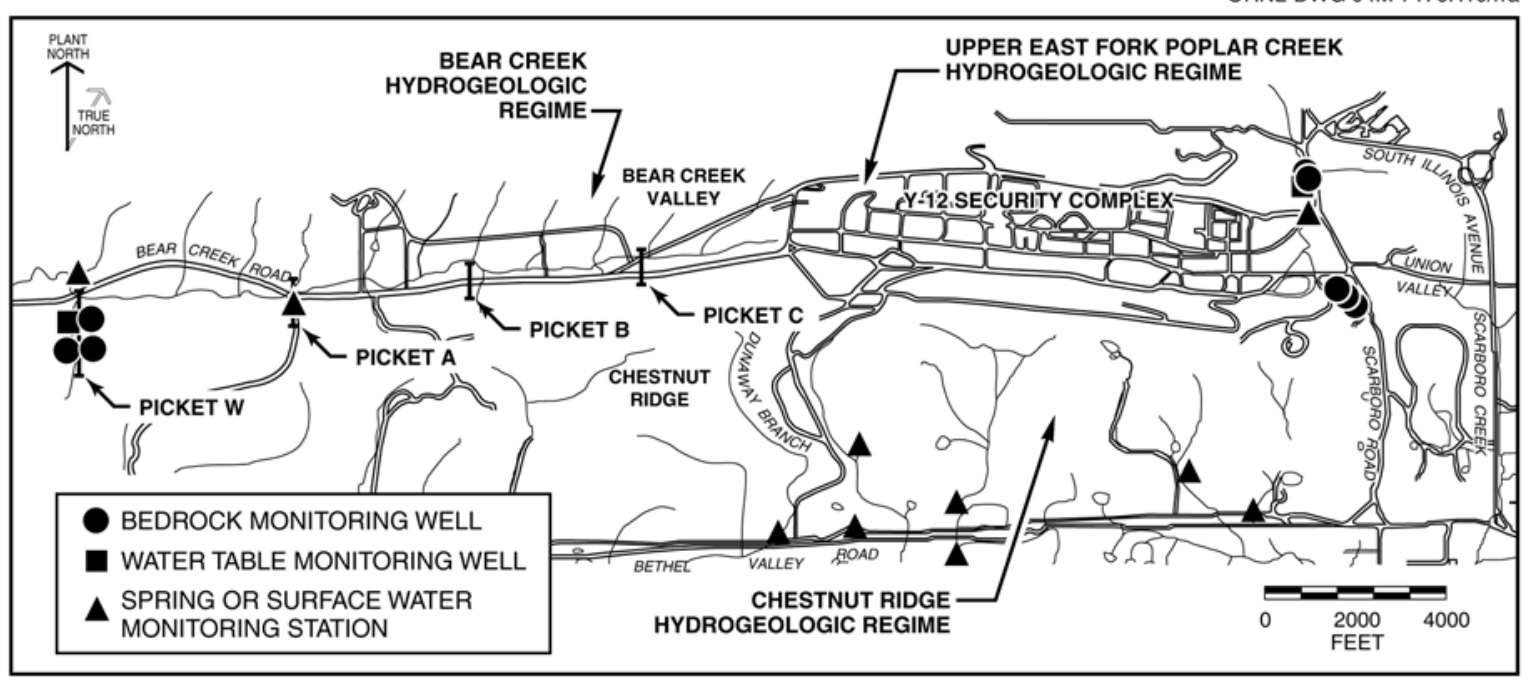

Fig. 6.20. Locations of ORR perimeter/exit pathway well, spring, and surface water monitoring stations in the Environmental Monitoring Plan for the Oak Ridge Reservation.

monitored during CY 2003 are the S-2 Site, the Fire Training Facility, the S-3 Site, the Waste Coolant Processing Facility, the 9418-3 Uranium Oxide Vault, petroleum underground storage tanks (USTs), New Hope Pond, Beta-4 Security Pits, Salvage Yard, and process/production buildings throughout the Y-12 Complex. Although it is located west of the current hydrologic divide that separates the Upper East Fork regime from the Bear Creek regime, the S-3 Site, now closed under RCRA, has contributed to groundwater contamination in the western part of this regime.

\section{Nitrate}

Nitrate concentrations in groundwater at $\mathrm{Y}-12$ exceed the $10-\mathrm{mg} / \mathrm{L}$ maximum drinking water contamination level (a complete list of national drinking water standards is presented in Appendix C) in a large part of the western portion of the Upper East Fork regime (Fig. 6.21). The two primary sources of nitrate contamination are the S-3 and S-2 sites. In CY 2003, Groundwater containing nitrate concentrations as high as 10,400 mg/L (Wells GW-108 and GW-109) occurred in the unconsolidated zone and at shallow bedrock depths just east of the S-3 Site. These results are consistent with results in previous years. The extent of the nitrate plume is essentially defined in the unconsolidated zone and the shallow bedrock zone. An increasing trend in nitrate concentrations at GW-606 has been observed (Fig. 6.22). This increase possibly indicates that the nitrate plume in the Maynardville Limestone has migrated into the eastern area of the Y-12 Complex from the S-2 and/or the S-3 sites. Historical results from Well GW-108 indicates a generally decreasing trend in near-source areas. 
Table 6.16. History of waste management units and underground storage tanks included in CY 2003 groundwater monitoring activities, Upper East Fork Poplar Creek Hydrogeologic Regime ${ }^{a}$

Site

New Hope Pond Historical data

Built in 1963. Regulated flow of water in Upper East Fork Poplar Creek before exiting the Y-12 Complex grounds. Sediments include PCBs, mercury, and uranium but not hazardous according to toxicity characteristic leaching procedure. Closed under RCRA in 1990

Salvage Yard Scrap Metal Storage Area

to 1950 to present for scrap metal storage. Some metals contaminated with low levels of depleted or enriched uranium. Runoff and infiltration are the principal release mechanisms to groundwater

Salvage Yard Oil/ Solvent Drum Storage Area

Salvage Yard Oil Storage

Tanks

Salvage Yard Drum

Deheader

Building 81-10 Area

Rust Garage Area

9418-3 Uranium Oxide Vault

Fire Training Facility

Beta-4 Security Pits

S-2 Site

Waste Coolant Processing Area

East End Garage

Coal Pile Trench Primary wastes included waste oils, solvents, uranium, and beryllium. Both closed under RCRA. Leaks and spills represent the primary contamination mechanisms for groundwater

Used from 1978 to 1986 . Two tanks used to store PCB-contaminated oils, both within a diked area

Used from 1959 to 1989. Sump tanks 2063-U, 2328-U, and 2329-U

received residual drum contents. Sump leakage is a likely release mechanism to groundwater

Mercury recovery facility operated from 1957 to 1962 . Potential historical releases to groundwater from leaks and spills of liquid wastes or mercury. The building structure was demolished in 1995

Former vehicle and equipment maintenance area, including four former petroleum USTs. Petroleum product releases to groundwater are documented

Originally contained an oil storage tank. Used from 1960 to 1964 to dispose of nonenriched uranium oxide. Leakage from the vault to groundwater is the likely release mechanism

Used for hands-on fire-fighting training. Sources of contamination to soil include flammable liquids and chlorinated solvents. Infiltration is the primary release mechanism to groundwater

Used from 1968 to 1972 for disposal of classified materials, scrap metals, and liquid wastes. Site is closed and capped. Primary release mechanism to groundwater is infiltration

Used from 1945 to 1951. An unlined reservoir received liquid wastes. Infiltration is the primary release mechanism to groundwater

Used from 1977 to 1985 . Former biodegradation facility used to treat waste coolants from various machining processes. Closed under RCRA in 1988 Used from 1945 to 1989 as a vehicle fueling station. Five USTs used for petroleum fuel storage were excavated, 1989 to 1993 . Petroleum releases to the groundwater are documented

Located beneath the current steam plant coal pile. Disposals included solid materials (primarily alloys). Trench leachate is a potential release mechanism to groundwater

\footnotetext{
${ }^{a}$ Abbreviations

$\mathrm{PCB}=$ polychlorinated biphenyl.

RCRA $=$ Resource Conservation and Recovery Act.

UST $=$ underground storage tank
} 


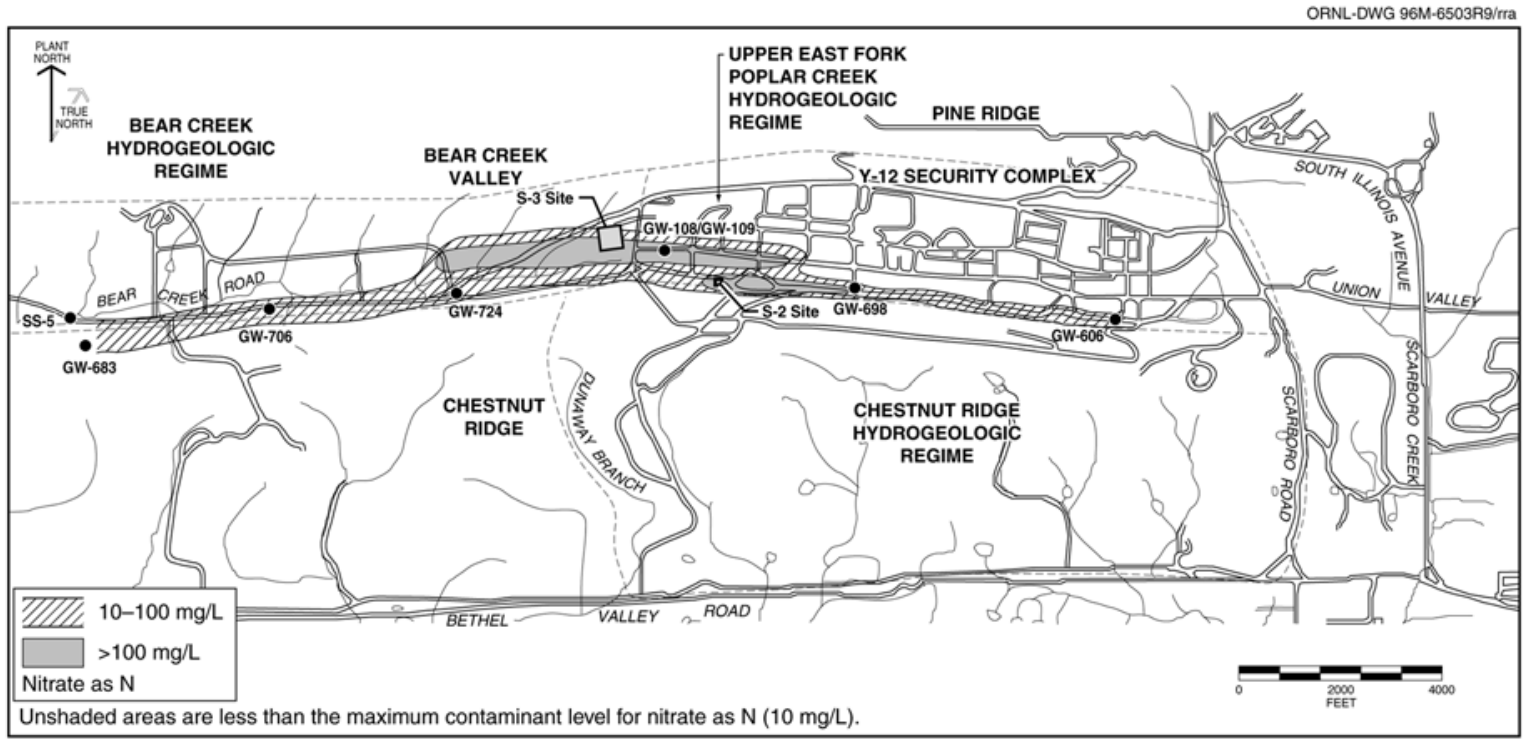

Fig. 6.21. Nitrate (as N) observed in groundwater at the Y-12 Complex.

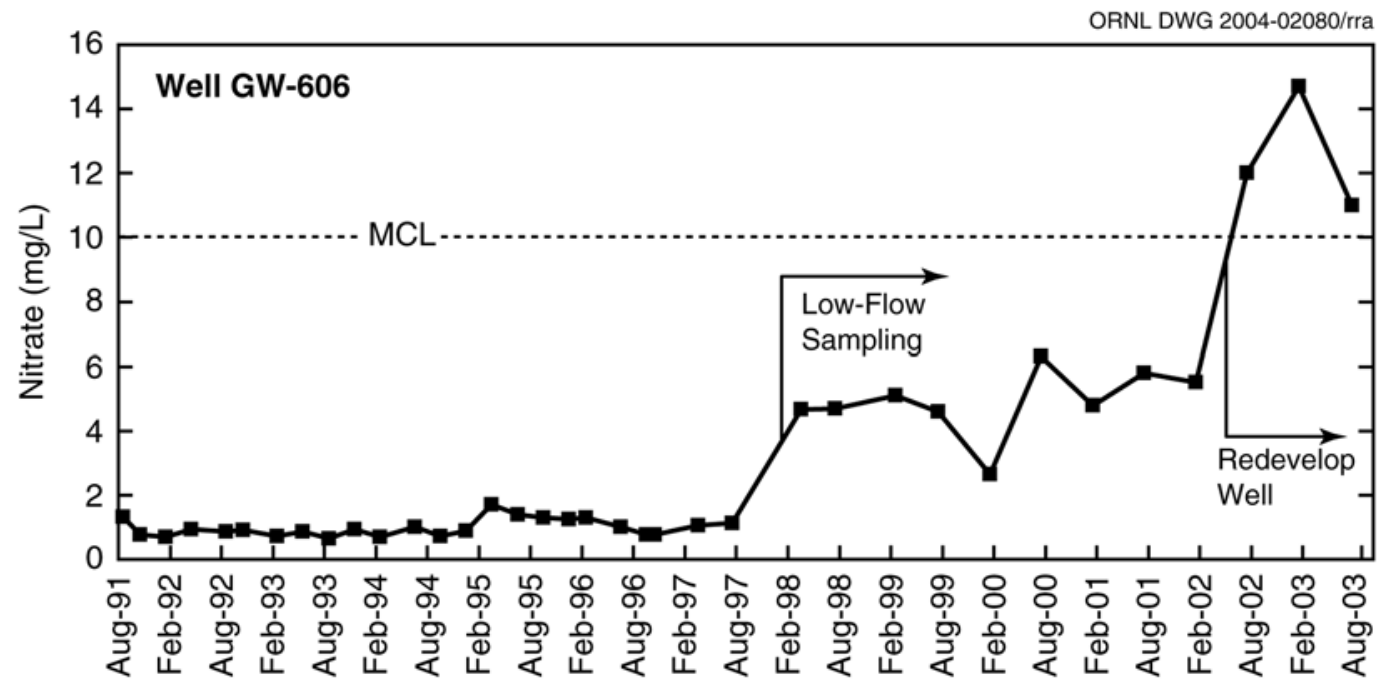

Fig. 6.22. Nitrate concentrations in well GW-606, at the eastern end of the Y-12 Complex.

\section{Trace Metals}

Concentrations of antimony, barium, beryllium, cadmium, chromium, copper, lead, mercury, nickel, thallium, and uranium exceeded drinking water standards during CY 2003 in samples collected from various monitoring wells and surface water locations downgradient of the S-2 Site, the S-3 Site, the Salvage Yard, and throughout the complex. Elevated concentrations of these metals in groundwater were most commonly observed from monitoring wells in the unconsolidated zone. Trace metals above standards tend to occur only adjacent to the source areas due to their low solubility in natural water systems on the ORR. However, some metals, such as uranium and mercury, are being transported through the surface water system and have been observed in concentrations above the drinking water standards. In December 2000, the EPA promulgated a drinking water standard of 0.03 $\mathrm{mg} / \mathrm{L}$ for uranium that went into effect in 2003. This standard was used to evaluate uranium concentrations in groundwater and surface water at the Y-12 Complex. Concentrations of uranium exceed this standard in a number of source areas (e.g., production areas and the Uranium Oxide Vault) and contribute this trace metal to Upper East Fork Poplar Creek. 


\section{Volatile Organic Compounds}

Because of the many source areas, volatile organic compounds are the most widespread groundwater contaminants in the East Fork regime. Dissolved volatile organic compounds in the regime primarily consist of chlorinated solvents and petroleum hydrocarbons. In CY 2003, the highest concentration of dissolved chlorinated solvents $(9688 \mu \mathrm{g} / \mathrm{L})$ was found in groundwater at Well GW-820 in the eastern portion of the Y-12 Complex (Fig. 6.23). The highest dissolved concentration of petroleum hydrocarbons obtained in CY $2003(21,391 \mu \mathrm{g} / \mathrm{L}$ at Well GW-658) occurred at the closed East End Garage.

The CY 2003 monitoring results generally confirm findings from the previous years of monitoring. A continuous dissolved plume of volatile organic compounds in groundwater in the bedrock zone extends eastward from the S-3 Site over the entire length of the regime (Fig. 6.23). The primary sources are the Waste Coolant Processing Facility and other waste-disposal and production areas throughout the Y-12 Complex.

Chloroethene compounds (tetrachloroethene, trichloroethene, dichloroethene, and vinyl chloride) tend to dominate the volatile organic plume composition in the western and central portions of Y-12. However, tetrachloroethene and isomers of dichloroethene are almost ubiquitous throughout the extent of the plume, indicating many source areas. Chloromethane compounds (carbon tetrachloride, chloroform, and methylene chloride) are the predominant volatile organic compounds in the eastern portion of Y-12.

Variability in concentration trends of chlorinated volatile organic compounds near source areas are seen within the East Fork Regime. As seen in previous years, data from most of the monitoring wells have remained relatively constant (i.e., stable) or have decreased since 1988. Other locations reveal an increasing trend, indicating that some plumes are still mobile (Fig. 6.24). Within the exit pathway, with the exception of wells GW-151 and GW-220, the general trends are also stable or decreasing (Fig. 6.25). These decreasing and stable trends west of New Hope Pond are indicators that the contaminants from source areas are attenuating due to factors such as dilution, dispersion, degradation, or adsorption. Wells within the vicinity of New Hope Pond and to the southeast are displaying the effects of the pumping well (GW-845) operated to capture the volatile organic compound plume prior to migration off of the ORR into Union Valley. Wells GW-151 and GW220 exhibit an increasing trend in volatile organic compound concentrations, indicating that little impact or attenuation from the plume capture system is apparent across lithologic units (perpendicular to strike). Preferential transport of groundwater contaminants is parallel to strike in the Knox Aquifer.

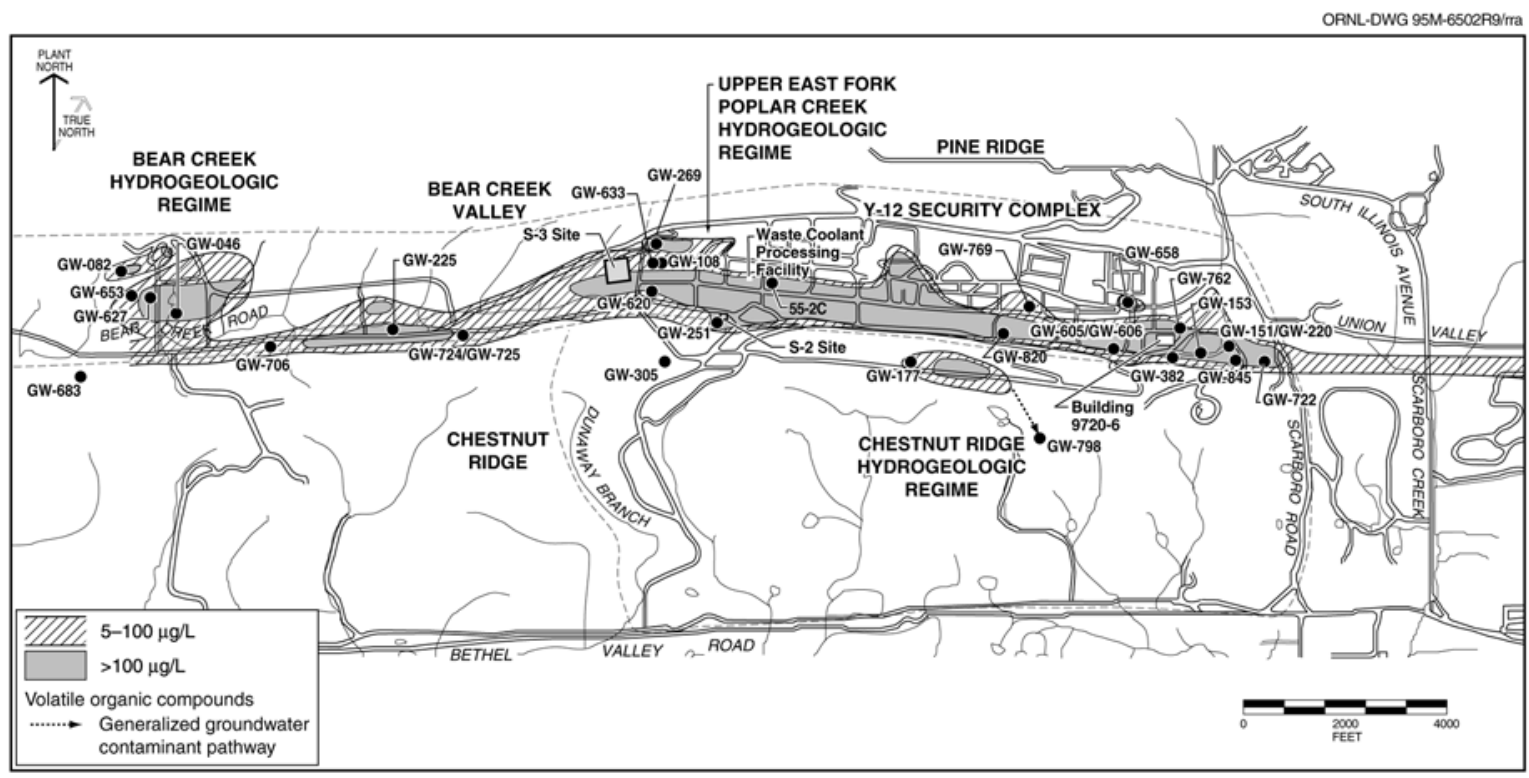

Fig. 6.23. Summed volatile organic compounds in groundwater at the Y-12 Complex. 

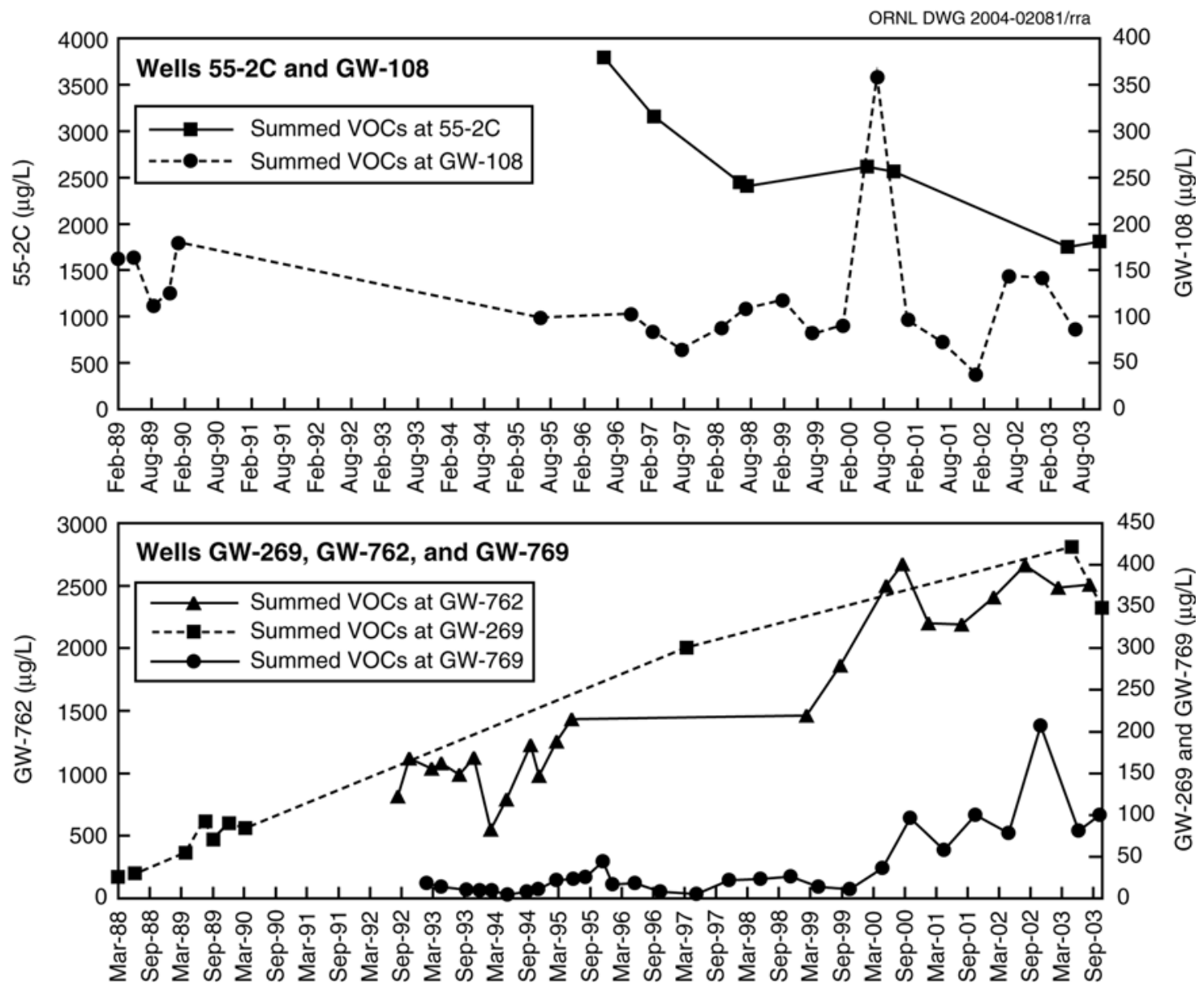

Fig. 6.24. Summed volatile organic compound concentrations in selected wells near source areas in the Upper East Fork Poplar Creek Hydrogeologic Regime.

Monitoring wells at two former petroleum hydrocarbon contaminant sources (Rust Garage Area and East End Garage) were sampled to evaluate the present condition of groundwater. Wells GW-633 and GW-658 are located at the west and east ends of the East Fork Regime, respectively. Well GW-633 has shown a significant increase in concentration since the early 1990s. Well GW-658 shows petroleum hydrocarbon concentrations consistent with those observed during the early 1990s. These observations indicate that there is still an accumulation of contaminants within and surrounding each well.

\section{Radionuclides}

The primary alpha-emitting radionuclides found in the East Fork regime during CY 2003 are isotopes of uranium. Groundwater with gross alpha activity greater than $15 \mathrm{pCi} / \mathrm{L}$ (the drinking water standard) occurs in scattered areas throughout the East Fork regime (Fig. 6.26). Historical data show that gross alpha activity consistently exceeds the drinking water standard and is most extensive in groundwater in the unconsolidated zone in the western portion of Y-12 near source areas such as the S-3 Site, the S2 Site, and the Y-12 Salvage Yard. The highest gross alpha activity $(1335 \mathrm{pCi} / \mathrm{L})$ was observed during CY 2003 in groundwater from Well GW-108, east of the S-3 site. Other areas of elevated gross alpha activity are present within the production areas in the western portion of Y-12, near the Former Oil Skimmer Basin, and east of the 9418-3 Uranium Oxide Vault.

The primary beta-emitting radionuclides observed in the East Fork regime during CY 2003 are uranium and ${ }^{99} \mathrm{Tc}$. Elevated gross beta activity in groundwater in the East Fork regime shows a pattern similar to that observed for gross alpha activity (Fig. 6.27) where uranium is the primary 

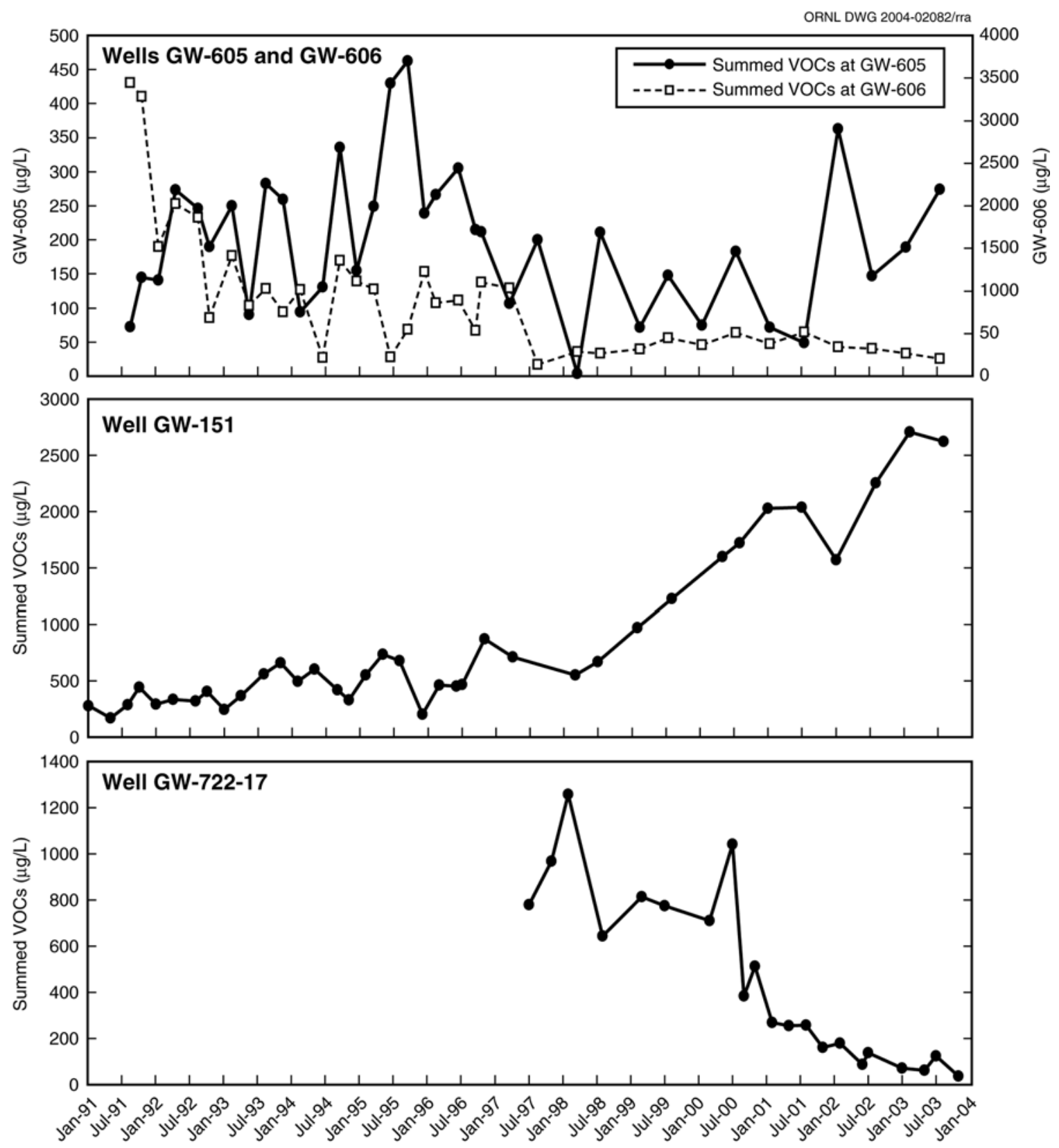

Note: Continuous pumping from well GW-845 began in October 2000

Fig. 6.25. Summed volatile organic compound concentrations in selected wells near New Hope Pond and exit pathway.

screening level of $50 \mathrm{pCi} / \mathrm{L}$ in groundwater in the western portion of the regime, with the primary source being the S-3 Site. The highest gross beta activity was observed during CY 2003 in groundwater from Well GW-109 (19,000 pCi/L), east of the S-3 site.

\section{Exit Pathway and Perimeter Monitoring}

Exit pathway groundwater monitoring activities in the East Fork regime in CY 2003 involved continued collection and trending of data from exit pathway monitoring stations. Data collected to date indicate that volatile organic compounds are the primary class of contaminants that are migrating through the exit pathways in the East Fork regime (Fig. 6.23). These compounds are migrating at depths of almost $500 \mathrm{ft}$ in the 


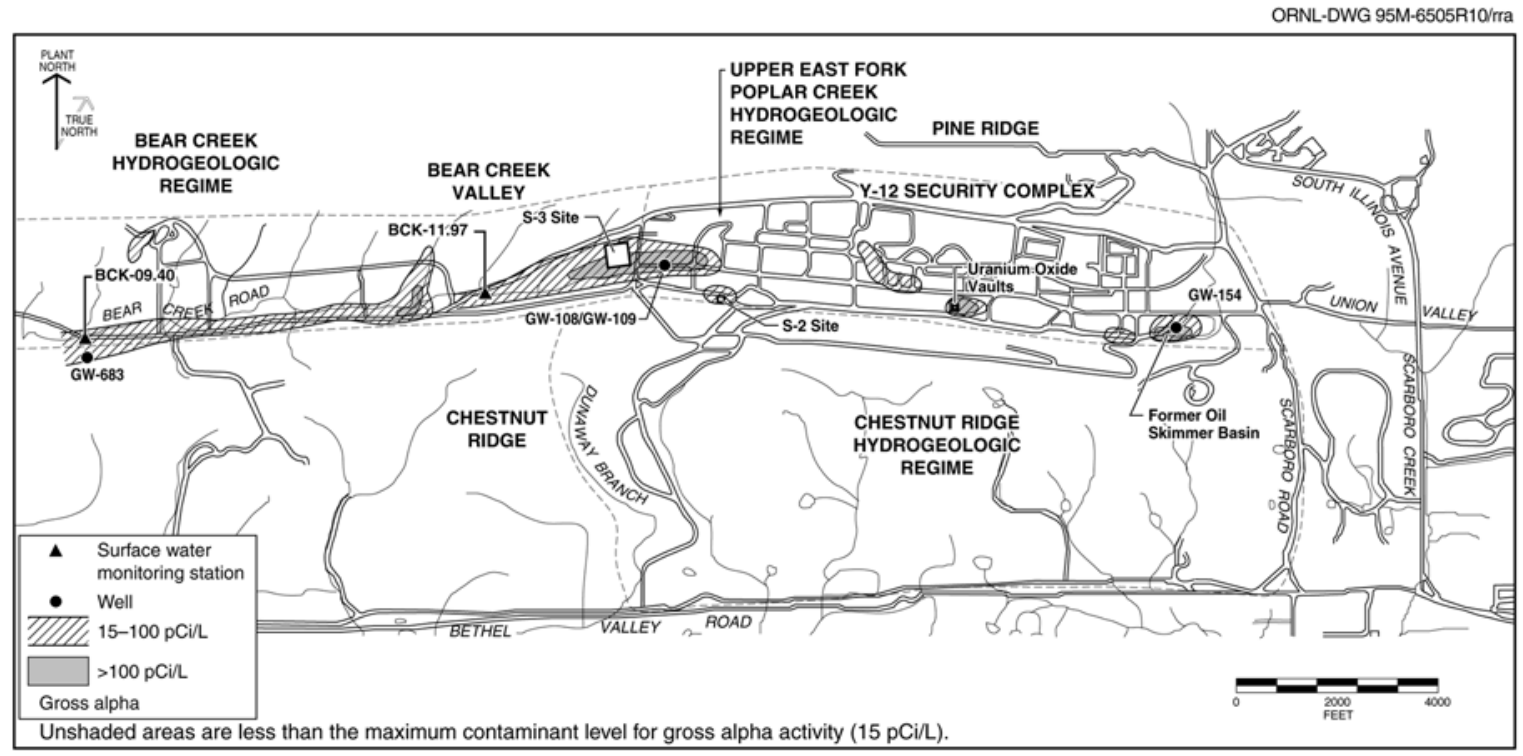

Fig. 6.26. Gross alpha activity in groundwater at the Y-12 Complex.

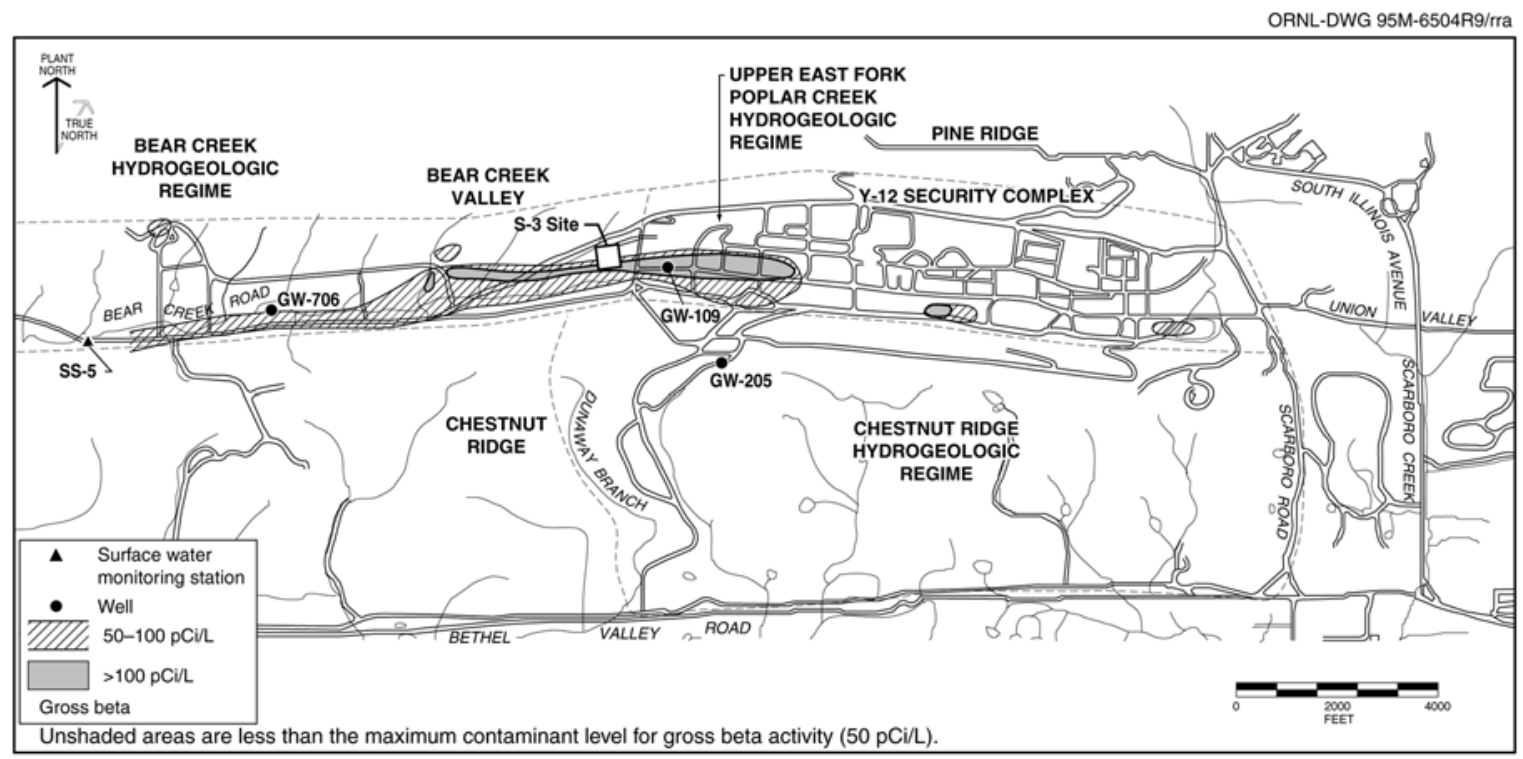

Fig. 6.27. Gross beta activity in groundwater at the Y-12 Complex.

Maynardville Limestone, the primary intermediate to the deep groundwater exit pathway on the East End of Y-12 (Fig. 6.28). Concentrations are typically higher at depth because most dilution and mixing with rainfall and Upper East Fork Poplar Creek occur in the shallow portions of the Maynardville limestone. In addition, most of the volatile organic contaminants at Y-12 are denser than water; therefore, they tend to migrate downward within the subsurface. The deep fractures and solution channels that constitute flow paths within the Maynardville Limestone appear to be well connected, resulting in the migration of these contaminants for substantial distances off the ORR into Union Valley to the east of Y-12.

In addition to the intermediate to deep pathways within the Maynardville Limestone, shallow groundwater within the water table interval near New Hope Pond, Lake Reality, and Upper East Fork Poplar Creek is also monitored. Historically, volatile organic compounds have been observed near Lake Reality from wells, a dewatering sump, and the New Hope Pond distribution channel underdrain. In this area, shallow groundwater flows north-northeast through the water table interval east of New Hope 
Pond and Lake Reality, following the path of the distribution channel for Upper East Fork Poplar Creek.

During CY 2003, the observed concentrations of volatile organic compounds at the New Hope Pond distribution channel underdrain continue to remain low. This may be because the continued operation of a groundwater plume-capture system in Well GW-845 (Fig. 6.28) south of the spillway may be reducing the levels of volatile organic compounds in the area. BJC completed the installation of this system in June 2000. This system pumps groundwater from the intermediate bedrock depth to mitigate off-site migration of volatile organic compounds. Groundwater is continuously pumped from the Maynardville Limestone at about $25 \mathrm{gpm}$, passes through a treatment system to remove the volatile organic compounds, and then discharges to Upper East Fork Poplar Creek.

As previously mentioned, monitoring wells near Well GW-845 have shown some encouraging response to pumping activities. The multi-port system installed in Well GW-722 permits sampling of ten discrete zones within the Maynardville Limestone between 87 and $560 \mathrm{ft}$ below ground surface. This well has been instrumental in characterizing the vertical extent of the east-end plume of volatile organic compounds and is critical in the evaluation of the effectiveness of the plume capture system. Monitoring results from some sampled zones in Well GW-722 indicate reductions in volatile organic compounds due to groundwater pumping upgradient at Well GW-845. Other wells, such as GW-153 and GW-382, also show decreases that
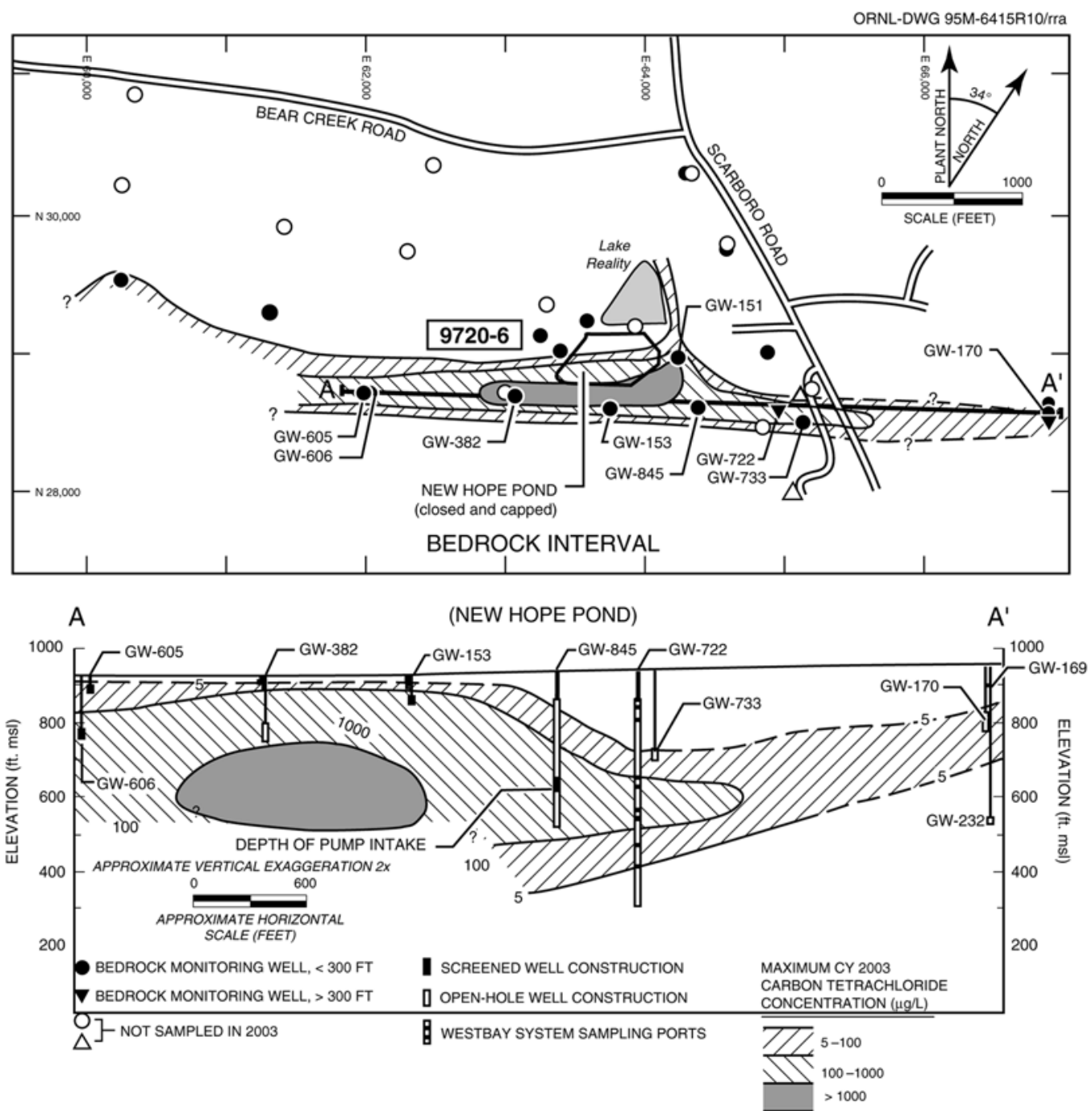

Fig. 6.28. Maximum carbon tetrachloride concentrations in Maynardville Limestone at depths between 200 and $500 \mathrm{ft}$. 
may be attributable to the plume capture system operation. These indicators show that operation of the plume capture system is decreasing volatile organic compounds upgradient and downgradient of Well GW-845.

Three wells, located in the large gap in Pine Ridge through which Upper East Fork Poplar Creek exits Y-12, are used to monitor shallow, intermediate, and deep groundwater intervals. Shallow groundwater moves through this exit pathway, and very strong upward vertical flow gradients exist; two of the three wells located in this area are artesian (water flows from the well casing due to unusually high naturally occurring water pressure). Continued monitoring of these wells since about 1990 has not shown that any contaminants are moving via this exit pathway.

Five sampling locations continue to be monitored north and northwest of Y-12 to evaluate possible contaminant transport from the ORR (Fig. 6.29). These locations are considered unlikely groundwater or surface water contaminant exit pathways; however, monitoring was performed due to recent public concerns regarding potential health impacts from Y-12 operations to nearby residences. Two of the stations monitored tributaries that drain the north slope of Pine Ridge on the ORR and discharge into the adjacent Scarboro Community. One location monitors an upper reach of Mill Branch, which discharges into the residential areas along Wiltshire Drive. The remaining two locations monitor Gum Hollow Branch as it discharges from the ORR and flows adjacent to the Country Club Estates community. Samples were obtained and analyzed for metals, inorganic parameters, volatile organic compounds, and gross alpha and gross beta activities. No results exceeded a drinking water standard, nor were there any indications that contaminants were being discharged from the ORR into these communities.

\subsubsection{Union Valley Monitoring}

Groundwater monitoring data obtained in 1993 provided the first strong indication that volatile organic compounds were being transported off the ORR through the deep Maynardville Limestone exit pathway. The Upper East Fork Poplar Creek remedial investigation (DOE 1998) provided a discussion of the nature and extent of the volatile organic compounds.

In CY 2003, monitoring of locations in Union Valley continued, showing an overall decreasing trend in the concentrations of contaminants forming the groundwater contaminant plume in Union Valley.

Under the terms of an interim record of decision, administrative controls, such as restriction on potential future groundwater use, have been established. Additionally, the previously discussed plume capture system (Well GW-845) was installed and initiated to reduce volatile organic compounds in Union Valley (DOE 2004).

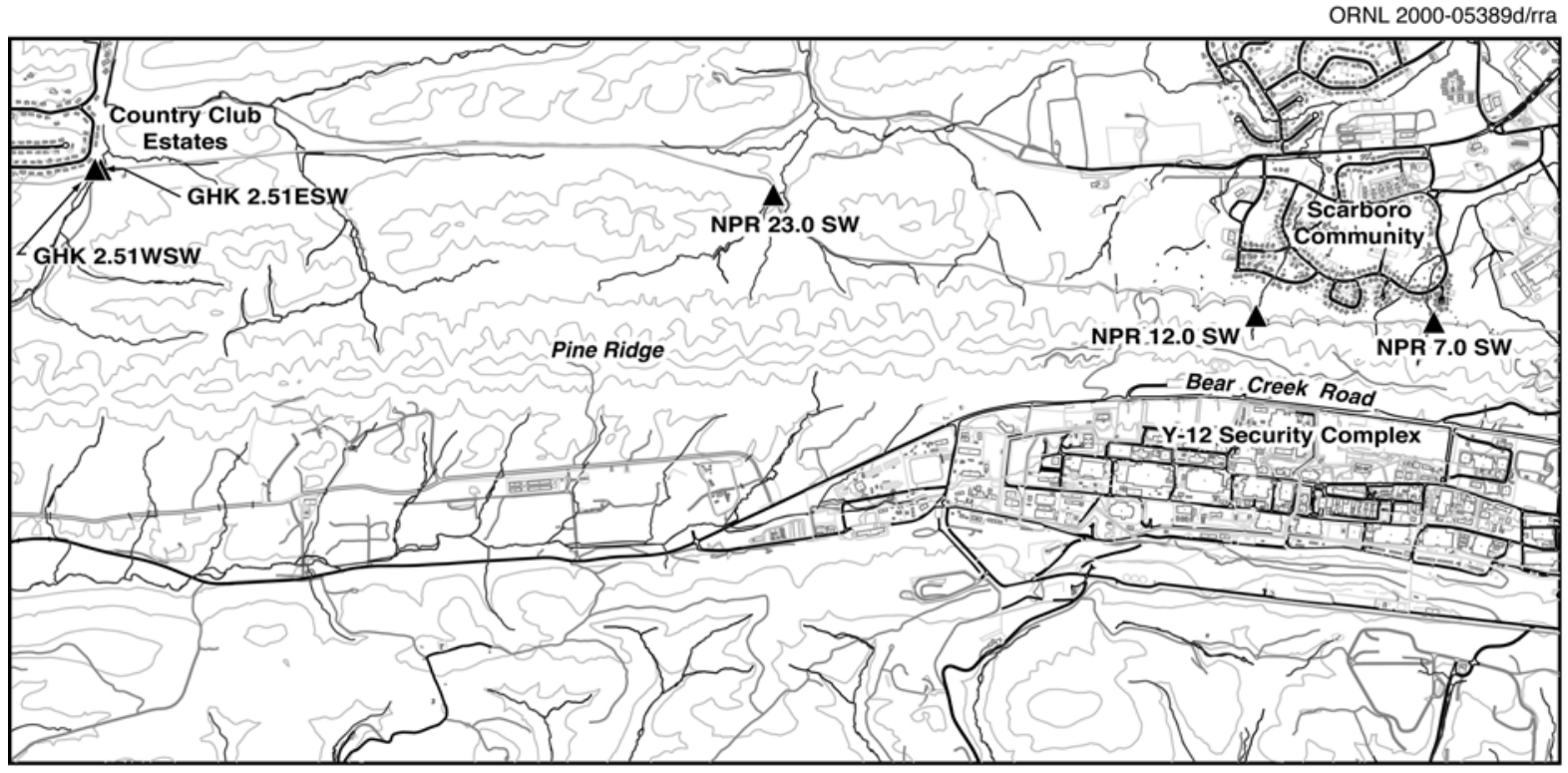

Fig. 6.29. Surface water sampling locations north of Pine Ridge, 2003. 


\subsubsection{Bear Creek Hydrogeologic Regime}

Located west of Y-12 in Bear Creek Valley, the Bear Creek regime is bounded to the north by Pine Ridge and to the south by Chestnut Ridge. The regime encompasses the portion of Bear Creek Valley extending from the west end of the Y-12 Complex to Highway 95. Table 6.17 describes each of the waste management sites within the Bear Creek regime.

\section{Plume Delineation}

The primary groundwater contaminants in the Bear Creek regime are nitrate, trace metals, volatile organic compounds, and radionuclides. The S-3 Site is a source of all four of these contaminants. The Oil Landfarm waste management area, consisting of the Oil Landfarm, the Boneyard/Burnyard, the Hazardous Chemical Disposal Area, and Landfill I, is a significant source of uranium, other trace metals, and volatile organic compounds. Other sources of volatile organic compounds include the Rust Spoil Area, and the Bear Creek Burial Grounds waste management area. Dense nonaqueous phase liquids (DNAPLs), heavier-than-water solvents that have a low water solubility, exist at depths as great as or greater than $270 \mathrm{ft}$ below the Bear Creek Burial Grounds. The DNAPLs consist primarily of volatile organic compounds such as tetrachloroethene, trichloroethene, 1,1dichloroethene, 1,2-dichloroethene, and high concentrations of PCBs.

Contaminant plume boundaries are essentially defined in the bedrock formations that directly underlie many waste disposal areas in the Bear Creek regime, particularly the Nolichucky Shale. The elongated shape of the contaminant plumes in the Bear Creek regime is the result of preferential transport of the contaminants parallel to strike in both the Knox Aquifer and the ORR Aquitards.

\section{Nitrate}

Unlike many groundwater contaminants, nitrate is highly soluble and moves easily with groundwater. The limits of the nitrate plume probably define the maximum extent of subsurface contamination in the Bear Creek regime. The horizontal extent of the nitrate plume is essentially defined in groundwater in the upper to intermediate part of the aquitard and aquifer [less than $300 \mathrm{ft}(91 \mathrm{~m})$ below the ground surface].

Data obtained during CY 2003 indicate that nitrate concentrations in groundwater exceed the drinking water standard in an area that extends west from the S-3 Site for approximately $11,000 \mathrm{ft}$ (3,352 m) down Bear Creek Valley (Fig. 6.21). Nitrate concentrations greater than $100 \mathrm{mg} / \mathrm{L}$ persist out to about $3000 \mathrm{ft}(915 \mathrm{~m})$ west of the S-3 Site, indicating no significant change from previous years. Historically, the highest nitrate concentrations are observed adjacent to the S-3 Site in groundwater in the unconsolidated zone and at shallow depths [less than $100 \mathrm{ft}(30.5 \mathrm{~m})$ below ground surface] in the Nolichucky Shale. Elevated concentrations of nitrate have been observed as deep as $740 \mathrm{ft}(226 \mathrm{~m})$ below ground surface. Surface water nitrate results exceeding the drinking water standard during CY 2003 were observed as far as 8,000 to $11,000 \mathrm{ft}(2,438$ to $3,352 \mathrm{~m}$ ) west of the S-3 Site. The extent of nitrate contamination in the surface waters of the Bear Creek regime appears to be shrinking when compared with the extents observed in CY 2002. This is possibly due to attenuation by dilution from rainfall, which was heavier than usual in CY 2003.

\section{Trace Metals}

During CY 2003, uranium, barium, cadmium, chromium, lead, beryllium, nickel, thallium, arsenic, and selenium have been identified from groundwater monitoring as the trace metal contaminants in the Bear Creek regime that exceeded drinking water standards. Historically, elevated concentrations of many of these metals were observed at shallow depths near the S-3 Site. Disposal of acidic liquid wastes at the S-3 Site reduced the $\mathrm{pH}$ of the groundwater, which allows the metals to remain in solution. Elsewhere in the Bear Creek regime, where natural geochemical conditions prevail, these trace metals may occur sporadically and in close association with source areas because conditions are typically not 
Table 6.17. History of waste management units included in CY 2003 groundwater monitoring activities, Bear Creek Hydrogeologic Regime ${ }^{a}$

\begin{tabular}{l}
\hline Site \\
\hline S-3 Site \\
Oil Landfarm \\
Boneyard \\
Burnyard \\
Hazardous Chemical \\
Disposal Area \\
Sanitary Landfill I \\
Bear Creek Burial Grounds: \\
A, C, and Walk-in Pits \\
Pear Creek Burial Grounds: \\
Ponds 1 and 2
\end{tabular}

Four unlined surface impoundments constructed in 1951. Received liquid nitric acid/uranium-bearing wastes via the Nitric Acid Pipeline until 1983. Closed and capped under RCRA in 1988. Infiltration was the primary release mechanism to groundwater

Operated from 1973 to 1982 . Received waste oils and coolants tainted with metals and PCBs. Closed and capped under RCRA in 1989. Infiltration was the primary release mechanism to groundwater. Part of the Oil Landfarm waste management area Used from 1943 to 1970 . Unlined shallow trenches used to dispose of construction debris and to burn magnesium chips and wood. Excavated and restored in 2002 Used from 1943 to 1968 . Wastes, metal shavings, solvents, oils, and laboratory chemicals were burned in two unlined trenches. Excavated and restored in 2002 Used from 1975 to 1981 . Built over the burnyard. Handled compressed gas cylinders and reactive chemicals. Residues placed in a small, unlined pit. Excavated and restored in 2002 as part of Boneyard/Burnyard remedial activities

Used from 1968 to 1982 . TDEC-permitted, nonhazardous industrial landfill. May be a source of certain contaminants to groundwater. Closed and capped under TDEC requirements in 1985. Part of the Oil Landfarm waste management area

$\mathrm{A}$ and $\mathrm{C}$ received waste oils, coolants, beryllium and uranium, various metallic wastes, and asbestos into unlined trenches and standpipes. Walk-in Pits received chemical wastes, shock-sensitive reagents, and uranium saw fines. Activities ceased in 1981. Final closure certified for A (1989), C (1993), and the Walk-in Pits (1995). Infiltration is the primary release mechanism to groundwater

Burial Grounds B, D, E, and J, unlined trenches, received depleted uranium metal and oxides and minor a mounts of debris and inorganic salts. Ponds 1 and 2, built in 1971 and 1972, respectively, captured waste oils seeping into two Bear Creek tributaries. The ponds were closed and capped under RCRA in 1989. Certification of closure and capping of Burial Grounds B and part of C was granted February 1995

Rust Spoil Area Used from 1975 to 1983 for disposal of construction debris, but may have included materials bearing solvents, asbestos, mercury, and uranium. Closed under RCRA in 1984. Site is a source of volatile organic compounds to shallow groundwater according to CERCLA remedial investigation

Spoil Area I Used from 1980 to 1988 for disposal of construction debris and other stable, nonrad wastes. Permitted under TDEC solid waste management regulations in 1986; closure began shortly thereafter. Soil contamination is of primary concern. CERCLA record of decision issued in 1996

SY-200 Yard Used from 1950 to 1986 for equipment and materials storage. No documented waste disposal at the site occurred. Leaks, spills, and soil contamination are concerns. CERCLA record of decision issued in 1996

Above-Grade LLW Storage Constructed in 1993. Consists of six above-grade storage pads used to store inert, Facility low-level radioactive debris and solid wastes packaged in steel containers

${ }^{a}$ Abbreviations

CERCLA = Comprehensive Environmental Response, Compensation, and Liability Act

LLW = low-level radioactive waste

$\mathrm{PCB}=$ polychlorinated biphenyl

RCRA = Resource Conservation and Recovery Act

TDEC $=$ Tennessee Department of Environment and Conservation 
favorable for dissolution and migration. In CY 2003, these trace metals were evident at elevated concentrations within the surface water and groundwater downgradient of the S-3 Site, the Bear Creek Burial Ground, and the Oil Landfarm waste management areas.

The most prevalent trace metal contaminant observed within the Bear Creek regime is uranium, indicating that geochemical conditions are favorable for its migration. The Boneyard/ Burnyard site has been identified as the primary source of uranium contamination of surface water and groundwater. Historically, uranium is observed at concentrations exceeding the drinking water standard of $0.03 \mathrm{mg} / \mathrm{L}$ in shallow monitoring wells, springs, and surface water locations downgradient from all of the waste areas. In 2002, BJC performed the final remedial actions at the Boneyard/Burnyard with the objective of removing materials contributing to surface water and groundwater contamination to meet existing record-of-decision goals. Approximately $86,000 \mathrm{yd}^{3}$ of waste materials were excavated and placed in the EMWMF (DOE 2004). Some evidence of improved water quality is indicated in Bear Creek. Uranium concentrations above the drinking water standard were still observed in surface water monitoring stations over 2.6 miles $(4.2 \mathrm{~km})$ from Bear Creek Burial Ground, the westernmost waste area. However, the apparent slight drop in concentrations in CY 2003 in surface water and spring locations downgradient of the Boneyard/Burnyard may be attributable to the remedial action performed in 2002.

Other trace metal contaminants that have been observed in the Bear Creek regime are boron, cobalt, and strontium. Concentrations of these metals have commonly exceeded background values in groundwater near contaminant source areas.

\section{Volatile Organic Compounds}

Volatile organic compounds are widespread in groundwater in the Bear Creek regime (Fig. 6.23). The primary compounds are tetrachloroethene, trichloroethene, 1,2-dichloroethene, 1,1-dichloroethane and vinyl chloride. In most areas, they are dissolved in the groundwater, and
DNAPL accumulations occur in bedrock more than $250 \mathrm{ft}(76 \mathrm{~m})$ below the Bear Creek Burial Ground waste management area. Groundwater in the aquitards that contains detectable levels of volatile organic compounds occurs primarily within about $1000 \mathrm{ft}(305 \mathrm{~m})$ of the source areas. The highest concentrations observed in CY 2003 in the Bear Creek regime occurred in the unconsolidated zone at the Bear Creek Burial Ground waste management area in monitoring Well GW-046, with a maximum summed volatile organic compound concentration of $18,602 \mu \mathrm{g} / \mathrm{L}$. The extent of the dissolved plumes of volatile organic compounds is greater in the underlying bedrock. The highest levels in bedrock, in the Bear Creek regime, occur just south of the Bear Creek Burial Ground waste management area. Historical levels have been as high as $7,000,000 \mu \mathrm{g} / \mathrm{L}$ in groundwater near the source area. The maximum summed volatile organic compound concentration observed in the Bear Creek regime from the bedrock interval was 4,786 $\mu \mathrm{g} / \mathrm{L}$ (well GW-082). Well GW-082 monitors the shallow (21 to $30 \mathrm{ft}$ below ground surface) bedrock interval downgradient of the Bear Creek Burial Ground waste management area. This well, along with Wells GW-627 and GW-653, continue to exhibit an increase in volatile organic compound concentration (Fig. 6.30). The increasing trends observed in wells GW-082, GW-627, and GW-653 indicate that some migration of volatile organic compounds is occurring. This migration through the aquitards parallel to the valley axis and toward the exit pathway (Maynardville Limestone) is occurring in both the unconsolidated and bedrock intervals.

Significant transport of volatile organic compounds has occurred in the Maynardville Limestone. Data obtained from exit pathway monitoring locations show that in the vicinity of the water table, an apparently continuous dissolved plume extends 10,000 to $12,000 \mathrm{ft}$ (3,048 to $3,660 \mathrm{~m}$ ) westward from the S-3 Site to just southwest of the Bear Creek Burial Ground waste management area. Typical summed concentrations observed in CY 2003 in the Maynardville Limestone range from $297 \mu \mathrm{g} / \mathrm{L}$ in the central part of the regime (Well GW-225) to less than detectable levels approximately 12,000 $\mathrm{ft}(3,660 \mathrm{~m})$ to the west of the $\mathrm{S}-3$ site. 

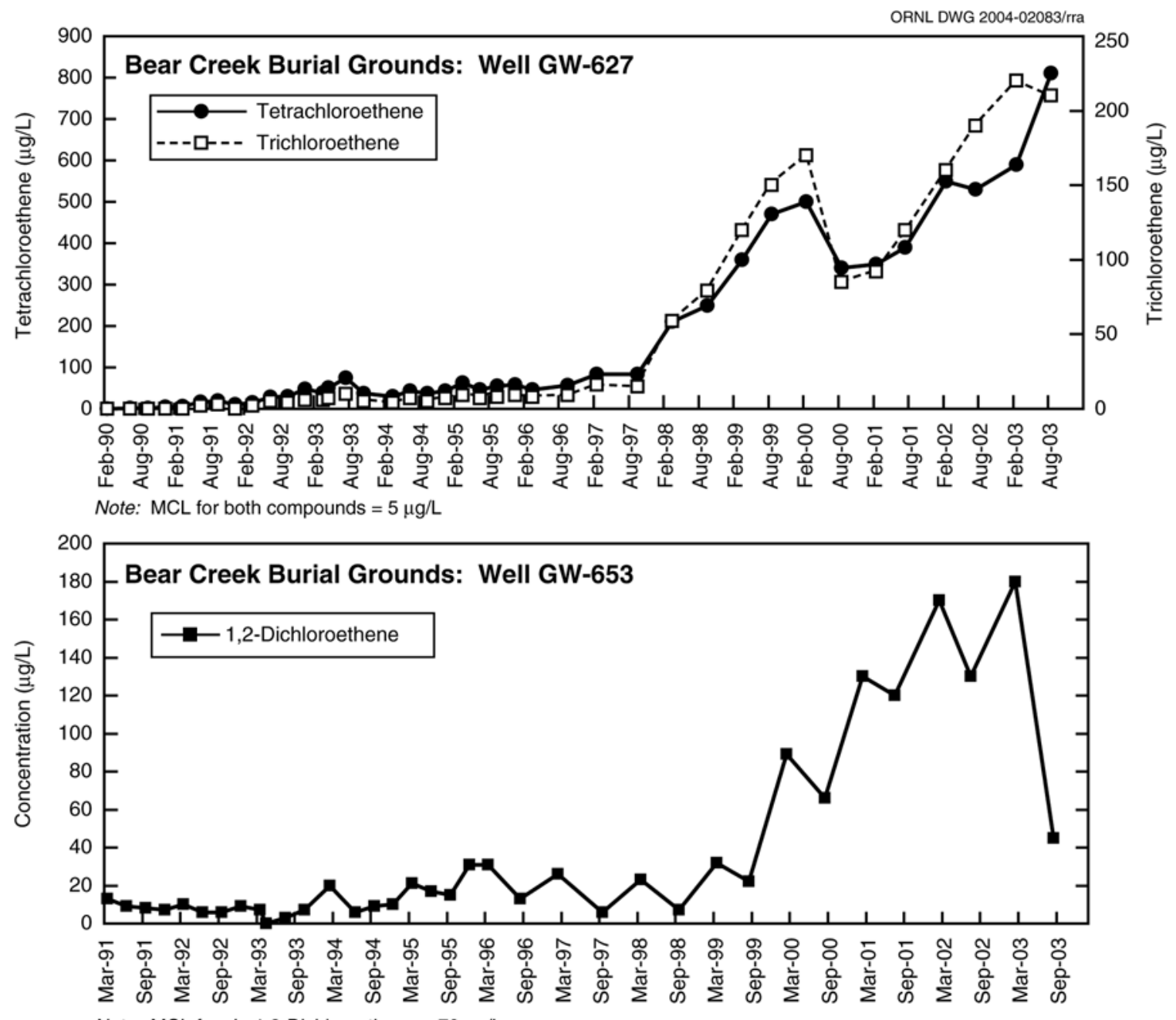

Note: $\mathrm{MCL}$ for cis-1,2-Dichloroethene $=70 \mu \mathrm{g} / \mathrm{L}$

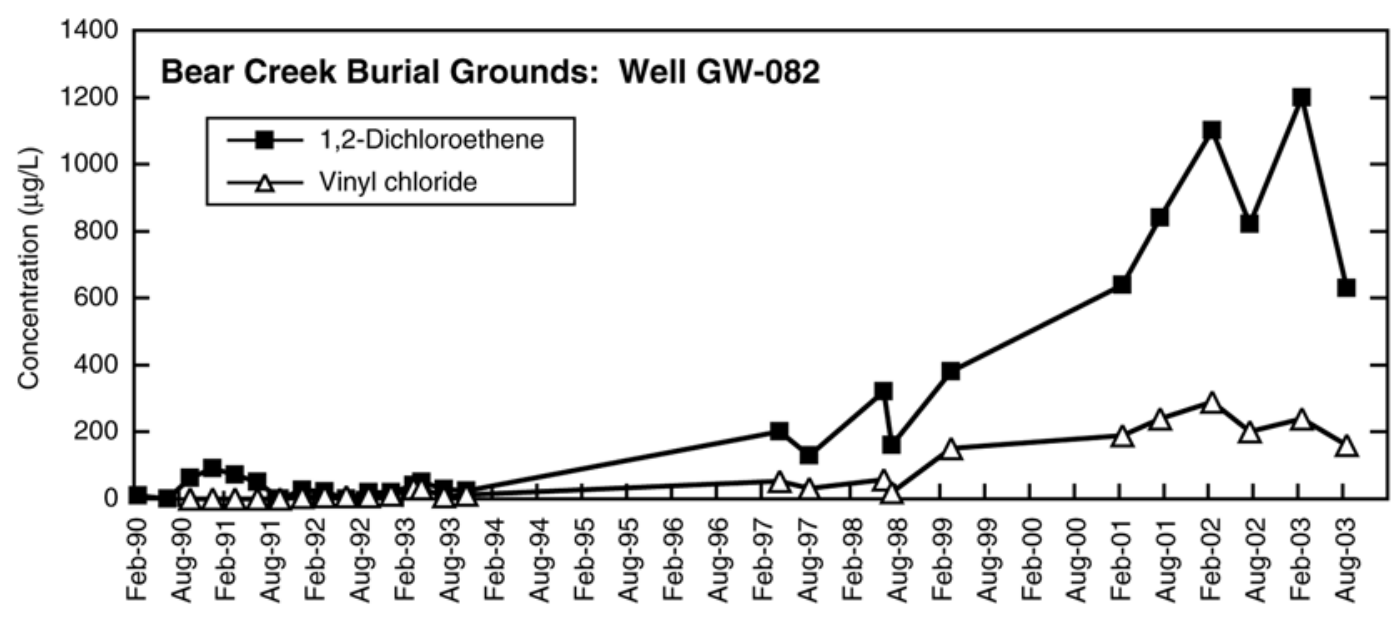

Note: MCLs: cis-1,2-Dichloroethene $=70 \mu \mathrm{g} / \mathrm{L}$; Vinyl chloride $=2 \mu \mathrm{g} / \mathrm{L}$

Fig. 6.30. Volatile organic compound concentrations in Bear Creek Burial Grounds wells GW-082, GW-653, and GW-627. 


\section{Radionuclides}

The primary radionuclides identified in the Bear Creek regime are isotopes of uranium and ${ }^{99} \mathrm{Tc}$. Neptunium-237, ${ }^{241} \mathrm{Am}$, radium, strontium, thorium, plutonium, and tritium are secondary and less widespread radionuclides, primarily present in groundwater near the S-3 Site.

Evaluations of the extent of these radionuclides in groundwater in the Bear Creek regime during CY 2003 were based primarily on measurements of gross alpha activity and gross beta activity. If the annual average gross alpha activity in groundwater samples from a well exceeded $15 \mathrm{pCi} / \mathrm{L}$ (the drinking water standard for gross alpha activity), then one (or more) of the alpha-emitting radionuclides (e.g., uranium) was assumed to be present in the groundwater monitored by the well. A similar rationale was used for annual average gross beta activity that exceeded $50 \mathrm{pCi} / \mathrm{L}$. Technetium-99, a more volatile radionuclide, is qualitatively screened by gross beta activity analysis and, at certain monitoring locations, is evaluated isotopically.

Groundwater with elevated levels of gross alpha activity occurs near the S-3 Site and the Oil Landfarm waste management areas (Fig. 6.26). In the bedrock interval, gross alpha activity exceeds $15 \mathrm{pCi} / \mathrm{L}$ in groundwater in the Nolichucky Shale only near source areas. Data obtained from exit pathway monitoring stations show that gross alpha activity in groundwater in the Maynardville Limestone exceeds the drinking water standard for almost $12,000 \mathrm{ft}(3,660 \mathrm{~m})$ west of the S-3 Site. Gross alpha activities above the drinking water standard in surface water samples were observed about 4.7 miles $(7.6 \mathrm{~km})$ west of the $\mathrm{S}-3$ Site (e.g., BCK 4.55; see Fig. 6.19). This is further reaching in the surface water than in previous years and is attributed to heavier rainfall following the remediation efforts at the Boneyard/Burnyard Area, which may have mobilized more uranium in Bear Creek.

The distribution of gross beta radioactivity in groundwater in the unconsolidated zone is similar to that of gross alpha radioactivity (Fig. 6.27). During CY 2003, gross beta activities exceeded $50 \mathrm{pCi} / \mathrm{L}$ within the Maynardville Limestone exit pathway for 8,000 to $10,000 \mathrm{ft}(2,438$ to $3,048 \mathrm{~m})$ from the S-3 Site (i.e., Well GW-706). It appears that the lateral extent of gross beta activity within the exit pathway groundwater interval has receded slightly from previous years. Surface water gross beta activities above the drinking water standard also exhibit this apparent receding characteristic. In 2002, gross beta activities in surface water exceeding the drinking water standard were observed about 3 miles $(4.8 \mathrm{~km})$ west of the S-3 Site, while in 2003, this distance from the S-3 Site shrank to 2.3 miles $(3.7 \mathrm{~km})$. The withdrawal of gross beta activity seems to contradict the observed character of gross alpha and uranium in the exit pathway. The primary source of uranium is the Oil Landfarm Area (i.e., Boneyard/ Burnyard). Differences should be expected because gross beta activity is used to qualitatively determine the extent to which ${ }^{99} \mathrm{Tc}$ has migrated from the S-3 Site. Heavy rainfall during CY 2003 may have caused a dilution effect, thus decreasing gross beta activities across Bear Creek Valley.

\section{Exit Pathway and Perimeter Monitoring}

Exit pathway monitoring began in 1990 to provide data on the quality of groundwater and surface water exiting the Bear Creek regime. The Maynardville Limestone is the primary exit pathway for groundwater. Bear Creek, which flows across the Maynardville Limestone in much of the Bear Creek regime, is the principal exit pathway for surface water. Various studies have shown that surface water in Bear Creek, springs along the valley floor, and groundwater in the Maynardville Limestone are hydraulically connected. The western exit pathway well transect (Picket W) serves as the ORR perimeter well location for the Bear Creek regime (Fig. 6.20).

Exit pathway monitoring consists of continued monitoring at four well transects (pickets) and selected springs and surface water stations. Groundwater quality data obtained during CY 2003 from the exit pathway monitoring wells indicate that contaminated groundwater does not consistently occur above drinking water standards beyond the western side of the Bear Creek Burial Ground waste management area (Fig. 6.31). However, nitrate and uraniumconcentrations and gross alpha and gross beta activities exceeding their respective drinking 

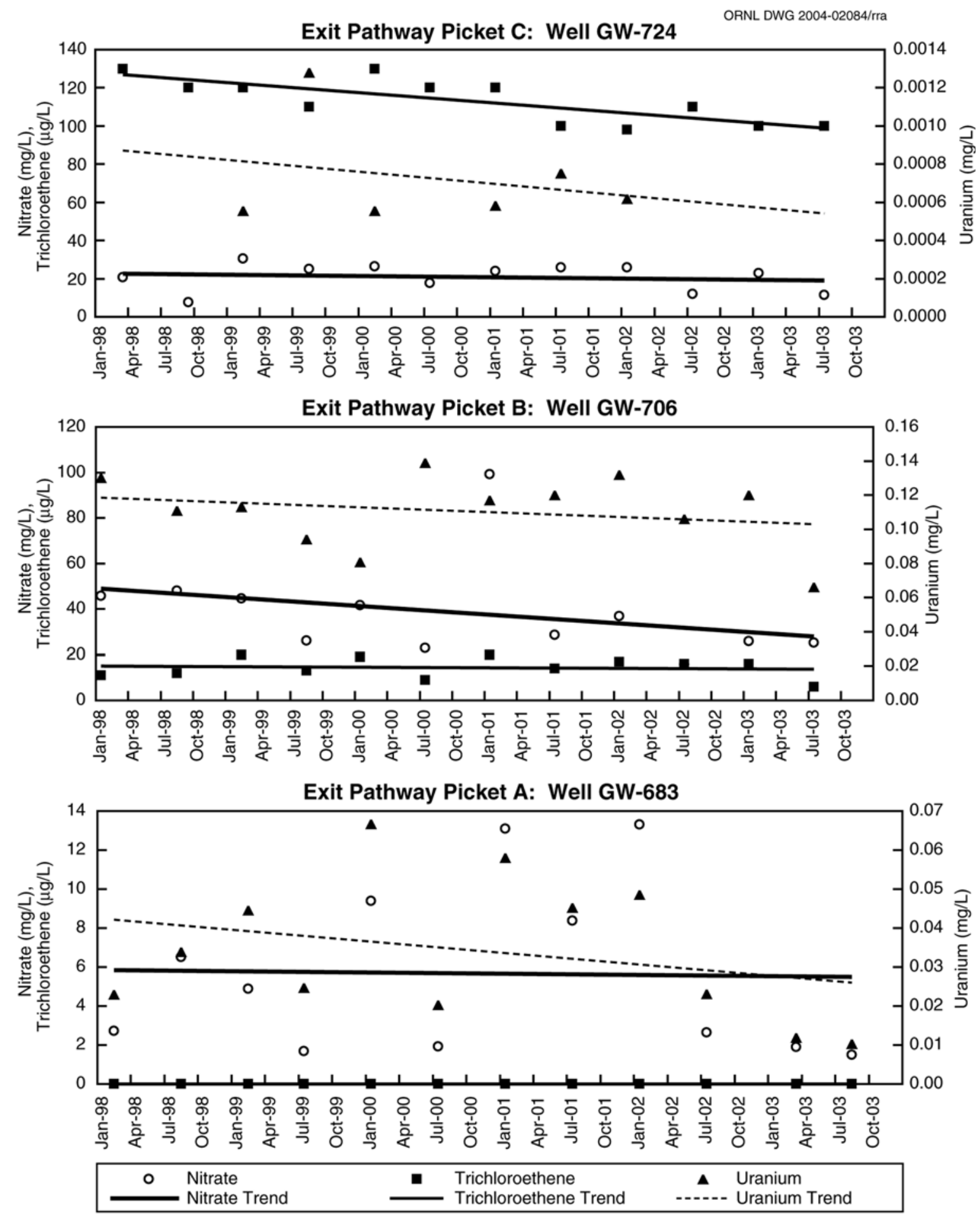

Note: Only nitrate and uranium results above the detection limit are plotted; non-detected trichloroethene results are plotted at zero.

Fig. 6.31. Concentrations of selected contaminants in exit pathway monitoring wells GW-683, GW706, and GW-724, in the Bear Creek Hydrogeologic Regime.

water standards have been observed in surface water west of the burial grounds (BWXT 2004).

Surface water and spring samples collected during CY 2003 indicate that spring discharges and water in upper reaches of Bear Creek contain many of the compounds found in the groundwater. The concentrations in the creek and spring discharge decrease with distance downstream of 
the waste disposal sites (Fig. 6.32). A long-term trend of slightly increasing gross alpha activity continues to be observed in middle and lower Bear Creek (BCK 9.40 and BCK 4.55). Remediation efforts at the Oil Landfarm Waste Management Area in CY 2002 are intended to reverse these trends.

\subsubsection{Chestnut Ridge Hydrogeologic Regime}

The Chestnut Ridge Hydrogeologic Regime is south of Y-12 and is flanked to the north by Bear Creek Valley and to the south by Bethel Valley Road (Fig. 6.19). The regime encompasses the portion of Chestnut Ridge extending from Scarboro Road, east of Y-12, to Dunaway Branch,
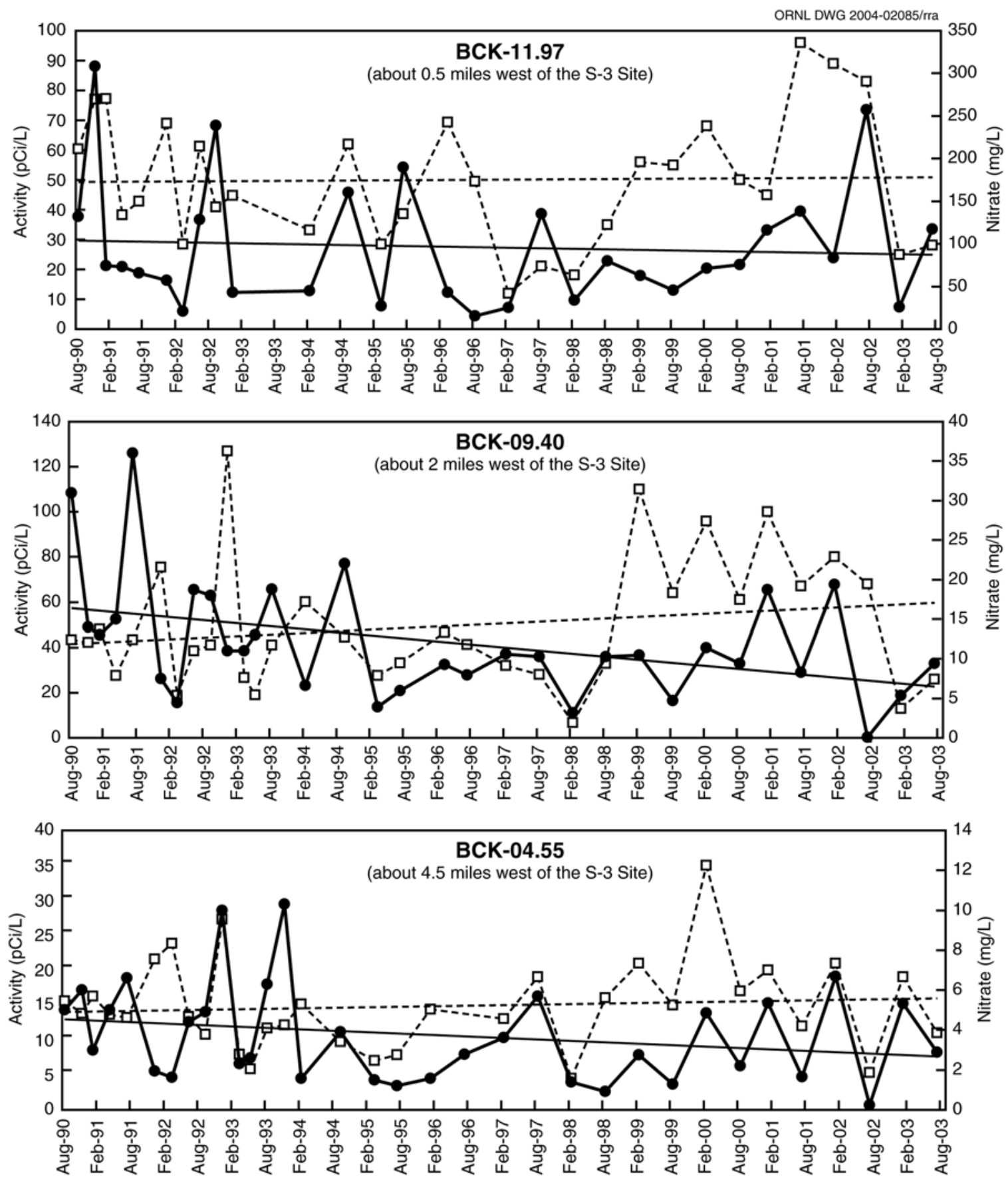

-- --- Alpha Activity $\longrightarrow$ Nitrate

Fig. 6.32. Concentrations of selected groundwater contaminants in Bear Creek. 
located just west of Industrial Landfill II.

The Chestnut Ridge Security Pits area is the only documented source of groundwater contamination in the regime. Contamination from the Security Pits is distinct and does not mingle with plumes from other sources. Table 6.18 summarizes the operational history of waste management units in the regime.

\section{Plume Delineation}

The horizontal extent of the volatile organic compound plume at the Chestnut Ridge Security Pits is reasonably well defined in the water table and shallow bedrock zones (Fig. 6.23). Groundwater quality data obtained during CY 2003 indicates that the western lateral extent of the plume of volatile organic compounds at the site has not changed significantly from previous years (GW-177, Fig. 6.33). However, an increase in volatile organic compound contaminants over the past several years at well GW-798 shows that some migration of the eastern plume is occurring (Fig. 6.32).

\section{Nitrate}

Nitrate concentrations were below the drinking water standard of $10 \mathrm{mg} / \mathrm{L}$ at all monitoring stations.

\section{Trace Metals}

Groundwater concentrations of trace metals exceeded regulatory standards during CY 2003 at five locations. Concentrations above the drinking water standard for nickel were observed in samples from four monitoring wells. Two surface water monitoring stations showed elevated concentrations of arsenic.

Nickel concentrations above the drinking water standard $(0.1 \mathrm{mg} / \mathrm{L})$ were observed from two well at the Industrial Landfill IV and from two wells at the United Nuclear Corporation site (Fig. 6.18). The presence of nickel in groundwater samples from monitoring wells at both the Landfill IV and the United Nuclear site is probably due to corrosion of well casings. This also accounts for the elevated concentrations of chromium seen in one of the wells at the United Nuclear Corporation Site. Nickel and chromium are both primary components of stainless steel, and the presence of both potentially indicates the occurrence of corrosion and subsequent dissolution of stainless steel well casing and screen materials (LMES 1999).

Elevated concentrations of arsenic above the drinking water standard $(0.01 \mathrm{mg} / \mathrm{L})$ were observed in two surface water monitoring location downstream from the Filled Coal Ash Pond, which is monitored under a CERCLA record of decision (DOE 2004). A constructed wetlands is being utilized to prevent surface water contamination by effluent from the Filled Coal Ash Pond. During CY 2003, the locations where elevated arsenic levels were detected are both upgradient and downgradient of this wetland area. Downgradient of the wetlands, concentrations are noticeably lower and surface water samples obtained approximately $2000 \mathrm{ft}(610 \mathrm{~m})$ downstream (Rogers Quarry) exhibit no detectable arsenic.

\section{Volatile Organic Compounds}

Efforts to delineate the extent of volatile organic compounds in groundwater attributable to the Chestnut Ridge Security Pits have been in progress since 1987. A review of historical data indicates that concentrations of volatile organic compounds in groundwater at the site have generally decreased since 1988. However, the CY 2003 monitoring in and around the Chestnut Ridge Security Pits presents a changing picture. Well GW-177 (western side of the Security Pits) was monitored, and stable levels of volatile organic compounds continued to be observed, indicating that interior portions of the plumes are not decreasing substantially. A general increasing trend in volatile organic compounds in groundwater samples from monitoring well GW-798 to the southeast and downgradient of the Chestnut Ridge Security Pits has been developing since CY 2000 (Fig. 6.33). The volatile organic compounds detected in CY 2003 are characteristic of the Chestnut Ridge Security Pits plume; and the constituent tetrachloroethene continued to 
Table 6.18. History of waste management units included in CY 2003 groundwater monitoring activities, Chestnut Ridge Hydrogeologic Regime ${ }^{a}$

\begin{tabular}{|c|c|}
\hline Site & Historical data \\
\hline $\begin{array}{l}\text { Chestnut Ridge Sediment } \\
\text { Disposal Basin }\end{array}$ & $\begin{array}{l}\text { Operated from } 1973 \text { to } 1989 \text {. Received soil and sediment from New Hope Pond and } \\
\text { mercury-contaminated soils from the Y-12 Complex. Site was closed under RCRA } \\
\text { in } 1989 . \text { Not a documented source of groundwater contamination }\end{array}$ \\
\hline Kerr Hollow Quarry & $\begin{array}{l}\text { Operated from 1940s to } 1988 \text {. Used for the disposal of reactive materials, } \\
\text { compressed gas cylinders, and various debris. RCRA closure (waste removal) was } \\
\text { conducted between } 1990 \text { and } 1993 \text {. Certification of closure with some wastes } \\
\text { remaining in place was approved by TDEC February } 1995\end{array}$ \\
\hline Chestnut Ridge Security Pits & $\begin{array}{l}\text { Operated from } 1973 \text { to } 1988 \text {. Series of trenches for disposal of classified materials, } \\
\text { liquid wastes, thorium, uranium, heavy metals, and various debris. Closed under } \\
\text { RCRA in 1989. Infiltration is the primary release mechanism to groundwater }\end{array}$ \\
\hline $\begin{array}{l}\text { United Nuclear Corporation } \\
\text { Site }\end{array}$ & $\begin{array}{l}\text { Received about } 29,000 \text { drums of cement-fixed sludges and soils demolition } \\
\text { materials, and low-level radioactive contaminated soils. Closed in 1992; CERCLA } \\
\text { record of decision has been issued }\end{array}$ \\
\hline Industrial Landfill II & $\begin{array}{l}\text { Central sanitary landfill for the Oak Ridge Reservation. Detection monitoring under } \\
\text { postclosure plan has been ongoing since } 1996\end{array}$ \\
\hline Industrial Landfill IV & $\begin{array}{l}\text { Permitted to receive only nonhazardous industrial solid wastes. Detection } \\
\text { monitoring under TDEC solid-waste-management regulations has been ongoing } \\
\text { since } 1988\end{array}$ \\
\hline Industrial Landfill V & $\begin{array}{l}\text { New facility completed and initiated operations April 1994. Baseline groundwater } \\
\text { monitoring began May } 1993 \text { and was completed January 1995. Currently under } \\
\text { TDEC solid-waste-management detection monitoring }\end{array}$ \\
\hline $\begin{array}{l}\text { Construction/Demolition } \\
\text { Landfill VI }\end{array}$ & $\begin{array}{l}\text { New facility completed and initiated operations December 1993. Baseline } \\
\text { groundwater quality monitoring began May } 1993 \text { and was completed December } \\
\text { 1993. Currently under permit-required detection monitoring per TDEC }\end{array}$ \\
\hline $\begin{array}{l}\text { Construction/Demolition } \\
\text { Landfill VII }\end{array}$ & $\begin{array}{l}\text { New facility; construction completed in December 1994. TDEC granted approval to } \\
\text { operate January 1995. Baseline groundwater quality monitoring began in May } 1993 \\
\text { and was completed in January } 1995 \text {. Permit-required detection monitoring per } \\
\text { TDEC was temporarily suspended October } 1997 \text { pending closure of } \\
\text { construction/demolition Landfill VI. Reopened and began waste disposal operations } \\
\text { in April } 2001\end{array}$ \\
\hline Filled Coal Ash Pond & $\begin{array}{l}\text { Site received Y-12 Steam Plant coal ash slurries. A CERCLA record of decision has } \\
\text { been issued. Remedial action complete }\end{array}$ \\
\hline
\end{tabular}

consistently exceed the drinking water standard (5 $\mu \mathrm{g} / \mathrm{L})$. These results indicate that there is some migration occurring through the developed fracture and conduit system of the karst dolostone to the southeast.

The volatile organic compound concentrations observed in Well GW-305, located immediately to the southeast of Landfill IV, are increasing (Fig. 6.34). Concentrations of the volatile organic compounds in Well GW-305 have remained below applicable drinking water standards. The drinking water standard for the volatile organic compound 1,1-dichloroethene is $7 \mu \mathrm{g} / \mathrm{L}$. During CY 2003, this compound was detected just below this standard $(4.3 \mu \mathrm{g} / \mathrm{L}, 4.6 \mu \mathrm{g} / \mathrm{L}, 6.4 \mu \mathrm{g} / \mathrm{L}$, and $6.0 \mu \mathrm{g} / \mathrm{L})$.

\section{Radionuclides}

In CY 2003, Gross alpha activities were below the drinking water standard of $15 \mathrm{pCi} / \mathrm{L}$ at 

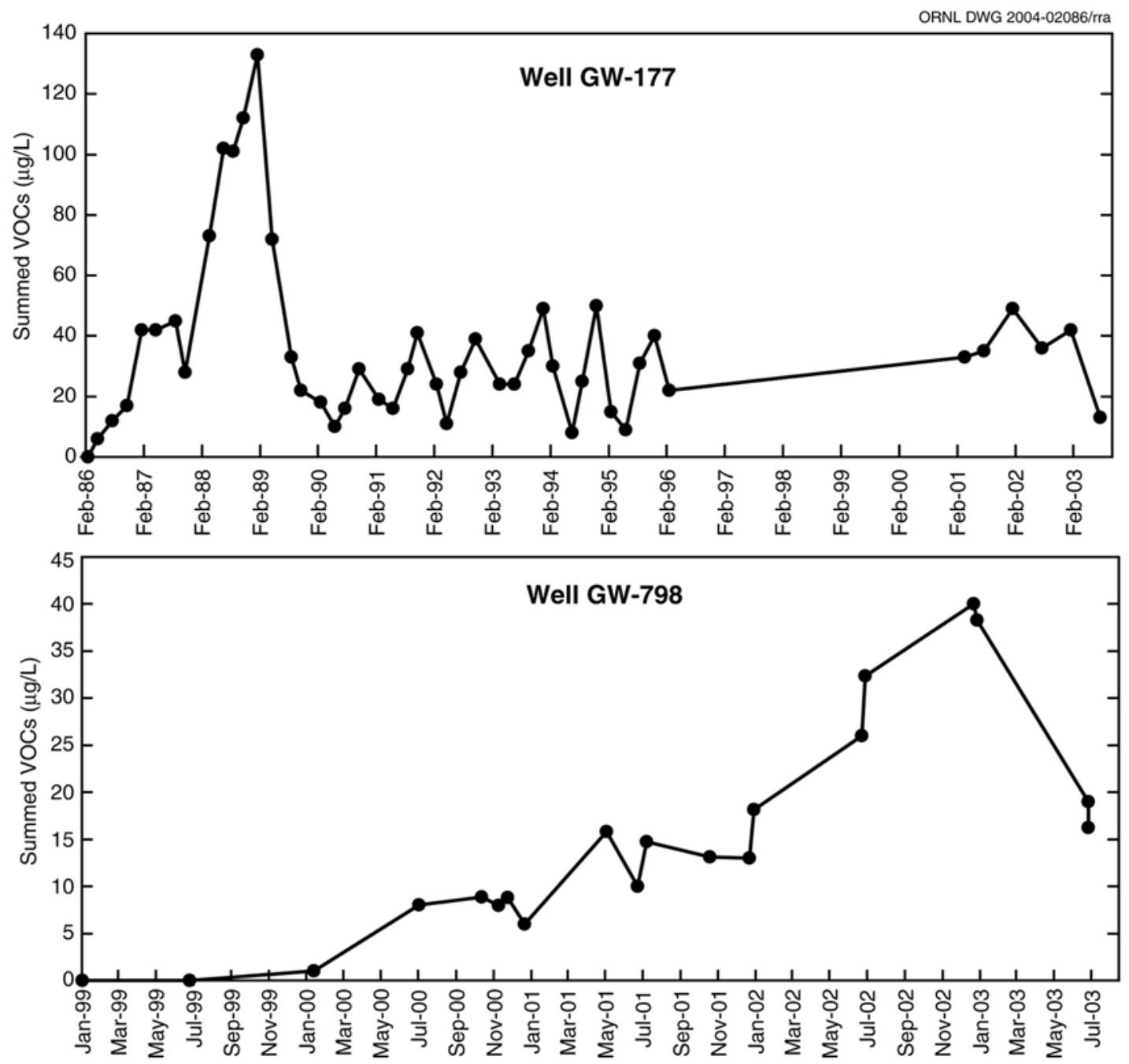

Fig. 6.33. Summed volatile organic compound concentrations in wells GW-177 and GW-798.

all monitoring stations but two. Monitoring wells GW-145, at the Kerr Hollow Quarry, and GW203, at the United Nuclear Corporation site, were sampled twice during the year. One of the samples from each well exceeded the standard. Gross beta activities were below the screening level of 50 $\mathrm{pCi} / \mathrm{L}$ at all monitoring stations except at monitoring well GW-205, at the United Nuclear Corporation site. This location has consistently exceeded $50 \mathrm{pCi} / \mathrm{L}$ gross beta activity since August 1999 with the exception of the sample from January 30, 2002 (47.23 pCi/L). Isotopic analyses show a correlative increase in the beta-emitting radionuclide ${ }^{40} \mathrm{~K}$, which is not a known contaminant of concern at the United Nuclear site. The source of the radioisotope is not known.

\section{Exit Pathway and Perimeter Monitoring}

Contaminant and groundwater flow paths in the karst bedrock underlying the Chestnut Ridge regime have not been well characterized by conventional monitoring techniques. Tracer studies have been used in the past to attempt to identify exit pathways. Based on the results of tracer studies to date, no springs or surface streams that represent discharge points for groundwater have been conclusively correlated to a waste management unit that is a known or potential groundwater contaminant source.

Monitoring of natural groundwater exit pathways is a basic monitoring strategy in a karst regime such as that of Chestnut Ridge. Perimeter springs and surface water tributaries were monitored to determine whether contaminants are exiting the downgradient southern side of the 


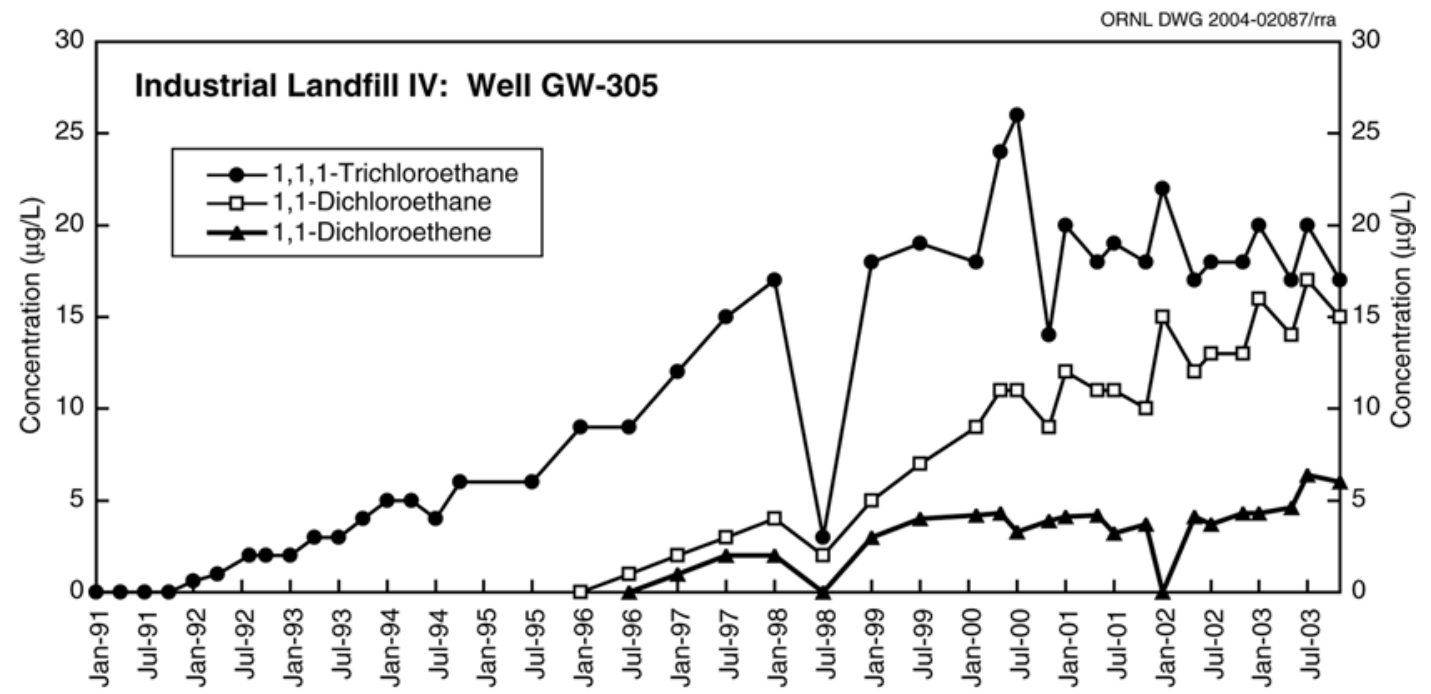

Note: MCLs: 1,1,1-Trichloroethane = $200 \mu \mathrm{g} / \mathrm{L} ; 1,1$-Dichloroethene $=7 \mu \mathrm{g} / \mathrm{L} ; 1$,1-Dichloroethane = not applicable

Fig. 6.34. Volatile organic compound concentrations in Industrial Landfill IV Well GW-305.

regime. Five springs and five surface water monitoring locations were sampled during CY 2003. No contaminants were detected at these natural discharge points.

\subsection{MODERNIZATION ACTIVITIES AT THE Y-12 NATIONAL SECURITY COMPLEX}

The National Nuclear Security Administration (NNSA) is embarking on a significant facility and infrastructure modernization program at the $\mathrm{Y}-12$ Complex. BWXT Y-12, LLC, pursuant to NNSA direction, will manage numerous construction projects as a part of this modernization program. The objectives of the program are to

- consolidate operations to reduce footprint and maintenance cost,

- reuse and upgrade facilities and site infrastructure systems to be used in the future,

- replace facilities when it is the most effective alternative (new construction), and

- disposition surplus facilities and materials (infrastructure reduction).

Overall implementation of the modernization program is consistent with the site-wide environmental impact statement for the Y-12 National Security Complex and its associated record of decision. Key considerations of the modernization strategy include maintaining compliance with regulatory requirements and coordinating NNSA's modernization activities with CERCLA requirements. The construction of new NNSA facilities is scheduled to begin prior to completion of remediation of the soils and groundwater of the Upper East Fork Poplar Creek characterization areas (see Sect. 3.4.3).

\subsubsection{New Construction}

New construction projects and initiatives in the design/planning stages include the following.

- Special Materials Capability Program projects.

- Purification Facility. The project is for the design and construction of a facility for the purification of a special material to provide historical production capacity. The original purification process was last operated about 1990. The evolution of health and safety requirements and considerations makes reuse of the original facility not viable. Construction started in August 2003 and is scheduled for completion in 2004.

- Beryllium Operational Efficiency. The project is in the planning/design stage to retrofit and upgrade to conform to the safety standards of an existing facility.

- Other Special Materials Facilities. Additional projects related to special 
materials are in the early conceptual stage.

- Highly Enriched Uranium Material Facility. The project will design and construct a facility for the storage of highly enriched uranium, including highly enriched uranium under International Atomic Energy Agency control. Design of the facility is complete; excavation and grading are anticipated to start in May 2004.

- Support Facilities. Support Facilities projects will be designed and constructed to include office space, record storage, a fire station, change houses, and other support facilities. Construction of a $7000-\mathrm{ft}^{2}$ change house was completed October 2003.

- Utilities Upgrade Projects. Several utility projects are being planned. An existing facility is being proposed for reuse under the Compressed Air Project, and construction is anticipated to begin in November 2004. Other utility system projects will include a steam plant life extension, potable water system upgrades, electrical distribution system upgrades and improvements, and upgrades to other utility distribution systems.

- Alternate Financed Development. NNSA intends to transfer two parcels of land at Y12, one near the current Administration building and the other on the east end of Scarboro Road, to a private developer who will finance, design, and build modern office and laboratory facilities for long-term lease by NNSA to support Y-12 missions. This is an innovative approach to facility modernization and should enhance productivity, employee health and safety, and the ability to attract and retain new employees. The transfer will require an environmental assessment resulting in a "finding of no significant impact" and approval from the state of Tennessee and EPA Region 4 for a CERCLA covenant deferral request.

\subsubsection{Infrastructure Reduction}

The Facility and Infrastructure Recapitalization Program is an NNSA initiative to revitalize the physical infrastructure, including demolishing deteriorated structures across the nuclear weapons complex. By removing excess buildings and equipment, the Y-12 Infrastructure Reduction campaign is helping clear the way for more modern and efficient structures. Infrastructure reduction contributes to the longterm viability of the Y-12 National Security Complex through more effective use of new and existing facilities and the elimination of excess facilities and their attendant costs. The initial goal of the infrastructure reduction program of reducing the Y-12 footprint by $500,000 \mathrm{ft}^{2}$ was achieved at the end of FY 2002. An additional $140,000 \mathrm{ft}^{2}$ was demolished in FY 2003, and $108,000 \mathrm{ft}^{2}$ is scheduled for demolition in FY 2004. 



\section{ORR Environmental Monitoring Programs}

In addition to environmental monitoring conducted at the three major Oak Ridge DOE installations, reservation-wide surveillance monitoring is performed to measure radiological parameters directly in environmental media adjacent to the facilities. Data from the ORR surveillance programs are analyzed to assess the environmental impact of DOE operations on the entire reservation and the surrounding area. Dose assessment information based on data from ORR surveillance programs is given in Chapter 8.

\subsection{METEOROLOGICAL MONITORING}

Nine meteorological towers provide data on meteorological conditions and on the transport and diffusion qualities of the atmosphere on the ORR. Data collected at the towers are used in routine dispersion modeling to predict impacts from facility operations and as input to emergency-response atmospheric models, which would be used in the event of accidental releases from a facility. Data from the towers are also used to support various research and engineering projects. Meteorological data, quality assurance notes, wind field graphics, and additional weather imagery are archived on site.

\subsubsection{Description}

The nine meteorological towers depicted in Fig. 7.1 include one 100-m (330-ft) tower (MT5) and one 60-m (200-ft) tower (MT6) at the Y-12 Complex, one 100-m (330-ft) tower (MT2) and two 30-m (100-ft) towers (MT3 and MT4) at ORNL, and one 60-m (200-ft) tower (MT1) and one $30-\mathrm{m}(100-\mathrm{ft})$ tower (MT7) at the ETTP. Additionally, ETTP has two satellite towers, M (208A) and N (208B), both $10 \mathrm{~m} \mathrm{(} 30 \mathrm{ft}$ ) high.

Meteorological data are collected at different altitudes (10,30, 60, and $100 \mathrm{~m}$ above ground) to assess the vertical structure of the atmosphere, particularly with respect to wind shear and stability. Stable boundary layers and significant wind shear zones (related to local ridge-and-valley terrain as well as the Great Valley) can significantly affect the movement of a plume after a facility release (Bowen et al. 2000). All of the towers collect data at the 10-m level. Additionally, selected towers collect data at the 30-, 60-, and 100-m levels. At each measurement level, temperature, wind speed, and wind direction are measured. Data needed to determine atmospheric stability (a measure of vertical mixing properties of the atmosphere) are measured at most towers. Barometric pressure is measured at one or more towers at each facility (MT1, MT2, MT5, and MT7). Precipitation is measured at MT5 and MT6 at the Y-12 Complex, at MT1 and MT7 at the ETTP, and at MT2 at ORNL; solar radiation is measured at MT5 and MT6 at the Y-12 Complex, MT1 and MT7 at the ETTP, and MT2 at ORNL.

Data from the towers at each site are collected by a dedicated control computer (DASMET). The towers are polled, and data are archived on both hard disk and compact disk. Values collected at 1min, 15-min, and hourly intervals are stored at two locations (ETTP for Y-12, ORNL for ORNL and ETTP). Long-term archives are kept of 1-min data at ORNL and ETTP and for all sites for 15-min and hourly data. The meteorological monitoring data from the ORR are summarized monthly for wind roses and daily as data tables. Quarterly calibrations of the instruments are managed by ORNL and Y-12 while the actual instrument tests are conducted for each site on the ORR by an outside contractor.

Fifteen-minute and hourly data are used directly at each site for emergency-response purposes, such as for input to dispersion models. Annual dose estimates are calculated from archived data (hourly values). Data quality is checked continuously against predetermined data constraints, and out-of-range parameters are marked invalid and are excluded from compliance modeling. Records of data problems/errors are routinely kept for all nine tower sites. 


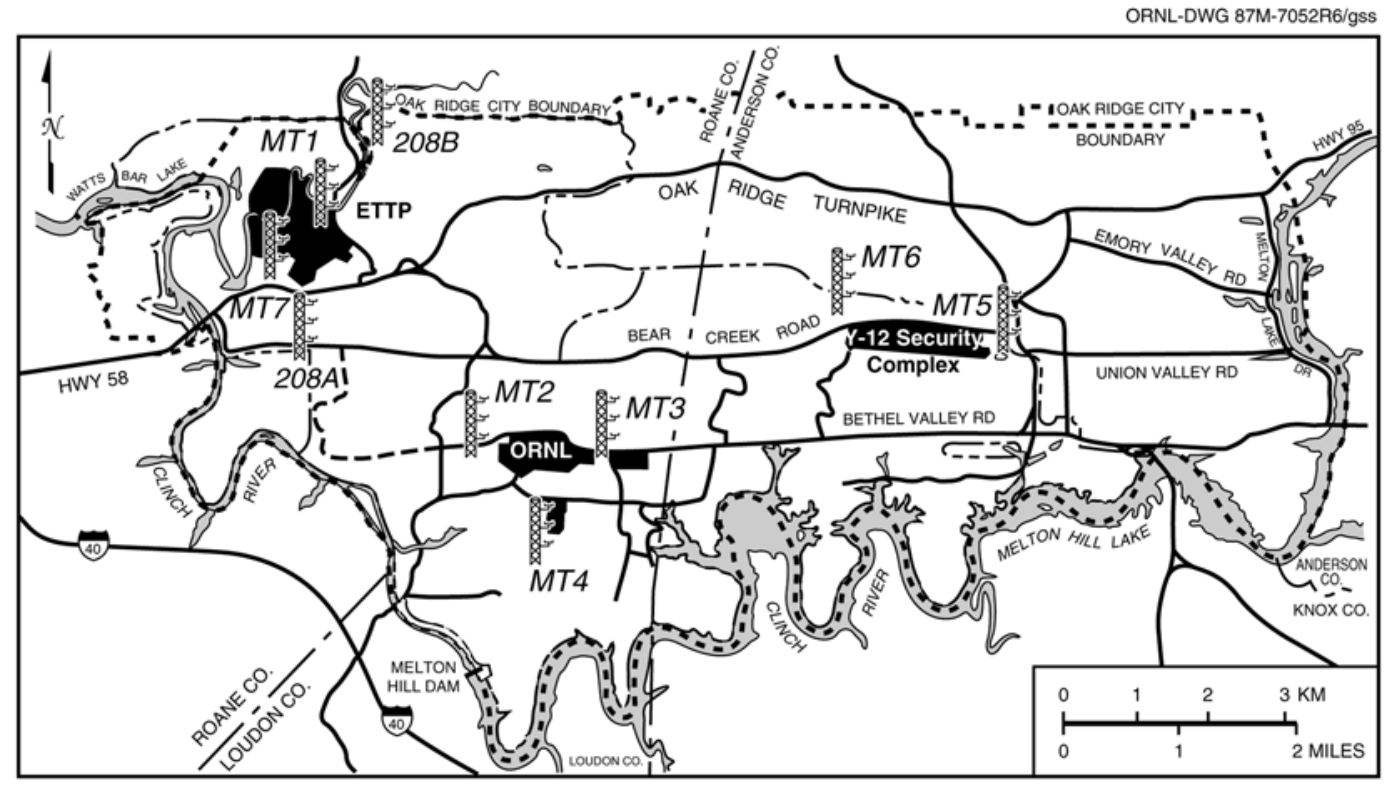

Fig. 7.1. The ORR meteorological monitoring network.

\subsubsection{Meteorological Impacts on Modeling Results}

Prevailing winds are generally up-valley from the southwest and west-southwest or down-valley from the northeast and east-northeast. This pattern is the result of the channeling effect of the ridges flanking the site. Winds in the valleys tend to follow the ridge axes, with limited cross-ridge flow within local valley bottoms. These conditions are dominant over most of the reservation, with the exception of the ETTP, which is located in a relatively open valley bottom and thus has more varied flow.

On the reservation, low-speed winds dominate near the surface level. This characteristic is typical of most near-surface measurements but is amplified by the nearby ridges. Winds sometimes accelerate near ridge top level (Birdwell 2003).

The atmosphere over the reservation is dominated by stable conditions on most nights and in early morning hours. These conditions, coupled with the low wind speeds and channeling effects of the valleys, result in poor dilution of material emitted from the facilities. However, high roughness values (caused by terrain and obstructions such as trees and buildings) are likely to mitigate these factors through the increased turbulence (mixing) that results. Such features are captured in the data input to the dispersion models and are reflected in the modeling studies conducted for each facility.

Precipitation data from tower MT2 are used in stream-flow modeling and in certain research efforts. The data indicate the variability of regional precipitation: the high winter rainfall amounts resulting from frontal systems and the uneven, but occasionally intense, summer rainfall associated with thunderstorms. 2003 was an extraordinarily wet year (70.14 in. at MT2 and 70.58 in. at MT1).

The average data recovery rate (a measure of acceptable data) across locations used for modeling during 2003 was $99.4 \%$ for ORNL sites (Towers MT2, MT3, MT4), and $97.4 \%$ for ETTP sites (Towers MT1, MT7).

\subsection{EXTERNAL GAMMA RADIATION MONITORING}

External gamma radiation monitoring is conducted to determine whether radioactive effluents from the ORR are increasing external radiation levels significantly above normal background levels. The data also provide a means for comparing results from year to year and establishing trends. 


\subsubsection{Data Collection and Analysis}

External gamma measurements (exposure rates) are recorded weekly at six ambient air stations from resident external gross gamma monitors (Fig. 7.2). Each consists of a dual-range, high-pressure ion chamber sensor and digital electronic count-rate meter and totalizer. Totalizing consists of multiplying the count rate by the time of exposure to obtain total exposure.

\subsubsection{Results}

Table 7.1 summarizes the data collected at each station during the year. Exposure rates from background sources in Tennessee range from 2.9 to $11 \mu \mathrm{R} / \mathrm{h}$ while the mean observed exposure rate for the reservation network for 2003 was $5.3 \mu \mathrm{R} / \mathrm{h}$ and the average at the reference location was 4.5 $\mu \mathrm{R} / \mathrm{h}$. The measured ORR exposure rate was within the range normal background levels in Tennessee, indicating that activities on the ORR do not increase external gamma levels in the area above normal background levels.

\subsection{AMBIENT AIR MONITORING}

In addition to exhaust stack monitoring conducted at the DOE Oak Ridge installations, ambient air monitoring is performed to measure radiological parameters directly in the ambient air adjacent to the facilities. Ambient air monitoring also provides a means to verify that contributions of fugitive and diffuse sources are insignificant, serves as a check on dose-modeling calculations, and would allow determination of contaminant levels at monitoring locations in the event of an emergency.

The following sections discuss the ambient air monitoring networks for the ORR. Other air monitoring programs are discussed in the site-specific chapters.

\subsubsection{ORR Ambient Air Monitoring}

The objectives of the ORR ambient air monitoring program are to perform surveillance of airborne radionuclides at the reservation perimeter and to collect reference data from a remote location not affected by activities on the ORR. The ORR perimeter air monitoring network includes stations 35, 37, 38, 39, 40, 42, 46, and 48 (Fig. 7.3). Reference samples are collected from Station 52 (Fort Loudoun Dam). Sampling was conducted at each ORR station during 2003 to quantify levels of alpha-, beta-, and gammaemitting radionuclides and ${ }^{3} \mathrm{H}$.

Atmospheric dispersion modeling was used to select appropriate sampler locations. The locations selected are those likely to be affected most by releases from the Oak Ridge facilities. Therefore, in the event of a release, no residence or business in the vicinity of the ORR should receive a radiation dose greater than doses calculated at the sampled locations. An additional station located at Fort Loudoun Dam, a site not affected by releases from the ORR, provides an estimate of background radionuclide concentrations.

The sampling system consists of two separate instruments. Particulates are captured on glassfiber filters in a high-volume air sampler. The filters are collected weekly, composited quarterly, then submitted to the laboratory for isotopic analysis. The second system is designed to collect tritiated water vapor. The sampler consists of a prefilter followed by an adsorbent trap consisting of indicating silica gel. The samples are collected weekly or biweekly, composited quarterly, then submitted to the laboratory for ${ }^{3} \mathrm{H}$ analysis.

The ORR ambient air network (Fig. 7.3) provides appropriate monitoring for all facilities within the reservation and thus eliminates the necessity for site-specific ambient air programs. As part of the ORR network, an ambient-air monitoring station located in the Scarboro community of Oak Ridge (Station 46) measures off-site impacts of the Y-12 Complex operation. Station 40 monitors the east end of the Y-12 Complex, and Station 37 monitors the overlap of Y-12 Complex, ORNL, and ETTP emissions. 


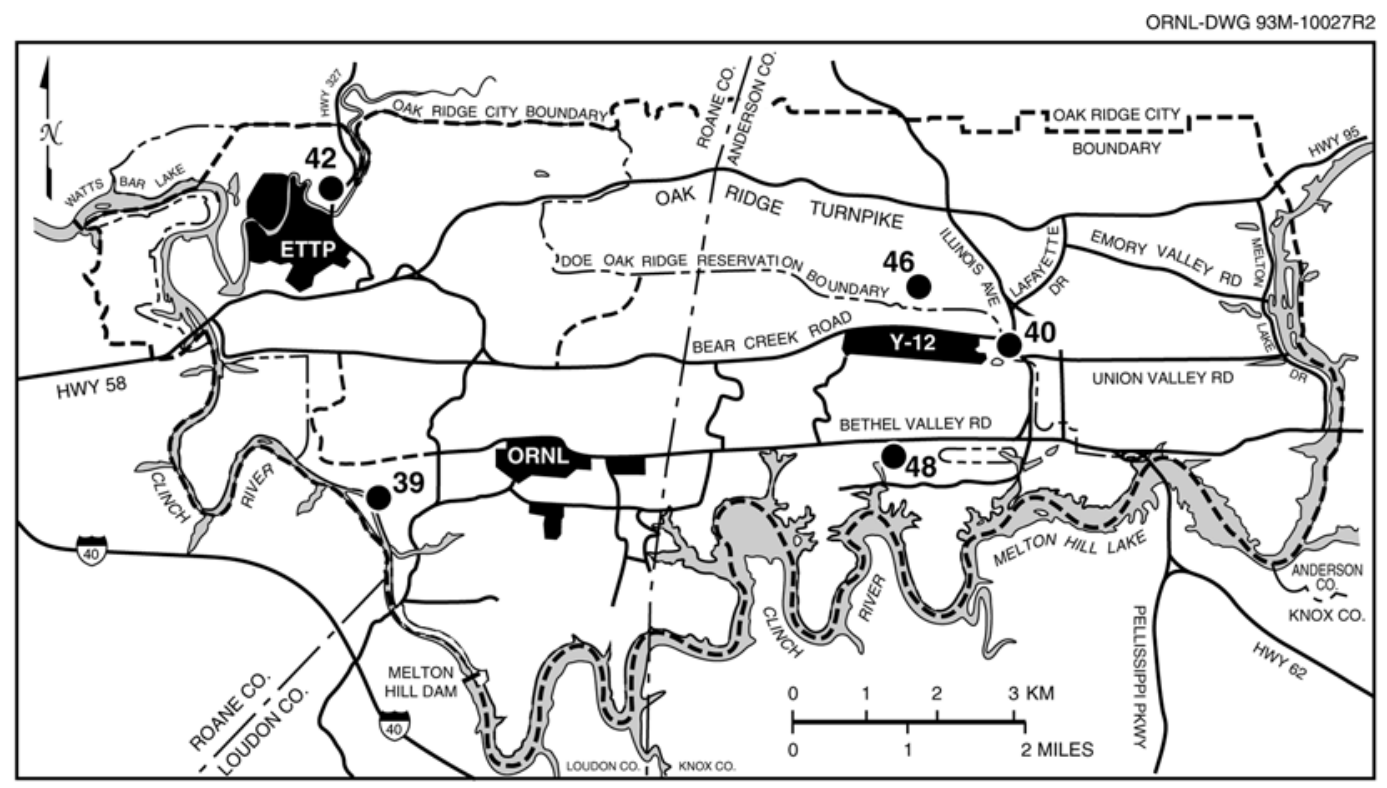

Fig. 7.2 External gamma radiation monitoring locations on the ORR.

Table 7.1. External gamma averages for the Oak Ridge Reservation, 2003

\begin{tabular}{cccccc}
\hline \multirow{2}{*}{$\begin{array}{c}\text { Monitoring } \\
\text { location }\end{array}$} & $\begin{array}{c}\text { Number of } \\
\text { data values } \\
\text { collected }\end{array}$ & \multicolumn{3}{c}{ Measurement $(\mu \mathrm{R} / \mathrm{h})^{a}$} & \multirow{2}{*}{$\begin{array}{c}\text { Standard error } \\
\text { of mean }\end{array}$} \\
\cline { 3 - 5 } 39 & 50 & 6.0 & 7.3 & 6.2 & 0.00003 \\
40 & 52 & 4.9 & 5.8 & 5.4 & 0.00002 \\
42 & 51 & 4.2 & 5.0 & 4.6 & 0.00003 \\
46 & 50 & 4.1 & 6.3 & 5.8 & 0.00006 \\
48 & 52 & 4.2 & 4.8 & 4.5 & 0.00002 \\
52 & 50 & 4.4 & 5.8 & 4.5 & 0.00003 \\
\hline
\end{tabular}

${ }^{a}$ To convert microroentgens per hour $(\mu \mathrm{R} / \mathrm{h})$ to milliroentgens per year, multiply by 8.760 .

Atmospheric dispersion modeling was used to select appropriate sampler locations. The locations selected are those likely to be affected most by releases from the Oak Ridge facilities. Therefore, in the event of a release, no residence or business in the vicinity of the ORR should receive a radiation dose greater than doses calculated at the sampled locations. To provide an estimate of background radionuclide concentrations, an additional station is located at Fort Loudoun Dam, a site not affected by releases from the ORR.

The sampling system consists of two separate instruments. Particulates are captured on glassfiber filters in a high-volume air sampler. The filters are collected weekly, composited quarterly, then submitted to the laboratory for isotopic analysis. The second system is designed to collect tritiated water vapor. The sampler consists of a prefilter followed by an adsorbent trap consisting of indicating silica gel. The samples are collected weekly or biweekly, composited quarterly, then submitted to the laboratory for ${ }^{3} \mathrm{H}$ analysis.

The ORR ambient air network (Fig. 7.3) provides appropriate monitoring for all facilities within the reservation and thus eliminates the necessity for site-specific ambient air programs. As part of the ORR network, an ambient-air monitoring station located in the Scarboro community of Oak Ridge (Station 46) measures off-site impacts of the Y-12 Complex operation. Station 40 monitors the east end of the Y-12 Complex, and Station 37 monitors the overlap of Y-12 Complex, ORNL, and ETTP emissions. 


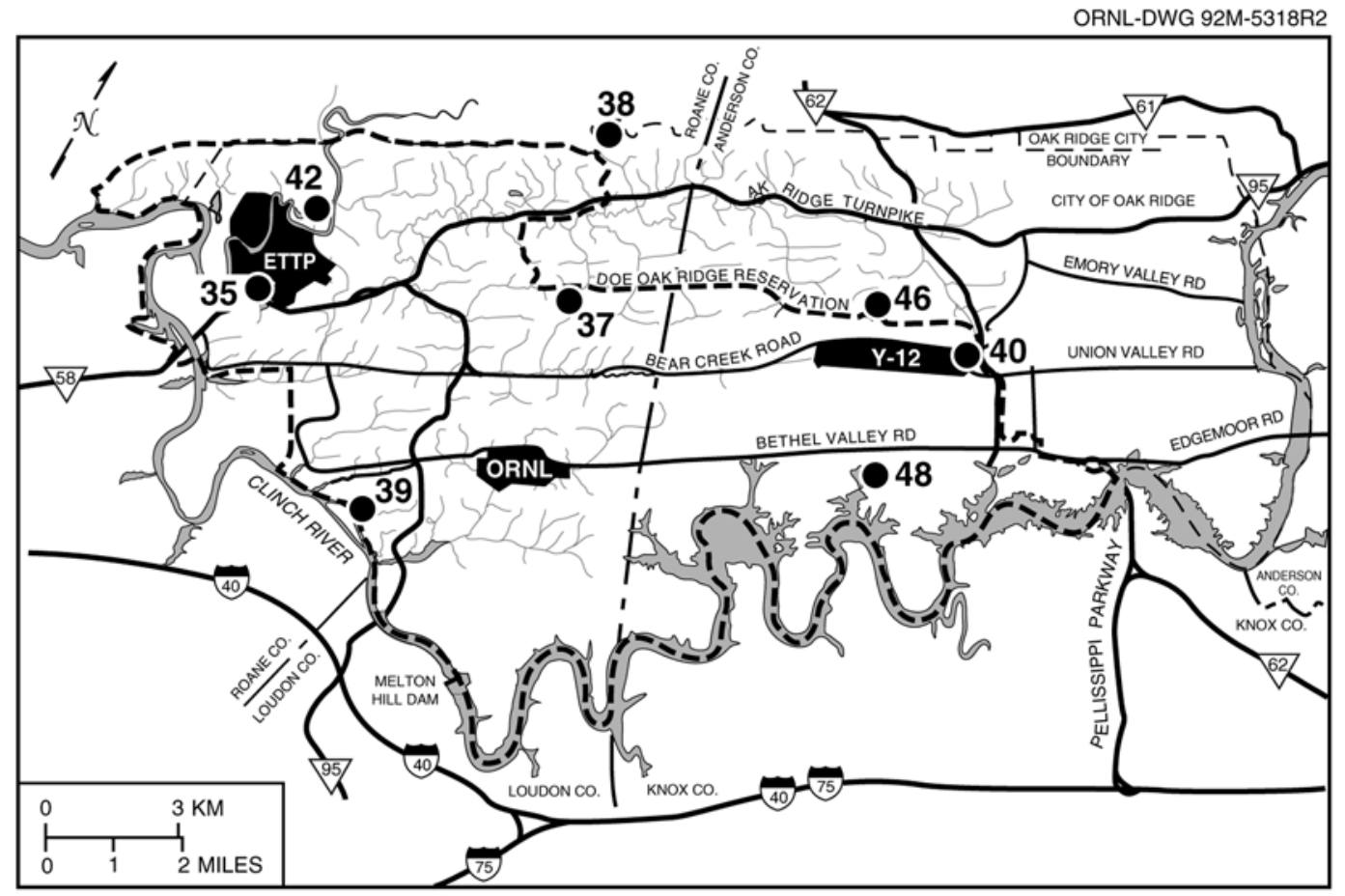

Fig. 7.3. Locations of ORR perimeter air monitoring stations.

\subsubsection{Results}

Data from the ORR ambient air stations are analyzed to assess the impact to air quality of DOE operations on the entire reservation. Each measured radionuclide concentration is compared with appropriate DOE derived concentration guides (DCGs), which serve as references for conducting environmental protection programs at DOE sites. All radionuclide concentrations measured at the ORR ambient air stations were less than $1 \%$ of applicable DCGs. Statistical significance testing is also performed to compare average radionuclide concentrations measured at ORR ambient air stations with concentrations measured at the reference location. This test reflects the mathematical probability of certain outcomes, but is not an indication of environmental significance. There were no calculated statistical differences in average concentrations of gross parameters, ${ }^{3} \mathrm{H},{ }^{7} \mathrm{Be}$, or ${ }^{40} \mathrm{~K}$. The concentrations of ${ }^{234} \mathrm{U},{ }^{235} \mathrm{U}$, and ${ }^{238} \mathrm{U}$ at the ORR ambient air stations were slightly higher than those observed at the background location at the $95 \%$ confidence level. A summary of radionuclide concentrations measured at the ambient air stations is presented in Table 7.2.
Table 7.3 represents the average concentration of three isotopes of uranium at each station for sampling years 2000, 2001, 2002, and 2003.

\subsection{SURFACE WATER MONITORING}

\subsubsection{ORR Surface Water Monitoring}

The ORR surface water monitoring program includes sample collection and analysis from three locations on the Clinch River. This program is conducted in conjunction with the ORNL surface water monitoring activities discussed in Chapter 5 to enable an assessment of the impacts of past and current DOE operations on the quality of local surface water. These programs are conducted in addition to the surface water monitoring required by NPDES permits for individual DOE ORR facilities; sampling location, frequency, and analytical parameters vary among them. Sampling locations include streams downstream of ORR waste sources, reference points on streams and reservoirs upstream of waste sources, and public water intakes (see Fig. 7.4 and Table 7.4).

Sampling frequency and parameters vary by site. Grab samples are collected and are analyzed for 


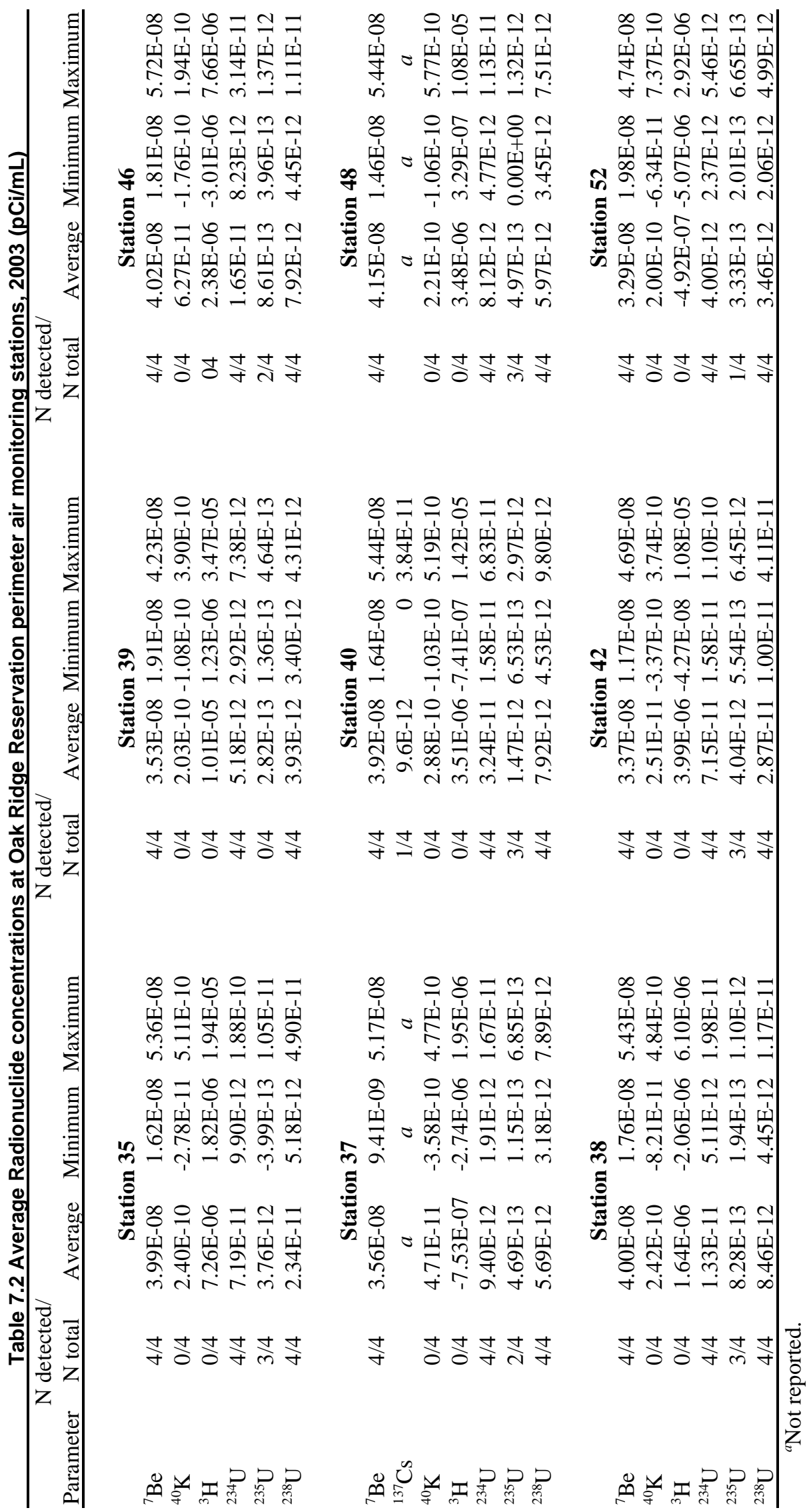


Table 7.3. Uranium concentrations in ambient air on the Oak Ridge Reservation

\begin{tabular}{|c|c|c|c|c|}
\hline \multirow{2}{*}{ Isotope } & \multicolumn{4}{|c|}{ Concentration $\left(10^{-15} \mu \mathrm{Ci} / \mathrm{mL}\right)$} \\
\hline & 2000 & 2001 & 2002 & 2003 \\
\hline \multicolumn{5}{|c|}{ Station 35} \\
\hline${ }^{234} \mathrm{U}$ & $9.8 \mathrm{E}-03$ & $2.1 \mathrm{E}-02$ & $2.0 \mathrm{E}-02$ & $6.9 \mathrm{E}-02$ \\
\hline${ }^{235} \mathrm{U}$ & $6.8 \mathrm{E}-04$ & $7.6 \mathrm{E}-04$ & $1.6 \mathrm{E}-03$ & $3.6 \mathrm{E}-03$ \\
\hline${ }^{238} \mathrm{U}$ & $1.1 \mathrm{E}-02$ & $3.0 \mathrm{E}-02$ & $2.1 \mathrm{E}-02$ & $2.3 \mathrm{E}-02$ \\
\hline \multicolumn{5}{|c|}{ Station 37} \\
\hline${ }^{234} \mathrm{U}$ & $8.5 \mathrm{E}-03$ & $1.2 \mathrm{E}-02$ & $9.3 \mathrm{E}-03$ & $9.1 \mathrm{E}-03$ \\
\hline${ }^{235} \mathrm{U}$ & $4.4 \mathrm{E}-04$ & $1.0-03$ & $1.1 \mathrm{E}-03$ & $4.6 \mathrm{E}-04$ \\
\hline${ }^{238} \mathrm{U}$ & $1.1 \mathrm{E}-02$ & $1.4 \mathrm{E}-02$ & $8.3 \mathrm{E}-03$ & $5.6 \mathrm{E}-03$ \\
\hline \multicolumn{5}{|c|}{ Station 38} \\
\hline${ }^{234} \mathrm{U}$ & $7.9 \mathrm{E}-03$ & $1.7 \mathrm{E}-02$ & $1.4 \mathrm{E}-02$ & $1.3 \mathrm{E}-02$ \\
\hline${ }^{235} \mathrm{U}$ & $1.1 \mathrm{E}-03$ & 7.9E-04 & $1.8 \mathrm{E}-03$ & $8.1 \mathrm{E}-04$ \\
\hline${ }^{238} \mathrm{U}$ & $9.5 \mathrm{E}-03$ & $2.7 \mathrm{E}-02$ & $1.1 \mathrm{E}-02$ & 8.3E-03 \\
\hline \multicolumn{5}{|c|}{ Station 39} \\
\hline${ }^{234} \mathrm{U}$ & $7.6 \mathrm{E}-03$ & $8.1 \mathrm{E}-03$ & $7.1 \mathrm{E}-03$ & $5.1 \mathrm{E}-03$ \\
\hline${ }^{235} \mathrm{U}$ & $5.7 \mathrm{E}-04$ & $1.5 \mathrm{E}-03$ & $3.3 \mathrm{E}-04$ & $2.8 \mathrm{E}-04$ \\
\hline${ }^{238} \mathrm{U}$ & $8.5 \mathrm{E}-03$ & 7.7E-03 & $7.1 \mathrm{E}-03$ & $3.9 \mathrm{E}-03$ \\
\hline \multicolumn{5}{|c|}{ Station 40} \\
\hline${ }^{234} \mathrm{U}$ & $2.8 \mathrm{E}-02$ & $5.0 \mathrm{E}-02$ & $2.6 \mathrm{E}-02$ & $3.1 \mathrm{E}-02$ \\
\hline${ }^{235} \mathrm{U}$ & $1.8 \mathrm{E}-03$ & $2.1 \mathrm{E}-03$ & $1.5 \mathrm{E}-03$ & $1.4 \mathrm{E}-03$ \\
\hline${ }^{238} \mathrm{U}$ & $1.2 \mathrm{E}-02$ & $1.65 \mathrm{E}-02$ & $1.30 \mathrm{E}-02$ & 7.8E-03 \\
\hline \multicolumn{5}{|c|}{ Station 42} \\
\hline${ }^{234} \mathrm{U}$ & $1.6 \mathrm{E}-02$ & $2.4 \mathrm{E}-02$ & $2.4 \mathrm{E}-02$ & $7.0 \mathrm{E}-02$ \\
\hline${ }^{235} \mathrm{U}$ & $1.3 \mathrm{E}-03$ & $1.1 \mathrm{E}-03$ & $2.5 \mathrm{E}-03$ & $3.9 \mathrm{E}-03$ \\
\hline${ }^{238} \mathrm{U}$ & $1.3 \mathrm{E}-02$ & $3.5 \mathrm{E}-02$ & $2.4 \mathrm{E}-02$ & $2.8 \mathrm{E}-02$ \\
\hline \multicolumn{5}{|c|}{ Station 46} \\
\hline${ }^{234} \mathrm{U}$ & $2.4 \mathrm{E}-02$ & $2.7 \mathrm{E}-02$ & $2.3 \mathrm{E}-02$ & $1.6 \mathrm{E}-02$ \\
\hline${ }^{235} \mathrm{U}$ & $1.9 \mathrm{E}-03$ & $1.2 \mathrm{E}-03$ & $1.2 \mathrm{E}-03$ & 8.4E-04 \\
\hline${ }^{238} \mathrm{U}$ & $1.4 \mathrm{E}-02$ & $1.9 \mathrm{E}-02$ & $1.4 \mathrm{E}-02$ & 7.8E-03 \\
\hline \multicolumn{5}{|c|}{ Station 48} \\
\hline${ }^{234} \mathrm{U}$ & $1.2 \mathrm{E}-02$ & $1.1 \mathrm{E}-02$ & $9.3 \mathrm{E}-03$ & 8.0E-03 \\
\hline${ }^{235} \mathrm{U}$ & $7.9 \mathrm{E}-04$ & $5.3 \mathrm{E}-04$ & $6.8 \mathrm{E}-04$ & 4.9E-04 \\
\hline${ }^{238} \mathrm{U}$ & $1.2 \mathrm{E}-02$ & $1.1 \mathrm{E}-02$ & $8.2 \mathrm{E}-03$ & $5.9 \mathrm{E}-03$ \\
\hline \multicolumn{5}{|c|}{ Station 52} \\
\hline${ }^{234} \mathrm{U}$ & $6.2 \mathrm{E}-03$ & $8.2 \mathrm{E}-03$ & $1.2 \mathrm{E}-02$ & $3.9 \mathrm{E}-03$ \\
\hline${ }^{235} \mathrm{U}$ & $7.8 \mathrm{E}-04$ & $5.7 \mathrm{E}-04$ & $9.3 \mathrm{E}-04$ & $3.2 \mathrm{E}-04$ \\
\hline${ }^{238} \mathrm{U}$ & $9.2 \mathrm{E}-03$ & $7.0 \mathrm{E}-03$ & $8.2 \mathrm{E}-03$ & $3.4 \mathrm{E}-03$ \\
\hline
\end{tabular}

general water quality parameters at all locations, and all are screened for radioactivity and are analyzed for specific radionuclides when appropriate. Two of the sites are also checked for volatile organic compounds and one is checked for PCBs. All three sites are analyzed for metals. Table 7.4 lists the specific locations and their sampling frequencies and parameters.

These sampling locations are classified by the state of Tennessee for recreation and domestic use. Tennessee water quality criteria associated with these classifications are used as references where they are applicable. The Tennessee water quality criteria do not include criteria for radionuclides.

\subsubsection{Results}

Comparisons of surface water sample results from locations upstream of DOE inputs with surface water results from samples obtained downstream of DOE inputs show that there were no statistically significant differences in any of the parameters of interest.

None of the locations had radionuclides detected above $4 \%$ of the respective DCG. No 


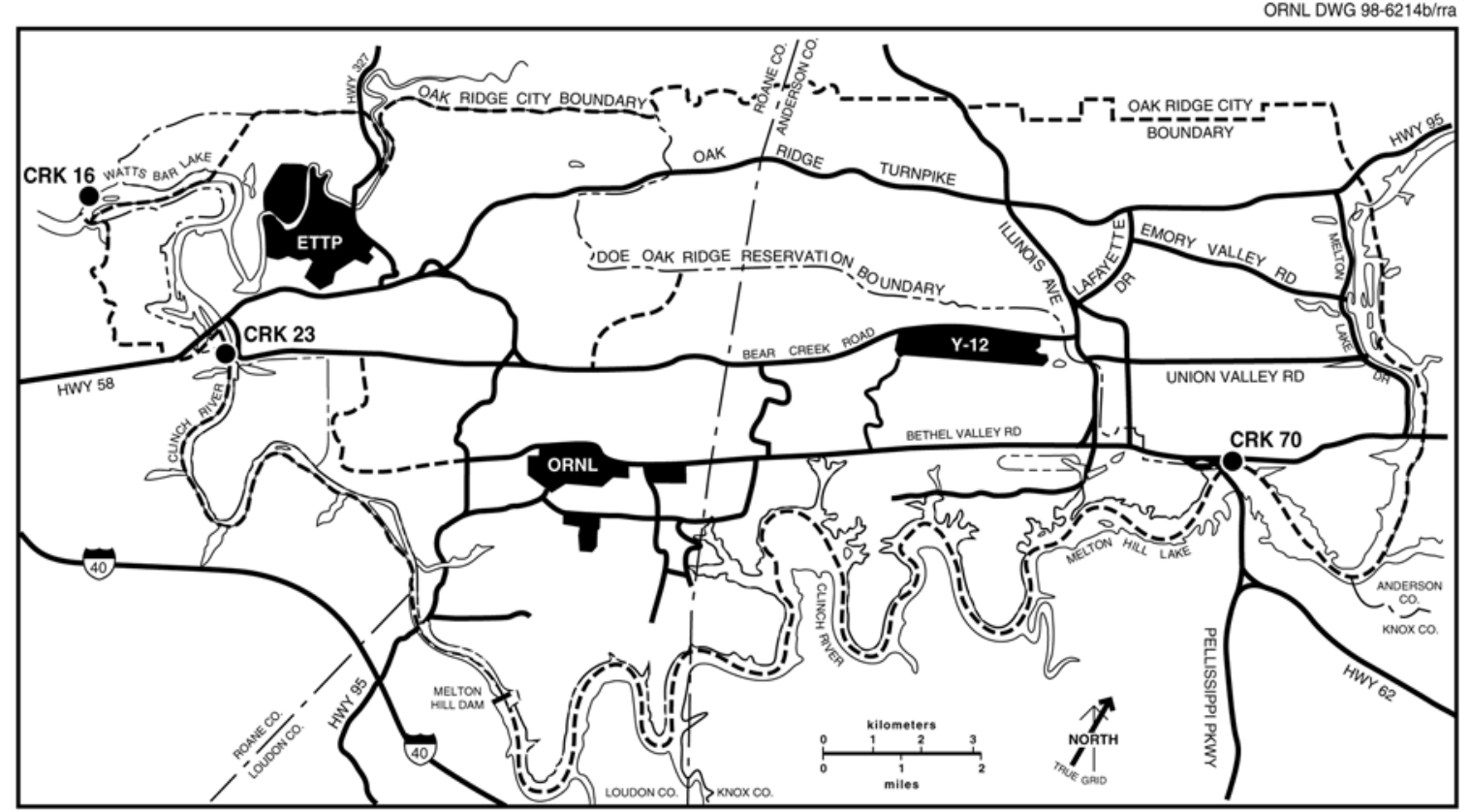

Fig. 7.4. Locations of ORR surface water surveillance sampling stations.

Table 7.4. Oak Ridge Reservation surface water sampling locations, frequencies, and parameters, 2003

\begin{tabular}{|c|c|c|c|}
\hline Location $^{a}$ & Description & Frequency & Parameters \\
\hline CRK 16 & $\begin{array}{l}\text { Clinch River downstream from } \\
\text { all DOE ORR inputs }\end{array}$ & Monthly & $\begin{array}{l}\text { Volatiles, metals, gross alpha, gross beta, } \\
\text { gamma scan, field measurements }{ }^{b}\end{array}$ \\
\hline CRK 23 & $\begin{array}{l}\text { Water supply intake for the } \\
\text { ETTP }\end{array}$ & Monthly & $\begin{array}{l}\text { Gross alpha, gross beta, total radioactive } \\
\text { strontium, gamma scan, }{ }^{3} \mathrm{H} \text {, field } \\
\text { measurements }{ }^{b}\end{array}$ \\
\hline CRK 70 & Solway Bridge & Monthly & $\begin{array}{l}\text { Volatiles, metals, gross alpha, gross beta, total } \\
\text { radioactive strontium, gamma scan, }{ }^{3} \mathrm{H} \text {, field } \\
\text { measurements }{ }^{b}\end{array}$ \\
\hline
\end{tabular}

${ }^{a}$ Locations identify bodies of water and locations on them (e.g., CRK $16=16 \mathrm{~km}$ upstream from the confluence of the Clinch and the Tennessee Rivers).

${ }^{b}$ Field measurements consist of dissolved oxygen, $\mathrm{pH}$, and temperature.

volatile organic compounds, other than acetone, which is a common laboratory contaminant, were detected in 2003.

\subsection{FOOD}

Collection and analysis of vegetation samples serve three purposes: to evaluate potential radiation doses received by people consuming foodcrops; to predict possible concentrations in meat, eggs, and milk from animals consuming hay; and to monitor trends in environmental contamination and possible long-term accumulation of radionuclides.

\subsubsection{HAY}

Hay from five areas on the ORR and one area immediately adjacent to the reservation is sampled annually. In previous years, hay from these six areas (Fig. 7.5) has been sold for silage, and each has the potential for deposition of airborne materials from ORR sources. Areas 1,2, and 3 are within the predicted air plume for an ORNL source and could be affected by ETTP sources. Areas 4, 5, and 6 are within the predicted air plumes for ETTP, ORNL, and Y-12 sources. Individual samples are collected from all six sites; a composite sample from areas 1, 2, and 3 and a composite sample from Areas 2, 4, and 5 are 


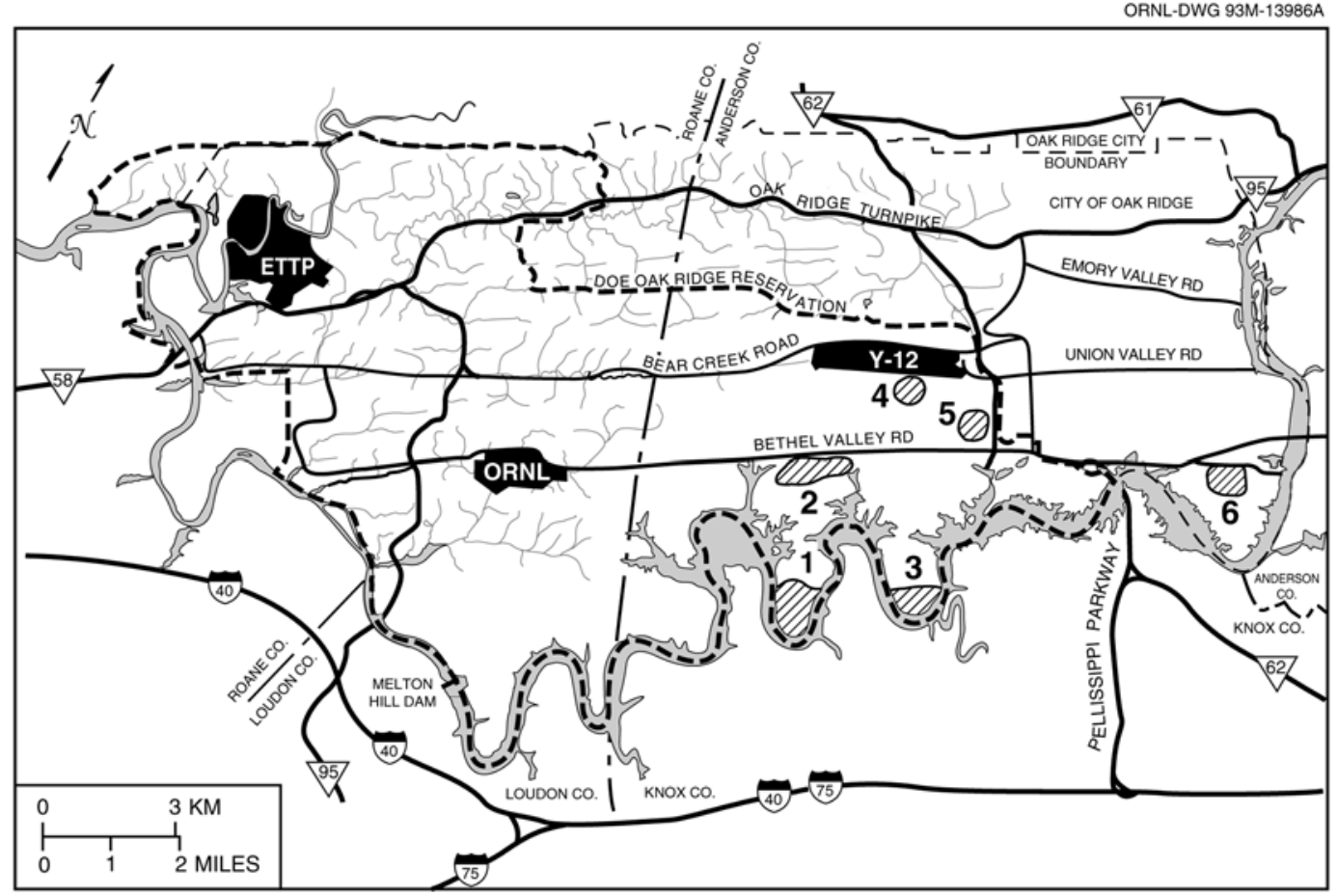

Fig. 7.5. Hay sampling locations on the ORR, indicated by numbered areas.

Table 7.5. Concentrations of radionuclides detected in hay, $2003(\mathrm{pCi} / \mathrm{kg})^{a, b}$

\begin{tabular}{|c|c|c|c|c|c|}
\hline $\begin{array}{l}\text { Gross } \\
\text { alpha }\end{array}$ & $\begin{array}{l}\text { Gross } \\
\text { beta }\end{array}$ & ${ }^{7} \mathrm{Be}$ & ${ }^{40} \mathrm{~K}$ & ${ }^{233 / 234} \mathrm{U}$ & ${ }^{238} \mathrm{U}$ \\
\hline \multicolumn{6}{|c|}{ Area 1-2-3 composite } \\
\hline 0.000092 & 0.0023 & 0.0032 & 0.0051 & $c$ & $c$ \\
\hline \multicolumn{6}{|c|}{ Area $2-4-5$ composite } \\
\hline 0.00010 & 0.0015 & 0.0052 & $\mathrm{c}$ & 0.0000088 & $c$ \\
\hline \multicolumn{6}{|c|}{ Area 6} \\
\hline 0.00014 & 0.0015 & 0.0037 & 0.0031 & 0.000020 & 0.000016 \\
\hline \multicolumn{6}{|c|}{ Area 7 - Norris reference location } \\
\hline 0.00013 & 0.0023 & 0.0057 & $c$ & 0.000012 & $c$ \\
\hline
\end{tabular}

${ }^{a}$ Detected radionuclides are detected above the minimum detectable activity.

${ }^{b} 1 \mathrm{pCi}=3.7 \mathrm{E}-02 \mathrm{~Bq}$.

${ }^{c}$ Value was not detected above the minimum detectable activity.

submitted for laboratory analyses. In addition, a sample from area 6 is submitted separately because it best represents the combined plumes from all three sites. A reference sample is collected from a site near Norris Dam (Area 7, not shown on Fig. 7.5), which is outside the influence of ORR sources.

\subsubsection{Results}

Hay samples were collected during July 2003, and samples were analyzed for gross alpha, gross beta, gamma emitters, and uranium isotopes. None of the locations had gamma-emitting radionuclides that were detected above minimum detectable activity, with the exception of naturally occurring radionuclides ${ }^{7} \mathrm{Be}$ and ${ }^{40} \mathrm{~K}$. Concentrations of radionuclides detected above minimum detectable activity in hay are shown in Table 7.5. 


\subsubsection{Vegetables}

Tomatoes, lettuce, and turnips were purchased from local farmers near the ORR. The locations were chosen based on availability and on their likelihood of being affected by routine releases from the Oak Ridge facilities.

\subsubsection{Results}

Samples were analyzed for gross alpha, gross beta, gamma emitters, and uranium isotopes. None of the vegetables had gamma-emitting radionuclides that were detected above minimum detectable activity, with the exception of the naturally occurring radionuclide ${ }^{40} \mathrm{~K}$. Concentrations of radionuclides detected above minimum detectable activity are shown in Table 7.6.

\subsubsection{Milk}

Ingestion is one of the pathways of exposure to radioactivity for humans. Radionuclides can be transferred from the environment to people via food chains such as the grass-cow-milk pathway. Milk is a potentially significant source to humans of some radionuclides deposited from airborne emissions because of the relatively large surface area that a cow can graze daily, the rapid transfer of milk from producer to consumer, and the importance of milk in the diet.

The 2003 milk-sampling program consisted of grab samples collected every other month from three locations (Fig. 7.6). One is a commercial dairy in Powell that processes milk from various locations in east Tennessee; the second dairy is in Claxton, and the third is in Maryville (a reference location). Milk samples are analyzed for gamma emitters and for total radioactive strontium $\left({ }^{89} \mathrm{Sr}+\right.$ ${ }^{90} \mathrm{Sr}$ ) by chemical separation and low-background beta counting. Liquid scintillation is used to analyze for ${ }^{3} \mathrm{H}$.

\subsubsection{Results}

Concentrations of radionuclides detected above minimum detectable activity in milk are presented in Table 7.7. Total radioactive strontium $\left({ }^{89} \mathrm{Sr}+{ }^{90} \mathrm{Sr}\right)$ was detected once each at Claxton and Maryville.

\subsection{FISH}

Members of the public could potentially be exposed to contaminants originating from DOEORO activities through consumption of fish caught in area waters. This exposure pathway is monitored by collecting fish from three locations on the Clinch River annually and analyzing edible fish flesh. The locations are as follows (see Fig. 7.7):

- Clinch River upstream from all DOE ORR inputs (CRK 70),

- Clinch River downstream from ORNL (CRK 32), and

- Clinch River downstream from all DOE ORR inputs (CRK 16).

Sunfish (Lepomis macrochirus, L. auritus, and Ambloplites rupestris) and catfish (Ictalurus punctatus) are collected from each of the three locations, filleted, and frozen. In 2003, two composite samples of each species at each location were analyzed for selected metals, pesticides, PCBs, and ${ }^{3} \mathrm{H}$, and two samples of each species at each location were analyzed for gross alpha, gross beta, and gamma-emitting radionuclides and for total radioactive strontium.

\subsubsection{Results}

TDEC has adopted the EPA method for establishing fish consumption advisories for carcinogenic contaminants found in fish collected in waters designated for recreation and domestic water supply. There is a "do not consume" fish advisory (applicable to typical fishermen consumers) for catfish in Melton Hill Reservoir in its entirety because of PCB contamination, and a precautionary fish advisory for catfish in the Clinch River arm of Watts Bar Reservoir because of PCB contamination (TDEC 1993). This advisory is applicable to atypical consumers, those persons who, because of physiological factors or previous exposures, are more sensitive to specific pollutants; this may include pregnant or nursing women, children, and subsistence fishermen.

In 2003, mercury and radionuclides were detected in both species of fish at all locations. The 2003 results also show PCB-1260 detected in the sunfish composite samples at all three 
Table 7.6. Concentrations of radionuclides detected in vegetables, $2003(\mathrm{pCi} / \mathrm{kg})^{a, b}$

\begin{tabular}{|c|c|c|c|c|c|c|}
\hline Location & $\begin{array}{l}\text { Gross } \\
\text { alpha }\end{array}$ & $\begin{array}{c}\text { Gross } \\
\text { beta }\end{array}$ & ${ }^{40} \mathrm{~K}$ & ${ }^{234} \mathrm{U}$ & ${ }^{235} \mathrm{U}$ & ${ }^{238} \mathrm{U}$ \\
\hline \multicolumn{7}{|c|}{ Lettuce } \\
\hline East of $Y-12, \# 1$ & 0.000023 & 0.0026 & 0.0057 & 0.0000074 & $c$ & $c$ \\
\hline East of Y-12, Claxton & 0.000036 & 0.0035 & 0.0063 & $c$ & $c$ & $c$ \\
\hline Northeast of Y-12, Scarboro \#1 & $c$ & 0.0016 & 0.0031 & $c$ & $c$ & 0.0000033 \\
\hline Northeast of Y-12, Scarboro \#2 & 0.000032 & 0.0032 & 0.0051 & 0.00001 & $c$ & 0.0000054 \\
\hline Southeast of ORNL & 0.00002 & 0.0023 & 0.0038 & $c$ & $c$ & $c$ \\
\hline West of ETTP & $c$ & 0.0022 & 0.0044 & 0.0000044 & & $c$ \\
\hline \multicolumn{7}{|c|}{ Tomato } \\
\hline East of $Y-12, \# 1$ & $c$ & 0.0022 & 0.0017 & $c$ & $c$ & $c$ \\
\hline East of Y-12, Claxton & $c$ & 0.0019 & 0.0019 & 0.0000039 & $c$ & $c$ \\
\hline Northeast of Y-12, Scarboro \#1 & $c$ & 0.0019 & $c$ & 0.0000031 & $c$ & $c$ \\
\hline Northeast of Y-12, Scarboro \#2 & $c$ & 0.0019 & 0.0016 & $c$ & 0.000002 & $c$ \\
\hline Southeast of ORNL & $c$ & 0.0017 & 0.0017 & $c$ & $c$ & $c$ \\
\hline West of ETTP & $c$ & 0.0021 & 0.0018 & $c$ & $c$ & $c$ \\
\hline \multicolumn{7}{|c|}{ Turnip } \\
\hline East of $\mathrm{Y}-12, \# 1$ & 0.00002 & 0.002 & 0.0031 & $c$ & $c$ & $c$ \\
\hline East of Y-12, Claxton & 0.000063 & 0.0038 & 0.0051 & $c$ & $c$ & $c$ \\
\hline Northeast of Y-12, Scarboro \#1 & 0.00002 & 0.0017 & 0.0023 & $c$ & $c$ & $c$ \\
\hline Northeast of Y-12, Scarboro \#2 & $c$ & 0.0021 & 0.0027 & $c$ & $c$ & $c$ \\
\hline Southeast of ORNL & 0.000031 & 0.0026 & 0.004 & $c$ & $c$ & $c$ \\
\hline West of ETTP & 0.000024 & 0.0023 & 0.0031 & $c$ & $c$ & $c$ \\
\hline
\end{tabular}

${ }^{a}$ Detected radionuclides are detected above the minimum detectable activity.

${ }^{b} 1 \mathrm{pCi}=3.7 \mathrm{E}-02 \mathrm{~Bq}$.

${ }^{\mathrm{c}}$ Value was not detected above the minimum detectable activity.

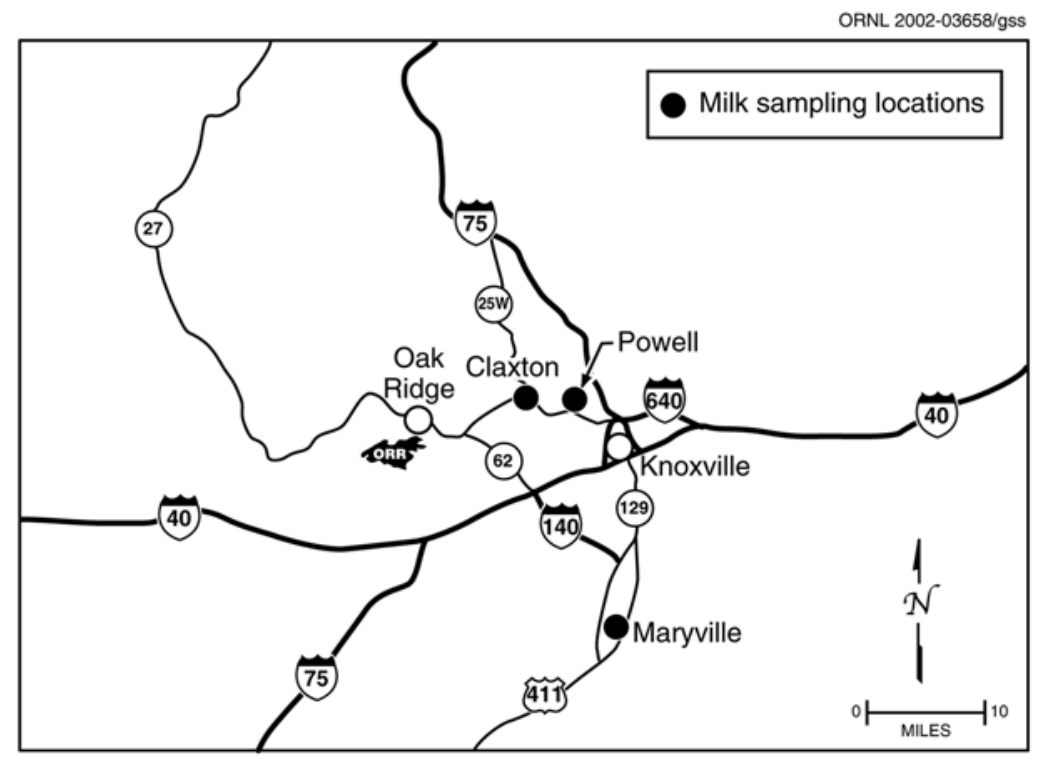

Fig. 7.6. Milk sampling locations in the vicinity of the ORR. 
Table 7.7. Concentration of radionuclides detected in raw milk, 2003

\begin{tabular}{|c|c|c|c|c|c|}
\hline \multirow{2}{*}{ Analysis } & \multirow{2}{*}{$\begin{array}{l}\text { No. detected/ } \\
\text { no. total }\end{array}$} & \multicolumn{3}{|c|}{ Detected concentration $(\mathrm{pCi} / \mathrm{L})^{a, b}$} & \multirow{2}{*}{$\begin{array}{c}\text { Standard } \\
\text { error } \\
\text { of mean }\end{array}$} \\
\hline & & Max & Min & Avg & \\
\hline \multicolumn{6}{|c|}{ Claxton } \\
\hline Potassium-40 & $6 / 6$ & $1,100^{*}$ & $1,600 *$ & $1,300 *$ & 85 \\
\hline Total rad Sr & $1 / 6$ & -0.31 & $1.2^{*}$ & $\sim 0.37$ & 0.2 \\
\hline \multicolumn{6}{|c|}{ Maryville } \\
\hline Potassium-40 & $6 / 6$ & $1,200 *$ & $1,500 *$ & $1,300 *$ & 40 \\
\hline Total rad Sr & $1 / 6$ & $0.44^{*}$ & $1.2^{*}$ & $0.8^{*}$ & 0.12 \\
\hline \multicolumn{6}{|c|}{ Powell } \\
\hline Potassium-40 & $6 / 6$ & $1,100 *$ & $1,500 *$ & $1,300^{*}$ & 55 \\
\hline
\end{tabular}

${ }^{a} 1 \mathrm{pCi}=3.7 \times 10^{-2} \mathrm{~Bq}$. Detected radionuclides are those detected above minimum detectable activity.

${ }^{b}$ Individual and average concentrations significantly greater than zero at the $95 \%$ confidence level are identified by an asterisk (*).

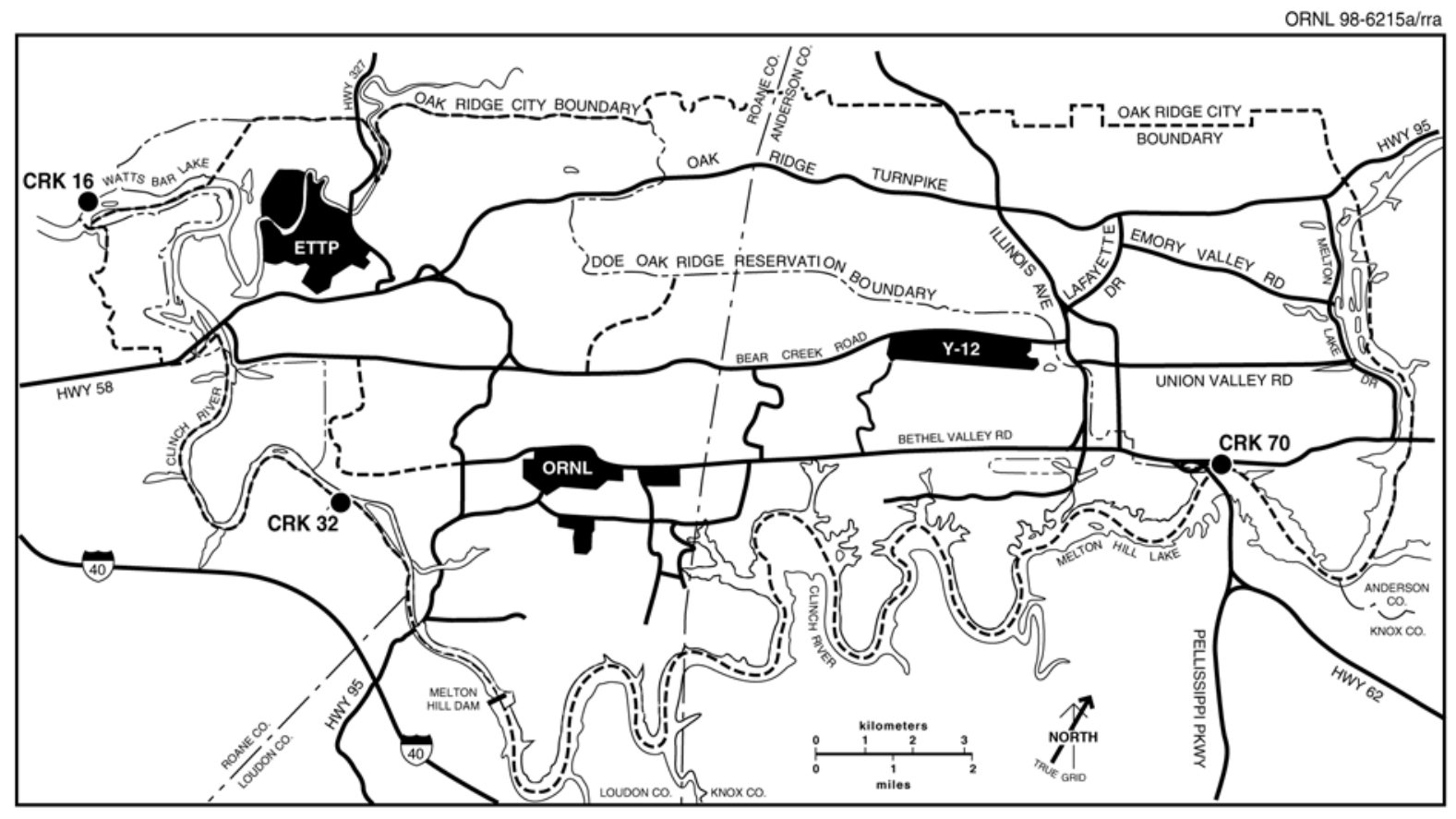

Fig. 7.7. Fish sampling locations for the ORR.

locations. PCB-1260 and PCB-1254 were detected in the catfish composite samples at all three locations; gamma-Chlordane, a pesticide, was also detected in the catfish composite samples collected at all three locations. Endosulfan sulfate and Heptachlor expoxide, also pesticides, were detected in one catfish composite sample at CRK 16.

\subsection{WHITE-TAILED DEER}

The eighteenth annual deer hunts managed by DOE and TWRA were held on the ORR during the final quarter of 2003. ORNL staff, TWRA personnel, and student members of the Wildlife Society (University of Tennessee Chapter) performed most of the necessary operations at the checking station. 
The 2003 hunts were held on three weekends. Shotgun/muzzleloader and archery hunts were held October 18-19, November 8-9, and December 6-7. About 550 shotgun/muzzleloaderpermitted hunters and 450 archery-permitted hunters participated in each hunt. The Tower Shielding area, Park City Road area, Chestnut Ridge area, and Poplar Creek Road area were opened for an archery-only hunt on all three weekends. There was a one-deer limit for the October hunt and a two-deer limit for the November and December hunts. In addition, only one antlered buck could be harvested. It had to have four or more one-inch antler points on one side of the rack or an outside antler spread of 15 inches or larger.

The year's total harvest was 256 deer. From the total harvest of 256 animals, $89(34.8 \%)$ were bucks and $167(65.2 \%)$ were does. The heaviest buck had seven antler points and weighed $161 \mathrm{lb}$ $(73.0 \mathrm{~kg})$. The greatest number of antler points (12) was found on one buck. The heaviest doe weighed $114 \mathrm{lb}(51.7 \mathrm{~kg})$.

Since 1985, 8519 deer have been harvested. Of these only 170 (2.0\%) have been retained due to potential radiological contamination. The heaviest buck was $218 \mathrm{lb}(98.9 \mathrm{~kg}$ ) (harvested in 1998), and the average weight is $85.5 \mathrm{lb}(38.8$ $\mathrm{kg}$ ). The oldest deer harvested was 12 years old; the average age is 1.9 years. For more information, see the ORNL wildlife webpage: http://www.ornl.gov/sci/rmal/huntinfo.htm.

\subsubsection{Results}

In the 2003 hunts, 256 deer were harvested. Of the deer harvested, two $(0.8 \%)$ were retained for exceeding the administrative release limits (1.5 times the background for beta activity in bone $(\sim 20 \mathrm{pCi} / \mathrm{g})$ or $5 \mathrm{pCi} / \mathrm{g}(0.19 \mathrm{~Bq} / \mathrm{g})$ of ${ }^{137} \mathrm{Cs}$ in edible tissue). The two retained deer exceeded the limit for beta-particle activity in bone. The average weight was $76.9 \mathrm{lb}(34.9 \mathrm{~kg})$ and the maximum weight of the released deer was $161 \mathrm{lb}$ $(73.0 \mathrm{~kg})$. The average ${ }^{137} \mathrm{Cs}$ concentration in the released deer was $0.7 \mathrm{pCi} / \mathrm{g}(0.026 \mathrm{~Bq} / \mathrm{g})$, and the maximum ${ }^{137} \mathrm{Cs}$ concentration in the released deer was $1.9 \mathrm{pCi} / \mathrm{g}(0.07 \mathrm{~Bq} / \mathrm{g})$.

It is assumed that $55 \%$ of the field weight is edible meat; therefore, the average deer would yield $51.5 \mathrm{lb}(23.4 \mathrm{~kg})$ of meat. Based on the average weight, the total harvest of edible meat ( 254 released deer) is estimated to be 13,081 lb (5946 kg).

\subsection{FOWL}

No new species were observed on the ORR in 2003 , and the 28 species that were observed are the fewest recorded in the last nine years. Species of interest observed on the ORR in 2003 include horned grebe (Podiceps auritus), snow goose (Chen caerulescens), American wigeon (Anas americana), northern shoveler (Anas clypeata), spotted sandpiper (Actitis macularia), and Bonaparte's gull (Larus philadelphia). A total of 151 Canada geese (Branta canadensis) were fitted with legbands. Of these, 100 were also fitted with nick collars. Six Canada geese from the $13+$ year age class were observed on the ORR in 2003, including one female known to be at least 15 years old. One of the five resident mute swans (Cygnus olor) at the ORNL Swan Pond died in December. Cause of death was determined to be sepsis resulting from a long-standing traumatic ventral lesion.

\subsubsection{Waterfowl Surveys - Canada Geese}

The consumption of Canada geese is a potential pathway for exposure of members of the public to radionuclides released from Oak Ridge operations because open hunts for Canada geese are held in counties adjacent to the ORR each year. To determine concentrations of gammaemitting radionuclides accumulated by waterfowl that feed and live on the ORR, Canada geese are rounded up each summer and are subjected to noninvasive gross radiological surveys. At a minimum, three geese, selected from the different round-up locations, are sacrificed to conduct further radiological analysis. The 2003 ORR roundup was conducted on June 24 and 25.

From the roundup, 95 geese were subjected to live whole-body gamma scans. These geese were collected from ETTP (25), ORNL (29), Clark Center (20), and Oak Ridge Marina (21). None of the 95 geese exceeded the administrative release limits. 


\subsubsection{Results}

The average ${ }^{137} \mathrm{Cs}$ concentration in the released geese was $0.24 \mathrm{pCi} / \mathrm{g}(0.009 \mathrm{~Bq} / \mathrm{g})$. The maximum ${ }^{137} \mathrm{Cs}$ concentration in the released geese was $0.97 \mathrm{pCi} / \mathrm{g}(0.036 \mathrm{~Bq} / \mathrm{g})$. Four adult geese were sacrificed for radiological analyses. The average weight of the geese screened during the roundup was $8.68 \mathrm{lb}(3.94 \mathrm{~kg})$. The maximum goose weight was $12.59 \mathrm{lb}(5.71 \mathrm{~kg})$. Laboratory analyses on the sacrificed geese demonstrate that the field screening approach is an appropriate method for quantifying radionuclide concentrations.

\subsubsection{Turkey Monitoring}

No wild turkey hunts were held on the ORR in 2003 due to security concerns. 


\section{Dose}

Activities on the Oak Ridge Reservation (ORR) have the potential to release small quantities of radionuclides and hazardous chemicals to the environment. These releases could result in exposures of members of the public to low concentrations of radionuclides or chemicals. Monitoring of materials released from the reservation and environmental monitoring and surveillance on and around the reservation provide data that are used to show that doses from released radionuclides and chemicals are in compliance with the law; the calculated doses are compared with existing state and federal criteria.

A hypothetical maximally exposed individual could have received a total effective dose equivalent (EDE) of about $0.2 \mathrm{mrem}(0.002 \mathrm{mSv})$ from radionuclides emitted to the atmosphere from all of the sources on the ORR in 2003; this is well below the National Emission Standards for Hazardous Air Pollutants standard of 10 mrem for protection of the public.

A worst-case analysis of exposures to waterborne radionuclides for all pathways combined gives a maximum possible individual EDE of about 2 mrem $(0.02 \mathrm{mSv})$, which is a small percentage $(<0.7 \%)$ of the individual dose attributable to natural sources of radiation. This dose is based on a person eating $21 \mathrm{~kg} / \mathrm{year}$ of the most contaminated accessible fish, drinking $730 \mathrm{~L} /$ year of the most contaminated drinking water, and using the shoreline near the most contaminated stretch of water for $67 \mathrm{~h} / \mathrm{year}$.

Calculations to determine possible doses from consumption of deer and geese harvested on or near the ORR resulted in the following: an individual who consumed an average-weight deer containing the average concentration of radionuclides could have received an EDE of about $0.7 \mathrm{mrem}$; an individual who consumed an average-weight goose containing the average concentration of radionuclides could have received 0.02 mrem. There were no turkey hunts on the ORR in 2003. In worst-case analyses, hypothetical persons who eat the heaviest deer and two geese, each containing the maximum concentration of measured radionuclides, could have received an EDE of 4 mrem.

\subsection{RADIATION DOSE}

Small quantities of radionuclides were released to the environment from operations at the ORR facilities during 2003. Those releases are described, characterized, and quantified in previous chapters of this report. This chapter presents estimates of potential radiation doses to the public from the releases. The dose estimates are performed using monitored and estimated release data, environmental monitoring and surveillance data, estimated exposure conditions that tend to maximize the calculated dose equivalents, and environmental transport and dosimetry codes that also tend to overestimate the calculated dose equivalents. Thus, the presented dose estimates do not necessarily reflect doses received by typical people in the vicinity of the ORR; they likely are overestimates.

\subsubsection{Terminology}

Exposures to radiation from nuclides located outside the body are called external exposures; exposures to radiation from nuclides deposited inside the body are called internal exposures. This distinction is important because external exposures occur only when a person is near or in a radionuclide-containing medium, whereas internal exposures continue as long as the radionuclides remain inside the person. Also, external exposures may result in uniform irradiation of the entire body, including all organs, while internal exposures usually result in nonuniform irradiation of the body and organs. When taken into the body, most radionuclides deposit preferentially in specific organs or tissues and thus do not irradiate the body uniformly.

A number of the specialized terms and units used to characterize exposures to ionizing radiation are defined in Appendix F. An important term to understand is "effective dose equivalent" (EDE). EDE is a risk-based dose equivalent that can be used to estimate health effects or risks to exposed persons. It is a weighted sum of dose equivalents to specified organs and is expressed in rem or sieverts $(1 \mathrm{rem}=0.01 \mathrm{~Sv})$.

One rem of effective dose equivalence, regardless of radiation type or method of delivery, has the same total radiological (in this case, also biological) risk effect. Because the doses being 
considered here are very small, EDEs are usually expressed in millirem (mrem), which is $1 / 1000$ of a rem. (See Appendix F, Table F.2, for a comparison and description of various dose levels.)

\subsubsection{Methods of Evaluation}

\subsubsection{Airborne Radionuclides}

The radiological consequences of radionuclides released to the atmosphere from ORR operations during 2003 were characterized by calculating, for each plant and for the entire ORR, EDEs to maximally exposed off-site individuals, to on-site members of the public where no physical access controls are managed by DOE, and to the entire population residing within $80 \mathrm{~km}$ ( 50 miles) of the center of the ORR. The dose calculations were made using the CAP-88 package of computer codes (Beres 1990), which was developed under EPA sponsorship to demonstrate compliance with 40 CFR 61, Subpart H, which governs the emissions of radionuclides other than radon from DOE facilities. This package implements a steadystate Gaussian plume atmospheric dispersion model to calculate concentrations of radionuclides in the air and on the ground and uses Regulatory Guide 1.109 (NRC 1977) food-chain models to calculate radionuclide concentrations in foodstuffs (vegetables, meat, and milk) and subsequent intakes by humans.

A total of 57 emission points on the ORR, each of which includes one or more individual sources, were modeled during 2003. This total includes 12 points at the Y-12 Complex, 34 points at ORNL, and 11 points at ETTP. Table 8.1 is a list of the emission point parameter values and receptor locations used in the dose calculations.

Meteorological data used in the calculations for 2003 were in the form of joint frequency distributions of wind direction, wind speed class, and atmospheric stability category. (See Table 8.2 for a summary of tower locations used to model the various sources.) During 2003, rainfall, as averaged over the four rain gauges located on the ORR, was $179 \mathrm{~cm}$ (70.5 in.). The average air temperature was $14.1^{\circ} \mathrm{C}\left(57.4^{\circ} \mathrm{F}\right)$, and the average mixing-layer height was $681.6 \mathrm{~m}(2236 \mathrm{ft})$. The mixing height is the depth of the atmosphere adjacent to the surface within which air is mixed.
For occupants of residences, the dose calculations assume that the occupant remained at home (actually, unprotected outside the house) during the entire year and obtained food according to the rural pattern defined in the NESHAP background documents (EPA 1989). This pattern specifies that $70 \%$ of the vegetables and produce, $44.2 \%$ of the meat, and $39.9 \%$ of the milk consumed are produced in the local area (e.g., a home garden). The remaining portion of each food is assumed to be produced within $80 \mathrm{~km} \mathrm{(50}$ miles) of the ORR. The same assumptions are used for occupants of businesses, but the resulting doses are divided by 2 to compensate for the fact that businesses are occupied for less than one-half a year and that less than one-half of a worker's food intake occurs at work. For collective EDE estimates, production of beef, milk, and crops within $80 \mathrm{~km}$ of the ORR was calculated using production rates provided with CAP- 88 .

\section{Results}

Calculated EDEs from radionuclides emitted to the atmosphere from the ORR are listed in Table 8.3 (maximum individual) and Table 8.4 (collective). The hypothetical maximally exposed individual for the ORR was located about $5930 \mathrm{~m}$ (3.7 miles) south of the main Y-12 National Security Complex release point, about $4550 \mathrm{~m}$ (2.8 miles) east-northeast of the 7911 stack at ORNL, and about $11,340 \mathrm{~m}$ (7.0 miles) east of the TSCA Incinerator (stack K-1435) at the ETTP. This individual could have received an EDE of about $0.2 \mathrm{mrem}(0.002 \mathrm{mSv})$, which is well below the NESHAP standard of $10 \mathrm{mrem}(0.10 \mathrm{mSv})$ and is less than $0.1 \%$ of the 300 mrem $(3 \mathrm{mSv})$ that the average individual receives from natural sources of radiation. The calculated collective EDE to the entire population within $80 \mathrm{~km}$ (50 miles) of the ORR (about 1,040,041 persons) was about 11 person-rem $(0.11$ person-Sv), which is approximately $0.004 \%$ of the 312,012 personrem that this population received from natural sources of radiation.

The maximally exposed individual for the Y-12 National Security Complex was located about $2310 \mathrm{~m}$ (1.4 miles) east-northeast of the main Y-12 National Security Complex release 
Table 8.1. Emission-point parameters and receptor locations used in the dose calculations

\begin{tabular}{|c|c|c|c|c|c|c|c|c|}
\hline \multirow[b]{2}{*}{ Source ID } & \multirow{2}{*}{$\begin{array}{l}\text { Stack height } \\
\text { (m) }\end{array}$} & \multirow{2}{*}{$\begin{array}{c}\text { Stack } \\
\text { diameter } \\
(\mathrm{m})\end{array}$} & \multirow{2}{*}{$\begin{array}{c}\text { Effective } \\
\text { exit gas } \\
\text { velocity } \\
(\mathrm{m} / \mathrm{s})\end{array}$} & \multirow{2}{*}{$\begin{array}{l}\text { Exit gas } \\
\text { temperature } \\
\left({ }^{\circ} \mathrm{C}\right)\end{array}$} & \multicolumn{4}{|c|}{$\begin{array}{l}\text { Distance }(\mathrm{m}) \text { and direction to the } \\
\text { maximally exposed individual }\end{array}$} \\
\hline & & & & & Plant $n$ & aximum & ORR & naximum \\
\hline X-1000 Lab Hoods & 15 & 0 & 0 & Ambient & 5950 & ENE & 5950 & ENE \\
\hline$X-2026$ & 22.9 & 1.05 & 11.3 & Ambient & 5650 & $\mathrm{E}$ & 5650 & $\mathrm{E}$ \\
\hline X-2099 & 3.66 & 0.18 & 23.32 & Ambient & 5650 & $\mathrm{E}$ & 5650 & $\mathrm{E}$ \\
\hline$X-2523$ & 7 & 0.3 & 0 & Ambient & 5680 & $\mathrm{E}$ & 5680 & $\mathrm{E}$ \\
\hline X-3000 Lab Hoods & 15 & 0 & 0 & Ambient & 5480 & $\mathrm{E}$ & 5480 & E \\
\hline $\mathrm{X}-3018$ & 61 & 4.11 & 0.23 & Ambient & 5480 & $\mathrm{E}$ & 5480 & $\mathrm{E}$ \\
\hline $\mathrm{X}-3020$ & 61 & 1.22 & 15.38 & Ambient & 5480 & $\mathrm{E}$ & 5480 & $\mathrm{E}$ \\
\hline X-3039 & 76.2 & 2.44 & 13.19 & Ambient & 5410 & $\mathrm{E}$ & 5410 & $\mathrm{E}$ \\
\hline X-3074 Group & 4 & 0.25 & 0 & Ambient & 5480 & $\mathrm{E}$ & 5480 & E \\
\hline$X-3544$ & 9.53 & 0.28 & 15.57 & Ambient & 5420 & $\mathrm{E}$ & 5420 & $\mathrm{E}$ \\
\hline$X-3608-1$ & 10.97 & 2.44 & 0.57 & Ambient & 5300 & $\mathrm{E}$ & 5300 & $\mathrm{E}$ \\
\hline$X-3608-2$ & 8.99 & 0.36 & 13.91 & Ambient & 5300 & $\mathrm{E}$ & 5300 & $\mathrm{E}$ \\
\hline X-4000 Lab Hoods & 15 & 0 & 0 & Ambient & 4980 & $\mathrm{E}$ & 4980 & $\mathrm{E}$ \\
\hline $\mathrm{X}-5505 \mathrm{M}$ & 11 & 0.30 & 2.79 & Ambient & 4710 & $\mathrm{E}$ & 4710 & $\mathrm{E}$ \\
\hline $\mathrm{X}-5505 \mathrm{NS}$ & 11 & 0.96 & 0 & Ambient & 4710 & $\mathrm{E}$ & 4710 & E \\
\hline X-6000 Lab Hoods & 15 & 0 & 0 & Ambient & 4530 & $\mathrm{E}$ & 4530 & $\mathrm{E}$ \\
\hline X-7000 Lab Hoods & 15 & 0 & 0 & Ambient & 3380 & $\mathrm{NE}$ & 3380 & $\mathrm{NE}$ \\
\hline $\mathrm{X}-7025$ & 4 & 0.3 & 13.16 & Ambient & 3520 & $\mathrm{E}$ & 3520 & $\mathrm{E}$ \\
\hline$X-7503$ & 30.5 & 0.91 & 9.36 & Ambient & 4610 & ENE & 4610 & ENE \\
\hline$X-7567$ & 3.8 & 0.20 & 4.65 & Ambient & 4610 & ENE & 4610 & ENE \\
\hline X-OHF T-13 & 1 & 0.305 & 0 & Ambient & 5600 & ENE & 5600 & ENE \\
\hline X-OHF 1944 & 0.38 & 0.2 & 0 & Ambient & 5600 & ENE & 5600 & ENE \\
\hline $\mathrm{X}-7830$ & 4.6 & 0.25 & 8.01 & Ambient & 5600 & ENE & 5600 & ENE \\
\hline X-7831-A & 0.38 & 0.97 & 0 & Ambient & 5600 & ENE & 5600 & ENE \\
\hline X-7856-CIP & 18.29 & 0.48 & 12.24 & Ambient & 5600 & ENE & 5600 & ENE \\
\hline$X-7860$ & 18.29 & 0.31 & 3.9 & Ambient & 5600 & ENE & 5600 & ENE \\
\hline X-7860 NHF D\&D & 0.38 & 0.2 & 0 & Ambient & 5600 & ENE & 5600 & ENE \\
\hline$X-7877$ & 13.9 & 0.41 & 13.56 & Ambient & 5600 & ENE & 5600 & ENE \\
\hline $\mathrm{X}-7911$ & 76.2 & 1.52 & 14.31 & Ambient & 4550 & ENE & 4550 & ENE \\
\hline $\mathrm{X}-7935$ & 14.6 & 0.46 & 14.2 & Ambient & 4550 & ENE & 4550 & ENE \\
\hline$X-7966$ & 6.1 & 0.29 & 8.18 & Ambient & 4550 & ENE & 5600 & ENE \\
\hline X-Decon Areas & 15 & NA & 0 & Ambient & 5410 & $\mathrm{E}$ & 5410 & E \\
\hline X-SIOU & 1 & 0.31 & 0 & Ambient & 5420 & $\mathrm{E}$ & 5420 & $\mathrm{E}$ \\
\hline X-STP & 7.6 & 0.20 & 12.48 & Ambient & 5560 & $\mathrm{E}$ & 5560 & E \\
\hline K-1004-D & 7.3 & 0 & 0 & Ambient & 1330 & W & 11780 & $\mathrm{E}$ \\
\hline K-1006-J & 1 & NA & 0 & Ambient & 370 & $\mathrm{~S}$ & 13090 & $\mathrm{E}$ \\
\hline K-1008-C & 4.52 & 0.51 & 10.46 & Ambient & 1330 & WSW & 11860 & $\mathrm{E}$ \\
\hline K-1407-U & 7.16 & 1.22 & 0.625 & Ambient & 1690 & WSW & 11670 & E \\
\hline K-1423 SWR & 7.62 & 0.71 & 10.02 & Ambient & 1280 & SW & 12200 & $\mathrm{E}$ \\
\hline K-1425 A & 1 & 0.5 & 0 & Ambient & 1920 & WSW & 11350 & E \\
\hline K-1435 & 30.5 & 1.37 & 5.26 & 79.1 & 1020 & SW & 12210 & ENE \\
\hline K-1435-C & 18.29 & 0 & 0 & Ambient & 1020 & SW & 12210 & ENE \\
\hline
\end{tabular}


Table 8.1 (continued)

\begin{tabular}{|c|c|c|c|c|c|c|c|c|}
\hline \multirow{2}{*}{ Source ID } & \multirow{2}{*}{$\begin{array}{l}\text { Stack height } \\
\text { (m) }\end{array}$} & \multirow{2}{*}{$\begin{array}{c}\text { Stack } \\
\text { diameter } \\
(\mathrm{m})\end{array}$} & \multirow{2}{*}{$\begin{array}{c}\text { Effective } \\
\text { exit gas } \\
\text { velocity } \\
(\mathrm{m} / \mathrm{s})\end{array}$} & \multirow{2}{*}{$\begin{array}{c}\text { Exit gas } \\
\text { temperature } \\
\left({ }^{\circ} \mathrm{C}\right)\end{array}$} & \multicolumn{4}{|c|}{$\begin{array}{l}\text { Distance }(\mathrm{m}) \text { and direction to the } \\
\text { maximally exposed individual }\end{array}$} \\
\hline & & & & & Plant & aximum & ORR & naximum \\
\hline K-1435 & 30.5 & 1.37 & 5.26 & 79.1 & 1950 & WSW & 11340 & $\mathrm{E}$ \\
\hline K-1435-C & 18.29 & NA & 0 & Ambient & 1950 & WSW & 11340 & $\mathrm{E}$ \\
\hline K-33 DD & 22.86 & 1.72 & 0 & Ambient & 1020 & $\mathrm{~S}$ & 13250 & E \\
\hline K-33 SC & 11.58 & 1.22 & 14.96 & Ambient & 1020 & $\mathrm{~S}$ & 13250 & E \\
\hline K-25 Guzzler & 3.7 & 0.403 & 36.3 & Ambient & 1690 & WSW & 11670 & $\mathrm{E}$ \\
\hline Y-9204-3 & 20 & NA & 0 & Ambient & 2290 & $\mathrm{NE}$ & 5720 & $\mathrm{~S}$ \\
\hline Y-9224 & 10 & NA & 0 & Ambient & 1330 & $\mathrm{NE}$ & 6440 & $S$ \\
\hline Y-9401-4 & 1 & NA & 0 & Ambient & 3610 & $\mathrm{NE}$ & 5240 & SSE \\
\hline$Y-9422-22$ & 3.96 & 0.153 & 0 & Ambient & 610 & NNW & 6950 & SSW \\
\hline Y-9616-7 Hood & 12.2 & 0.25 & 0.69 & Ambient & 4180 & $\mathrm{NE}$ & 5080 & SSE \\
\hline Y-9616-7 Degas & 12.2 & 0.2 & 4.36 & Ambient & 4180 & $\mathrm{NE}$ & 5080 & SSE \\
\hline Y-9623 & 8.5 & NA & 0.64 & Ambient & 2500 & $\mathrm{NE}$ & 5730 & $S$ \\
\hline Y-Monitored & 20 & NA & 0 & Ambient & 2310 & ENE & 5930 & $\mathrm{~S}$ \\
\hline Y-EMWMF & 1 & 0.305 & 0 & Ambient & 5370 & $\mathrm{NE}$ & 4810 & SSE \\
\hline Y-Union Valley Lab & 4.27 & 0.76 & 13.44 & Ambient & 730 & WSW & 7860 & SSW \\
\hline Y-Unmonitored & 20 & NA & 0 & Ambient & 2310 & ENE & 5930 & $S$ \\
\hline $\begin{array}{l}\text { Y-Unmonitored Lab } \\
\text { Hoods }\end{array}$ & 20 & NA & 0 & Ambient & 2310 & ENE & 5930 & $S$ \\
\hline
\end{tabular}

point. This individual could have received an EDE of about 0.2 mrem $(0.002 \mathrm{mSv})$ from $\mathrm{Y}-12$ National Security Complex emissions. Inhalation and ingestion of uranium radioisotopes (i.e., ${ }^{232} \mathrm{U}$, ${ }^{233} \mathrm{U},{ }^{234} \mathrm{U},{ }^{235} \mathrm{U},{ }^{236} \mathrm{U}$, and ${ }^{238} \mathrm{U}$ ) accounted for essentially all (>99\%) of the dose. The contribution of Y-12 Complex emissions to the 50-year committed collective EDE to the population residing within $80 \mathrm{~km}$ of the ORR was calculated to be about 5.5 person-rem ( 0.055 person-Sv), which is approximately $51 \%$ of the collective EDE for the ORR.

The maximally exposed individual for ORNL was located about $5410 \mathrm{~m}$ (3.4 miles) east of the 3039 stack and $4550 \mathrm{~m}$ (2.8 miles) east-northeast of the 7911 stack. This individual could have received an EDE of about $0.2 \mathrm{mrem}(0.002 \mathrm{mSv})$ from ORNL emissions. Radionuclides contributing $1 \%$ or more to the dose include ${ }^{138} \mathrm{Cs}$ (48\%), ${ }^{41} \mathrm{Ar}(18 \%),{ }^{241} \mathrm{Am}(6.2 \%),{ }^{212} \mathrm{~Pb}(5.6 \%)$, ${ }^{191} \mathrm{Os}(3.2 \%),{ }^{233} \mathrm{U}(2.9 \%),{ }^{234} \mathrm{U}(2.9 \%),{ }^{138} \mathrm{Xe}$ (2\%), ${ }^{88} \mathrm{Kr}(1.5 \%)$, and ${ }^{239} \mathrm{Pu}(1.1 \%)$. The contribution of ORNL emissions to the collective EDE to the population residing within $80 \mathrm{~km}$ of the ORR was calculated to be about 4.6 personrem (0.046 person-Sv), which is approximately $43 \%$ of the collective EDE for the ORR.
The maximally exposed individual for the ETTP was located at a business about $1950 \mathrm{~m}$ (1.2 miles) west-southwest of the TSCA Incinerator stack (K-1435). The EDE received by this individual was calculated to be about $0.03 \mathrm{mrem}(0.0003 \mathrm{mSv})$. About $91 \%$ of this dose is from ingestion and inhalation of uranium radioisotopes, about $7.2 \%$ is from thorium radioisotopes, and about $0.64 \%$ is from ${ }^{3} \mathrm{H}$. The contribution of ETTP emissions to the collective EDE to the population residing within $80 \mathrm{~km}$ of the ORR was calculated to be about 0.7 personrem $(0.007$ person-Sv), which is approximately $7 \%$ of the collective EDE for the reservation. As noted below, based on measured air concentrations of radionuclides at ETTP Station $\mathrm{K}$ 9, the dose to the maximally exposed individual for ETTP is about $0.3 \mathrm{mrem} / \mathrm{year}(0.003$ $\mathrm{mSv} /$ year), which takes into account part-time occupancy of a business location.

The reasonableness of the calculated radiation doses can be inferred by comparison with radiation doses that could be received from measured air concentrations of radionuclides 
Table 8.2. Summary of ORR meteorological towers, sampling heights, and sources

\begin{tabular}{|c|c|c|}
\hline Tower & $\begin{array}{l}\text { Height } \\
\text { (m) }\end{array}$ & Source \\
\hline \multicolumn{3}{|r|}{ Y-12 Complex } \\
\hline MT6 & $60^{a}$ & All sources \\
\hline \multicolumn{3}{|r|}{ ETTP } \\
\hline MT1 & 10 & $\mathrm{~K}-1435 \mathrm{C}$ \\
\hline MT1 & 60 & $\mathrm{~K}-1435$ \\
\hline MT7 & 30 & $\mathrm{~K}-33 \mathrm{SC}$ \\
\hline MT7 & 10 & $\begin{array}{l}\text { K-33 D\&D, K-1004-D, K-1008-C, K-1407-U, K-1423-SWR, K-25 Guzzler, } \\
\text { K-1425A, K-1066-J }\end{array}$ \\
\hline \multicolumn{3}{|r|}{ ORNL } \\
\hline MT4 & 10 & X-7567, X-7830MV, X-7831-A, X-7966 \\
\hline MT4 & 30 & $\begin{array}{l}\text { X-7503, X-7856-CIP, X-7860, X-7860 D\&D, X-7877, X-7911, X-7935, } \\
\text { X-Lab Hoods (7000), X-T-13, X-1944 }\end{array}$ \\
\hline MT3 & 10 & $\mathrm{X}-7025$ \\
\hline MT3 & 30 & X-Lab Hoods (6000) \\
\hline MT2 & 100 & X-3018, X-3020, and X-3039 \\
\hline MT2 & 30 & $\begin{array}{l}\text { X-2026, X-3544, X-5505, X-Decon areas, X-Lab Hoods (1000-5000), and } \\
\text { X-SIOU }\end{array}$ \\
\hline MT2 & 10 & X-2099, X-2523, X-3074, X-3608, and X-STP \\
\hline
\end{tabular}

${ }^{a}$ Wind speeds adjusted to match conditions at a height of $20 \mathrm{~m}$.

Table 8.3. Calculated radiation doses to maximally exposed off-site individuals from airborne releases during 2003

\begin{tabular}{lll}
\hline \multirow{2}{*}{ Plant } & \multicolumn{2}{c}{$\begin{array}{c}\text { Total effective dose equivalents } \\
{[\mathrm{mrem}(\mathrm{mSv})]}\end{array}$} \\
\cline { 2 - 3 } & \multicolumn{1}{c}{ Plant max } & \multicolumn{1}{c}{ ORR max } \\
\hline ORNL & $0.2(0.002)^{a}$ & $0.2(0.0019)$ \\
ETTP & $0.03(0.0003)^{b}$ & $0.003(0.00003)$ \\
Y-12 & $0.2(0.002)^{c}$ & $0.04(0.0004)$ \\
Entire ORR & \multicolumn{1}{c}{$d$} & $0.24(0.0024)^{e}$ \\
\hline
\end{tabular}

${ }^{a}$ The maximally exposed individual was located $5410 \mathrm{~m}$ (3.4 miles) E of X-3039 and $4550 \mathrm{~m}$ (2.8 miles) ENE of X-7911.

${ }^{b}$ The maximally exposed individual was located 1950 m (1.2 miles) WSW of K-1435.

${ }^{c}$ The maximally exposed individual is located $2310 \mathrm{~m}$ (1.4 miles) ENE of the Y-12 National Security Complex release point.

${ }^{d}$ Not applicable.

${ }^{e}$ The maximally exposed individual for the entire ORR is the ORNL maximally exposed individual.
Table 8.4. Calculated collective EDEs from airborne releases during 2003

\begin{tabular}{lll}
\hline \multirow{2}{*}{ Plant } & \multicolumn{2}{c}{ Effective dose equivalents $^{a}$} \\
\cline { 2 - 3 } & (Person-rem) & (Person-Sv) \\
\hline ORNL & 4.6 & 0.046 \\
ETTP & 0.7 & 0.007 \\
Y-12 & 5.5 & 0.055 \\
Entire ORR & 10.8 & 0.108 \\
\hline
\end{tabular}

${ }^{a}$ Collective effective dose equivalents to the 1,040,041 persons residing within $80 \mathrm{~km}$ (50 miles) of the ORR. 
(Table 7.2) at the ORR perimeter air monitoring stations (PAMs) and the remote air monitoring station (RAM) (Fig. 7.3). Hypothetical individuals assumed to reside at the PAMs could have received EDEs between 0.02 and $0.2 \mathrm{mrem} /$ year (0.0002 and $0.002 \mathrm{mSv} /$ year); these EDEs include contributions from naturally occurring (background) radionuclides, radionuclides released from the ORR, and radionuclides released from any other sources. If contributions from strictly naturally occurring radionuclides $\left({ }^{7} \mathrm{Be}\right.$ and $\left.{ }^{40} \mathrm{~K}\right)$ are omitted, the EDEs range from about 0.01 to $0.1 \mathrm{mrem} /$ year $(0.0001$ and 0.001 $\mathrm{mSv} /$ year) (Table 8.5). An indication of doses from sources other than those on the ORR can be obtained from the EDE calculated at the RAM (Station 52), which was less than $0.01 \mathrm{mrem} /$ year $(0.0001 \mathrm{mSv} / \mathrm{year})$. (The isotopes ${ }^{7} \mathrm{Be}$ and ${ }^{40} \mathrm{~K}$ were not included in the RAM calculation, either.)

Of particular interest is a comparison of doses calculated using measured air concentrations of radionuclides (except ${ }^{7} \mathrm{Be}$ and ${ }^{40} \mathrm{~K}$ ) that could have been emitted from the ORR at PAMs located near the maximally exposed individuals for each plant and doses calculated for those individuals using CAP-88 and measured emissions. PAM 40 is located near the maximally exposed individual for the Y-12 Complex; the EDE calculated using measured air concentrations was $0.04 \mathrm{mrem} / \mathrm{year}$ (0.0004 mSv/year), which is less than the $0.2 \mathrm{mrem} /$ year $(0.002 \mathrm{mSv} /$ year) calculated using CAP-88. PAM 48 is located near the maximally exposed individual for ORNL (in an adjacent wind direction at a further distance), the EDE calculated using measured air concentrations was $0.15 \mathrm{mrem} /$ year $(0.0015 \mathrm{mSv} /$ year $)$, which is less than the $0.2 \mathrm{mrem} /$ year $(0.002 \mathrm{mSv} /$ year $)$ calculated using CAP-88. At PAM 39, which is located near the receptor location for the second highest exposed individual, the EDE calculated using measured air concentrations was $0.1 \mathrm{mrem} /$ year $(0.001 \mathrm{mSv} /$ year $)$, which is less than the $0.2 \mathrm{mrem} /$ year $(0.002 \mathrm{mSv} /$ year $)$ (rounded value) calculated using CAP-88. The EDEcalculated using measured air concentrations at Station $\mathrm{K} 9$ was approximately $0.5 \mathrm{mrem} /$ year ( $0.005 \mathrm{mSv} /$ year) for full occupancy. Because the ETTP maximum location is a business, the actual dose would be about $0.3 \mathrm{mrem} / \mathrm{year}$
(0.003 mSv/year), which is about ten times higher than the modeled value of $0.03 \mathrm{mrem} / \mathrm{year}$ (0.0003 mSv/year).

The dose estimates based on calculated and measured radionuclide concentrations are in reasonable agreement, with the exception of Station K9, given the differences in distances and directions between maximally exposed individuals and the monitoring stations, and given that the CAP- 88 model may overestimate doses by a factor of 2. Also, the ambient air monitors collect naturally occurring radionuclides and those emitted from non-ORR sources.

\subsubsection{Waterborne Radionuclides}

Radionuclides discharged to surface waters from the ORR enter the Tennessee River system by way of the Clinch River and various feeder streams (see Sect. 1.4 for the surface water setting of the ORR). Discharges from the Y-12 Complex enter the Clinch River via Bear Creek and East Fork Poplar Creek, both of which enter Poplar Creek before it enters the Clinch River, and by discharges from Rogers Quarry into McCoy Branch and then into Melton Hill Lake. Discharges from ORNL enter the Clinch River via White Oak Creek. Discharges from the ETTP enter the Clinch River either directly or via Poplar Creek. This section discusses the potential radiological impacts of these discharges to persons who drink water; eat fish; and swim, boat, and use the shoreline at various locations along the Clinch and Tennessee rivers.

Two methods are used to estimate potential radiation doses to the public. The first method uses radionuclide concentrations in the medium of interest (i.e., in water and fish) that were determined by laboratory analyses of actual water and fish samples (see Sects. 7.4 and 7.9). The second method estimates radionuclide concentrations in water and fish that were calculated from measured radionuclide discharges and known or estimated stream flows. The advantage of the first method is the use of radionculide concentrations actually measured in water and fish; disadvantages are the inclusion of naturally occurring radionuclides especially in gross alpha- and beta-activity measurements, the possibility that some radionuclides of ORR origin might be present in quantities too low to be 


\begin{tabular}{ccc}
\multicolumn{3}{c}{$\begin{array}{c}\text { Table 8.5. Hypothetical effective dose } \\
\text { equivalents from living at ORR and ETTP } \\
\text { ambient-air monitoring stations }\end{array}$} \\
\hline \multirow{2}{*}{ Station } & Effective dose equivalent ${ }^{a}$ \\
\cline { 2 - 3 } & mrem/year & mSv/year \\
\hline 35 & 0.1 & 0.001 \\
37 & 0.02 & 0.0002 \\
38 & 0.04 & 0.0004 \\
39 & 0.1 & 0.001 \\
40 & 0.04 & 0.0004 \\
42 & 0.1 & 0.001 \\
46 & 0.03 & 0.0003 \\
48 & 0.02 & 0.0002 \\
52 & 0.01 & 0.0001 \\
K2 & 0.3 & 0.003 \\
K6 & 0.9 & 0.009 \\
K9 & 0.5 & 0.005 \\
K10 & 0.2 & 0.002 \\
\hline As & &
\end{tabular}

${ }^{a}$ Assumes full-time occupancy; for business location the estimated EDE is half of the EDE.

measured, and the possibility that the presence of some radionuclides might be overstated (e.g., present in a quantity below the detection limit). The advantages of the second method are that most radionuclides discharged from the ORR will be quantified and that naturally occurring radionuclides will not be considered or will be accounted for separately; the disadvantage is the use of models to estimate the concentrations of the radionuclides in water and fish. However, using the two methods should allow the potential radiation doses to be bounded.

\section{Drinking Water}

Several water treatment plants along the Clinch and Tennessee River systems could be affected by discharges from the ORR. No in-plant radionuclide concentration data are available for any of these plants; all of the dose estimates given below likely are high because they are based on measurements taken away from the processing plants. For purposes of assessment, it was assumed that maximally exposed individuals would drink $730 \mathrm{~L}$ of water during 2003 and that the average person would drink $370 \mathrm{~L}$.

The only water treatment plant located on Melton Hill Lake that could be affected by discharges from the ORR is a Knox County plant. Water from this plant is not sampled. However, the plant is located near surface water sampling location CRK 58. Based on detected concentrations of identifiable radionuclides that could have come from the ORR, no individual should have received an EDE above background levels. If unidentified alpha and beta activities, which are believed to be due to naturally occurring radionuclides, are taken into account, a highly exposed individual could have received an EDE of about $5 \mathrm{E}-11 \mathrm{mrem}(5 \mathrm{E}-13 \mathrm{mSv})$ from drinking this water. Based on known radionuclide discharges to Melton Hill Lake, a highly exposed individual could have received an EDE of about 3E-7 mrem (3.7E-9 mSv), even if unidentified alpha and beta activities are included.

The ETTP (Gallaher) water plant draws water from the Clinch River near CRK 23. For assessment purposes, we assume that workers obtain half their annual water $(370 \mathrm{~L})$ intake at work. No in-plant water-sampling data are available. Based on water samples taken above the water plant's intake, workers could have received EDEs as high as $0.3 \mathrm{mrem}(0.003 \mathrm{mSv})$, and the collective EDE to the approximately 2500 workers could have been about 0.7 personrem $(0.007$ person-Sv). If the unidentified alpha and beta activities are included, the EDEs could have been $0.7 \mathrm{mrem}$ and 2 person-rem $(0.007 \mathrm{mSv}$ and 0.02 person-Sv). Using radionuclide discharge data, the maximum individual EDE was estimated to be $1 \mathrm{E}-4 \mathrm{mrem}(1 \mathrm{E}-6 \mathrm{mSv})$; the collective EDE was $2 \mathrm{E}-4$ person-rem (2E-6 person-Sv). Including unidentified alpha and beta activities increases the hypothetical doses to $2 \mathrm{E}-4$ mrem and $2 \mathrm{E}-4$ personrem (2E-6 mSv and 2E-6 person-Sv).

The Kingston and Rockwood municipal water plants draw water from the Tennessee River not very far from its confluence with the Clinch River. No water samples are taken from the Tennessee River near these plants. Radionuclide discharge data and Clinch River water sample data were used to estimate the maximum individual EDE as $0.1 \mathrm{mrem}(0.001 \mathrm{mSv})$; the collective EDE to the estimated 21,068 water users could have been about 2 person-rem (0.02 person-Sv). Including 
unidentified alpha and beta activities could increase these dose estimates to $0.3 \mathrm{mrem}$ and 3 person-rem $(0.003 \mathrm{mSv}$ and 0.03 person-Sv).

Several water treatment plants are located on tributaries of Watts Bar Lake and Chickamauga Lake. Based on discharge and Clinch River water data, persons drinking water from these plants could not have received EDEs greater than the 0.09 mrem $(0.0009 \mathrm{mSv})$ calculated for Kingston and Rockwood water.

Using the maximum EDE derived by either method (measured water concentration or modeled from discharges) and using the community and noncommunity drinking water populations served (Oak Ridge to Chattanooga), the estimated collective EDE from all drinking water locations was about 12 person-rem $(0.12$ person-Sv).

\section{Fish}

Fishing is quite common on the Clinch and Tennessee River systems. For purposes of assessment, it was assumed that avid fish eaters would have consumed $21 \mathrm{~kg}$ of fish during 2003 and that the average person would have consumed $6.9 \mathrm{~kg}$ of fish. EDEs were calculated from measured radionuclide contents in fish (see Sect. 7.9), the measured concentrations of radionuclides in water, and the calculated concentrations from discharges as input to the LADTAP XL code (Hamby 1991).

Fish samples were collected from Melton Hill Lake above all ORR inputs (CRK 70), from the upper part of the Clinch River (CRK 32), and from the Clinch River below all ORR inputs (CRK 16). Based on these samples, avid fish consumers could have received, from statistically significant detected radionuclides that could have been discharged from the ORR, a 50-year committed EDE between 0 and 0.1 mrem $(0$ and $0.001 \mathrm{mSv}$ ), depending on type of fish and harvest location, excluding ${ }^{40} \mathrm{~K}$ (a naturally occurring radionuclide) and unidentified alpha and beta activities. Consuming catfish taken from CRK 70 could have resulted in an EDE of 0.01 mrem $(0.0001 \mathrm{mSv})$, whereas eating sunfish from that location could have resulted in no EDE. Eating catfish taken from CRK 32 could have resulted in an EDE of 0.05 mrem $(0.0005 \mathrm{mSv})$; eating sunfish from that location could have resulted in an EDE of $0.1 \mathrm{mrem}(0.001 \mathrm{mSv})$. Eating catfish taken from CRK 16 could have resulted in an EDE of $0.01 \mathrm{mrem}(0.0001 \mathrm{mSv})$; eating sunfish from that location also could have resulted in an EDE of $0.03 \mathrm{mrem}(0.0003 \mathrm{mSv})$. The presence of naturally occurring ${ }^{40} \mathrm{~K}$ adds between 1 and 2 mrem $(0.001$ and $0.002 \mathrm{mSv})$ to the above doses.

Unidentified beta and alpha activities were detected in many of the fish samples. Excess beta and alpha activities were estimated by subtracting activities of identified beta- and alpha-particleemitting radionuclides from the corresponding unidentified activities. If the excess unidentified beta and alpha activities were from the naturally occurring radionuclides ${ }^{234} \mathrm{Th}$ and ${ }^{226} \mathrm{Ra}$, respectively, the hypothetical avid fish consumer could have received an EDE between zero and 0.6 mrem $(0.006 \mathrm{mSv})$. Eating catfish taken from CRK 70 could have resulted in an EDE of 0.2 mrem (2E-03 $\mathrm{mSv}), 91 \%$ of which is due to excess beta activity; eating sunfish from that location could have resulted in no EDE from radionuclides other than ${ }^{40} \mathrm{~K}$, a naturally occurring radionuclide. Eating catfish taken from CRK 32 could have resulted in an EDE of 0.2 mrem (0.002 $\mathrm{mSv}), 77 \%$ of which is due to excess beta activity; eating sunfish from that location could have resulted in an EDE of 0.6 mrem $(0.006 \mathrm{mSv}), 81 \%$ of which is due to excess alpha and beta activity. Eating catfish taken from CRK 16 could have resulted in an EDE of 0.3 mrem $(0.003 \mathrm{mSv}), 96 \%$ of which is due to excess beta activity; eating sunfish from that location could have resulted in an EDE of 0.03 mrem $(0.0003 \mathrm{mSv})$, none of which is due to excess alpha or beta activity. It is believed that essentially all of the excess activities are due to naturally occurring radionuclides, not to radionuclides that were discharged from the ORR.

Water samples were collected from Melton Hill Lake (CRK 70, 66, and 58); from the Clinch River below Melton Hill Dam (CRK 32, 23, and 16); from East Fork Poplar Creek, just before it joins Poplar Creek (EFK 0.1) and downstream of its floodplain (EFK 5.4); and from Poplar Creek, after it is formed by East Fork Poplar Creek and prior to its joining the Clinch River. Based on water concentrations of identified radionuclides that could have come from the ORR in these samples, avid fish consumers could have received 
EDEs of about 2E-11 mrem (2E-11 mSv) from fish taken from Melton Hill Lake and between 3E4 to $1 \mathrm{mrem}$ (3E-6 to $0.01 \mathrm{mSv}$ ) from the Clinch River; between 0.04 and 1 mrem $(0.0004$ and $0.01 \mathrm{mSv}$ ) from fish taken from Poplar Creek; and between 0.1 and 2 mrem $(0.001$ and $0.02 \mathrm{mSv})$ from fish taken from East Fork Poplar Creek. It should be noted that catching and consuming fish from East Fork Poplar Creek is discouraged strongly by state of Tennessee postings banning such activities. Thus, we do not consider consumption of fish from East Fork Poplar Creek to be a credible exposure pathway.

If the unidentified alpha and beta activities are included, the above EDEs could be about 2 mrem $(0.002 \mathrm{mSv})$ from Melton Hill Lake fish; between $3 \mathrm{E}-4$ and 3 mrem (3E-6 and $0.03 \mathrm{mSv}$ ) from Clinch River fish; about $1 \mathrm{mrem}(0.01 \mathrm{mSv})$ from fish taken from Poplar Creek; and between 2 and 3 mrem ( 0.02 and $0.03 \mathrm{mSv}$ ) from fish taken from East Fork Poplar Creek. Radium-226 was detected in two water samples, though not above the quantified limit, collected at CRK 16 (by a method not recommended by the EPA). If these ${ }^{226} \mathrm{Ra}$ concentrations were into account, the estimated EDE from consuming fish at CRK 16 would be about 9 mrem $(0.09 \mathrm{mSv})$.

Based on radionuclide discharges to Melton Hill Lake, the Clinch River, and the Poplar Creek system, maximum EDEs to avid fish consumers could have been $5 \mathrm{E}-7$ mrem $(5 \mathrm{E}-$ $9 \mathrm{mSv}), 3 \mathrm{E}-4 \mathrm{mrem}(3 \mathrm{E}-6 \mathrm{mSv})$, and $1 \mathrm{mrem}$ $(0.01 \mathrm{mSv})$, respectively.

Using the maximum EDE derived from either method (fish tissue or modeled from water concentrations) and taking into account fish harvest data from Melton Hill, Watts Bar, and Chickamauga reservoirs, the collective EDE from eating fish from the above locations and from the Tennessee River system down to Chattanooga could have been 3 person-rem (0.03 person-Sv).

\section{Other Uses}

Other uses of the ORR area waterways include swimming or wading, boating, and use of the shoreline. A highly exposed other user was assumed to swim or wade for $27 \mathrm{~h} /$ year, boat for $63 \mathrm{~h} /$ year, and use the shoreline for $67 \mathrm{~h} /$ year. Measured and calculated concentrations of radionuclides in water and the LADTAP XL code were used to estimate potential EDEs from these activities. When compared with EDEs from eating fish from the same waters, the EDEs from these other uses are relatively insignificant.

Based on the above-noted water samples, highly exposed other users could have received EDEs less than 7E-4 mrem (7E-6 mSv) from using Melton Hill Lake, between 1E-05 and 0.3 mrem (1E-07 and 3E-03 mSv) from using the Clinch River, between 3E-03 and 0.1 mrem (3E-05 and $1 \mathrm{E}-3 \mathrm{mSv}$ ) from using Poplar Creek, and between 5E-04 and 0.4 mrem (5E-06 and $0.004 \mathrm{mSv}$ ) from using East Fork Poplar Creek. If the unidentified alpha and beta activities are included, the above EDEs could be about $9 \mathrm{E}-4 \mathrm{mrem}(9 \mathrm{E}-6 \mathrm{mSv})$ from using Melton Hill Lake, between 3E-5 and 0.3 mrem (3E-7 and $0.003 \mathrm{mSv}$ ) from using the Clinch River, between 3E-3 and 0.1 mrem (3E-5 and $0.001 \mathrm{mSv}$ ) from using Poplar Creek, and between 7E-4 and 0.4 mrem (7E-6 and $0.004 \mathrm{mSv}$ ) from using East Fork Poplar Creek.

Based on radionuclide discharges to the Clinch River-Poplar Creek system, a user could have received an EDE between $1 \mathrm{E}-8$ and 0.03 mrem (1E-10 and 3E-4 mSv).

Using the EDEs derived from exposure to identified radionuclides and estimates of populations boating, wading, and using the shoreline, the maximum collective EDE from all other water uses could have been about 5 personrem $(0.05$ person-Sv).

\section{Summary}

Table 8.6 is a summary of potential EDEs from identified waterborne radionuclides around the ORR. Adding worst-case EDEs for all pathways in a water-body segment gives a maximum individual EDE of about 2 mrem $(0.02 \mathrm{mSv})$ to a person obtaining his or her full annual complement of fish, drinking water, and participation in other water uses from the Clinch River. The maximum collective EDE to the 50 -mile population could be as high as 20 personrem $(0.20$ person-Sv). These are small percentages of individual and collective doses attributable to natural background radiation, about $0.7 \%$ and $0.006 \%$, respectively. 
Table 8.6. Summary of annual maximum individual EDEs from waterborne radionuclides $(\mathrm{mrem})^{2}$

\begin{tabular}{|c|c|c|c|c|}
\hline Type of sample & Drinking water & Eating fish & Other uses & Total of highest \\
\hline \multicolumn{5}{|c|}{ Melton Hill Lake, CRK 70, CRK 66, CRK 58} \\
\hline Fish $^{b}$ & & 0.01 & & \\
\hline Water $^{c}$ & $5 \mathrm{E}-11$ & $2 \mathrm{E}-11$ & $7 \mathrm{E}-4$ & $7 \mathrm{E}-4$ \\
\hline Discharge $^{d}$ & $3 \mathrm{E}-7$ & $5 \mathrm{E}-7$ & $1 \mathrm{E}-8$ & $8 \mathrm{E}-7$ \\
\hline Maximum & $3 \mathrm{E}-7$ & 0.01 & $7 \mathrm{E}-4$ & 0.01 \\
\hline \multicolumn{5}{|c|}{ Upper Clinch River, CRK 23, Gallaher Water Plant, CRK 32} \\
\hline Fish $^{b}$ & & 0.1 & & \\
\hline Water $^{c}$ & 0.5 & 1 & 0.3 & 2 \\
\hline Discharge $^{d}$ & $1 \mathrm{E}-4$ & $3 \mathrm{E}-4$ & $2 \mathrm{E}-5$ & $4 \mathrm{E}-4$ \\
\hline Maximum & 0.5 & 1 & 0.3 & 2 \\
\hline \multicolumn{5}{|c|}{ Lower Clinch River, CRK 16} \\
\hline Fish $^{b}$ & & 0.03 & & \\
\hline Water $^{c}$ & $\mathrm{NA}^{e}$ & 1 & 0.3 & 1 \\
\hline Discharge $^{d}$ & $\mathrm{NA}^{e}$ & $3 \mathrm{E}-4$ & $2 \mathrm{E}-5$ & $3 \mathrm{E}-4$ \\
\hline Maximum & $\mathrm{NA}^{e}$ & 1 & 0.3 & 1 \\
\hline \multicolumn{5}{|c|}{ Upper Watts Bar Lake, Kingston Municipal Water Plant } \\
\hline Water $^{c}$ & 0.1 & 0.3 & 0.07 & 0.5 \\
\hline Discharge $^{d}$ & $3 \mathrm{E}-5$ & $7 \mathrm{E}-5$ & $7 \mathrm{E}-6$ & $1 \mathrm{E}-4$ \\
\hline Maximum & 0.1 & 0.3 & 0.07 & 0.5 \\
\hline \multicolumn{5}{|c|}{ Lower System (Lower Watts Bar Lake and Chickamauga Lake) } \\
\hline Water $^{c}$ & 0.09 & 0.2 & 0.06 & 0.4 \\
\hline Discharge $^{d}$ & $3 \mathrm{E}-5$ & $6 \mathrm{E}-5$ & $6 \mathrm{E}-6$ & $1 \mathrm{E}-4$ \\
\hline Maximum & 0.09 & 0.2 & 0.06 & 0.4 \\
\hline \multicolumn{5}{|c|}{ Poplar Creek } \\
\hline Water $^{c}$ & $\mathrm{NA}^{e}$ & 0.9 & 0.1 & 1 \\
\hline Discharge $^{d}$ & $\mathrm{NA}^{e}$ & 1 & 0.03 & 1 \\
\hline Maximum & $\mathrm{NA}^{e}$ & 1 & 0.1 & 1 \\
\hline
\end{tabular}

${ }^{a} 1 \mathrm{mrem}=0.01 \mathrm{mSv}$.

${ }^{b}$ Doses based on measured radionuclide concentrations in fish tissue.

${ }^{c}$ Doses based on measured radionuclide concentrations in water.

${ }^{d}$ Doses based on measured discharges of radionuclides from on-site outfalls.

${ }^{e}$ Not at drinking water supply locations.

\subsubsection{Radionuclides in Other Environmental Media}

The CAP-88 computer codes are used to calculate radiation doses from ingestion of meat, milk, and vegetables that contain radionuclides released to the atmosphere. These doses are included in the dose calculations for airborne radionuclides. However, some environmental media, including the three mentioned, are sampled as part of the surveillance program. The following dose estimates are based on environmental 
sampling results and may include contributions from radionuclides occurring in the natural environment, released from the ORR, or both.

\section{Milk}

Milk collected at two locations near the ORR and at a remote location was found to contain small quantities of radio-strontium (Sect. 7.6.3). The sample data were used to calculate potential EDEs to hypothetical persons who drank $310 \mathrm{~L}$ (NRC 1977) of sampled milk during the year.

These hypothetical persons could have received an EDE of about 0.04 mrem $(0.0004$ $\mathrm{mSv}$ ) from drinking milk from the near locations and about 0.05 mrem $(0.005 \mathrm{mSv})$ from the remote location, excluding the contribution from ${ }^{40} \mathrm{~K}$, a naturally occurring radionuclide.

\section{Food Crops}

The food-crop sampling program is described in Sect. 7.6.2. Samples of tomatoes, lettuce, and turnips were obtained from six local gardens. These vegetable types are representative of fruitbearing, leafy, and root vegetables. All radionuclides found in the food crops are found in the natural environment and in commercial fertilizers, and all but ${ }^{7} \mathrm{Be}$ and ${ }^{40} \mathrm{~K}$ also are emitted from the ORR.

Dose estimates are based on hypothetical consumption rates of vegetables that contain statistically significant amounts of certain radionuclides that could have come from the ORR. Based on a nationwide food consumption survey (EPA 1997), a hypothetical home gardener was assumed to have eaten $32 \mathrm{~kg}(71 \mathrm{lb})$ of homegrown tomatoes, $10 \mathrm{~kg}(22 \mathrm{lb})$ of homegrown lettuce, and $37 \mathrm{~kg}(82 \mathrm{lb})$ of homegrown turnips. The hypothetical gardener could have received a 50-year committed EDE of between 0.01 and 0.1 mrem $(0.0001$ and $0.001 \mathrm{mSv}$ ), depending on garden location. Of this total, between 0.02 and 0.04 mrem $(0.0002$ and $0.0004 \mathrm{mSv}$ ) could have come from eating tomatoes, between 0.01 and 0.05 mrem $(0.0001$ and $0.0005 \mathrm{mSv}$ ) from eating lettuce, and between 0.02 and 0.05 mrem $(0.0002$ and $0.0005 \mathrm{mSv})$ from eating turnips. The highest dose to a gardener could have been about $0.1 \mathrm{mrem}(0.001)$ from consuming all three types of homegrown vegetables.

Many of the samples contained detected activities of unidentified beta- and alpha-particleemitting radionuclides. By subtracting identified activities of beta- and alpha-particle-emitting radionuclides from the unidentified beta and alpha activities, excess beta and alpha activities were estimated. If the excess unidentified beta and alpha activities were ${ }^{90} \mathrm{Sr}$ and ${ }^{210} \mathrm{Po}$, respectively, a hypothetical home gardener could have received an EDE of between 4 and 10 mrem (0.04 and $0.1 \mathrm{mSv}$ ). Of this total, between 1 and 9 mrem $(0.01$ and $0.09 \mathrm{mSv})$ could have come from eating tomatoes, between 0.1 and 0.6 mrem $(0.001$ and $0.006 \mathrm{mSv}$ ) from eating lettuce, and between 0.8 and $4 \mathrm{mrem}(0.008$ and $0.04 \mathrm{mSv})$ from eating turnips. It is believed that most of the excess unidentified beta and alpha activities are due to naturally occurring or fertilizer-introduced radionuclides, not radionuclides discharged from the ORR.

An example of a naturally occurring and fertilizer-introduced radionuclide is ${ }^{40} \mathrm{~K}$, which is specifically identified in the samples and accounts for most of the beta activity found in them. (Potassium-40 actually accounts for all the beta activity found in leafy-vegetable samples.) The presence of ${ }^{40} \mathrm{~K}$ in the samples adds, on average, around $4 \mathrm{mrem}(0.04 \mathrm{mSv})$ to the hypothetical home gardener's EDE.

\section{White-Tailed Deer}

The TWRA conducted three 2-day deer hunts during 2003 on the Oak Ridge Wildlife Management Area, which is part of the ORR, as described in Sect. 7.8. A total of 256 deer were killed during these hunts and were brought to the TWRA checking station. At the station, a bone sample and a tissue sample were taken from each deer. These samples were field-counted for radioactivity to ensure that the deer met release criteria - that is, less than $20 \mathrm{pCi} / \mathrm{g}(0.74 \mathrm{~Bq} / \mathrm{g})$ of beta-particle activity in bone or $5 \mathrm{pCi} / \mathrm{g}$ $(0.19 \mathrm{~Bq} / \mathrm{g})$ of ${ }^{137} \mathrm{Cs}$ in edible tissue. Two of the deer exceeded the limit for beta-particle activity in bone and were confiscated. The remaining 254 deer were released to the hunters.

For the 2003 deer hunts, a new counting system was installed at the field counting station. 
This counting system provides better specific isotopic information as compared to the previous field counting system. The average ${ }^{137} \mathrm{Cs}$ concentration in tissue of the 254 released deer, as determined by field counting, was $0.7 \mathrm{pCi} / \mathrm{g}$ $(0.026 \mathrm{~Bq} / \mathrm{g})$; the maximum ${ }^{137} \mathrm{Cs}$ concentration in a deer was $1.9 \mathrm{pCi} / \mathrm{g}(0.063 \mathrm{~Bq} / \mathrm{g})$. In 2003, tissue samples from three deer were submitted for laboratory analysis.

Based on field analysis data for the deer harvested in 2003, an individual who consumed a deer harvested on the ORR could have received an average EDE of about $0.7 \mathrm{mrem}(0.007 \mathrm{mSv})$. The maximum EDE to a hunter who consumed a deer harvested from the ORR in 2003 was estimated to be 4 mrem $(0.04 \mathrm{mSv})$. About 19 hunters (one hunter or more from the same household) harvested two deer from the ORR in 2003. In two cases three deer were harvested by members of the same household. The maximum EDE, based on ${ }^{137} \mathrm{Cs}$ concentrations determined by field analyses, to a hunter who consumed three harvested deer was estimated to be about 2 mrem (0.02 mSv).

The collective EDE from eating all the harvested venison from the ORR with a 2003 average field-derived ${ }^{137} \mathrm{Cs}$ concentration of $0.7 \mathrm{pCi} / \mathrm{g}(0.026 \mathrm{~Bq} / \mathrm{g})$ and an average weight of $76.9 \mathrm{lb}(34.9 \mathrm{~kg})$ is estimated to be about 0.2 person-rem (0.002 person-Sv).

\section{Canada Geese}

During the 2003 goose roundup, 95 geese were weighed and subjected to whole-body gamma scans. The average ${ }^{137} \mathrm{Cs}$ concentration in the released geese was $0.24 \mathrm{pCi} / \mathrm{g}(0.009 \mathrm{~Bq} / \mathrm{g})$. The maximum ${ }^{137} \mathrm{Cs}$ concentration in the released geese was $0.97 \mathrm{pCi} / \mathrm{g}(0.036 \mathrm{~Bq} / \mathrm{g})$. The average weight of the geese screened during the roundup was about $8.68 \mathrm{lb}(3.9 \mathrm{~kg})$. The maximum goose weight was about $12.59 \mathrm{lb}(5.7 \mathrm{~kg})$. If a person consumed a released goose with an average weight of $8.68 \mathrm{lb}(3.9 \mathrm{~kg})$ and an average ${ }^{137} \mathrm{Cs}$ concentration of $0.24 \mathrm{pCi} / \mathrm{g}(0.009 \mathrm{~Bq} / \mathrm{g})$, the estimated EDE would be about 0.024 mrem $(0.00024 \mathrm{mSv})$. The maximum estimated EDE to an individual who consumed a hypothetical released goose with the maximum ${ }^{137} \mathrm{Cs}$ concentration of $0.97 \mathrm{pCi} / \mathrm{g}(0.036 \mathrm{~Bq} / \mathrm{g})$ and the maximum weight of $12.6 \mathrm{lb}(5.7 \mathrm{~kg})$ was about 0.1 mrem $(0.001 \mathrm{mSv})$. As mentioned above, a new counting system was installed at the field counting station, thereby providing better specific isotopic information than had been obtained by the previous field counting system.

It is possible that one person could eat more than one goose that spent time on the ORR. Most hunters harvest on average one to two geese per hunting season (USFWS 1995). If one person consumed two hypothetical geese of maximum weight with the highest measured concentration of ${ }^{137} \mathrm{Cs}$, that person could have received an EDE of about 0.3 mrem $(0.003 \mathrm{mSv})$.

To follow up on a special study initiated in 1998, muscle samples were analyzed from four geese sacrificed during the 2003 roundup. One goose each from ETTP, ORNL (sewage treatment pond area), the Oak Ridge Marina, and Clark Center Park were sacrificed and the tissue analyzed. Requested radioisotopic analyses, in addition to the routine analyses of ${ }^{137} \mathrm{Cs}$ and ${ }^{90} \mathrm{Sr}$, included uranium $\left({ }^{234} \mathrm{U}\right.$ and $\left.{ }^{238} \mathrm{U}\right)$ and transuranics, such as ${ }^{239} \mathrm{Pu}$ and ${ }^{241} \mathrm{Am}$. Based on statistically significant radionuclide concentrations (excluding ${ }^{40} \mathrm{~K}$, a naturally occurring radionuclide) and the actual weights of the geese, the estimated EDEs ranged from about 0.05 to $0.1 \mathrm{mrem}$ ( 0.0005 to $0.001 \mathrm{mSv})$.

\section{Eastern Wild Turkey}

No wild turkey hunts were held on the ORR in 2003 due to security concerns.

\section{Direct Radiation}

External exposure rates from background sources in the state of Tennessee average about $6.4 \mu \mathrm{R} / \mathrm{h}$ and range from 2.9 to $11 \mu \mathrm{R} / \mathrm{h}$. These exposure rates translate into annual EDE rates that average $42 \mathrm{mrem} /$ year $(0.42 \mathrm{mSv} /$ year $)$ and range between 19 and 72 mrem/year, or 0.19 and $0.72 \mathrm{mSv} /$ year (Myrick et al. 1981). External radiation exposure rates are measured at a number of locations on and off the ORR. The average exposure rate at PAMs around the ORR during 2003 was about $5.3 \mu \mathrm{R} / \mathrm{h}$. This rate corresponds to an EDE rate of about $33 \mathrm{mrem} /$ year ( $0.47 \mathrm{mSv} /$ year). All measured exposure rates at or near the ORR boundaries are near background levels. 
External exposure rate measurements taken during 1997 along a 1.7-km (1.1-mile) length of Clinch River shoreline averaged $8.4 \mu \mathrm{R} / \mathrm{h}$ and ranged between 6.9 and $9.3 \mu \mathrm{R} / \mathrm{h}$. This corresponds to an average exposure rate of about $2.0 \mu \mathrm{R} / \mathrm{h}(1.5 \mathrm{E}-03 \mathrm{mrem} / \mathrm{h})$ above background. A potential maximally exposed individual would be a hypothetical fisherman who was assumed to have spent $5 \mathrm{~h} /$ week $(250 \mathrm{~h} /$ year) near the point of average exposure on the Clinch River shoreline. This hypothetical maximally exposed individual could have received an EDE of about 0.4 mrem (4E-03 mSv) above background during 2003.

As described in Sect. 4.12, the potential above-background annual EDE to a hypothetical maximally exposed individual would be about 1 mrem from gamma radiation and 0 mrem from neutron radiation along the bank of Poplar Creek near the K-1066-J Cylinder Yard; 2 mrem (1.25 mrem from gamma radiation and 0.75 mrem from neutron radiation) along the bank of Poplar Creek near the K-1066-E Cylinder Yard; about 1 mrem from neutron radiation attributable to the K-770 Scrap Yard, which is along the near bank of the Clinch River; and about 5 mrem (1.75 mrem from gamma radiation and 3 mrem from neutron radiation) in the parking lot along the edge closest to the K-1066-K Cylinder Yard. However, the parking lot is for employees and has no public facilities.

\subsubsection{Doses to Aquatic Biota}

\subsubsection{Aquatic Biota}

DOE Order 5400.5, Chapter II, sets an absorbed dose rate limit of $1 \mathrm{rad} /$ day $(0.01 \mathrm{~Gy} /$ day $)$ to native aquatic organisms from exposure to radioactive material in liquid wastes discharged to natural waterways (see Appendix F for definitions of absorbed dose and the rad). To demonstrate compliance with this limit, absorbed dose rates to aquatic organisms were calculated using the Radionuclide Biota Concentration Guide Calculator (Rev 2.0), a companion electronic calculation tool to the DOE technical standard entitled A Graded Approach for Evaluating Radiation Doses to Aquatic and Terrestrial Biota (DOE 2002b).
The intent of the graded approach is to protect populations of aquatic organisms from the effects of exposure to anthropogenic ionizing radiation. Certain organisms are more sensitive to ionizing radiation than others. Therefore, it is generally assumed that protecting the more sensitive organisms will adequately protect other, less sensitive organisms. Depending on the radionuclide, either aquatic organisms (e.g., crustaceans or mollusks) or riparian organisms (e.g., raccoons) are often considered to be the more sensitive and are the limiting organisms for the general screening phase of the graded approach for aquatic organisms. The graded approach for evaluating radiation doses to aquatic biota consists of a three-step process that involves (1) data assembly, (2) general screening of mediaspecific radionuclide concentrations to mediaspecific biota concentration guides, and (3) sitespecific screening and analysis. In the general screening phase, surface water radionuclide concentrations and sediment radionuclide concentrations can be compared to the mediaspecific biota concentration guidelines using default parameters. This aquatic dose assessment was based primarily on surface water sampling data except at two locations at Y-12 where both surface water and sediment sampling data were available.

At ORNL, doses to aquatic organisms are based on surface water concentrations at seven different sampling locations: MEK 0.2, WCK 1.0 and 2.6, First Creek, Fifth Creek, Raccoon Creek, and Northwest Tributary. All but two of these locations, WCK 1.0 (White Oak Creek at the Dam) and WCK 2.6, passed the initial general screening (using default parameters for biota concentration guides). At WCK 1.0 and 2.6, the default bioaccumulation factors for ${ }^{137} \mathrm{Cs}$ in fish were adjusted to reflect on-site bioaccumulation of these radionuclides in fish. Riparian organisms are the limiting receptor for ${ }^{137} \mathrm{Cs}$ in surface water; however, the best available bioaccumulation data for White Oak Creek are for fish. Because fish are consumed by riparian organisms (e.g., raccoons), adjustment of the fish bioaccumulation factor modified the bioaccumulation of ${ }^{137} \mathrm{Cs}$ in riparian organisms. This resulted in absorbed dose rates to aquatic organisms below the DOE aquatic dose limit of $1 \mathrm{rad} /$ day at all seven ORNL locations. 
At the Y-12 Complex, doses to aquatic organisms were estimated from surface water concentrations at eight different sampling locations: East Fork Poplar Creek at Surface Water Hydrological Information Support System Station 9422-1 (Station 17), Bear Creek kilometer (BCK) 4.55 (formerly Outfall 304), Rogers Quarry Discharge Point S19 (formerly Outfall 302), Discharge Point S17 (tributary to the Clinch River), Outfall 501 (Central Pollution Control Facility), Outfall 502, Outfall 512, and Outfall 551. With the exception of Outfall 502, all locations passed the general screening. For Outfall 502 , the default bioaccumulation factors for ${ }^{137} \mathrm{Cs}$ in fish were adjusted to reflect ORR bioaccumulation of these radionuclides in fish. Riparian organisms are the limiting receptors for ${ }^{137} \mathrm{Cs}$ in surface water, and the best available bioaccumulation data for East Fork Poplar Creek are for fish. This resulted in absorbed dose rates to aquatic organisms below the DOE aquatic dose limit of $1 \mathrm{rad} /$ day at all eight Y-12 locations.

At ETTP, doses to aquatic organisms were estimated from surface water concentrations at nine different sampling locations: Mitchell Branch at K1700 and at MIK 1.4 (upstream location) and MIK 0.4, Poplar Creek at K-716 (downstream), K1007-B and K-1710 (upstream location), K901A (downstream of ETTP operations), K-1407-J (the Central Neutralization Facility), and East Fork Poplar Creek ( $0.1 \mathrm{~km}$ upstream on East Fork Poplar Creek). All of these locations passed the initial general screening (using default parameters for biota concentration guides).

\subsubsection{Terrestrial Biota}

DOE Order 450.1 and 5400.5 include requirements to demonstrate radiation protection of biota within terrestrial systems as well as aquatic systems.

As required by CERCLA, baseline ecological risk assessments have been conducted for a number of watershed areas on the ORR. The results of these assessments provide the basis for selection of future terrestrial biota sampling locations on the ORR. The ecological impacts identified in the assessments for the following sites are summarized below.

ORNL is divided into two watershed areas, the Bethel Valley watershed and the Melton
Valley watershed. The Bethel Valley watershed, as approached in the baseline ecological risk assessment, was divided into four geographical areas: the Raccoon Creek area, West Bethel Valley, Central Bethel Valley, and East Bethel Valley. Based on the results of the assessment for Bethel Valley (DOE 1999b), the only area where there appear to be potential risks to terrestrial organisms exposed to radiological contaminants was West Bethel Valley, but the risks were not widespread. Potential risks from exposure to radionuclides in surface soil were identified for soil invertebrates and all wildlife receptors (e.g., soil invertebrates, shrews, white-footed mice, red fox, deer, red-tailed hawk, turkey, and mink) except plants. Cesium-137 was the risk driver for all receptors. Uranium-234 was an additional radionuclide of concern for turkeys at this location.

In the Melton Valley watershed ecological assessment (DOE 1997a), ecological risks were estimated for plants, soil invertebrates, and terrestrial wildlife exposed to radionuclide contaminants in surface soil within each subbasin in the watershed for which surface soil data were available. Radiological data were available for 28 subbasins. Radionuclide exposures resulted in potential risks to terrestrial biota at 16 subbasins. Radionuclide risks were highest in the East Seep subbasin, with Cs-137 driving risks for all receptors. In 5 subbasins, calculated dose rates were above limits for plants. Estimated doses exceeded dose limits for soil invertebrates in 7 subbasins and for wildlife receptors (e.g., shrews and mice) in 16 subbasins. However, doses to piscivorous wildlife (e.g., mink, kingfisher, great blue heron) were below dose limits to all piscivorous receptors. The data collected for a recent Melton Valley ecological monitoring report (DOE 2004b) indicate that the ecological contaminants of concern in Melton Valley surface soil, surface water, and sediment pose little or no risk to wildlife receptors. This report suggests that the earlier ecological risk assessment overestimated the exposure and risk to wildlife receptors.

The Y-12 site was divided into two watershed areas, Upper East Fork Poplar Creek and Bear Creek. In the Upper East Fork Poplar Creek watershed, the characterization area encompasses Upper East Fork Poplar Creek, Lake Reality, the 
main industrialized part of the Y-12 Plant, and the East End carbon tetrachloride plume (which extends into Union Valley) (DOE 1998). Upper East Fork Poplar Creek extends from its headwaters at the North/South Pipe downstream to Station 17, where it crosses the Y-12 Plant property boundary and becomes Lower East Fork Poplar Creek. The baseline ecological risk assessment addresses only surface water and sediment exposures to contaminants in Upper East Fork Poplar Creek, Lake Reality, wetlands and seep associated with the East End carbon tetrachloride plume because the characterization area includes no substantial habitat for terrestrial biota. Risks were estimated from radionuclides measured in surface water collected from sampling stations within the Upper East Fork Poplar Creek characterization area. Radionuclide concentrations in Upper East Fork Poplar Creek surface water do not appear to present a significant risk to any of the assessment endpoints. Dose rates were below the recommended limits for fish, benthic invertebrates, and piscivorous wildlife (mink and belted kingfisher).

The Bear Creek watershed consists of Bear Creek from its confluence with Lower East Fork Poplar Creek to the headwaters at the western edge of the Y-12 Plant, the associated floodplain and tributaries, and the source area in upper Bear Creek Valley (DOE 1997c). The primary sources considered in the ecological assessment were the waste and secondary contamination at the S-3 Ponds, the Bone Yard/Burn Yard, Sanitary Landfill 1, and Bear Creek Burial Grounds. No detectable radiation effects are anticipated for individual terrestrial biota (plant, earthworm, terrestrial, or semi-aquatic wildlife receptors) frequenting Bear Creek, its floodplain, or source area sites. The overall current dose rate was below the effects thresholds for all receptors at all of these sites. Alpha radiation exposures related to ingestion of contaminated prey accounted for virtually all of the dose for all receptors. External exposures were determined to be inconsequential.

At ETTP data were aggregated within subwatersheds and used to evaluate possible risks to fish and other aquatic organisms, piscivorous wildlife, terrestrial plants, soil invertebrates, and terrestrial wildlife receptors (BJC 2004d, 2004e). The primary areas of concern for aquatic organisms appear to be the K-901-A Holding Pond, the K-1007 P1 Pond, and Mitchell Branch. Potential risks to aquatic organisms or piscivorous or aerial insectivorous wildlife receptors were evident or likely in these three water bodies while potential risks at other ETTP water bodies (the K720 Slough, K-770 Embayment, K-1007 P3, P4, and P5 Ponds, and upper reach of Mitchell Branch) were considerably lower and less extensive. Maximum PCB concentrations in fish from K-1007 P1 were an order of magnitude higher than in fish from the K-901 Pond or Mitchell Branch. Dose rate calculations for fish, benthic invertebrates, and piscivorous wildlife indicated radionuclides in surface water and sediment were unlikely to be a concern for these receptors.

While all subwatersheds included at least one surface soil analyte with a maximum concentration exceeding benchmark levels for at least one terrestrial receptor, metals and/or PCBs in the K-770 Scrapyard within the Powerhouse subwatershed, the K-25 North Trash Slope within the K-27/K-29/K-1064 subwatershed, and portions of the habitat area along Mitchell Branch in the Mitchell Branch subwatershed appear to pose the greatest likelihood of unacceptable risks to terrestrial receptors. These same areas also had radionuclide levels potentially resulting in doses above threshold levels for one or more terrestrial receptors. In all cases internal exposures to uranium isotopes were identified as the primary contributors to elevated radiation dose levels. Dose rates from soil at the K-901/K-1070-A, Duct Island, K-1007, Contractor's Spoil, and K-33 subwatersheds were below dose rate limits for all receptors.

The DOE Environmental Management Program in in the process of planning an ORRwide ecological risk assessment and monitoring strategy to provide consistent and comprehensive protection of ecological resources on the ORR.

\subsubsection{Current-Year Summary}

A summary of the maximum EDEs to individuals by pathway of exposure is given in Table 8.7. It is very unlikely (if not impossible) that any real person could have been irradiated by all of these sources and pathways for the duration 
Table 8.7. Summary of maximum potential radiation dose equivalents to an adult during 2003 and locations of the maximum exposures

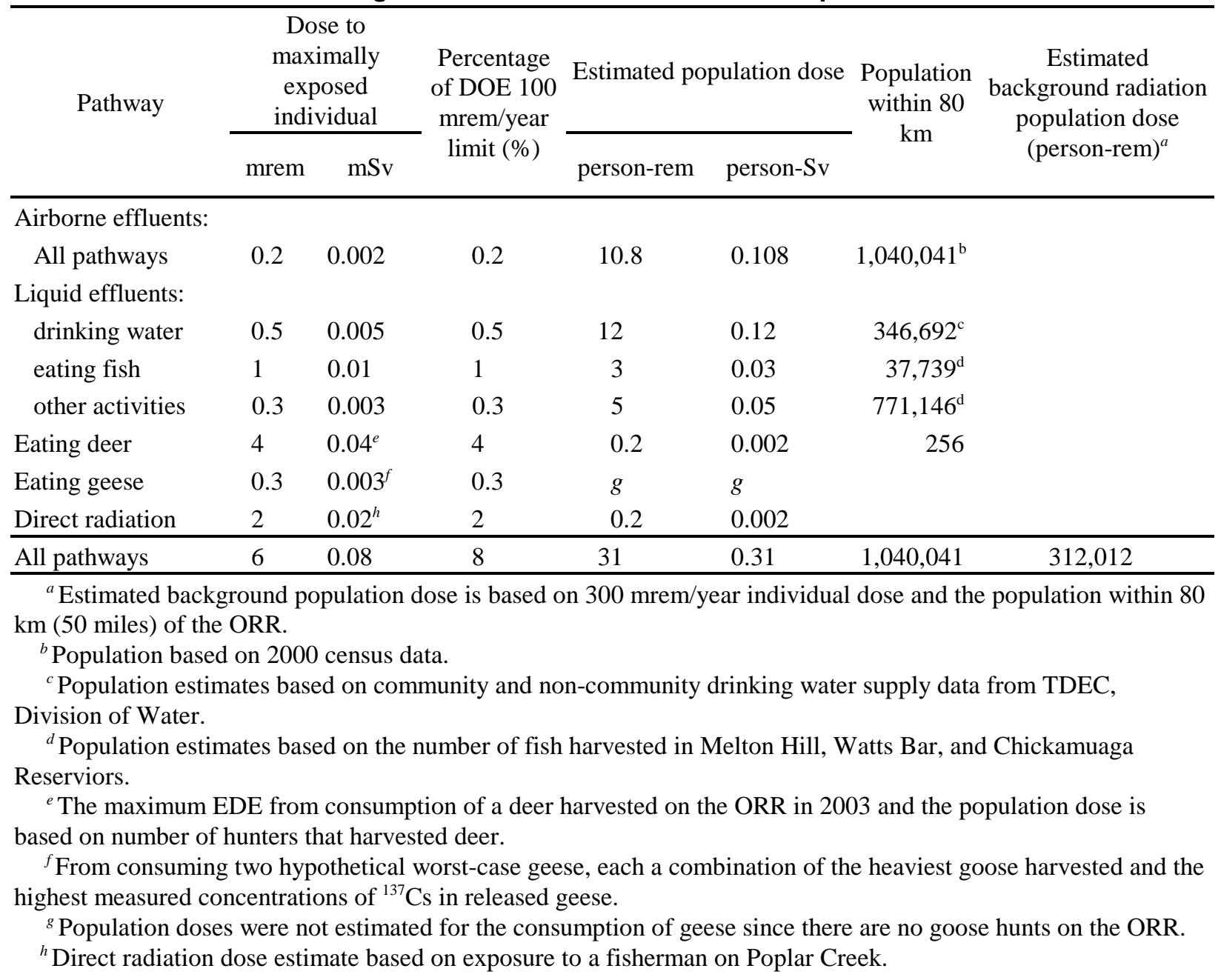

of 2003; however, if someone were, that person could have received a total EDE of about 4 mrem $(0.4 \mathrm{mSv})$; of this total, $0.2 \mathrm{mrem}(0.002 \mathrm{mSv})$ would have come from airborne emissions, 0.5 mrem $(0.005 \mathrm{mSv})$ from drinking Clinch River water, $1 \mathrm{mrem}(0.01 \mathrm{mSv})$ from eating fish from the Clinch River, 2 mrem (0.02 mSv) from fishing on Poplar Creek inside the ETTP, and 0.3 mrem $(0.003 \mathrm{mSv})$ from other water uses on the Clinch River. This dose is about $1 \%$ of the annual dose [300 mrem ( $3 \mathrm{mSv})$ ] from background radiation. If this person also was the person who received the highest EDEs from eating wildlife harvested on the ORR, that person could not have received an additional committed EDE greater than about 4 mrem $(0.04 \mathrm{mSv})$.
DOE Order 5400.5 limits to no more than 100 mrem $(1 \mathrm{mSv})$ the EDE that an individual may receive from all exposure pathways from all radionuclides released from the ORR during 1 year. As described in the preceding paragraph, the 2003 maximum EDE should not have exceeded about $6 \mathrm{mrem}(0.6 \mathrm{mSv})$, or about $6 \%$ of the limit given in DOE Order 5400.5. For further information, see Table F.2 in Appendix F, which provides a summary of dose levels associated with a wide range of activities.

The total collective EDE to the population living within a 50-mile $(80-\mathrm{km})$ radius of the ORR was estimated to be less than 31 person-rem ( 0.31 person-Sv). This dose is about $0.01 \%$ of the 312,012 person-rem (3123 person-Sv) that this 
population received from natural sources during 2003.

\subsubsection{Five-Year Trends}

Dose equivalents associated with selected exposure pathways for the years from 1999 to 2003 are given in Table 8.8. The variations in values over this 5-year period likely are not statistically significant. The dose estimates for direct irradiation along the Clinch River have been corrected for background.

\subsubsection{Potential Contributions from Non-DOE Sources}

There are several non-DOE facilities on or near the ORR that could contribute radiation doses to the public. These facilities submit annual reports to demonstrate compliance with NESHAP regulations and the terms of their operating licenses. DOE requested information pertaining to potential radiation dose to members of the public who also could have been affected by releases from these facilities. Seven facilities responded to the DOE request. Based on these responses, no member of the public should have received an EDE greater than 3.3 mrem $(3.3 \mathrm{E}-02 \mathrm{mSv})$ due to airborne releases from any of these facilities. The maximally exposed individual dose of 3.3 mrem/year was estimated at one of the facilities boundary. Three facilities responded regarding water releases; two facilities had no water releases, and one facility had releases to the sanitary sewer system that complied with site, state, and NRC regulatory requirements.

\subsection{CHEMICAL DOSE}

\subsubsection{Drinking Water Consumption}

To evaluate the drinking water pathway, hazard quotients (HQs) were estimated upstream and downstream of the ORR discharge points (see Table 8.9 and refer to Appendix $G$ for a detailed description of the chemical dose methodology). As in 2000 through 2002, chemical analytes were measured only in surface water samples collected at CRK 70 and CRK 16. CRK 70 is located upstream of all DOE discharge points, and CRK 16 is located downstream of all DOE discharge points. As shown in Table 8.9, HQs were less than 1 for detected chemical analytes for which there are reference doses or maximum contaminant levels. Acceptable risk levels for carcinogens typically range from $10^{-4}$ to $10^{-6}$. Risk values greater than $10^{-5}$ were calculated for the intake of arsenic in water collected at both upstream and downstream locations.

\subsubsection{Fish Consumption}

Chemicals in water can be accumulated by aquatic organisms that may be consumed by humans. To evaluate the potential health effects from the fish consumption pathway, HQs were estimated for the consumption of noncarcinogens, and risk values were estimated for the consumption of carcinogens detected in sunfish and catfish collected both upstream and downstream of the ORR discharge points. In the current assessment, a fish consumption rate of 60 $\mathrm{g} /$ day ( $0.13 \mathrm{lb} /$ day) [21 kg/year (46 lb/year)] is assumed for both the noncarcinogenic and carcinogenic pollutants; this is the same fish consumption rate used in the estimation of the maximally exposed radiological dose from consumption of fish. TDEC uses a method developed by EPA to establish fish consumption advisories for carcinogenic pollutants [as described in TDEC 1200-4-3-.03 (j) (TDEC 2004)]. Using the mean daily consumption rate of $6.5 \mathrm{~g}$ /day would reduce both the HQ values and the risk values by a factor of approximately 10 . (See Appendix $\mathrm{G}$ for a detailed description of the chemical dose methodology.)

As shown in Table 8.10, for consumption of sunfish, HQ values of less than 1 were calculated for the detected analytes at all three locations. For consumption of catfish, HQ values were less than 1 for all detected analytes except for Aroclor-1254 and Aroclor-1260 at all three locations.

For carcinogens in sunfish and catfish, risk values greater than $10^{-5}$ were calculated for the intake of arsenic and Aroclor-1260 found in sunfish and catfish collected at all three locations. In catfish, risk values greater than $10^{-5}$ were calculated for Aroclor-1254 and Aroclor-1260 at all three collection locations. TDEC has issued a fish advisory that states that catfish should not be 
Table 8.8. Trends in total effective dose equivalent (mrem) ${ }^{a}$ for selected pathways

\begin{tabular}{lccccc}
\hline \multicolumn{1}{c}{ Pathway } & 1999 & 2000 & 2001 & 2002 & 2003 \\
\hline All air & 0.7 & 0.4 & 0.8 & 0.3 & 0.2 \\
Fish consumption (Clinch River) & 4 & 1 & 0.2 & 0.3 & 1 \\
Drinking water (Kingston) & 0.16 & No data & $0.03^{b}$ & $0.04^{b}$ & 0.1 \\
Direct radiation (Clinch River) & $0.4^{c}$ & $0.4^{c}$ & $0.4^{c}$ & $0.4^{c}$ & 0.4 \\
Direct radiation (Poplar Creek) & $2^{c}$ & $1^{c}$ & $2^{c}$ & $2^{c}$ & $2^{d}$ \\
\hline
\end{tabular}

${ }^{a} 1 \mathrm{mrem}=0.01 \mathrm{mSv}$.

${ }^{b}$ Based on water samples from the Clinch River System.

${ }^{c}$ These values have been corrected by removing the contribution of natural background radiation and by using International Commission on Radiological Protection recommendations for converting external exposure to effective dose equivalent.

${ }^{d}$ Included gamma and neutron radiation measurement data.

Table 8.9. 2003 chemical hazard quotients and estimated risks for for drinking water ${ }^{2}$

\begin{tabular}{|c|c|c|}
\hline \multirow{2}{*}{ Chemical } & \multicolumn{2}{|c|}{ Hazard quotient } \\
\hline & CRK $70^{b}$ & CRK $16^{c}$ \\
\hline Antimony & $\sim 0.01$ & 0.009 \\
\hline Arsenic & $\sim 0.2$ & $\sim 0.2$ \\
\hline Acetone & $\sim 0.0002$ & $\sim 0.0001$ \\
\hline Barium & 0.01 & 0.02 \\
\hline Beryllium & $\sim 0.0006$ & 0.0008 \\
\hline Boron & 0.005 & 0.005 \\
\hline Cadmium & $\sim 0.003$ & $\sim 0.004$ \\
\hline Chromium & $\sim 0.007$ & $\sim 0.01$ \\
\hline Lead & 0.1 & $\sim 0.2$ \\
\hline Manganese & 0.01 & 0.01 \\
\hline Mercury & $\sim 0.006$ & $\sim 0.008$ \\
\hline Molybdenum & 0.004 & 0.003 \\
\hline Nickel & 0.002 & 0.002 \\
\hline Selenium & 0.009 & 0.009 \\
\hline Silver & $\sim 0.0005$ & $\sim 0.00006$ \\
\hline Strontium & 0.6 & 0.004 \\
\hline Thallium & 0.1 & 0.08 \\
\hline Uranium & 0.002 & $\sim 0.003$ \\
\hline Vanadium & $\sim 0.005$ & $\sim 0.005$ \\
\hline Zinc & $\sim 0.0006$ & 0.003 \\
\hline \multicolumn{3}{|c|}{ Risk for carcinogens } \\
\hline Arsenic & $\sim 9 \mathrm{E}-5$ & $\sim 4 \mathrm{E}-5$ \\
\hline
\end{tabular}

${ }^{a} \mathrm{~A}$ tilde $(\sim)$ indicates that estimated values were used in the calculation.

${ }^{b}$ Melton Hill Reservoir above city of Oak Ridge input.

${ }^{c}$ Clinch River downstream of all DOE inputs. 
Table 8.10. 2003 chemical hazard quotients (HQs) and estimated risk for carcinogens in fish ${ }^{2}$

\begin{tabular}{|c|c|c|c|c|c|c|}
\hline \multirow{2}{*}{ Parameters } & \multicolumn{3}{|c|}{ Sunfish } & \multicolumn{3}{|c|}{ Catfish } \\
\hline & CRK $70^{b}$ & CRK $32^{c}$ & CRK $16^{d}$ & CRK $70^{b}$ & CRK $32^{c}$ & CRK $16^{d}$ \\
\hline \multicolumn{7}{|c|}{ HQs for metals } \\
\hline Antimony & & & $\sim 0.1$ & & & \\
\hline Arsenic & 0.36 & 0.24 & 0.3 & 0.3 & 0.2 & $\sim 0.3$ \\
\hline Barium & 0.003 & 0.004 & 0.004 & 0.0008 & 0.0006 & 0.0005 \\
\hline Beryllium & 0.0007 & 0.001 & 0.006 & $\sim 0.0007$ & $\sim 0.0002$ & \\
\hline Cadmium & & & $\sim 0.02$ & 0.02 & $\sim 0.01$ & $\sim 0.01$ \\
\hline Chromium & 0.03 & 0.03 & 0.03 & 0.02 & & $\sim 0.005$ \\
\hline Lead & & 0.2 & $\sim 0.2$ & 0.2 & $\sim 0.2$ & 0.1 \\
\hline Manganese & 0.009 & 0.008 & 0.01 & 0.001 & 0.0009 & 0.001 \\
\hline Mercury & 0.07 & 0.3 & 0.3 & 0.6 & 0.4 & 0.2 \\
\hline Nickel & 0.001 & $\sim 0.0008$ & $\sim 0.0008$ & $\sim 0.002$ & & \\
\hline Selenium & 0.2 & 0.2 & 0.1 & 0.05 & 0.04 & 0.06 \\
\hline Silver & & & & $\sim 0.005$ & & \\
\hline Strontium & 0.002 & 0.003 & 0.003 & 0.0002 & 0.0002 & 0.0002 \\
\hline Thallium & 0.1 & 0.1 & 0.1 & 0.06 & 0.05 & 0.07 \\
\hline Uranium & 0.0001 & 0.0002 & 0.0003 & 0.0001 & 0.0001 & 0.0001 \\
\hline Vanadium & $\sim 0.002$ & $\sim 0.002$ & $\sim 0.003$ & & & \\
\hline Zinc & 0.05 & 0.05 & 0.04 & 0.02 & 0.02 & 0.02 \\
\hline \multicolumn{7}{|c|}{ HQs for pesticides and Aroclors } \\
\hline Aroclor-1254 & & & & 1.6 & $\sim 2.6$ & 1.2 \\
\hline Aroclor-1260 & 0.98 & $\sim 0.78$ & 0.95 & 7.8 & 30.4 & 5.8 \\
\hline Chlordane,gamma & & & & 0.002 & $\sim 0.003$ & 0.005 \\
\hline Endosulfan sulfate & & & & & & 0.0005 \\
\hline Heptaclor epoxide & & & & & & $\sim 0.2$ \\
\hline \multicolumn{7}{|c|}{ Risks for carcinogens } \\
\hline Arsenic & $7 \mathrm{E}-5$ & $5 \mathrm{E}-5$ & $5 \mathrm{E}-5$ & $5 \mathrm{E}-5$ & $4 \mathrm{E}-5$ & $\sim 6 \mathrm{E}-5$ \\
\hline Aroclor-1254 & & & & $3 \mathrm{E}-5$ & $\sim 5 \mathrm{E}-5$ & $2 \mathrm{E}-5$ \\
\hline Aroclor-1260 & $2 \mathrm{E}-5$ & $\sim 1 \mathrm{E}-5$ & $2 \mathrm{E}-5$ & $1 \mathrm{E}-4$ & $5 \mathrm{E}-4$ & $9.9 \mathrm{E}-5$ \\
\hline Chlordane, gamma & & & & $2 \mathrm{E}-7$ & $\sim 2 \mathrm{E}-7$ & $4 \mathrm{E}-7$ \\
\hline Heptaclor epoxide & & & & & & $\sim 7 \mathrm{E}-6$ \\
\hline PCBs (mixed) $)^{e}$ & $2 \mathrm{E}-5$ & $\sim 1 \mathrm{E}-5$ & $2 \mathrm{E}-5$ & $2 \mathrm{E}-4$ & $6 \mathrm{E}-4$ & $1 \mathrm{E}-4$ \\
\hline
\end{tabular}

${ }^{a} \mathrm{~A}$ tilde $(\sim)$ indicates that estimated values were used in the calculation, and a blank space indicates that the parameter was undetected.

${ }^{b}$ Melton Hill Reservoir, above Oak Ridge city input.

${ }^{c}$ Clinch River, downstream of ORNL.

${ }^{d}$ Clinch River, downstream of all DOE inputs.

${ }^{e}$ Mixed PCBs consists of the summation of Aroclors detected or estimated. 
consumed from Melton Hill Reservoir (in its entirety) because of PCB contamination and has issued a precautionary fish consumption advisory for catfish in the Clinch River arm of Watts Bar Reservoir (TDEC 1993). 


\section{Quality Assurance}

The overall goal of a well-designed and well-implemented sampling and analysis program is to measure accurately what is really there. Environmental decisions are made on the assumption that analytical results are, within known limits of accuracy and precision, representative of site conditions. Many sources of error exist that could affect the analytical results. Factors to consider as sources of error include improper sample collection, handling, preservation, and transport; inadequate personnel training; and inappropriate analytical methods, data reporting, and record keeping. A quality assurance program is designed to minimize these sources of error and to control all phases of the monitoring process.

\subsection{INTRODUCTION}

The application of a quality assurance/quality control (QA/QC) program for environmental monitoring activities at the ORR is essential for generating data of known and defensible quality. Each aspect of the environmental monitoring program, from sample collection to data management, must address and meet applicable quality standards.

\subsection{FIELD SAMPLING QUALITY ASSURANCE}

Field sampling QA encompasses many practices that minimize error and evaluate sampling performance. Some key quality practices include the following:

- use of standard operating procedures for sample collection and analysis;

- use of chain-of-custody and sample-identification procedures;

- instrument standardization, calibration, and verification;

- technician and analyst training;

- sample preservation, handling, and decontamination; and

- use of QC samples, such as field and trip blanks, duplicates, and equipment rinses.

Because of changing technologies and regulatory protocols, training of field personnel is a continuing process. To ensure that qualified personnel are available for the array of sampling tasks to be accomplished, training programs by the EPA and by private contractors have been used to supplement internal training. Examples of topics addressed include the following:
- planning, preparation, and record keeping for field sampling;

- well construction and groundwater sampling;

- surface water, leachate, and sediment sampling;

- soil sampling;

- stack sampling;

- decontamination procedures; and

- health and safety considerations.

\subsection{ANALYTICAL QUALITY ASSURANCE}

The contract analytical laboratories have wellestablished QA/QC programs, well-trained and highly qualified staff, and excellent equipment and facilities. Current, approved analytical methodologies employing good laboratory and measurement control practices are used routinely to ensure analytical reliability. The analytical laboratories conduct extensive internal QC programs with a high degree of accuracy, participate in several external QA programs, and use statistics to evaluate and continuously improve performance. Thus, QA and QC are daily responsibilities of all employees.

\subsubsection{Internal Quality Control}

Analytical activities are supported by the use of standard materials or reference materials (e.g., materials of known composition that are used in the calibration of instruments, methods standardization, spike additions for recovery tests, and other practices). Certified standards traceable to the National Institute of Standards and Technology (NIST), other DOE sources, or EPA are used for such work. The laboratories operate 
under specific QA/QC criteria. Additionally, separate QA/QC documents relating to analysis of environmental samples associated with regulatory requirements are developed.

QA/QC measurement control programs external to the sample analysis groups have single-blind control samples submitted to the analytical laboratories to monitor performance. The results of such periodic measurement programs are statistically evaluated and reported to the laboratories and their customers. Most reports are issued quarterly, and some laboratories compile annual summary reports. These reports assist in evaluating the adequacy of analytical support programs and procedures. If serious deviations are noted by the QA/QC groups, the operating laboratories are promptly notified so that corrective actions can be initiated and problems can be resolved. QC data are stored in an easily retrievable manner so that they can be related to the analytical results they support.

\subsubsection{External Quality Assurance}

In addition to the internal programs, all contract analytical laboratories participate in external QA programs. The QA programs generate data that are readily recognizable as objective packets of results. The external QA programs typically consist of the contract laboratories analyzing a sample of unknown composition provided by various DOE- or EPAapproved proficiency-testing supplier organizations. The organizations know the true composition of the sample and provide the contract laboratories with a data report on their analytical performance. The sources of these programs are laboratories within DOE and the commercial sector. The following sections describe the external QA programs in which contract analytical laboratories may be required to participate.

\subsubsection{EPA Water Pollution and Water Supply Performance Studies}

Participation in the Water Pollution Program and the Water Supply Program studies is required by most states for laboratories performing analyses of water samples for regulatory programs. The Water Supply Program is used by the state of Tennessee to certify laboratories for drinking water analysis. To maintain a certification, a laboratory must meet a specified set of criteria relating to technical personnel, equipment, work areas, QA/QC operating procedures, and successful analysis of QA samples. This program is also used by other states as part of their certification programs. Participation in the Water Pollution program satisfies the EPA and NPDES program requirement for laboratories performing Clean Water Act analyses to participate in a Discharge Monitoring Report Quality Assurance Program.

Since October 24, 1999, all water pollution and water supply studies except for whole effluent toxicity testing have been performed by private companies. NIST certifies non-EPA proficiency testing providers to prepare performance evaluation samples and to evaluate laboratory performance. EPA continues to issue standard operating procedures for use in the water supply and water pollution programs.

\subsubsection{American Industrial Hygiene Association Proficiency Analytical Testing Program}

The American Industrial Hygiene Association (AIHA) administers the Proficiency Analytical Testing Program as part of its AIHA accreditation process for laboratories performing analyses of industrial hygiene air samples.

\subsubsection{Intercomparison Radionuclide Control Program}

The EPA Intercomparison Radionuclide Control Program administered by the National Exposure Research Laboratory at Las Vegas has been replaced by a vendor-supplied program approved by EPA. Samples are composed of a water matrix. The state of Tennessee requires participation for drinking water certification of radionuclide analysis. This program is also used by other states as part of their laboratory certification process. 


\subsubsection{AlHA Environmental Lead Proficiency Analytical Testing Program}

The Environmental Lead Proficiency Analytical Testing Program is administered by AIHA. This program was established in 1992 to evaluate analysis of environmental lead samples in paint, soil, and dust wipes. The participating laboratory can analyze each matrix at four levels. In addition, a laboratory may request to become accredited for lead analysis in this program.

\subsubsection{DOE Mixed Analyte Performance Evaluation Program}

The Mixed Analyte Performance Evaluation Program is a program set up by the DOE Radiological and Environmental Sciences Laboratory in conjunction with the Laboratory Management Division of the Office of Technology Development to evaluate analysis of mixed-waste samples. Participation is required by DOE for laboratories that perform environmental analytical measurements in support of environmental management activities.

\subsubsection{DOE Environmental Measurements Laboratory Quality Assessment Program}

The Radionuclide Quality Assessment Program is administered by the DOE Environmental Measurements Laboratory in New York. Various matrices, such as soil, water, air filters, and vegetation, are submitted semiannually for analysis of a variety of radioactive isotopes. All matrices, except air filters, are actual materials obtained from the environment at a DOE facility. A statistical report is issued by Environmental Measurements Laboratory for each study.

\subsubsection{Proficiency Environmental Testing Program}

The Proficiency Environmental Testing Program is a service purchased from an outside vendor and is used by some contract analytical laboratories to meet the need for a QA program for environmental analyses. The samples are supplied by the commercial company at concentrations that meet the EPA-established guidelines. Data from the laboratory are reported to the supplier. The commercial supplier provides a report on the evaluated data to the laboratory. The report includes a percentage recovery of the referenced value, deviation from the mean of all reported data, specific problems in a laboratory, and other statistical information.

\subsubsection{Quality Assessment Program for Subcontracted Laboratories}

A competitive award system has been established by the BJC Sample Management Office to place analytical work that is required by BJC. The Sample Management Office provides single-point sample management for $\mathrm{BJC}$ projects/programs and BJC subcontractors. Commercial laboratories approved by the Sample Management Office are required to comply with the requirements set forth in the Integrated Contractor Procurement Team Basic Ordering Agreement terms and conditions. Oversight of subcontracted commercial laboratories is performed by the DOE Environmental Management Consolidated Audit Program, which is supported by the Sample Management Office. DOE, the Sample Management Office, and other subcontractors from across the DOE complex work together in the Environmental Management Consolidated Audit Program to conduct on-site laboratory reviews and to monitor the performance of all subcontracted laboratories. Awards are made to laboratories to provide analytical support to BJC projects based on the best value added to the project. Best value is a graded approach that comprises price and performance history.

BJC manages the Integrated Performance Indicator Program to report quality indicators that will assess trends for commercial analytical laboratories used to support BJC projects (and their subcontractors) within the DOE-ORO. The objective of the Integrated Performance Indicator Program is to evaluate all analytical laboratories 
based on a set of standardized performance criteria that can then be quantitatively tracked and trended. BJC management uses these performance indicators to develop performance indicator factors, which are used as modifier factors when evaluating cost bids. In this approach, the low bidder may not win the work unless they have a favorable performance indicator factor score.

A limited basic order agreement with commercial laboratories has been established by UT-Battelle for the procurement of analytical services to characterize environmental and was te samples. Laboratories included in the agreement are required to comply with the terms and conditions of the Integrated Contractor Procurement Team Contract, Basic Order Agreement. A statement of work for each project specifies any additional QA/QC requirements and includes detailed information data deliverables, turnaround times, and required methods.

\subsubsection{Single-Blind PE Program}

If applicable, laboratories participate in several external single-blind performance evaluation programs. All results that are officially reported by the responsible agency (EPA or DOE) during the period of evaluation are used in computing the single-blind performance evaluation score. Single-blind performance evaluation program results are categorized into radiochemistry, organic, and inorganic methodology areas.

\subsubsection{Double-Blind Performance Evaluation Program}

Double-blind performance evaluation programs are employed to quantitatively evaluate the total laboratory process. Performance samples are submitted to laboratories with batches of actual field samples in order to ensure that the laboratory is not able to distinguish them as QA samples. Once the project data have been received, the performance evaluation results are evaluated and scored. Double-blind performance evaluation program results are categorized into radiological, organic, and inorganic methodology areas.

The BJC SMO combines single- and doubleblind performance evaluation scores to obtain a total Integrated Performance Indicator Program performance evaluation score. A laboratory must score $80 \%$ or better to remain in good standing. A score of 64 to $79 \%$ would result in a laboratory being placed on probation.

\subsection{DATA MANAGEMENT, VERIFICATION, AND VALIDATION}

Verification and validation of environmental data are performed as components of the data collection process, which includes planning, sampling, analysis, and data review. Verification and validation of field and analytical data collected for environmental monitoring and restoration programs are necessary to ensure that data conform with applicable regulatory and contractual requirements. Validation of field and analytical data is a technical review performed to compare data with established quality criteria to ensure that data are adequate for the intended use. The extent of project data verification and validation activities is based on project-specific requirements.

Over the years, the environmental data verification and data validation processes used by ORR environmental programs have evolved to meet continuing regulatory changes and monitoring objectives. For routine environmental effluent monitoring and surveillance monitoring, data verification activities may include processes of checking whether (1) data have been accurately transcribed and recorded, (2) appropriate procedures have been followed, (3) electronic and hard-copy data show one-to-one correspondence, and (4) data are consistent with expected trends. For example, the requirements for self-monitoring of surface-water and wastewater effluents under the terms of an NPDES permit require the permittee to conduct the analyses as defined in 40 CFR 136 and to certify that the data reported in the monthly discharge monitoring report are true and accurate.

Typically, routine data verification actions alone are sufficient to document the truthfulness 
and accuracy of the discharge monitoring report. For restoration projects, routine verification activities are more contractually oriented and include checks for data completeness, consistency, and compliance against a predetermined standard or contract.

Certain projects may perform a more thorough technical validation of the data as mandated by the project's data quality objectives. For example, sampling and analyses conducted as part of a remedial investigation to support the CERCLA process may generate data that are needed to evaluate risk to human health and the environment, to document that no further remediation is necessary, or to support a multimillion-dollar construction activity and treatment alternative. In that case, the data quality objectives of the project may mandate a more thorough technical evaluation of the data against predetermined criteria. For example, EPA has established functional guidelines for validation of organic and inorganic data collected under the protocol of the EPA's Contract Laboratory Program. These guidelines are used to offer assistance to the data user in evaluating and interpreting the data generated from monitoring activities that require Contract Laboratory Program performance.

The validation process may result in identifying data that do not meet predetermined QC criteria (in flagging quantitative data that must be considered qualitative only) or in the ultimate rejection of data from its intended use. Typical criteria evaluated in the validation of Contract Laboratory Program data include the percentage of surrogate recoveries, spike recoveries, method blanks, instrument tuning, instrument calibration, continuing calibration verifications, internal standard response, comparison of duplicate samples, and sample-holding times.

Integration of compliance-monitoring data for the ORR with sampling and analysis results from remedial investigations is a function of the Oak Ridge Environmental Information System (OREIS). OREIS is necessary to fulfill requirements prescribed in both the Federal Facility Agreement and the Tennessee Oversight Agreement and to support data management activities for DOE. The Federal Facility Agreement, a tripartite agreement among DOE, EPA Region 4, and the state of Tennessee, requires DOE to maintain one consolidated database for environmental data generated at DOE facilities on the ORR. According to the Federal Facility Agreement, the consolidated database is to include data generated pursuant to the agreement as well as data generated under federal and state environmental permits. The Tennessee Oversight Agreement further defines DOE staff obligations to develop a quality-assured, consolidated database of monitoring information that will be shared electronically on a near-real-time basis with the state staff.

OREIS is the primary component of the data management program for restoration projects, providing consolidated, consistent, and welldocumented environmental data and data products to support planning, decision-making, and reporting activities. OREIS provides a direct electronic link of ORR monitoring and remedial investigation results to EPA Region 4 and the TDEC/DOE Oversight Division. 

Appendix A: Errata 



\section{Appendix A: Errata}

The following corrections pertain to Oak Ridge Reservation Annual Site Environmental Report for 2002, DOE/ORO/2159, Oak Ridge National Laboratory, Oak Ridge, Tennessee, September 2003.

In Sect. 5.9.1, page 5-27, second paragraph, first full paragraph, the first sentence should read as follows.

UT-Battelle's WAG perimeter monitoring network and the ORNL plant perimeter groundwater surveillance program involved 49 wells in 2002.

In. Sect. 5.9.3.1, page 5-30, the last sentence in the first paragraph under "WAG Results" should be replaced with text that reads as follows.

Seven radiological contaminant concentrations exceeded their respective reference values in 2002 (tritium in Well 1152; tritium in Well 1156; gross beta, total radioactive strontium, and tritium in Well 1191 (also an exit pathway well); tritium in Well 1190 (also an exit pathway well); and gross beta activity in Well 1244. From 1991 to 2002, a statistically significant decrease in tritium concentration trend was detected for Well 1190 (at a level of significance of 0.01).

In Sect. 5.9.3.8, page 5-34, first paragraph, the third sentence should read as follows.

Consequently, only six wells $(860,857,858,859,1236$, and 1239) will be discussed herein. 

Appendix B: Glossary 



\section{Glossary of Environmental Terms}

absorption, atomic - The process by which the number and energy of particles or photons entering a body of matter is reduced by interaction with the matter.

accuracy - The closeness of the result of a measurement to the true value of the quantity.

ACM - Asbestos-containing materials.

aliquot - The quantity of sample being used for analysis.

alkalinity - A measure of the buffering capacity of water, and because $\mathrm{pH}$ has a direct effect on organisms as well as an indirect effect on the toxicity of certain other pollutants in the water, the buffering capacity is important to water quality.

alpha particle - A positively charged particle emitted from the nucleus of an atom; it has the same charge and mass as that of a helium nucleus (two protons and two neutrons).

ambient air - The surrounding atmosphere as it exists around people, plants, and structures.

analyte - A constituent or parameter that is being analyzed.

analytical detection limit - The lowest reasonably accurate concentration of an analyte that can be detected; this value varies depending on the method, instrument, and dilution used.

anion - A negatively charged ion.

aquifer - A saturated, permeable geologic unit that can transmit significant quantities of water under ordinary hydraulic gradients.

aquitard - A geologic unit that inhibits the flow of water.

ash - Inorganic residue remaining after ignition of combustible substances.

assimilate - To take up or absorb into the body.

atom - The smallest particle of an element capable of entering into a chemical reaction.

atomic absorption spectrometry (AA) - Chemical analysis performed by vaporizing a sample and measuring the absorbance of light by the vapor.

Atomic Energy Commission (AEC) - A federal agency created in 1946 to manage the development, use, and control of nuclear energy for military and civilian applications. It was abolished by the Energy Reorganization Act of 1974 and was succeeded by the Energy Research and Development Administration (now part of the U.S. Department of Energy and the U.S. Nuclear Regulatory Commission).

base/neutral and acid extractables (BNA) - A group of organic compounds analyzed as part of Appendix IX of 40 CFR 264 and the U.S. Environmental Protection Agency (EPA) list of priority pollutants. 
beta particle - A negatively charged particle emitted from the nucleus of an atom. It has a mass and charge equal to those of an electron.

biota - The animal and plant life of a particular region considered as a total ecological entity.

blank - A control sample that is identical, in principle, to the sample of interest, except that the substance being analyzed is absent. In such cases, the measured value or signal for the substance being analyzed is believed to be a result of artifacts. Under certain circumstances, that value may be subtracted from the measured value to give a net result reflecting the amount of the substance in the sample. EPA does not permit the subtraction of blank results in EPA-regulated analyses.

calibration - Determination of variance from a standard of accuracy of a measuring instrument to ascertain necessary correction factors.

carcinogen - A cancer-causing substance.

cation - A positively charged ion.

CERCLA-reportable release - A release to the environment that exceeds reportable quantities as defined by the Comprehensive Environmental Response, Compensation, and Liability Act (CERCLA).

chain-of-custody — A form that documents sample collection, transport, analysis, and disposal.

chemical oxygen demand - Indicates the quantity of oxidizable materials present in water and varies with water composition, concentrations of reagent, temperature, period of contact, and other factors.

chlorocarbons - Compounds of carbon and chlorine, or carbon, hydrogen, and chlorine, such as carbon tetrachloride, chloroform, and tetrachloroethene. They are among the most significant and widespread environmental contaminants. Classified as hazardous wastes, chlorocarbons may have a tendency to cause detrimental effects, such as birth defects.

closure - Specifically, closure of a hazardous waste management facility under Resource Conservation and Recovery Act (RCRA) requirements.

compliance - Fulfillment of applicable requirements of a plan or schedule ordered or approved by government authority.

concentration - The amount of a substance contained in a unit volume or mass of a sample.

conductivity - A measure of water's capacity to convey an electric current. This property is related to the total concentration of the ionized substances in water and the temperature at which the measurement is made.

confluence - The point at which two or more streams meet; the point where a tributary joins the main stream.

contamination - Deposition of unwanted material on the surfaces of structures, areas, objects, or personnel.

cosmic radiation - Ionizing radiation with very high energies, originating outside the earth's atmosphere. Cosmic radiation is one source contributing to natural background radiation.

\section{B-4 Appendix B: Glossary}


count - A measure of the radiation from an object or device; the signal that announces an ionization event within a counter.

curie (Ci) - A unit of radioactivity. One curie is defined as $3.7 \times 10^{10}$ (37 billion) disintegrations per second. Several fractions and multiples of the curie are commonly used:

kilocurie $(\mathbf{k C i})-10^{3} \mathrm{Ci}$, one thousand curies; $3.7 \times 10^{13}$ disintegrations per second.

millicurie (mCi) $-10^{-3} \mathrm{Ci}$, one-thousandth of a curie; $3.7 \times 10^{7}$ disintegrations per second.

microcurie $(\mu \mathbf{C i})-10^{-6} \mathrm{Ci}$, one-millionth of a curie; $3.7 \times 10^{4}$ disintegrations per second.

picocurie (pCi) $-10^{-12} \mathrm{Ci}$, one-trillionth of a curie; 0.037 disintegrations per second.

DAPC - Division of Air Pollution Control (state of Tennessee).

daughter - A nuclide formed by the radioactive decay of a parent nuclide.

decay, radioactive - The spontaneous transformation of one radionuclide into a different radioactive or nonradioactive nuclide, or into a different energy state of the same radionuclide.

dense nonaqueous phase liquid (DNAPL) - The liquid phase of chlorinated organic solvents. These liquids are denser than water and include commonly used industrial compounds such as tetrachloroethene and trichloroethene.

derived concentration guide (DCG) - The concentration of a radionuclide in air or water that, under conditions of continuous exposure for one year by one exposure mode (i.e., ingestion of water, submersion in air, or inhalation), would result in either an effective dose equivalent of $0.1 \mathrm{rem}(1 \mathrm{mSv})$ or a dose equivalent of $5 \mathrm{rem}(50 \mathrm{mSv})$ to any tissue, including skin and lens of the eye. The guides for radionuclides in air and water are given in DOE Order 5400.5.

desorption - The process of removing a sorbed substance by the reverse of adsorption or absorption.

dilution factor - The mathematical factor by which a sample is diluted to bring the concentration of an analyte in a sample within the analytical range of a detector (e.g., $1 \mathrm{~mL}$ sample $+9 \mathrm{~mL}$ solvent $=1: 10$ dilution, or a dilution factor of 10).

disintegration, nuclear - A spontaneous nuclear transformation (radioactivity) characterized by the emission of energy and/or mass from the nucleus of an atom.

dissolved oxygen - A desirable indicator of satisfactory water quality in terms of low residuals of biologically available organic materials. Dissolved oxygen prevents the chemical reduction and subsequent leaching of iron and manganese from sediments.

dose - The energy imparted to matter by ionizing radiation. The unit of absorbed dose is the rad, equal to 0.01 joules per kilogram in any medium.

absorbed dose - The quantity of radiation energy absorbed by an organ, divided by the organ's mass. Absorbed dose is expressed in units of $\mathrm{rad}$ (or gray) ( $1 \mathrm{rad}=0.01 \mathrm{~Gy}$ ). 
dose equivalent - The product of the absorbed dose ( $\mathrm{rad})$ in tissue and a quality factor. Dose equivalent is expressed in units of rem (or sievert) $(1 \mathrm{rem}=0.01$ sievert).

committed dose equivalent - The calculated total dose equivalent to a tissue or organ over a 50 -year period after known intake of a radionuclide into the body. Contributions from external dose are not included. Committed dose equivalent is expressed in units of rem (or sievert).

committed effective dose equivalent - The sum of the committed dose equivalents to various tissues in the body, each multiplied by the appropriate weighting factor. Committed effective dose equivalent is expressed in units of rem (or sievert).

effective dose equivalent - The sum of the dose equivalents received by all organs or tissues of the body after each one has been multiplied by an appropriate weighting factor. The effective dose equivalent includes the committed effective dose equivalent from internal deposition of radionuclides and the effective dose equivalent attributable to sources external to the body.

collective dose equivalent/collective effective dose equivalent - The sums of the dose equivalents or effective dose equivalents of all individuals in an exposed population within a 50 -mile $(80-\mathrm{km})$ radius, and expressed in units of person-rem (or person-sievert). When the collective dose equivalent of interest is for a specific organ, the units would be organ-rem (or organ-sievert). The 50-mile distance is measured from a point located centrally with respect to major facilities or DOE program activities.

dosimeter - A portable detection device for measuring the total accumulated exposure to ionizing radiation.

dosimetry - The theory and application of principles and techniques involved in the measurement and recording of radiation doses. Its practical aspect is concerned with using various types of radiation instruments to make measurements.

downgradient - In the direction of decreasing hydrostatic head.

downgradient well - A well that is installed hydraulically downgradient of a site and may be capable of detecting migration of contaminants from a site.

DRH - Division of Radiological Health (state of Tennessee).

drinking water standard (DWS) - Federal primary drinking water standards, both proposed and final, as set forth by the EPA.

duplicate result - A result derived by taking a portion of a primary sample and performing the identical analysis on that portion as is performed on the primary sample.

duplicate samples - Two or more samples collected simultaneously into separate containers.

effluent - A liquid or gaseous waste discharge to the environment.

effluent monitoring - The collection and analysis of samples or measurements of liquid and gaseous effluents for purposes of characterizing and quantifying the release of contaminants, assessing radiation exposures of members of the public, and demonstrating compliance with applicable standards. 
Environmental Restoration - A DOE program that directs the assessment and cleanup of its sites (remediation) and facilities contaminated with waste as a result of nuclear-related activities.

exposure (radiation) - The incidence of radiation on living or inanimate material by accident or intent. Background exposure is the exposure to natural background ionizing radiation. Occupational exposure is the exposure to ionizing radiation that takes place during a person's working hours. Population exposure is the exposure to the total number of persons who inhabit an area.

external radiation - Exposure to ionizing radiation when the radiation source is located outside the body.

fecal coliform - The coliform group comprises all of the aerobic, non-spore-forming, rod-shaped bacteria. Testing determines the presence or absence of coliform organisms.

formation - A mappable unit of consolidated or unconsolidated geologic material of a characteristic lithology or assemblage of lithologies.

friable asbestos - Asbestos that is brittle or readily crumbled.

gamma ray - High-energy, short-wavelength electromagnetic radiation emitted from the nucleus of an excited atom. Gamma rays are identical to $\mathrm{X}$ rays except for the source of the emission.

gamma spectrometry - A system consisting of a detector, associated electronics, and a multichannel analyzer that is used to analyze samples for gamma-emitting radionuclides.

genotoxicology - The study of the effects of chemicals or radioactive contaminants on the genetics of individual animals or plants.

grab sample - A sample collected instantaneously with a glass or plastic bottle placed below the water surface to collect surface water samples (also called dip samples).

groundwater, unconfined - Groundwater exposed to the unsaturated zone.

half-life, biological - The time required for a biological system, such as that of a human, to eliminate by natural processes half the amount of a substance (such as a radioactive material) that has entered it.

half-life, radiological - The time required for half of a given number of atoms of a specific radionuclide to decay. Each nuclide has a unique half-life; half-lives can range in duration from less than a second to many millions of years.

halogenated compound - An organic compound bonded with one of the five halogen elements (astatine, bromine, chlorine, fluorine, or iodine).

halomethane - Any compound that includes a methane group $\left(\mathrm{CH}_{3}\right)$ bonded to a halogen element (astatine, bromine, chlorine, fluorine, or iodine).

hardness - Water hardness is caused by polyvalent metallic ions dissolved in water. In fresh water, these are mainly calcium and magnesium, although other metals such as iron, strontium, and manganese may contribute to hardness. 
heavy water - Water in which the molecules contain oxygen and deuterium, an isotope of hydrogen that is heavier than ordinary hydrogen.

herbaceous - Having little or no woody tissue.

hydrogeology — Hydrologic aspects of site geology.

hydrology - The science dealing with the properties, distribution, and circulation of natural water systems.

in situ - In its original place; field measurements taken without removing the sample from its origin; remediation performed while groundwater remains below the surface.

internal dose factor - A factor used to convert intakes of radionuclides to dose equivalents.

internal radiation - Internal radiation occurs when radionuclides enter the body by ingestion of foods, milk, and water, and by inhalation. Radon is the major contributor to the annual dose equivalent for internal radionuclides.

ion - An atom or compound that carries an electrical charge.

ion exchange - Process in which a solution containing soluble ions is passed over a solid ion exchange column that removes the soluble ions by exchanging them with labile ions from the surface of the column. The process is reversible so that the trapped ions are removed (eluted) from the column and the column is regenerated.

irradiation - Exposure to radiation.

isotopes - Forms of an element having the same number of protons in their nuclei but differing in the number of neutrons.

lower limit of detection (LLD) - The smallest concentration/amount of analyte that can be reliably detected in a sample at a $95 \%$ confidence level.

maximally exposed individual - A hypothetical individual who remains in an uncontrolled area and would, when all potential routes of exposure from a facility's operations are considered, receive the greatest possible dose equivalent.

mercury - A silver-white, liquid metal solidifying at $-38.9^{\circ} \mathrm{C}$ to form a tin-white, ductile, malleable mass. It is widely distributed in the environment and biologically is a nonessential or nonbeneficial element. Human poisoning from this highly toxic element has been clinically recognized.

microbes - Microscopic organisms.

migration - The transfer or movement of a material through the air, soil, or groundwater.

millirem (mrem) - The dose equivalent that is one one-thousandth of a rem.

milliroentgen $(\mathbf{m R})$ - A measure of X-ray or gamma radiation. The unit is one-thousandth of a roentgen. 
minimum detectable activity — The smallest activity of a radionuclide that can be distinguished in a sample by a given measurement system at a preselected counting time and at a given confidence level.

monitoring - A process whereby the quantity and quality of factors that can affect the environment and/or human health are measured periodically in order to regulate and control potential impacts.

natural radiation - Radiation arising from cosmic and other naturally occurring radionuclide sources (such as radon) present in the environment.

nuclide - An atom specified by its atomic weight, atomic number, and energy state. A radionuclide is a radioactive nuclide.

outfall - The point of conveyance (e.g., drain or pipe) of wastewater or other effluents into a ditch, pond, or river.

parts per billion (ppb) - A unit measure of concentration equivalent to the weight/volume ratio expressed as micrograms per liter or nanograms per milliliter.

parts per million (ppm) - A unit measure of concentration equivalent to the weight/volume ratio expressed as milligrams per liter.

person-rem - Collective dose to a population group. For example, a dose of 1 rem to 10 individuals results in a collective dose of 10 person-rem.

pH - A measure of the hydrogen ion concentration in an aqueous solution. Acidic solutions have a $\mathrm{pH}$ from 0 through 6 , basic solutions have a $\mathrm{pH}>7$, and neutral solutions have a $\mathrm{pH}=7$.

piezometer - An instrument used to measure the potentiometric surface of the groundwater. Also, a well designed for this purpose.

precision - The closeness of approach of a value of similar or replicate results to a common value in a series of measurements.

priority pollutants - A group of approximately 130 chemicals (about 110 are organics) that appear on an EPA list because they are toxic and relatively common in industrial discharges.

process sewer - Pipe or drain, generally located underground, used to carry off process water and/or waste matter.

process water - Water used within a system process.

purge - To remove water prior to sampling, generally by pumping or bailing.

quality assurance (QA) - Any action in environmental monitoring to ensure the reliability of monitoring and measurement data.

quality control (QC) - The routine application of procedures within environmental monitoring to obtain the required standards of performance in monitoring and measurement processes. 
quality factor - The factor by which the absorbed dose (rad) is multiplied to obtain a quantity that expresses, on a common scale for all ionizing radiation, the biological damage to exposed persons. It is used because some types of radiation, such as alpha particles, are more biologically damaging than others.

rad - The unit of absorbed dose deposited in a volume of material.

radioactivity - The spontaneous emission of radiation, generally alpha or beta particles or gamma rays, from the nucleus of an unstable isotope.

radioisotopes - Radioactive isotopes.

radionuclide - An unstable nuclide capable of spontaneous transformation into other nuclides by changing its nuclear configuration or energy level. This transformation is accompanied by the emission of photons or particles.

reclamation - Recovery of wasteland, desert, etc., by ditching, filling, draining, or planting.

reference material - A material or substance with one or more properties that is sufficiently well established and used to calibrate an apparatus, to assess a measurement method, or to assign values to materials.

regression analysis - A collection of statistical techniques that serve as a basis for drawing inferences about relationships among quantities in a scientific system.

release - Any discharge to the environment. "Environment" is broadly defined as any water, land, or ambient air.

rem - The unit of dose equivalent (absorbed dose in rads $\times$ the radiation quality factor). Dose equivalent is frequently reported in units of millirem (mrem), which is one one-thousandth of a rem.

remediation - The correction of a problem. See Environmental Restoration.

RFI Program - RCRA Facility Investigation Program; EPA-regulated investigation of a solid waste management unit with regard to its potential impact on the environment.

RFI/RI Program - RCRA Facility Investigation/Remedial Investigation Program; on the ORR, the expansion of the RFI Program to include CERCLA and hazardous substance regulations.

roentgen - A unit of exposure from $\mathrm{X}$ or gamma rays. One roentgen equals $2.58 \times 10^{-4}$ coulombs per kilogram of air.

screened interval - In well construction, the section of a formation that contains the screen, or perforated pipe, that allows water to enter the well.

seepage basin - An excavation that receives wastewater. Insoluble materials settle out on the floor of the basin, and soluble materials seep with the water through the soil column, where they are removed partially by ion exchange with the soil. Construction may include dikes to prevent overflow or surface runoff. 
self-absorption - Absorption of radiation by the sample itself, preventing detection by the counting instrument.

sensitivity - The capability of a methodology or an instrument to discriminate between samples with differing concentrations or containing varying amounts of analyte.

settleable solids — Material settling out of suspension within a defined period.

settling basin - A temporary holding basin (excavation) that receives wastewater, which is subsequently discharged.

sievert (Sv) - The SI (International System of Units) unit of dose equivalent, $1 \mathrm{~Sv}=100 \mathrm{rem}$.

slurry - A suspension of solid particles (sludge) in water.

specific conductance - The ability of water to conduct electricity; this ability varies in proportion to the amount of ionized minerals in the water.

spike - The addition of a known amount of reference material containing the analyte of interest to a blank sample.

spiked sample - A sample to which a known amount of some substance has been added.

split sample - A sample that has been portioned into two or more containers from a single sample container or sample-mixing container.

stable - Not radioactive or not easily decomposed or otherwise modified chemically.

stack - A vertical pipe or flue designed to exhaust airborne gases and suspended particulate matter.

standard deviation - An indication of the dispersion of a set of results around their average.

standard reference material (SRM) - A reference material distributed and certified by the National Institute of Standards and Technology.

statistical significance testing - A procedure for decision making and data evaluation based on mathematical probability that provides a consistent, scientific methodology for collecting, analyzing, and presenting data. Statistical significance testing reflects the mathematical likelihood of certain outcomes but says nothing about its environmental significance.

storm water runoff - Surface streams that appear after precipitation.

strata - Beds, layers, or zones of rocks.

substrate - The substance, base, surface, or medium in which an organism lives and grows.

surface water - All water on the surface of the earth, as distinguished from groundwater.

temperature - The thermal state of a body considered with its ability to communicate heat to other bodies. 
terrestrial radiation - Ionizing radiation emitted from radioactive materials, primarily potassium-40, thorium, and uranium, in the earth's soils. Terrestrial radiation contributes to natural background radiation.

total activity - The total quantity of radioactive decay particles that are emitted from a sample.

total dissolved solids - Dissolved solids and total dissolved solids are terms generally associated with freshwater systems and consist of inorganic salts, small amounts of organic matter, and dissolved materials.

total organic halogens - A measure of the total concentration of organic compounds that have one or more halogen atoms.

total solids — The sum of total dissolved solids and suspended solids.

total suspended particulates - The concentration of particulates in suspension in the air irrespective of the nature, source, or size of the particulates.

transect - A line across an area being studied. The line is composed of points where specific measurements or samples are taken.

transmissive zone - A zone of sediments sufficiently porous and permeable to allow the flow of groundwater through the zone.

transuranic waste - Solid radioactive waste containing primarily alpha-emitting elements heavier than uranium.

transuranium elements - Elements with higher atomic weights than uranium; all 13 known transuranic elements are radioactive and are produced artificially.

trip blank - A sample container of deionized water that is transported to a well-sampling location, treated as a well sample, and sent to the laboratory for analysis; trip blanks are used to check for contamination resulting from transport, shipping, and site conditions.

tritium $\left({ }^{3} \mathbf{H}\right)$ - The hydrogen isotope with one proton and two neutrons in the nucleus. It emits a low-energy beta particle ( $0.0186 \mathrm{MeV}$ maximum) and has a half-life of 12.5 years.

t-test - Statistical method used to determine whether the means of groups of observations are equal.

turbidity - A measure of the concentration of sediment or suspended particles in solution.

unconsolidated zone - Soil zone located above the water table.

uncontrolled area - Any area to which access is not controlled for the purpose of protecting individuals from exposure to radiation and radioactive materials.

upgradient - In the direction of increasing hydrostatic head.

volatile organic compounds - Used in many industrial processes; the levels of these carcinogenic compounds must be kept to a minimum. They are measured by volatile organic content analyses. Common examples include trichloroethane, tetrachloroethene, and trichloroethene.

\section{B-12 Appendix B: Glossary}


watershed - The region draining into a river, river system, or body of water.

wetlands - Lowland areas, such as a marshes or swamps, inundated or saturated by surface water or groundwater sufficiently to support hydrophytic vegetation typically adapted for life in saturated soils.

wind rose - A diagram in which statistical information concerning direction and speed of the wind at a location is summarized. 



\section{Appendix C: Reference Standards and Data for Water}



Table C.1. Reference standards for radionuclides in water ( $\mathrm{pCi} / \mathrm{L}$ )

\begin{tabular}{|c|c|c|c|}
\hline Parameter $^{a}$ & $\begin{array}{l}\text { National primary drinking } \\
\text { water standard }^{b}\end{array}$ & $4 \%$ of $\mathrm{DCG}^{c}$ & $\mathrm{DCG}^{d}$ \\
\hline${ }^{241} \mathrm{Am}$ & & 1.2 & 30 \\
\hline${ }^{214} \mathrm{Bi}$ & & 24,000 & 600,000 \\
\hline${ }^{109} \mathrm{Cd}$ & & 400 & 10,000 \\
\hline${ }^{143} \mathrm{Ce}$ & & 1,200 & 30,000 \\
\hline${ }^{60} \mathrm{Co}$ & & 200 & 5,000 \\
\hline${ }^{51} \mathrm{Cr}$ & & 40,000 & $1,000,000$ \\
\hline${ }^{137} \mathrm{Cs}$ & & 120 & 3,000 \\
\hline${ }^{155} \mathrm{Eu}$ & & 4,000 & 100,000 \\
\hline Gross alpha ${ }^{e}$ & 15 & & \\
\hline Gross beta (mrem/year) & $4^{f}$ & & \\
\hline${ }^{3} \mathrm{H}$ & $20,000^{g}$ & 80,000 & $2,000,000$ \\
\hline${ }^{131} \mathrm{I}$ & & 120 & 3,000 \\
\hline${ }^{40} \mathrm{~K}$ & & 280 & 7,000 \\
\hline${ }^{237} \mathrm{~Np}$ & & 1.2 & 30 \\
\hline${ }^{234 m} \mathrm{~Pa}$ & & 2,800 & 70,000 \\
\hline${ }^{238} \mathrm{Pu}$ & & 1.6 & 40 \\
\hline${ }^{239 / 240} \mathrm{Pu}$ & & 1.2 & 30 \\
\hline${ }^{226} \mathrm{Ra}$ & $5^{h}$ & 4 & 100 \\
\hline${ }^{228} \mathrm{Ra}$ & $5^{h}$ & 4 & 100 \\
\hline${ }^{106} \mathrm{Ru}$ & & 240 & 6,000 \\
\hline${ }^{90} \mathrm{Sr}$ & $8^{g}$ & 40 & 1,000 \\
\hline${ }^{99} \mathrm{Tc}$ & & 4,000 & 100,000 \\
\hline${ }^{228} \mathrm{Th}$ & & 16 & 400 \\
\hline${ }^{230} \mathrm{Th}$ & & 12 & 300 \\
\hline${ }^{232} \mathrm{Th}$ & & 2 & 50 \\
\hline${ }^{234} \mathrm{Th}$ & & 400 & 10,000 \\
\hline Thorium, natural & & 2 & 50 \\
\hline${ }^{234} \mathrm{U}$ & & 20 & 500 \\
\hline${ }^{235} \mathrm{U}$ & & 24 & 600 \\
\hline${ }^{236} \mathrm{U}$ & & 20 & 500 \\
\hline${ }^{238} \mathrm{U}$ & & 24 & 600 \\
\hline Uranium, natural & & 24 & 600 \\
\hline Uranium, total ${ }^{i}$ & $30 \mu \mathrm{g} / \mathrm{L}^{j}$ & 20 & 500 \\
\hline
\end{tabular}

${ }^{a}$ Only the radionuclides included in the Oak Ridge Reservation monitoring programs are listed.

${ }^{b} 40$ CFR Part 141 National Primary Drinking Water Regulations Subparts B and G.

${ }^{c}$ Four percent of the derived concentration guide represents the DOE criterion of 4 mrem effective dose equivalent from ingestion of drinking water.

${ }^{d}$ U.S. DOE Order 5400.5 Chapter III, "Derived Concentration Guides for Air and Water."

${ }^{e}$ Excludes radon and uranium.

fPer the discussion in 40 CFR 141.26(b), compliance with the $4 \mathrm{mrem} / \mathrm{year}$ standard can be assumed if the average annual gross beta particle activity is less than $50 \mathrm{pCi} / \mathrm{L}$ and if the average annual concentrations of ${ }^{3} \mathrm{H}$ and ${ }^{90} \mathrm{Sr}$ are less than $20,000 \mathrm{pCi} / \mathrm{L}$ and $8 \mathrm{pCi} / \mathrm{L}$, respectively, provided that, if both radionuclides are present, the sum of their annual dose equivalents to bone marrow is less than $4 \mathrm{mrem} / \mathrm{year}$. In the text of this document, $50 \mathrm{pCi} / \mathrm{L}$ is referred to as the "screening level."

${ }^{8}$ These values are not maximum contaminant levels (MCLs), but are concentrations that result in the effective dose equivalent of the MCL for gross beta emissions, which is 4 mrem/year.

${ }^{h}$ Applies to combined ${ }^{226} \mathrm{Ra}$ and ${ }^{228} \mathrm{Ra}$.

${ }^{i}$ Minimum of uranium isotopes.

${ }^{j}$ Effective December 8, 2003. 
Table C.2. Reference standards for chemicals and metals in water

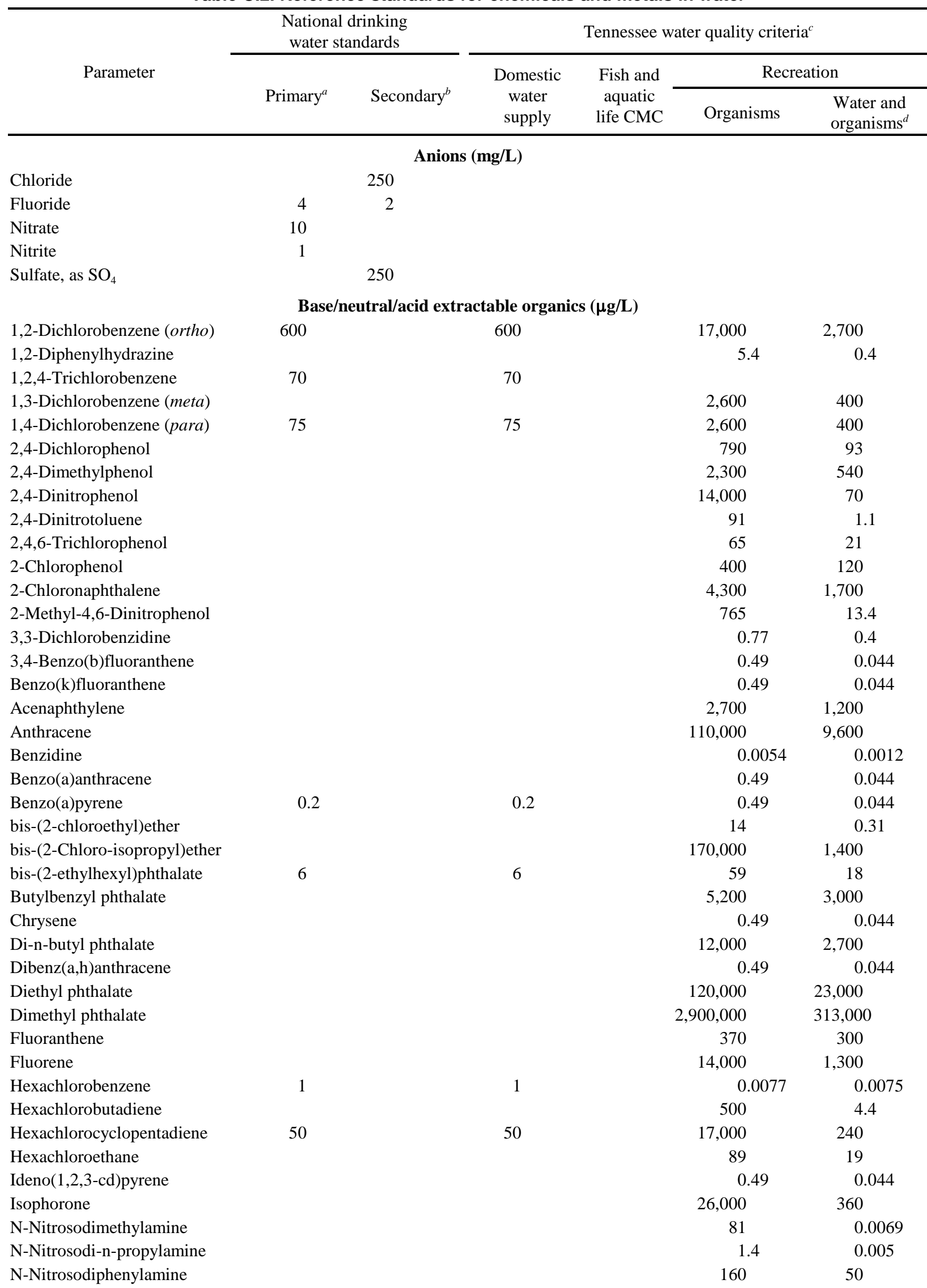


Table C.2. (continued)

\begin{tabular}{|c|c|c|c|c|c|c|}
\hline \multirow{3}{*}{ Parameter } & \multicolumn{2}{|c|}{$\begin{array}{l}\text { National drinking } \\
\text { water standards }\end{array}$} & \multicolumn{4}{|c|}{ Tennessee water quality criteria ${ }^{c}$} \\
\hline & \multirow[b]{2}{*}{ Primary $^{a}$} & \multirow[b]{2}{*}{ Secondary $^{b}$} & \multirow{2}{*}{$\begin{array}{l}\text { Domestic } \\
\text { water } \\
\text { supply }\end{array}$} & \multirow{2}{*}{$\begin{array}{l}\text { Fish and } \\
\text { aquatic } \\
\text { life CMC }\end{array}$} & \multicolumn{2}{|c|}{ Recreation } \\
\hline & & & & & Organisms & $\begin{array}{l}\text { Water and } \\
\text { organisms }^{d}\end{array}$ \\
\hline Nitrobenzene & & & & & 1,900 & 17 \\
\hline Pentachlorophenol (pH 7.8) & 1 & & 1 & 20 & 82 & 2.8 \\
\hline Phenol & & & & & $4,600,000$ & 21,000 \\
\hline Pyrene & & & & & 11,000 & 960 \\
\hline \multicolumn{7}{|c|}{ Field measurements } \\
\hline Chlorine, (TRC), $\mu \mathrm{g} / \mathrm{L}$ & & & & 19 & & \\
\hline Dissolved oxygen, mg/L & & & & 5 & & \\
\hline Temperature, ${ }^{\circ} \mathrm{C}$ & & & 30.5 & 30.5 & 30.5 & 30.5 \\
\hline Turbidity, $\mathrm{JTU}^{e}$ & 1 & & & & & \\
\hline $\mathrm{pH}$, standard units & & $(6.5,8.5)$ & $(6.0,9.0)$ & $(6.5,9.0)$ & $(6.0,9.0)$ & $(6.0,9.0)$ \\
\hline \multicolumn{7}{|c|}{ Metals (mg/L) } \\
\hline Aluminum & & $0.05-0.2$ & & & & \\
\hline Antimony & 0.006 & & 0.006 & & 4.30 & 0.014 \\
\hline Arsenic & $0.01^{f}$ & & 0.050 & 0.360 (III) & 0.050 & 0.050 \\
\hline Barium & 2 & & 2 & & & \\
\hline Beryllium & 0.004 & & 0.004 & & & \\
\hline Cadmium & 0.005 & & 0.005 & $0.0039^{g}$ & & \\
\hline Chromium, total & 0.1 & & 0.1 & & & \\
\hline Chromium (hexavalent) & & & & 0.016 & & \\
\hline Copper & $1.3^{h}$ & 1 & & $0.0177^{g}$ & & \\
\hline Iron & & 0.3 & & & & \\
\hline Lead & $0.015^{h}$ & & 0.005 & $0.0817^{g}$ & & \\
\hline Manganese & & 0.05 & & & & \\
\hline Mercury & 0.002 & & 0.002 & 0.00169 & 0.000051 & 0.00005 \\
\hline Nickel & & & 0.1 & $1.418^{g}$ & 4.6 & 0.61 \\
\hline Selenium & 0.05 & & 0.050 & 0.02 & & \\
\hline Silver & & 0.1 & & $0.0041^{g}$ & & \\
\hline Thallium & 0.002 & & 0.002 & & 0.0063 & 0.0017 \\
\hline Zinc & & 5 & & $0.117^{g}$ & & \\
\hline \multicolumn{7}{|c|}{ Others } \\
\hline Asbestos (fibers/L) & $7,000,000$ & & & & & \\
\hline Chlorine (TRC) & & & & 0.019 & & \\
\hline $\begin{array}{l}\text { Coliform bacteria (no./100 } \\
\mathrm{mL} \text {, geometric mean }\end{array}$ & & & 1,000 & 1,000 & 200 & 200 \\
\hline $\begin{array}{l}\text { Coliform bacteria (no./100 } \\
\mathrm{mL} \text {, individual sample }\end{array}$ & & & 5,000 & 5,000 & 1,000 & 1,000 \\
\hline Color (color units) & & 15 & & & & \\
\hline Cyanide (mg/L) & 0.2 & & 0.2 & 0.022 & 220 & 0.7 \\
\hline $\begin{array}{l}\text { E. coli (no./100 mL, } \\
\text { geometric mean) }\end{array}$ & & & & & 126 & 126 \\
\hline Odor (threshold odor number) & & 3 & & & & \\
\hline Total dissolved solids (mg/L) & & 500 & 500 & & & \\
\hline \multicolumn{7}{|c|}{ Pesticides/herbicides/PCBs $(\mu \mathrm{g} / \mathrm{L})$} \\
\hline 2,3,7,8-TCDD (Dioxin) & 0.00003 & & 0.00003 & & 0.000001 & 0.000001 \\
\hline $2,4-\mathrm{D}$ & 70 & & 70 & & & \\
\hline 2,4,5-TP (Silvex) & 50 & & 50 & & & \\
\hline $4,4^{\prime}-\mathrm{DDT}$ & & & & 1.1 & 0.0059 & 0.0059 \\
\hline $4,4^{\prime}-\mathrm{DDE}$ & & & & & 0.0059 & 0.0059 \\
\hline
\end{tabular}


Table C.2 (continued)

\begin{tabular}{|c|c|c|c|c|c|c|}
\hline \multirow{3}{*}{ Parameter } & \multicolumn{2}{|c|}{$\begin{array}{l}\text { National drinking } \\
\text { water standards }\end{array}$} & \multicolumn{4}{|c|}{ Tennessee water quality criteria ${ }^{c}$} \\
\hline & \multirow[b]{2}{*}{ Primary $^{a}$} & \multirow[b]{2}{*}{ Secondary $^{b}$} & \multirow{2}{*}{$\begin{array}{c}\text { Domestic } \\
\text { water } \\
\text { supply }\end{array}$} & \multirow{2}{*}{$\begin{array}{l}\text { Fish and } \\
\text { aquatic } \\
\text { life CMC }\end{array}$} & \multicolumn{2}{|c|}{ Recreation } \\
\hline & & & & & Organisms & $\begin{array}{l}\text { Water and } \\
\text { organisms }^{d}\end{array}$ \\
\hline $4,4^{\prime}-\mathrm{DDD}$ & & & & & 0.0084 & 0.0083 \\
\hline $\mathrm{a}-\mathrm{BHC}$ & & & & & 0.13 & 0.039 \\
\hline b-BHC & & & & & 0.46 & 0.14 \\
\hline Alachlor & 2 & & 2 & & & \\
\hline Aldicarb & 3 & & & & & \\
\hline Aldicarb sulfoxide & 4 & & & & & \\
\hline Aldicarb sulfone & 2 & & & & & \\
\hline Aldrin & & & & 3.0 & 0.0014 & 0.0013 \\
\hline Atrazine & 3 & & 3 & & & \\
\hline Carbofuran & 40 & & 40 & & & \\
\hline Chlordane & 2 & & 2 & 2.4 & 0.0059 & 0.0057 \\
\hline Dalapon & 200 & & 200 & & & \\
\hline 1,2-Dibromo-3-chloropropane & 0.2 & & 0.2 & & & \\
\hline Di(ethylhexyl)adipate & 400 & & 400 & & & \\
\hline Dieldrin & & & & 2.5 & 0.0014 & 0.0014 \\
\hline \multicolumn{7}{|l|}{ Di(ethylhexyl)phthalate ${ }^{i}$} \\
\hline Dinoseb & 7 & & 7 & & & \\
\hline Diquat & 20 & & 20 & & & \\
\hline a-Endosulfan & & & & 0.22 & 240 & 110 \\
\hline b-Endosulfan & & & & 0.22 & 240 & 110 \\
\hline Endosulfan sulfate & & & & & 240 & 110 \\
\hline Endothall & 100 & & 100 & & & \\
\hline Endrin & 2 & & 2 & 0.18 & 0.81 & 0.76 \\
\hline Endrin aldehyde & & & & & 0.81 & 0.76 \\
\hline Ethylene dibromide & 0.05 & & 0.05 & & & \\
\hline Glyphosate & 700 & & 700 & & & \\
\hline Heptachlor & 0.4 & & 0.4 & 0.52 & 0.0021 & 0.0021 \\
\hline Heptachlor epoxide & 0.2 & & 0.2 & 0.52 & 0.0011 & 0.001 \\
\hline g-BHC (Lindane) & 0.2 & & 0.2 & 2.0 & 0.63 & 0.19 \\
\hline Methoxychlor & 40 & & 40 & & & \\
\hline Oxamyl (Vydate) & 200 & & 200 & & & \\
\hline PCB-1242 & & & & & 0.00045 & 0.00044 \\
\hline PCB-1254 & & & & & 0.00045 & 0.00044 \\
\hline PCB-1221 & & & & & 0.00045 & 0.00044 \\
\hline PCB-1232 & & & & & 0.00045 & 0.00044 \\
\hline PCB-1248 & & & & & 0.00045 & 0.00044 \\
\hline PCB-1260 & & & & & 0.00045 & 0.00044 \\
\hline PCB-1016 & & & & & 0.00045 & 0.00044 \\
\hline PCB, total & 0.5 & & 0.5 & & 0.00045 & 0.00044 \\
\hline Picloram & 500 & & 500 & & & \\
\hline Simazine & 4 & & 4 & & & \\
\hline Toxaphene & 3 & & 3 & 0.73 & 0.0075 & 0.0073 \\
\hline \multicolumn{7}{|c|}{ Volatile organics $(\mu \mathrm{g} / \mathrm{L})$} \\
\hline $1,1,1$-Trichloroethane & 200 & & 200 & & & \\
\hline 1,1-Dichloroethene & 7 & & 7 & & 32 & 0.57 \\
\hline 1,1,2-Trichloroethane & 5 & & 5 & & 420 & 6 \\
\hline 1,1,2,2-Tetrachloroethane & & & & & 110 & 1.7 \\
\hline 1,2-Dichloroethane & 5 & & 5 & & 990 & 3.8 \\
\hline 1,2-Dichloroethene ${ }^{j}$ & & & & & & \\
\hline
\end{tabular}


Annual Site Environmental Report

Table C.2 (continued)

\begin{tabular}{|c|c|c|c|c|c|c|}
\hline \multirow{3}{*}{ Parameter } & \multicolumn{2}{|c|}{$\begin{array}{l}\text { National drinking } \\
\text { water standards }\end{array}$} & \multicolumn{4}{|c|}{ Tennessee water quality criteria ${ }^{c}$} \\
\hline & \multirow[b]{2}{*}{ Primary $^{a}$} & \multirow[b]{2}{*}{ Secondary $^{b}$} & \multirow{2}{*}{$\begin{array}{c}\text { Domestic } \\
\text { water } \\
\text { supply }\end{array}$} & \multirow{2}{*}{$\begin{array}{l}\text { Fish and } \\
\text { aquatic } \\
\text { life CMC }\end{array}$} & \multicolumn{2}{|c|}{ Recreation } \\
\hline & & & & & Organisms & $\begin{array}{l}\text { Water and } \\
\text { organisms }^{d}\end{array}$ \\
\hline cis-1,2-Dichloroethene & 70 & & 70 & & & \\
\hline trans-1,2-Dichloroethene & 100 & & 100 & & 140,000 & 700 \\
\hline 1,2-Dichloropropane & 5 & & 5 & & 39 & 0.52 \\
\hline cis-1,3-Dichloropropene & & & & & 1,700 & 10 \\
\hline trans-1,3-Dichloropropene & & & & & 1,700 & 10 \\
\hline Acrolein & & & & & 780 & 320 \\
\hline Acrylonitrile & & & & & 6.6 & 0.59 \\
\hline Benzene & 5 & & 5 & & 710 & 12 \\
\hline Bromodichloromethane & $100^{k}$ & & & & 460 & 5.6 \\
\hline Bromoform & $100^{k}$ & & & & 3,600 & 43 \\
\hline Carbon tetrachloride & 5 & & 5 & & 44 & 2.5 \\
\hline Chlorobenzene & 100 & & 100 & & 21,000 & 680 \\
\hline Chloroform & $100^{k}$ & & & & 4,700 & 57 \\
\hline Dibromochloromethane & $100^{k}$ & & & & 340 & 4.1 \\
\hline Ethylbenzene & 700 & & 700 & & 29,000 & 3,100 \\
\hline Methylbromide & & & & & 4,000 & 48 \\
\hline $\begin{array}{l}\text { Methylene chloride } \\
\text { (Dichloromethane) }\end{array}$ & 5 & & 5 & & 16,000 & 47 \\
\hline Styrene & 100 & & 100 & & & \\
\hline Tetrachloroethene & 5 & & 5 & & 88.5 & 8 \\
\hline Toluene & 1,000 & & 1,000 & & 200,000 & 6,800 \\
\hline Trichloroethene & 5 & & 5 & & 810 & 27 \\
\hline Trihalomethanes, total & $100^{k}$ & & & & & \\
\hline Vinyl chloride & 2 & & 2 & & 5,250 & 20 \\
\hline Xylene, total & 10,000 & & 10,000 & & & \\
\hline
\end{tabular}

${ }^{a} 40$ CFR Part 141-National Primary Drinking Water Regulations, Subparts B and G, as amended.

${ }^{b} 40$ CFR Part 143-National Secondary Drinking Water Regulations, as amended.

${ }^{c}$ Rules of Tennessee Department of Environment and Conservation, Division of Water Pollution Control, Chapter 1200-4-3, General Water Quality Criteria, as amended. CMC = criterion maximum concentration.

${ }^{d}$ These criteria, for the protection of public health, pertain to the consumption of water and organisms. They are applied only to waters designated for both recreation and domestic water supply.

${ }^{e}$ Jackson turbidity unit (JTU) and nephelometric turbidity unit (NTU) are roughly equivalent in the range of 25 to 1000 JTU.

${ }^{f}$ As of January 23, 2006.

${ }^{8}$ The standard is a function of total hardness. The values in this table correspond to a total-hardness value of $100 \mathrm{mg} / \mathrm{L}$.

h"Action level" for initiation of corrosion control studies and treatment techniques, applicable to community water systems and nontransient, noncommunity water systems.

${ }^{i}$ See bis(2-ethylhexyl)phthalate.

${ }^{j}$ See cis-1,2-Dichlorethene and trans-1,2-Dichloroethene.

${ }^{k}$ Limit for total trihalomethanes (bromodichloromethane + bromoform + chloroform + dibromochloromethane). 



\section{Appendix D: NPDES Noncompliances}





\section{Table D.1. Summary of Y-12 Complex National Pollutant Discharge Elimination System (NPDES) Excursions, 2003}

\begin{tabular}{clll} 
Excursion & \multicolumn{1}{c}{ Date } & \multicolumn{1}{c}{ Location } & \multicolumn{1}{c}{ Incident } \\
\hline & & & \\
$2003-0001$ & 22-Jan-03 & Monitoring Point 201 & Permit limit exceedance; daily chlorine 0.237 mg/L \\
$2003-0002$ & 31-Jan-03 & Monitoring Point 201 & Permit limit exceedance; monthly chlorine 0.018 mg/L \\
$2003-0003$ & 17-Feb-03 & Outfall 55 & Permit limit exceedance; daily Hg 0.00581 mg/L \\
$2003-0004$ & 18-Feb-03 & Outfall 55 & Permit limit exceedance; daily Hg 0.00691 mg/L \\
$2003-0005$ & 15-Apr-03 & Outfall 200 & Permit limit exceedance; daily Oil \& Grease 24.9 mg/L \\
$2003-0006$ & 18-Nov-03 & Outfall 55 & Permit limit exceedance; daily chlorine $1.04 \mathrm{mg} / \mathrm{L}$
\end{tabular}

On January 22, 2003, at 1350 hours, a water sample taken at in-stream Monitoring Point 201 revealed an elevated total residual chlorine reading of $0.237 \mathrm{mg} / \mathrm{L}$, which exceeded the permitted daily maximum concentration of $0.019 \mathrm{mg} / \mathrm{L}$ (Exceedance 2003-0001). Additional data analysis for the month of January revealed the monthly average concentration for total residual chlorine was $0.018 \mathrm{mg} / \mathrm{L}$. This exceeded the permitted monthly maximum of $0.011 \mathrm{mg} / \mathrm{L}$

(Exceedance 2003-0002).

The cause of these total residual chlorine exceedances was a failure of the dechlorination system for raw water. The thermostat that controls the heat trace on the main sodium bisulfite feed line failed, resulting in freezing and blockage of the main sodium bisulfite feed line. Efforts to thaw the line were unsuccessful. Raw water was turned off at approximately 2145 hours, and total residual chlorine levels at the in-stream monitoring point returned to $<0.05 \mathrm{mg} / \mathrm{L}$. Raw water flow resumed on January 25, 2003, and dechlorination was accomplished via a temporary line to the raw water basin.

There were no observed adverse affects on aquatic life attributable to this event.

\section{Excursions 2003-0003 \& 2003-0004}

On February 17, 2003, at 1010 hours, a water sample taken at Outfall 55 revealed an elevated Mercury $(\mathrm{Hg})$ reading of $0.00581 \mathrm{mg} / \mathrm{L}$, which exceeded the daily permitted limit of $0.004 \mathrm{mg} / \mathrm{L}$ (Exceedance 2003-0003). Also, on February 18, 2003, at 0915 hours, a second water sample taken at this same outfall produced a $\mathrm{Hg}$ reading of $0.00691 \mathrm{mg} / \mathrm{L}$ (Exceedance 2003-0004). This outfall is authorized to discharge sump waters, cooling waters and storm water from Building 9201-2.
A new sodium bisulfite feed line for the raw water basin, with associated heat trace, was installed.
No specific corrective actions were undertaken for this event as it was due to excessive rainfall, and the system functioned as designed. 
Both of these samples were taken soon after the Y-12 Complex experienced extremely heavy rainfall. This rainfall event totaled 7.68 in. over a three-day period (February 14-16, 2003) as measured by the meteorological tower on the East End of the Y-12 Complex. During this event, storm water flows and groundwater flows were significantly increased at Outfall 55. In addition to the increased volume of water from the normal sources that discharge through Outfall 55, the East End Mercury Treatment System was put in by-pass mode to discharge excess water from the Building 9201-2 sump to Outfall 55 because it could not treat the increased volume of water that it received from February 13, 2003, to February 16, 2003. The water that was bypassed $(21,800 \mathrm{gal})$ was filtered but was not carbon treated before being discharged. The bypass is necessary during excess water inflow conditions in order to protect the Building 9101-2 sump pump motors from flooding and being rendered inoperable. Treated sump water from the East End Mercury Treatment System continued to discharge through Outfall 550.

Excursion 2003-0005

On April 15, 2003, at 0850 hours, a water sample taken at Outfall 200 (North/South pipe) on East Fork Poplar Creek revealed an elevated oil and grease reading of $24.9 \mathrm{mg} / \mathrm{L}$ which exceeded the permitted daily maximum concentration of $15.0 \mathrm{mg} / \mathrm{L}$.

The specific cause of this exceedance is unknown. There was no observed oil sheen on the creek at the time the sample was taken, and the technician reported no unusual conditions at the creek location. There had been no rain at the Y-12 Complex over the previous three days. A survey of construction and maintenance activities around the complex did not reveal a potential source for this exceedance. Additionally, there is no record of a reported spill that would have accounted for this elevated oil and grease reading. All normal laboratory quality control aspects were well within acceptable limits.

Oil and grease samples are taken by the "grab" method in two 1-L glass jars. The analysis for one of the jars produced a below detect result. The result was 24.9 $\mathrm{mg} / \mathrm{L}$ for the other jar. It is suspected but not confirmed that there may have been a globule of oil or grease in the jar that produced the elevated result. All other sample results for 2003 have been below the detection limit. There were no observed adverse affects on aquatic life attributable to this event.
In the future, the residue from laboratory analysis that produce an elevated reading for oil and grease will be retained. The residue will be further analyzed to determine the type of oil or grease that is present. This may aid in determining the origin of the exceedance. 
Table D.1 (continued)

\section{Excursion 2003-0006}

On November 18, 2003, three water samples were taken at Outfall 55 on East Fork Poplar Creek. The three samples revealed chlorine levels of $1.92 \mathrm{mg} / \mathrm{L}$ (taken at 13:25), $1.2 \mathrm{mg} / \mathrm{L}$ (taken at 13:35) and <0.05 $\mathrm{mg} / \mathrm{L}$ (taken at 16:00). These sample results produced an average daily maximum concentration of 1.04 $\mathrm{mg} / \mathrm{L}$, exceeding the limit of $0.5 \mathrm{mg} / \mathrm{L}$.

The discharge from Outfall 55 consists of roof drains, cooling water, and sump water from Building 9201-2. The cooling water from the building passes through one of five tablet dechlorination units prior to discharge through the outfall. This is a low-flow outfall and the discharge rate at the time the first sample was taken was $11.1 \mathrm{gal} / \mathrm{min}$.

An investigation was initiated to locate the source of the chlorine. On November 19, 2003, it was discovered that one of the tablet dechlorination units was malfunctioning, as indicated by a chlorine sample result of $1.99 \mathrm{mg} / \mathrm{L}$ from the outlet side of the dechlorination unit. Closer investigation revealed that although the tubes of the dechlorination unit appeared to be full of tablets, the dechlorination tablets had hung inside one of the feeder tubes and thus the water was not making contact with the dechlorination tablets. The tablets were reseated inside the tube, and subsequent chlorine readings demonstrated that the dechlorination unit was then functioning properly.

Further investigation revealed additional sources of chlorinated discharges through Outfall 55:

- The building fire sprinkler header was leaking a small amount ( $0.1 \mathrm{gal} / \mathrm{min})$ of chlorinated water into a drain that that was routed to Outfall 55. This drain line was promptly rerouted to the sanitary sewer system.

- The drain line on an icemaker was found to be connected to the downstream side of one of the dechlorination units. This drain line has since been rerouted to pass through the dechlorination unit prior to discharge.

- The discharge from two air-conditioning units that operated off once-through cooling water was entering Outfall 55 without first passing through one of the dechlorination units. These air conditioners were taken out of service on December 5, 2003, and the drain lines are no longer physically connected to Outfall 55.
The malfunctioning dechlorination unit has been replaced. The new dechlorination unit is of a larger capacity (more tubes) and reduces the potential for failure of the dechlorination unit.

The known chlorine sources were rerouted, as previously discussed.

A new administrative control was instituted for the occupants of the building that requires the building manager to review and approve all new water discharges. The building manager is responsible for ensuring that any new discharges are properly dechlorinated or are routed to the sanitary sewer system. 
Table D.2. Summary of East Tennessee Technology Park (ETTP) National Pollutant Discharge Elimination System (NPDES) excursions, 2003

\begin{tabular}{|c|c|c|c|c|}
\hline Date & Location & Excursion & Explanation & Corrective action \\
\hline $01 / 21 / 03$ & Outfall 100 & $\begin{array}{l}\text { Unpermitted } \\
\text { discharge }\end{array}$ & $\begin{array}{l}\text { Diesel fuel leaked from a } \\
\text { vendor's vehicle at ETTP } \\
\text { during storm conditions, and } \\
\text { the spilled fuel entered the } \\
\text { storm drain system, resulting in } \\
\text { an oil sheen in one area of the } \\
\text { K-1007-P1 Pond }\end{array}$ & $\begin{array}{l}\text { Containment and cleanup } \\
\text { efforts prevented spilled fuel } \\
\text { from entering Poplar Creek; } \\
\text { the vehicle was repaired and } \\
\text { hauled off the ETTP site on a } \\
\text { flatbed truck }\end{array}$ \\
\hline $07 / 29 / 03$ & Outfall 200 & $\begin{array}{l}\text { Unpermitted } \\
\text { discharge }\end{array}$ & $\begin{array}{l}\text { Sanitary sewer line clean-out } \\
\text { port outside the K-1423 } \\
\text { building break room } \\
\text { overflowed due to blockage in } \\
\text { the sanitary sewer line; the } \\
\text { grayish water entered a nearby } \\
\text { storm drain catch basin and } \\
\text { discharged into Mitchell } \\
\text { Branch }\end{array}$ & $\begin{array}{l}\text { The blocked section of sanitary } \\
\text { sewer line was isolated; the } \\
\text { waste was pumped through a } \\
\text { hose to a nearby sanitary sewer } \\
\text { lift station, and the line was } \\
\text { excavated and replaced }\end{array}$ \\
\hline
\end{tabular}


Table D.3. Summary of Oak Ridge National Laboratory National Pollutant Discharge Elimination System (NPDES) excursions, 2003

\begin{tabular}{|c|c|c|c|c|}
\hline Date & Location & Excursion & Explanation & Corrective action \\
\hline $01 / 14 / 03$ & 302 & $\mathrm{pH}$ & $\begin{array}{l}\text { A leaking underground pipe } \\
\text { containing sodium hydroxide } \\
\text { used in Building } 3544 \text { is } \\
\text { believed to have contributed to } \\
\text { the pH excursion. }\end{array}$ & $\begin{array}{l}\text { The leaking portion of the pipe } \\
\text { has been bypassed. }\end{array}$ \\
\hline $12 / 16 / 03$ & $\mathrm{X} 01$ & $\begin{array}{l}\text { Total suspended } \\
\text { solids }\end{array}$ & $\begin{array}{l}\text { During low effluent flow } \\
\text { conditions, the water/foam } \\
\text { level drops within the chamber } \\
\text { and the level drops to the level } \\
\text { of the compositor intake tube } \\
\text { causing foam to be taken into } \\
\text { compositor. A combination of } \\
\text { low flow and foam } \\
\text { accumulation is believed to be } \\
\text { the cause of the accumulated } \\
\text { residue in the compositor and } \\
\text { the total suspended solids } \\
\text { excursion. }\end{array}$ & $\begin{array}{l}\text { The intake tube has been } \\
\text { relocated such that foam will } \\
\text { not be taken into the } \\
\text { compositor during low-flow } \\
\text { conditions. }\end{array}$ \\
\hline
\end{tabular}



Appendix E: Air Permits 

Table E.1. Air permits at the Y-12 Complex, 2003

\begin{tabular}{|c|c|c|c|c|}
\hline $\begin{array}{l}\text { Y-12 Complex } \\
\text { source number }\end{array}$ & $\begin{array}{c}\text { Source reference } \\
\text { number }\end{array}$ & $\begin{array}{c}\text { Permit } \\
\text { number }\end{array}$ & Stack & Stack description \\
\hline \multirow[t]{3}{*}{ Y-9201-1-A } & 01-0020-15 & $730303 \mathrm{P}$ & 582 & Weld booths sanders and grinders \\
\hline & & & 583 & Metal sanders and grinders \\
\hline & & & 584 & Plasma torch \\
\hline Y-9201-1-B & 01-0020-59 & $730310 \mathrm{P}$ & 586 & Tool grinding machine shop \\
\hline \multirow[t]{2}{*}{ Y-9201-1-C } & 01-0020-17 & $036057 \mathrm{P}$ & 278 & Graphite carbon machine shop \\
\hline & & & 279 & Graphite carbon machine shop \\
\hline Y-9201-1W-A & 01-0020-99 & 036129P & 272 & Paint spray booth \\
\hline \multirow[t]{4}{*}{ Y-9201-5-G } & 01-0020-44 & $730308 \mathrm{P}$ & 412 & DeVilbiss hood \\
\hline & & & 413 & Acid pickling tanks \\
\hline & & & 75 & Arc melt \\
\hline & & & 76 & Scrap metal recycle \\
\hline \multirow[t]{2}{*}{ Y-9201-5E-B } & $01-0020-21$ & $730305 \mathrm{P}$ & 71 & Machine hood exhaust \\
\hline & & & 72 & Chip vacuum system \\
\hline Y-9201-5N-A & 01-1020-18 & $730314 \mathrm{P}$ & 67 & Machine shop exhaust \\
\hline \multirow[t]{4}{*}{ Y-9201-5N-B } & 01-0020-30 & 030484P & 239 & Plating tanks and hoods \\
\hline & & & 240 & Plating tanks and hoods \\
\hline & & & 241 & Plating tanks and hoods \\
\hline & & & 454 & Plating hoods \\
\hline Y-9201-5W-I & $01-0020-21$ & $730305 \mathrm{P}$ & $\mathrm{I}(00)$ & Machining equipment \\
\hline \multirow[t]{2}{*}{ Y-9202-A } & 01-0020-06 & 031696P & 160 & Laboratory beryllium \\
\hline & & & 161 & Laboratory beryllium \\
\hline \multirow[t]{4}{*}{ Y-9204-2-B } & 01-0020-71 & 025954P & 313 & Caustic scrubber stack exhaust \\
\hline & & & 314 & Caustic scrubber exhaust \\
\hline & & & 317 & Lithium metal wash station \\
\hline & & & 318 & Lithium cell pan wash station \\
\hline \multirow[t]{7}{*}{ Y-9204-2-D } & 01-1020-57 & $730327 \mathrm{P}$ & 342 & Salvage vats \\
\hline & & & 344 & Lithium chloride crystallizer \\
\hline & & & 345 & Lithium chloride crystallizer \\
\hline & & & 346 & Neutralizer \\
\hline & & & 347 & Process tank \\
\hline & & & 349 & Reactor wash station \\
\hline & & & 350 & Reactor wash station \\
\hline \multirow[t]{5}{*}{ Y-9204-2-E } & 01-1020-55 & $730325 \mathrm{P}$ & 357 & Glove box and oven \\
\hline & & & 359 & Machine dust dumping station \\
\hline & & & 361 & Gloveboxes \\
\hline & & & 363 & Glovebox and four ovens \\
\hline & & & 364 & Dry powder process \\
\hline \multirow[t]{4}{*}{ 9204-2-E1 } & 01-1020-55 & $730325 \mathrm{P}$ & 351 & Rotary dryer \\
\hline & & & 358 & Gloveboxes, sonic sifter \\
\hline & & & 360 & Rotary dryer \\
\hline & & & 362 & Glovebox \\
\hline
\end{tabular}


Table E.1 (continued)

\begin{tabular}{|c|c|c|c|c|}
\hline $\begin{array}{l}\text { Y-12 Complex } \\
\text { source number }\end{array}$ & $\begin{array}{c}\text { Source reference } \\
\text { number }\end{array}$ & $\begin{array}{l}\text { Permit } \\
\text { number }\end{array}$ & Stack & Stack description \\
\hline Y-9204-2-G & 01-1020-79 & $730329 \mathrm{P}$ & $\begin{array}{l}371 \\
372\end{array}$ & $\begin{array}{l}\text { Metal working machine shop } \\
\text { Metal working machine shop }\end{array}$ \\
\hline Y-9204-2E-A & 01-0020-68 & $730312 \mathrm{P}$ & 101 & Lathes \\
\hline \multirow[t]{9}{*}{ Y-9204-4-A } & $01-1020-56$ & $032416 \mathrm{P}$ & 415 & Wash tank \\
\hline & & & 416 & Exhaust from press pit area \\
\hline & & & 417 & Dye penetrant hood exhaust \\
\hline & & & 85 & 7500-ton press, vertical turret lathe \\
\hline & & & 86 & 1500-ton press \\
\hline & & & 87 & 1000-ton press, quench tank \\
\hline & & & 88 & Grit blaster \\
\hline & & & 93 & Vacuum quench furnace \\
\hline & & & 95 & Two salt baths \\
\hline \multirow[t]{4}{*}{ Y-9206-B } & 01-0020-03 & $731689 \mathrm{P}$ & 13 & South stack incinerator \\
\hline & & & 15 & West stack \\
\hline & & & 17 & Steam cleaning hoods \\
\hline & & & 211 & Hood 29 and 30 \\
\hline \multirow[t]{11}{*}{ Y-9212-A } & 01-1020-72 & $743807 \mathrm{P}$ & 111 & Reduction fluid bed \\
\hline & & & 112 & Conversion fluid beds \\
\hline & & & 134 & B-Wing and C-1 Wing exhaust \\
\hline & & & 141 & Reduction fluid bed \\
\hline & & & 142 & Conversion fluid beds \\
\hline & & & 27 & D-Wing room 1010 hoods \\
\hline & & & 28 & Reduction shear and room \\
\hline & & & 33 & Headhouse equipment incinerator \\
\hline & & & 40 & B-1 sampling lab hood \\
\hline & & & 432 & Muffle furnaces (2) vent room 229 \\
\hline & & & 518 & HF dock cylinder/vaporizer \\
\hline \multirow[t]{4}{*}{ Y-9212-B } & 01-0020-02 & $730301 \mathrm{P}$ & 110 & $\mathrm{U}$ metal and $\mathrm{U}$ metal alloy \\
\hline & & & 38 & $\mathrm{U}$ metal drying and briquetting process \\
\hline & & & 43 & Exhaust from machine shop \\
\hline & & & 48 & Chip washing and drying \\
\hline \multirow[t]{6}{*}{ Y-9212-C } & 01-0020-05 & 025984P & 113 & Dissolver trays/scrubber \\
\hline & & & 114 & Shear and hacksaw hood \\
\hline & & & 128 & Precipitation process \\
\hline & & & 26 & Drum receiving/sampling hood and glovebox \\
\hline & & & 290 & Tube furnace/gas purge vent \\
\hline & & & 44 & Leaching and dissolving hoods \\
\hline
\end{tabular}


Table E.1 (continued)

\begin{tabular}{|c|c|c|c|c|}
\hline $\begin{array}{l}\text { Y-12 Complex } \\
\text { source number }\end{array}$ & $\begin{array}{c}\text { Source reference } \\
\text { number }\end{array}$ & $\begin{array}{l}\text { Permit } \\
\text { number }\end{array}$ & Stack & Stack description \\
\hline & & & 45 & Muffle furnace dry hoods \\
\hline & & & 46 & Tray dissolver hoods \\
\hline & & & 47 & Tray dissolver hoods/room 1 \\
\hline Y-9212-M & 01-0020-21 & $730305 \mathrm{P}$ & 1083 & Air bearing operations cleaning hood \\
\hline Y-9215-A & 01-0020-37 & $731839 \mathrm{P}$ & 3 & Machine shop hood exhaust - M-wing \\
\hline \multirow[t]{2}{*}{ Y-9215-B } & 01-1020-51 & $732125 \mathrm{P}$ & 1 & O-wing metal working operations \\
\hline & & & 4 & O-wing metal working operations \\
\hline \multirow[t]{2}{*}{ Y-9215-C } & 01-1020-52 & $730323 \mathrm{P}$ & 6 & Base of rolling mill \\
\hline & & & 7 & Metal process area \\
\hline \multirow[t]{4}{*}{ Y-9215-D } & $01-1020-53$ & $025966 \mathrm{P}$ & 10 & Roll mill exhaust \\
\hline & & & 11 & Furnace/quench tank/conveyor exhaust \\
\hline & & & 12 & Hydraulic shear exhaust \\
\hline & & & 9 & Rolling mill/salt bath \\
\hline Y-9401-3-A & 01-1020-31 & 034809F & 170 & Coal- or natural-gas-fired boiler \\
\hline Y-9401-3-B & 01-1020-32 & 034809F & 170 & Coal- or natural-gas-fired boiler \\
\hline Y-9401-3-C & 01-1020-33 & 034809F & 171 & Coal- or natural-gas-fired boiler \\
\hline Y-9401-3-D & $01-1020-34$ & 034809F & 171 & Coal- or natural-gas-fired boiler \\
\hline \multirow[t]{4}{*}{ Y-9404-9-C } & 01-1020-19 & $730315 \mathrm{P}$ & 324 & Urethane warming ovens \\
\hline & & & 325 & Urethane warming oven \#3 \\
\hline & & & 326 & PVC oven \#4 \\
\hline & & & 327 & PVC oven \#5 \\
\hline Y-9720-32-C & 01-1020-99 & $742886 \mathrm{I}$ & 435 & Classified paper waste incinerator \\
\hline Y-9767-13-A & 01-0020-35 & 036292P & $\mathrm{A}(00)$ & Chilled water circulating system \\
\hline Y-9767-4-B & 01-0020-38 & 036293P & $\mathrm{B}(00)$ & Chilled water circulating system \\
\hline \multirow[t]{2}{*}{ Y-9811-6-A } & 01-1020-82 & $029415 \mathrm{P}$ & 377 & Dry ash handling system \\
\hline & & & 378 & Dry ash handling system \\
\hline \multirow[t]{5}{*}{ Y-9998-A } & 01-0020-13 & 038154P & 60 & Five swaging machines \\
\hline & & & 61 & Foundry operations \\
\hline & & & 62 & Hood \\
\hline & & & 64 & Nitric acid pickling tank \\
\hline & & & 813 & Sintering furnaces \\
\hline Y-9998-B & $01-1020-84$ & 029584P & 172 & Machining beryllium source \\
\hline Y-9998-F & 01-1020-12 & $950266 \mathrm{P}$ & 143 & Metal-forming facility \\
\hline Fugitive & 01-1020-89 & $046044 \mathrm{P}$ & 00 & Plantwide fugitive sources \\
\hline
\end{tabular}


Table E.2. Oak Ridge National Laboratory air permits, $2003^{a}$

\begin{tabular}{|c|c|c|c|c|}
\hline $\begin{array}{l}\text { ORNL source } \\
\text { number }\end{array}$ & Source description & $\begin{array}{l}\text { Emission source } \\
\text { reference number }\end{array}$ & $\begin{array}{l}\text { TDEC permit } \\
\text { number }\end{array}$ & Permit type \\
\hline 2519 & $\begin{array}{l}\text { Steam Plant Boilers 1-6, } \\
516 \mathrm{mmBtu} / \mathrm{h} \text {, Boiler } 6 \text { - } \\
\text { NSPS }\end{array}$ & $73-0112-03$ & $055957 \mathrm{~F}$ & Operating \\
\hline $3039^{b}$ & $\begin{array}{l}\text { Off Gas \& Hot Cell } \\
\text { Ventilation }\end{array}$ & 73-0112-93 & 739974P & Operating \\
\hline 3502 & Manipulator Boot Shop & 73-0112-05 & $947267 \mathrm{P}$ & Operating \\
\hline $3608^{b}$ & Air Stripper & 73-0112-37 & 730489P & Operating \\
\hline 7007 & Paint Shop & 73-0112-09 & $743190 \mathrm{P}$ & Operating \\
\hline 7015 & Plasma Arc Torch & $73-1106-47$ & $947142 \mathrm{P}$ & Operating \\
\hline 7602 & Boiler, $16.75 \mathrm{mmBtu}$ & 73-0112-24 & 027090F & Operating \\
\hline 7603 & Boiler, $6.048 \mathrm{mmBtu}$ & $73-0112-25$ & $740219 \mathrm{~F}$ & Operating \\
\hline 7911 & HFIR and REDC & $73-0112-82$ & 034381P & Operating \\
\hline 8600 & $\begin{array}{l}\text { SNS CLO Boilers 2- } \\
14.65 \mathrm{mmBtu} / \mathrm{hr} \text { Boilers } \\
\text { (NSPS) }\end{array}$ & 73-0112-33 & $956640 \mathrm{~F}$ & Construction \\
\hline 8910 & $\begin{array}{l}\text { SNS CUB Boilers 2- } \\
8.37 \mathrm{mmBtu} / \mathrm{hr} \text { Boilers }\end{array}$ & 73-0112-07 & $954786 \mathrm{~F}$ & Operating \\
\hline NTRC & $\begin{array}{l}\text { National Transportation } \\
\text { Research Center }\end{array}$ & 0941-02 & 0941-02 & $\begin{array}{l}\text { Operating } \\
\text { (Knox County) }\end{array}$ \\
\hline
\end{tabular}

${ }^{a}$ Abbreviations

$\mathrm{CLO}=$ Central Laboratory and Office

CUB $=$ Central Utility Building

HFIR = High Flux Isotope Reactor

NSPS $=$ New Source Performance Standards

REDC $=$ Radiochemical Engineering Development Center

SNS $=$ Spallation Neutron Source

${ }^{b}$ Operated by Bechtel Jacobs 
Table E.3. East Tennessee Technology Park air permits, 2003

\begin{tabular}{|c|c|c|c|c|}
\hline ETTP source number & $\begin{array}{l}\text { Emission source } \\
\text { reference number }\end{array}$ & $\begin{array}{l}\text { Permit } \\
\text { number }\end{array}$ & Source description & $\begin{array}{l}\text { Permit } \\
\text { type }\end{array}$ \\
\hline K1202ST1 & $73-1106-20$ & 033203P & $\begin{array}{l}\text { Tank storing waste oils and } \\
\text { solvents for incinerator }\end{array}$ & Operating \\
\hline K1202ST2 & $73-1106-41$ & 034392P & $\begin{array}{l}\text { Tank storing waste oils and } \\
\text { solvents for incinerator }\end{array}$ & Operating \\
\hline K1420AI & 73-0106-82 & 034619P & Flammable materials storage tank & Operating \\
\hline K1425WOSA & 73-0106-11 & 029895P & $\begin{array}{l}\text { Waste oil and solvent storage } \\
\text { tanks }\end{array}$ & Operating \\
\hline K1425WOSB & 73-0106-11 & 029895P & $\begin{array}{l}\text { Waste oil and solvent storage } \\
\text { tanks }\end{array}$ & Operating \\
\hline K1425WOSC & 73-0106-11 & 029895P & $\begin{array}{l}\text { Waste oil and solvent storage } \\
\text { tanks }\end{array}$ & Operating \\
\hline K1425WOSD & 73-0106-11 & 029895P & $\begin{array}{l}\text { Waste oil and solvent storage } \\
\text { tanks }\end{array}$ & Operating \\
\hline K1435TSCAINCIN & 73-0106-78 & 032449I & $\begin{array}{l}\text { Toxic Substances Control Act } \\
\text { Incinerator }\end{array}$ & Operating \\
\hline K1435CTANKFARM & 73-0106-75 & 037460P & $\begin{array}{l}\text { Tank farm for hazardous liquid } \\
\text { wastes }\end{array}$ & Operating \\
\hline K1407CNFAIRSTRIPPER & 73-0106-90 & $045253 \mathrm{P}$ & $\begin{array}{l}\text { Air stripper for removing volatile } \\
\text { organic compounds at Central } \\
\text { Neutralization Facility }\end{array}$ & Operating \\
\hline K1775TVS & 73-0106-91 & $944465 \mathrm{P}$ & $\begin{array}{l}\text { Low-level mixed waste } \\
\text { vitrification system }\end{array}$ & $\begin{array}{l}\text { Permit to } \\
\text { construct }\end{array}$ \\
\hline ETTPFUGITIVEEMISSIONS & 73-1106-38 & $043016 \mathrm{P}$ & $\begin{array}{l}\text { Number of sources logged into } \\
\text { permit }\end{array}$ & Operating \\
\hline
\end{tabular}


Oak Ridge Reservation

Table E.4. Periods of excess emissions and out-of-service conditions for Y-12 Steam Plant east and west opacity monitors in 2003

\begin{tabular}{|c|c|c|c|}
\hline Date & Stack & Condition & Comments \\
\hline February 28 & East & Opacity monitoring malfunction & The east stack opacity monitor window stuck \\
\hline March 5 & $\begin{array}{l}\text { East and } \\
\text { West }\end{array}$ & $\begin{array}{l}\text { Opacity monitoring systems were } \\
\text { taken out of service until May } 2003\end{array}$ & $\begin{array}{l}\text { The old opacity monitors were replaced with } \\
\text { new opacity monitors }\end{array}$ \\
\hline May 22 & West & $\begin{array}{l}\text { Opacity monitoring system } \\
\text { malfunction }\end{array}$ & Due to a power outage at the steam plant \\
\hline June 13 & $\begin{array}{l}\text { East and } \\
\text { West }\end{array}$ & $\begin{array}{l}\text { Opacity monitoring system } \\
\text { malfunction }\end{array}$ & Due to a power outage at the steam plant \\
\hline August 8 & East & $\begin{array}{l}\text { Opacity monitoring system } \\
\text { malfunction }\end{array}$ & $\begin{array}{l}\text { The opacity monitor was failing calibration } \\
\text { because it was analyzing opacity average and } \\
\text { not opacity instantaneous }\end{array}$ \\
\hline November 3 & West & $\begin{array}{l}\text { Opacity monitoring system } \\
\text { malfunction }\end{array}$ & $\begin{array}{l}\text { Due to a misalignment of the opacity monitor } \\
\text { optical head, which was shifting as a result of } \\
\text { a loose mounting bracket }\end{array}$ \\
\hline November 18 & West & $\begin{array}{l}\text { Opacity monitoring system was } \\
\text { taken out of service }\end{array}$ & $\begin{array}{l}\text { To repair the mounting brackets of the opacity } \\
\text { monitor head assembly }\end{array}$ \\
\hline
\end{tabular}




\section{Appendix F: Radiation}





\section{Appendix F: Radiation}

This appendix presents basic facts about radiation. The information is intended to be a basis for understanding the potential doses associated with releases of radionuclides from the Oak Ridge Reservation (ORR), not as a comprehensive discussion of radiation and its effects on the environment and biological systems.

Radiation comes from natural and human-made sources. People are exposed to naturally occurring radiation constantly. For example, cosmic radiation; radon in air; potassium in food and water; and uranium, thorium, and radium in the earth's crust are all sources of radiation. The following discussion describes important aspects of radiation, including atoms and isotopes; types, sources, and pathways of radiation; radiation measurement; and dose information.

\section{ATOMS AND ISOTOPES}

All matter is made up of atoms. An atom is "a unit of matter consisting of a single nucleus surrounded by a number of electrons equal to the number of protons in the nucleus" (Alter 1986). The number of protons in the nucleus determines an element's atomic number or chemical identity. With the exception of hydrogen, the nucleus of each type of atom also contains at least one neutron. Unlike protons, the neutrons may vary in number among atoms of the same element. The number of neutrons and protons determines the atomic weight. Atoms of the same element that have different numbers of neutrons are called isotopes. In other words, isotopes have the same chemical properties but different atomic weights (Fig. F.1).

For example, the element uranium has 92 protons. All isotopes of uranium, therefore, have 92 protons. However, each uranium isotope has a different number of neutrons. Uranium-238 has 92 protons and 146 neutrons; uranium-235 has 92 protons and 143 neutrons; and uranium-234 has 92 protons and 142 neutrons.

Some isotopes are stable, or nonradioactive; some are radioactive. Radioactive isotopes are called radionuclides or radioisotopes. In an attempt to become

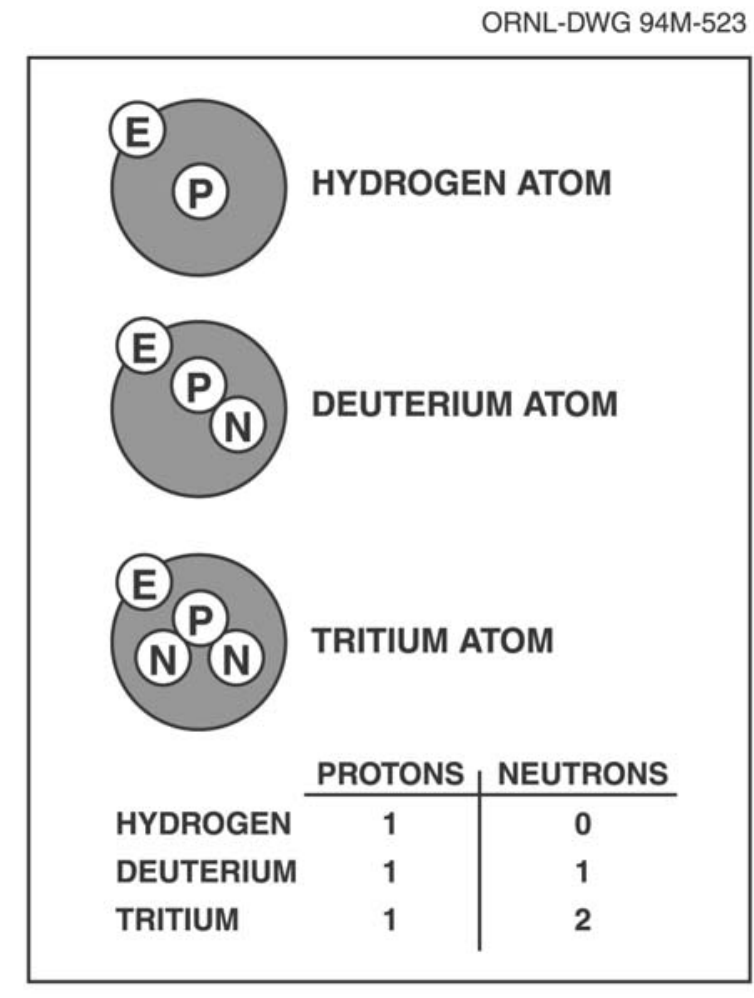

Fig. F.1. The hydrogen atom and its isotopes. stable, radionuclides "throw away," or emit, rays or particles. This emission of rays and particles is known as radioactive decay. Each radioisotope has a "radioactive half-life," which is the average time that it takes for half of a specified number of atoms to decay. Halflives can be very short (fractions of a second) or very long (millions of years), depending on the isotope (Table F.1). 
Table F.1. Radionuclide nomenclature

\begin{tabular}{|c|c|c|c|c|c|}
\hline Radionuclide & Symbol & Half-life & Radionuclide & Symbol & Half-life \\
\hline Americium-241 & ${ }^{241} \mathrm{Am}$ & 432.2 years & Plutonium-238 & ${ }^{238} \mathrm{Pu}$ & 87.75 years \\
\hline Americium-243 & ${ }^{243} \mathrm{Am}$ & $7.38 \mathrm{E}+3$ years & Plutonium-239 & ${ }^{239} \mathrm{Pu}$ & $2.41 \mathrm{E}+4$ years \\
\hline Antimony-125 & ${ }^{125} \mathrm{Sb}$ & 2.77 years & Plutonium-240 & ${ }^{240} \mathrm{Pu}$ & $6.569 \mathrm{E}+3$ years \\
\hline Argon-41 & ${ }^{41} \mathrm{Ar}$ & 1.827 hours & Potassium-40 & ${ }^{40} \mathrm{~K}$ & $1.2777 \mathrm{E}+9$ years \\
\hline Beryllium-7 & ${ }^{7} \mathrm{Be}$ & 53.44 days & Promethium-147 & ${ }^{147} \mathrm{Pm}$ & 2.6234 years \\
\hline Californium-252 & ${ }^{252} \mathrm{Cf}$ & 2.639 years & Protactinium- $234 m$ & ${ }^{234 m} \mathrm{~Pa}$ & 1.17 minutes \\
\hline Carbon-14 & ${ }^{14} \mathrm{C}$ & $5.730 \mathrm{E}+3$ years & Radium-226 & ${ }^{226} \mathrm{Ra}$ & $1.6 \mathrm{E}+3$ years \\
\hline Cerium-141 & ${ }^{141} \mathrm{Ce}$ & 32.50 days & Radium-228 & ${ }^{228} \mathrm{Ra}$ & 5.75 years \\
\hline Cerium-143 & ${ }^{143} \mathrm{Ce}$ & 1.38 days & Ruthenium-103 & ${ }^{103} \mathrm{Ru}$ & 39.35 days \\
\hline Cerium-144 & ${ }^{144} \mathrm{Ce}$ & 284.3 days & Ruthenium-106 & ${ }^{106} \mathrm{Ru}$ & 368.2 days \\
\hline Cesium-134 & ${ }^{134} \mathrm{Cs}$ & 2.062 years & Strontium-89 & ${ }^{89} \mathrm{Sr}$ & 50.55 days \\
\hline Cesium-137 & ${ }^{137} \mathrm{Cs}$ & 30.17 years & Strontium-90 & ${ }^{90} \mathrm{Sr}$ & 28.6 years \\
\hline Cobalt-58 & ${ }^{58} \mathrm{Co}$ & 70.80 days & Technetium-99 & ${ }^{99} \mathrm{Tc}$ & $2.13 \mathrm{E}+5$ years \\
\hline Cobalt-60 & ${ }^{60} \mathrm{Co}$ & 5.271 years & Thorium-228 & ${ }^{228} \mathrm{Th}$ & 1.9132 years \\
\hline Curium-242 & ${ }^{242} \mathrm{Cm}$ & 163.2 days & Thorium-230 & ${ }^{230} \mathrm{Th}$ & $7.54 \mathrm{E}+4$ years \\
\hline Curium-244 & ${ }^{244} \mathrm{Cm}$ & 18.11 years & Thorium-232 & ${ }^{232} \mathrm{Th}$ & $1.405 \mathrm{E}+10$ years \\
\hline Iodine-129 & ${ }^{129} \mathrm{I}$ & $157 \mathrm{E}+7$ years & Thorium-234 & ${ }^{234} \mathrm{Th}$ & $2.41 \mathrm{E}+1$ day \\
\hline Iodine-131 & ${ }^{131} \mathrm{I}$ & 8.04 days & Tritium & ${ }^{3} \mathrm{H}$ & 12.28 years \\
\hline Krypton-85 & ${ }^{85} \mathrm{Kr}$ & 10.72 years & Uranium-234 & ${ }^{234} \mathrm{U}$ & $2.445 \mathrm{E}+5$ years \\
\hline Krypton-88 & ${ }^{88} \mathrm{Kr}$ & 2.84 hours & Uranium-235 & ${ }^{235} \mathrm{U}$ & $7.038 \mathrm{E}+8$ years \\
\hline Manganese-54 & ${ }^{54} \mathrm{Mn}$ & 312.7 days & Uranium-236 & ${ }^{236} \mathrm{U}$ & $2.3415 \mathrm{E}+7$ years \\
\hline Neptunium-237 & ${ }^{237} \mathrm{~Np}$ & $2.14 \mathrm{E}+6$ days & Uranium-238 & ${ }^{238} \mathrm{U}$ & $4.468 \mathrm{E}+9$ years \\
\hline Niobium-95 & ${ }^{95} \mathrm{Nb}$ & 35.06 days & Xenon-133 & ${ }^{133} \mathrm{Xe}$ & $5.245 \mathrm{E}+9$ years \\
\hline Osmium-185 & ${ }^{185} \mathrm{Os}$ & 93.6 days & Xenon-135 & ${ }^{135} \mathrm{Xe}$ & 9.11 hours \\
\hline Phosphorus-32 & ${ }^{32} \mathrm{P}$ & 14.29 days & Yttrium-90 & ${ }^{90} \mathrm{Y}$ & 64.1 hours \\
\hline Polonium-210 & ${ }^{210} \mathrm{Po}$ & 138.378 days & Zirconium-95 & ${ }^{95} \mathrm{Zr}$ & 64.02 days \\
\hline
\end{tabular}

Source: DOE 1989. Radioactive Decay Data Tables: A Handbook of Decay Data for Application to Radioactive Dosimetry and Radiological Assessments, DOE/TIC-11026.

\section{RADIATION}

Radiation, or radiant energy, is energy in the form of waves or particles moving through space. Visible light, heat, radio waves, and alpha particles are examples of radiation. When people feel warmth from sunlight, they are actually absorbing the radiant energy emitted by the sun.

Electromagnetic radiation is radiation in the form of electromagnetic waves. Examples include gamma rays, ultraviolet light, and radio waves. Particulate radiation is radiation in the form of particles. Examples include alpha and beta particles. Radiation also is characterized as ionizing or nonionizing because of the way in which it interacts with matter. 


\section{lonizing Radiation}

Normally, an atom has an equal number of protons and electrons; however, atoms can lose or gain electrons in a process known as ionization. Some forms of radiation (called ionizing radiation) can ionize atoms by "knocking" electrons off atoms. Examples of ionizing radiation include alpha, beta, and gamma radiation.

Ionizing radiation is capable of changing the chemical state of matter and subsequently causing biological damage. By this mechanism, it is potentially harmful to human health.

\section{Non-ionizing Radiation}

Non-ionizing radiation bounces off or passes through matter without displacing electrons. Examples include visible light and radio waves. At this time, it is unclear whether non-ionizing radiation is harmful to human health. In the discussion that follows, the term radiation is used to describe ionizing radiation.

\section{SOURCES OF RADIATION}

Radiation is everywhere. Most occurs naturally; a small percentage is human-made. Naturally occurring radiation is known as background radiation.

\section{Background Radiation}

Many materials are naturally radioactive. In fact, this naturally occurring radiation is the major source of radiation in the environment. Although people have little control over the amount of background radiation to which they are exposed, this exposure must be put into perspective. Background radiation remains relatively constant over time and is present in the environment today much as it was hundreds of years ago.

Sources of background radiation include uranium in the earth, radon in the air, and potassium in food. Background radiation is categorized as cosmic, terrestrial, or internal, depending on its origin.

\section{Cosmic Radiation}

Energetically charged particles from outer space continuously hit the earth's atmosphere. These particles and the secondary particles and photons they create are called cosmic radiation. Because the atmosphere provides some shielding against cosmic radiation, the intensity of this radiation increases with altitude above sea level. For example, a person in Denver, Colorado, is exposed to more cosmic radiation than a person in New Orleans, Louisiana.

\section{Terrestrial Radiation}

Terrestrial radiation refers to radiation emitted from radioactive materials in the earth's rocks, soils, and minerals. Radon $(\mathrm{Rn})$, radon progeny (the relatively short-lived decay products from the decay of the radon isotope $\left.{ }^{222} \mathrm{Rn}\right)$, potassium $\left({ }^{40} \mathrm{~K}\right)$, isotopes of thorium $(\mathrm{Th})$, and isotopes of uranium (U) are the elements responsible for most terrestrial radiation.

\section{Internal Radiation}

Radionuclides in the environment enter the body with the air people breathe and the foods they eat. They also can enter through an open wound. Natural radionuclides that can be inhaled and ingested include isotopes of uranium and its progeny, especially radon $\left({ }^{222} \mathrm{Rn}\right)$ and its progeny, thoron $\left({ }^{220} \mathrm{Rn}\right)$ and its progeny, 
potassium $\left({ }^{40} \mathrm{~K}\right)$, rubidium $\left({ }^{87} \mathrm{Rb}\right)$, and carbon $\left({ }^{14} \mathrm{C}\right)$. Radionuclides contained in the body are dominated by ${ }^{40} \mathrm{~K}$ and ${ }^{210} \mathrm{Po}$; others include ${ }^{87} \mathrm{Rb}$ and ${ }^{14} \mathrm{C}$ (NCRP 1987).

\section{Human-Made Radiation}

In addition to background radiation, there are human-made sources of radiation to which most people are exposed. Examples include consumer products, medical sources, fallout from atmospheric atomic bomb tests, and industrial by-products. No atmospheric testing of atomic weapons has occurred since 1980 (NCRP 1987).

\section{Consumer Products}

Some consumer products are sources of radiation. The radiation in some of these products, such as smoke detectors and airport X-ray baggage inspection systems, is essential to the performance of the device. In other products, such as televisions and tobacco products, the radiation occurs incidentally to the product's function.

\section{Medical Sources}

Radiation is an important tool of diagnostic medicine and treatment and is the main source of exposure to the public from human-made radiation. Exposure is deliberate and directly beneficial to the patients exposed. In general, medical exposures from diagnostic or therapeutic X-rays result from beams directed to specific areas of the body. Thus, all body organs generally are not irradiated uniformly. Nuclear medicine examinations and treatments involve the internal administration of radioactive compounds, or radiopharmaceuticals, by injection, inhalation, consumption, or insertion. Even then, radionuclides are not distributed uniformly throughout the body. Radiation and radioactive materials also are used in the preparation of medical instruments, including the sterilization of heat-sensitive products such as plastic heart valves.

\section{Other Sources}

Radioactive fallout, the by-product of nuclearweapons testing in the atmosphere, is a source of radiation. Other sources of radiation include emissions of radioactive materials from nuclear facilities such as uranium mines, fuel-processing plants, and nuclear power plants; transportation of radioactive materials; and emissions from mineral-extraction facilities.

\section{PATHWAYS OF RADIONUCLIDES}

People can be exposed to radionuclides in the environment through a number of routes (Fig. F.2). Potential routes for internal and/or external exposure are referred to as pathways. For example, radionuclides in the air could fall on a pasture. The grass then could be eaten by cows, and the radionuclides deposited on the grass would show up in milk. People drinking the milk would be exposed to this radiation. People could also inhale the airborne radionuclides.

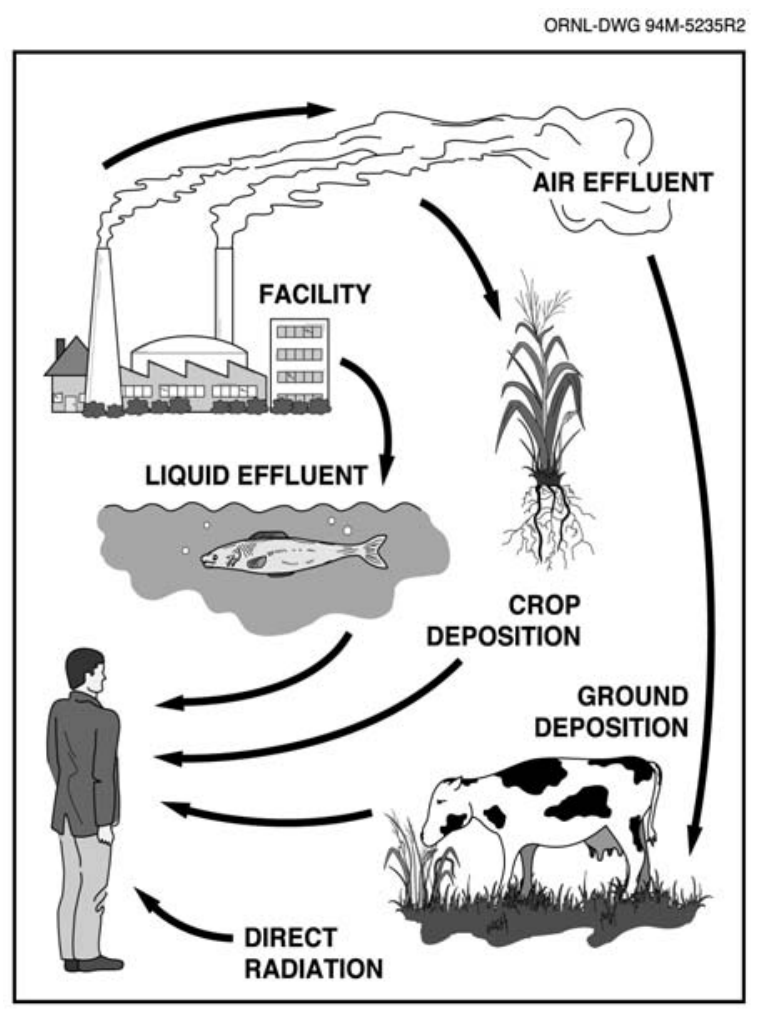

Fig. F.2. Examples of radiation pathways. 
Similarly, radionuclides in water could be ingested by fish, and people eating the fish would also ingest the radionuclides in the fish tissue. People swimming in the water would be exposed also.

\section{MEASURING RADIATION}

To determine the possible effects of radiation on the health of the environment and people, the radiation must be measured. More precisely, its potential to cause damage must be ascertained.

\section{Activity}

When we measure the amount of radiation in the environment, what is actually being measured is the rate of radioactive decay, or activity. The rate of decay varies widely among the various radioisotopes. For that reason, $1 \mathrm{~g}$ of a radioactive substance may contain the same amount of activity as several tons of another material. This activity is expressed in a unit of measure known as a curie (Ci). More specifically, one curie equals $3.7 \times 10^{10}(37,000,000,000)$ atomic disintegrations per second (dps). In the international system of units, $1 \mathrm{dps}$ equals 1 becquerel $(\mathrm{Bq})$.

\section{Absorbed Dose}

The total amount of energy absorbed per unit mass of the exposed material as a result of exposure to radiation is expressed in a unit of measure known as a rad. In this case, it is the effect of the absorbed energy (the biological damage that it causes) that is important, not the actual amount. In the international system of units, 100 rad equals 1 gray (Gy).

\section{Dose Equivalent}

The measure of potential biological damage to specific body organs or tissues caused by exposure to and subsequent absorption of radiation is expressed in a unit of measure known as a rem. One rem of any type of radiation has the same total damaging effect. Because a rem represents a fairly large dose equivalent, dose equivalents are usually expressed as millirem (mrem), which is $1 / 1000$ of a rem. In the international system of units, 1 sievert (Sv) equals $100 \mathrm{rem}$; 1 millisievert (mSv) equals $100 \mathrm{mrem}$. Specific types of dose equivalents are defined as follows:

- committed dose equivalent: the total dose equivalent to an organ during the 50-year period following intake.

- effective dose equivalent (EDE): the weighted sum of dose equivalents to a specified list of organs. The organs and weighting factors are selected on the basis of risk to the entire body. "EDE" is the unit used in the Annual Site Environmental Report.

- committed effective dose equivalent: the total effective dose to specified organs in the human body during the 50-year period following intake.

- collective effective dose equivalent: the sum of effective dose equivalents of all members of a given population.

\section{Dose Determination}

Determining dose is an involved process in which complex mathematical equations based on several factors, including the type of radiation, the rate of exposure, weather conditions, and typical diet, are used. Basically, radioactive decay, or activity, generates radiant energy. People absorb some of the energy to which they are exposed. The effect of this absorbed energy is responsible for an individual's dose. Whether radiation is natural or human-made, it has the same effect on people. 
Many terms are used to report dose. The terms take several factors into account, including the amount of radiation absorbed, the organ absorbing the radiation, and the effect of the radiation over a 50-year period. The term "dose," in this report means the committed EDE, which is the total effective dose equivalent that will be received during a specified time ( 50 years) from radionuclides taken into the body in the current year, and the EDE attributable to penetrating radiation from sources external to the body.

\section{Dose Conversion Factor}

A dose conversion factor is defined as the dose equivalent received from exposure to a unit quantity of a radionuclide by way of a specific exposure pathway. Two types of dose conversion factors exist. One type gives the committed dose equivalent (rem) resulting from intake (by inhalation and ingestion) of a unit activity $(1.0 \mu \mathrm{Ci})$ of a radionuclide. The second gives the dose equivalent rate (millirem per year) per unit activity $(1.0 \mu \mathrm{Ci})$ of a radionuclide in a unit (cubic or square centimeters) of an environmental compartment (air volume or ground surface). All dose conversion factors used in this report were approved by the U.S. Department of Energy or by the U.S. Environmental Protection Agency (DOE 1988a; DOE 1988b; EPA 1993).

\section{Comparison of Dose Levels}

Table F.2 presents a scale of dose levels, with an example of the type of exposure that may cause such a dose, or the special significance of such a dose. This information is intended to help the reader become familiar with a range of doses that various individuals may receive.

\section{Dose from Cosmic Radiation}

The average annual dose equivalent to people in the United States from cosmic radiation is about $27 \mathrm{mrem}(0.27 \mathrm{mSv})$ (NCRP 1987). The average dose equivalent caused by cosmic radiation in Tennessee is about $45 \mathrm{mrem}$ per year $(0.45 \mathrm{mSv}$ per year) (Tsakeres 1980). When shielding and the time spent indoors are considered, the dose for the surrounding population is reduced to $80 \%$, or about $36 \mathrm{mrem}(0.36 \mathrm{mSv})$ per year.

\section{Dose from Terrestrial Radiation}

The average annual dose from terrestrial gamma radiation is about $28 \mathrm{mrem}(0.28 \mathrm{mSv})$ in the United States but varies geographically across the country (NCRP 1987). Typical reported values are about $16 \mathrm{mrem}$ $(0.16 \mathrm{mSv})$ on the Atlantic and Gulf coastal plains and about $63 \mathrm{mrem}(0.63 \mathrm{mSv})$ on the eastern slopes of the Rocky Mountains. The average external gamma exposure rate in the vicinity of the ORR is about $7.8 \mu \mathrm{R} / \mathrm{h}$, which results in an equivalent dose of about $51 \mathrm{mrem}$ per year $(0.51 \mathrm{mSv}$ per year).

\section{Dose from Internal Radiation}

The major contributors to the annual dose equivalent for internal radionuclides are the short-lived decay products of radon, which contribute an average dose of about $200 \mathrm{mrem}(2.00 \mathrm{mSv})$ per year. This dose estimate is based on an average radon concentration of about $1 \mathrm{pCi} / \mathrm{L}(0.037 \mathrm{~Bq} / \mathrm{L})(\mathrm{NCRP} 1987)$.

The average dose from other internal radionuclides is about $39 \mathrm{mrem}(0.39 \mathrm{mSv})$ per year, which is predominantly attributed to the naturally occurring radioactive isotope of potassium, ${ }^{40} \mathrm{~K}$. The concentration of radioactive potassium in human tissues is similar in all parts of the world (NCRP 1987). 
Table F.2. Comparison and description of various dose levels

\begin{tabular}{|c|c|}
\hline Dose level & Description \\
\hline $1 \mathrm{mrem}$ & Approximate daily dose from natural background radiation, including radon \\
\hline $2.5 \mathrm{mrem}$ & Cosmic dose to a person on a one-way airplane flight from New York to Los Angeles \\
\hline 10 mrem & $\begin{array}{l}\text { Annual exposure limit set by the U.S. Environmental Protection Agency (EPA) for exposures } \\
\text { from airborne emissions from operations of nuclear fuel cycle facilities, including power plants, } \\
\text { uranium mines, and mills }\end{array}$ \\
\hline 45 mrem & Average yearly dose from cosmic radiation received by people in the Paducah, Kentucky, area \\
\hline 46 mrem & $\begin{array}{l}\text { Estimate of the largest dose any off-site person could have received from the March 28, } 1979 \text {, } \\
\text { Three Mile Island nuclear accident }\end{array}$ \\
\hline 66 mrem & Average yearly dose to people in the United States from human-made sources \\
\hline 100 mrem & $\begin{array}{l}\text { Annual limit of dose from all U.S. Department of Energy (DOE) facilities to a member of the } \\
\text { public who is not a radiation worker }\end{array}$ \\
\hline 110 mrem & Average occupational dose received by U.S. commercial radiation workers in 1980 \\
\hline 244 mrem & Average dose from an upper gastrointestinal diagnostic X-ray series \\
\hline 300 mrem & $\begin{array}{l}\text { Average yearly dose to people in the United States from all sources of natural background } \\
\text { radiation }\end{array}$ \\
\hline 1 to 5 rem & $\begin{array}{l}\text { Level at which EPA Protective Action Guidelines state that public officials should take } \\
\text { emergency action when this is a probable dose to a member of the public from a nuclear } \\
\text { accident }\end{array}$ \\
\hline $5 \mathrm{rem}$ & $\begin{array}{l}\text { Annual limit for occupational exposure of radiation workers set by the U.S. Nuclear Regulatory } \\
\text { Commission and DOE }\end{array}$ \\
\hline 10 rem & $\begin{array}{l}\text { Estimated level at which an acute dose would result in a lifetime excess risk of death from } \\
\text { cancer of } 0.8 \%\end{array}$ \\
\hline $25 \mathrm{rem}$ & $\begin{array}{l}\text { EPA guideline for voluntary maximum dose to emergency workers for non-lifesaving work } \\
\text { during an emergency }\end{array}$ \\
\hline 75 rem & EPA guideline for maximum dose to emergency workers volunteering for lifesaving work \\
\hline 50 to $600 \mathrm{rem}$ & $\begin{array}{l}\text { Level at which doses received over a short period of time produce radiation sickness in varying } \\
\text { degrees. At the lower end of this range, people are expected to recover completely, given proper } \\
\text { medical attention. At the top of this range, most people will die within } 60 \text { days }\end{array}$ \\
\hline
\end{tabular}

Adapted from Westinghouse Savannah River Company 1994. Savannah River Site Environmental Report for 1993, Summary Pamphlet, WSRC-TR-94-076 (WSRC 1994). 


\section{Dose from Consumer Products}

The U.S. average annual dose to an individual from consumer products is about 10 mrem $(0.10 \mathrm{mSv})$ (NCRP 1987); however, not all members of the U.S. population are exposed to all of these sources.

\section{Dose from Medical Sources}

Nuclear medicine examinations, which involve internal administration of radiopharmaceuticals, generally account for the largest portion of dose from human-made sources. However, the radionuclides used for specific tests are not distributed uniformly throughout the body. In these cases, the concept of EDE, which relates the significance of exposures of organs or body parts to the effect on the entire body, is useful in making comparisons. The average annual EDE from medical examinations is $53 \mathrm{mrem}(0.53 \mathrm{mSv})$, including $39 \mathrm{mrem}(0.39 \mathrm{mSv})$ for diagnostic $\mathrm{X}$ rays and $14 \mathrm{mrem}(0.14 \mathrm{mSv})$ for nuclear medicine procedures (NCRP 1989). The actual doses to individuals who receive such medical exams are much higher than these values, but not everyone receives such exams each year (NCRP 1989).

\section{Doses from Other Sources}

A few additional sources of radiation contribute minor doses to individuals in the United States. The dose to the general public from nuclear fuel cycle facilities, such as uranium mines, mills, fuel-processing plants, nuclear power plants, and transportation routes, has been estimated at less than $1 \mathrm{mrem}(0.01 \mathrm{mSv})$ per year (NCRP 1987).

Small doses to individuals occur as a result of radioactive fallout from atmospheric atomic bomb tests, emissions of radioactive materials from nuclear facilities, emissions from certain mineral extraction facilities, and transportation of radioactive materials. The combination of these sources contributes less than $1 \mathrm{mrem}$ (0.01 mSv) per year to an individual's average dose (NCRP 1987). 


\section{Appendix G: Chemicals}





\section{Appendix G: Chemicals}

This appendix presents basic facts about chemicals. The information is intended to be a basis for understanding the dose or relative toxicity assessment associated with possible releases from the Oak Ridge Reservation (ORR), not a comprehensive discussion of chemicals and their effects on the environment and biological systems.

\section{PERSPECTIVE ON CHEMICALS}

The lives of modern humans have been greatly improved by the development of chemicals such as pharmaceuticals, building materials, housewares, pesticides, and industrial chemicals. Through the use of chemicals, we can increase food production, cure diseases, build more efficient houses, and send people to the moon. At the same time, we must be cautious to ensure that our own existence is not endangered by uncontrolled and overexpanded use of chemicals (Chan et al. 1982).

Just as all humans are exposed to radiation in the normal daily routine, humans are also exposed to chemicals. Some potentially hazardous chemicals exist in the natural environment. In many areas of the country, soils contain naturally elevated concentrations of metals such as selenium, arsenic, or molybdenum, which may be hazardous to humans or animals. Even some of the foods we eat contain natural toxins. Aflatoxin is a known toxin found in peanuts, and cyanide is found in apple seeds. However, exposures to many more hazardous chemicals result from the direct or indirect actions of humans. Building materials used for the construction of homes may contain chemicals such as formaldehyde (in some insulation materials), asbestos (formerly used in insulations and ceiling tiles), and lead (formerly used in paints and gasoline). Some chemicals are present as a result of application of pesticides and fertilizers to soil. Other chemicals may have been transported long distances through the atmosphere from industrial sources before being deposited on soil or water.

\section{PATHWAYS OF CHEMICALS FROM THE ORR TO THE PUBLIC}

Pathways refer to the route or way in which a person can come in contact with a chemical substance. Chemicals released to the air may remain suspended for long periods of time, or they may be rapidly deposited on plants, soil, and water. Chemicals may also be released as liquid wastes called effluents, which can enter streams and rivers.

People are exposed to chemicals by inhalation (breathing air), ingestion (eating exposed plants and animals or drinking water), or by direct contact (touching the soil or swimming in water). For example, fish that live in a river that receives effluents may take in some of the chemicals present. People eating the fish would then be exposed to the chemical. Less likely would be exposure by directly drinking from the stream or river.

The public is not normally exposed to chemicals on the ORR because access to the reservation is limited. However, chemicals released as a result of ORR operations can move through the environment to off-site locations, resulting in potential exposure to the public.

\section{DEFINITIONS}

\section{Toxicity}

Chemicals have varying types of effects. Chemical health effects are divided into two broad categories: adverse or systemic effects (noncarcinogens) and cancer (carcinogens). Sometimes a chemical can have both a toxic and a carcinogenic effect. The toxic effect can be acute (short-term severe health effect) or chronic (longer-term persistent health effect). Toxicity is often evident in a shorter length of time than the carcinogenic effect. The potential health effects of noncarcinogens range from skin irritation to fatality. Carcinogens cause or increase the incidence of malignant neoplasms or cancers. 
Toxicity refers to an adverse effect of a chemical on human health. Every day we ingest chemicals in the form of food, water, and sometimes medications. Even those chemicals usually considered toxic are usually nontoxic or harmless below a certain concentration.

Concentration limits or advisories are set by government agencies for some chemicals that are known or are thought to have an adverse effect on human health. These concentration limits can be used to calculate a chemical dose that would not harm even individuals who are particularly sensitive to the chemical.

\section{Dose Terms for Noncarcinogens}

\section{Reference Dose}

A reference dose is an estimate of a daily exposure level for the human population, including sensitive subpopulations, that is likely to be without an appreciable risk of deleterious effects during a lifetime. Units are expressed as milligrams of chemical per kilogram of an adult's body weight per day ( $\mathrm{mg} / \mathrm{kg}^{-}$day). These values are given in Table G.1.

Values for reference doses are derived from doses of chemicals that result in no adverse effect or the lowest dose that showed an adverse effect on humans or laboratory animals. Uncertainty factors are typically used in deriving reference doses. Uncertainty adjustments may be made if animal toxicity data are extrapolated to humans to account for human sensitivity, extrapolated from subchronic to chronic no-observedadverse-effect-levels, extrapolated from lowest-observed-adverse-effect-levels to no-observed-adverse-effectlevels, and to account for database deficiencies. The use of uncertainty factors in deriving reference doses is thought to protect the sensitive human populations. The U.S. Environmental Protection Agency (EPA) maintains the Integrated Risk Information System data base, which contains verified reference doses and up-to-date health risk and EPA regulatory information for numerous chemicals.

\section{Primary maximum contaminant levels}

For chemicals for which reference doses are not available in Integrated Risk Information System, national primary drinking water maximum contaminant levels, expressed in milligrams of chemical per liter of drinking water, are converted to reference dose values by multiplying by 2 liters (L) (the average daily adult water intake) and dividing by $70 \mathrm{~kg}$ (the reference adult body weight). The result is a "derived" reference dose expressed in milligrams per kilogram per day $(\mathrm{mg} / \mathrm{kg}$-day). These values are given in Table G.1.

\section{Dose Term for Carcinogens}

\section{Slope Factor}

A slope factor is a plausible upper-bound estimate of the probability of a response per unit intake of a chemical during a lifetime. The slope factor is used to estimate an upper-bound probability of an individual developing cancer as a result of a lifetime exposure to a particular level of a potential carcinogen. Units are expressed as risk per dose (mg/kg-day). These values are given in Table G.1.

The slope factor converts the estimated daily intake averaged over a lifetime exposure to the incremental risk of an individual developing cancer. Because it is unknown for most chemicals whether a threshold (a dose below which no adverse effect occurs) exists for carcinogens, units for carcinogens are set in terms of risk factors. Acceptable risk levels for carcinogens range from $10^{-4}$ (risk of developing cancer over a human lifetime of 1 in 10,000) to $10^{-6}$ (risk of developing cancer over a human lifetime is 1 in 1,000,000). In other words, a certain chemical concentration in food or water could cause a risk of one additional cancer for every $10,000\left(10^{-4}\right)$ to $1,000,000\left(10^{-6}\right)$ exposed persons, respectively.

\section{G-4 Appendix G: Chemicals}


Table G.1. Chemical reference doses and slope factors used in drinking water and fish intake analysis

\begin{tabular}{|c|c|c|c|c|c|}
\hline \multicolumn{3}{|c|}{ Elements } & \multicolumn{3}{|c|}{ Compounds } \\
\hline Chemical & Factor & Reference $^{a}$ & Chemical & Factor & Reference $^{a}$ \\
\hline Antimony & $4.0 \mathrm{E}-04$ & RfD & Acetone & $9.0 \mathrm{E}-01$ & RfD \\
\hline Arsenic & $3.0 \mathrm{E}-04$ & RfD & Aroclor-1254 & $2.0 \mathrm{E}-05$ & RfD \\
\hline & $1.5 \mathrm{E}+00$ & SF & Aroclor-1260 & $2.0 \mathrm{E}-05$ & $\operatorname{RfD}^{b}$ \\
\hline Barium & $7.0 \mathrm{E}-02$ & RfD & Chlordane $(\alpha, \gamma)$ & $5.0 \mathrm{E}-04$ & RfD \\
\hline Beryllium & $2.0 \mathrm{E}-03$ & RfD & & $3.5 \mathrm{E}-01$ & SF \\
\hline Boron & $9.0 \mathrm{E}-02$ & RfD & $4,4^{\prime}-\mathrm{DDD}$ & $2.4 \mathrm{E}-01$ & SF \\
\hline Cadmium & $5.0 \mathrm{E}-04$ & RfD & $4,4^{\prime}-\mathrm{DDE}$ & $3.4 \mathrm{E}-01$ & SF \\
\hline Chromium & $3.0 \mathrm{E}-03$ & RfD & $4,4^{\prime}$-DDT & $5.0 \mathrm{E}-04$ & RfD \\
\hline Lead & $1.4 \mathrm{E}-04$ & $c, d$ & Dieldrin & $5.0 \mathrm{E}-05$ & RfD \\
\hline Manganese & $1.4 \mathrm{E}-01$ & RfD & & $1.6 \mathrm{E}+01$ & SF \\
\hline Mercury & $3.0 \mathrm{E}-04$ & $\operatorname{RfD}^{e}$ & Endosulfan sulfate & $1.7 \mathrm{E}-03$ & $c, f$ \\
\hline Molybdenum & $5.0 \mathrm{E}-03$ & RfD & Endrin & $3.0 \mathrm{E}-04$ & RfD \\
\hline Nickel & $2.0 \mathrm{E}-02$ & RfD & Heptachlor epoxide & $1.3 \mathrm{E}-05$ & RfD \\
\hline Selenium & $5.0 \mathrm{E}-03$ & RfD & & $9.1 \mathrm{E}+00$ & SF \\
\hline Silver & $5.0 \mathrm{E}-03$ & RfD & PCBs (mixed) & $2.0 \mathrm{E}+00$ & $\mathrm{SF}^{g}$ \\
\hline Strontium & $6.0 \mathrm{E}-01$ & RfD & & & \\
\hline Thallium & 5.7E-05 & $c, h$ & & & \\
\hline Uranium & $3.0 \mathrm{E}-03$ & RfD & & & \\
\hline Vanadium & $7.0 \mathrm{E}-03$ & RfD & & & \\
\hline Zinc & $3.0 \mathrm{E}-01$ & RfD & & & \\
\hline
\end{tabular}

${ }^{a} \mathrm{RfD}$ : reference dose $\left(\mathrm{mg} \mathrm{kg}^{-1} \mathrm{day}^{-1}\right)$; SF: slope factor (risk per $\mathrm{mg} \mathrm{kg}^{-1} \mathrm{day}^{-1}$ ).

${ }^{b}$ The RfD for Aroclor-1254 is also used for Aroclor-1260.

${ }^{c}$ The WQC are given in units of micrograms per liter. To convert the concentration to an $\operatorname{RfD}\left(\mathrm{mg} \mathrm{kg}^{-1} \mathrm{day}^{-1}\right)$, divide by 1000 (to convert to milligrams per liter), multiply by the consumption rate ( $2 \mathrm{~L} /$ day), and divide by the mass of a reference man, $70 \mathrm{~kg}$.

${ }^{d}$ This value is based on the 2004 Tennessee WQC for lead for domestic water supplies.

${ }^{e}$ An EPA-approved oral chronic RfD, SF, or other guideline for elemental mercury in water or aquatic organisms is not available. Most guidelines refer to "recoverable" or inorganic mercury. RfD values exist for several inorganic mercury salts. The EPA oral RfD for soluble mercuric chloride $\left(\mathrm{HgCl}_{2}\right)$ is $3.0 \mathrm{E}-04 \mathrm{mg} / \mathrm{kg} / \mathrm{day}$.

${ }^{f}$ This value is based on the 2004 Tennessee Water Quality Criterion (WQC) for endosulfan sulfate for ingestion of water and aquatic organisms $(62 \mu \mathrm{g} / \mathrm{L})$.

${ }^{8}$ The cancer potency of PCB mixtures is determined using a three-tiered approach. This value is the upper bound slope factor for the High Risk and Persistence Tier.

${ }^{h}$ This value is based on the 2004 Tennessee WQC for thallium for domestic water supplies, which reflects the maximum contaminant level value $(2 \mu \mathrm{g} / \mathrm{L})$.

\section{MEASURING CHEMICALS}

Environmental samples are collected in areas surrounding the ORR and are analyzed for those chemical constituents most likely to be released from the ORR. Typically, chemical concentrations in liquids are expressed in terms of milligrams or micrograms of chemical per liter of water; concentrations in solids (soil and fish tissue) are expressed in terms of milligrams or micrograms of chemical per gram or kilogram of sample material.

The instruments used to measure chemical concentrations are sensitive; however, they have limits below which they cannot detect the chemicals of interest. Concentrations detected below the reported analytical detection limits of the instruments are recorded by the laboratory as estimated values, which have a greater 
uncertainty than those concentrations detected above the detection limits of the instruments. Health effect calculations using these estimated values are indicated with tildes $(\sim)$ or "J." The tilde indicates that estimated values were used in estimating the average concentration of a chemical. "J" indicates that the chemical concentration is detected below the reported analytical detection limits of the instruments and is recorded by the laboratory as an estimated value.

\section{RISK ASSESSMENT METHODOLOGY}

\section{Exposure Assessment}

To evaluate an individual's exposure by way of a specific exposure pathway, the intake amount of the chemical must be determined. For example, chemical exposure by drinking water and eating fish from the Clinch River is assessed in the following way. Clinch River surface water and fish samples are analyzed to estimate chemical contaminant concentrations. It is assumed that individuals drink $2 \mathrm{~L}$ ( 0.53 gal) of water per day directly from the river, which amounts to $730 \mathrm{~L}(193 \mathrm{gal})$ per year, and that they eat $0.06 \mathrm{~kg}$ of fish per day from the river $(21 \mathrm{~kg}$ per year). Estimated daily intakes or estimated doses to the public are calculated by multiplying measured (statistically significant) concentrations in water by $2 \mathrm{~L}$ or those in fish by $0.06 \mathrm{~kg}$. This intake is first multiplied by the exposure duration (30 years) and exposure frequency (350 days/year), and then divided by an averaging time (30 years for noncarcinogens and 70 years for carcinogens). These assumptions are conservative, and in many cases they result in higher estimated intakes and doses than an actual individual would receive.

\section{Dose Estimate}

When the contaminant oral daily intake via exposure pathways has been estimated, the dose is determined. For chemicals, the dose to humans is measured as milligrams per kilogram-day (mg/ kg-day). In this case, the "kilogram" refers to the body weight of an adult individual. When a chemical dose is calculated, the length of time an individual is exposed to a certain concentration is important. To assess offsite doses, it is assumed that the exposure duration occurs over 30 years. Such exposures are called "chronic" in contrast to short-term exposures, which are called "acute."

The daily intake or dose from ingestion of water is estimated by the following equation:

$$
\text { Intake }(\mathrm{mg} / \mathrm{kg}-\text { day })=\frac{C W \times I R \times E F \times E D}{B W \times A T}
$$

where

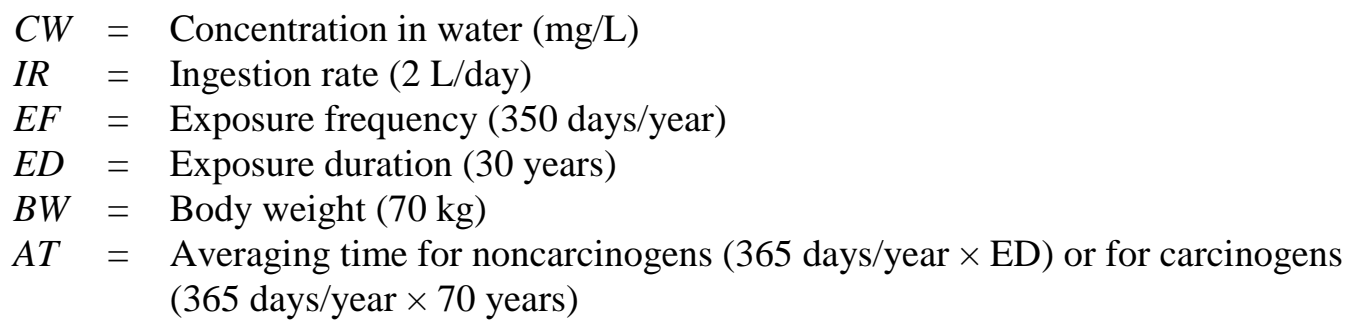

The daily intake rate or dose from consumption of fish obtained by recreational anglers is estimated by the following equation:

\section{G-6 Appendix G: Chemicals}




$$
\text { Intake }(\mathrm{mg} / \mathrm{kg}-\text { day })=\frac{C W \times I R \times E F \times E D}{B W \times A T}
$$

where

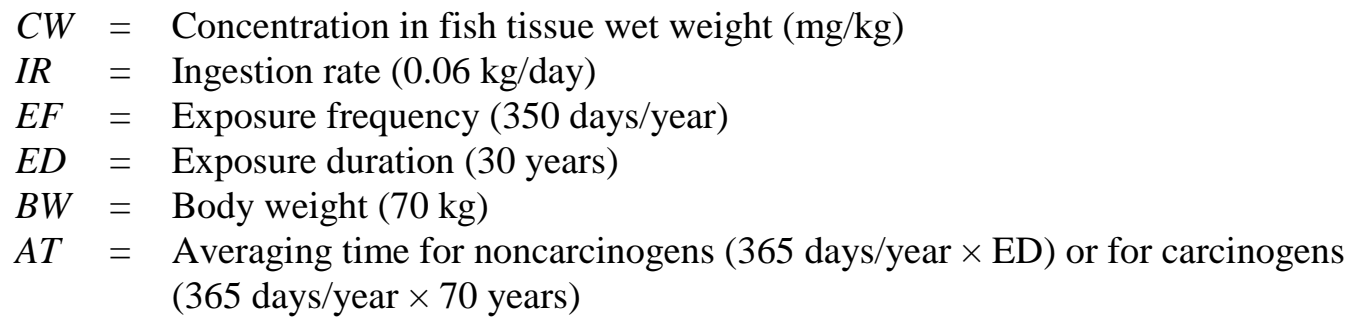

\section{Calculation Methodology}

Current risk assessment methodologies use the term hazard quotient to evaluate noncarcinogenic health effects. Because intakes are calculated in milligrams per kilogram per day in the hazard quotient methodology, they are expressed in terms of dose. The hazard quotient is a ratio that compares the estimated exposure dose or intake (I) to the reference dose as follows:

where

$$
H Q=\frac{I}{R f D},
$$

$H Q=$ hazard quotient (unitless),

$I=$ estimated intake or dose ( $\mathrm{mg} / \mathrm{kg}$-day),

$R f D=$ reference dose (mg/kg-day).

Hazard quotient values of less than 1 indicate an unlikely potential for adverse health effects, whereas hazard quotient values greater than 1 indicate a concern for adverse health effects or the need for further study.

To evaluate carcinogenic risk, slope factors are used instead of reference doses. In previous reports, the estimated dose from ingesting water or fish from rivers and streams surrounding the ORR is compared to the chronic daily intake $\mathrm{I}\left(10^{-5}\right)$ derived from assuming a human lifetime risk of developing cancer of $10^{-5}(1 \mathrm{in}$ 100,000). However, as in typical risk assessments, risk levels are derived as follows:

$$
\text { Risk }=I \times S F,
$$

where

$$
\begin{array}{ll}
\mathrm{I} & =\text { estimated intake or }(\mathrm{mg} / \mathrm{kg} \text {-day) }, \\
S F & =\text { slope factor, oral (risk per } \mathrm{mg} / \mathrm{kg} \text {-day) } .
\end{array}
$$

To estimate the risk of inducing cancers from ingestion of water and, the estimated dose or intake (I) is multiplied by the slope factor (risk per $\mathrm{mg} / \mathrm{kg}$-day). As mentioned earlier, acceptable risk levels for carcinogens range from $10^{-4}$ (risk of developing cancer over a human lifetime of 1 in 10,000 ) to $10^{-6}$ (risk of developing cancer over a human lifetime is 1 in 1,000,000). The tilde ( ) indicates that estimated values were used in estimating the average concentrations of a chemical. 



\section{References}





\section{References}

Note: In this report we refer to a number of documents (e.g., plans, reports) that are intended for internal use. For the most part, these documents function as a means of communication between governmental agencies and the tenant companies on the Oak Ridge Reservation or as the means by which analytical laboratories deliver results. As such, these documents are not readily available to the public and therefore are not cited in the list of references.

Adams, S. M., et al. 2000. Oak Ridge Y-12 Plant Biological Monitoring and Abatement Program (BMAP) Plan. Y/TS-1613-R2. Oak Ridge Y-12 National Security Complex, Oak Ridge, Tennessee.

Alter, H. 1986. A Glossary of Terms in Nuclear Science and Technology, American Nuclear Society, La Grange Park, Illinois.

ANSI. 1969. Guide to Sampling Airborne Radioactive Materials in Nuclear Facilities. ANSI N13.1-1969R. American National Standards Institute, Washington, D.C.

Beres, D. A. 1990. The Clean Air Act Assessment Package-1988 (CAP-88): A Dose and Risk Assessment Methodology for Radionuclide Emissions to Air, SC\&A, Inc., McLean, Virginia.

Birdwell, K. R. 1996. A Climatology of Winds over a Ridge and Valley Terrain within the Great Valley of Eastern Tennessee. Murray State University, Murray, Kentucky.

Birdwell, K. R. 2003. Vertical Transport and Mixing During Winter over a Ridge-and-Valley Terrain (not published).

BJC. 2002. Sampling and Analysis Plan for the Water Resources Restoration Program for Fiscal Year 2003 Oak Ridge Reservation, Oak Ridge, Tennessee. BJC/OR-1173. Bechtel Jacobs Company LLC, Oak Ridge, Tennessee.

BJC. 2003. Sampling and Analysis Plan for the Water Resources Restoration Program for Fiscal Year 2004 Oak Ridge Reservation, Oak Ridge, Tennessee. BJC/OR-1483. Bechtel Jacobs Company LLC, Oak Ridge, Tennessee.

BJC. 2003d. Groundwater Quality Assessment Report for Solid Waste Storage Area 6 at Oak Ridge National Laboratory, Oak Ridge, Tennessee, CY 2002, Bechtel Jacobs Company, LLC Oak Ridge, Tennessee.

BJC. 2003e. Groundwater Quality Assessment Report for Solid Waste Storage Area 6 at Oak Ridge National Laboratory, Oak Ridge, Tennessee. BJC/OR-1767. Bechtel Jacobs Company LLC, Oak Ridge, Tennessee.

BJC. 2004a. Calendar Year 2003, Resource Conservation and Recovery Act Annual Groundwater Monitoring Report for the Chestnut Ridge Hydrogeologic Regime at the U. S. Department of Energy Y12 National Security Complex, Oak Ridge, Tennessee. (BJC/OR-1732). Bechtel Jacobs Company LLC, Oak Ridge, Tennessee. 
BJC. 2004b. Calendar Year 2003, Resource Conservation and Recovery Act Annual Groundwater Monitoring Report for the Bear Creek Hydrogeologic Regime at the U. S. Department of Energy Y-12 National Security Complex, Oak Ridge, Tennessee. (BJC/OR-1730). Bechtel Jacobs Company LLC, Oak Ridge, Tennessee.

BJC. 2004c. Calendar Year 2003, Resource Conservation and Recovery Act Annual Groundwater Monitoring Report for the Upper East Fork Poplar Creek Hydrogeologic Regime at the U. S. Department of Energy Y-12 National Security Complex. BJC/OR-1731. Bechtel Jacobs Company LLC, Oak Ridge, Tennessee.

BJC. 2004d. Preliminary Ecological Risk Evaluation for the East Tennessee Technology Park: Aquatic. BJC/OR-1708. Bechtel Jacobs Company LLC, Oak Ridge, Tennessee.

BJC. 2004e. Preliminary Ecological Risk Evaluation for the East Tennessee Technology Park: Terrestrial. BJC/OR-1763. Bechtel Jacobs Company LLC, Oak Ridge, Tennessee.

Bonine, T. M. 2002. Operational Monitoring Plan for the High Flux Isotope Reactor Site: Final Design. Oak Ridge National Laboratory, Oak Ridge, Tennessee.

Bonine, T. M. 2003. Annual Monitoring Plan for the High Flux Isotope Reactor Site. Oak Ridge National Laboratory, Oak Ridge, Tennessee.

Bonine, T. M., and R. H. Ketelle. 2002. Summary of Baseline Operational Monitoring Activities at the High Flux Isotope Reactor Site. Oak Ridge National Laboratory, Oak Ridge, Tennessee.

Bonine, T. M., and R. H. Ketelle. 2004. Summary of 2002/2003 Annual Monitoring Activities at the High Flux Isotope Reactor Site: Monitoring Period August 2002 through August 2003. Oak Ridge National Laboratory, Oak Ridge. Tennessee.

Bowen, B. M., J. A. Baars, and G. L. Stone. 2000. "Nocturnal Wind Shear and its Potential Impact on Pollutant Transport."Journal of Applied Meteorology 39(3), 437-45.

BWXT. 2002. Storm Water Pollution Prevention Plan for the Oak Ridge Y-12 Plant. Y/TS-1180/R4. BWXT Y-12, L.L.C., OakRidge, Tennessee.

BWXT. 2004. Calendar Year 2003 Groundwater Monitoring Report, U.S. Department of Energy Y-12 National Security Complex, Oak Ridge, Tennessee. Y/SUB/04-030332/1. BWXT Y-12, L.L.C., Oak Ridge, Tennessee.

Chan, P. K., G. P. O'Hara, and A. W. Hayes. 1982. "Principles and Methods for Acute and Subchronic Toxicity." Principles and Methods of Toxicology. Raven Press, New York.

DOE. 1988a. External Dose-Rate Conversion Factors for Calculation of Dose to the Public.

DOE/EH-0070. U.S. Department of Energy, Washington, D.C.

DOE. 1988b. Internal Dose Conversion Factors for Calculation of Dose to the Public. DOE/EH-0071. U.S. Department of Energy, Washington D.C.

DOE. 1989. Radioactive Decay Data Tables: A Handbook of Decay Data for Application to Radioactive Dosimetry and Radiological Assessments. DOE/TIC-11026. U.S. Department of Energy,

Washington, D.C.

\section{R-4 References}


DOE. 1997a. Remedial Investigation Report for Melton Valley Watershed at Oak Ridge National Laboratory, Oak Ridge, Tennessee. Vol. 1. DOE/OR/01-1546/V1\&D2. U.S. Department of Energy, Washington, D.C.

DOE. 1997c. Report on the Remedial Investigation of Bear Creek Valley at the Oak Ridge Y-12 Plant, Oak Ridge, Tennessee. DOE/ORR/01-1455/V1/V6\&D2. U.S. Department of Energy, Washington, D.C.

DOE. 1998. Report on the Remedial Investigation of the Upper East Fork Poplar Creek Characterization Area at the Oak Ridge Y-12 Plant, Oak Ridge, Tennessee. DOE/OR/01-1641/V1-V4\&D2. U. S. Department of Energy, Office of Environmental Management, Oak Ridge, Tennessee.

DOE. 1999. Accelerating Clean-Up: Paths to Closure. U.S. Department of Energy Oak Ridge Operations Office, Oak Ridge, Tennessee.

DOE. 1999b. Remedial Investigation/Feasibility Study for Bethel Valley Watershed at Oak Ridge National Laboratory, Oak Ridge, Tennessee. DOE/OR/01-1748/V1/V2\&D2. U.S. Department of Energy, Washington, D.C.

DOE. 2001a. Cultural Resource Management Plan, DOE Oak Ridge Reservation, Anderson and Roane Counties, Tennessee. DOE/ORO 2085. U.S. Department of Energy, Washington, D.C.

DOE. 2001b. Environmental Assessment, Oak Ridge National Laboratory Facilities Revitalization Project. DOE/EA-1362. U.S. Department of Energy, Washington, D.C.

DOE. 2001d. Oak Ridge Reservation Annual Site Environmental Report for 2000. DOE/ORO/2119. Oak Ridge National Laboratory (UT-Battelle, LLC), Oak Ridge Y-12 National Security Complex (BWXT Y-12, L.L.C.), and East Tennessee Technology Park (Bechtel Jacobs Company LLC), Oak Ridge, Tennessee.

DOE. 2001f. Remediation Effectiveness Report/CERCLA 5-Year Review for the U.S. Department of Energy Oak Ridge Reservation. DOE/OR/01-1941, D1\&D2. U.S. Department of Energy, Washington, D.C.

DOE. 2002a. Annual Update of the Solid Waste Management Units for the Oak Ridge Reservation. Submitted.

DOE. 2002b. DOE Standard: A Graded Approach for Evaluating Radiation Doses to Aquatic and Terrestrial Biota. DOE-STD-1153-2002. U.S. Department of Energy, Washington, D.C.

DOE. 2002c. Final Supplemental Analysis for Purification Facility Site-Wide Environmental Impact Statement for the Y-12 National Security Complex. DOE/EIS-0309/SA-1. U.S. Department of Energy, Washington, D.C.

DOE. 2003. Environmental Monitoring Plan for the Oak Ridge Reservation. U.S. Department of Energy Oak Ridge Operations Office. DOE/OR-1066/R5. U.S. Department of Energy, Oak Ridge, Tennessee.

DOE. 2003a. 2003 Remediation Effectiveness Report for the U.S. Department of Energy, Oak Ridge Reservation, Oak Ridge, Tennessee. DOE/OR/01-2058\&D1. U.S. Department of Energy, Washington, D.C. 
DOE. 2003c. Engineering Study Work Plans for Groundwater Actions: Bethel Valley. DOE/OR/012035\&D2. U.S. Department of Energy, Washington, D.C.

DOE. 2004. 2004 Remediation Effectiveness Report for the U. S. Department of Energy, Oak Ridge Reservation. DOE/OR/01-2133\&D1. U.S. Department of Energy, Oak Ridge, Tennessee.

DOE. 2004b. Ecological Monitoring Report for the Melton Valley Watershed, Oak Ridge National Laboratory, Oak Ridge, Tennesse. DOE/OR/01-2061\&D. Bechtel Jacobs Company LLC, Oak Ridge, Tennessee.

DOE. 2004c. Environmental Monitoring on the Oak Ridge Reservation: 2003 Results. DOE/ORO/2186. Oak Ridge National Laboratory (UT-Battelle LLC), Oak Ridge Y-12 National Security Complex (BWXT Y-12, L.L.C.), and East Tennessee Technology Park (Bechtel Jacobs Company LLC), Oak Ridge, Tennessee.

EPA. 1989. Risk Assessments Methodology, Environmental Impact Statement, NESHAPs for Radionuclides, Background Information. Vol. 1. EPA/520/1-89-005. U.S. Environmental Protection Agency, Washington, D.C.

EPA. 1995. Compilation of Air Pollutant Emission Factors AP-42, Fifth Edition, Volume 1: Stationary Point and Area Sources. U.S. Environmental Protection Agency, Research Triangle Park, North Carolina. January 1995.

EPA. 1997. Exposure Factors Handbook, Vol. II. Food Ingestion Factors, EPA/600/P-95/002Fb, U.S. Environmental Protection Agency, Office of Research and Development, Washington, D.C.

EPA. 1998. Compilation of Air Pollutant Emission Factors AP-42, Fifth Edition, Volume 1: Stationary Point and Area Sources. U.S. Environmental Protection Agency, Research Triangle Park, North Carolina. September 1998.

Farnsworth, R. K., E. S. Thompson, and E. L. Peck. 1982. Evaporation Atlas for the Contiguous 48 United States. NOAA Technical Report NWS 33. National Weather Service, Office of Hydrology, Washington, D.C.

Hamby, D. M. 1991. LADTAP XL: An Improved Electronic Spreadsheet Version of LADTAP II. DE93003179. Westinghouse Savannah River Company, Aiken, South Carolina.

Hatcher, R. D., et al. 1989. Field Guide and Perspective on the Geology and Hydrology of the Oak Ridge Reservation. Oak Ridge National Laboratory/University of Tennessee, Oak Ridge, Tenn.

Kszos, L. A., et al. 1997. Biological Monitoring and Abatement Program Plan for the Oak Ridge National Laboratory. ORNL/TM-13432. Oak Ridge National Laboratory, Oak Ridge, Tennessee.

LMER. 1996. Oak Ridge Reservation Annual Site Environmental Report for 1995. ES/ESH-69. Lockheed Martin Energy Systems, Inc., Oak Ridge, Tennessee.

LMES. 1995. Oak Ridge Reservation Annual Site Environmental Report for 1994. ES/ESH-57. Lockheed Martin Energy Systems, Inc., Oak Ridge, Tennessee.

LMES. 1997a. Wetland Survey of Selected Areas in the Oak Ridge Y-12 Plant Area of Responsibility, Oak Ridge, Tenn. Y/ER-27. Lockheed Martin Energy Systems, Inc., Oak Ridge, Tennessee. 
LMES. 1997b. Radiological Monitoring Plan for the Oak Ridge Y-12 Plant: Surface Water. Y/TS-1704. Lockheed Martin Energy Systems, Inc., Oak Ridge, Tennessee.

LMES. 1999. Technical Explanation for the Detected Increase in Nickel in Groundwater Monitoring Well GW-305 at the Industrial Landfill IV, IDL-47-103-0075, Department of Energy Y-12 Plant, Anderson County, TN., Environment, Safety, and Health Organization. (Y/TS-1774). Lockheed Martin Energy Systems, Inc., Oak Ridge, Tennessee.

LMES and H\&R. 1995. Radiological Monitoring Plan for the Oak Ridge Y-12 Plant: Surface Water. Y/SUB/92-TK532C/4. Lockheed Martin Energy Systems, Inc. and H\&R Technical Associates, Inc., Oak Ridge, Tennessee.

Loar, J. M., et al. 1991. Oak Ridge National Laboratory Biological Monitoring and Abatement Program for White Oak Creek Watershed and the Clinch River. ORNL/TM-10370. Oak Ridge National Laboratory, Oak Ridge, Tennessee.

MMES. 1993. Identification and Characterization of Wetlands in the Bear Creek Watershed. Y/TS-1016. Martin Marietta Energy Systems, Inc., Oak Ridge, Tennessee.

MMES. 1994a. Compliance Plan: National Emission Standards for Hazardous Air Pollutants for Airborne Radionuclides on the Oak Ridge Reservation, Oak Ridge, Tennessee. ES/ESH-45. Martin Marietta Energy Systems, Inc., Oak Ridge, Tennessee.

MMES 1994b. Evaluation of the Ambient Air Monitoring Program at the Oak Ridge Y-12 Plant. Y/TS-1157/R1. Martin Marietta Energy Systems, Inc. Oak Ridge, Tennessee.

Moore, G. K. 1988. Concepts of Groundwater Occurrence and Flow Near Oak Ridge National Laboratory, Tennessee. ORNL/TM-10969. Martin Marietta Energy Systems, Inc., Oak Ridge, Tennessee.

Myrick, T. E., et al. 1981. State Background Radiation Levels: Results of Measurements Taken During 1975-1979. ORNL/TM-7343. Oak Ridge National Laboratory, Oak Ridge, Tennessee.

National Park Service. 2003. “Anderson County, Tennessee.” National Register of Historic Places. http://www.nationalregisterofhistoricplaces.com/.

Nativ, R., A. Halleran, and A. Hunley. 1997. The Deep Hydrogeologic Flow System Underlying the Oak Ridge Reservation-Assessing the Potential for Active Groundwater Flow and Origin of the Brine. ORNL/GWPO-18. Oak Ridge National Laboratory, Oak Ridge, Tennessee.

NCRP. 1987. Ionizing Radiation Exposure of the Population of the United States. NCRP Report No. 93. National Council on Radiation Protection and Measurements, Washington, D.C.

NCRP. 1989. 1989 Exposure of the U.S. Population from Diagnostic Medical Radiation. NCRP Report No. 100. National Council on Radiation Protection and Measurements, Bethesda, Maryland.

NOAA. 2001. Local Climatological Data Annual Survey With Comparative Data, Oak Ridge, Tenn. National Oceanic and Atmospheric Administration, National Climatic Data Center, Asheville, North Carolina. 
NRC. 1977. Calculation of Annual Doses to Man from Routine Releases of Reactor Effluents for the Purpose of Evaluating Compliance with 10 CFR 50. Regulatory Guide 1.109, Appendix I, Revision 1. NRC Office of Standards Development, U.S. Nuclear Regulatory Commission, Washington, D.C.

ORNL. 1999. ORR Comprehensive Integrated Plan. Oak Ridge National Laboratory, Oak Ridge, Tennessee.

ORNL. 2002. Oak Ridge National Laboratory Land and Facilities Plan. Oak Ridge National Laboratory, Oak Ridge Tennessee.

ORO. 1997. Final Environmental Assessment, Lease of Land and Facilities Within the East Tennessee Technology Park, Oak Ridge, Tennessee. DOE/EA-1175. U.S. DOE Oak Ridge Operations Office, Oak Ridge, Tennessee.

ORO. 2003. Environmental Assessment Addendum for the Proposed Title Transfer of East Tennessee Technology Park and Facilities. DOE/EA-1175-A. U.S. Department of Energy, Oak Ridge Office, Oak Ridge, Tennessee.

ORSSAB. 2003. Oak Ridge Reservation Educational Resource Guide. Oak Ridge Site Specific Advisory Board, Oak Ridge, Tennessee.

Rosensteel, B. 1996. Wetland Survey of the X-10 Bethel Valley and Groundwater Operable Units at Oak Ridge National Laboratory, ORNL/ER-350, Oak Ridge National Laboratory, Oak Ridge, Tennessee.

SNS. 1999a. Construction and Operation of the Spallation Neutron Source Facility: Final Environmental Impact Statement. Vol. 1 and 2. DOE/EIS-0247. U.S. Department of Energy Office of Science, Washington, D.C.

SNS. 1999b. Construction and Operation of the Spallation Neutron Source Facility: Final Environmental Impact Statement Summary. DOE/EIS-0247. U.S. Department of Energy Office of Science, Washington, D.C.

SNS. 2001. Project Description and Wetland Mitigation Plan, Spallation Neutron Source Bethel Valley Access Road, Anderson County and Roane County, Tennessee. Spallation Neutron Source, Oak Ridge, Tennessee.

TDEC. 1993. Current Fish Advisories-News. Tennessee Department of Environment and Conservation. Wednesday, Nashville, Tennessee, March 24, 1993.

TDEC. 2003. Tennessee Department of Environment and Conservation DOE Oversight Division Environmental Monitoring Report: January through December 2002. Tennessee Department of Environment and Conservation, Nashville, Tennessee. March 2003. (http://www.state.tn.us/ environment/doeo/EMR\%202002.pdf).

TDEC. 2004. General Water Quality Criteria, Criteria of Water Uses-Toxic Substances. TDEC 1200-4.03 (j). Tennessee Department of Environment and Conservation Tennessee Water Quality Control Board, Division of Water Pollution Control. Revised January 2004.

Tsakeres, F. S. 1980. Radiological Assessment of Residences in the Oak Ridge Area. ORNL/TM-7392/V1. Oak Ridge National Laboratory, Oak Ridge, Tennessee. 
Tucci, P. 1992. Hydrology of Melton Valley at Oak Ridge National Laboratory, Tennessee. U.S. Geological Survey Water Resources Investigation Report 92-4131. Nashville, Tennessee.

TVA. 1972. Upper Bear Creek Experimental Project: A Continuous Daily-Streamflow Model. Research Paper No. 8, Tennessee Valley Authority Division of Water Control Planning, Knoxville, Tennessee.

U.S. Census. 2002. eire.census.gov.

USFWS. 1995. Preliminary Estimates of Waterfowl Harvest and Hunter Activity in the United States. U.S. Fish and Wildlife Service, Washington, D.C.

UTCBER. 2000. Population Projection for Tennessee Counties and Municipalities, 2000-2020. University of Tennessee Center for Business and Economic Research, Knoxville, Tennessee. (March).

WSRC. 1994. Savannah River Site Environmental Report for 1993. Summary Pamphlet. SSRC-TR-076. Westinghouse Savannah River Company, Aiken, South Carolina. 


\section{The following references were not found in the 8/18/04 draft:}

BJC. 2001. Water Resources Restoration Program Sampling and Analysis Plan for Fiscal Year 2002 Oak Ridge Reservation, Oak Ridge, Tennessee. BJC/OR-960. Bechtel Jacobs Company LLC, Oak Ridge, Tennessee.

BJC. 2002a. ETTP Storm Water Pollution Prevention Program Baseline Document. BJC/OR-777. Bechtel Jacobs Company LLC, Oak Ridge, Tennessee.

BJC. 2002b. Sampling and Analysis Plan for the Water Resources Restoration Program for Fiscal Year 2003 Oak Ridge Reservation, Oak Ridge, Tennessee. BJC/OR-1173. Bechtel Jacobs Company, LLC, Oak Ridge, Tennessee.

BJC. 2003a. Calendar Year 2002, Resource Conservation and Recovery Act Annual Groundwater Monitoring Report for the Upper East Fork Poplar Creek Hydrogeologic Regime at the U.S. Department of Energy Y-12 National Security Complex, Oak Ridge, Tennessee. BJC/OR-1333. Bechtel Jacobs Company LLC, Oak Ridge, Tennessee.

BJC. 2003b. Calendar Year 2002, Resource Conservation and Recovery Act Annual Groundwater Monitoring Report for the Bear Creek Hydrogeologic Regime at the U.S. Department of Energy Y-12 National Security Complex, Oak Ridge, Tennessee. BJC/OR-1334. Bechtel Jacobs Company LLC, Oak Ridge, Tennessee.

BJC. 2003c. Calendar Year 2002, Resource Conservation and Recovery Act Annual Groundwater Monitoring Report for the Chestnut Ridge Hydrogeologic Regime at the U.S. Department of Energy Y-12 National Security Complex, Oak Ridge, Tennessee. BJC/OR-1335. Bechtel Jacobs Company LLC, Oak Ridge, Tennessee.

BWXT. 2003. Calendar Year 2002 Groundwater Monitoring Report, U.S. Department of Energy Y-12 National Security Complex, Oak Ridge, Tennessee. Y/SUB/03-021559/1. , BWXT Y-12, L.L.C., Oak Ridge, Tennessee.

DOE. 1997b. Report on the Remedial Investigation of the Upper East Fork Poplar Creek Characterization Area at the Oak Ridge Y-12 Plant, Oak Ridge, Tennessee. DOE/OR/01-1641/V1/V6\&D0. U.S. Department of Energy, Washington, D.C.

DOE. 1999c. Remedial Investigation Report for the East Tennessee Technology Park, Oak Ridge, Tennessee, DOE/OR/01-1778/V1/V4\&D1. Vol. 1 and Vol. 4. U.S. Department of Energy, Washington, D.C.

DOE. 2001c. Final Site-Wide Environmental Impact Statement for the Y-12 National Security Complex. DOE/EIS0309. U.S. Department of Energy, Washington, D.C

DOE. 2001e. Oak Ridge Reservation Environmental Impact Assessment for Transportation of Low-Level Radioactive Mixed Wastes from the Oak Ridge Reservation to Off-Site Treatment or Disposal Facilities. DOE/EA-1315. U.S. Department of Energy, Washington, D.C.

EPA. 1993. External Exposure to Radionuclides in Air, Water, and Soil, Federal Guidance Report No. 12. EPA 402-R-93-081. U.S. Environmental Protection Agency, Washington, D.C.

ISO. 1996. "Environmental Management Systems Specifications with Guidance for Use.” International Organization for Standardization, Geneva.

Jones, S. B. 1999. Technical Explanation for the Detected Increase in Nickel in Groundwater Monitoring Well GW305 at the Industrial Landfill IV, IDL-47-103-0075, Department of Energy Y-12 Plant, Anderson County, TN. Y/TS1774. Oak Ridge Y-12 Security Complex, Oak Ridge, Tennessee. 